\title{
JOHANN SLEIDAN AND THE PROTESTANT VISION OF HISTORY
}

\author{
Alexandra H. Kess
}

A Thesis Submitted for the Degree of PhD at the University of St Andrews

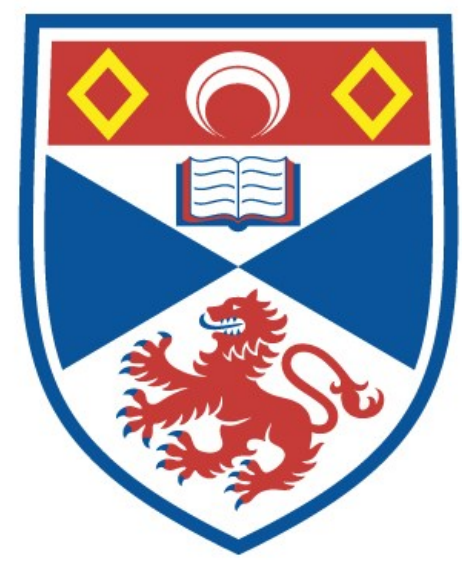

2004

Full metadata for this item is available in

St Andrews Research Repository at:

http://research-repository.st-andrews.ac.uk/

Please use this identifier to cite or link to this item: http://hdl,handle.net/10023/13238

This item is protected by original copyright 


\section{JOHANN SLEIDAN \\ AND \\ The Protestant Vision \\ OF \\ HISTORY}

ALEXANDRA H. KeSS

Thesis submitted for the degree of Ph.D. at the University of St. Andrews, January 2004

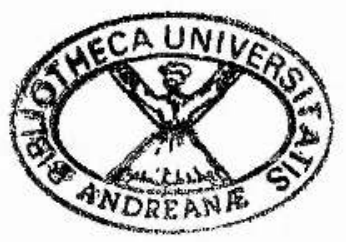


ProQuest Number: 10166792

All rights reserved

INFORMATION TO ALL USERS

The quality of this reproduction is dependent upon the quality of the copy submitted.

In the unlikely event that the author did not send a complete manuscript and there are missing pages, these will be noted. Also, if material had to be removed, a note will indicate the deletion.

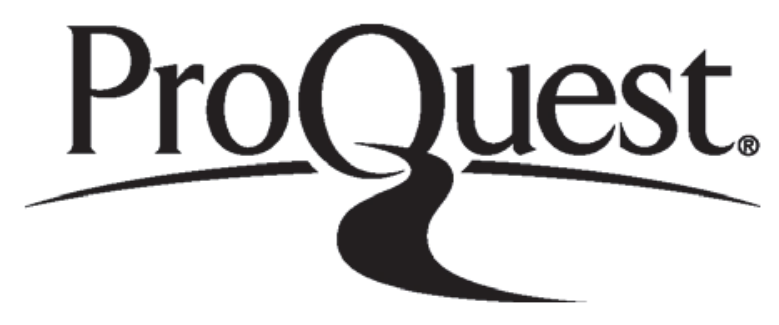

ProQuest 10166792

Published by ProQuest LLC (2017). Copyright of the Dissertation is held by the Author.

All rights reserved.

This work is protected against unauthorized copying under Title 17, United States Code Microform Edition (C) ProQuest LLC.

ProQuest LLC.

789 East Eisenhower Parkway

P.O. Box 1346

Ann Arbor, MI 48106 - 1346 


\section{Declaration}

(i) I, Alexandra Helene Kess, hereby certify that this thesis, which is approximately 100,000 words in length, has been written by me, that it is the record of work carried out by me and that it has not been submitted in any previous application for a higher degree.

Date $15 / .0 .3 / .2004$. Signature of candidate $\cdot t$

(ii) I was admitted as a research student in September 2000 and as a candidate for the degree of Doctor of Philosophy in September 2001; the higher study for which this is a record was carried out in the University of St. Andrews between 2000 and 2003.

Date $15 / 03 / 2004 . .5$ Signature of candidate

(iii) I hereby certify that the candidate has fulfilled the conditions of the Resolution and Regulations appropriate for the degree of Doctor of Philosophy in the University of St. Andrews and that the candidate is qualified to submit this thesis in application for that degree.

Date $15 / 3 / 2004$....................... Signature of supervisor ...

In submitting this thesis to the University of St. Andrews I understand that I am giving permission for it to be made available for use in accordance with the regulations of the University Library for the time being in force, subject to any copyright vested in the work not being affected thereby. I also understand that the title and abstract will be published, and that a copy of the work may be made and supplied to any bona fide library or research worker.

Date $15 / .03 / .2004 .4$ Signature of candidate $C$ 


\section{Abstract}

The main focus of interest in this $\mathrm{PhD}$ dissertation is the Reformation historian and diplomat Johann Sleidan (1506-1556). Born in Schleiden and brought up together with Strasbourg's famous Jean Sturm, Sleidan soon entered a period of active political life with his employment at the chancellory of Cardinal Jean Du Bellay in Paris in the mid-1530s. There and later in Strasbourg his main concern was to encourage a rapprochement or possible alliance between France and the German Protestants. It was also in Paris that Sleidan discovered history as his second passion. After translating key French historians into Latin, Sleidan moved on to produce his own works of a political-historical nature. His main work, De statu religionis et reipublicae Carolo Quinto Caesare commentarii, 'Commentaries on religion and state under Emperor Charles V', published in 1555, was initially commissioned by the Schmalkaldic League as the official history of the Reformation. Despite early hostile reactions, this history was an immediate success with the buying public, published in numerous editions and by the year 1560 circulated in six different languages.

Chapters one to three explore Sleidan's biography in depth. The collection and analysis of contemporary correspondence has provided the cornerstone for a new narrative of Sleidan's life In the second half of this thesis I move to a detailed study of his principal published works. Chapter four concentrates on Sleidan's main work, the Commentaries. After placing this history in the context of contemporary German history writing, I examine this work in detail, treating its genesis, character, and methodology. I examine the unexpectedly hostile reactions to the first edition and its very rapid success with purchasers. I then move on to consider the longer-term reaction to Sleidan's great work, 
first in Germany and then in France. I explore the controversies aroused by Sleidan's work, among both Catholics and Protestants, and in contrast, the great respect for his scholarship that also straddled the religious confessions.

Sleidan provided the context through which I have been able to analysise the life of a scholar in the sixteenth century, and the works of one of the foremost historians of the new evangelical movement. His life and his works have not, until this point, been placed in a broader context. His work as a translator and historian provides an excellent example of the movement of text around the cultural communities of Europe. Sleidan played a vital part in this process by offering Latin translations of leading French historians which would later be translated into other languages, and by publishing his own works in German or Latin, which were then translated into many other vernaculars. But Sleidan was also engaged in the world of public affairs. Sleidan's position in Du Bellay's chancellery in Paris has provided a new picture of French evangelism. This contact was not given up when Sleidan moved to Strasbourg. The Franco-imperial city has been shown again as one of the cultural centres of Europe from where an intellectual and political elite operated on a cross-national and cross-confessional level. Strasbourg with its francophone scholars was also the Schmalkaldic League's gateway to France. Sleidan's connections as a diplomat linked Germany and France, and have formed the basis for a new study of those in the Franco-German world who shared Sleidan's concerns to promote peace across the religious divide. 


\section{Acknowledgements}

A work of such scope and effort would not have been possible without the support and help of many. On the practical side, this work could not have been undertaken without financial assistance from various sides. My thanks go to the David and Dorothy Daniell William Tyndale foundation, the Royal Historical Society and the Modern History Department of the University of St Andrews for their valuable and generous contributions. During the course of this work, I spent many months in libraries in Great Britain, Germany and France, all of which have been extremely helpful. I would like to thank especially the helpful and friendly staff of Special Collections at the University Library in St Andrews, of the Fonds anciens at the Bibliothèque Municipale in Lyon, and the staff of the Handschriften-lesesaal at the Bayerische Staatsbibliothek in Munich under Dr. Claudia Fabian.

Throughout the last years I could also enjoy the friendship and support of many friends in both Great Britain and Germany; many thanks go here especially to Caroline Dean for her share in the proof-reading of this thesis. My gratitude is owed especially to friends and colleagues in the University of St Andrews, most of all the Reformation Studies Institute, where I spent a pleasurable time; Prof. Andrew Pettegree, Dr. Bruce Gordon and Dr. Jeffrey Ashcroft offered constant help and support. Here I would also like to thank Dr. David and Christine Gascoigne as well as the extended Pettegree family, Jane, Megan, Sophie, Don and Connie, for their help and friendship in the last years. Thanks also to my colleagues in the French Book Project, most of all Dr. Sandy Wilkinson and Dr. Malcolm Walsby. Within the circle of the Institute and Book Project I could enjoy the friendship of many, staff, secretaries and colleagues, in particular Lauren Kim and Michael Springer. I am extremely grateful to my family, my parents Ellen and Hans Kess, and my grandparents Gerda and Kurt Meiss, for all their support throughout the years. I would also like to thank Matthew Hall for his constant help and support in so many ways. My utmost thanks go to my supervisor, Prof. Andrew Pettegree. His patient help, advice and friendship turned this study period into an extremely delightful time. 


\section{Abbreviations and editorial conventions}

ADB Allgemeine Deutsche Biographie

ARG Archiv für Reformationsgeschichte/Archive for Reformation History

BSHPF Bulletin de la Société de l'Histoire du Protestantisme Français

CR Corpus Reformatorum, vols. 1- 8, Bretschneider, Karl Gottlieb (ed.), (Halle 1834-41), vols. 39-44, Baum, Wilhelm, Cunitz, Eduard, and Reuss, Eduard (eds.), (Braunschweig 1873-76) repr. Bad Feilnbach 1990

ELJB Elsass-Lothringisches Jahrbuch

LP Brodie, R.H./Gairdner J., Letters and Papers, Foreign and Domestic, of the Reign of Henry VIII, preserved in the Public Record Office, the British Museum and elsewhere in England, vols. XX/II, XXI/I, London 1907-1908

SCJ Sixteenth Century Journal

PC Virck, Hans, Winckelmann, Otto, and Friedensburg, Walter et al. (eds.), Politische Correspondenz der Stadt Strasbourg im Zeitalter der Reformation, vols. 3-5, vol. 3: Strasbourg 1898; vols. 4-5: Heidelberg 1928-1933

ZGO Zeitschrift für die Geschichte des Oberrheins

The spelling of sixteenth century Latin and English was left untouched. Sixteenth century French was standardized according to modern spelling in the case of ' $s$ ' and ' $\mathrm{f}$, ' $\mathrm{i}$ ' and ' $\mathrm{j}$ ', and ' $u$ ' and ' $v$ '. The contractions ' $\tilde{a}$ ', ' $\tilde{e}$ ', 'õ', and ' $\tilde{u}$ ' in sixteenth century French and German printed texts were expanded to 'an/am', 'en/em', 'on/om', and 'un/um'. 


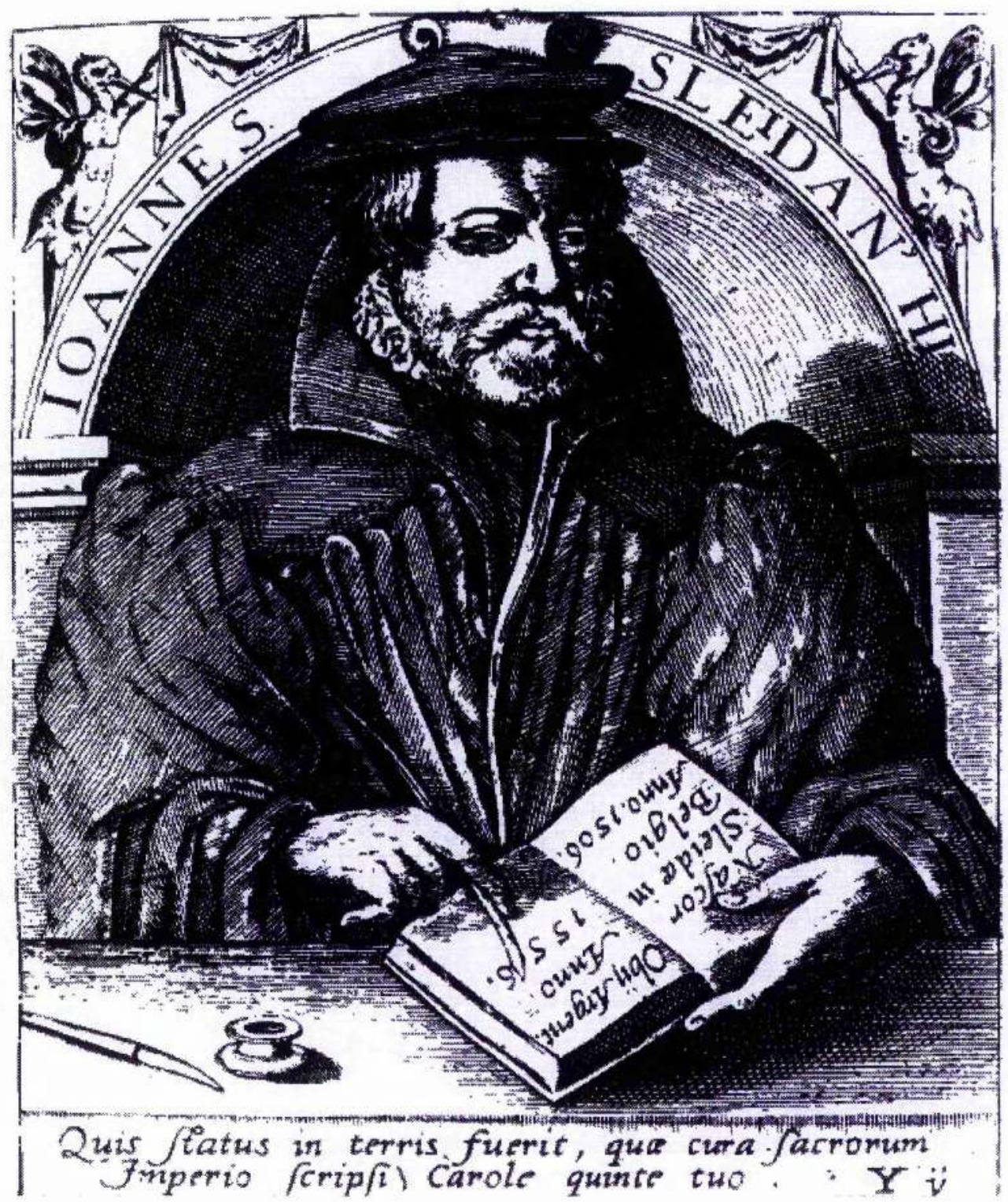

Anonymous copper engraving of Johann Sleidan, preserved in the National Library of Luxembourg (attributed to the early seventeenth century). A similar woodcut of Sleidan is included in Théodore de Bèze's Vrais pourtraits des hommes illustres en pieté et doctrine, s.1. (Jean de Laon) 1581, fol. I2r, showing Sleidan blind on the right eye. 


\section{ConTEnTs}

\section{Declarations}

Abstract

Acknowledgements

Abbreviations and editorial conventions

Engraving of Johann Sleidan

Introduction

p. 1

Chapter 1: The Making of a Historian - Sleidan in France

p. 10

1. Early years and education

2. Sleidan's years in France

3. Sleidan in the service of Jean Du Bellay

4. Sleidan's epitome of Jean Froissart (1537)

5. The battle for an alliance with the German Protestants

6. The Orations to the Estates and to the Emperor (1541/1544)

7. Accusations and disappointments - Sleidan's final months in France

Chapter 2: In the service of the Schmalkaldic League

p. 40

1. Sleidan's arrival in Strasbourg: planning a career

2. Sleidan's version of Philipppe de Commynes (1545)

3. Sleidan's inner circle and their influence: the Du Bellays, Sturms, Bucer and Calvin

4. Sleidan's religious conviction

5. Alea iacta est: Sleidan as official historian of the Schmalkaldic League

6. Diplomat of the Schmalkaldic League - and France?

7. The mission to England

8. Domestic happiness

9. The end of the Protestant hopes? - The Schmalkaldic War 
1. Looking towards England

a. Sleidan's version of Philipppe de Commynes' work on Charles VIII (1548)

b. Sleidan' translation of Claude de Seyssel (1548)

c. The Summary of Plato's doctrine on state and laws (1548)

2. At the Council of Trent $1551 / 1552$

3. Diplomat for Strasbourg and Protestant historian

4. The Commentaries on State and Religion under Emperor Charles V(1555)

5. The Four Empires (1556)

6. 'Another one of our best and most venerable friends, Sleidan, is dead...'

\section{Chapter 4: The Making of the Commentaries}

A. German historiography

1. Predecessors of Sleidan

a. Sebastian Franck

b. Johann Carion and Philip Melanchthon

2. A contemporary project: Matthias Flacius Illyricus

B. The Commentaries

1. The need for a Protestant history

2. Composing the Commentaries

3. The publication of the Commentaries and the aftermath

4. Sleidan's sources and methodology

5. Sleidan and the quest for veracity

6. Public responses to the Commentaries

7. Sleidan is dead - but not forgotten

Chapter 5: Sleidan's reception in Germany

1. The race for a German translation

2. The distribution of Sleidan's work 
3. Reactions and echos in German history writing
a. Johannes Gropper
b. Laurentius Surius
c. Caspar Gennep - and Cyriakus Spangenberg
d. Johannes Avicinius
e. Friedrich Hortleder

Chapter 6: Sleidan and the French historians

p. 199

1. Sleidan's Commentaries in France: French demand and Crespin's supply

2. French historiography

3. Jean de Hainault

4. Pierre de la Place, official historian of the Protestant party

5. Théodore de Bèze - a Calvinist praising Sleidan

6. A banned Protestant contra Sleidan: Henri Lancelot Voisin de la Popelinière and Jean Bodin

7. A Catholic refutation: the work of Simon Fontaine

8. Catholic polemic: Florimond de Raemond

9. Sleidan as a source for Catholic historiography: Noel Tallepied

10. Gabriel de Saconay: Sleidan in Catholic polemic

11. League polemic discovers Sleidan

12. Sleidan canonized? Nicolas Vignier and Paolo Sarpi

13. Jacques-Auguste de Thou and Theodore Agrippa d'Aubigné: a fate shared

Conclusion

p. 248

Appendix I: Sleidan's correspondence and related documents

p. 254

Appendix II: Dedications, prefaces, postscripts, poems

p. 308

Appendix III: Sleidan's lost letters

p. 311

Appendix IV: Title page illustrations

p. 318

Bibliography

p. 324 


\section{INTRODUCTION}

'People learnt a new history because they acquired a new religion. Conversion meant literally the discovery of a new history from Adam and Eve to contemporary events. ${ }^{1}$ With this statement Arnaldo Momigliano referred to the fourth century, and the conversion to Christianity. More than thousand years later another, similar phenomenon occured, one that would equally shake and shape history: the Reformation. Suddenly the Corpus Christianorum was split into Catholics and Protestants. Both parties needed to justify themselves, and did so in various ways: polemical debates, theological writings, and even armed fights. History became another tool in this confessional battle, it was used as a weapon of propaganda as Donald R. Kelley put it. ${ }^{2}$

The writing of history had occupied mankind for a long time, but reached a new peak in the sixteenth century. Renaissance humanism had reconfirmed the study of history, and with the 'ad fontes'-call had also provided new methodological guidelines. The Reformation with all its theological and political implications provided a new impetus and a new need for the writing of history. The Catholics had to defend their authority as the true, apostolic church, the Protestants had to prove that it was in fact they themselves who had always embodied this true church. History had to be rewritten. As Bruce Gordon has demonstrated, history had to serve as a defence against the opposed confessional group, and create a common identity for the fellow believers. ${ }^{3}$ Furthermore, it was to

\footnotetext{
${ }^{1}$ Arnaldo Momigliano, 'Pagan and Christian Historiography in the Fourth Century A.D.', Essays in Ancient and Modern Historiography, Oxford 1977, p.110.

${ }^{2}$ 'Probably the most characteristic mode of early modern propaganda even in the religious controversies was the historical.' (Donald R. Kelley, The Beginning of Ideology: Consciousness and Society in the French Reformation, Cambridge 1981, p. 247).

${ }^{3}$ On Protestant identity and the role of history cf. the various contributions in Bruce Gordon, (ed.), Protestant History and Identity in Sixteenth-Century Europe, 2 vols., Aldershot 1996, and especially Gordon's introductory article 'The Changing Face of Protestant History and Identity in the Sixteenth Century', vol. 1, pp. 1-22. On p. 10 he notes that ' $[t]$ he most important humanist legacy for the Reformation was the creation
} 
provide a continuation of salvation history, and, on the political side, work towards a consolidation of state and religion.

The official political organisation of the German Protestants, the Schmalkaldic League, soon recognised this important function of history. A history of the Reformation was needed, and Johann Sleidan (1506-1556) was appointed as 'historiographus protestantium, ${ }^{4}$ Johann Philippson von Schleiden with his position at the core of French and German politics was one of the most qualified to write a history of the Reformation. During his lifetime he witnessed the coming of entirely new perspectives in scholarship, history, theology and politics; Leonard da Vinci, Erasmus of Rotterdam, Martin Luther and Niccolò Machiavelli all changed the world in their own way. It was Sleidan's aim to describe these 'important commotions and wonderful changes' in his most famous work, De statu religionis et reipublicae Carolo Quinto Caesare commentarii, 'Commentaries on religion and state under Emperor Charles V'. ${ }^{5}$

Sleidan provided the first comprehensive contemporary history of the Reformation, spanning its vital period from 1517 to 1555 , from Luther's 95 Theses to the Peace of Augsburg. The Commentaries became a stunning monument to the Reformation as well as to Sleidan's scholarship. The work was read across Europe and caused strong reactions among Protestants and Catholics alike. In his attempt to base his history of current events entirely on original document sources linked together in a neutral narrative, Sleidan's approach was quite modern. Yet he could certainly profit from other historians introducing

of a Protestant textual community, a Europe-wide circle of learned men who shared a common language and whose intellectual and religious exchanges took place through common modes of inquiry.'

${ }^{4}$ Sleidan proudly signed a letter to Henry VIII with this title (cf. Appendix I, No. 97).

${ }^{5}$ The Commentarii were first published in 1555 by Wendelin Rihel and heirs in Strasbourg; in the following I shall refer to this work as 'Commentaries'. The quotation is taken from Sleidan's dedication to the Commentaries, quoted from the 1559 edition Ioan. Sleidani, De Statu Religionis \& Reipublicae, Carolo Quinto, Caesare, Commentariorum libri XXVI, Strasbourg (Josias Rihel), fol. a3v: 'gravissimi motus \& mirae vicissitudines'. 
new aspects into historiography in the early decades of the sixteenth century. He made these innovations his own by applying them to the most recent history.

In the early Church, Eusebius of Caesarea with his Ecclesiastical History was the first and most prominent historian to take on this challenge, which earned him praise as 'father of church history'. ${ }^{6}$ For the Reformation, Johann Sleidan was to assume this role. He became what Donald R. Kelley described as 'the Thucydides as well as the Eusebius of early Protestantism' and the 'father of Reformation history'. ${ }^{7}$ By 1560 , only five years after the first publication, altogether 48 editions of the Commentaries in six languages had been published. By 1600 , this number had increased to 95 editions, not to mention the various editions of complete works, tables and extracts. $^{8}$

Sleidan's extraordinary popularity lasted well beyond his own century. The situation today is different: Sleidan has rarely merited the attention of a modern scholar, and the main biographies and encyclopaedias in German, French and English rarely mention his name. Works about the sixteenth century, even those examining topics where Sleidan's role had been important, are largely silent about the Reformation historian or leave him languishing in the footnotes. This has not always been the case. In his own time, Sleidan attracted considerable attention from contemporary scholars - from those who would refute him or those who simply drew on his work as an archive of facts and documents. For several centuries, the Commentaries remained the main work on

\footnotetext{
${ }^{6} \mathrm{Cf}$. the edition by Hugh Jackson Lawlor, John Ernest Leonard Oulton, Eusebius, Bishop of Caesarea. The Ecclesiastical History and the Martyrs of Palestine, 2 vols., London 1927/28.

${ }^{7}$ Donald R. Kelley, 'Johann Sleidan and the Origins of History as a Profession', Journal of Modern History $52(1980)$, pp. $577,597$.

${ }^{8}$ These and other calculations in this thesis as well as identification signatures are derived from the bibliography of Emil van der Vekene, Johann Sleidan (Johann Philippson). Bibliographie seiner gedruckten Werke und der von ihm übersetzten Schriften von Philipe de Comines, Jean Froissart und Claude de Seyssel. Mit einem bibliographischen Anhang zur Sleidan-Forschung, Stuttgart 1996.
} 
Reformation history for Protestants and Catholics alike, an interest reflected also in critical scholarship.

In 1617/1618 Friedrich Hortleder published two monumental volumes of documents appertaining to the Reformation, with the partial aim of providing testimony for Sleidan's account in the Commentaries. ${ }^{9}$ He also included a letter by Sleidan to Philip of Hesse, along with two letters between the Landgrave and John Frederic of Saxony concerning Sleidan's employment as historiographer. For over a century, Sleidan continued to be read and published in various forms, including continuations, but no further light was shed on the historian. In 1753, finally, Johann Friedrich Noodt, a Danish minister, published 15 letters between Sleidan and Jacob Sturm, the stettmeister of Strasbourg, dating from the year $1545 .^{10}$ Shortly after, the German scholar Carl Christian Am Ende discovered Sleidan and published various writings on his life and editions of the Commentaries. This was complimented by the publication of a three-volume annotated version of the Commentaries in 1785 , which sought to provide references to the documents Sleidan had used and other literature, as well as point out differences between editions. ${ }^{11}$

Towards the second half of the nineteenth century, Sleidan developed into a popular topic for historians in Germany. In 1843, Theodor Paur published an interesting work concentrating on the Commentaries and its sources, which in 1879 was

\footnotetext{
${ }^{9}$ Friedrich Hortleder, Der Römischen Keyser- und königlichen Maiesteten: Auch des Heiligen Römischen Reichs Geistlicher und Weltlicher Stände / Churfürsten /Fürsten / Graffen / Reichs- und anderer Stätte / ... Handlungen und Außschreiben, 2 vols., Frankfurt/Main (Hartm. Palthenius/Nicolaus Hoffmann) 1617-1618 (exact title see bibliography).

${ }^{10}$ Johann Friedrich Noodt, 'Epistolarum Jo. Sleidani hactenus ineditarum fasciculus prior', Brem-und Verdische Bibliothek, worin zur Aufnahme der Wissenschaften, insbesonderheit der theologischen, philologischen und historischen, allerley brauchbare Abhandlungen und Anmerkungen mitgetheilt werden, vol. 1/II, (s.l.) 1753, pp. 87-122, and 'Epistolarum Jo. Sleidani hactenus ineditarum fasciculus posterior', ibid., vol. 1/III, pp. 103-128.

${ }^{11}$ Carl Christian Am Ende (ed.), Ioannis Sleidani de Statu religionis et reipublicae Carolo quinto Caesare Commentarii, 3 vols., Frankfurt/Main 1785. Cf. the bibliography on his other contributions to the Sleidanscholarship.
} 
complimented by a dissertation by Wilhelm Weise. ${ }^{12}$ In 1864 , F.W. Kampschulte published an article on Sleidan's role as Protestant historiographer. ${ }^{13}$ In 1870 , L. Geiger published several letters between Sleidan and Jean Du Bellay from the years 1542 till 1547. ${ }^{14}$ At the same time the Strasbourg professor Heinrich Baumgarten focused on Sleidan and began to collect his letters. In 1878 , he published a short outline of Sleidan's correspondence, together with biographical notes. ${ }^{15}$ In 1881 finally, a complete edition of Sleidan's correspondence was published Baumgarten. ${ }^{16}$ This corpus encompassed 182 letters, including 138 written by Sleidan and 32 addressed to him; a further 12 letters which refer to the historian from and to third parties were also included.

Subsequently, the interest in Sleidan increased further. At the beginning of the twentieth century, more of Sleidan's correspondence was published by the French historian V.-L. Bourrilly, who also contributed articles on Sleidan's life in France. ${ }^{17}$ Various scholars, including Paul Kalkoff, C. Oberreiner and Karl Schottenloher, subsequently made valuable contributions concerning Sleidan's life and work. Until 1930 Adolf Hasenclever dominated the scholarship on Sleidan, publishing a flood of writings on Sleidan and connected topics, including also further correspondence. ${ }^{18}$ Additional valuable material came to light with the publication of Strasbourg's political correspondence in the sixteenth

\footnotetext{
${ }^{12}$ Theodor Paur, Johann Sleidans Commentare über die Regierungszeit Karls V., Leipzig 1843; Wilhelm Weise, Über die Quellen der Commentare Sleidans, Halle 1879.

${ }^{13}$ Kampschulte, F.W., 'Über Johann Sleidanus als Geschichtsschreiber der Reformation', Forschungen zur deutschen Geschichte 4 (1864), pp.59-69.

${ }^{14}$ L. Geiger, 'Briefe Joh. Sleidans an den Kardinal Joh. Du Bellay, 1542-1547', Forschungen zur deutschen Geschichte 10 (1870), pp.167-198.

${ }^{15}$ Hermann Baumgarten, Über Sleidans Leben und Briefwechsel, Strasbourg 1878.

${ }^{16}$ Hermann Baumgarten, Sleidans Briefwechsel, Strasbourg 1881.

${ }^{17}$ V.-L. Bourrilly, 'Deux nouvelles lettres de Jean Sleidan', BSHPF 55 (1906), pp. 212-219, and 'Jean Sleidan et le Cardinal Du Bellay. Premier séjour de Jean Sleidan en France (1533-1540)’, BSHPF 50 (1901), pp. 225-245. On Bourrilly's other works, see bibliography.

${ }^{18}$ Hasenclever's works, include for example Sleidan-Studien. Die Entwicklung der politischen Ideen Joh. Sleidans bis zum Jahre 1545, Bonn 1905; cf. bibliography.
} 
century by Otto Winckelmann and others. ${ }^{19}$ One member of the editorial team, Walter

Friedensburg, dedicated his further studies to Sleidan and published an interesting monograph as well as a number of articles on Sleidan's life and the Commentaries. ${ }^{20}$

From the 1940s onwards there was a marked decline in the interest in studies of Sleidan, until in 1969 Jean Rott published a valuable list of Sleidan's correspondence which included further letters. ${ }^{21}$ In 1977 A.G. Dickens published an article on Sleidan's role as a Reformation historian, followed by Donald R. Kelley with an article on Sleidan and the profession of history. ${ }^{22}$ Thereafter, in 1986 Ingeborg Berlin Vogelstein published her $\mathrm{Ph} . \mathrm{D}$ dissertation on Sleidan, concentrating on the sources used and the adoption of Sleidan by German historians of the seventeenth and eighteenth century. ${ }^{23}$ She completed her study of Sleidan with the publication of an article of a rather general nature, which was also the outlook of two articles published by Laurence Druez in the mid-nineties. ${ }^{24}$ In 1996, finally, the head librarian Emil van der Vekene of the national library in Luxembourg published a comprehensive bibliography of the works and translations of Sleidan.

\footnotetext{
${ }^{19}$ Hans Virck, Otto Winckelmann, J. Bernays, Harry Gerber, and Walter Friedensburg (eds.), Politische Correspondenz der Stadt Strasbourg im Zeitalter der Reformation, 5 vols., especially vol. 3: Strasbourg 1898, vols. 4-5: Heidelberg 1928-1933 (hereafter PC).

${ }^{20}$ Cf. especially Walter Friedensburg, Johannes Sleidanus. Der Geschichtsschreiber und die Schicksalsmächte der Reformationszeit, Leipzig 1935.

${ }^{21}$ Jean Rott, 'Nouveaux Documents sur Jean Sleidan Historien de la Réforme (1506-1556)', Bulletin Philologique et Historique (Jusqu'à 1610) du Comité des Travaux Historiques er Scientifiques, Année 1967/II, Paris 1969, pp. 551-647.

${ }^{22}$ A.G. Dickens, 'Johannes Sleidan and Reformation History', R. Buick Knox (ed.), Reformation, Conformity and Dissent. Essays in honour of Geoffrey Nuttall, London 1977, pp. 17-43; 'Johann Sleidan and the Origins of History as a Profession', Journal of Modern History 52 (1980), pp. 577-598.

${ }^{23}$ Ingeborg Berlin Vogelstein, Johann Sleidan's Commentaries. Vantage Point of a Second Generation Lutheran, Rochester 1986.

${ }^{24}$ Cf. Ingeborg Berlin Vogelstein, 'Johann Sleidan's Commentaries: New Insights from an Old History', Storia della Storiografia 11 (1987), pp. 5-21; Laurence Druez, 'État présent des études sleidaniennes', Bibliothèque d'Humanisme et Renaissance 58 (1996), pp. 685-700, and by the same author, 'L'Humaniste Allemand Jean Sleidan: De la Diplomatie à l'Histoire', Cahiers de Clio 123 (1995), pp. 15-32.
} 
This survey of existing scholarship on Sleidan seems to have yielded a rich harvest. Upon closer examination, however, one notices that all these contributions are mere isolated parts of the large jigsaw that is Sleidan's life and work. Put together, these parts do not fit, and large spaces are left. In various cases, myths rather than facts became formative for studies on Sleidan. As yet there is no comprehensive biography of Sleidan, and multiple aspects of his works are still to be researched. A study of Sleidan helps to shed further light on various aspects of sixteenth century history, not only on matters of historiography and scholarship, but also on the role of the Schmalkaldic League and the city of Strasbourg. These fields have been explored in several fine studies by Thomas Brady and Miriam Usher Chrisman. ${ }^{25}$ Sleidan's role in the circle around Cardinal Du Bellay at the French court sheds further light on the concept of reform-minded 'Catholiques critiques' articulated by Thierry Wanegffelen in his recent study of French Catholicism before the Council of Trent. ${ }^{26}$ Similarly, the reception of Sleidan's works in France is a further demonstration of the care with which French statesmen and theologians would study the German confessional model in the immediate aftermath of the Peace of Augsburg, a phenomenon to which Olivier Chrestin has recently drawn our attention. ${ }^{27}$

In this thesis, I will not and cannot explore all the known or unknown corners and angles of Sleidan studies. For example, I shall not investigate the full prehistory of the development of historical writing before Sleidan or compare differences between editions of the Commentaries. Instead, I have attempted to reconstruct with the help of as comprehensive as possible a corpus of primary materials a reliable biography of Sleidan, a

\footnotetext{
${ }^{25}$ Thomas A. Brady, Ruling Class, Regime and Reformation at Strasbourg, 1520-1555, Leiden 1978; Turning Swiss: Cities and Empire, 1450-1550, Cambridge 1981; Protestant Politics: Jacob Sturm (14891553) and the German Reformation, New Jersey 1995; The Politics of the Reformation in Germany. Jacob Sturm (1489-1553) of Strasbourg, Atlantic Highlands, NJ 1997. Amongst Miriam Usher Chrisman's works

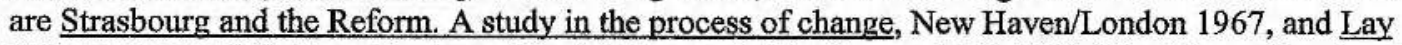
Culture, Learned Culture. Books and Social Change in Strasbourg, 1480-1599, New Haven/London 1982. ${ }^{26}$ Thierry Wanegffelen, Une difficile fidélité. Catholiques malgré le concile en France XVIe - XVIIe siècles, Paris 1999.

${ }^{27}$ Olivier Christin, La paix de religion. L'autonomisation de la raison politique au XVIe siècle, Paris 1997.
} 
study which leads inevitably to a considerable shift of emphasis in our understanding of his public career. This part of the narrative is considerably enriched by the addition of some 250 items of correspondence which I have added to the traditional corpus. With this additional material the biography of the great Reformation historian developed in this thesis provides the most comprehensive and most plausible reconstruction of his life. A central theme of this reconstruction will be to demonstrate the extent to which Sleidan's work placed him as one of a handful of crucial intermediaries between German and French political and cultural life, an aspect of his career which extents almost throughout his active life. In the second half of the thesis, I have expanded on this theme with an analysis of Sleidan's role in the historical writing of both countries until the early seventeenth century. Such a study touches upon many aspects of the reception of Sleidan's works that are so far largely unknown.

Chapters one to three are dedicated to Sleidan's biography. The analysis of the correspondence of Sleidan and his contemporaries provides a lively and interesting picture not only of Sleidan's life, but also of related topics like the reform attempts in France under Francis I and the political actions of the German Protestants. Attention has also been given to inner aspects of Sleidan's life such as his religious convictions and personal influences. Chapter four offers a survey of Protestant German history writing before Sleidan. The second part of the chapter is dedicated to an in-depth analysis of Sleidan's main work, the Commentaries, and closely investigates its genesis from its spiritual birth in 1544 until publication in 1555 , subsequent translations and editions as well as the immediate aftermath. Chapters five and six then explore Sleidan's reception in both Germany and France. Both chapters do not quite show the picture one would expect, and offer interesting material which has so far not been explored. They also underline and compliment the tenor of the biography, which showed Sleidan's close connections to both 
Germany and France, the two countries he regarded as his home. In return, both countries sought to make Sleidan their own. 


\section{Chapter 1: THE MAKING OF A Historian}

A study of the achievements of a historic figure cannot be undertaken without examining the life of the person in question. In the case of Johann Sleidan such a study proves interesting and useful in many respects. Sleidan's biography is in numerous ways linked with the history of his time. As a diplomat in the services of France, Germany and possibly England he was one of the people who made the history he later described. $\mathrm{He}$ was acquainted with many leading figures of his age in both the religious and political sphere, be it Philip Melanchthon and Jean Calvin or Francis I and Henry VIII. In this respect, a biography of Sleidan evolves from a mere depiction of a single life to a valuable portrayal of a whole era, ranging across nations, confessions and professions. Throughout both this and the following chapters we will explore the life of Johann Sleidan in detail. In this process we have to proceed with some caution, because while Sleidan became largely renowned through his literary achievements, the history of his life has been heavily embellished by later commentators, sympathetic and hostile.

The reconstruction of a precise biography therefore requires a double process of investigation and sceptical interpretation of the least well authenticated narratives. In what follows I have attempted to base my own reconstruction of his life most thoroughly on primary material, being principally the corpus of letters to and from Sleidan, and those of third parties that mention Sleidan. I also discuss what can be inferred of his sentiments and loyalties by the networks of friends and connections through which he moved in the course of an extraordinarily varied career. Through this double process we can see that Sleidan was already an extraordinary individual, even before the outstanding contribution of his history is acknowledged. Brought up in the German Empire, he moved easily between different worlds: the scholarly and diplomatic, the German and Francophone. He would 
also take on a slightly more ambiguous confessional position than is usually acknowledged. Although Sleidan is known to us first and foremost as the official historiographer of the Lutheran movement, his personal affinities lay clearly with two groups somewhat detached from the Lutheran mainstream: French humanist intellectuals sometimes described as evangelicals, and the circle of Bucer and Calvin. An understanding of this complex network of personal connections helps us to understand and to some extent anticipate the initially hostile reaction to his published history, even among the circle of those who commissioned him to write it.

Reconstructing as comprehensive a corpus of correspondence as possible has proved crucial to this study as other sources simply fail to provide the necessary evidence. The Commentaries offer hardly any information on Sleidan's own life, and certainly not his private circumstances. Likewise, Sleidan's contemporaries offer few insights: scant details are all that is to be found in sources such as Johann Marbach's diary, or the biographical sketches offered by Heinrich Panthaleon and Michael Beuther in their translations of Sleidan. ${ }^{1}$ Despite the considerable attention Sleidan received in FrancoGerman academic circles throughout the nineteenth and early twentieth century, scholarship has failed to offer a reliable account of his life. Rather, it has tended to provide only half-information, often based on hearsay rather than sound research. Thus it fails to draw attention to the many interesting aspects of Sleidan's life and work. To enable the reconstruction of a far more precise biography of Sleidan I therefore chose to rely predominantly on primary material, in the form of Sleidan's correspondence and that correspondence between other contemporary figures in which he is mentioned.

\footnotetext{
${ }^{1} \mathrm{Cf}$. my introduction.
} 
In the late nineteenth century Hermann Baumgarten collected 182 letters connected with Sleidan. Through widespread research I was able to increase this number dramatically to 438 documents. This corpus as described in Appendix I to this thesis will form the basis of my biography of Sleidan. With the help of this material, I was able to shed light on many aspects and implications of Sleidan's life and events of the time hitherto underestimated or even unknown. Sleidan spent his life in France and Germany; even after his return to Strasbourg he maintained strong personal and intellectual contacts with France. These dual roots are also reflected in the reception of Sleidan in his spiritual home countries which we will examine in the second half of this thesis. For now we will present Sleidan's biography and explore his career and role as a historian, which offers a natural division into three parts: Sleidan's youth and years in France, his brief employment by the Schmalkaldic League, and finally his years in Strasbourg. In this chapter, we will concentrate on the formative years of Sleidan until 1544.

\section{Early years and education}

Johann Philipson was born in 1506 in Luxembourg in the town Schleiden in the Eifel mountains on the Western side of the Rhine, as the oldest of seven children. ${ }^{2}$ His parents, Elisabeth Wanhalterin and Philip, a merchant, belonged to the wealthy middle class and thus were able to offer a decent education to their children. ${ }^{3}$ Sleidan's father was a prominent man: he was a councillor of Schleiden, and since 1521 supplier of the castle of the local count Dietrich of Manderscheid. He was also one of the biggest master smiths in the area and thus received an annual share of the profits of the local mining industry. ${ }^{4}$

\footnotetext{
${ }^{2}$ Sleidan had two brothers and four sisters; cf. Jules Rathgeber, 'Jean Sleidan', BSHPF 22 (1873), p. 338.

${ }^{3}$ Cf. Vogelstein, Johann Sleidan's Commentaries, p. 6.

${ }^{4}$ Cf. Rott, 'Nouveaux Documents', pp. 557-558. After the death of Sleidan's father in 1542, these offices passed to his second son, Wilhelm, and later to the third son, Sigebert. The two married the sisters Catherine and Gertrude de Dalbenden. These were relatives, or possibly even daughters of Thonis (Anthoine) Dalbenden, secretary of Dietrich IV of Manderscheid and tutor of his sons and formerly also of Jean Sturm. One of Sleidan's sisters married Jean Rosenkrantz, also a secretary of the Manderscheids, and two others married members of the Nass family, also holding important offices in Schleiden and area.
} 
Sleidan attended the local school of Johann Neuburg together with his friend Johann (Jean) Sturm (1507-1589), the future rector of the first Strasbourg Gymnasium and founder of the Strasbourg academy, a man who was to play an influential role throughout his life. ${ }^{5}$ In 1519 or 1520 Sleidan went to Liège to study at the school of St. Jerome, founded in 1496 by the Brothers of the Common Life, and then went on to a humanistic education at the academy of Cologne. ${ }^{6}$ It was then that he assumed the humanist name Sleidanus after his home town Schleiden.

In 1524 Sleidan joined Jean Sturm in Louvain to study at the Trilingual College established by Jerome Busleiden in $1517 .^{7}$ At Louvain, he attended lectures by the professor of Greek, Rutger Rescius, and Conrad Goclenius, professor of Latin. Amongst his fellow students, alongside Jean Sturm, were Jean Günther d'Andernach, Barthélemy Le Masson (Latomus), Jacques Omphalius, and Claude Baduel, who were all to play important roles in France or Germany. ${ }^{8}$ About Sleidan's appearance only one description has been preserved, in the form of the account of Martin Crusius' Annales Suevici, where the author describes a dinner in Strasbourg which Sleidan attended. Sleidan is portrayed as 'a tall and well-built man, a manly appearance with a healthy colour of his face, but blind

\footnotetext{
${ }^{5}$ Cf. Baumgarten, Sleidans Leben, p. 46. On Jean Sturm, see Charles Schmidt,La vie et les travaux de Jean Sturm, premier recteur du Gymnase et de l'Académie de Strasbourg, Paris 1855; Spitz, Lewis W., Sher Tinsley, Barbara, Johann Sturm on Education. The Reformation and Humanist Learning, St. Louis 1995, as well as the many works by Jean Rott (see bibliography).

${ }^{6} \mathrm{Cf}$. Dickens, 'Sleidan and Reformation History', p.18; Baumgarten, Sleidans Leben, p. 46.

${ }^{7}$ Cf. Schmidt, Jean Sturm, p. 5; Dickens, 'Sleidan and Reformation History', p.18; Baumgarten, Sleidans Leben, p. 47.

${ }^{8}$ Cf. Schmidt, Jean Sturm, p. 6. The medical doctor Jean Günther d'Andernach was also one of the protégés of the Du Bellay brothers,and dedicated two of his translations to his patrons. The 1530 translation of Galen, Claudii Galeni Pergameni de Euchymia et Cachoymia, seu de Bonis malisque succis generandis, was dedicated to Guillaume Du Bellay, and the 1532 translation of another medical work, Pauli Aeginetae opus de re medica, was dedicated to Jean Du Bellay. It is interesting to note that both works were published by Simone de Colines in Paris, who in 1538 published Sleidan's epitome of Froissart; see below (cf. V.L. Bourilly, Guillaume Du Bellay, Seigneur de Langey 1491-1543, Paris 1904, pp. 118-120).
} 
in one - the left - eye. ... Uniting dignity, warmth and friendliness, he was in every respect a person to be admired'?

During his studies in Louvain, Sleidan engaged himself in reading many classical authors, and also spent time translating from the classical languages. Some of these early translations have survived. In 1528, Johannes Soter in Cologne edited and published a collection of Latin epigrams, translated from Greek, Epigrammata aliquot graeca veterum. About a hundred of these are signed with Sleidan's name. The next years in Sleidan's life remain shadowy. We know that some time before 1533 he returned to Schleiden to supervise the education of Franz, the son of Count Dietrich von Manderscheid (15011551), an important local ruler who tolerated Protestantism. ${ }^{10}$ In the spring of 1530 Sleidan was back in Liège, as we can infer from Sleidan's first extant letter addressed to Rutger Rescius, his former professor of Greek.

In this letter, Sleidan unfortunately tells us nothing about his situation, but refers Rescius to a second letter, written to Jean Sturm, that accompanied it. This, he said, had more to say about his present circumstances. ${ }^{11}$ Unfortunately, this letter has not been preserved, and the letter to Rescius itself contains no clues as to Sleidan's situation. What the letter to Rescius offers to us, however, is an insight into the present priorities of the

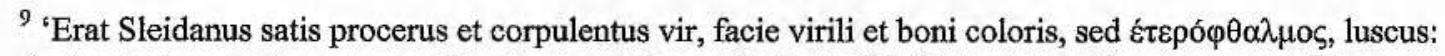
dextro tantum oculo cernens. Gravitas in eo, humanitate et affabilitate mixta. Omnino venerabli aspectu.' (My translation; Martin Crusius, Annales Suevici sive Chronica rerum gestarum antiquissimae et inclytae Suevici gentis, Frankfurt (Nicolaus Bassaeus) 1596, vol. 3, p. 676; Appendix. I, No. 203.) Contemporary portraits of Sleidan, like that in Theodore Bèze, Vrais pourtraits des hommes illustres en pieté et doctrine, du travail desquels Dieu s'est servi en ces derniers temps, pour remettre sus la vraye religion en divers pays de la Chrestienté. Avec les descriptions de leur vie et de leurs faits plus memorables, s.l. (Jean de Laon) 1581, fol. I2r, show Sleidan as blind on the right eye.

${ }^{10} \mathrm{Cf}$. Sleidan's letter to Cardinal Du Bellay from 10 May 1546 (Appendix I, No. 165), in which Sleidan informs Du Bellay about his visit of his former pupil Franz von Manderscheid. Franz's father, the tolerant Dietrich von Manderscheid, did personally not embrace Protestantism, but tolerated Protestants in his county. The Reformation in Schleiden and surrounding areas was officially established in 1559 by Dietrich VI von Manderscheid; cf. Vogelstein, Sleidan's Commentaries, p.8.

11 'Literas igitur ad illum mitto, quibus mearum rerum statum expono.' (My translation, from Sleidan's letter to Rutgerus Rescius, spring 1530, quoted in Baumgarten, Briefwechsel, No. 1; Appendix I, No. 1)
} 
then 24-year old Sleidan, for his interests seem to be already set in the direction of his future career as diplomat and historian. He considered the political situation of Germany

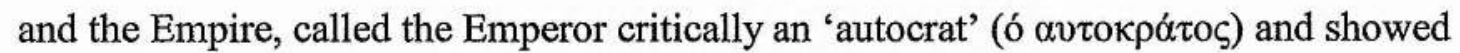
himself informed about the Augsburg Diet and the actions of Elector John Frederic of Saxony and Philip of Hesse, the leaders of the Protestant Schmalkaldic League and his future employers. What we can also safely assume from this letter is that Sleidan was already a Protestant by the time, judging by his interest in Protestant affairs and his warm admiration for Melanchthon: 'Who is more diligent than Philip, who is more perfect in this land $?^{, 12}$

That Sleidan should praise Melanchthon rather than Luther does not come as a surprise. Sleidan was only a child during the early years of the Reformation when Luther was the most dominant man. By 1530 Melanchthon had joined Luther in the leadership of the Protestants, assuming a calm position of moderation, which was more appealing to humanists such as Sleidan. Sleidan's adoration of Melanchthon emphasises that he was very much a second generation Lutheran. This younger generation had not experienced the rapid landslide the Reformation had initially caused. It is worth pointing out here that Sleidan, born in 1506 , was a contemporary of Calvin with strong links to France. Whereas Calvin experienced a Catholic upbringing in France, Sleidan was brought into much closer context with the German Reformers due to his German upbringing, but it was Bucer and Calvin to whom he was closest.

\footnotetext{
12 'Quid enim diligentius Philippo, quid absolutius hac parte?' (My translation; ibid.). In the late nineteenth century and early twentieth century, the fact how much this first letter allows us to define Sleidan as a Protestant was discussed by the three great scholars of Sleidan, Hermann Baumgarten, Adolf Hasenclever and Walter Friedensburg. Baumgarten in Sleidans Leben, pp. 48-49, rather tentatively portrayed Sleidan as an ardent Protestant, which was refuted by Adolf Hasenclever in Sleidan-Studien. Die Entwicklung der politischen Ideen Joh. Sleidans bis zum Jahre 1545, Bonn 1905, pp. 4-5, who underlined the appeal the Reformation and Melanchthon had on humanists. Thirty years later, Walter Friedensburg in Johannes Sleidanus, pp. 8-10, backed up Baumgarten's original thesis by underlining the danger of openly sending a letter supporting Protestantism into Louvain in 1530.
} 


\section{Sleidan's years in France}

Around 1533, Sleidan travelled to France to study law in Orléans where his name appeared in the university register in $1535 .^{13}$ We know that Sleidan was in Paris at some point in 1534 but it is unclear whether he also studied there for a short while since his name does not appear in any university registers. ${ }^{14}$ Here events conspired to effect a major and decisive change in his career. By this time his friend Jean Sturm was also settled in Paris, but in December 1536 Sturm left France due to the increased persecutions of Protestants after the 1534 Affair of the Placards. He decided to settle in Strasbourg, the free imperial city just across the border from France, where he founded the famous Gymnasium and academy. In Paris, Sturm had been employed as a secretary by Cardinal Jean Du Bellay (1498-1562), to whom he seems to have recommended Sleidan upon his departure. The Cardinal, a brilliant diplomat and head of the anti-Habsburg party at the French Court, was one of the important figures of the French reform movement and politics under Francis I, his chief aim being to win the German Protestants for an alliance against the Emperor.

A flood of letters places Sleidan in the chancellery of Du Bellay, and sheds light on both his responsibilities there as well as the role of his employer. The first extant letters

\footnotetext{
${ }^{13}$ In the dedicationof his Commentaries to August of Saxony Sleidan mentions: 'And as to the French transactions, I saw many of them in the IX years I lived in that Kingdom.' Sleidan returned to Germany between mid-1542 and late 1544, which means that 1533 was the approximate year of his arrival in France (cf. Sleidan, transl. Edmund Bohun, The General History of the Reformation of the Church from the errors and corruptions of the Church of Rome: begun in Germany by Martin Luther, with the progress thereof in all parts of Christendom, from the year 1517, to the year 1556. To which is added a continuation to the end of the Council of Trent in...1562, London (Edward Jones for Abel Swall/Henry Bonwicke) 1689, fol. a2v). The university register Primus Liber Procuratorum venerabilis Alemaniae Nationis almae Universitatis Aurelianensis of Orléans (1444-1546) mentions that 'Joannes Sleidanus, Coloniensis diocesis' was matriculated on 8 December 1535, without telling us how long Sleidan stayed in Orléans. A second hand later added to this notice: 'Hic est qui transcribit Philippum de Comineis. Vir doctus. Hic 24 [sic] libros de statu religionis sub Carolo Quinto Imperatore elegantissimo conscripsit, cum libro de quatuor monarchiis.' (Baumgarten, Sleidans Leben, p. 52; Appendix I, No. 2).

${ }^{14}$ A study period of Sleidan in Paris cannot be proved since his name does not appear in any university documents of the time. Additionally, as Hasenclever, Sleidan-Studien, p. 11-12, points out, in Paris only canon law was taught, whereas Orléans offered a faculty of civil law. Sleidan's visit to Paris is refered to in Joannes Wierius, De praestigiis daemonum, Basle 1568, p. 525: 'Ibi (Parisiis) tunc temporis quoque cum Joanne Sturmio ... simul degebat doctissimus ille Joannes Sleidanus.' (quoted in Baumgarten, Sleidans Leben, p. 51, fn. ${ }^{* *}$ ). According to E. Doumerge, Sleidan taught the future Dukes Georg and Richard of Pfalz-Simmern during his time in Orléans (E. Doumerge, Jean Calvin, p. 466, fn. 2, quoted in Hasenclever, 'Johann Sleidan und Frankreich', ELJB 10 (1931), p. 110, fn. 32).
} 
which place Sleidan in his new position as secretary of Jean Du Bellay date from the year 1538, and already give clues as to which part Sleidan played in Du Bellay's office. In May, Du Bellay contacted Sleidan from Avignon, informing him that all letters from and to Jean Sturm should go through his hands; for safety's sake names should be omitted in all correspondence. ${ }^{15}$ In October, Sleidan informed the Cardinal about Sturm's position as rector of the Strasbourg Gymnasium and updated him on the situation between the Protestants and Catholics in Germany. ${ }^{16}$ All this suggests that Sturm's departure from Paris by no means destroyed his relations with his former employer, but rather Sturm's position in Strasbourg complemented that of Sleidan in Paris. The wily Du Bellay may even have improved his network of connections with German opinion formers.

In his new post in France Sleidan seems to have occupied a pivotal role as a contact between the French court and leaders of the German Protestants. It is immediately clear from his surviving correspondence that Sleidan was trusted on both sides. It was Martin Bucer, the moderate German Reformer with close affinities to the Swiss Reformation, who demonstrates Sleidan's link to the German Protestants by advising Louis Du Tillet in October 1539 to send any correspondence through Sleidan. ${ }^{17}$ More importantly, a few weeks later Bucer mentioned to Gereon Sailer that the Protestants had a man in Paris who had kept them informed about French affairs for a while, which can only refer to Sleidan. ${ }^{18}$ This information is backed up by a report from December of the same year by Jacob Sturm, the influential Strasbourg politician, and his colleague, in a report from a meeting of the Schmalkaldic League at Arnstadt. It mentions that Jean Sturm had a good contact in

\footnotetext{
${ }^{15}$ Cf. Appendix I, No. 3.

${ }^{16}$ Cf. Appendix I, No. 4.

${ }^{17}$ Cf. the letter by Martin Bucer to Louis Du Tillet from 8 October 1539 (Appendix I, No. 6). Louis Du Tillet, the brother of the bishop Jean Du Tillet, had embraced Calvin's teachings but was later brought back into the Catholic church by his brother.

${ }^{18}$ Cf. Martin Bucer's letter to Dr. Gereon Sailer, 23 October 1539 (Appendix I, No. 7).
} 
Paris with access to the king's counsellors, which again must mean Sleidan. ${ }^{19}$ On 17 January 1540, the council of XIII of Strasbourg informed Philip of Hesse that they had a well-connected friend at the French court. In July Martin Bucer reconfirmed this to the Landgrave: 'The Cardinal of Paris has a good and close friend here, through whom he has sent us much valuable information for the last three years, ${ }^{, 20}$.

This shows that Sleidan's role in Du Bellay's chancellery by far exceeded that of an ordinary secretary. Instead, Sleidan's time in Paris was to be spent largely in the service of the Protestant cause, and he assumed the role of a leading diplomat for French-German relations, upon which he was to build later. Apart from this political education, the time in Paris was equally profitable for the future historian Sleidan, since these were also the years when he began his first significant scholarly work. One can easily understand why the well-educated Sleidan must have relished bouts of leisure between his diplomatic duties in a household such as that of the Du Bellays. Even in the cultivated milieu of Paris in the 1530 s the household of the Du Bellays stood out as a centre of letters. Not only Jean Du Bellay, but also his brothers, too, notably Guillaume, had established reputations as patrons of the arts, cultivating close relationships with leading members of both the university community and the publishing industry. ${ }^{21}$

\footnotetext{
19 'Nun hatt Johann Sturmius khontschafft zu einer person zu parisz, der ein freier zugangk zu ettlichen trefflichen des konigs Rätten hatt, durch wellche man vill gelegenheit erfarren mochte. Were deszhalb unser guttbeduncken, das, so man vernner hyenyin schicken woltte, den sturmyn ansprechen, seinem man zu schreiben, der khann die erfarnusz vill basz und worhafftiger thun, dan ein eintzyger knecht erfarren mochte.' (Jacob Sturm's and Batt von Duntzenheim's report to Strasbourg, 3 December 1539, in PC 2, No. 655, p. 656; Appendix I, No. 8).

20 '...der cardinal von Paris hat einen guten vertraweten freund hie, durch den er unsz hat nun ein jar oder drei fil getrewer anzeig zuschreiben lassen.' (my translation; Max Lenz, Briefwechsel Landgrafs Philipps des Großmütigen von Hessen mit Bucer, 3 vols., Leipzig 1880/87/91, vol. 1, No. 75, p. 197; Appendix I, No. 14). The letter from the XIII of Strasbourg to Philip of Hesse from 17 January 1540 is taken from PC 3, No. 10, p. 12; Appendix I, No. 10, speaking of 'einem guten freund, so unserer religion ganz geneigt und am französischen hove bei etlichen grossen herren und des königs räten wol bekannt'.

${ }^{21}$ Amongst the protégés of Jean Du Bellay were for example the famous authors and poets Claude Chappuys, François Rabelais, as well as Joachim Du Bellay, a relative.
} 
In such an atmosphere the young scholar-diplomat must have been eager to demonstrate his scholarly credentials, but it is highly significant that whereas many in such a position looked to the classics to make their reputation (one thinks of Calvin's 1532 commentary on Seneca's De clementia), Sleidan chose a work of history. This choice was in itself, however, highly significant, for in 1537 , Sleidan published a concise Latin translation of the works of Jean Froissart (ca. 1337-1404) under the title Frossardi, nobilissimi scriptoris gallici, historiarum opus omne, iam primum et breviter collectum et latino sermone redditum, first published in Paris by Simon de Colines. We will examine this work further in due course.

\section{Sleidan in the service of Jean Du Bellay}

Sleidan's employment at the chancellery of Jean Du Bellay made him the link between reform-minded French and the German Protestants. ${ }^{22}$ To fully appreciate his important position, we need to examine central figures at the French court, Francis I (1494-1547) and his influential sister Marguerite de Navarre (1492-1549) as well as the Du Bellay brothers. The atmosphere at the French court in the 1520s was rather liberal and open-minded. Francis I as a Renaissance king fostered learning and arts, and thus was supportive of humanist influence. His sister Marguerite, queen of Navarre since 1529, was the most influential person in his life, and it was through her, a spiritual, learned writer herself, that Francis came into contact with Protestant thought.

Around 1520, the reform-minded Guillaume Briçonnet, then bishop of Meaux, formed a circle of like-minded scholars around himself, including Jacques Lefèvre

\footnotetext{
${ }^{22}$ On Sleidan's years in France, cf. Friedensburg, 'Vom französischen Agenten zum Geschichtsschreiber des deutschen Protestantismus; Ein Beitrag zur Lebens- und Entwicklungsgeschichte Johann Sleidans', ELJB 11 (1932), pp.109-147; Hasenclever, Sleidan-Studien and 'Sleidan und Frankreich'. The best source of information are however the documents in Appendix I. I have expanded on this theme in my forthcoming article 'Diplomacy, evangelism and dynastic war - the brothers Du Bellay at the service of Francis I', to appear in Alec Ryrie, Luc Racaut (eds.), Moderate Voices in the European Reformation, Aldershot 2004.
} 
d'Étaples, Guillaume Farel, Michel d'Arande, and Gerard Roussel. This group soon caught the attention of Marguerite, who started an extensive correspondence with Briçonnet and others, read their writings and even invited members of the Meaux group to preach at the court. $^{23}$ - It is difficult to label this group, since it cannot be put firmly into the Catholic or the Protestant camp. Indeed, many never openly converted to Protestantism, and were later denounced by Calvin as Nicodemites. Even the term 'liberal' with all its modern connotations is slightly problematic to employ. People like Marguerite and the Du Bellays are characterised in the recent study by Thierry Wanegffelen as 'Catholiques critiques'. He showed that the borders between Protestantism and Catholicism, especially in France with its unique concept of the Gallican church, were far from being clear and firmly established before the Council of Trent. ${ }^{24}$ Many Catholics welcomed the call for reform, and borders between Catholics and Protestants were fluent.Such moderate 'liberals' often met sharp disapproval from traditionalists. From 1522 onwards, the Meaux circle caught the attention of the Sorbonne and subsequently had to live under their close scrutiny. Marguerite's connections to this circle and her influence on Francis I were a bone of contention for the Paris doctors, especially when many of their planned actions against the Meaux group and other reform-minded people were undermined by the royal court. ${ }^{25}$ At the court itself, Marguerite's influence on her brother to foster a rapprochement with the German Protestants attracted severe criticism from the

\footnotetext{
${ }^{23}$ For the correspondence of Marguerite de Navarre, see Pierre Jourda, Répertoire analytique et chronologique de la correspondance de Marguerite d'Angouleme, duchesse, d'Alencon, reine de Navarre (1492-1549), Paris 1930, reprint Geneva 1973, and items printed in A.L. Herminjard, Correspondance des Réformateurs dans les pays de langue francaise, 9 vols., Geneva/Paris/Basle/Lyon 1866-1897. Between June 1521 and November 1524 alone 120 letters between Marguerite and Guillaume Briçonnet have been preserved. The relations to Protestantism of Marguerite de Navarre and to an extent also Francis's I are only hinted at in published literature, and were made the central theme of an unpublished $\mathrm{PhD}$ dissertation by Jonathan Andrew Reid, King's Sister - Queen of Dissent. Marguerite of Navarre (1492-1549) and her Evangelical Network, University of Arizona 2001.

${ }^{24} \mathrm{Cf}$. Wanegffelen, Une difficile fidélité, p. 1 for the concept of the 'Catholiques critiques', and chapter 2 'Le Concile des Tridentins' on pre-Tridentine France.

${ }^{25}$ Cf. V.-L. Bourrilly, 'François Ier et les Protestants: Les essais de concorde en 1535', Bulletin de la Société de l'Histoire du Protestantisme Francais 49 (1900), pp. 337-365, 477-495.
} 
pro-Habsburg party around Anne de Montmorency, Grand Master (1526) and Constable of France (1538). ${ }^{26}$

These connections, though obscure to historians, seem to have been clear enough to contemporaries. The suspicions with which conservatives regarded Marguerite's protegés were mirrored by exaggerated hopes on the Protestant side. These are reflected in the large number of works dedicated to Marguerite and Francis I by leading Protestants. Amongst these were Wolfgang Capito's In Hoseam prophetam commentarius (1528) dedicated to Marguerite, and Huldrych Zwingli's De vera et falsa religione commentarius, which was dedicated to Francis I (March 1525), while his later Christianae fidei brevis et clara expositio ad regem Christianum (July 1531) was dedicated to both Marguerite and Francis I. ${ }^{27}$ Similarly, Martin Bucer dedicated his S. Psalmorum libri quinque from July 1529 to one of Francis' sons, and Jean Calvin addressed his Institutiones in August 1535 to Francis I. ${ }^{28}$

One of the figures in the liberal circle around Marguerite was Jean Du Bellay, whom she recommended in 1531 for the see of Paris, probably the most important ecclesiastical post in France. Accordingly, Jean Du Bellay (1492-1560) became bishop of

\footnotetext{
${ }^{26}$ Apparently Montmorency advised Francis I that if he wanted to get rid of the heretics, he had better start with his sister ('Extraits de Brantome' in Le Roux de Lincy, Anatole de Montaiglon, eds., Heptaméron des nouvelles de très illustre princesse Marguerite d'Angouleme, reine de Navarre, 4 vols., (Paris 1880), vol.1, 133-134, in Reid, King's Sister, p. 59).

${ }^{27}$ In his dedication, Wolfgang Capito mentioned as outstanding examples of scholars and preachers Michel d'Arande, Gérard Roussel, and Le Fèvre d'Étaples, the key members of the Meaux circle. This also shows that the reformers in Germany and elsewhere were well aware of the existence of this group as well as their connection to Marguerite de Navarre (for the text of Capito's dedication see also A.L. Herminjard, Correspondance des Réformateurs dans les pays de langue francaise, 9 vols., Geneva/Paris/Basle/Lyon 18661897, vol. 2, No. 227). Cf. the articles by Olivier Millet, 'Wolfgang Fabricius Capiton à Marguerite de Navarre (1528): Dédicace de In Hoseam prophetam commentarius', Revue Francaise d'Histoire du Livre N.S. 50 (1986), pp. 201-216, and in the same volume, Bernard Roussel, 'La dédicace à François Ier du $D e$ vera et falsa religione Commentarius de H. Zwingli (mars 1525)', pp. 187-199.

${ }^{28}$ Bucer published this commentary on the psalms under the pseudonym Aretius Felinus, a name by which he is frequently referred to in correspondence later on. On this dedication, cf. Hobbs, R.G., 'Le félin et le dauphin: Martin Bucer dédie ses commentaires sur le psautier au fils de François Ier', Revue Francaise d'Histoire du Livre N.S. 50 (1986), pp. 217-232.
} 
Paris in 1533 and cardinal in 1535 . With his brothers, he formed one of the most influential families of the time: Guillaume Du Bellay (1491-1543), Sieur du Langey, governour of Piedmont and Turin, was one of Francis' most trusted men and chief ambassador to Germany; Martin Du Bellay (1495-1559) fought decisive battles for France as major-general. ${ }^{29}$ However, the most famous of the Du Bellay family was to be their cousin, Joachim Du Bellay (1522/25-1560), the celebrated author and poet.

The continuous sequence of wars between France and the Empire naturally made Francis I look for an ally against Charles V. Amongst his options were the German Protestants, who had transformed into a political body with the foundation of the Schmalkaldic League in 1531 under the leadership of John Frederic of Saxony and Philip of Hesse. In the spring of 1532 Guillaume Du Bellay was sent on his first mission to Germany to make initial contacts with the Protestants, who had called for Francis's support after the consecration of Ferdinand as king of the Romans. ${ }^{30}$ During two further embassies to Germany he also met Bucer to discuss a joint visit with Melanchthon to France for a religious colloquy, sanctioned by Francis, who officially invited the German theologians to France. ${ }^{31}$ These first attempts to form an alliance were halted due to several factors. On the German side, there was a marked ambiguity concerning an alliance with France, essentially a Catholic country. In France itself, the political climate changed after the

\footnotetext{
${ }^{29} \mathrm{The} \mathrm{Du}$ Bellay brothers have not been a popular topic of sixteenth century historians. Only Guillaume Du Bellay has been made the focus of a biography in Bourrilly's Guillaume Du Bellay; the same author also published a few articles on Jean Du Bellay, see bibliography and below. For biographical remarks on the Du Bellay brothers, see M. Petitot (ed.), Collection complète des Mémoires relatifs a l'Histoire de France, depuis le régne de Philippe-Auguste, jusqu'au commencement du dix-septième siècle; avec des notices sur chaque auteur, et des observations sur chaque ouvrage, vol. XVII: Les Mémoires de Martin Du Bellay (et al.), Paris 1821, and the entries in Michel Simonin (ed.), Dictionnaire des Lettres Françaises. Le XVIe siècle, Farese 2001.

${ }^{30}$ Cf. Bourilly, Guillaume Du Bellay, pp. 123-148.

${ }^{31}$ Ibid., pp. 173-213; Schmidt, Jean Sturm, pp. 12-15. Cf. the correspondence between the German Protestants, the Du Bellay brothers and Francis I of these years in Corpus Reformatorum, Vols. 1- 8, Karl Gottlieb Bretschneider, (ed.), (Halle 1834-41), Vols. 39-44, Wilhelm Baum, Eduard Cunitz, and Eduard Reuss (eds.), (Braunschweig 1873-76, repr. Bad Feilnbach 1990) (hereafter CR), vol. 2, No. 1195, 1204, $1205,1262,1268,1275,1280,1283$.
} 
Affair of the Placards in 1534 and the ensuing persecutions of Protestants in France.

Additionally, both the conservatives at court and the Sorbonne were very reluctant to enter any religious discussions with the Protestants, let alone those from the Empire. ${ }^{32}$ In 1536 , Guillaume Du Bellay was sent on his fourth and last mission to Germany during another war between France and the Emperor. The truce of Nice heralded a period of peace in which there was no necessity for an alliance with the German Protestants, and a period of pro-imperial, conservative court policy under the leadership of Montmorency followed until his fall in 1540.

In the last years before his death in 1543 Guillaume Du Bellay devoted his time mainly to his administrative duties, and Jean Du Bellay took over the lead role in the political endeavours for an alliance with the German Protestants. ${ }^{33}$ For this purpose, like his brother he made use of a team of German scholars and students in Paris, such as Jean Sturm, Ulrich Geiger (Chelius), and Johann Sleidan. These were complemented by a group of French students in the Empire, like Claude Baduel, Guillaume Bigot and Barnabé de Voré, Seigneur de la Fosse. Upon their return to their home country, members of both groups would often still keep up their old contacts. ${ }^{34}$ Like the Meaux circle and Marguerite de Navarre, Jean Du Bellay did not escape the watchful eyes of the Sorbonne either, and already in 1530 he was accused of secret Protestantism. ${ }^{35}$ The turbulent events

\footnotetext{
${ }^{32}$ It was in the aftermath of the Affair des Placards and the following persecutions that Jean Sturm had left Paris, making way in his position with Du Bellay for his friend Sleidan. In Strasbourg, Jean Sturm was to become one of the main supporters of an alliance between France and the German Protestants, and a protégé of many French which came into Strasbourg in the following decades due to persecutions in France; cf. Schmidt, Jean Sturm, pp. 14-16.

${ }^{33}$ For Jean Du Bellay's connections, see Rémy Scheurer, Correspondance du cardinal Jean du Bellay, 2 vols., Paris 1969-73.

${ }^{34}$ Cf. Schmidt, Jean Sturm, pp. 12-15.

${ }^{35}$ Cf. Bourrilly/ Nathaniel Weiss, Nathaniel,'Jean Du Bellay, les Protestants et la Sorbonne', BSHPF 52 (1903), pp. 97-127, 193-231; 53 (1906), pp. 97-143; also Francis M. Higman, Censorship and the Sorbonne. A bibliographical study of books in French censured by the faculty of theology of the university of Paris, 1520-1551, Geneva 1979, p. 33.
} 
surrounding the Affair of the Placards only served to reinforce conservative suspicions of the Du Bellays and their German contacts.

These were difficult and perilous times for those who had publicly associated themselves with the advance of the evangelical cause. In the tense and increasingly bitter contest for influence conservatives were keen to associate reformers with the foreign Lutheran heresy. The radicalism of the Placards only made this task easier. For Marguerite and her allies it became ever more important to emphasise their credentials as 'bons français'. It is this context which gives a particular significance to Johann Sleidan's first major authorial project in the service of Du Bellay. As we have seen, Sleidan's anticipated role when he entered the service of Du Bellay was to replace Jean Sturm as the principal link to German Protestantism, but circumstances now presented him the new opportunity to develop the skills which would be his major claim to the recognition of posterity.

\section{Sleidan's epitome of Jean Froissart (1537)}

In 1537, with Du Bellay's encouragement and almost certainly at his instigation, Sleidan published his first work, a Latin epitome of the chronicle of Jean Froissart (1337 - after 1404), Frossardi, nobilissimi scriptoris gallici, historiarum opus omne, iam primum et breviter collectum et latino sermone redditum. This choice is highly significant. Froissart's chronicle is the great patriotic retelling of the rebirth of France after the Hundred Years' War, a long and detailed relation of these events with many digressions and extensive descriptive passages. Froissart's works compiled around the court achieved an immediate and enormous success, circulated first in manuscripts, and later in major lavish folio editions. A new edition was only recently published in Paris around the time of Sleidan's translation. Froissart's history was one of the great early works of French history writing, and we need therefore to examine in some detail why Sleidan, the German 
law student in the service of Du Bellay, should have engaged with Froissart as his first authorial task. This was in many ways an unusual choice. A more normal literary endeavour would have been an edition or commentary on one of the major Latin authors, such as that undertaken by Calvin as first work of his literary career. Sleidan instead chose French history.

The cleric and diplomat Froissart had lived in France, the Low Countries and England, throughout his life in contact or in the service of various nobles. ${ }^{36}$ His chronicles of these countries were immensely popular at his time and continued to be published for centuries. In his work, Froissart concentrated on the state of affairs and wars between France and England, culminating in the truce of 1399 . The protagonists of the narrative are the kings and army leaders. Following a strict chronological line, the author's aim was to achieve impartiality and veracity. Froissart placed great weight on the importance of eye-witness accounts as for him these secured a greater historical value. For an unbiased narration of events he tried to leave out all judgements or comments and report the mere facts. All these objectives were to be propagated later on by Sleidan himself.

Sleidan did not translate the complete text of these chronicles, but composed a Latin epitome, first published in Paris in 1537 by Simon de Colines. This work in octavo omitted the name of the translator Sleidan on the title page; in later editions - the first of which followed only in 1562 - these details were included. ${ }^{37}$ Simon de Colines was

\footnotetext{
${ }^{36}$ For biographical notes on Froissart, see Paul Archambault, Seven French chroniclers. Witness to history, Syracuse 1974, pp. 59-61; Peter F. Ainsworth, Jean Froissart and the Fabric of History. Truth. Myth, and Fiction in the Chroniques, Oxford 1990; F.S. Shears, Froissart. Chronicler and Poet, London 1930.

${ }^{37}$ Sixteenth century editions of Sleidan's translation of Froissart as listed by Vekene in Bibliographie (the classification numbers are Vekene's):

F/a 001(Paris: Simon de Colines) 1537 (8o)

F/a 014 Paris: André Wechel $1562(80)$

F/a 015 Paris: (André Wechel for) Jacques Dupuys 1562 (80)

F/a 020 Paris: Andre Wechel 1569 (8o)

F/a 022 (Paris: Gilles Robinet) 1576 (8o)
} 
probably not by mere chance chosen as printer for Sleidan's first work. In 1520, he had taken over Henri (I) Estienne's press, and until his death in 1546 he was famous for fine editions of Latin classics and humanist writings, including works by those associated with the liberal, pro-Protestant humanist circle, most notably Lefèvre d'Étaples. ${ }^{38}$

This first work in a line of translations of French historians by Sleidan was dedicated to Jean Du Bellay, at whose instigation the work had probably come into being. In this long and eloquent preface signed in Paris on 12 July 1537, Sleidan tells us that he had occupied all the time he could spare from his studies of law translating this work since he saw the person of the historian and the jurist in a very close relationship. He offers a eulogy on the importance of learning and the focal position of kings and other rulers, who often consulted histories to search for advice. This was especially important at a time such as Sleidan's when so many important events stirred people and countries. Since Froissart's description of kings and peoples excelled the description of all other historians, he deserved to be translated into Latin so he could be accessible to a larger audience. In his sense, Sleidan hoped that the Cardinal could make good use of his translation since he was entrusted with so many important and secret missions by his king Francis I. ${ }^{39}$

Why did Sleidan choose a French historian, and not the usual Latin or Greek classic as the focus of his first work? In his dedication, Sleidan himself offers only one clue in his praise of the Ciceronian values of history as masterfully illustrated by Froissart. But such an explanation does not fully suffice. A possible explication for Sleidan's motives seems to lie in the patriotic nature of Froissart's chronicle. Truly, Sleidan himself had been born

\footnotetext{
F/a 023 Wittenberg s.n. 1576 (8o, print identical with F/a 022)

${ }^{38}$ On de Colines, cf. Philippe Renouard, Bibliographie des éditions de S. de Colines (520-1546), Paris 1894, and J. Veyrin-Forrer, 'Simon de Colines, imprimeur de Lefèvre d'Étaples', Jacques Lefêvre d'Étaples (1450?-1536). Actes du colloque d'Étaples, Paris 1995, pp. 97-118.

${ }^{39} \mathrm{Cf}$. the preface in Sleidan (transl.), Frossardi, nobilissimi scriptoris gallici, historiarum opus omne, iam primum et breviter collectum et latino sermone redditum, Paris (Simon de Colines) 1537.
} 
in German lands and was thus not really under an obligation to express his admiration of France though working in Paris. Yet if we move away from Sleidan as a person and look at his close surroundings, it is the Du Bellay party that immediately springs into mind. With the continuous accusations against members of this pro-Protestant circle, further heightened after the Affair of the Placards, it was very much in their interest to proclaim their patriotism and status as good French citizens. Why not encourage their link to Germany, the young, gifted Sleidan, to compose this work on Froissart, the notorious patriot, who had so skillfully exclaimed his adoration for France and its monarchy? Such a manoeuvre was not too unusual; one only need to think of the ongoing struggle between Catholics and Protestants trying to appropriate Augustine to their side as a justification for their teachings.

\section{The battle for an alliance with the German Protestants}

It was a turbulent and multi-faceted time when Sleidan entered the chancellery of Jean Du Bellay, and in this challenging atmosphere the young scholar thrived. He could not only develop his skills as a historian, but the ongoing battle for an alliance between France and Germany proved an excellent training field for Sleidan's diplomatic skills, too. Both the French and the Germans repeatedly looked at him for his help in Franco-German negotiations over the following years. As the letters mentioned above show, both his employer and the German Protestants soon recognised the importance of his position and the value of his talents. One of Sleidan's first important missions was to the colloquy of Hagenau in June and July 1540 , where he was to meet some of the most influential people of the time and pave the way for his future career as historian of the German Protestants. At Hagenau, he met again his old friend Jean Sturm, who had been sent as a delegate for Strasbourg. Jean Sturm was accompanied by Jacob Sturm (1489-1553), the influential stettmeister of Strasbourg and one of the leading figures of the Schmalkaldic League, who 
was to become a close friend of Sleidan and one of his main patrons. ${ }^{40}$ The delegation was completed by Jean Calvin (1509-1564), then resident at Strasbourg. Sleidan had been in contact with Calvin since May 1539, and remained in correspondence with him until his death. $^{41}$

Also present at Hagenau was Martin Bucer (1491-1551), another important patron of Sleidan. Bucer, aware of Sleidan since at least October 1539, introduced him at the colloquy of Hagenau and gave him the opportunity to present his mission and objectives. ${ }^{42}$ However, Francis's I official ambassador was not Sleidan, but the abbot Lazare de Baïf, who was charged to convince the German Protestants that Francis would not form an alliance with the Emperor. ${ }^{43}$ Jean Du Bellay insisted on sending Sleidan to accompany Baif on this mission with the official function as his interpreter. The second task Jean and Guillaume Du Bellay had set him was to hold secret negotiations with Hesse about an alliance between France and the German Protestants. ${ }^{44}$ Sleidan conducted these negotiations, which were received favourably, especially by Philip of Hesse. ${ }^{45}$

Back in Paris, Du Bellay tried his best to convince Francis I to pursue these plans of alliance. ${ }^{46}$ He had found new allies at the court with Admiral Chabot de Brion and

\footnotetext{
${ }^{40}$ On Jacob Sturm, cf. Brady, Protestant Politics, esp. pp.137-40.

${ }^{41}$ Cf. Sleidan's letter to Calvin from 22 May 1539, the first of several extant letters between the two men, in which he thanks Calvin for trusting him, a stranger (the phrase 'homo ignotus' suggests that prior to this date Calvin had not been familiar with Sleidan); cf. Baumgarten, Briefwechsel, No. 2; Appendix I, No. 4.

${ }^{42} \mathrm{Cf}$. the description of this by the Hesse councillors to Philip of Hesse from 23 July 1540; Appendix I, No. 15 .

${ }^{43}$ Baiff was paid 1.800 livres tournois for this mission which was to last from 16 May till 14 August 1540; cf. Catalogue des actes de Francois Ier, Vols. 4-10, Paris 1890-1908, vol. 4, No. 11492, p. 107. Cf the biography by Lucien Pinvert, Lazare de Baïf (1496(?)-1547), Paris 1900.

${ }^{44}$ Cf. Schmidt, Jean Sturm, pp. 49-51; cf. Sleidan's letter to Jean Sturm from 10 October 1540; Appendix I, No. 20.

${ }^{45}$ Cf. Sleidan's letter to Jean Sturm from 10 October 1540 (Appendix I, No. 20), and Martin Bucer's letter to Philip of Hesse, 20 July 1540 (Appendix I, No. 14). From the Catalogue des actes de Francois Ier, vol. 4, No. 11517 , p. 113 and No. 11524 , p. 115 , we know that for this mission Sleidan received 562 livres and 10 sous on 4 June 1540, and another 225 livres on 7 June (cf. Appendix I, No. 12 and 13).

${ }^{46}$ For the continued efforts in 1540 to arrange an alliance between France and Germany, confer the letters between Sleidan, the Sturms, Jean Du Bellay and Bucer in Appendix I, No. 20 till 25.
} 
Francis' mistress, the Duchesse d'Étampes. When Count Guillaume de Fürstenberg was sent to Germany for further negotiations, the anti-Protestant faction under the chancellor Guillaume Poyet and Cardinal François de Tournon insisted that he was to be accompanied by Barnabé Voré. ${ }^{47}$ Voré's instructions were to lure the French Protestants back into France where they would be charged with heresy and punished. ${ }^{48}$ Du Bellay discovered the plan and instructed Sleidan to warn the German Protestants about Voré's true motives. ${ }^{49}$ Plans for an alliance had once again failed; and neither would Sleidan's efforts succeed when the Hagenau colloquy was reconvened at Worms later the same year.

New hopes for an alliance between France and the German Protestants were fostered in the year 1541 with the forthcoming marriage of Jeanne d'Albret, Marguerite de Navarre's daughter, and the pro-Protestant Duke of Cleves, a relative of the Elector of Saxony. ${ }^{50}$ Again, an immediate diplomatic effort failed. ${ }^{51}$ Meanwhile, the Emperor had summoned a diet in Regensburg for early that year, to which Sleidan was sent as a diplomat. On 31 January he arrived in Strasbourg together with his fellow agent, Maurus Morelet du Museau, Sieur de Marche-Ferrières, known as a friend of the Protestants. ${ }^{52}$ After giving reports to the Strasbourg council, they travelled to Regensburg to meet fellow diplomats, theologians and political rulers, and to conduct negotiations with the Protestants

\footnotetext{
${ }^{47}$ Voré had already taken part in a mission in 1535 , when he had still harboured pro-Protestant feelings.

${ }^{48} \mathrm{Cf}$. Schmidt, Jean Sturm, pp. 51-52.

${ }^{49} \mathrm{Cf}$. the letter of Martin Bucer to the Saxon Chancellor Franz Burkhardt (Appendix I, No. 24).

${ }^{50}$ Despite the outrage of the Emperor, who tried to prevent the marriage and declared Cleves an outlaw, the wedding took place on 14 June 1541. Cleves was in favour of Protestantism but had not signed the Confessio Augustana yet.

${ }^{51}$ Louis Regnier de la Planche was sent to Saxony and Cleve for new negotiations, but again to no avail (cf. Schmidt, Jean Sturm, p.52). La Planche, in favour of the Protestants, also served as an ambassador for Marguerite de Navarre, who sent him to England for negotiations (cf. R.H. Brodie, J. Gairdner, Letters and Papers, Foreign and Domestic, of the Reign of Henry VIII, preserved in the Public Record Office, the British Museum and elsewhere in England, vols. XX/II, London 1907, No. 942).

${ }^{52}$ Cf. Bucer's letter to Philip of Hesse, 4 February 1541 (Appendix I, No. 26). In this letter, Bucer used again the opportunity to recommend Sleidan to Philip of Hesse, and also informed him that Sleidan had recentiy composed the 'Oration to the States'.
} 
on behalf of France. ${ }^{53}$ The meetings with Philip of Hesse were fruitless. After his

bigamous marriage in March 1540, an offense punishable by death, Philip was dependent

on the Emperor's good will. Hence he was forced to decline a mission to France so as not

to upset Charles V. ${ }^{54}$ Since his efforts had once again been thwarted, Sleidan left the diet

by the end of April and apparently went back to France. ${ }^{55}$

The Orations to the Estates and to the Emperor (1541/1544)

In his employment for Jean Du Bellay, Sleidan gained his first experiences as diplomat, attending diets and colloquies, where he witnessed the negotiations about the religious and political issues. His first own thoughts about the political situation in Germany and the duties of the rulers were put down on paper in the form of Ain beschaidner historischer unschmählicher Bericht an alle Churfürsten, Fürsten und Stennde des Reichs. ${ }^{56}$ This oration to the estates, written in German, critically examined the relation between the Emperor and the Pope and their roles in state and religion. It was first published anonymously in 1541 , followed by another two editions in the same year, one of which carried the anagram 'Baptista Lasdenus' on the title page. ${ }^{57}$

\footnotetext{
${ }^{53} \mathrm{Cf}$. the letter of the XIII of Strasbourg to Francis I from 22 February 1541, in which they mention their meeting with Sleidan and Morelet (Appendix I, No. 30).

${ }^{54}$ Cf. Philip of Hesse's letter to Morelet, (11) February 1541 (Appendix I, No. 29), in which he denied sending a mission to France due to the persecutions there and the Emperor's willingness to make peace with the Protestants. In another letter, he agreed that Strasbour or Saxony could send legates to France (Lenz, Briefwechsel, vol. 2, No. 117).

${ }^{55}$ On 29 April 1541 Jacob Bedrotus mentioned to Simon Grynaeus that after the diet of Regensburg Sleidan stopped by in Strasbourg on his way back to France (Appendix I, No. 31).

${ }^{56}$ Hasenclever, Sleidan-Studien, pp. 27-34, suggests that Sleidan had written the Oration to the Estates in direct response to his experiences at Hagenau.

${ }^{57}$ There is some confusion as to which edition of these was the first one. Vekene, Briefwechsel, in accordance with Eduard Böhmer (ed.), Zwei Reden an Kaiser und Reich von Johannes Sleidanus, Tübingen 1879 , p. 266, specified Ain beschaidner historischer unschmählicher Bericht an alle Churfürsten, Fürsten und Stennde des Reichs (published anonymously, probably by Melchior Kriegstein in Augsburg in 1541, C/b 001), as the first edition of the 'Oration to the States', printed a second time in that year by Valentin Otmar $(\mathrm{C} / \mathrm{b}$ 002). Both Böhmer and Vekene classify a different edition of this work, Oration an alle Churfürsten. Fürsten und Stende des Reichs (C/b 003), which appeared under the pseudonym Baptista Lasdenus and was published anonymously by Kraft Müller in Strasbourg, as the third edition of 1541. Richard Wolff in 'Sleidaniana', ZGO 62 (N.F.23, 1908), pp.265-275, argues that this edition published under Baptista Lasdenus was the first edition, since it contained four spelling mistakes listed on fol. M4v under 'Errata', which are corrected in all other editions. Additionally, he analysed Sleidan's preface to the 1544 Latin edition of both Orationes, in which Sleidan points out that he only unwillingly used a pseudonym since his
} 
This oration, of similar tenor to Luther's 1520 tract To the Christian nobility, traces the development of the Pope into the greedy Antichrist. ${ }^{58}$ It calls upon the estates, the political rulers, to overthrow this usurpation. Sleidan described how in earlier centuries, the relation between Pope and Emperor had been sound. However, after the coronation of Charlemagne the Pope had striven for more and more power until he had reached superiority and revealed himself as the Antichrist. ${ }^{59}$ Sleidan then continued to analyse the specific situation of Germany, which lacked the unity to be able to fight problems effectively. It was the magistrates' duty to work together for the welfare of the state and God's praise. ${ }^{60}$ The oration ends with an appeal to the political leaders to insist on a council (the old idea of the 'gravamina' of the German nation), fight the Turk and live up to their obligations as rulers. ${ }^{61}$

The counterpart to this oration, Oration an Keiserliche Maiestat, Von dem das der jetzige Religionshandel kein menschlich sonder Gottes werck und wunderthat sei, an oration to the Emperor, was first published in German in 1544, possibly by Georg Messerschmid in Strasbourg, again under the pseudonym Baptista Lasdenus. ${ }^{62}$ This second tract follows a similar line to the first oration, calling the Emperor to action in the

friends urged him to do so due to his long absence from Germany; Wolff, 'Sleidaniana', especially pp. 265268 , points out that if Sleidan had been so reluctant to use a pseudonym he would not have had two editions published without any name and then a third edition under a pseudonym; additionally, Sleidan did not mention an anonymous edition at all. - Another German edition of this work was published under 'Baptista Lasdenus' in 1542 (Strasbourg: Johann Knobloch the Younger, C/b 004). In 1567, Josias Rihel finally published two editions of this oration $(\mathrm{C} / \mathrm{b} 009$ and $\mathrm{C} / \mathrm{b}$ 010), stating Sleidan as author on the title page. ${ }_{58}$ W.G. Moore, La Réforme Allemande et la Littérature Francaise. Recherches sur la Notoriété de Luther en France, Publications de la Faculté des Lettres de l'Université de Strasbourg 52, Strasbourg 1930, pp. 412-414 offers a short analysis of these similarities.

${ }^{59}$ Baptista Lasdenus (=Johann Sleidan), Oration an alle Churfürsten/Fürsten/ und Stende des Reichs/ Von des Bapsttumbs auffkommen und abnemen/ auch von seinen Practicken/ und was man sich endtlich/ diser zeit/ zu im versehen soll, s.l. (Strasbourg: Kraft Müller) 1541, fols. A3r-B2v, D2r-G2v.

${ }^{60}$ Ibid., fols. $\mathrm{H} 3 \mathrm{v}-\mathrm{K} 3 \mathrm{v}$.

${ }^{61}$ Tbid., fols. L2v-M4v.

${ }^{62}$ Baptista Lasdenus (=Johann Sleidan), Oration an Keiserliche Maiestat. Von dem/ Das der ietzige Religionshandel/ kein menschlich/sonder Gottes werck und wunderthat sei. Idem/ Das der Eide/ damit jre Maiestat dem Bapst verwandt/ tyrannische/ und gar nit zuhalten sei, (Strasbourg: Georg Messerschmid) 1544. Heinrich Ulmann, 'Zur politischen Entwicklung Sleidans im Jahre 1544', ZGO 49 (N.F.10, 1895), pp. 547-564 argues that Sleidan had this oration written already in 1542, but did not publish it until two years later (p. 559). 
face of the papal abuse. The oration begins with a brief survey of the scheme of the four empires taken from the prophet Daniel, a theme on which Sleidan later elaborated in his 1556 De quatuor summis imperiis. In the body of the text, Sleidan outlined the papal abuse of the Holy Roman Empire and especially Germany. ${ }^{63}$ At the end, Sleidan underlined Germany's wish for a council and warned the Emperor of the evil doings of the Pope. $^{64}$

Sleidan's Oration to the Emperor was published four times in 1544, all under the pseudonym Baptista Lasdenus. ${ }^{65}$ In August of the same year, Sleidan also published a Latin, slightly altered version of both orations, Ioannis Sleidani orationes duae. Una ad Carolum Quintum Caesarem. Altera ad Germaniae principes omnes, ac ordines Imperij. This work was printed with the author's real name on the title page by Crato Mylius (=Kraft Müller) in Strasbourg, who had also published a German Oration to the Estates in 1541 ; only one other edition was published of this Latin version. ${ }^{66}$ Meanwhile, a French translation of the Oration to the Estates had been published, one in 1542 by Johann Knobloch the Elder in Strasbourg and another in 1543 by Jean Girard in Geneva, both omitting the name of author and printer. ${ }^{67}$ The Genevan edition must have been rather

\footnotetext{
${ }^{63}$ Baptista Lasdenus (=Johann Sleidan), Oration an Kayserliche Mayestat. Von dem / Das der yetzige Religionshandel / kain menschlich / sonder Gottes werck / und wunderthat sey. Item / Das der Eide / damit ire Maiestat dem Bapst verwandt / tyrannisch / und gar nit zuhalten sey, s.1. (Augsburg: Heinrich Stainer) 1544 , fols. A2v-B4v.

${ }^{64}$ Ibid., fols. E4v-J4v. Hasenclever, Sleidan-Studien, pp. 27-34, suggests that Sleidan had written the Oration to the Estates in direct response to his experiences at Hagenau, and had composed the Oration to the Emperor in 1542 as Charles V then pursued a more lenient line with the German Protestants.

${ }^{65}$ Cf. Vekene, Bibliographie, $\mathrm{C} / \mathrm{b} 005$ and $\mathrm{C} / \mathrm{b}$ 006: (Strasbourg: Georg Messerschmid); C/b 007: (Nuremberg: Georg Wachter); C/b 008: (Augsburg: Heinrich Stainer).

${ }^{66} \underline{\text { Ioannis Sleidani orationes duae. Una ad Carolum Quintum Caesarem. Altera ad Germaniae principes }}$ omnes, ac ordines Imperii, Strasbourg (Krafft Müller) 1544 (C/a 001); another edition in 1598 in Helmstedt: Jakob Lucius heirs, (C/a 002). The Orationes were of course also included in the Latin edition of Sleidan's works.

${ }^{67}$ Vekene, Bibliographie, C/c 001: Escript adresse aux Electeurs, Princes, \& aultres Estatz, Strasbourg (Johann Knobloch the Elder); C/c 002: D'un nouveau chef qui au temps des empereurs s'esleva a Rome, (Geneva: Jean Girard); another eđition Traité d'un nouveau Chef, qui au temps des Empereurs s'esleva a Rome (around 1557-1560) in Geneva: François Jaquy/ Antoine Davodeau/ Jacques Bourgeois, C/c 003. Wolff, 'Sleidaniana', pp. 271-272 suggests - rather unconvincingly - that Jean Calvin was the translator of the French version. From the existing evidence, no translator can be specified. - Crato Mylius himself was
} 
popular in France, since it was listed in the 1547 Paris Index librorum prohibitorum. ${ }^{68}$

Interestingly, in 1544, an Italian translation of the Oration to the Estates was published in Rome, omitting Sleidan's name. ${ }^{69}$ In 1558 , Jean Crespin, who printed many other works by Sleidan, published a French edition of both orations, Deux oraisons historiales de Iean Sleidan. ${ }^{70}$ In 1559 , a Spanish version of the Two Orations by Juan Pérez de Pineda was published in Geneva by Jean Crespin. ${ }^{71}$ By the end of the century, two Latin editions of both orations had been published, as well as ten editions of one or both orations in German, four in French, one in Spanish and one in Italian.

A work of such content and distribution did not escape the inquisition, and various editions of the Orations were put on the Indices librorum prohibitorum. The Latin translation was included in the 1550 Louvain Index, the 1551 Portugal Index and the 1559 Spain Index. ${ }^{72}$ The Italian Oration to the Estates was listed in the 1549 Venice Index, the Roman Indices of 1559/1564 and 1590/1593, and the Spanish Index of $1583 .^{73}$ Similarly, Sleidan's pseudonym Baptista Lasdenus was put on the list of banned authors in the 1554

\footnotetext{
an educated man and had studied under Melanchthon. His family stayed close friends with Sleidan and his family. Sleidan's wife became the godmother of his son Philip (cf. Chrisman, Lay Culture, Learned Culture, pp. 19-21, 26).

${ }_{68}$ J.M. de Bujanda (ed.), Index des Livres Interdits: I. Index de L'Université de Paris 1544, 1545, 1547. 1549, 1551, 1556, Geneva/Sherbrooke 1985, No. 388, pp. 335-6.

${ }^{69}$ Il Capo finto nuovamente dalla lingua tedesca nella Italiana tradotto, Rome: Marc Antonio de Prati heirs (Vekene, Bibliographie C/e 001). According to Bujanda (ed.), Index des Livres Interdits: III. Index de Venise 1549. Venise et Milan 1554, Geneva/Sherbrooke 1987, p. 197, this is also one of the works seized during the 1551 search of the inquisition for prohibited books at the booksellers Lucio Paolo Roselli and Pietro Cocco.

${ }^{70}$ Vekene, Bibliographie, C/c 004.

${ }^{71}$ Dos informaciones my utiles, la una dirigida a la Magestad del Emperador Carlo quinto deste nombre: $Y$ la otra, a los estados del Imperio, s.1./s.n. 1559 (Vekene, Bibliographie, C/f 001).

${ }^{72}$ Bujanda (ed.), Index des Livres Interdits: II. Index de L'Université de Louvain 1546, 1550, 1558, Geneva/Sherbrooke 1986, No. 142, p. 267; Bujanda (ed.), Index des Livres Interdits: IV. Index de 1'Inquisition Portugaise 1547, 1551, 1561, 1564, 1581, Geneva/Sherbrooke 1995, No. 282, pp. 268-269; Bujanda (ed.), Index des Livres Interdits: V. Index de 1'Inquisition Espagnole 1551, 1554, 1559 , Geneva/Sherbrooke 1984, No. 259, p. 388.

${ }^{73}$ Bujanda (ed.), Index de Venise 1549, Venise et Milan 1554, No. 130, p. 197; Bujanda (ed.), Index des Livres Interdits: VIII. Index de Rome 1557, 1559, 1564, Geneva/Sherbrooke 1990, No. 143, p. 669, and No. 400, p. 586; Bujanda (ed.), Index des Livres Interdits: IX. Index de Rome 1590, 1593, 1596. Avec étude des index de Parme 1580 et Munich 1582, Geneva/Sherbrooke 1994, No. 0292, p. 428.
} 
Venice and Milan Index, the 1561 Portugal Index, the 1583 Spanish Index and the $1559 / 1564$ Roman Index. ${ }^{74}$

As we have seen, Sleidan's Orations were published anonymously or under the pseudonym Baptista Lasdenus. In fact, none of the vernacular editions were published under Sleidan's name until after his death. In contrast to this, the Latin edition of both orations of 1544 stated the author's real name on the title page. This gradual unwrapping from anonymity certainly deserves some attention. Sleidan himself offered an explanation in his preface to the Latin edition, pointing out that he had published the German Orations only reluctantly under a pseudonym since his friends had insisted that this would be wiser as he was still living in France at the time. ${ }^{75}$ This explains why Sleidan published the German editions anonymously, but not why Sleidan revealed his real name in the Latin edition. One wonders whether at that point, on the brink of moving back to Germany and as an established diplomat and scholar, he felt safe enough to publish this work under his real name. Another explanation could be that a Latin version, accessible only by the educated elite and aiming for intellectual discussion rather than popular agitation, would have been regarded as less potentially damaging to the author. Such a seemingly higher tolerance towards works in Latin rather than the vernacular will also be observable when we later look at the publication of the Commentaries.

Sleidan's Two Orations were his first steps as an author, and in several ways also the foundation stone for his future career. In the Oration to the Emperor, Sleidan gave a

\footnotetext{
${ }^{74}$ Works quoted above; Venice/Milan: No. 63, p. 227; Portugal: No. 88; Spain: No. 121, p. 185; Rome: No. 66, p. 374.

75 'Scriptae sunt a me lingua Germanica Orations duae, quae prodierunt sub nomine Baptistae Lasdeni, et prodierunt sub eo nomine, non tam mea quadam sponte, quam sic volentibus amicis, qui putabant meis rationibus ita convenire, quamdiu non esse in Germania, iisque locis haererem, in quibus argumentum hoc minus gratum est atque plausibile. Quantum enim ad me pertinet, liberalius et magis ingenuum semper esse putavi, non dissimulare vel tegere nomen in libro, quem edi quis velit, ne quid agi videatur callide magis quam vere, tametsi fiere posse non negarim, ut sit locus aliquando dissimulatione.' (Johann Sleidan, Orationes duae, fol. A2r).
} 
brief outline of the Danielic scheme of the four monarchies, which he later made the topic of a whole work, the Four Empires. The political ideas reflected in both orations, the responsibilities of the temporal authorities and the characterisation of the Reformation as an official, political event rather than a popular movement, are continued in the Commentaries later on. With the Two Orations, Sleidan manifested his interest in contemporary politics, and it was this work (and the 1545 Commynes-translation) which Martin Bucer used as an advertissement to Philip of Hesse to convince him to employ Sleidan for the Schmalkaldic League. In a letter from February 1541, Bucer praised Sleidan's Oration to the Estates so much that Philip of Hesse immediately asked to send him a copy. ${ }^{76}$ When Sleidan had to participate in the 1545 mission to England shortly after his employment as historiographer by the League, he used the opportunity to advertise his cause. He sent a copy of the Latin Two Orations to Henry VIII, who graciously accepted it. $^{77}$ To Jacob Sturm and Jean Du Bellay Sleidan remarked that his work had brought him the hatred of the Emperor, but the admiration of Luther. ${ }^{78}$

Until the nineteenth century scholars speculated that in 1542 Sleidan published another political work, a short writing on the Turk, inspired by the capture of Ofen in Hungary by the Ottomans. ${ }^{79}$ This writing, allegedly bearing the title De capta Buda a Solimanno anno 1542 , was identified by Richard Wolff in the early $20^{\text {th }}$ century as an

\footnotetext{
${ }^{76}$ Cf. Appendix I, No. 26, 28.

${ }^{77}$ Cf. Appendix I, No. 97, 98 .

${ }^{78} \mathrm{Cf}$. Sleidan's letter to Jacob Sturm from 13 April 1545: 'Certe delatum est ad me Caesarem intellexisse de orationibus meis latinis et vehementer fuisse commotum. Malevoli vocant libellum famosum, sed in eo mihi faciunt iniuriam et scio, ubi latet famositas. Verum Miltitzius Witteberga scripsit ad Cratonem [Crato Mylius, that is Krafft Müller, the printer of the Orationes] scriptum illud meum magno applausu fuisse apud ipsos exceptum, adeo quidem, ut Lutherus qui id idem argumentum fere tractavit fateatur, se meis orationibus adiutum esse.' (Baumgarten, Briefwechsel, No. 22, p. 46; Appendix I, No. 59). Similarly, Sleidan's letter to Jean Du Bellay from 14 May 1545: 'Opusculum quod hieme superiori ad te misi [Orationes duae] magnum odium mihi conciliavit apud Caesarem, sed praeter opinionem nihil accedit et multo pluris facio ipsius Lutheri iudicium, qui longe secus de eo pronunciavit, ut huc perscriptum est.' (Baumgarten, Briefwechsel, No. 27, p. 54; Appendix I, No. 66).

${ }^{79}$ Cf. for example Rathgeber, 'Jean Sleidan', p. 341; Pierre François Le Courayer (transl./ed.), Histoire de la Reformation ou Mémoires de Jean Sleidan, Sur l'état de la réligion et de la république sous l'empire de Charles Quint, The Hague (Frederic Staatman) 1767, vol. 1, p. XXXIX.
} 
excerpt from Sleidan's Commentaries. ${ }^{80}$ This summary of Sleidan's account of the Turkish attacks on Hungary in 1541 and 1542 had been composed by Nicolaus Reussner for a collection of historical views on the Ottoman Empire, published in $1603 .{ }^{81}$ Indeed, this work falsely attributed to Sleidan appears in no archival or bibliographical catalogues, nor is it mentioned anywhere in Sleidan's correspondence or the Commentaries.

Accusations and disappointments - Sleidan's final months in France

Soon after his return from the Regensburg diet, Sleidan's mediating position between France and Germany brought him into trouble. He was denounced at the French Court for allegedly having incited members of the Schmalkaldic League to protest against persecution of Protestants in France and thus prevented further negotiations between the two parties. ${ }^{82}$ Both Strasbourg and Jean Du Bellay tried their best to defend their legate, but Sleidan had an even better ally at the French court in the form of Marguerite de Navarre. She trusted Sleidan and was able to convince Francis I of his innocence, as she wrote in a letter to Calvin: 'I have received your letter through Sleidan, who it was not difficult to justify in front of the king, considering the testimonies he has had of his service, in which he puts more faith than any false rumours spread about him... . 83

Sleidan remained in his position and continued his work under Du Bellay, but gradually lost his belief in the possibility of an alliance between France and the German Protestants. This, together with the increasing hostility towards the Protestants in France and the personal allegations against him, made him turn to Germany again. Already in

\footnotetext{
${ }^{80}$ Wolff, 'Sleidaniana', pp.273-275.

${ }^{81}$ Nicolaus Reussner (ed.), Rerum Memorabilium in Pannonia sub Turcarum imperatoribus, a capta Constantinopoli usque ad hanc aetatem, bello militiaque gestarum, Frankfurt (Claudius Marnius/Johannes Aubrius heirs) 1603.

${ }^{82} \mathrm{Cf}$. the letter of the Strasbourg council to Francis I from 23 June 1541 (Appendix I, No. 32).

${ }^{83}$ 'J'ay receu vostre letter par Selidanus, lequel je n'ay eu grand peine de justifier envers le Roy, veu les bons tesmoings qu'il a eu de son service, ausquels il a adjousté plus de foy que à tous les Rapports faux qu'on luy eust sceu faire...' (My translation; Herminjard, Correspondance, vol. 7, No. 1017, pp. 198-199; Appendix I, No. 33).
} 
June 1542, when he had informed Du Bellay about the death of his father, he mentioned his family's wish for him to return home. He must have voiced this wish to Du Bellay before, because in the same letter he asked whether he had spoken to the King concerning his plans to return to his native country. ${ }^{84}$ The distrust in certain circles at the court and the continuous unsuccessful attempts to arrange an alliance with the German Protestants must have reinforced Sleidan's wish to return to his home country, but he remained in his duties as long as there was some hope left.

In early 1544 Sleidan was still in France, as in January of that year he was sent with Jean Du Bellay and others to attend the diet of Speyer to attempt once more the longsought after alliance. ${ }^{85}$ As the Emperor had got to know about that mission and wanted to prevent it, he refused the group permission to enter imperial territory. Sleidan, as the only German present, was sent by himself to represent France; Du Bellay had a document printed explaining their situation and the position of the French king. ${ }^{86}$ The diet of Speyer turned out to be a complete inversion of all hopes of a Franco-German alliance. Pushed against the wall, the German Protestants were forced to agree to the Emperor's declaration of war against France as they hoped for religious toleration. Yet these hopes were not fulfilled and after the peace of Crépy in September that year the Protestants feared that the

\footnotetext{
${ }^{84}$ Cf. Sleidan to Du Bellay, 19 June 1542 (Appendix I, No. 35). According to Nikolaus Reinartz, 'Der Schleidener Stadtschreiber Paul Petri (1510-1588) und seine Verschronik', Mitteilungen der Westdeutschen Gesellschaft für Familienkunde 7/12 (1933), col. 453-454, Sleidan's father died on 27 April 1547 on a journey to Cologne.

${ }^{85}$ On 7 January 1544 the treasury was ordered to pay 225 livres out to Jean Du Bellay and the chancellor d'Alençon (François Olivier) to pay to Sleidan to attend them on their missions to the diets of Speyer and Worms (Appendix I, No. 38).

${ }^{86}$ Sleidan refered to this writing in his letter to Du Bellay from 2 May 1544, reporting about the diet of Speyer (Appendix I, No. 40). Du Bellay's tract in question must be Oraison escripte suyuant lintention du Roy treschrestien, aux Serenissimes, Reuerendissimes, Tresillustres, Tresexcellens, Magnifiques, Treshauls Seigneurs, \& a tous les estas du sainct Empire assemblez en la ville de Spire, Paris (Robert Estienne) 1544; cf. also another writing attributed to Du Bellay in 1544, Defense pour le Roy de France Treschrestien, a lencontre des iniures \& detractions de laques Omphalius, faicte nagueres en Latin par vng Seruiteur du Roy, \& maintenant traduicte en Francois par Simon Brunel, Paris (Robert Estienne) 1544, written during the time of the diet of Worms, again defending the position of the French king and advertising an alliance between France and the German Protestants.
} 
Emperor could turn against them since he was not occupied with a war. ${ }^{87}$ Additionally, in the secret articles of the peace treaty Francis promised not to form an alliance with England and to support the Emperor in case he should wage a war against the Schmalkaldic League. ${ }^{88}$ All this completely disappointed Protestant hopes, and new negotiations with possible allies were needed.

The new rapprochment between Emperor and the king of France brought an inevitable cooling in relations with German Protestants. The repercussions at court meant defeat for the liberal circle around Du Bellay and triumph for his enemies, the staunchly Catholic pro-Habsburg faction. The influence of the Du Bellays was declining, and with that the safe position of their protegés. Disappointed with the failure of their communal enterprise and upset about the personal consequences of this in the form of never-ending accusations and intrigues, Sleidan realised that his time in France was over. Having pondered the possibilty of returning to Germany for the last years, Sleidan finally decided on leaving France.

In these last months in France, when the changed political situation left Sleidan with more time at his hands, he fulfilled Martin Bucer's wish of translating one of his catechisms, Kürtzer Catechismus, from German into Latin. This catechism, addressed to the church and schools of Strasbourg, was published by Wendelin Rihel in Strasbourg, Sleidan's future main publisher and friend, as Catechismus ecclesiae et scholae

\footnotetext{
${ }^{87}$ Cf. Schmidt, Jean Sturm, pp. 57-58; also Rodolphe Reuss, Histoire de Strasbourg depuis ses origines jusqu'à nos jours, Paris 1922, p. 135 who remarks that many cities objected to accepting this declaration of war but finally had to give in.

${ }^{88}$ Cf. R.J. Knecht, Renaissance Warrior and Patron: Reign of Francis I, Cambridge 1994, pp. 492-494. In January 1545 Sleidan informed Jacob Sturm about the secret articles of Crépy ('Ex Lotharingia scriptum est ad me de conditionibus pacis...'; Baumgarten, Briefwechsel, No. 18; Appendix I, No. 46).
} 
Argentoratensis. ${ }^{89}$ This work is largely unknown amongst theologians and historians alike, and seems to have only survived in a fragment conserved in the Basle university library. ${ }^{90}$ It can both be seen as a service for the friend Martin Bucer as well as a manifestation of an interest in theological matters. For Sleidan personally and professionally, this acquaintance with Bucer proved invaluable upon his return to Germany.

Sleidan's usefulness at the French court was coming to an end. He was in any case by now much in demand in Germany. His presence at Hagenau and Speyer as well as his efforts had won him considerable reputation in his homeland. Personal family considerations combined to make this change more attractive. However, the years in France left an indelible impact on Sleidan's personality and work, and even after his return to Germany he continued to look to French authors for inspiration and enlightenment. His return to Strasbourg was followed by two translations of major pieces of French history writing. In Strasbourg, Sleidan's knowledge of French politics was again put into good use when political events encouraged the restoration of negotiations between France and the Empire. Sleidan took back with him from France an established double reputation as author and diplomat with a recognised expertise in France. These aspects would continue to characterise his activity even as he now passed into the service of the German Empire.

\footnotetext{
${ }^{89} \mathrm{Cf}$. Baumgarten, Briefwechsel, mentioning on p. XVIII that a copy of part of this translation has survived in the Thomas archive in Strasbourg under the title Ex catechismo ecclesiae et scholae Argentoratensis a Mart. Bucero conscripto et ab Joanne Sleidano ex germanico in latinum converso anno 1544. Ferdinand Mentz and A. Erichson in their bibliography of Bucer's writings, Bibliographische Zusammenstellung der gedruckten Schriften Butzers, Strasbourg 1891, list this catechism, which escaped the eyes of many, on p. 139, No. 58a: Cathe/chismvs ec-/clesiae et scho-/lae Argentoratensis. / [printer's device] / Argentorati ex aldibus/ Vuendelini Rihelij. Anno 1544 (pp. 63 [1], in 8o) and remark: 'Dies ist der Catechismus minor versus a Joh. Sleidano, welchen Hubert in seinem Verzeichniß der Bucerischen Schrifften unter 1544 erwähnt.' Jean Muller, Bibliographie Strasbourgeoise. Bibliographie des ouvrages imprimés à Strasbourg (Bas-Rhin) au XVIe siècle (Répertoire bibliographique des livres imprimés au France au seizième siècle 148), Vol. 3, Baden-Baden 1986, lists this work on p. 406, No. 113, but is unaware of the connection to Sleidan.

${ }^{90}$ Cf. Jean Rott, Jean Sleidan, p. 580.
} 


\section{CHAPTER 2: IN THE SERVICE OF THE SCHMALKALDIC LEAGUE}

The change of the political and religious climate had forced Sleidan to leave France in 1544, but for the rest of his life France was never to leave him, as his biography shows. Sleidan's return to Germany was not entirely a happy one. True, he had contemplated such a move since the death of his father in 1542, but the hope that the long-sought for FrenchGerman alliance might eventually be arranged kept him at Du Bellay's chancellery in Paris. There, in the centre of French diplomacy, he felt his services for the communal cause could be of best use. However, the diet of Regensburg proved another disappointment for the alliance plans. Having spent so much time and effort with the $\mathrm{Du}$ Bellays to convince the French of the merits of such an alliance, it must have been devastating for him to see now the German willingness crumble so dramatically. Sleidan himself did not explain why he left France, but one may think that with the failure of the alliance negotiations and the subsequent decline of the star of the Du Bellays Sleidan felt that he could be of more use in Germany. Which other city would offer more to Sleidan than Strasbourg, the imperial city on the French border near his birth town, home to his closest friends Jean Sturm, Martin Bucer and Jacob Sturm, promising a good chance of employment?

\section{Sleidan's arrival in Strasbourg: planning a career}

We do not know when exactly Sleidan finally moved back to Germany, but we can safely say that he moved there in early 1544 , and not in 1542 as often assumed. ${ }^{1}$ Evidence from his correspondence suggests that he did not return to France after the Diet of Speyer, but

\footnotetext{
${ }^{1}$ Across the centuries, many scholars have assumed that Sleidan moved to Germany already in 1542 , as for example in the middle of the nineteenth century Schmidt, Jean Sturm, p. 78, and most recently Robert Faerber, 'Bucer et Jean Sturm', Christian Krieger, Marc Lienhard (eds.), Martin Bucer and Sixteenth Century Europe. Actes du colloque de Strasbourg (28-31 aout 1991), vol.1, Leiden/New York/Cologne 1993, p. 332.
} 
remained in Strasbourg. From there he reported to Du Bellay about the meetings at Speyer on 2 May $1544 .^{2}$ From then onwards, Sleidan's letters are adressed from Strasbourg. Contrary to his initial plans, Sleidan did not attend the Diet of Worms at the end of that year, possibly so as not to suggest too close a relationship with France of which other diplomats like Jean Sturm were accused. ${ }^{3}$ Sleidan nevertheless seems to have remained in the service of France for a few more years, as a letter by Du Bellay to the new king Henry II from 1547 suggests. $^{4}$ Du Bellay's plea to continue paying a salary to Sleidan seems to have been in vain, however. The two men continued to be in close contact over the next years, and Sleidan continually informed him about private and political affairs.

Sleidan's move to Strasbourg was not a journey into the unknown. He had visited the city before and was most likely heartily welcomed by his friends. One can almost be sure that the Sturms and Bucer would have helped Sleidan with his prime needs, like housing and employment. Sleidan was not an unknown man when he arrived at Strasbourg. In the near decade Sleidan had spent in France he had made many valuable contacts, and he had earned himself an excellent reputation in several fields. He had been an important diplomat and contact man in France for the German Protestants and the link to the French court, during a time when agitation towards an alliance between France and the German Protestants was at its most intense. He had not only translated a French historian into Latin and thus demonstrated considerable humanist skills, he had also aided the circle around Du Bellay with this defence and legitimisation of their cause. By 1544 , his Two Orations had been published in German, Latin, French and Italian, and had won

\footnotetext{
${ }^{2}$ See Sleidan to Jean Du Bellay, 2 May 1544 (Appendix I, No. 40). Additionally, Bucer mentioned in a letter to Philip of Hesse from 5 August 1544 that Sleidan had been in Strasbourg for a few months (Appendix I, No. 42). Additionally, from Jacob Sturm's correspondence we can conclude that Sleidan did not return to France after the Diet of Speyer and had been in Strasbourg since February 1544 (PC 3, No. 448).

${ }^{3}$ On 7 January 1547 Du Bellay had been paid 225 livres to hand out to Sleidan for attending the Diets of Speyer and Worms, see above (Catalogue de François Ier, No. 13537, pp. 542-543). In March 1544 Jacob Sturm reported suspicions against Francophiles at the Diet of Strasbourg and warned Jean Sturm and Uirich Geiger of 'French practices' (Jacob Sturm to XIII of Strasbourg, 23 March 1544, PC 3, No. 448, p. 474).

${ }^{4}$ On the implications of this letter (Appendix I, No.185), see below.
} 
Luther's approval. All this considered, Sleidan could have had serious hopes for occupying an important position in Strasbourg.

Indeed, the Strasbourg-based reformer Martin Bucer had already had his eye on Sleidan to assist in constructing his vision of a German or even pan-European Reformation. Bucer had known Sleidan since at least 1539 and was convinced of his qualities. ${ }^{5}$ Around the time of Sleidan's return Bucer had contemplated the need for a Protestant history together with the political spokesman of the Schmalkaldic League, Jacob Sturm. The man they envisaged as author of this history had just arrived in Strasbourg, still young, but with considerable experiences as diplomat and historian, and looking for employment. The man was Johann Sleidan. Of course, both Bucer and Sturm were realistic enough to know that for such a task considerable financial and material support were also needed. Why not convince the Schmalkaldic League, the political organ of the German Protestants, to take on board such a project? ${ }^{6}$

Both Sturm and Bucer had good contacts with Landgrave Philip of Hesse, with John Frederic of Saxony the ruler of the League. Jacob Sturm was one of the most prominent politicians of the League, and Bucer had assisted at many diets and colloquies and had done Philip personal favours by helping with the defeat of Anabaptism and fostering of the Reformation in Hesse. Bucer did not hesitate to introduce the Landgrave to his plans. Sleidan was not unknown to Philip of Hesse, since Bucer had ensured that Philip had seen copies of Sleidan's Orations, and later would also inform him about the translation of Commynes. Accordingly, in the second half of 1544 Bucer wrote several letters to Philip of Hesse to underline the need for a Protestant history and recommended

\footnotetext{
${ }^{5} \mathrm{Cf}$. the letters mentioning Sleidan as a contact in Paris and Bucer's advocacy of Sleidan towards Philip of Hesse as discussed in chapter 1 .

${ }^{6}$ We will look at the circumstances of Sleidan's employment in greater detail in chapter 4.
} 
Sleidan as the ideal author. ${ }^{7}$ It is clear from these conversations that Sleidan was by this point well and widely known in Germany. His service in France had brought him into contact with many of the leading figures of German Protestantism, particularly when he attended in person the negotiations of Hagenau and Speyer. His published work, like the epitome of Froissart and his Two Orations, also highlighted his qualifications as a historian. But in other respects Sleidan was not an unproblematic choice for an assignment of this sensitivity. For the members of the Schmalkaldic League his connections on the one hand with France and on the other with Bucer must have raised grave questions.

Martin Bucer (1491-1551) in particular was a difficult and problematic figure for German Protestants. Originally a Dominican from Selestat, he had come to Strasbourg in 1523. There he soon assumed a central position in the Reformation of the Strasbourg churches, as examined by Chrisman. ${ }^{8}$ He worked closely with Jacob Sturm ever since Philip of Hesse had introduced the two men to each other at the colloquy of Hagenau. ${ }^{9}$ From the mid-1530s onwards Bucer rose to what Brady called 'a Protestant churchman of Imperial rank', working for his vision of a Pan-European reformation. ${ }^{10}$ By nature a conciliator, he had striven now for over a decade to reconcile conflicting positions among the German and Swiss churches. The result was a series of theological writings that found favour with neither party, and helped raise accusations against him as a Zwinglian. Even in an age which put little value on brevity, Bucer's tendency to longwindedness and to bury contentious points in obscurity exasperated even his friends among the reformers. By 1544 , few of the orthodox Lutherans would have counted themselves amongst this number.

\footnotetext{
${ }^{7}$ Again, this will be examined more closely in chapter 4.

${ }^{8}$ Miriam Usher Chrisman, Strasbourg and the Reform. A study in the process of change, New Haven/London 1967.

${ }^{9}$ On Bucer, see especially Martin Greschat's biography Martin Bucer: Ein Reformator und seine Zeit, Munich 1990.

${ }^{10} \mathrm{Cf}$. Thomas A. Brady, "The Earth is the Lord's, and our homeland as well": Martin Bucer and the politics of Strasbourg', Krieger, Lienhard, Martin Bucer, pp. 129-143 (quotation p. 130).
} 
Bucer's time at Strasbourg came to an end with his fierce protest against the Augsburg Interim. His decision to abandon his church in Strasbourg rather than accept the Augsburg Interim was a seminal moment for German Protestantism. In 1549, he left for exile in England, assisting with the English Reformation until his death in $1551 .^{11}$

In this context, Bucer becomes especially interesting in relation to various other important people based in Strasbourg at the time of Sleidan's arrival. There is first of all his connection with Philip of Hesse, which has been explored in an interesting article by Wulczyn. The Landgrave valued the conciliatory reformer very much since their communal attempts to bring about a union between Lutherans and Zwinglians. Bucer not only assisted with the Reformation in Hesse, but defended Philip after his bigamy. ${ }^{12}$ It was through the Landgrave that Bucer became a close ally of Jacob Sturm, the influential stettmeister of Strasbourg and spokesman of the Schmalkaldic League. Together the two men not only reformed the Strasbourg churches, but also formed a unique political and theological team at the head of the League until their views diverged and they finally fell out over the acceptance of the Interim. The two men were joined in the intellectual elite of Strasbourg by Jean Sturm, Sleidan's childhood friend, who Bucer accomodated in his house after his arrival in Strasbourg in early 1537 . With Bucer at the head of the ecclesiastical part of Strasbourg life, Jacob Sturm as political leader and Jean Sturm as the head of education, the three formed what Faerber called correctly a 'triumvirat'. ${ }^{13}$ It was also Bucer who had invited Calvin, another influential man in the life of Sleidan, to Strasbourg. So Bucer's advocacy of Sleidan would have brought its own dangers. On the

\footnotetext{
"Sleidan honoured his old friend and patron with a poem called 'Ergo te rapuit dira', which has been published by Adolf Hasenclever, 'Ein poetischer Nachruf Johann Sleidans auf Martin Bucer', ZGO 65 (N.F. 26), 1911, pp. 715-718; Appendix II, No. 13.

${ }^{12}$ On the relation between Martin Bucer and Philip of Hesse, cf. Heidi Wulczyn, 'The relationship between Martin Bucer and Philip of Hesse: A reforming politician and a political reformer', Krieger, Lienhard, Martin Bucer, pp. 451-459.

${ }^{13}$ Faerber, Robert, 'Bucer et Jean Sturm', p. 331.
} 
other hand, with three of his closest friends in Strasbourg, the city on the Rhine provided a convenient and safe location for Sleidan. He was quickly integrated in society, and Bucer and Jacob Sturm rallied for his employment as official historiographer of the Schmalkaldic League.

\section{Sleidan's version of Philippe de Commynes (1545)}

Sleidan was most certainly aware of the plans to write a history of the Reformation. He attempted to advertise his skills by composing a free Latin version of a work of another French historian, Philippe de Commynes (1447-1511). As he did before with Froissart, Sleidan translated the French original into Latin as De rebus gestis Ludovici, eius nominis vndecimi, Galliarum Regis, \& Caroli, Burgundiae Ducis, Philippi Cominaei, viri patrici, \& equestris ordinis, Commentarii. This work, an account of the Burgundian war which had also deeply affected Strasbourg and Alsace, was published under Sleidan's name an impressive four times in $1545 .^{14}$ The fact that two editions were published in Strasbourg and two in Paris shows the interest in a Latin version of Commynes in France and the Empire, and also hints at Sleidan's popularity in both countries. ${ }^{15}$ To make sure his skills

\footnotetext{
${ }^{14}$ The classification numbers are again taken from Vekene, Bibliographie:

F/a 002 Paris: Christian Wechel 1545 (80)

F/a 003 Paris: Jean Roigny \& Christian Wechel 1545 (8o)

F/a 004 Strasbourg : Kraft Müller 1545 (Colophon: Crato Mylius, Feb. 1545) (4o)

F/a 005 (slightly different title) Strasbourg: Wendelin Rihel 1545 (Colophon 22 Feb. 1545) (8o)

Later editions in the sixteenth century are:

F/a 008 Paris: André Wechel 1561 (80)

F/a 009 Paris: (André Wechel for) Jacques Dupuys 1561 (80)

F/a 012 slightly different TP: Strasbourg: Josias Rihel ca. 1562/64 (8o)

F/a 017 Paris:(André Wechel for) Jacques Dupuys 1568/9 (80)

F/a 018 Paris: Andre Wechel 1569 (reprint of 1568/9 Wechel-Dupuys) 80

F/a 019 Paris:(André Wechel for) Jacques Dupuys 1569 (8o)

F/a 021 different title: Basle: Sebastian Henricpetri (1574) 80

F/a 029 Basle: Sebastian Henricpetri (1599) (80)

${ }^{15}$ On the immense popularity of Sleidan's Latin adaption of Commynes Jung remarked in 1821: 'Des Français même, tels que $\mathrm{De}$ Thou, préféraient alors la traduction de Sleidan à l'original, écrit dans in langage barbare.' (M. Jung, 'Jean Sleidan, Historien contemporain de la Réformation', Doin, Guillaume T. (ed.), Musée des Protestans Célèbres, ou Portaits et Notices biographiques et littéraires des personnages les plus énimens dans l'histoire de la réformation et du protestantisme, Vol.I,2, Paris 1821, p. 128).
} 
were noticed, Sleidan dedicated this work to his potential employers, the leaders of the Schmalkaldic League, John Frederic of Saxony and Philip of Hesse.

Philippe de Commynes had been the councillor of Charles of Burgundy until 1477, at which date he swapped sides and occupied the same position at the court of Louis XI. After Louis' death he fell into disfavour; though rehabilitated under Charles VIII he never regained his former influence. ${ }^{16}$ His Mémoires covered the years 1464 till 1498, the reigns of Louis XI and Charles VIII. Commynes was very popular amongst sixteenth century French political thinkers and features often in the works of H. Estienne, Du Haillan, Bodin and Montaigne, to name but a few. The Mémoires were still written in the traditional style of chronicles and annals. Like Froissart, Commynes intended to write from his own experiences and to use eyewitness reports. His aim was to educate people, especially the princes, so that they would be good rulers; his intent was to remain impartial and not to flatter.

In the dedication, devoted to Philip of Hesse and John Frederic of Saxony, signed on 1 January 1545 in Strasbourg, Sleidan used the occasion to underline the need for a Protestant history, and recommended himself for such a task. Commynes with his propagation of absolute veracity for the historian had set an example to posterity and had created a valuable portrait of his time. With Commynes, Sleidan emphasised the necessity of a description of one's own epoch, especially in times as troubled and at the same time as great as his own. ${ }^{17}$ This, he pointed out, had already been attempted by classical historians

\footnotetext{
${ }^{16}$ For biographical notes on Commynes, see Archambault, Seven French chroniclers, pp. 101-2; Heidrun Baumann in Der Geschichtsschreiber Philippe de Commynes und die Wirkung seiner politischen Vostellungen in Frankreich um die Mitte des 16. Jahrhunderts, Munich 1981 offers an examination of Commynes' influence on French political thought in the mid-sixteenth century.

${ }^{17} \mathrm{Cf}$. Philippi Cominaei Equitis, de rebus gestis Ludovici undecimi, Galliarum regis, \& Caroli, Burgundiae Ducis, Commentarii. Ex gallico facti Latini, a Ioanne Sleidano. Adiecta est brevis quaedam illustratio rerum, \& Galliae descriptio, Strasbourg (Josias Rihel) s.d., fols. *3r-*4r.
} 
like Thucydides, Caesar, Polybius and Tacitus, and was fully accomplished by Commynes. Sleidan did not just confine himself to the usual niceties of dedications, but towards the end addressed the leaders of the League in striking boldness. He underlined that for a project of such rank and importance as a Reformation history the archives of Saxony, Hesse and their allies would have to be accessible to him. ${ }^{18}$ His demands formulated, he did not forget to express his admiration for Jacob Sturm, his friend and other leading character in the Schmalkaldic League. ${ }^{19}$

Once again Sleidan surprises. He must have been very convinced of his forthcoming employment as historian of the Schmalkaldic League to demand unlimited access to the Protestant archives from their rulers. This in itself is remarkable enough, but why did Sleidan use another translation of a French author to advertise himself as official historian to German Protestants? One can only speculate about Sleidan's motives. Apart from Sleidan's interest in all things French one possible reason could be Commynes' emphasis on the importance of a contemporary's account of events and his excellence of historical description and values, which could well have served as a potential role model for Sleidan's intended history. Additionally, Commynes had put strong emphasis on the importance of the nobility and princes in a state, a view that would naturally flatter the rulers of Hesse and Saxony. On another level, by making another French author accessible to a wider audience, Sleidan possibly also tried subtly to express his wish for an alliance between France and the German Protestants.

Having written and published this translation of Commynes, Sleidan and Bucer decided to help fate. In late January 1545 , Sleidan himself sent a copy of the work to

\footnotetext{
${ }^{18}$ Ibid., fol. *4r: 'Oportet enim eum, qui verè \& integrè tractare haec omnia velit, ex vestris bibliothecis instructum prodire, \& a vobis sociisque; vestris materiam scribendi desumere.'

${ }^{19}$ Ibid., fol. *4v.
} 
Jacob Sturm, pointing out the reference to him in the dedication and asked him to support his employment. ${ }^{20}$ Bucer reminded Philip of Hesse of his wish to employ Sleidan as official historian, and sent him a copy of Sleidan's translation of Commynes. Bucer's insistence on Sleidan's employment was successful, as in March 1545 Philip reported to Bucer that the Protestant cities and states had agreed to employ Sleidan. ${ }^{21}$ Bucer was delighted, and sent Sleidan to Worms to discuss the terms of his contract. ${ }^{22}$ After a few negotiations, the contract was settled and Sleidan was officially employed by the Schmalkaldic League as diplomat, translator and historiographer to compose a history of the Reformation, with a salary of 350 florentines per year. ${ }^{23}$ Sleidan was overjoyed with his new position, thanked Jacob Sturm and Bucer and also informed his old patron Jean Du Bellay about his employment. Full of energy he completely immersed himself in the project and as soon as May he had worked out the chapter divisions for his history and sent them to Hesse and Saxony for approval. In June he had started writing, and by July the first book of the Commentaries was completed. ${ }^{24}$

Sleidan's arrival in Strasbourg in early 1544 had quickly advanced his career. The young jurist and diplomat with a deep interest in history had quickly established himself in his new and final home. He had published another Latin version of a French historian, and he had found a promising employment: that as the official historian of the Schmalkaldic League. One wonders whether plans for a Protestant history had been conceived already before Sleidan moved to Strasbourg. The speed of events in Strasbourg - the rallying of Bucer and Jacob Sturm for Sleidan as League historian almost immediately after the latter's arrival, Sleidan's translation of Commynes with its dedication to the leaders of the

\footnotetext{
${ }^{20}$ Sleidan to Jacob Sturm, 25 January 1545 (Appendix I, No. 46).

${ }^{21}$ Philip of Hesse to Martin Bucer, 27 March 1545 (Appendix I, No. 54).

${ }^{22}$ Martin Bucer to Philip of Hesse, 7 April 1545 (Appendix I, No. 57).

${ }^{23}$ Undated contract (Appendix I, No. 169).

${ }^{24}$ Cf. Appendix I, No. 67, 79, 342. We will examine this in chapter 4.
} 
League and his following rapid employment - all point in this direction. Unfortunately, this part of Sleidan's biography cannot be unveiled with the extant information. But before we accompany Sleidan further through his life in Strasbourg, we will pause here and take stock of the man who the Schmalkaldic League employed for such a vital position, and the influences, personal and religious, that had formed him. This will allow us to suggest why the League chose Sleidan as their official historian.

\section{Sleidan's inner circle and their influence: the Du Bellays, Sturms, Bucer and Calvin}

When Sleidan came to Strasbourg in 1545 , he had already made a name for himself through his skills and zeal. During the years in Paris and his diplomatic duties for Jean Du Bellay he became acquainted with an important circle of men who were to be influential for the rest of his life. We have seen that the names which appeared again and again were an interesting mix from France and Germany, the Du Bellays in Paris, Jean and Jacob Sturm in Strasbourg, Bucer, and Calvin. All of them had strong personal ties with Sleidan, and were patron and friend alike. And all of them were involved in his employment as historian of the Schmalkaldic League and the long years of composing the Commentaries in different ways. It becomes necessary here to refer back to Sleidan's time in France, but also to glimpse into his future as portrayed in chapter three.

During his childhood, youth and studies Sleidan's closest friend was Jean Sturm. Their families both lived in Schleiden, with their fathers both working for Count Dietrich of Manderscheid. The two boys went to school together, and even spent much of their university life together. A close friend throughout life, Jean Sturm also stood at Sleidan's bed when he died. He was one of the driving forces behind an alliance between the German and French Protestants, and all his life he tried to do his best to encourage this, being engaged in many diplomatic missions for these purposes. During his time in Paris, 
Jean Sturm was employed in the chancellery of Cardinal Jean Du Bellay, and it was he who recommended Sleidan for this post when he left Paris for Strasbourg. In Strasbourg, he became invaluable as a pillar of the educational system, and a fosterfather of FrancoGerman relations and moderate Protestantism. He became the contact man of the Du Bellays in Germany, and formed together with Jacob Sturm and Martin Bucer a triumvirate pressing for a pro-French policy, and Sleidan's employment as historiographer of the Schmalkaldic League.

Jean Sturm had left Paris in December 1536, and his position in the circle of Jean Du Bellay was taken over by his friend Sleidan. As we have seen above, Jean Du Bellay was part of the anti-Habsburg, pro-German Protestant party at the French court, and as the Cardinal and bishop of Paris in a very influential position. It was through him that Sleidan was introduced to the French court, and became involved in Du Bellay's mission of arranging an alliance between the French and German Protestants. Sleidan became Du Bellay's link to the German Protestants, and the Cardinal sent him on various missions. Thus Sleidan became acquainted with men like Bucer, Jacob Sturm and Calvin, who were to play an important part in his later life. Even after his return to Germany, Sleidan was for several years still in contact with his old employer, on whose help and support he often counted.

Jean Du Bellay was supported in his Protestant-friendly policy by his diplomat brother Guillaume Du Bellay, Sieur de Langey, who had been the driving force behind the negotiations with the German Protestants in the 1530s. Apart from his political work, Guillaume Du Bellay was also active as a writer and composed, amongst other works, the Ogdoades, a Latin account of the reign of Francis I. The Ogdoades were actually not published until after the death of both Guillaume Du Bellay and Sleidan. Only fragments 
of this work survived, which were later translated and continued by Guillaume's brother Martin Du Bellay and edited by Réné Du Bellay, in the form of the Mémoires. ${ }^{25}$

Guillaume Du Bellay's historical writings could well have had a certain influence on

Sleidan as suggested by Bourrilly. ${ }^{26}$ Like Sleidan, Du Bellay underlined the value of history and the need to use original documents. From Sleidan's remarks to Jacob Sturm we know that he was acquainted with Guillaume Du Bellay and even worked occasionally as his secretary. ${ }^{27}$

One of Sleidan's first official missions in the service of Jean Du Bellay had been the colloquy of Hagenau in 1540. At this diet, he met Jacob Sturm, since 1526 the influential stettmeister of Strasbourg, subject of several excellent studies by Brady. From his early career onwards, Sturm had worked towards an alliance of Strasbourg with Hesse and Saxony, and in 1529 had attended the Marburg colloquy together with Martin Bucer at

\footnotetext{
${ }^{25}$ Martin Du Bellay, Les Mémoires de Mess. Martin Du Bellay Seigneur de Langey. Contenans le discours de plusieurs choses advenues au Royaume de France, depuis l'an M.D.XII. jusqu'au trespas du Roy François premier, ausquels l'Autheur a inseré trois livres, \& quelques fragmens des Ogdoades de Mess. Guillaume Du Bellay Seigneur de Langey son frere, Paris (Pierre L'Huillier) 1569. Unfortunately, this work, containing material assembled by Guillaume and Martin Du Bellay and edited by René Du Bellay, does not mention. Sleidan at all.

${ }^{26}$ Bourrilly in his biography Guillaume DuBellay, pp. 397-398 emphasised Guillaume Du Bellay's influence an Sleidan as a historian: 'Il est dependant un historien qui doit à Guillaume du Bellay peut-être sa vocation, assurément sa méthode: nous voulons parler de Sleidan. ... Langey donna à Sleidan ses idées sur l'histoire. Est-ce lui encore qui lui suggéra celle d'écrire ses Commentaires. ... La manière don't Sleidan procéda pour recueillir ses documents et don't il les utilisa, cette façon de résumer les textes, de paraître s'effacer derrière une analyse fidèle, tout en donnant au récit, malgré tout et involontairement sans doute, une allure partiale, tout cela crée plus que des analogies entre les Ogdoades et les Commentaires. On peut donc, ce nous semble, revendiquer pour Langey l'honneur d'avoir contribué, dans une large mesure, à la formation du plus célèbre historien protestant du XVIe siècle.' Friedensburg in 'Vom französischen Agenten zum Geschichtsschreiber', pp.114-116, also followed this line. In the prologue to the Ogdoades, Guillaume $\mathrm{Du}$ Bellay did indeed express similar thoughts on the value of history and the use of original documents as Sleidan later did (cf. Martin Du Bellay, Mémoires, fols. ãã1r - ere3v). As we will see in chapters 5 and 6, however, such an argumentation was not unique at his time. Although Sleidan might well have read parts of Guillaume Du Bellay's historical works, we cannot for certain establish a direct literary and historical influence on him, or one that is more prominent than any other.

${ }^{27}$ In 1542, Guillaume Du Bellay had Sleidan transcribe his correspondence with the Marquis del Vasto on the subject of the murder of the legates Frégose and Rincon as well as a discourse on this affair he wanted to distribute in Germany. Cf. Sleidan's letter to Jacob Sturm from 4 April 1545 (Appendix I, No. 56, Baumgarten, Briefwechsel, No. 20): 'Mitto tibi... quasdam epistolas quas ante triennium descripsi ex Gallico domini Langaei autographo, ipsius mandato. Videbis in iis totum negotium de Rincone et Caesare Fregoso... $\therefore$
} 
the invitation of Philip of Hesse. ${ }^{28}$ From then onwards the two men worked together and were amongst the leading characters of Strasbourg and the Schmalkaldic League. Despite his reservations towards France, Jacob Sturm saw the advantages of close relations to the direct neighbour, and supported Jean Sturm and Sleidan in their negotiations with France. ${ }^{29}$ He became close friends with Sleidan, and supported his career, especially by recommending him together with Bucer as historian to the Schmalkaldic League. He supervised the composition of the first sixteen books of the Commentaries; Sleidan was devastated by his death in 1553 and wrote a poem in his memory. ${ }^{30}$

At Hagenau, Sleidan had also made the acquaintance of Martin Bucer, who had dominated the Reformation in Strasbourg from 1523 till his emigration to England in 1549. The moderate and tolerant reformer became Sleidan's patron until the end of his life, and had a decisive influence on his career. He openly encouraged an alliance with the French Protestants, and had been aware of Sleidan's important position in Jean Du Bellay's chancellery since 1539 , when he used him as a contact man in Paris and possibly also made Jacob Sturm and the Schmalkaldic League aware of him. ${ }^{31}$ By 1540 , Bucer had successfully drawn the attention of both the city of Strasbourg and Philip of Hesse to Sleidan. ${ }^{32}$

Another acquaintance from the colloquy of Hagenau was Jean Calvin, who was then sent along with the Sturms to represent the city of Strasbourg. Calvin already knew who Sleidan was, since Sleidan had already contacted him in 1539 and expressed deep veneration for him. By 1541, Sleidan had become a trusted link between Marguerite of

\footnotetext{
${ }^{28}$ Cf. Brady, "The Earth is the Lord's", pp.131-135.

${ }^{29}$ Cf. Brady, Protestant Politics, pp. 150-161.

${ }^{30}$ Cf. Appendix I, No. 342; Appendix II, No. 14.

${ }^{31}$ Cf. Appendix I, No. 6-8,

${ }^{32}$ Cf. Appendix I, No. 10, 14, 15, 16, 26, 28.
} 
Navarre and Calvin. ${ }^{33}$ Over the years, the two men remained in contact, and during the final years of the composition of the Commentaries Sleidan frequently contacted Calvin for advice. $^{34}$ After Sleidan had become involved in the French church in Strasbourg, Calvin expressed his satisfaction, and was kept informed about its affairs by Sleidan. ${ }^{35}$

\section{Sleidan's religious conviction}

The question of Sleidan's religious beliefs is an interesting one. Since Sleidan was employed to write a Protestant history of the Reformation, it is only legitimate to ask which sort of Protestantism Sleidan adhered to and which Reformers he was close to. For such an important position, one would naturally expect a staunch Lutheran. However, as we shall see, the answer to this question is not quite what one would naturally assume. To find a possible answer we shall first investigate hints Sleidan gave us himself in his Commentaries. We shall then concentrate on what can be deduced from Sleidan's correspondence. For a comprehensive analysis it is inevitably necessary here to take letters from his later years into account.

In his apology to his Commentaries, Sleidan tells us that he rejoiced 'exceedingly' to be a follower of 'the doctrine of the Gospel', without being more specific. ${ }^{36}$ The history he described is predominantly that of Lutheranism, based on Germany, with excurses to other countries, mainly France and England. Zwinglianism features only occasionally, but is generally regarded as a marginal phenomenon with a potential tendency for radicalism. Zwingli himself is characterised as nothing more than a Zurich phenomenon. ${ }^{37}$ Sleidan condemned Anabaptism sharply, and portrayed Thomas Müntzer as a fanatic, attracting

\footnotetext{
${ }^{33}$ Cf. chapter 1; Appendix I, No. 5, 33.

${ }^{34}$ See the discussion later on and Appendix I.

${ }^{35}$ Cf. Calvin's letter to Sleidan from 1554, Appendix I, No. 319.

${ }^{36}$ 'Nam licet hanc Euangelii doctrinam, beneficio Dei restitutam, libenter profiteor, \& ad eum coetum aggregatum esse me vehementer gaudeo...' (Sleidan, De Statu Religionis (Rihel: 1559), fol. a4r).

${ }^{37} \mathrm{Cf}$. ibid., books $1-4$, esp. fols. C1r, F6v, H4r.
} 
Luther's disapproval. ${ }^{38}$ Calvin is mentioned only a few times, and then only very briefly, mainly as first minister of the French church in Strasbourg, as a delegate to the German colloquies, or in connection with Geneva. ${ }^{39}$

Throughout his work, Sleidan tried to follow his principle to remain impartial. Even the Catholic church is not criticised directly, but Sleidan managed to bring in some not very impressive examples of Catholic behaviour, whereas he generally avoided embarrassing stories about Protestants. Sleidan had been commissioned to write his history by the political organisation of the German Lutherans, and thus obviously had to emphasise events crucial to the Lutheran cause. Yet this does not fully explain why Zwingli and especially Calvin remain only marginal figures. Luther himself necessarily features frequently, but his portrayal comes nowhere near the usual Protestant hagiography of the time. Rather, when Sleidan described Luther's death and achievements, it is Luther's courage and his contributions to the German language he emphasised, not so much the Reformation. ${ }^{40}$ One may wonder whether the virtual absence of Zwinglianism and Calvinism is representative of Sleidan's view or his Lutheran employers, especially when considering that both Jacob Sturm and Peter Paul Vergerio read, commented on and 'improved' the Commentaries - or at least parts of them in the case of Sturm - 'when necessary, ${ }^{41}$

If anybody dominates the religious scene, then it is Luther. Luther was the one who started the Reformation, and is valued as such, but as nothing more. The role he plays in

\footnotetext{
${ }^{38} \mathrm{Cf}$. ibid., books 5-6, esp. fols. H4r-v, L2r.

${ }^{39} \mathrm{Cf}$. ibid., fols. Y4v, KK1r. See below.

${ }^{40} \mathrm{Cf}$. ibid., fols. Ti5v-6v.

${ }^{41}$ In May 1555 Sleidan mentioned to the Council of Augsburg that Sturm had read and corrected the Commentaries: ' $\ldots$ hab auch herren Jacob Sturmen seliger gedächtnusz umb erklärung allezeit, so offt nöhtig geweszt, ersucht [...]. Er hat auch vor seiner krankheit der bücher 16 gelesen und, wo es die notturft erfordert, corrigirt.' (Baumgarten, Briefwechsel, No. 139; Appendix I, No. 342). In October 1554 Vergerio reported to Chirstoph of Württemberg that he had worked through the Commentaries with Sleidan (Appendix I, No. 324).
} 
the Commentaries is determined by historical, not ideological reasons. At the time when Sleidan was politically active, from around 1540 onwards, Luther's importance was already decreasing, and this becomes clear in the Commentaries. It is important to note here that Sleidan wrote his history from the perspective of the lawyer and politician, the Reformation for him was much more a logical event based on reason and political events, rather than a spiritual mass movement. As he pointed out himself, his maxims were impartiality and truth, which meant portraying the different parties and their standpoints without any judgment.

If we turn to Sleidan's correspondence, we can shed some more light on the question of his religious beliefs. Although Sleidan wrote predominantly a history of Lutheranism, we hear no praise of Luther in his correspondence. Unfortunately, no letters between Luther and Sleidan are extant, but from Sleidan's remarks we can conclude that the two men were in correspondence. Sleidan mentioned several times in his letters that he contacted Luther for information and material, and the Wittenberg Reformer had expressed admiration for Sleidan's Two Orations. ${ }^{42}$ For the early years of his history, Sleidan had used Luther's works as far as they were published, as we can deduce from his correspondence. $^{43}$ None of his letters, however, betray any open adoration of Luther.

Similarly, Melanchthon occupies only a marginal role in Sleidan's correspondence, but in contrast to Luther Sleidan offered his personal opinions on him. One letter from Sleidan to Melanchthon has been preserved, and one from Melanchthon to Sleidan; it is the letters in which Sleidan refers to Melanchthon, however, which are interesting. ${ }^{44}$ In his very first extant letter from spring 1530, addressed to his old professor Rescius, Sleidan

${ }^{42}$ Cf. Appendix I, No. 59, 66, 71, 72 .

${ }^{43}$ Cf. Appendix I, No. $77,78,79,81$.

${ }^{44}$ Cf. Appendix I, No. 249, 405. 
showed warm admiration for Melanchthon, and praised him as most diligent and perfect. ${ }^{45}$ All in all, this seems to be more a humanist view than a religious statement. In 1550 , Sleidan remarked at a dinner in the house of the noble von Werthern in Strasbourg - with the other guests being the printer and martyrologist Ludwig Rabus and the theologian Caspar Hedio - that he thought Melanchthon was too moderate. ${ }^{46}$ This view was shared by Calvin, who complained to Sleidan about Melanchthon's timidity in a letter of 27 August $1554 .{ }^{47}$ Despite Melanchthon's negative verdict about Sleidan's Commentaries, he invited Sleidan for dinner and even presented him with one of his works, as Hotman reported. ${ }^{48}$ Melanchthon's extant letter to Sleidan from August 1556 is perfectly amicable and does not make any reference to the Commentaries. ${ }^{49}$ All in all, although the two men met each other and were in correspondence, one can certainly not make the case for Sleidan as a follower of Melanchthon, best illustrated by Sleidan's frustration with Melanchthon's moderation.

Jean Calvin occupied only a marginal role in the Commentaries. He made his main appearances in the year 1532 as first minister of the French church in Strasbourg, and in the year 1555 in the context of the uprisings in Geneva against the French exiles. ${ }^{50}$ In Sleidan's correspondence, however, the reformer becomes much more important. Only one letter from Calvin to Sleidan has been preserved, dating from 1554, but nine letters from Sleidan to Calvin: one from 1539, two from 1553, three from 1554, two from 1555

\footnotetext{
${ }^{45}$ Cf. Appendix I, No. 1; see chapter 1.

${ }^{46}$ We know about this scene from Crusius' Annales suevici, p. 676 (Appendix I, No. 203).

${ }^{47}$ 'De Philippi [Melanchthon] consensu quantopere una in re mihi gratulari debeam nescio: quando in summis captitibus vel philosophis se venditans sanam doctrinam aperte oppugnat: vel ne in se quorundam irritet odia, sensum suum astute, saltem parum ingenue, tegit. Dominus eum fortiore spiritu instruat, ne gravem ex eius timiditate iacturam sentiat posteritas.' (Baumgarten, Briefwechsel, No. 134; Appendix I, No. 319).

${ }^{48}$ Cf. Melanchthon's letter to Christoph Leib, criticising Sleidan (Appendix I, No. 341; cf. chapter 3).

Hotman's letter can be found in CR 44, No. 2447; Appendix I, No. 391.

${ }^{49} \mathrm{Cf}$. Appendix I, No. 404.

${ }^{50}$ Cf. Sleidan, De Statu Religionis (Rihel: 1559 ), fols. Y4v, KK1r.
} 
and finally one from $1556 .{ }^{51}$ These letters, spanning almost all of Sleidan's active life as diplomat and historian, refer to several other letters between the two men which are unfortunately lost. Sleidan's letter to Calvin from 22 May 1539 was his first letter to the reformer who was to become so important for him, as Sleidan called himself an 'unknown man'. ${ }^{52}$ He thanked Calvin for trusting him to ask him for a favour, a connection which seems to have been established by their mutual friend Jean Sturm. A year later, at the diet of Hagenau, the two men met for the first time, Sleidan as a legate of the French court and Du Bellay, Calvin as a legate of Strasbourg.

For a period of thirteen years no correspondence between the two survived, but in the vital period when Sleidan was completing the Commentaries he wrote to Calvin several times for material and advice. Calvin seems to have assisted Sleidan in finding material especially about matters appertaining to France, like the persecutions of the Waldensians. Sleidan in turn sent him abstracts from the Commentaries and finally a completed copy for comments. Apart from this correspondence concerning Sleidan's historical work, the two men also conversed about political and religious matters: both shared the view that Melanchthon was too hesitant. ${ }^{53}$ When Sleidan was appointed one of the administrators of the French church in Strasbourg, which in its early phase had been led by Calvin, the two men had even more topics to discuss. Calvin expressed his joy about Sleidan's involvement, and Sleidan kept his friend informed about the church's affairs. ${ }^{54}$

From the extant information is is difficult to say how strong Calvin's influence on Sleidan's religious views was. The Commentaries do not place Calvin in the centre of the Reformation. This, however, could be explained with two reasons: firstly, there is the

${ }^{51}$ Cf. Appendix I, No. 298, 300, 306, 317, 319, 320, 360, 368, 387

${ }_{53}^{52}$ Sleidan wrote 'homo ignotus' (Baumgarten, Briefwechsel, No. 2; Appendix I, No. 5).

${ }^{53}$ Cf. Appendix I, No. 203 and 319.

${ }^{54}$ Cf. chapter 2; Cf. Appendix I, No. 319, 320. 
possibility that the involvement of Jacob Sturm, Peter Paul Vergerio and Peter Martyr

Vermigli in proofreading and editing the Commentaries could have had an influence on the portrayal of the different groups within Protestantism. Secondly, one should not neglect the timeframe: when the Commentaries were published in 1555 , Calvin was already at the forefront of European reformers and had made a vital contribution with his Institutions, but he had not yet acquired his role as the leader of a new, distinct Protestant group, that is Calvinism.

It is most interesting in this context, however, that Sleidan's connections to Calvin and his role in the Commentaries sufficed for some of his contemporaries to classify him as a Calvinist, as is demonstrated in a mock poem from 1570. The author Johannes Avicinius, a Jesuit, called Sleidan 'a Calvinist, a liar', a view that was possibly shared by many others. ${ }^{55}$ Caspar Gennep in his 1559 refutation of the Commentaries went even further: he found Sleidan's religious convictions so opaque that he called him an atheist. ${ }^{56}$

It seems as if Sleidan cannot be put into any category within Protestantism other than that of a general moderate reformed one. At the time when the Commentaries were published, however, during the Diet of Ausgburg when the fate of Protestantism in

\footnotetext{
55 'Wie dann auch gwesen ist ist Schleidan/ Ein Calvinist, verlogner Mann. ...', in: Johannes Avicinius, Chronologia Evangelica. Das ist ein Summarischer Außzug der Newevangelischen Chronicken/ darinn der Anfang/ erweiterung/ unnd früchten des newen Christenthumbs/ wie es D. Martin Luther selbst/gepflanzt hat/ ordenlich beschriben/ unnd menigklich zulesen in lustige Reymen gestellt, Ingolstadt (Alexander Weissenhorn d.J.) 1570, fol. 20v. We shall examine this work in greater detail in chapter 5 when discussing Sleidan's reception in Germany.

${ }^{56}$ 'Ob er auch gleichwol die Augspurgische Confession sehr über die Catholische Religion erhibt/ ist doch auß seym schreiben leichtlich abzunemmen/ das er der Religion keyner anhengig ist/....'; Caspar Gennep, Epitome Warhaftiger Beschreibung der Vornembsten Händel/so sich in Geistlichen unnd Weltlichen sachen/ Vom Jar unsers Herren M.D. biß in das jar der mynderen zal Lix. zugetragen vnd verlauffen haben. ... Mit anzeigung wie offt und vil Sleidanus mehe auß neigung des Affects/dan liebe der Warheit/ etliche dyng beschriben hat, Cologne (Caspar Gennep) 1559, fols. [ ]2v-[ ]3r. It is difficult, however, to explain this unusual characterisation of Sleidan's confession. Did Gennep think indeed that Sleidan's portrayal of Protestants and Catholics was so impartial that he could not discern Sleidan's own view of events? This would go against the thoughts Gennep uttered in his preface. The characterisation of Sleidan as an atheist might be rather attributed to polemics, since an atheist would have earned contempt from Protestants and Catholics alike. Besides, which credibility would have been attributed to a non-Christian account of the Reformation?
} 
Germany was to be decided, this was a potentially dangerous position. This was all the more the case when such a conviction was underlying the first Protestant - and, to be more precise, the first Lutheran - history of the Reformation. Additionally, the fact that Sleidan was based in tolerant Strasbourg would further heighten already existing suspicions against him. Strasbourg's tendencies towards Zwinglianism and its French outlook had more than once caught the attention of the Empire and the other German Protestants. ${ }^{57}$

\section{Alea iacta est: Sleidan as official historian of the Schmalkaldic League}

Now that we have examined in detail Sleidan's circle of acquaintances and what could be said about his religious conviction, it is time to ask why of all qualified people it was Sleidan who was chosen as the official historian of the Schmalkaldic League. After all, the League was the official political organ of the German Protestant - that is Lutheran princes, and as such the first political Lutheran organisation in the homeland of Protestantism. Sleidan seems not to have been the most obvious choice for fulfilling such an important role: he was young, could not look back on a long career in Germany, and he had a rather French background. So was Sleidan the only choice, and why was he appointed for this pivotal task for the establishment of German Protestantism?

Martin Bucer and Jacob Sturm appeared to be very adamant on their choice of Sleidan as the historian of the Schmalkaldic League. None of the extant correspondence on this issue mentions another name for this post, and we are not aware of any other candidate. There is only one reference to hesitancy towards Sleidan's employment, as expressed by Bucer in a letter to Philip of Hesse from 15 March 1545. After underlining Sleidan's skills again, Bucer expressed his concern that Saxony might not agree with Sleidan's employment and wonders whether they wanted to have somebody else employed

\footnotetext{
${ }^{57}$ On the Zwinglian tendencies of Strasbourg, see Ekkehart Fabian, Die Entstehung des Schmalkaldischen Bundes und seiner Verfassung, Tübingen 1956.
} 
as historiographer. ${ }^{58}$ Am Ende suggested that Christoph von Carlowitz, the Saxon Chancellor, would have preferred the scholar Hieronymus Wolff as the author of the planned Protestant history. ${ }^{59}$ However, Bucer's letter is the only one that even hints that there were other possible candidates; neither Jacob Sturm nor Philip of Hesse mentioned any rumours of that kind.

It is a little surprising that the first and seemingly only choice for this important office as official historiographer of the German Protestants should be Sleidan. Certainly the League would have had a wider range of able scholars to choose from. The first name who springs in mind here is that of Philip Melanchthon, who from the early stages of his career onwards had professed a profound interest in history, and had proved his ability for example with his involvement in Carion's Chronicon, published in $1532 .^{60}$ Yet Melanchthon's name never came up as possible candidate, and in fact his name never appeared in connection with the Commentaries throughout the ten years of their composition - only after the publication did Melanchthon express his disapproval. As we can see from Sleidan's correspondence, the two men were aware of each other and both cared enough to send their regards through mutual friends.

The key to Sleidan's employment seems to lie with Martin Bucer and Jacob Sturm. Although Sleidan was employed by the Schmalkaldic League, it had not been the League's official leaders, the princes of Hesse and Saxony, who had initially suggested a historical project of this kind. Instead, the idea for the Protestant history had originated from Bucer and Sturm, and their choice was Sleidan. In 1544/45, Martin Bucer still played a strong

\footnotetext{
${ }^{58}$ Cf. Appendix I, No. 50.

${ }^{59}$ Carl Christian Am Ende remarked that Hieronymus Wolff himself mentioned in his Commentariolo de vitae suae ratione ac fortuna that Christoph von Carlowitz had offered him the position which had been so destructive for Sleidan (Vermischte Anmerkungen über den berähmten Geschichtsschreiber Johann Sleidan, Nuremberg 1780 , fols. a3r-v).

${ }^{60}$ On Carion' Chronicon and Melanchthon's contributions, see chapter 4.
} 
role in Strasbourg, in the Schmalkaldic League, and indeed at the forefront of the European Reformation. He was the right hand of Philip of Hesse and close ally of Jacob Sturm. At the time of Sleidan's employment both were at the forefront of the German Reformation and the political organisation of the German Protestants. Equally, one should not forget that Sleidan was not only employed as a historian, he was also to fulfill diplomatic duties for the League, as his contract specified. ${ }^{61}$ Sleidan with his language skills and excellent contacts to France was a valuable asset at a time when the German Protestants still tried to form an alliance with France, an even more urgent issue in the face of rumours about a war.

\section{Diplomat of the Schmalkaldic League - and France?}

It was possibly already the threatening shadow of such a war with the Emperor that necessitated Sleidan's first diplomatic duty as a diplomat of the Schmalkaldic League.

Once again, an alliance with France and possibly even England was to be negotiated. Such a duty was not new to Sleidan, whose time in France had largely been spent pursuing this policy. In France, Sleidan had been the connection of the German Protestants with the reform-friendly circle around the Du Bellays and through them even to the French court. Now, in Germany, Sleidan was still one of the prime links to France and an expert in all things French. Such a dual role seems also to be reflected in Sleidan's professional situation. Officially, he was now historian and diplomat of the Schmalkaldic League. However, there are indications that at least until 1547 Sleidan still had certain obligations towards France, as a letter by Jean Du Bellay from 1547 and other correspondence suggests. Such a double engagement would indeed raise a question over a conflict of loyalties.

${ }^{61}$ For an examination of Sleidan's contract with the Schmalkaldic League, cf. chapter 4. 
This letter from the Cardinal to Henry II from August 1547 deserves a closer look. Du Bellay pointed out the good services Sleidan had offered to France. Hence he had been granted a yearly pension of 100 écus, which he had been paid 'secretly', and he now hoped to continue to receive it even under Henry II. Du Bellay explained that Sleidan, a very skillful man, had become the secretary of the Protestant states with the permission of the (French!) king. Due to the Schmalkaldic war, his future seemed uncertain, and he was in need of support. Considering Sleidan's many services for France, which could become useful again, he advised the continuation of Sleidan's payment. ${ }^{62}$

The Cardinal's letter not only shows his faithfulness towards his old protégé, but far more than that, it suggests that until the summer of 1547 Sleidan was still in the service of France, while at the same time in the Empire he was working for the Schmalkaldic League. An examination of Sleidan's correspondence of the years 1544 until 1547 offers the same interpretation: frequent contacts with Du Bellay informed the Cardinal about events in Germany and the proceedings of the League; simultaneously, Sleidan's letters unraveled events in France to Sturm. This double engagement was to cause Sleidan uncomfortable moments. In May 1546, when Sleidan was accused of misrepresenting French policy, he threatened to quit his employment for France if his innocence was not believed. $^{63}$ Likewise, one might assume that the Schmalkaldic League had been aware of Sleidan's double engagement since they continued turning towards Sleidan for information

\footnotetext{
62 'Sire, du temps du feu roy vous m'avez assez oüy parler de Sleidanus, qui estoit secrétaire des estats protestants, où il estoit entré par permission dudit sr., afin d'avoir plus de moyen de luy faire service, sans faillir toutesfois de faire son devoir envers eux; ... si vostre bon plaisir est de l'entretenir en ce qu'il avoit dudit feu roy, qui n'estoit que cent escus de pension, qui secretement luy estoient payez par le trésorier de l'espargne, comme il se peut voir par les recepissez. ...Il n'y en a guères d'autres de son estat garnis qui soient de sçavoir ny d'esprit et expérience d'affaires tant que luy, et en fidélité nul de là le passe. Il est vray que ses moyens sont affoiblis par la ruine des estats telle que dessus et par la prison de princes, mais encores pourra-i1, l'occasion advenant et à point nommé, vous faire grand service; ...' (Jean Du Bellay to Henry II, 13 August 1547; Baumgarten, Briefwechsel, No. 80; Appendix I, No. 185).

${ }^{63}$ Cf. Appendix I, No. 165.
} 
on the situation in France and were aware of the continuous rumours of Sleidan's connections with France. For both sides, Sleidan was an extremely valuable asset.

\section{The mission to England}

Wherever his loyalties lay, Sleidan had to fulfill his diplomatic duties towards the Schmalkaldic League. He was once again required to assist in renewed negotiations between France and the German Protestants. As we have seen above, the peace of Crépy in September 1544 had stalled momentum in the German Protestants' search for possible allies. However, attempts to regain a diplomatic initiative took on a renewed urgency in the face of the threat of an attack by the Emperor. In May 1545 Bucer had suggested that Sleidan should compose a French tract for the Emperor to show him that he was indeed in a position to reform the church. ${ }^{64}$ This writing was possibly never composed, but fears among the German Protestants of a Franco-Imperial alliance and French fears of an alliance between the German Protestants and the English made the French and the German Protestants move closer to each other again.

With this in mind, the Schmalkaldic League offered the help of its legates to France and England to help negotiate a peace between the two quarreling countries, and thereby work towards an alliance between the three parties. The plans for such an enterprise were quickly made: one group of legates, that is Jean Sturm, Johann von Nidbruck - Sleidan's future father-in-law - and Christoph von Venningen, was to travel to France, the other, Sleidan and the Hesse marshal Ludwig von Baumbach, was to conduct negotiations with the English. At the anticipated conclusion of this venture, all parties were to meet in

\footnotetext{
${ }^{64}$ Cf. Appendix I, No. 70, 72 and 76. On 29 May 1545 Bucer wrote to Jacob Sturm about this writing to the Emperor he wanted Sleidan to compose, and lined out the intended content: 'Sleidano suasi, ut, quia imperatori imperii ratio maxima, tractaret hos tres locos: potestatem imperatoris esse supra omnem animam, eiusque esse reformare ecclesias, episcopos omnes pares et habere ministerium omnino a procuratione concilii (?)remotum.' (PC 3, No. 570, p. 599; Appendix I, No. 70).
} 
Northern France for negotiations. ${ }^{65}$ Such a mission, difficult in itself, was even more fragile when considering that at the same time official negotiations were taking place at Calais between France, England and the Emperor, who obviously was keen to thwart the German Protestants' plans.

On 28 August 1545, Sleidan and his companions, the Hesse Marshal Ludwig von Baumbach and Philip von Nidbruck, left Strasbourg. ${ }^{66}$ After meeting with their legates to France and the French at Amiens, they arrived at Windsor on 19 September. ${ }^{67}$ Soon after their arrival at the court, Sleidan seized the moment and advertised his own work as Protestant historiographer to Henry VIII. ${ }^{68}$ He also informed William Paget, one of Henry's VIII principal secretaries and also involved in the negotiations with France and the German Protestants, about his project. ${ }^{69}$ To foster the negotiations, Sleidan composed a writing about the jurisdiction of the Pope in France, which he sent to both Francis I and Henry VIII. ${ }^{70}$ Unfortunately, this writing has not been preserved.

The negotiations themselves, conducted at Ardres and Calais and missions to the respective courts, however, proved to be hard. Neither France nor England would make concessions concerning the main disagreements between them, the question of Boulogne and the future husband of Mary Stewart, heiress to the Scottish throne. Sleidan and

\footnotetext{
${ }^{65} \mathrm{Cf}$. Appendix I, No. 83, and 88-93. Sleidan himself would have prefered to be part of the mission to France, as he explained to Jacob Sturm in July 1545 (Appendix I, No. 87).

${ }^{66}$ Philip von Nidbruck was the son of Johann von Nidbruck and Sleidan's future brother-in-law.

${ }^{67}$ For their itinerary, see Appendix I, No.142. A large number of documents on these missions have been preserved, cf. Appendix I, No. 93-152.

68 'Je congnois mon ignorance en ce que je ose presenter à vostre majeste royalle une chose si petite comme ce present livre par moy composue, mais cognoissant vostre doulceur et humanité estre si grande, qu'elle n'en scauroit estre plus en ung tel prince et monarche, je me suis enhardy de vous en faire offre, suppliant tres humblement vostre majesté de le prendre en gré et supporter benignement les faultes qui y peuvent estre.' (Baumgarten, Briefwechsel, No. 44, p. 90; Appendix I, No. 97, see also another letter to Henry VIII under No. 131). In a letter to Paget from 24 October 1545 he called himself '...serviteur ...de (la ville de Strasbourg)...comme aussi de toute la ligue des protestans' (Baumgarten, Briefwechsel, No. 51, p.97; Appendix I, No. 107).

${ }^{69}$ Cf. Appendix I, No. 124. On Sleidan's efforts for the Commentaries during this mission to England, see chapter 4 .

${ }^{70}$ Wiliam Paget mentions such a writing in his letter to Petre (Appendix I, No. 136).
} 
Baumbach left on 12 October to join the main negotiations in Calais, where the meetings between France, England and the Emperor took place. Paget, who later joined them at Calais, seemed not to have been too impressed with the German legates as we can conclude from his unflattering remark to King Henry VIII: 'This Sturmius, Sir, is a great practisioner and whatsoever he sayth is all togidre French; but yet, if he had not been, the rest of his colleges be such shepe, except Bruno, who is more witty and grave ten [=than] inventive, we had broken up er this tyme. ${ }^{71}$ Unfortunately, despite the Protestants' efforts the different parties could not come to any agreements, and the negotiations had to be broken off. $^{72}$ At the same time rumours arose that the Emperor was preparing a war against the Schmalkaldic League. Although Sleidan was only one of several ambassadors and seems not to have taken a leading role in these negotiations, he certainly used every opportunity to acquaint himself with the English governing class and make them aware of his scholarly aspirations. This initial contact would certainly put him into an advantageous position when the collapse of the Schmalkaldic League soon left him without employer.

\section{Domestic happiness}

Sleidan left Calais on 6 January 1546 and returned to Strasbourg. He remained for four days, before he left for the meeting of the Schmalkaldic League at Frankfurt on 3 February to report about the mission. ${ }^{73}$ In March, he was back in Strasbourg and between the $13^{\text {th }}$ and $15^{\text {th }}$ of the same month he married Jola von Nidbruck in the church of St. Wilhelm. ${ }^{74}$

\footnotetext{
${ }^{71}$ Quotation from Baumgarten, Briefwechsel, p.xv; also Brodie, R.H./Gairdner J., Letters and Papers, Foreign and Domestic, of the Reign of Henry VIII, preserved in the Public Record Office, the British Museum and elsewhere in England, vols. XX/II, XXI/I, London 1907-1908 (hereafter LP), vol. XX/II, No. 917, pp. 459-460; Appendix I, No. 125.

${ }^{72}$ Already in November 1546 Jean Du Bellay, who had worked for a Franco-German alliance for the last decade, had given up hopes for a successful outcome of the negotiations, and remarked to Wotton that the Evangelical cause was over ('actum est de negocio Evangelii', Wotton to Paget, 28 November 1546, LP $\mathrm{XXI} / \mathrm{II}$, No. 457 , pp. 214-216).

${ }^{73}$ Cf. Appendix I, No. 142-147.

${ }^{74}$ In a letter from 12 March 1546, Sleidan announced the wedding for 15 March to Jean Du Bellay (Appendix I, No. 153). The church register of the church of St. Wilhelm lists the wedding under 13-14 March (Appendix I, No. 156).
} 
His young bride was the daughter of Johann von Nidbruck, known as Dr. Bruno or Hans von Metz, who had taken part in the parallel French delegation during Sleidan's mission to England. ${ }^{75}$ Nidbruck himself was an important personality in Alsace; originally from Metz, the religious persecutions forced him to move to Strasbourg in 1543. During his diplomatic career, he worked in the services of France, the Schmalkaldic League, England and Strasbourg, similar to Sleidan. ${ }^{76}$ Sleidan's marriage cemented his position in the upper bourgeoisie. His father-in-law, a diplomatic colleague from the 1545 mission to England and France, moved in the same circles. In taking on the responsibilities of a family, Sleidan indicated that at the time he considered that his future lay in Strasbourg where he gave a good indication of wanting to settle.

The marriage was to all appearances a successful and happy one, although Sleidan provides little detail about his domestic circumstances in his correspondence. We do not even know the age of his bride at the time they married or where the family lived. The young couple moved amongst the educated elite of Strasbourg. Next to the Sturms and Bucer they were also good friends with the printers Wendelin Rihel and also Crato Mylius (Krafft Müller), both of whom printed Sleidan's work. Sleidan's wife became the godmother of Mylius' son Philip, and after the death of the Sleidans Wendelin Rihel's son Josias was to become the guardian of their children. ${ }^{77}$ Later also Peter Martyr Vermigli and Francis Hotman moved in Sleidan's circle. Sleidan's marriage was blessed with three children, all of them girls. The oldest, Magdalena, was baptized in March 1547, followed

\footnotetext{
${ }_{75}^{75}$ Cf. Appendix I, No. $153,156,158$.

${ }^{76}$ On Johann von Nidbruck, cf. e.g. Rott, 'Nouveaux Documents', p. 559, fn. 2. One of Jola's brothers, Philip, married into the upper class of Strasbourg, and one of her sisters married the baron Franz von Mörsberg. Mörsberg amassed great debts, so that after Nidbruck's death his inheritance was used to pay off Mörsberg's debts. Josias Rihel, the girls' guardian, complained to the Strasbourg city council in 1564 that because of these debts Sleidan's orphaned daughters had inherited nothing from Nidbruck (cf. Appendix I, No. 436).

${ }^{77}$ Concerning Josias Rihel's role as guardian of Sleidan's daughters, cf. Appendix I, No. 47. On Mylius cf. Miriam Usher Chrisman, Lay Culture, p. 26.
} 
by Maria, born between 1548 and 1552 , and Jola, baptized on 15 March $1553 .^{78}$ To

Sleidan's great grief his wife did not survive childbed and was buried only a few days after little Jola's baptism, on 21 March. ${ }^{79}$ When Johann Marbach suggested a year later that he marry the daughter of a friend, Sleidan briskly turned the offer down; a second marriage was out of question for him. ${ }^{80}$

Despite these new domestic responsibilities as the head of a family, Sleidan was not excused from further diplomatic journeys on behalf of the League. Later that year, Sleidan was supposed to travel together with his father-in-law to England for a second mission, this time to obtain French support for the impending Schmalkaldic war, while Jean Sturm and Johann Keudel were sent to France, but he was otherwise engaged. ${ }^{81}$ The domestic bliss with his young wife, who he introduced to his family and his former pupil Count Franz von Manderscheid in the summer of that year, was marred by new accusations against him in early $1546 .^{82}$ Exactly as had been the case five years before, his double engagement for France and the Schmalkaldic League brought him no luck and he was accused of misrepresenting French policy and the French position regarding an alliance with the German Protestants. ${ }^{83}$ The League defended him and wrote to Francis on his behalf. Sleidan, who was very much upset about the affair, himself wrote to the French king and to Du Bellay to clear his name.

\footnotetext{
${ }^{78}$ Cf. Appendix I, No. 181, 291.

${ }^{79}$ Cf. Appendix I, No. 293.

${ }^{80}$ Cf. Appendix I, No. 302.

${ }^{81}$ Cf. Appendix I, No. 174, 175. On these negotiations, see Schmidt, Jean Sturm, pp. 68-70, Reuss, Histoire de Strasbourg, p. 135.

${ }^{82}$ Sleidan mentioned these visits to Jean Du Bellay (Appendix I, No. 165).

${ }^{83}$ Cf. Appendix I, No. 149, 153, 154, 155, 156, 161, 162, 165, 166, 167, 170. In his letter to Philip of Hesse from 15 May 1546, Sleidan remarked that the Du Bellays had many enemies at the French court due to continuous rumours that they were secret Protstants (Appendix I, No. 167).
} 
The end of the Protestant hopes? - The Schmalkaldic War

Not long after this, any deliberations about an alliance between France and the League were put to an end with the outbreak of the Schmalkaldic war in July 1546. Sleidan still retained his optimism for a while and composed a tract on the relation between the Emperor and the Pope which he intended to be published; this he sent to Du Bellay for his opinion. He even suggested that the Cardinal should give a copy of this writing to the Pope as the work of a Catholic to make sure he would read it. ${ }^{84}$ Unfortunately, like the earlier tract on a similar topic which Sleidan had sent to Francis I and Henry VIII, this writing did not survive. After his initial optimism, even Sleidan gave up hope.

The Protestants had tried in vain to obtain support from France for a possible war, but the defection of Maurice of Saxony into the imperial camp sealed their fate. The leaders of the League were put under the Imperial ban, the Emperor attacked, and city after city had to submit to the imperial forces. The devastating battle of Mühlberg in April 1547 led to the imprisonment of Philip of Hesse and John Frederic of Saxony. With its cause defeated and its leaders imprisoned, the Schmalkaldic League was dissolved, and Protestant hopes were in disarray. The political climate in Europe further changed with the deaths of Francis I and Henry VIII in early 1547 and the 1548 Augsburg Interim. For Sleidan, the capture of his patrons and the dissolution of the League meant a halt to his work on the Commentaries.

One could only imagine the impact of these calamitous events as Sleidan observed them from Strasbourg. At a time when the whole future of German Protestantism hung by a thread, the future of its official history must have seemed of scant importance, but for Sleidan the personal implications were also very serious. The dissolution of the League

${ }^{84}$ Cf. Sleidan's letter to Du Bellay from 25 January 1547 (Appendix I, No. 180). 
meant, of course, the end of his salary since his contract was with an organisation that no longer existed. Even had he been minded to continue his work, Charles' victory meant that the principal archives of the League would now no longer be available, at least for a time. Sleidan described his desparate situation to Jean Du Bellay, now established in Rome, who tried his best for his old protégé, petitioning the new king Henry II to continue paying a pension to Sleidan, but both his and Sleidan's influence in France were over. ${ }^{85}$

Following the defeat of the League Sleidan could not expect help from either the German Protestants or France. Freed of diplomatic duties and with the collapse of his principal venture Sleidan instinctively turned to other scholarly projects. He made good use of the compulsory spare time and gave his attention again towards the translations of works by French historians into Latin. He wrote a Latin version of another work by Philippe de Commynes on the reign of Charles VIII, Philippi Cominaei equitis, de Carolo Octavo, Galliae rege, \& bello Neapolitano, Commentarii, and translated a political work by Claude de Seyssel into Latin as Claudii Sesellii, viri partricii, de republica Galliae \& regum officiis, both published in 1548 . Together with the edition of Seyssel, Sleidan also published a work of his own, a short tract on state and law derived from Plato, Summa doctrinae Platonibus de republica et legibus.

These three works came into being at the end of a short yet very important epoch in Sleidan's life. In these few years after he had moved to Strasbourg he had fully established himself in society. His marriage with Jola meant his social establishment as husband and father, he was blessed with a happy family. Professionally, he once again fulfilled diplomatic tasks, this time primarily for the Schmalkaldic League, working in the same

\footnotetext{
${ }^{85}$ Jean Du Bellay to Henry II, 13 August 1547 (Appendix I, No. 185), see above. Since with the ascendancy of Henry II the political situation in France had changed, the Cardinal left for Rome, where he died in 1560.
} 
field as in his time in France. His prime obligation towards the League was the composition of a Protestant history. With the collapse of the League also came the collapse of Sleidan's employment, and once again he had to face insecure times. In this vacuum, Sleidan further practised his historical skills by devoting his time to the works mentioned above. In a sense, they stand for the end of one era, that of Sleidan's employment by the League, which had promised a bright future. Yet Sleidan did not dwell long on what was past, but composed these works as a path to a new future. He needed a new employer or at least financial support to fulfill his task to write the history of the Reformation. Like so many others at this time, he set his hopes on England, and dedicated these three works to the elite of what at the time had become the haven of Protestantism. 


\section{CHAPTER 3: IN THE SERVICE OF STRASBOURG}

We have seen in the previous chapter that the dissolution of the Schmalkaldic League had abruptly ended Sleidan's contract and with it his task to write the official history of Protestantism. Sleidan's will to pursue this task, however, was unbroken. There is little doubt that he was exploring a new field for his talents. Closer inspection of his works from 1548 reveal that Sleidan had already begun to think imaginatively of how he might sustain his career following the collapse of the League. Like many a leading Protestant at this juncture, Sleidan's eyes turned to England. In the hope of support, Sleidan dedicated all three of these works from 1548 to leading figures in England, the new king Edward VI, the Duke of Somerset, and William Paget.

\section{Looking towards England}

At a time when continental Protestantism seemed everywhere on retreat, the dawn of a new Protestant regime in England seemed to many continental Protestants the only bright light on the horizon. This sense of providential opportunity was fully shared by the new leaders of the Edwardian regime, who soon bent their energies to entice the leaders of continental Protestantism to assist the creation of a new Protestant state in England. Cranmer in particular saw the opportunity both to offer England as a refuge and recruit leading figures of the established Protestant churches to assist in the creation of a new church polity.

Invitations were dispatched to most of the leading figures of the Reformed and Lutheran churches, and several significant figures soon made their way to England, including most notably Martin Bucer, Peter Martyr Vermigli and Paul Fagius. It must be of little surprise that Bucer's protegés should have considered a similar step. If Strasbourg 
now had little to offer to Sleidan, then he was better placed than many to take advantage of the new opportunities opening up across the Channel. Many of the new regime were known personally to him from the diplomatic negotiations of 1544 to 1545 , and his choice of recipients for the dedications of his works of 1548 reveal a shrewd understanding of the new English power structures. Let us now turn to examine these works.

\section{Sleidan's version of Philippe de Commynes' work on Charles VIII (1548)}

The first of Sleidan's 1548 works was a Latin version of yet another work of Philippe de Commynes, Philippi Cominaei equitis, de Carolo Octavo, Galliae rege, \& bello Neapolitano, Commentarii, published by Wendelin Rihel in Strasbourg, bearing Sleidan's name on the title page. ${ }^{1}$ In 1545 , Sleidan had addressed his Latin version of Commynes' work on Charles VIII and the Burgundian war to Philip of Hesse and John Frederic of Saxony, in the hope to find employment as historian. Now he looked towards England for financial support. Sleidan's dedication to his second adaptation of a work by Commynes was addressed to the Protector Edward Duke of Somerset, signed in Strasbourg in May 1548.

In this dedication, Sleidan praised the outstanding achievement of Julius Caesar as a historian. Caesar was to be admired and imitated for his adherence to the principles of history as expressed in his avoidance of partiality and his clear, unaffected description of the truth. He declared Commynes to be a historian of equal rank, of great importance both as historian and politician. In his concluding sentences, Sleidan expressed his admiration of Somerset and hoped that Commynes' description of events in France and Italy would

\footnotetext{
${ }^{1}$ Other sixteenth-century editions from Vekene, Bibliographie:

F/a 006 Strasbourg: Wendelin Rihel (80) 1548

F/a 010 Paris: André Wechel 1561 (8o)

F/a 011 Paris: (A. Wechel for) Jacques Dupuys 1561 (80)

F/a 013 Strasbourg: Josias Rihel 1562/64 (8o).
} 
help him rule the great country of England. Furthermore, he also recommended the book as valuable reading for the young King Edward and expressed his admiration of the archbishop of Canterbury.

Again one wonders why Sleidan chose again to offer a Latin version of another French history. Sleidan was fully aware that his choice was an unusual one. In the postscript to this work, a life of Commynes under the heading 'Johann Sleidan to the reader' he addressed the question himself: 'Somebody might ask, why are you, a German, interested in Commynes?' He then explains that he chanced upon the works of Commynes through a very learned friend, Matthew of Arras, who had worked with Commynes and thus knew him personally. He had warmly recommended Commynes as one of the best historians, and had even read Sleidan's 1545 version of Commynes. Since so many different accounts of French history were offered, Sleidan considered it valuable to render into Latin the best and most recent history, that is Commynes'. ${ }^{2}$ It is doubtful whether these were the real or only motives of Sleidan for composing this version of Commynes. We have pointed out before Commynes' view of history and his emphasis on the important role of the princes. These were possible ideas that Sleidan wanted to introduce to Somerset and through him to young Edward, from whom he wanted to obtain support in these bleak times.

\footnotetext{
2 'Quaerat aliquis, unde haec de Cominaeo, tibi, homini Germano? Dicam paucis. Est apud Carnutes in Galliis, vir cum primis honestus \& eruditus Mattheus Arrebus. Is domestice novit Cominaeum, eique famulatus est, ac praeceptor deinde fuit è filia nepotis, quem paulo supra Ducem Stampensem. Legit hic forte alteram Cominaei historiam, de Ludovico vndecimo \& Carolo Burgundiae Duce, quam superioribus annis Latinam feci, \& delectatus, ut ait, argumento, propter heri fui praestantissimi viri memoriam, ea quae supra commemoravimus, peramicum quendam mihi communicavit. Et quoniam illius laudes verecunde suo scripto praedicat, idcirco maiorem ei fidem tribuendam esse putavi, ac pergratum mihi fuit, quod eadem fere, quae per Galliam saepe \& ab aliis audiueram, ex ipso, qui familiarius ac propius omnia novisset, cognoscerem.' (Philippi Cominaei equitis, Strasbourg: Wendelin Rihel 1548, fol. Q6v).
} 


\section{Sleidan' translation of Claude de Seyssel (1548)}

To make sure that his plea was heard in England, Sleidan also dedicated his second Latin version of a French historian of that year to England. Shortly after Commynes, Sleidan published a translation of Claude de Seyssel's Grande Monarchie de France (1519) under the title Claudii Sesellii, viri partricii, de republica Galliae \& regum officiis. Like the Commynes, this work was published by his friend Wendelin Rihel in Strasbourg, who also was the first to publish Sleidan's own works. ${ }^{3}$ Like Froissart and especially Commynes, Seyssel (ca. 1450-1520) had also been closely connected to the royal court at his time. He served as a diplomat and counsellor to Louis XII before embarking on a career in the church, culminating in his consecration as archbishop of Turin in 1517. Apart from his functions in church and state, Seyssel had also devoted his time to translating histories by Eusebius, Thucydides, Appian and Xenophon.

Like the translation of Commynes of the same year, Sleidan also addressed the translation of Seyssel to England, this time to the young King Edward VI. In his dedication, composed in Strasbourg in June 1548, he underlined the importance of Aristotle and Plato for political thought. In the sixteenth century, Sleidan saw their outstanding approaches continued by Seyssel, whom he praised for his various achievements as statesman, cleric and historian. ${ }^{4} \mathrm{He}$ underlined Seyssel's excellent portrayal and criticism of the troubled times in which he had lived. ${ }^{5}$ In the usual formulation of a dedication to a king, Sleidan praised Edward's wisdom and learning, and warmly recommended the reading of both Commynes and Seyssel to him.

\footnotetext{
${ }^{3}$ Only two editions of this work were published, cf. Vekene, Bibliographie:

F/a 007 Strasbourg: Wendelin Rihel 1548 (80)

F/a 016 Strasbourg: (Josias Rihel, his device) 1562.

${ }^{4}$ Cf. Johann Sleidan (transl.), Claudii Sesellii, viri partricii, de republica Galliae \& regum officiis,

Strasbourg: Wendelin Rihel 1548, fols. a2r, a4r.

${ }^{5}$ Ibid., fol. a7r.
} 
Again one may ask why of all works waiting for translation, Sleidan chose the French histories by Commynes and de Seyssel to dedicate them to England? Certainly a translation of a French history to win the approval of the Germans and especially the English was not the most obvious choice for such a task. England's antagonism with France had continued throughout several centuries and was again the cause of war under Henry VIII. Sleidan's Latin versions of Froissart, de Seyssel and Commynes are a manifestation of his interest and admiration for his second home France, and demonstrate that their historical principles were largely his own. Sleidan's wish was to make those French histories which he considered the best accessible to a wider audience. His epitome of Froissart had served the cause of the Du Bellays, and with Commynes Sleidan had emphasised the need and value of a contemporary history. Possibly even de Seyssel's emphasis on a strong monarchy verging on absolutism could appeal not only to the French, but also to German and English Protestants at a time when the political rulers were seen as leaders in the faith. Both Commynes and de Seyssel had pointed out the strong role and obligation of the government, endorsed by Sleidan, who had emphasised to both Edward VI and Somerset the duties of godly princes. This would also have included the protection of the Protestant faith.

If we look at the historians themselves, one can certainly see parallels both between the lives and works of Sleidan and the three historians he must have regarded as role models. Froissart, Commynes and de Seyssel had all led an active life, being involved in the government of state and church of their time. They had served their country and rulers in various ways, being involved in many important missions and events. All three had underlined the importance of providing their contemporaries with an account of the most recent history, which Sleidan used as an argument to advertise himself as future historian of the Schmalkaldic League. Although Froissart, Commynes and de Seyssel did not 
emphasise the need to use primary sources yet, they laid great weight on the importance of their own experiences and eyewitness accounts, just as Sleidan would do later.

Additionally, all three of them used their prefaces and introductions to their work to underline veracity and impartiality as the prime aims of a historian. In all his own works, Sleidan was to highlight these values as essential for the writing of history.

Editions of Commynes and de Seyssel sold successfully and were published well into the next century. This popularity is further highlighted by later translations from Sleidan's Latin versions and compilation of his translations, like the 1578 compilation Tres gallicarum rerum scriptores nobilissimi, or the 1584 Duo gallicarum rerum scriptores, containing Froissart and Commynes. ${ }^{6}$ Furthermore, Sleidan's Latin translation of Commynes' Mémoires served as the basis for Caspar Hedio's German translation of this work as Histori Ursprung und Ursach des Burgundischen Kriegs in 1551/52. ${ }^{7}$

Interestingly from the late 1560 s onwards even many French editions of Commynes' Mémoires or Chroniques were published with Sleidan's epistle and annotations to his Latin translation. ${ }^{8}$

\footnotetext{
${ }^{6} \mathrm{Cf}$. Vekene, Bibliographie:

F/a 024: Tres gallicarum rerum scriptores nobilissimi: Philippus Cominaeus de rebus gestis a Ludovico XI et Carolo VIII, Francorum regibus: Frossardus in brevem Historiarum memorabilium epitomen contractus: Claudius Sesellius de Republ. Galliae, \& Regum officiis, Frankfurt/Main (Andreas Wechel) 1578 (20; includes Summa doctrina)

F/a 025 Duo gallicarum rerum scriptores, Frankfurt/Main: Andreas Wechel heirs 1584 (80), another edition by the same printers in 1594: F/a 028.

Part of Sleidan's translation of Froissart also features in F/a 026 Rerum Britannicarum. Heidelberg (Hieronyums Commelinus) 1587 (2o), and F/a 027 Rerum Britannicarum (Heidelberg Hieronyums Commelinus for) Lyon: René Postellier 1587 (2o).

${ }^{7}$ Cf. Vekene, Bibliographie: F/b 001: Strasbourg (Wendelin Rihel) 1551-52 (4o); another edition in 1566 (Strasbourg: Josias Rihel), F/b 002.

${ }^{8}$ Cf. Vekene, Bibliographie: F/b 003: Paris: Pierre du Pré 1567 (80); F/b 004: Paris: Mathurin Prévost 1567 (80); F/B 005: Paris: Claude Micard (80); F/b 006: (Rouen: George 1'Oyselet) for Claude Micard (Paris) 1576 (8o); F/b 007 (Rouen: George l'Oyselet) for Claude Micard (Paris) 1577 (8o); F/b 008: Paris: Vincent Normand 1577 (8o); F/b 009: Paris: Abel l'Angelier 1577 (8o); F/b 010: Paris: Nicolas Bonfons 1579 (8o); F/b 011: Paris: Abel l'Angelier 1579 (8o); F/b 012A: [Geneva] (Antoine Blanc for) Jacques Chouet 1593 (12o); F/b 012B: [Geneva] (Antoine Blanc for) Jacques Chouet 1593 (12o); F/b 013: s.1. Jacques Chouet 1596; F/b 014: Antwerp: Martin Nutius 1596 (120); F/b 015: Antwerp: Martin Nutius 1597 (120). 14 further such editions followed until 1714. All of these editions mentioned Sleidan on the title page, with the
} 


\section{The Summary of Plato's doctrine on state and laws (1548)}

Let us now turn again to Sleidan's work as a historian in 1548 . Together with the 1548 version of Commynes discussed above Sleidan had published a work of his own. This short tract, Summa doctrinae Platonis de republica et legibus, a summary of Plato's doctrine on state and law, was dedicated to another influential person in England, this time William Paget. ${ }^{9}$ In his dedication, Sleidan praised the usefulness of the Platonic teachings for a ruler; since Plato's works were rather long and complicated, he offered a summary of the best ideas. These explanations are followed by praise of Paget's qualities as a politician. ${ }^{10}$ In the tract itself, Sleidan portrayed the good and the evil ruler, and treated general topics like laws, war, and the education of young people - hinting at Edward VI. After summarising Plato's first book on laws, the tract ends with a short list of the main points of the Platonic teaching. The Summary of Plato's doctrine on state and laws never reached the popularity of Sleidan's other works. It was only published three times in Latin together with the translation of de Seyssel. Georg Lauterbeck published one German translation of this work, and also included it in six editions of his book on how to be a good ruler. ${ }^{11}$

exception of the two editions printed by Martin Nutius in Antwerp in 1596 and 1597, when censorship must have made this necessary.

${ }^{9}$ This work was first published as Claudii Sesellii, viri partricii, de republica Galliae \& regum officiis. Libri duo. Ioanne Sleidano, Interprete. Adiecta est summa doctrinae Platonis, de Repub. \& Legibus, Strasbourg: Wendelin Rihel, 1548.

${ }^{10}$ The dedication to William Paget is signed in June 1548; ibid., fols. $73 \mathrm{r}-47$ [ $\left.=74\right] \mathrm{r}$.

${ }^{11}$ The Summa doctrinae Platonis was published in Strasbourg by Rihel in 1548 (Vekene, Bibliographie, F/a 007) and 1562 (F/a 016), and included in a compilation of the translations of the works of Commynes, Froissart and Seyssel, Tres gallicarum rerum scriptores nobilissimi, published in 1578 in Frankfurt/Main by Andreas Wechel (F/a 024). The German translation of this tract by Georg Lauterbeck was first published in 1554 (Eisleben: Jakob Bärwald, B/b 001), and included in six editions of his political work on how to rule a state, published between 1561 and 1600 (B/b 003-B/b 007). I consulted the 1572 edition, Georg Lauterbeck, Regentenbüch Auffs fleissigst und herrlichst itzt von newen ubersehen / vnd durchaus an vielen orten Corrigiert / Gemehret / und Gebessert, Leipzig (Johannes Marttroff) 1572, which includes Sieidan's tract as 'Ein Dialogus oder Gesprech von der Platonischen Lehre/ ob auch/ und wie weit dieselbige zu Regierung des gemeinen nutzes dienlich sey'. Lauterbeck introduces Sleidan's work in the form of a dialogue between a mayor and a secretary. The mayor calls his secretary back to ask him about the Platonic teaching he had mentioned. The secretary then underlines the importance of Platonic teaching for any ruler and mentions that a well-educated man named Sleidan had recently written a short tract on this topic in Latin. The mayor shows interest and wishes for the work to be translated into German so everybody could make use of such 
Like so many others, Sleidan had put his hopes on England. As father of a family, emigration to England was not the obvious option, but by dedicating all three works he published in 1548 to England, he had counted on receiving financial support for his history project. Furthermore, he hoped to benefit from Bucer's influence at the English court. ${ }^{12}$ Sleidan himself also contacted Christopher Mont, who had been Henry's VIII Germanborn agent, to convince the English court of his cause. ${ }^{13}$ The few extant letters connected with Sleidan from the years 1548 and 1549 are silent on this issue. Then, in May 1550, John Cheke approached Bucer on this matter and assured him that Cranmer was willing to ask for the payment of Sleidan's pension, but it would take some time. ${ }^{14}$ In March 1551 finally Sleidan was officially granted an annual stipend of 200 gold crowns, but payment was delayed. $^{15}$

In England itself, Bucer tried to do his best for his friend. Together with Peter Martyr Vermigli and John à Lasco he handed in a supplication to the English court on behalf of Sleidan. Its purpose was to convince the king and Cranmer to support Sleidan, but again there was no immediate response. ${ }^{16}$ Even on his death bed, Bucer urged William

good a work (fols. L14r-L16v). The German translation of the Summary of Plato's doctrine on state and laws then follows.

${ }^{12}$ Cf. Sleidan's letter to Martin Bucer from 20 March 1550, in which he asks to recommend him to Cranmer (Appendix I, No. 197).

${ }^{13}$ Cf. Appendix I, No. 208.

${ }^{14}$ John Cheke to Martin Bucer, 11 May 1550 (Appendix I, No. 198).

${ }^{15}$ Sleidan referred to this promise in a letter to John Cheke and William Cecil from 15 March 1553, in which he asked to see after the payment of his pension (Appendix I, No. 290). Already in December 1550 Sleidan had complained about the delay of well deserved payment through the English court to Johann von Nidbruck: 'Sie machens eben lang, und mögt gern eins oder anders wissen. Wo der Checus und $\mathrm{d}$. $\mathrm{Pa}$ [get] wie ich ächte, ernstlich bei ewrem hern wölten anhalten, düncket mich alles, er wurd sichs annemen und durchdringen. Meine bitt ist, wöllet d. Aretio [Bucer] meinen dienst sagen und ermanen uf eine endtliche antwurt zu handlen. Mogt im auch anzeigen, quid Mont[ius] responderit. - Das auch der rever.mus [Cranmer] so gar ein Lentulus ist, hatt ich keineswegs gemeinet, so er sich eine zeit lang so gütig erzeigt. Wan solche lewt einen feilen, wem solt man dann glauben? Sollt ich dan so gar nit von inen bedacht werden, müsst es mich meiner zeit, arbeit und unkostens zum wenigsten gerewen.' (Baumgarten, Briefwechsel, No. 88; Appendix I, No. 207).

${ }^{16}$ Bucer apparently enclosed this supplication in a letter to the Earl of Northampton from late December 1550. 'Quamobrem cum Dominus ante quinque annos dederit, ut historiam huiusmodi coeperit contexere Ioannes Sleydanus..., consyderantes haec mecum Doctiss(imi) et religiosiss(imi) viri D. Ioannes a Lasco et Doctor Petrus Martyr et perpendentes quanto sereniss(imus) et vere christianiss(imus) Rex noster flagret 
Cecil to support this supplication and sustain Sleidan. ${ }^{17}$ Roger Ascham, a friend of Jean Sturm, also tried to use his influence for Sleidan's benefit, who in February 1552 complained to Ascham that he had not received any payment yet. ${ }^{18}$ After this date, we hear no more of the issue regarding England.

In Strasbourg, Sleidan now not only had to cope with financial problems, but also had to defend himself against new allegations. Together with Jean Sturm, his father-in-law Johann von Nidbruck and Ulrich Geiger in 1548 he was once again accused of 'French practices', this time by Anton Perrenot de Granville, bishop of Arras and imperial minister. ${ }^{19}$ Sleidan was forced to write an apology, defending himself against allegations of conspiracies with France against the Emperor. ${ }^{20}$ The enemies of Strasbourg's Francophile policy were not quickly appeased, and again in 1549, during the struggle about the introduction of the Interim, both the city of Strasbourg and its diplomats were suspected of 'having secret practices with foreign potentates and rulers'. ${ }^{21}$

studio ad illustrandam gloriam filii, quod etiam parvo salario opus sit Sleydano, ut ad perficiendam sanctam istam redonati nobis Evangelii historiam se rursus totum conferat, ausi sumus nos tres eidem Sereniss(imae) Regiae Majestati pro hac re supplicare, uti Illustriss(ima) Celsitudo tua leget ex eius nostrae supplicationis exemplo, quod una mitto.' (Hasenclever, Sleidan-Studien, pp. 46-47; Appendix I, No. 208) The supplication itself has not survived. John à Lasco was leading the strangers' church in London at the time, and Peter Martyr was professor at Oxford.

${ }^{17}$ Martin Bucer to William Cecil, 18 February 1551 (Appendix I, No. 210).

${ }^{18}$ See Appendix I, No. 201, 258. Baumgarten, Sleidans Leben, pp. 83-84, quotes Strype, Memorials of Cranmer, Oxford 1840, vol. 1, pp. 595-596 on the question of Sleidan's pension: 'About the end of March, anno 1551, he [Cranmer] procured for him [Sleidan] from king Edward an honorary pension of 200 crowns a year, as some aid for carrying on his Commentaries, which he then was busy about .... But upon the stirs at court the payment of this pension was neglected a great while: which caused Sleidanus to call upon the Archbishop more than once, as also upon his friends Cheke and Cecyl.' In 1550, Ascham remarked to Edward Raven that the distrust in England against Sleidan's father-in-law Johann von Nidbruck, rumoured to be a double agent, was also negative for Sleidan's cause (Appendix I, No. 201).

${ }^{19}$ Cf. Appendix I, No. 186, 187. Cf. also Franziskus Petri, 'Strassburgs Beziehungen zu Frankreich während der Reformationszeit', ELJB 8 (1929), pp. 134-165; 10 (1931), pp. 123-192.

${ }^{20} \mathrm{Cf}$. Sleidan's writing to the bishop in Adolf Hasenclever, 'Ein ungedruckter Brief Johann Sleidans aus dem Jahre 1548', ZGO 83 (N.F. 44), 1930, pp. 134-136; Appendix I, No. 188.

${ }_{21}$ The Emperor had heard 'als solten in der statt Strassburg etliche heimlich sorckliche praticken mit frembden potentaten und herschaften fürgon.' (PC 4/2, No. 902, 27 May 1549). On the same day, the Strasbourg council wrote to Kopp to defend themselves against any such accusations: '...dann wir ie von keinen sollichen practicken wissen, das wir auch ungern jemants dieselben gstatten wollten.' (PC 4/2, No. 901). 


\section{At the Council of Trent 1551/1552}

The Protestant acceptance of the Augsburg Interim 1548 necessitated a Protestant participation at the Council of Trent, which had been convened again for the year 1551 by Pope Julius III. As Strasbourg was the main motor in trying to unite the defeated Protestants for a concerted stand, Sleidan was sent as a legate to Trent to report the proceedings and prepare for the sending of the Protestant theologians. He was to be accompanied by the minister Matthäus Negelinus, a pupil of Fagius, who functioned as his scribe. ${ }^{22}$ A considerable number of Sleidan's letters from that time, mainly addressed to Strasbourg's council of XIII, along with his summarising report, have been preserved. Together with his account of the Council of Trent in his Commentaries (Books 22 and 23) these offer a very lively and valuable insider portrait of this event. ${ }^{23}$

Sleidan left Strasbourg on 3 November 1551 for Tübingen, where he was to meet Christoph of Württemberg and several theologians to receive instructions. ${ }^{24}$ From there he continued his journey via Kempten and Innsbruck to arrive in Trent on 21 November. ${ }^{25}$ Sleidan's legal training proved especially valuable in the long negotiations about the safe conduct of the Protestants. Yet he was soon to become disillusioned with the Council and the conduct of both Catholics and Protestants. On the Catholic side, he criticised the rigid stubbornness of the theologians, who were unwilling to grant the Protestants the necessary hearings. His opinion of the conduct of his own side was not much better, however, since he complained bitterly about the confused and disunited position of the Protestants. His

\footnotetext{
${ }^{22}$ Negelinus had gone to England with Bucer and Fagius in 1549 and returned after the latter's death to Strasbourg to become minister of the St. Wilhelm Church; cf. Hollaender, 'Sleidaniana', ZGO 53 (1899), p. 433 , fn. 1; see also Pierre Janelle, 'Le voyage de Martin Bucer et Paul Fagius de Strasbourg en Angleterre en 1549.', Revue d'Histoire et de Philosophie religieuses 8/2 (1928), pp. 162-177. On Sleidan's and Negelinus' payment see Appendix I, No. 268.

${ }^{23}$ The majority of Sleidan' official correspondence from Trent, but almost no private letters, has been preserved in the 'Acta consilii Tridenti' in the Thomasarchiv in Strasbourg, cf. Baumgarten, Briefwechsel, p.166. See Appendix I, No. 214-264 for this period.

${ }^{24}$ Cf. Appendix I, No. 217, 218, 220.

${ }^{25}$ For Sleidan's itinerary and travel reports, cf. Appendix I, No. 220, 223, 228, 250, 254, 258, 263, and 264.
} 
disappointment regarding the sessions was clearly reflected in his letters to the Strasbourg

council, in which he sharply commented on the 'papal stupidity' and other matters. ${ }^{26}$

Disillusioned with the aims of the Council, Sleidan asked the XIII and Jacob Sturm

for permission to return to Strasbourg and used his spare time to travel to Venice with the

Saxon legate Wolff Köller from 3 to 16 February $1552 .^{27}$ Always the historian, Sleidan

used this trip to purchase books useful for his Commentaries, like Bembo's history of

Venice. ${ }^{28}$ With the sanction of Strasbourg, but against the will of the Council Sleidan

finally left Trent on 28 March 1552 and was back in Strasbourg by mid-April $1552 .{ }^{29}$

\section{Diplomat for Strasbourg and Protestant historian}

Since the collapse of the Schmalkaldic League in 1547, Sleidan had been without a real

employer and had been obliged to knock on many doors to earn money for both his family

and his history. Although he had fulfilled several obligations for Strasbourg, he was not

\footnotetext{
${ }^{26}$ Cf. Baumgarten, Briefwechsel, No. 117, p.246: 'bäbstliche blödigkeit' (Appendix I, No. 264). In a letter to the XIII of Strasbourg from 20 November 1551 Sleidan desribed a typical session of the Council: 'The theologians, for the majority monks, announce the articles, which then are ratified in the following session by the word 'placet'. Nobody is asked, nobody has a vote, expect for the bishops who sit around with their white, pointed hats, and the legate with a golden one. The legates of king and emperor are present, but they are not asked, nor are the abbots or other prelates.' (My translation: 'Die theologen, so den gröszeren theil mönch sind, stellen solche artikel, folgends in der session wirds bestetigt durch das wörtlin placet. Es wird niemant gefragt, hat auch niemant keine stimm, dan allein die bischoff, die sitzen da mit iren weiszen spitzhüten, und der legat mit einem guldinen. Die keis. und königl. Gesandten sind woll dabei, man fragt sie aber nit, auch sonst keinen abt noch andern prelaten.' (Baumgarten, Briefwechsel, No. 94, p. 175; Appendix I, No. 228). On 10 December Sleidan criticised the Council's will for reform: 'They re-erect their former habit and teaching completely, this and nothing else. [...] They read the books of our scholars, and extract the articles from them, which they consequently dispute and anathematize. [...] To sum up, they do whatever they want to, they say that the Scripture did not have voice but needed a judge who reads it and interprets its meaning; this indeed was what the Council did and everybody had to accept this.' (My translation: 'Sie richten ir vorig wesen und leer genzlich widerumb auf, das und kein anders. [...] Sie lesen unserer gelerten bücher, daraus ziehen sie die artikel, welche sie folgends disputiren und verdammen. [...] Summa, sie thunt was sie wöllen, sagen, die schrift seie sprachlos, sie müss ein richter haben, der sie ausspreche und wie sie zu verstohn sei auslege, das thu aber das concilium und dabei soll sich ein jeder finden lassen.' (Baumgarten, Briefwechsel, No. 97, p. 186; Appendix I, No. 231).

${ }^{27}$ Cf. Appendix I, No. 244, 247. For Sleidan's itinerary and travel report, cf. Appendix I, No. 250, 254, and 258.

28 'Emi Venetiis historiam Bembi de republica Veneta: num ea sit vobis antehac visa nescio. Paulus etiam Jovius tomum primum sui temporis historiarum edidit.' (Sleidan to Roger Ascham, 29 February 1552, Baumgarten, Briefwechsel, No. 111; Appendix I, No. 258).

${ }^{29}$ Cf. Appendix I, No. 264 and 265.
} 
yet fully employed. Upon his arrival, the desperate situation he found Strasbourg in gave him the chance to prove his qualifications. During his absence, the political landscape in Germany had changed again with the revolt of Duke Maurice of Saxony against Charles V. In January 1552, Henri II had formed a secret alliance with Maurice and other princes against the Emperor, and his ransacking army marched towards Germany. ${ }^{30}$ In spring 1552, the army was plundering Alsace and Lorraine, and Strasbourg was under threat. Once again Sleidan could prove his linguistic and diplomatic skills. In May 1552, he was sent together with Friedrich von Gottesheim and Peter Sturm to negotiate with Henri II and Constable Montmorency. ${ }^{31}$ Negotiations were successful, and the danger was averted. The council of Strasbourg showed itself extremely grateful for the positive outcome of this mission, and formally engaged Sleidan as civil servant. On 24 June 1552 Sleidan signed his four-year contract, in which he pledged to assist the council at any time 'be it with advice, speeches, riding, writing, thinking or any other ways according to my best knowledge', 32

Despite his obligations towards Strasbourg, Sleidan was still busy working at the Commentaries. Since the promised pension from England had not arrived yet, Sleidan made a last effort to claim it in September 1552. He sent an account of the Schmalkaldic war as Commentarii belli Germanici in gratiam R. Eduardi VI. descripti 1552 to Edward VI in the hope that this would trigger the payment of his promised pension. ${ }^{33} \mathrm{He}$ also

\footnotetext{
${ }^{30}$ On 15 January 1552 Henry II, Maurice of Saxony, Wilhelm of Hesse and Johann Albrecht of Mecklenburg had signed a secret treaty at Chambord against the Emperor. In May 1552 the French army took over Lorraine and occupied Toul, Verdun and Metz, directing themselves towards Strasbourg (cf. Marc Lienhard, Jakob Willer (eds.), Straßburg und die Reformation, Kehl/Strasbourg/Basle 1982, pp. 291-293).

${ }^{31}$ Cf. PC 5, No. 229-234; Appendix I, No. 270-276.

32 'Auch ermelten meinen herren meister und rath in iren sachen, so sie mir jeder zeit bevelhen und an mich begeren werden, es sei mit rathen, reden, reiten, schreiben, bedenken oder in alle andere weg nach meiner besten verstentmus, wie einem getreuwen burger und bestelten wol eignet und geburt, zum vleissigsten $\mathrm{zu}$ dienen' (my translation, cf. Baumgarten, Sleidans Leben, p. 115; Appendix I, No. 278). His annual salary was 150 Strasbourg Gulden plus expenses. Cf also Appendix I, No. 282, 286-288.

${ }^{33}$ Sleidan to Edward VI, 2 September 1552 (Appendix I, No. 281). This description has survived in the British Library as 'Commentarii belli Germanici' (Ms. Cotton, Galba B. XI, fols. 64r-73v). The inscription
} 
informed William Cecil about this writing and asked him to intercede for his pension. ${ }^{34}$ In December, he reminded Cecil of the issue again and also asked him for material concerning Henry VIII to be used for his history. ${ }^{35}$ In February 1553, Sleidan sent another historical description to Edward VI, this time of the last session of the Council of Trent. ${ }^{36}$ By March 1553, his efforts had still not been rewarded and he sent another reminder to William Cecil and John Cheke. ${ }^{37}$ This was to be Sleidan's last effort concerning England as far as we know. No answer by Cecil or Cheke has been preserved.

With his formal employment by Strasbourg, Sleidan had finally found another employer that would enable him to care sufficiently for his family and also allow him to continue his historic work. He was meanwhile the happy father of two daughters and his beloved wife was expecting their third child. This domestic happiness was ended abruptly in March 1553. Shortly after giving birth to another daughter, Jola, Sleidan's wife died. The desperate Sleidan was left a widower, having to care for three daughters, one of them a newborn baby. ${ }^{38}$ Only half a year later, in October, when he was still in deep mourning for his wife, he had to stand at another grave, that of his old patron and friend Jacob Sturm. Again, Sleidan was devastated, having lost his wife and one of his best friends. As an expression of his grief, Sleidan wrote a poem in his memory, published in Jean Sturm's commemoration of Jacob Sturm. ${ }^{39}$

\footnotetext{
'Joan. Sleidano authore' was still in existence at Baumgarten's time (cf. Baumgarten, Sleidans Leben, p. 88), but has been lost probably due to restoration work on the manuscripts as Rott suggested ('Nouveaux Documents', p. 563, fn. 3).

${ }^{34}$ Sleidan to William Cecil, 20 September 1552 (Appendix I, No.283).

${ }^{35}$ Sleidan to William Cecil, 17 December 1552 (Appendix I, No. 289).

${ }^{36}$ Sleidan mentioned this document in a letter to William Cecil and John Cheke from 15 March 1553 (Appendix I, No. 290).

${ }^{37}$ Appendix I, No. 277, 290.

${ }^{38}$ Cf. Appendix I, No. 291, 293. In June 1553, Sleidan signed a letter with 'Joan. Sleidanus, lugens uxorem suavissimam' (mourning for his very lovely wife; Baumgarten, Briefwechsel, No. 129; Appendix I, No. 295).

${ }^{39}$ The poem 'Extincto jam sole, Deum' on the death of Jacob Sturm was included by Jean Sturm in his Consolatio ad senatum Argentinensem de morte ... Jacobi Sturmii, Strasbourg: Wendelin Rihel 1553; cf. also Baumgarten, Sleidans Leben, p. 95; Appendix II, No. 14.
} 
Sleidan tried to distract himself from his grief by absorbing himself totally in his task of writing a history of the Reformation. Despite these tragic events and the lack of financial support, he persevered in his work on the Commentaries. ${ }^{40}$ Having started in June 1545 , it took Sleidan only around a month to finish book one. By the outbreak of the Schmalkaldic War in 1546, a further 4 books had been penned. By March 1553 he had reached book 10 , the year 1536 , and only half a year later he had covered another ten years in his narrative. On 2 April 1554, he proudly announced to Calvin, whose help and advice he had used several times in these years, that his 25 books on the religion and state under Emperor Charles V were completed. ${ }^{41}$ Apart from the work at his history, Sleidan still had to fulfill his administrative and diplomatic obligations towards the city of Strasbourg. On behalf of the city, he was sent as legate to the meeting of the Protestant states at Naumburg in May 1554, the last religious colloquy he was to attend. ${ }^{42}$

In Strasbourg itself, part of Sleidan's responsibilities was also the administration of schools and churches. In the course of the Reformation the school system in Strasbourg had been expanded, especially under the influence of Jean Sturm. The council had instituted three of its members as 'scholarchs' to supervise education in the city, Jacob Sturm, Jakob Meyer and Friedrich von Gottesheim. After Jacob Sturm's death in 1553 his brother Peter followed him in this office; Sleidan was often called upon to assist as a fourth person. In this position he managed to bring his old friend Peter Martyr Vermigli back to

\footnotetext{
${ }^{40}$ Cf. Appendix I, No. 290 and 294, where Sleidan asked both the English and the Saxon court to send their promised payments.

${ }^{41}$ 'Absolvi totum opus et ad hoc usque tempus habeo confectum... . Libri sunt 25, titulus est de statu religionis et reipublicae statu Carolo quinto Caesare.' (My translation; Baumgarten, Briefwechsel, No. 132; Appendix I, No. 306). Sleidan's work at the Commentaries will be analysed in detail in chapter 4.

${ }^{42}$ Sleidan's attendence at this colloquy has been a grey area in scholarship since several historians alluded to it, but found no confirmation in Sleidan's letters (as collected in Baumgarten). Evidence from correspondence collected in other sources, like that of Melanchthon or the city of Strasbourg, however, confirms Sleidan's presence at Naumburg (cf. Appendix I, No. 307, 309-313).
} 
Strasbourg, who from January 1554 onwards acted as minister and professor. ${ }^{43}$ Kingdon suggested that during these years 1553 till 1556 it was predominantly Sleidan from whom Peter Martyr picked up Lutheran political arguments. ${ }^{44}$

Due to his fluency in French, and possibly also because of his friendship with Calvin, Sleidan became involved in the problems of the French church in 1554. Strasbourg with its location between France and the Empire had always been a Francophile city, and when the religious persecutions in France began, a huge wave of immigrants moved towards Strasbourg. To cater for their religious needs, the French church had been founded in 1538, and Calvin functioned as its minister during his time in Strasbourg. ${ }^{45}$ This church flourished in the tolerant climate, but with the Interim in 1548 and the emigration of Bucer and other tolerant reformers the situation became more difficult. While the Strasbourg ministers opted for a stricter Lutheranism, Jean Garnier, the minister of the French church, moved closer to Calvin, Bullinger and the Swiss churches. ${ }^{46}$ In 1554, the relations between the French church and the other Strasbourg churches became even more tense over the controversy within the French church over the signing of the Confessio Augustana. ${ }^{47}$

In the course of this controversy, Sleidan was appointed together with Friedrich von Gottesheim and Jean Stösser as 'Kirchenpfleger', church governor, to negotiate between

\footnotetext{
${ }^{43}$ Cf. Appendix I, No. 300 and 306; also Otto Winckelmann, 'Zur Geschichte Sleidans und seiner Kommentare', ZGO 53 (N.F.14, 1889), pp. 593-595. Martyr was in Strasbourg from 1542-48, accompanied Bucer to England, which he left again under Mary Tudor to return to Strasbourg from 1553-1556. ${ }^{44}$ Robert M. Kingdon, 'The Political Thought of Peter Martyr Vermigli', Joseph C. McLelland (ed.), Peter Martyr Vermigli and Italian reform, Waterloo/Ontario 1980, examined Martyr's political views and the influence of Lutheranism on his thoughts on pp. 121- 139. On p. 137 he suggests this important influence of Sleidan on Peter Martyr.

${ }^{45}$ Cf. Philippe Denis, Les églises d'étrangers en pays rhénans (1538-1564), pp. 40-61.

${ }^{46}$ Cf. Jean Lebeau, Jean-Marie Valentin, L'Alsace au siècle de la Réforme 1482-1621, Nancy 1985, p. 153.

${ }^{47}$ Denis, Les églises d'étrangers, pp. 97-108. Denis (p. 108) reports that when the new minister Alexandre wanted the catechism and liturgy translated into French, the magistrate advised him to use the catechism by Bucer which Sleidan had translated into French in 1544 (cf. Timotheus Wilhelm Röhrich, Mittheilungen aus der Geschichte der evangelischen Gemeinden des Elsasses, vol. 3, Strasbourg 1855, p. 46).
} 
the two parties. ${ }^{48}$ Together with his colleagues, with the theologian Johann Marbach or by himself, Sleidan conducted many hearings between the different parties. ${ }^{49}$ Calvin congratulated Sleidan heartily on the news of his involvement in the French church, and Sleidan kept him informed on the state of the negotiations and affairs. ${ }^{50}$ Although the controversies of 1554 were eventually solved, the troubles surrounding the French church never ceased, and it was finally closed by Marbach in 1563.

\section{The Commentaries on State and Religion under Emperor Charles V(1555)}

In April 1554 Sleidan had announced to Calvin that he had finished his Commentaries. Contrary to Sleidan's expectations, this was not the end, but only the beginning of his troubles concerning his main work. Due to the changing political situation the Protestants now became uneasy about the publication of a potentially troublesome work such as the Commentaries. Thus Peter Paul Vergerio (1498-1565), the former bishop and since 1552 Protestant adviser of Duke Christoph of Württemberg, was sent to Strasbourg to convince Sleidan to delay publication or at least to help avoid controversy by omitting or rephrasing

\footnotetext{
${ }^{48}$ Denis, Les églises d'étrangers, pp. 97-106. The church governors were also to keep the often unstable situation of the French church under control, as the presence of 'die welschen', as the French-speaking inhabitants in Strasbourg were called, often were the cause of anger in Strasbourg. This tensions was further heightened when persecutions of Protestants in France increased. According to Alfred Erichson, L'Eglise francaise de Strasbourg au seizième siècle d'apres des documents inédits, Strasbourg 1896, p. 36, Sleidan was already a governor of the French church in January 1554. On the office of a Kirchenpfleger in Strasbourg, see Chrisman in Strasbourg and the Reform, pp. 208-211. On p. 209, she points out that of the three Kirchenpfleger one was drawn from the Schöffen, one from the magistrate, and one from the citizens. ${ }^{49}$ Cf. Appendix I, No. 304, 305, 309, 319, 320, 321 and 325.

50 'When I got to know recently from our brother $\mathrm{N}$. that of the three that the senate has chosen to govern the (small) French church you are one, I was very delighted, as it befits the situation: and I am sure that this joy will be lasting. Thus I conclude therefore that this office has been bestowed more by divine than by human counsels on you, who by your faith and prudence will settle whatever unrest Satan has created.' (My translation; Calvin to Sleidan, Geneva 27 August 1554; Baumgarten, Briefwechsel, No. 134, p. 270; Appendix I, No. 319: 'Quum ex fratris nostri N. literis nuper intellixissem ex tribus, quos regendae Gallicae ecclesiolae senatus praefecit, te esse unum, vehementer, ut par erat, gavisus sum: et hoc mihi gaudium fore diuturnum confido. Sic enim statuo tibi divinitus magis quam humano consilio provinciam hanc fuisse iniunctam, qui tua fide et prudentia componas quidquid hactenus turbarum movit satan: ...'.) On 8 August 1555 Calvin, grieved with the fall of the French Church of Strasbourg, wrote to Peter Martyr Vermigli considering the reconstruction of the same: 'You will have for faithful workmen, I imagine, in this task, M. Sturm and Sleidan.', cf. Jules Bonnet (ed.), Letters of John Calvin. Compiled from the original manuscripts and edited with historical notes, vol. 3, New York 1972, p.218; Appendix I, No. 359.
} 
offensive passages. $^{51}$ In February 1555 the senate was threatened to stop the publication of the Commentaries, but after long discussions they nevertheless decided to go ahead with it. $^{52}$

In April 1555 Sleidan's De statu religionis et reipublicae Caesare Carolo Quinto, Caesare, Commentarii, was published by his friend Wendelin Rihel in Strasbourg. ${ }^{53}$ The Commentaries contained 25 books, covering the years 1517 to 1555 ; book 26, first included in the 1558 edition, was posthumously compiled from Sleidan's notes. Originally composed for the Schmalkaldic League, this work was intended as the founding stone of Protestant historiography, and it was to live up to this aim. The work was first published in April 1555. Its impact was immediate and printing presses across Europe did not stop publishing this work for decades, even centuries. Sleidan's instant best-seller earned him not only lasting fame but also antipathy. The troubles that had accompanied the whole process of writing and publication paled in significance compared to the agitated reactions to the completed book, from both the Catholic and Protestant camps. Sleidan's striving for impartiality had won him the favour of neither party. He was greatly grieved by the strong reactions towards the work to which he had dedicated ten years of his life, and within two months of the first publication of the Commentaries, he saw himself forced to write an apology for his work. ${ }^{54}$ Although Sleidan was devastated by all the negative reactions to the Commentaries, he continued his historical efforts and completed another work, De quatuor summis imperiis.

\footnotetext{
${ }^{51}$ Cf. Appendix I, No. 318, 323 and 324. For a detailed account of the genesis of the Commentaries and the troubles surrounding their publication see chapter 4 . Vergerio had been bishop and diplomat under Paul III, and in 1540/41 attended the diets of Worms and Regensburg, where he would have met Sleidan. In 1549, he converted to Protestantism and in 1552 became the adviser of Christoph of Württemberg (on Vergerio, cf. Anne Jacobson Schutte, Pier Paolo Vergerio: The Making of an Italian Reformer, Geneva 1977; Christian Heinrich Sixt, Petrus Paulus Vergerius, päpstlicher Nuntius, katholischer Bischof und Vorkämpfer des Evangeliums, Braunschweig 1855).

${ }^{52}$ Cf. Appendix I, No. 327, 328, 333.

${ }^{53}$ We will offer a detailed description of this work in chapter 4.

${ }^{54}$ Cf. Appendix I, No. 348, 353.
} 


\section{The Four Empires (1556)}

In the preface to the Commentaries, Sleidan had referred to the biblical scheme of the four monarchies, a theme that he pursued in De quatuor summis imperiis libri tres. This work, the Four Empires, was published almost a year after the Commentaries, in June 1556, describing the history of mankind following the scheme of the four monarchies set forth by the prophet Daniel $(2: 21){ }^{55}$ Sleidan dedicated this work to the young prince Eberhard of Württemberg, the son of Christoph of Württemberg, underlining the importance of history and learning, and expressing the wish that this book might be useful for the education of all young people. ${ }^{56}$ In this preface, he briefly summarised Nebuchadnezzar's dream of a statue with a head of gold, a silver chest and arms, a brass belly and iron legs with feet of iron and clay, and its interpretation by Daniel as representative of the four empires of Babylon, Persia, Greece and Rome. Sleidan then gave a brief survey of historians who wrote on these different empires, hoping to offer a summary of the extant knowledge with his own work.

In Sleidan's view, the course of the world's history followed exactly Daniel's prophecy: In the first part of the Four Empires, he outlined the history of the empires of Babylon, Persia, and Greece, which lead to the fourth, the Roman Empire. Based on the premise that the Roman Empire continued in the Holy Roman Empire with its centre in Germany, Sleidan elaborated in the second part on the history of this last empire from the early church until the Middle Ages. Book three looked back on the last centuries and then focused on the present time, and examined the current state of what was left of the Roman Empire. Sleidan observed all the signs of the apocalyptic end prophesied in the Bible: the Empire was weak, the Turks attacked, the papacy was corrupt, religious turmoil, storms,

\footnotetext{
55 The whole theory of the four monarchies is expanded in Daniel 7-11.

${ }^{56}$ Eberhard's father, Christoph of Württemberg, gave Sleidan 30 florentines for this dedication (Appendix I, No. 422).
} 
floods, eclipses, all heralded the imminent end: 'The course of this world shal take an end in this empyre, \& none other shall follow... The people of God then shalbe vexed through the whole earth., ${ }^{57}$ There are no allusions to the Reformation yet, but throughout the work the inadequacy and evil character of the Catholic Church is emphasized.

In the Four Empires, Sleidan showed himself very much rooted in traditional historiography, offering a more theological than political interpretation of man's history from the Fall to the apocalyptic end. The ideas underlying this work were nothing new. The Danielic notion of the four monarchies had been the basis of many historical interpretations, and had only recently been sanctioned as what one might call the official Protestant view of history by Philip Melanchthon in his preface and adaptation of Carion's Chronicon, first published in $1532 .^{58}$ Sleidan's interpretation of the Holy Roman Empire as the continuation of the ancient Roman Empire followed the notion of Translatio Imperii (ad Teutonicos), a translation of the Empire (to the Germans), set forth by Otto von Freising (ca. 1114-1158). He argued that the Roman Empire was continued in the form of the Holy Roman Empire, whose fourth king Conrad II (1024-1037) was at the same time the 93rd Roman Emperor. ${ }^{59}$ This notion had been of importance for German historiography until the sixteenth century, if not further, and with its strong nationalist tendency offers an explanation for the fact that the Four Empires, though immensely

\footnotetext{
${ }^{57}$ The quotation is taken from the 1563 English translation by Stephan Wythers, A briefe Chronicle of the foure principall Empyres, London (Rowland Hall) 1563, fols. Dd1r-v, Dd3r.

${ }^{58}$ On the Chronicon Carionis and Philip Melanchthon's role, see chapter 4. By the middle of the sixteenth century, historiography had moved away from this traditional interpretation of history, and historians like Jean Bodin openly criticised such a concept in his 'Method for the easy comprehension of history' (I consulted a 1610 edition, Ioannis Bodini Methodus ad facilem historiarum cognitionem; accurate denuo recusa : Subiecto rerum Indice, Geneva : Jacob Stoer 1610, first published in 1569). Bodin devoted a special section to refute the notion of the four monarchies as postulated by historians like Melanchthon and Sleidan (p. 264/fol. R4v); cf. chapter 6.

${ }^{59}$ Cf. William Stanford Reid, 'The four Monarchies of Daniel in Reformation Historiography', Historical Reflections 8 (1981), p. 116. Otto von Freising was the uncle of Frederic Barbarossa, studied in Paris, then joined the Cistercians and became abbot in Morimond. Matthias Flacius Illyricus, to whom we shall come back in chapter 4 in connection with the Commentaries, developed this idea in his De Translatione Imperii Romani ad Germanos. Item de electione episcoporum, quod aeque ad plebem pertineat (Basle: Johannes Opporinus).
} 
popular in Germany until the nineteenth century, never reached a similar popularity in other countries.

Although it was published a year later than the Commentaries, the Four Empires almost naturally set the background for the Protestant history and serve as a quasi introductory work. From a modern historian's point of view, the Four Empires is not particularly satisfying, and we find no real quotations complete with source or a detailed chronology. A considerable number of Roman and Greek historians are mentioned, but one cannot judge whether their works had actually been consulted or not. Since in the sixteenth century printed florilegia of legal quotations or references to the church fathers and the bible existed, one may speculate whether a similar thing was available for historians. The dominating theme is that of constant decline, resulting in an apocalyptic end. In the Four Empires, Sleidan viewed history through a theological prism, highlighting the apocalyptic preoccupation which was so common for the Protestants of that time.

Donald R. Kelley noted the traditional character of the Four Empires and the lack of knowledge as to when Sleidan composed this work. This has led him to suggest that it might have been written around 1541-44, since Sleidan mentioned the notion of the four monarchies in his Oration to the Emperor. ${ }^{60}$ In Sleidan's other works or correspondence no allusion is made to the composition of this work, leaving room for speculation. Sleidan himself mentioned it only once in a letter to Christoph of Württemberg from 16 June 1556, a letter Kelley was probably not aware of. In this letter, Sleidan wrote to Christoph that he was grateful for being allowed to dedicate the work to Christoph's son, and remarked that

\footnotetext{
${ }^{60}$ On the Oration to the Emperor, see above. Cf. Kelley's article 'Johann Sleidan', p. 596.
} 
he had added additional material from Cicero and Catholic works. ${ }^{61}$ Although the Four Empires in a chronological sense precedes the Commentaries and is far more traditionally and theologically orientated, there is actually nothing in Sleidan's correspondence or that of his contemporaries that would suggest an earlier composition. In any case, there would be no reason why Sleidan should not have published the Four Empires straight away, since he did not hold back other, potentially more offensive works.

Sleidan's Four Empires had been published in June 1556, and only three months later Hubert Languet reported to Melanchthon that the work was already sold out. ${ }^{62}$ In contrast to the Commentaries, the Four Empires did not provoke any criticism or public outcry; on the contrary, the work was used as a teaching manual by both Catholics and Protestants over the next centuries. As with all his other works, the fact that Sleidan was officially condemned by the Catholic church as a 'heretic of the first class' did not really deter Catholics from using this work. Instead, various orders, especially the Jesuits, used it quite openly for teaching purposes. A copy of the Four Empires preserved in Munich, formerly owned by the Jesuits, bore the inscription 'Approbatus per P. Gerardum Massetum 1580' (approved by Father Gerhard Massetus in 1580) - the only concession to the Index being that the name of author, printer and dedicat had been erased, along with a few seemingly offensive passages in the text itself. ${ }^{63}$ Other copies I came across were owned by the Augustinians and Capucins; on the title page of an edition owned by the Jesuits in Chantilly somebody had remarked that the book was 'heretic' and listed on the Tridentine Index. ${ }^{64}$

\footnotetext{
${ }^{61}$ This letter from 16 June 1556 has been published by Adolf Hasenclever, 'Sleidaniana', ZGO 63 (N.F. 24, 1909), pp. 112-114; cf. Appendix I, No. 399.

${ }^{62} \mathrm{Cf}$. Languet's letter from 18 September 1556 (Appendix I, No. 408). On Hubert Languet, see chapter 4.

${ }^{63} \mathrm{Cf}$. Baumgarten, Briefwechsel, p.xxviii. I could not identify this copy in the Bayerische Staatsbibliothek.

${ }^{64}$ The Jesuit copy from Chantilly is preserved in the Fontaine-collection in the Bibliothèque Municipale at Lyon, pressmark SJ ID 105/133, with the inscriptions 'heretici' and 'à l'index ex conc. trid.'. The copy owned by the Capucins can be found in the same library under the pressmark SJ IC 224/102, a 1559 Genevan
} 
Like the Commentaries, the Four Empires was first published in Latin by the Rihels in Strasbourg in two editions in 1556 and a third one in $1557 .^{65}$ By 1558 , the work was also printed in Geneva, and by 1560 five different editions had appeared. By the end of the century these had amounted to seventeen. ${ }^{66}$ In 1558 , a German edition was published by Nicolas Bryllinger in Basle, who had also published an unauthorised German translation of the Commentaries, followed by another German edition printed in Leipzig in $1557 .^{67}$ Crespin in Geneva published a French translation in 1557 in three editions, followed by another three in 1558 , when a French edition was also published anonymousiy in Strasbourg. ${ }^{68}$ By 1565, the Four Empires had been published in eight editions, and was also included in four French editions of Sleidan's works; after this year, no more French editions were printed until 1700. An English edition appeared in 1563, and a Dutch translation in 1583, which was included in the four editions of Sleidan's Commentaries in 1584 , and one in $1596 .^{69}$

\section{'Another one of our best and most venerable friends, Sleidan, is dead...,70}

The success of the Four Empires seemed to have helped Sleidan through the hard time after the publication of the Commentaries. He seems to have taken new courage from this recognition of his skills as a historian, and apparently turned towards another project. Its aim was to pay homage to his old friend and patron Martin Bucer in the form of a

edition by Conrad Badius! Reid in 'The Four Monarchies' (p. 122) mentions that the Four Empires were used for teaching purposes atTrinity College, Dublin, and also at Glasgow university (probably even by Andrew Melville), where in 1648 the university required all students to read this work.

${ }^{65} \mathrm{Cf}$. Vekene, Bibliographie, D/a 001- D/a 003.

${ }^{66}$ Cf. ibid., D/a $004-\mathrm{D} / \mathrm{a} 017$.

${ }^{67}$ Tbid., D/b 001 and $\mathrm{D} / \mathrm{b} 002$.

${ }^{68}$ Ibid., D/c 001- D/c 007.

${ }^{69}$ Ibid., D/g 001 (an English edition translated by Stephan Wythers and published in London by Rowland Hall); Dutch editions: D/d 001, E/d 002-E/d 006. Similarly to the Commentaries, various summaries, extracts, tables and continuations of the Four Empires were published, the first one to appear in 1602/03 (cf. Vekene, Bibliographie, D/k 001-D/k 012).

70 'Verum alius est optimi et sanctissimi amici nostri exitus, Sleidani inquam.' (My translation; François Hotman to Jean Calvin, 8 November 1556; CR 44, No. 2546; Appendix I, No. 415). 
biography. ${ }^{71}$ However, the hardships of the last years Sleidan had to endure had been too much for him, and in the middle of the process of collecting the necessary material, Sleidan fell ill in August 1556. Neither the exact date nor the reason for Sleidan's death are known.

In September, Conrad Hubert and Francis Hotman, professor of civil law in Strasbourg since 1555 and protégé of Sleidan and Calvin, both reported that Sleidan had caught a light fever. ${ }^{72}$ Michael Beuther, Sleidan's German translator, remarked that Sleidan had had a wound on his leg, did not allow it to heal and possibly caught an infection. ${ }^{73}$ This account is confirmed by the sixteenth-century Strasbourg architect and chronicler Daniel Specklin, while other commentators attributed his death to the plague. ${ }^{74}$ Contrary to everybody's expectation, however, Sleidan did not recover from his illness. Aged prematurely and desperate, he died in the presence of his old friend Jean Sturm and Conrad Hubert, Bucer's former secretary. The city register of Strasbourg reported his death on 30 October, whereas Conrad Hubert mentioned that Sleidan died on 31 October and was buried on 1 November with all honours. ${ }^{75}$ He was buried at the St. Wilhelm church, where he had married and buried his beloved wife and baptised his children.

\footnotetext{
${ }^{71}$ Cf. Pollet, Martin Bucer, p.196.

${ }^{72}$ Cf. Conrad Hubert to Caspar von Nidbruck, 16 September 1556 (Appendix I, No. 407), and Francis Hotman to Jean Calvin, 22 September 1556 (Appendix I, No. 409). Kelley speculates that Sleidan's death occurred as a result of the plague, cf. Kelley, 'Sleidan', p.590. Hotman had been recommended by Calvin to Jean Sturm and Sleidan. Sleidan in turn recommended him to Melanchthon (cf. Appendix I, No. 352, 391), and also arranged Hotman's employment as professor of law in Strasbourg in 1556 (cf. the excellent study by Donald R. Kelley, Francois Hotman: A Revolutionary's Ordeal, Princeton/New Jersey 1973, p. 83).

${ }_{74}^{73}$ Sleidan/ Beuther (transl.), Der erste [und ander] Theyl Ordenlicher Beschreibunge, fol. $)(6 \mathrm{r}$.

74 'Den 31. October sterbe der hochgelert und weitberühmt herr Johann Sleidanus zu Straszburg. Er hatte im ein flusz am schenckel lassen zuheilen, daruf er darnach gar kein gesunde stundt mehr, und hat solchs nit geacht.' (Rodolphe Reuss (ed.), Les Collectanées de Daniel Specklin. Chronique Strasbourgeoise du seizième

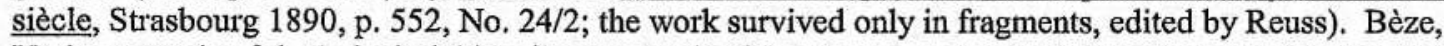
Vrais pourtraits, fol. I3r had Sleidan die as a result of the plague, an interpretation shared by Kelley, 'Johann Sleidan', p. 590.

${ }^{75}$ Strasbourg city register: 'Sleid. Jões gehet alhier mit tod ab den 30. Octob. 1556.' (Baumgarten, Sleidans Leben, p. 104; Appendix I, No. 413). On 25 November 1556 Conrad Hubert wrote to Caspar von Nidbruck: 'Paulo post, ultima Octobris ille noster carissimus, ille inquam desideratissimus me et Sturmio astantibus in beatam concessit patriam. Eius funus calend. Novembris honorifice ad sepulturam deductum, requiescit ad S. Gallum.' (Baumgarten, Briefwechsel, pp. xxix-xxx; Appendix I, No. 417). Hotman informed Calvin that
} 
It seems as if soon rumours occurred that Sleidan had not died a natural death. Caspar von Nidbruck, Sleidan's relative who had been in close contact with him especially around the publication of the Commentaries, wrote to Jean Sturm to ask him to make sure that there was no doubt about the circumstances of Sleidan's death and the fact that Sturm and Hubert had been present when he died. ${ }^{76}$ Friedrich Hortleder, who in the early seventeenth century edited a source collection on the Reformation, reported that many people speculated as to what had been the cause of Sleidan's death, hinting at murder. ${ }^{77}$

Sleidan's death was most tragic for his immediate family, especially his three little daughters. Shortly after Sleidan's death, Caspar von Nidbruck had asked Hubert to look after their well-being. ${ }^{78}$ The girls' grandfather, Johann von Nidbruck, wrote to the Strasbourg council in November 1556 and thanked them for caring for his grandchildren. ${ }^{79}$ In March 1557, Sleidan's brothers petitioned to be sent Sleidan's books and papers, but did not enquire after his children. ${ }^{80}$ The printer Josias Rihel, whose family had been close friends with Sleidan and published most of his works, was appointed guardian of Sleidan's children, at the wish of Sleidan and his family. He looked after the girls and invested Sleidan's money for them. In 1564, he complained to the Strasbourg council that after the death of the children's grandfather Johann von Nidbruck, the Nidbruck family had not

Sleidan had died peacefully on 5 November (Appendix I, No. 415); the compiler of the 26th book of the Commentaries, Courteau, added in 1559 that Sleidan died on 31 October (cf. Baumgarten, Sleidans Leben, p. 104). Beuther in his description of Sleidan's life in Der erste [und ander] Theyl Ordenlicher Beschreibunge omitted the date of Sleidan's death.

${ }^{76} \mathrm{Cf}$. Caspar von Nidbruck to Jean Sturm, 4 February 1557 (Appendix I, No. 424). On the person of Caspar von Nidbruck and his relations with Sleidan see Chapter 4.

77 'Weil aber/ fürnemblich umb der Teutschen Kriegshistori willen/ ein anders erfolgt/ und nicht wenig hohes und niders Standes Personen deroselben sich beschweret/ Der löbliche Sleidanus auch/ weiß nicht in was vor welche/ Aber doch solche gefahr/gerahten/ daß er zum exempel der gefährligkeit/ welche rechtschaffenen historicis bißweilen zubegegnen pfleget/ mit fürgestellet wirdt/ zugeschweigen/ was von der ursach seines todtes/ etliche geargwöhnet haben sollen.' (Hortleder, Der Römischen Keyser- und königlichen Maiesteten, vol. 2, 'Vorrede', fol. a4v.

${ }^{78}$ Cf. Appendix I, No. 424 and 427.

${ }^{79}$ Cf. Appendix I, No. 414.

${ }^{80} \mathrm{Cf}$. Appendix I, No. 426. Christoph of Württemberg asked the Council to send the books Sleidan had borrowed for the writing of his Commentaries back to Vergerio (Appendix I, No. 428). 
given them any of their legitimate inheritance. ${ }^{81}$ This was the last that was heard of Sleidan's family.

We have seen that Sleidan's life was as eventful and varied as his works. While the Four Empires were more of a theological character, the Commentaries, and earlier on the Two Orations, reflected Sleidan's political interest. His translations of French historians on the other hand were both a tribute to historiography and humanism, manifesting Sleidan's interest, but also serving as a training ground for the future historian and an advertisement of his skills. His efforts were rewarded when in 1545 he was employed as the official historiographer of the Schmalkaldic League. With the dissolution of the League in 1547 , however, Sleidan's hardships began. He died prematurely and in despair, robbed of his beloved wife and persecuted for his Commentaries.

A work of such popularity and public interest as well as a milestone for historiography deserves a closer look. In the next chapter, we will focus on Sleidan's Commentaries on religion and state under Emperor Charles $V$. Consideration will be given to possible influences on Sleidan, the events leading up to his employment by the Schmalkaldic League, and the composition of the Commentaries. We will trace the troubles surrounding the publication of this work, and the unforeseen dramatic aftermath. An analysis of the different editions of Sleidan's work will highlight its extreme popularity, and show its importance and influence, especially in Sleidan's home countries, Germany and France.

${ }^{81}$ Cf. Appendix I, No. 436. 


\section{CHAPTER 4: THE MAKING OF THE COMMENTARIES}

In the three biographical chapters, we have assembled all the evidence we have about Sleidan's life in France and Germany, his missions as a diplomat, and his work as a scholar. This gave us a clear picture of Sleidan's life, far more comprehensive than previous accounts. Still, when considering the background of the Commentaries, we will come across many unsolved questions and oddities. We know what happened, but are still confused about why. Why was Sleidan employed to write the history of the Reformation, considering his contacts with France, Bucer and Calvin? Why was England interested in Sleidan's history? What provoked the strong reactions from Protestants and Catholics after the publication of the Commentaries? And why was this initial scepticism totally confounded by extraordinary sales figures? In the next chapters, we will explore these questions.

In this chapter, we will examine contemporary German Protestant histories to investigate other important approaches to history which could have influenced Sleidan. We will then take a close look at the genesis of the Commentaries, and examine the circumstances under which the work was composed. ${ }^{1}$ We will trace their roots in Sleidan's employment as official historiographer by the Schmalkaldic League, the sources he used, the people who got involved, and the methods he applied. Dark clouds were already looming over Sleidan's lifework before it was even printed, and the reactions to it were unforeseen. After the publication of his Commentaries, Sleidan had to spent the remaining one and a half years of his life defending his work and himself against seemingly endless

\footnotetext{
${ }^{1}$ Walter Friedensburg, 'Die Entstehung der Kommentarien Sleidans', ELJB 12, (1933), pp. 83-108 traces this period in Sleidan's life, but not always precisely. Again I will base the examination of the Commentaries primarily on the documents assembled in Appendix I since those enable a much more complete picture than a summary of the existing literature which only offers an incomplete and confused picture.
} 
accusations and allegations. At the same time, printing presses across Europe did not stop printing his works.

The same conflicting imperatives which threatened to shipwreck Sleidan's endeavours and which left him discouraged and harried in his final years, had also come to play on the first attempts to frame on the Protestant view of the past. This will become clear if we cast an eye over other Protestant history writing in the German lands; both those who preceded Sleidan chronologically like the histories by Carion, Melanchthon and Franck (and thus might possibly have influenced his works) and other related projects, which either followed or in the case of Matthias Flacius Illyricus proceeded in parallel.

\section{$\underline{\text { Predecessors of Sleidan }}$}

Humanism and renaissance had given a new impetus to the writing of history, a discipline that had been popular for many centuries across different countries and religions. The invention of the printing press together with the tools provided by humanism enabled more wide-ranging access to original sources and documents, a rich fund historians began to use on a large scale. ${ }^{2}$ A new incentive to the quest for one's own history was added with the rise of the national states and patriotism. Additionally, the opposition between Protestantism and Catholicism created by Luther's Reformation constituted a special need for Protestant historiography. Its prime function was to reinterpret the 'Catholic' history and from thence to explain the present history. History writing had been discovered as a polemical tool in an age of confessional struggle. ${ }^{3}$ It is not surprising that the first attempts

\footnotetext{
${ }^{2}$ There is an extensive body of work on historical writing in the Renaissance and humanism period, cf. Peter Burke, The Renaissance Sense of the Past, London 1969; Nancy Struever, The Language of History in the Renaissance, Princeton 1970; Donald R. Kelley, Foundations of Modern Historical Scholarship, New York/London 1970.

${ }^{3}$ On the Protestant use of history, see for example Gordon's article, 'The Changing Face of Protestant History and Identity in the Sixteenth Century', pp. 1-22.
} 
to embark on such an enterprise were made in the country whence the Reformation originated, Germany. ${ }^{4}$

Sleidan's Commentaries constitute the first comprehensive contemporary history of the Reformation, covering its vital period from 1517 to 1555 , from Luther's 95 Theses to the Peace of Augsburg. Sleidan's aim was to present the 'history of religion and state under Charles V' in a truthful and neutral way. His endeavour earned him the title 'father of Reformation history', most recently by Donald R. Kelley, placing him in an almost 'apostolic line' with Eusebius of Caesarea, commonly called 'father of church history'. 5 However, as we will see, he did not pursue an entirely new approach. While he was able to profit from the developments in the methodology of perceiving and writing history introduced by other historians in the early decades of the sixteenth century, he made their innovations and methods his own by applying them to the most recent history.

\section{Sebastian Franck}

From the early phase of Protestant historiographical development emanate the works of an outcast, the spiritual theologian, chronicler and printer Sebastian Franck (1499-1542). ${ }^{6}$ With his spiritual interpretation of the Bible and the denial of all church authority he was by no means a typical early Protestant. Taking side with the reformed movement after 1525 , he pursued his own theology concentrating on God's inner word and rejected the

\footnotetext{
${ }^{4}$ For German historiography, see for example Wegele, F.-X., Geschichte der deutschen Historiographie seit dem Auftreten des Humanismus, Munich/Leipzig 1885; Menke-Glückert, E., Die Geschichtsschreibung der Reformation und Gegenreformation. Bodin und die Begründung der Geschichtsmethodologie durch Bartholomäus Keckermann, Osterwieck/Harz 1912; Eduard Fueter, Geschichte der neueren Historiographie, Berlin 1936.

${ }^{5}$ Kelley, 'Johann Sleidan', p. 577.

${ }^{6}$ The multi-faceted character of Sebastian Franck has not been the subject of major research yet, especially in English. For bibliographical information, see Klaus Kaczerowsky, Sebastian Franck: Bibliographie, Wiesbaden 1976. Both Hans Hillerbrand, A Fellowship of Discontent, New York 1967, and Steven Ozment, Mysticism and Dissent, New Haven 1973, also review Franck's life and work. One of the most detailed accounts is to be found in André Seguenny, Les Spirituels. Philosophie et religion chez les jeunes humanistes allemands au seizième siècle, Bibliotheca Dissidentium, scripta et studia No. 8, Baden-Baden/Bouxwiller 2000, chapter 4: 'Sebastian Franck: 1'homme est ses idées'.
} 
teachings of Luther, Zwingli and the Anabaptists. In an attempt to interpret the divine word, he published numerous works of diverse character, amongst them also several histories.

In his Chronica, Zeytbuch und gschychtbibel, published in 1531, Franck set out to explain his own view of God's role in human history, a conception fundamentally different from that of mainstream Reformers. ${ }^{7}$ In the core of all Christian historiography, be it Catholic or Reformed, stood the firm belief that it was in history that God revealed himself and his will to mankind. Man's role was to interpret this will so one might learn from it. Franck's approach came from the opposite perspective: for him history showed exactly the absence of God. Mankind could learn much more from history than from doctrines; if he understood history man could fulfil his divine vocation. Yet man's free will allowed him to chose whether he accepted this role of history as magistra vitae. ${ }^{8}$ In Franck's view, history taught evil to the evil man and good to the good man. As the title geschychtbibel shows, for Franck history was a holy scripture comparable to the Bible. It was in those groups condemned as heretics throughout the centuries that Franck saw the embodiment of God's inner word. With this approach he was among the first to interpret the line of heresies from the foundation of the Church as constituting a continuous chain of God's true witnesses. This view, perfected by Matthias Flacius Illyricus in his Catalogus testium

\footnotetext{
${ }^{7}$ This work was first published in Strasbourg (Balthasar Beck) in 1531. I could only get hold of the 1543, continued version of this work, Chronica Zeitbuch unnd Geschichtbibell von anbegyn biß in diss gegenwertig M.D.xliij. iar verlengt/ Darinn bede Gottes und der welt lauff/ händel/ aert/ wort/ werck/ thun/ lassen/ $\mathrm{kriegen} / \mathrm{wesen} / \mathrm{und}$ leben ersehen und begriffen wirdt. ... Summa hierinn findestu gleich ein begriff/ summari/innhalt und schatzkammer/nit aller/sonder der Chronickwirdigsten/außerlesnen Historien...., s.1. 1543. On this work, cf. André Seguenny, 'Historia Magistra Vitae. Quelques rémarques à propos de la Chronique de Sébastien Franck', Marijn de Kroon, Marc Lienhard, Horizons Européens de la Réforme en Alsace. Das Elsass und die Reformation im Europa des XVI. Jahrhunderts, Strasbourg 1980, pp. 107-118. Seguenny (p. 112) points out that Franck inserted many passages almost verbatim from the chronicles of Schedel and Naukler in his Chronica Zeitbuch unnd Geschichtbibell.

${ }^{8}$ Cf. Franck, Chronica Zeitbuch unnd Geschichtbibell, fols. a3v-a5v.
} 
veritatis from 1552 , which will be examined later, was to become a cornerstone of Protestant history. ${ }^{9}$

Despite his different interpretation of God's role in history, Franck's historic works incorporated several aspects which were continued in later Protestant historiography. In his preface ('Vorrede') to this history, Franck emphasised his use of sources, carefully examined to use only the best. ${ }^{10}$ He even provided the reader with a list of authors consulted for his work, including classical authors and church fathers like Eusebius, Augustine, Plutarch and Pliny, medieval chroniclers, and also humanists and Reformers like Valla, Luther and Bullinger. ${ }^{11}$ Similarly to Sleidan in his Commentaries, Franck pointed out his impartial approach and love for the truth. ${ }^{12}$

The first part of this work, 'Erst Chronic', exams history from Adam until Jesus, largely following the outline of the Old Testament. This is interrupted by occasional discussions of theological and philosophical topics and reflections on ancient mythology. The second part, 'Chronica der Keyser', illuminated the line of emperors from ancient Rome to Charles V, preceded by the famous 'Vorrede vom Adler', a preface on the eagle in which Franck characterized the emperor as 'the only useless animal'. In the last part of this work, 'Chronica von alle Bäpsten', largely annalistic in character, Franck analysed the

\footnotetext{
${ }^{9} \mathrm{Cf}$. Matthias Flacius Illyricus, Catalogus testium veritatis, qui ante nostram aetatem reclamarunt, Basle 1556.

${ }^{10}$ Cf. Franck, Chronica Zeitbuch unnd Geschichtbibell, fol. a2v.

${ }^{11} \mathrm{Ibid}$., fol. A7v. These are historians which Sleidan also referred to in his Four Empires, whereas his Commentaries with their concentration on the Reformation period relied primarily on sixteenth century works and documents.

${ }^{12}$ Ibid., fol. a3v. Even Martin Luther himself, an opponent of Franck, unwillingly paid tribute to Franck's impartiality: 'Denn aus seinen Büchern wist Du nicht wohl lernen, was ein Christ glauben oder ein frommer Mann tun soll; er kanns und wills auch nicht lehren. Ja, das vil mehr ist, de wirst aus seinen Büchern nicht wissen, was er doch selbst gläubet, oder für ein Mann sei; ...' In the same writing Luther had remarked that Franck had made use of the popularity of history to spread his own poisonous messages: Franck 'hat dennoch das Grifflin funden, dass er gewusst, wie die Historienbücher von andern sonderlich gerne gelesen werden und lieb gehalten sind .... Also hat er ihm sonderlich vorgekommen, Historien zu schreiben, damit er seinen Gift unter dem Honig und Zucker desto mächtiger unter die Leute brächte und desto grösseren Schaden täte.' (Hermann Böhlau (ed.), D. Martin Luthers Werke, Kritische Gesammtausgabe, [WA], Weimar 1883-, vol. 54, p. 172).
} 
Catholic church under different aspects, examining the papacy, heresies, religious practices etc., a more thematic approach - in contrast to the common purely annalistic style - later pursued by the Magdeburg Centuriators. ${ }^{13}$ In the section on heretics he linked the true church with the chain of heretics throughout the centuries; the label 'heretic' for him assumed the character of honour.

Franck's Chronica, Zeytbuch und gschychtbibel was published at a time of heightened sensibility towards Protestant, non-conformist books, especially when they stemmed from authors connected with spiritualism or anabaptism. ${ }^{14}$ Like Sleidan's Commentaries, Franck's work was first published in Strasbourg, and the tumult that followed would have echoes in the reaction to the publication of the Commentaries 25 years later. The city had to cope with a diplomatic crisis. Jacob Sturm was warned by the archbishop of Mainz concerning Franck's pernicious book; Erasmus wrote against Franck. Franck was imprisoned for a while, his book was banned in Strasbourg and an investigation into censorship violations was initiated. Even Charles V and King Ferdinand were informed about Franck's work. In the end, Franck was banished from Strasbourg. ${ }^{15}$

With his Germaniae Chronicon from 1538, Franck provided the reader with a history and cosmography of Germany from Noah to Charles V. Like the Chronica, Zeytbuch und gschychtbibel this was written in German. ${ }^{16}$ Again, he offered a list of

\footnotetext{
${ }^{13}$ Franck start his examination with Adam and carried it on to his time, as summarised on fol. A7v: 'Erst Chonic des alten Testaments/ die alt welt genant/ was sich verlauffen hab von Adam biß auff Christum. Chronica der Keyser und weltlichen Historien von Christi geburt biß auff Carolum v.

Chronica von allen Bäpsten/ iren guten oder bösen Decreten/ tahten etc. nach ordnung der jar und jar zal. ...' His examination of the Roman Catholic Church and the papacy makes up more than half of the book.

${ }^{14}$ In the same year, a commentary on Micah by Hans Denck was published, as well as Michael Servet's De trinitatis erroribus, both causing rejection amongst Protestants and Catholics alike.

${ }^{15}$ On the reactions of the publication of Franck's Chronica, Zeytbuch und gschychtbibel see André Seguenny, Répertoire des non-conformistes religieux des seizième et dix-septième siècles, Bibliotheca Dissidentium vol. 7, Baden-Baden 1986, pp. 44-45.

${ }^{16}$ Sebastian Franck, Germaniae Chronicon. Von des gantzen Teutschlands aller Teutschen völcker herkommen / Namen / Händeln / Guten und bösen Thaten/ Reden/ Rächen/ Kriegen/ Sigen/ Niderlagen/
} 
sources, ranging from Pliny and Tacitus to Rhenanus, Carion, Wimpfeling, Peuttinger,

Celtis and Brant. ${ }^{17}$ His use of sources, however extensive it was, did not go further than a mere copying down of different passages with little analysis and even less criticism. In the preface he voiced his discontent that Germany was so neglected by historians that one could think it was a nation of barbarians. Hence it was about time that the Germans dared to write books in their own language, and his work was to set an example. ${ }^{18}$ This statement offers an interesting motive for the rise of literature in the vernacular in the sixteenth century. Once more he proclaimed his impartiality, void of affections and judgements. $^{19}$

As we have seen, with the outsider Franck we have in many respects the first steps, however tentative and imperfect, towards the evolution of a Protestant historiography. He was to insist on the need for impartiality and veracity in any historical account. To secure this, history writing had to be based on a wide range of sources, primary ones at best. Obviously a historian in the early sixteenth century did not examine these sources with a very critical eye, but the first step was taken towards a modern style of history writing. Franck's preferred methodology was to investigate history not merely chronologically, but also with a thematic approach. History was portrayed as less based on cosmological and

Stifftungen/ Veränderungen der Sitze/ Reich/Länder/ Religion/ Gesatze/ Policei/Spraach/ Völcker/ und $\underline{\text { sitten/ Vor unnd nach Christi geburt/ Von Noe biß auff Carolum V. Ankunfft unnd Stifftung der Reich/ }}$ Bistumb/ Füstenthumb/ Herschafftenn/ Stett/ Clöster und Stifft. . .Auß glaubwirdigen angenommen/ Geschichtschreibernn / zu ruck diß blats verzeichenet/ zusamen getragen/ Unnd die Teutschen den Teutschen zu Teutsch/sich selbs darin/ als in einem Spiegel zu ersehen/fürgestelt, Augsburg (Alexander Weyssenhorn) 1538 .

${ }_{17}^{17}$ Ibid., fol. aalv.

${ }^{18}$ Ibid., fols. aa2r-v.

${ }^{19}$ Ibid., fol. bb3r: 'Ich hab mich auch geflissen den faden der oration also zu richten/ das ich niemant geschmitzt noch gehofiert haben/ parteisch geacht werde / sonnder on alle affect/ hon unnd schmitz/ wie all sach gefunden/ gesetzt.....Zum letzten handel ich hie nichts vom glauben/ was recht odder unrecht Göttlich odder unchristenlich ist/ sonder wie ein historicus / guts unnd böß/ wie es die that unnd histori gibt. Ich bin hie ein schreiber unnd kein censor frembder that oder rede/ wort odder werck/ unnd habe ja die person eins historischreibers/ so vil mir möglich anzogen/ das ich wider oder für niemant/ schreib/ dann als vil die that unnd red/ der thetter torheyt/ weißheit/ eer odder uneer mit sich pringt.' 
supernatural events, but formed primarily by social and economic factors. ${ }^{20}$ Franck also underlined the need for a vernacular history to teach the people about their past. From a theological point of view, his historiography was based on the notion of a line of God's true witnesses from the days of the early church to his age. To an extent he was indeed the forerunner paving the way towards a new approach to history, as he hoped to be. ${ }^{21}$ Seguenny even called his historical works 'the start of modern historiography in Germany'. ${ }^{22}$

Franck's spiritual theology and insistence of what one may call an early version of a deus absconditus was a shocking approach for his time, and combined with his other equally controversial teachings led to his expulsion from Strasbourg in $1532 .^{23}$

Melanchthon disapproved of the chronicle and called it 'ein Schmachbuch', a shameful book, a blind history in character, written in contempt and full of errors. ${ }^{24}$ However, Melanchthon's remarks at least provide convincing proof that Franck's books were widely read, something that could be inferred also by the large number of surviving copies.

\footnotetext{
${ }^{20}$ In the later Chronicon Carionis, discussed below, supernatural phenomena and cosmic events still played an important role, especially for the astronomer Carion, but also for Melanchthon. Franck occasionally referred to these phenomena, but examined them critically and did not see them as formative for history. In the sixteenth century strange astronomic events like comets, abnormal births, catastrophes and political turmoils were widely regarded as signs of a divine judgement. They were signs by God to admonish the sinners to turn around and repent. The huge number of literature published in this field in the sixteenth century shows how popular and wide-spread these beliefs were.

${ }^{21}$ Ibid., fol. bb3r.

${ }^{22}$ Seguenny, 'Historia Magistra Vitae', p. 112: 'En raison des postulats méthodologiques, tel que la critique des sources, l'élimination des événements surnaturels ou, lorsqu'ils sont mentionnés, l'adjonction d'un commentaire critique ayant pour but d'éveiller le scepticisme du lecteur, la recherche de la source des événemens dans le domaine économique ou social - en raison de tout cela, la Chronique de Franck constitue en Allemagne le début de l'historiographie moderne.'

${ }^{23}$ Cf. Patrick Hayden-Roy, 'Franck, Sebastian', in The Oxford Encyclopedia of the Reformation, vol. 2, p. 134.

${ }^{24}$ Cf. Melanchthon's 1539 preface to Caspar Hedio's Ein Außerleßne Chronick von anfang der welt bis auff das jar nach Christi unsers eynigen Heylands Gepurt M.D.xliii, Strasbourg (Krafft Müller) 1539, fol. cc3v : 'Man tregt sich jetzund mit Sebastian Francken Chronicka/ welche billich er möchte eyn schmach buch / dan eyn Historia/genant werden. Dann neben den geschichten/ hat er seine declamationes daran gehenget/ lobliche weltliche Potestaten schantlich gelestert/ und sonst vil onwarheit dabei geschriben/ schmucket die Anabaptisten/ und ist wohl zu mercken auß dem gesang was er für eyn vogel ist. Polybius spricht/ Oculus historiae est veritas. das achtet Sebastian Franck wenig/ sondern macht eyn blinde historien/ darein er seine eygne affectus außgossen. Dazu irret er als ein ungelerter/ oft in der zeit/ und in den geschichten... .'
} 
Franck's works indeed enjoyed a long lasting life in editions in German, Dutch, and French. $^{25}$

\section{Johann Carion and Philip Melanchthon}

Philip Melanchthon was a stern critic of historical writing; it was after all a subject in which he took a close personal interest. ${ }^{26}$ Just as he had condemned Franck, 25 years later he would pronounce an equally fierce verdict on Sleidan. But in the meantime he had made his own contribution to the continuing genre of Reformation history writing. One year after Franck first published his Chronica, Zeytbuch und gschychtbibel, another, more important and much better known, history appeared, a work that became known as Chronicon Carionis. ${ }^{27}$ Melanchthon's role in this work allows us to consider this as the closest thing to an officially approved scheme of historical writing in the first generation of the Wittenberg reform. ${ }^{28}$ As such, it could scarcely not impact on Sleidan's consciousness as he set about his own historical ventures.

Johann Carion (1499-1537) became the court astronomer of the Catholic Joachim I of Brandenburg in 1521, a position he held until his death in $1537 .^{29}$ Carion, pupil of

\footnotetext{
${ }^{25}$ For bibliographical information on Franck, see Klaus Kaczerowsky, Sebastian Franck: Bibliographie, Wiesbaden 1976, and Christoph Dejung, 'Sebastian Franck', Bibliotheca Dissidentium, vol.7, pp. 39-119, Baden-Baden 1986. Franck's works were very popular and read across Europe. Kaczerowsky in his Bibliographie lists sixteen German editions and seven Dutch editions of the Chronica Zeitbuch unnd Geschichtbibell alone for the sixteenth century.

${ }^{26}$ For English literature on Melanchthon, see Lowell C. Green, Melanchthon in English: New Translations into English with a Registry of Previous Translations. A Memorial to William Hammer, 1909-1976, Sixteenth Century Bibliography, vol. 22, Saint Louis 1982; Clyde L. Manschreck, Melanchthon: The Quiet Reformer, Westport, Conn. 1975; Michael Rogness, Philip Melanchthon: Reformer without Honor, Minneapolis 1969.

${ }^{27}$ Accessible by me was only the 1570 edition, printed by the heirs of Georg Rhaw, who printed the first, 1532, edition: Johann Carion, Chronica Carionis ganz new Latine geschrieben. Von dem Ehrwirdigen Herrn Philippo Melanchthone verdeutscht, Wittenberg (Georg Rhawen heirs) 1570.

${ }^{28}$ Luther's view of history was rather similar to Melanchthon, but he concentrated on theology rather than history in his works. Cf. Markus Wriedt, 'Luther's Concept of History and the Formation of an Evangelical Identity', Gordon, Bruce (ed.), Protestant History and Identity in Sixteenth-Century Europe, vol.1: The Medieval Inheritance, Aldershot 1996, pp. 31-45.

${ }^{29}$ Cf. Gotthard Münch, 'Das Chronicon Carionis Philippicum', Sachsen und Anhalt 1 (1925), pp. 199-283, especially pp. 201-204.
} 
Luther and university friend of Melanchthon, soon directed his focus towards primary material to write an all encompassing history of the world, consulting classical historians like Herodotus and Livy, medieval chronicles and more recent works like Naucler's chronicle. ${ }^{30}$ After completion, he sent the German manuscript to Melanchthon, who reworked it to a great extent and added a preface under his name. The Chronicon was published under Carion's name in 1532 and became immediately very popular, which was also due to Melanchthon's involvement. In 1558 and 1560 Melanchthon edited two parts of a revised, Latin version of the Chronicon, covering the history of the world until Charlemagne. Kaspar Peucer, Melanchthon's son-in-law, added two further Latin volumes in 1562 and 1565 , carrying the narrative to the time of Charles V. ${ }^{31}$

The Chronicon is split up into three books, corresponding to the 6000 -year scheme of the so-called prophecy of Elijah (1 Kings 19), dividing up the history of the world into three periods of 2000 years each, with the first 2000 years of barrenness, then 2000 years under the law, followed by 2000 years dominated by the Messiah. ${ }^{32}$ Each age of the world is examined in relation to church and state, taking further the tentative approach of Franck and leading the way for a fully developed thematic analysis within the Magdeburg Centuries. In addition to this time-frame, we find a partition into Daniel's scheme of the four empires (Dan. 2:21), Babylonia, Persia, Greece and Rome, with the fourth empire corresponding to the last 2000 years under the Messiah. ${ }^{33}$ For Melanchthon, this last

\footnotetext{
${ }^{30} \mathrm{Cf}$. Münch, 'Das Chronicon Carionis', pp. $207 \mathrm{ff}$. .

${ }^{31}$ For the genesis of the Chronicon cf. Joachim Knape, 'Melanchthon und die Historien', ARG 91 (2000), p. 119.

${ }^{32}$ Cf. Melanchthon's preface in Carion, Chronica Carionis, fol. 10r: 'Sechs tausent jar bleibt diese Welt/ darnach wird sie verbrennen./ Zwey tausent öde./ Zwey tausent jar das Gesetz./ Zwey tausent jar die zeit Messie./ Und vmb unser Sünde willen/ die gros und viel sind/ werden die jar hieran mangeln/ welche mangeln werden.' The common structure in the fifteenth and early sixteenth century in Germany was the division into six to seven ages of the world, as e.g. practised by Hermann Schedel in his Weltchronik 1493. ${ }^{33} \mathrm{Cf}$. ibid., fols. 11v-13v. Sleidan would pick up this division into four empires in his 1556 De quatuor summis imperiis libri tres. For the concept of the periodisation of history, cf. Uwe Neddermayer, Das Mittelalter in der deutschen Historiographie vom 15. bis zum 18. Jahrhundert. Geschichtsgliederung und Epochenverständnis in der frühen Neuzeit, Cologne/Vienna 1988.
} 
empire found its culmination in the Holy Roman Empire and in the German people, with the Ottoman Empire as an enemy from outside, and the papacy as the inner enemy. In his view there was no doubt that the last third of the world ages, and with it the fourth empire, were approaching the end. This of course was also the view of the astronomer Carion, who saw cosmic phenomena rather than political and social events as the prime motor of history.

Even in his early career Melanchthon had put a special emphasis on history, and in his opening lecture at the university of Wittenberg in 1518 he underlined the importance of history, portraying it in classical Ciceronian style as the teacher of life and as the origin of all arts and sciences. ${ }^{34}$ In 1520 , he appealed, albeit unsuccessfully, to the Wittenberg university to introduce history as a proper academic subject, thereby attributing it a place on its own alongside theology. ${ }^{35}$ In the following decades, Melanchthon excelled as initiator, author, editor and corrector of diverse chronicles and histories by Naukler, Hedio, Spalatin, Tacitus and Sallust, to name but a few. ${ }^{36}$ He distinguished between a 'history' as a portrayal of a singular event or stream of similar events, and the 'chronicle' as a comprehensive account. ${ }^{37}$ History for him was one of the main tools of communication between God and mankind, an outward expression of the divine Heilsplan. History testifies to the existence of God.

\footnotetext{
${ }^{34} \mathrm{Cf}$. Knape, 'Melanchthon und die Historien', p. 114-115.

${ }^{35}$ So far history was only part of the artes liberales; despite Melachthon's constant efforts, it was not introduced at Wittenberg university until 1555. On this topic, see E.C. Scherer, Geschichte und Kirchengeschichte an den deutschen Universitäten, Freiburg/Breisgau 1927.

${ }^{36} \mathrm{Cf}$. for example Melanchthon's preface to Hedio's Ein Außerleßne Chronick; annotations by Melanchthon to $\mathrm{C}$. Crispi Salustii Historici Clarissimi, de Catilinae coniuratione, et bello lugurthino historiae, Cologne (Johannes Gymnicus) 1532.

${ }^{37}$ Cf. Mencke-Glückert, Geschichtsschreibung der Reformation und Gegenreformation, pp. 45-46. This distinction was also important to Sleidan as during the negotiations about his contract as historiographer of the Schmalkaldic League he wrote to Jacob Sturm on 3 July 1545 that he wished to have the term 'chronicle' replaced by 'history' (Appendix I, No. 81).
} 
It is in the preface to the Chronicon Carionis that Melanchthon explained at length his view of history. History-writing had been performed by both pagans and Christians alike (starting with the Bible), with the dual purpose of learning about one's past and possible future, and to be taught by it. ${ }^{38}$ God revealed himself in history, and therefore he inspired the writing of histories from the beginning of the church onwards. History serves to commemorate the past, it provides guidelines during hard times, sets examples of just behaviour and teaches people to fear God. ${ }^{39}$ By examining history man can learn about God's will. Similarly to Franck, and later on Flacius, Melanchthon held the conviction that throughout history there had always been one group, however small, who had represented the true faith. True believers had often been persecuted but had still never ceased to exist. $^{40}$

Carion's, and even more so Melanchthon's legacy to Protestant historiography was manifold. The utilisation of Daniel's four monarchies as a structuring principle for a history was widely followed, and fully expanded by Sleidan in the Four Empires. Additionally, the attempt to distinguish between a secular and ecclesiastical history and a more thematic treatment of events, rather than merely chronological, was formative for later historiography, as was the emphasis on primary sources. As we have seen above, the chain of witnesses of the true church throughout the centuries is another important feature of the Chronicon Carionis. This way of arguing provided the Protestant church with a justification of their existence and enabled them to defend themselves against the Catholic claim that the Protestant church was a late invention: it became the Protestant counterpart to the Catholic notion of an apostolic succession. As mentioned above, the author to

\footnotetext{
${ }^{38}$ Cf. Melanchthon's preface in Carion, Chronica Carionis, especially fol. $5 \mathrm{r}$ : 'Summa alle Historien leren allerley nötige Regeln / im gantzen leben vnd manchfeltigen rahtschlegen nützlich zu gebrauchen / vnd ist ein besondere weisheit in exempeln betrachten / zu welchen Regeln gemeines lebens jede bequem und dienstlich sind,'

${ }^{39} \mathrm{Cf}$. ibid., fols. $1 \mathrm{v}-2 \mathrm{r}$.

${ }^{40}$ Cf. ibid., fols. $5 \mathrm{v}-6 \mathrm{r}$ and $9 \mathrm{r}-\mathrm{v}$.
} 
further develop this interpretation was Matthias Flacius Illyricus with his Catalogus testium veritatis in 1552.

\section{A contemporary project: Matthias Flacius Illyricus}

One of the most fascinating aspects of Sleidan's work is that he set to his task of compilation at a time when German reformers and statesmen were so acutely conscious of their place in history. We see this, of course, in the large measure of cooperation Sleidan both looked for and received in his search for official documents to include. But it is equally pertinent to remember that in parallel with Sleidan another great milestone of Protestant history writing was in composition: the work initiated by Matthias Flacius Illyricus, which is known to history as the Magdeburg Centuries.

It is worth at this stage attempting an explicit comparison between these two initially dissimilar works, for while they demonstrate many common features, they adopt at times different solutions for interpreting the past. Each of course had a different purpose: while Sleidan offered an interpretation of recent events, Flacius attempted an ambitious scheme to anchor the Protestant present in the contested centuries going back to the birth of Christianity. Sleidan and Flacius both adopted a highly programmatic scheme for the organisation of this past, both based on their reading of scripture. Official approval of their work was for both men so important that they constantly asked for the advice of a large number of scholars and politicians. Each of them would go to any lengths to ensure the veracity and correctness of their accounts. By providing an account of the history of the church up to the sixteenth century in the case of Flacius and the history of the Reformation in the case of Sleidan, the two works complement each other in a certain way. There were also fascinating personal connections, not least in the scholarly figure of the imperial diplomat Caspar von Nidbruck, Sleidan's relative, who acted for both men as a vital 
conduit in the acquisition of works. Yet Nidbruck's attitude to the two projects was strikingly different. While Flacius was a connection he would openly acknowledge, his contact with Sleidan remains shrouded in secrecy.

Two decades after Franck and Melanchthon elaborated on the idea of a chain of God's true witnesses throughout the centuries, culminating in the Protestant church, this concept was resumed by Matthias Flacius Illyricus (1520-1575). ${ }^{41}$ A former student of Melanchthon, he became professor of Hebrew at Wittenberg in 1544, maintaining close connections to his former teacher and Luther himself. The subsequent split of the Lutherans after the death of their leader resulted for Flacius in a split with Melanchthon and his Philippists, and forced him to move to Magdeburg, the centre of the Gnesiolutherans. His increasingly radical view of Protestantism turned him more and more into a religious and political outcast. His influence on both historiography and theology remains nevertheless indisputable.

From the 1540 s onwards Flacius turned his attention to church history. His early works in this field concentrate on editing and translating manuscripts for printed editions. ${ }^{42}$ Flacius soon saw the need to provide a Protestant church history to revisit the past fifteen centuries of the (Roman) Catholic church from a Protestant point of view. He felt that a project of such dimensions would exceed both his time and abilities. Thus in the summer

\footnotetext{
${ }^{41}$ For an outline of Flacius' life, cf. Peter F. Barton, 'Matthias Flacius Illyricus', Die Reformationszeit II, ed. Martin Greschat, Stuttgart/Berlin/Cologne/Mainz 1981, pp. 277-294; Martina Hartmann, Humanismus und Kirchenkritik: Matthias Flacius Illyricus als Erforscher des Mittelalters, Stuttgart 2001, pp. 13-16. As with Franck, Flacius is a topic rarely encountered in English literature: see Oliver K. Olson, 'Matthias Flacius Illyricus', Shapers of Religious Traditions in Germany, Switzerland, and Poland, 1560-1600, ed. Jill Raitt, New Haven 1981. There is no evidence that Flacius and Sleidan were in contact.

${ }^{42}$ Amongst these are the 1548 and 1550 editions of Zwey Capitel Polydori Vigilij vom Namen und Stifftern der Meß, an extract from Polydor Vigilius arguing that the mass and biblical canon had not been institutionalized from the early church onwards, and Carmina vetusta ante trecentos annos scripta, quae deplorant inscitiam Evangelii et taxant abusus ceremoniarum, a medieval criticism of the neglect of the gospel and abuse of the church ceremonies (cf. Heinz Scheible, Die Entstehung der Magdeburger Zenturien. Ein Beitrag zur Geschichte der historiographischen Methode, Schriften des Vereins für Reformationsgeschichte 183, Gütersloh 1972, p.17).
} 
of 1552 he employed a scholar to compose a detailed plan for a church history starting with Christ, a project that rapidly failed. ${ }^{43}$

By that time, however, Flacius was determined to pursue his plan of portraying the history of God's witnesses throughout the centuries, a concept stemming from the prophet Elijah in 1 Kings 19. Simultaneously, through examining church history, he intended to prove that the pope was Antichrist. The first of these objectives was pursued in an earlier work, the Catalogus testium veritatis, qui ante nostram aetatem reclamarunt Papae, published with Johannes Opporinus in Basle in late 1552. In this work, he listed about 400 witnesses of the truth and critics of the pope, perfecting the preparatory line of thought of Franck and Melanchthon. ${ }^{44}$ With this 'checklist' of people and areas to be covered, Flacius turned his attention towards another work of much larger scale, the writing of a Protestant ecclesiastical history, starting with Jesus Christ. Since he realised that both Catholic libraries and archives, and possibly also collections in the hand of the Philippists would inevitably be inaccessible to him, Flacius put his hopes for support mainly on one man, Caspar von Nidbruck.

Nidbruck (1525-1557) was the nephew of the diplomat Johann von Nidbruck, better known as Hans or Bruno von Metz, the father-in-law of Sleidan. Caspar von Nidbruck, who had studied under Melanchthon, Calvin and also Flacius, had been promoted by 1550 to the role of councillor at the court of the future Maximilian II, then king of Bohemia. Since 1553 he also acted as councillor for Ferdinand and was well respected at the court of Charles V. ${ }^{45}$ He had gained this important position through the mediation of Franz Dryander (Francisco de Enzinas), to whom he had to promise not to mention his Protestant

\footnotetext{
${ }^{43}$ Ibid., p.15.

${ }^{44}$ The 1562 Strasbourg edition already included about 430 witnesses.

${ }^{45}$ For more biographical information, see R. Holtzmann, 'Niedbruck, Kaspar von', ADB 52 (repr. Berlin 1971), pp. 621-629.
} 
connections. Nidbruck, with his vital position at the Habsburg courts and contacts to important men like Calvin, Melanchthon, Bucer, Sleidan, Christoph of Württemberg, and Ottheinrich of Palatine seemed the ideal person for Flacius to collaborate with for his project.

On 10 November 1552 Flacius sent a letter to Nidbruck, the first in a long sequence between 1552 and 1557 concerning the Magdeburg centuries. These letters were collected and published by Victor Bibl in the nineteenth century. ${ }^{46}$ In this first letter Flacius sent an outline of a monumental church history to Nidbruck, who apparently already knew about this project and had promised support. ${ }^{47}$ This plan, which he called Scheda, followed the same line as the Catalogus testium veritatis, with the aim of showing how the (Catholic) church strayed from the original truth, whereas the biblical 7,000 witnesses of the truth (1 Kings 19) secured an unbroken chain of true believers. With this argumentation he hoped to deny the Catholic point of view that the Protestant church was nothing but a modern invention. The Scheda also included a list of sources to be consulted, containing writings before Gregory the Great, investigation and trial acts against 'pious people', writings against the Antichrist, Catholic writings against the true believers, and city and town chronicles and annals. Additionally, wise and old people were to be consulted about their knowledge of witnesses and writings concerning them. Nidbruck received this letter on 28 February 1553, and answered the following day. ${ }^{48}$ He suggested employing at least three

\footnotetext{
${ }^{46}$ Victor Bibl, 'Der Briefwechsel zwischen Flacius und Nidbruck', Jahrbuch der Gesellschaft für die Geschichte des Protestantismus in Österreich 17 (1896), pp.1-24; (18)1897, pp.201-238; (19) 1898, pp. 96110 ; (20) 1899, pp. 83-116. For the 11 (preserved) Latin letters concerning the Magdeburg Centuries exchanged between Melanchthon and Nidbruck from 1553 till $1556 \mathrm{cf}$. by the same author, 'Melanchthon und Nidbruck', Jahrbuch der Gesellschaft für die Geschichte des Protestantismus in Österreich 1897, pp. 3455. The scope of collaboration between Flacius, Nidbruck, Melanchthon and other important people merits an examination in its own right and can only be touched upon in this work. For a detailed examination of the genesis of the Magdeburg Centuries, see Scheible, Entstehung der Magdeburger Zenturien.

${ }^{47}$ Bibl, 'Briefwechsel' (1896), pp. 8ff. .

${ }^{48}$ Printed in A. Horawitz, 'Beiträge zu den Sammlungen von Briefen Philipp Melanchthons', Sitzungsberichte der Wiener Akademie, Philosophisch-historische Klasse 76 (1874), pp. 319-323.
} 
people to assist in this project, with each of them responsible for different aspects of the work, such as collecting material, writing or correcting mistakes.

Around the turn of the year 1553/1554 Flacius drafted a detailed plan for the ecclesiastical history, Consultatio de conscribenda accurata et erudita historia ecclesiae, a consultation on the writing of an accurate and erudite church history to be sent to possible supporters of the project. ${ }^{49}$ The necessary money to run such a project was to be gathered largely from princely sponsors, and it was also financed by the Fugger family. The Consultatio, similar to the earlier Scheda, contained an outline of the history, along with practicalities like scholars to be consulted and employed, the general purpose and virtue of such a work, and the sources to be used. The impressive task mentioned in the Scheda was to encompass all theologians and historians, printed or not, along with Waldensian writings.

Meanwhile, Nidbruck fulfilled his part of the project and used all his powers and connections to find material for Flacius' project. $^{50}$ He was in the fortunate position of collecting books and manuscripts at the express wish of King Maximilian for the Vienna court library, the 'Hofbibliothek'. Supported by the king in any possible way, Nidbruck could purchase valuable material for this official purpose and transport it to Vienna in his own special way. He employed various people to travel across Europe and purchase material on his behalf. One of the two most important book hunters was Hubert Languet, who was sent to Italy with a recommendation from Melanchthon to Cardinal Jean Du

\footnotetext{
${ }^{49}$ On surviving editions of the Consultatio de conscribenda accurata et erudita historia ecclesiae, in qua potissimum doctrinae ac religionis forma, quo tempore ac loco qualis fuerit, diligenter exponetur see Scheible, Entstehung, p. 24 fn. 29.

${ }^{50}$ In his quest to find supporters for Flacius' project, Nidbruck also contacted Basilius Amerbach on 6 July 1554 but apparently to no avail. Cf. Hartmann, Alfred, Die Amerbachkorrespondenz, 10 vols., Basle 194295 , vol. 9 (1554-55), No. 3783 , p. 365 .
} 
Bellay at Rome to find books in Italy and France. ${ }^{51}$ The second, even more important delegate was a friend of Nidbruck, Georg Tanner, professor of Greek at the university of Vienna. He was also sent to Italy with recommendations of the court to the senate of Venice, the dukes of Florence, Ferrara, Mantua and others. ${ }^{52}$ The material gathered in this way was then shipped to Regensburg to the house of the superintendent Nicolaus Gallus, where Marcus Wagner, in the service of the Centuriators, was allowed to work with it for half a year. ${ }^{53}$

By 1554 the project had officially started. The four most important colleagues of Flacius were the minister and superintendent Johannes Wigand, the medical doctor Martin Copus, the rector Gottschalk Prätorius, and the dean and rector Matthäus Judex. The members of this group were given guidelines as to the gathering and assembly of the material, and were to meet every week. The general layout was to be chronological, moving from a general idea to a more specific treatment of different topics. In the margins the sources were to be cited so the reader could look them up.

The structure finally agreed upon was to dedicate a book to each century - hence the name Magdeburg Centuries - and within each book to present the gathered material under sixteen different topics: general characteristics, the state of the church, persecutions, doctrines, heresies, ceremonies and rites, the politics and government of the church,

\footnotetext{
${ }^{51}$ Cf. Victor Bibl, 'Nidbruck und Tanner. Ein Beitrag zur Entstehungsgschichte der Magdeburger Centurien und zur Charakteristik König Maximilians II.', Archiv für österreichische Geschichte 85 (1898), p. 421. Hubert Languet (1518-1581) was born in 1518 in Vitteaux, Bourgogne, and in 1549 went to Wittenberg to study under Melanchthon. They became good friends, and Melanchthon acquainted him with Caspar von Nidbruck and various theologians as well as political leaders. From 1560 onwards Languet became chief ambassador to France in the service of the Elector August of Saxony (cf. Henri Chevreul, Étude sur le XVIe Siècle. Hubert Languet, Paris 1852, reprint Nieuwkoop 1967). - We do not know of Jean Du Bellay's reaction to this quest, nor do we know whether he was aware of the production of the Magdeburg Centuries and that the collected books were destined for the Centuriators first. Had he been aware of the books' destiny then his possible support would have underlined his reconciliatory position towards the Protestants, as would the fact that he was contacted in the first place.

${ }^{52}$ Bibl, 'Nidbruck und Tanner', pp. 417-418. In this function, Tanner also contacted John Cheke for help, who had fled to Italy under Mary Tudor.

${ }^{53}$ Cf. Bibl, 'Briefwechsel' (1896), p. 3; Bibl, 'Nidbruck und Tanner', p. 383.
} 
schism, councils, important people within the church, heretics, martyrs, miracles, Jewish external or other political events, non-Christian religions, the imperial politics. Flacius explained this outline in the preface to the first volume, it is the structure underlying all volumes, with only slight variations in formulation.

For a couple of years Nidbruck and Flacius were in permanent contact, discussing various aspects of the work, the acquisition of material and organisation of work and workers. Nidbruck tried to help as much as possible, and also frequently contacted Melanchthon for advice. ${ }^{54}$ At Flacius' urgent request Nidbruck had sent the outline of the Magdeburg Centuries to Calvin for his opinion. Calvin replied on 13 February 1557 in a rather critical way; he did not approve of treating each century in a separate volume, nor was he convinced of the merit of examining every century under the same topics. ${ }^{55}$

Despite his deep involvement in the cause of the Magdeburg centuries, Nidbruck always made certain to cover up his connections to the Protestants, especially in the case of Sleidan and Flacius. In his correspondence with them he usually omitted his own name or signed under a pseudonym, just calling the addressee 'friend'. The fruitful cooperation between Flacius and Nidbruck finally ended in April 1557 with Flacius' departure from Magdeburg. Not long after this, in September 1557 Nidbruck died in mysterious circumstances.

We cannot but speculate about the role of Maximilian in this whole process of sending the books purchased for the court library through the hands of the Centuriators. There had been rumours for a time about the king's indulgence towards Protestants, a policy which increased even more since the official toleration of Protestantism in the peace

\footnotetext{
${ }^{54}$ Bibl, 'Melanchthon und Nidbruck', pp. 34-55.

${ }^{55}$ CR 43, pp. 68-88; CR 48, pp. 448-450; also Scheible, Entstehung, p. 47.
} 
of Augsburg in $1555 .^{56}$ Nidbruck's involvement in Flacius' project was not a secret, and the nature of the books he acquired was certainly modelled on the programme of the Magdeburg Centuries. This apparently did not escape the pope either, who is said to have criticised Maximilian for his 'Lutheran library'. ${ }^{57}$ Even Maximilian's involvement in Flacius' history project was the focus of rumours. The Saxon councillor Dr. Ulrich Mordeisen mentioned in a letter to his colleague Dr. Georg Cracau that "not long ago Maximilian had courted Illyricus and sent him many a gift and also money, ${ }^{58}$ Similarly, Melanchthon wondered why 'those who have urged me to be moderate now support the errors of Flacius. ${ }^{59}$

Spring 1559 saw the publication of the first three Centuries, the Ecclesiastica Historia, dedicated to Christian of Denmark and King Maximilian, their secret fosterfather, and signed by Flacius, Wigand, Judex and Faber. ${ }^{60}$ Century four followed in 1560 , by which time the initial staff had already changed after Flacius, Wigand and Judex had moved to Jena, but still continued their work. Conflicts within the group resulted in the dismissal of all three at the end of 1561 , but the project was carried on with a different team. Due to further theological and dogmatic disagreements between different factions that developed within this group, further cooperation soon became impossible. The last century to be completed, the thirteenth, was published in January 1574. Centuries fourteen and fifteen survive only in fragments. The Magdeburg Centuries were to be an internationally accessible source and hence published in Latin. Two members of the

${ }^{56}$ Cf. Bibl, 'Nidbruck und Tanner', p. 393.

${ }^{57}$ Cf. Bibl, 'Nidbruck und Tanner', p. 383; also Hartmann, Humanismus und Kirchenkritik, p. 57.

58 '...da doch eben Maximilianus zuvor den Illyricum hovirt und ime allerlei geschengk und gelt zugeschickt.' (Bibl, 'Nidbruck und Tanner', p. 401).

${ }^{59}$ CR 9, p. 832.

${ }^{60}$ Full title: Ecclesiastica Historia, integram Ecclesiae Christi ideam, quantum ad locum. Propagationem. Persecutionem. Tranquillitatem, Doctrinam, Haereses, Ceremonias, Gubernationem. Schismata, Synodos, Personas, Miracula, Martyria, Religiones extra Ecclesiam, \& statum Imperii politicum attinet, secundum singulas Centurias, perspicuo ordine complectens: singulari diligentia \& fide ex vetustissimis \& optionis historicis, patribus, \& aliis scriptoribus congesta: Per aliquot studiosos \& pios viros in urbe Magdeburgica, Basle (Johannes Oporinus) 1559. 
editorial board, Johannes Wigand and Matthäus Judex, themselves translated Centuries one to four into German. Centuries one to three were published in 1560 , Century four followed in 1565 and was to be the last one to be translated. ${ }^{61}$ Only centuries one to four were translated into French by the Genevan minister François Bourgoing and published in two volumes in 1560 and 1562 by Artus Chauvin in Geneva. ${ }^{62}$ Chauvin was only granted the permission to print this work by the Council of Geneva if he promised to leave out any 'Lutheran and German doctrine'.63

Flacius had organised his historiographical venture very well. The cooperation with Nidbruck had proved very fruitful, masses of books and manuscripts passed through the hands of the Centuriators. Flacius' own efforts to obtain advice and support from other scholars also made a valuable contribution. Before a century was actually published, it went through the hands of a number of scholars who could bring in their expertise. Flacius was also in contact with John Bale, through whom he hoped to get access to certain books available in England, especially after the dissolution of the monasteries. Almost certainly the books requested were manuscript works since few books of academic quality were printed in England before the $17^{\text {th }}$ century, and these few were popular works already published in multiple editions on the continent. Flacius dedicated Century four to Elizabeth of England, and send a messenger over with a copy and a request for assistance in obtaining access to books, including a list of desired works. Elizabeth handed this

\footnotetext{
${ }^{61}$ Kirchenhistoria/ darinnen ordenlich und mit höchstem vleiss beschrieben werden die gschicht der Kirchen Christi ... (Centuries I-III); KirchenHistoria/ die Vierde Centuria/ Oder das Vierde Hundert Jhar ... (Century IV); both were published by Thomas Rebart in Jena).

${ }^{62}$ The title of the work is L'Histoire ecclesiatique, proposant l'entiere et vraye forme de l'eglise de nostre Seigneur Iesu Christ. It does mention Flacius and some of his colleagues on the title page, but omits Geneva as place of print. - François Bourgoing's daughter happened to be te second wife of the Genevan printer Jean Crespin (cf. Gilmont, Jean Crespin, p. 216).

63 '...sans la doctrine des Lutherines at Allemans qui les ont recuillies'. (Gilmont, Jean Crespin, p. 128). Cf. by the same author, 'La naissance de l'historiographie protestante', Andrew Pettegree, Paul Nelles, and Philip Conner (eds.), The Sixteenth-Century French Religious Book, Aldershot 2001, p. 120.
} 
request over to Matthew Parker, who in turn got back to John Bale for advice. ${ }^{64}$ Various books were exchanged by messengers between Magdeburg and England, but the extent of this exchange remains unknown.

The Centuriators wanted to make their work as comprehensive and precise as possible. Even after the publication, further advice was sought. An interesting example for this process has been preserved in a copy of Centuries one to three in the Bayerische Staatsbibliothek in Munich. This original 1559 edition, published by Opporinus in Basle, was originally given by the 'inspectors and governors' of the Magdeburg Centuries to Count Johann Albrecht of Mansfeld, as the inscription inside the cover says. The count then seems to have handed it over to the reformer and historian Cyriakus Spangenberg, a partisan of Flacius, who inscribed 'and my generous patron in turn gave it to me, Cyriakus Spangenberg, 2 July $1559^{\prime}$. Soon after, the book went from Spangenberg over into the hands of Strasbourg's Jean Sturm, who added his signature with the date 16 August 1559, followed by a Latin poem which could also stem from him. ${ }^{65}$

The Magdeburg Centuries certainly merit an important place in Protestant historiography. From predecessors like Franck, Melanchthon and Flacius, their chief contributor, they inherited certain innovations in the historiographical method, such as an intense use of sources. Additionally, it is from these predecessors that the idea of a chain

\footnotetext{
${ }^{64}$ Cf. Norman L Jones, 'Matthew Parker, John Bale and the Magdeburg Centuriators', SCJ 3/12 (1981), pp. 36-41. The author also draws attention to a remark of John Bale in a letter to Matthew Parker that the Catalogus testium veritatis had been 'set fourthe by me and Illyricus.' For Bale's co-authorship there exists no evidence, however (cf. p. 36). - Matthew Parker was a famous collector of antiquarian manuscripts; $c f$. for example Timothy Graham's analysis of Parker's conservation of an eleventh-century copy of King Alfred's translation of the Regula pastoralis, 'Matthew Parker and the conservation of Manuscripts; the case of Cul Ms Ii.2.4 (Old English Regula pastoralis, $\mathrm{s} . \mathrm{xi}^{3 / 4}$ )', Transactions of the Cambridge Bibliographical Society X (1995), pp. 630-641.

${ }^{65}$ This copy is preserved in the Bayerische Staatsbibliothek in Munich, pressmark H.eccl. 190/1-3. The 'inspectores et gubernatores' gave the copy to Count Johann Albrecht of Mansfeld. Spangenberg inserted 'Et Generosus Comes iterum michi Cyriaco Spangenberg dato...'. Sturm added his 'Joannes Sturmius', followed by a Latin eulogy of the work, the 'Augusta'.
} 
of true believers stems, the concept Flacius hoped to prove with this monumental work. The method of analysing history under certain topics, or loci - an approach propagated by Melanchthon -was very peculiar to the Magdeburg Centuries at a time when an annalistic structure was still dominant; today of course a thematic treatment is the norm.

What makes the Magdeburg Centuries interesting for us in this context are the various connections in their genesis with Sleidan and his Commentaries. In a direct comparison, the two works share nothing but roughly the same time of publication and their Protestant authorship. The Magdeburg Centuries was a group project scanning the centuries since Christ's birth for multiple evidence that the Protestant church was in fact the true church. The Commentaries on the other hand were the work of an individual author employed by the Protestant authorities to portray the history of the Reformation. It is in this respect that the two works perfectly complement one another as two parts of a justification of the Reformation.

A comparison of the genesis of both works highlights further similarities. Both try to produce a reliable account based on sources in an attempt to justify themselves against the Catholic church on a scholarly level. In preparation for their main work, the two scholars composed smaller works and send them out to possible patrons and supporters. Flacius wrote his Catalogus testium veritatis, Sleidan published the Two Orations as well as various translation of Froissart, de Seyssel and Commynes. Both projects received support by various parties, and to a large extent relied on the generosity of different rulers. Important fellow historians and theologians were contacted: Calvin for example received samples and outlines of both works. 
What links the two historians on a personal level is the man involved in both, Caspar von Nidbruck, the undercover Protestant with a vital influence at all Habsburg courts. It is the middleman Nidbruck who provides the most interesting connection between the two. Both Flacius and Sleidan repeatedly turned to him for advice. Nidbruck was prepared to give this desired advice, but only in as much secrecy as possible. It is surprising that out of the two historians it is Flacius, and not Sleidan, a relative, who received the greatest support from Nidbruck. Of the 23 extant letters exchanged between Nidbruck and Sleidan, 21 stem from the years 1555 and 1556, the time just before and after the publication of the Commentaries. Eleven are written by Sleidan, ten by Nidbruck; their content shows that not all letters have been preserved. The letters provide no evidence that Sleidan received any material to work from through Nidbruck. Instead the councillor repeatedly appealed to Sleidan to remain moderate and careful and not to show any rash reaction. In the course of their correspondence Nidbruck seemed increasingly embarrassed by their connection and warned Sleidan not to disclose their contact to anyone. Flacius on the other hand received every possible help from Nidbruck - this despite the fact that he was a controversial theologian who eventually had to flee from one city to another until he died as an outcast in Strasbourg in 1567. Nevertheless, Flacius seemed to have been a less dangerous liaison for Nidbruck than the diplomat Sleidan.

Nidbruck's involvement in the Magdeburg Centuries is not openly mentioned in the correspondence with Sleidan. However, in a letter from June 1555 Nidbruck reminded Sleidan to send back 'the Magdeburg script' - could this be a draft of Century one? ${ }^{66}$ In September of the same year Nidbruck touched upon the subject again and allowed Sleidan

\footnotetext{
${ }^{66}$ 'Remitte etiam ad me scriptum Maideburgensium ...' (My translation; Baumgarten, Briefwechsel, No. 142; Appendix I, No. 347).
} 
to keep the 'Magdeburg script', but appealed to him not to lose it. ${ }^{67}$ A letter from July 1555 to Sleidan seems to bear witness to Nidbruck's activities as collector of books for Flacius: 'When you meet my uncle [Hans/Bruno von Nidbruck], ask him if he has a packet of books in Strasbourg which I have bought in London, England, and which he himself has arranged to be transported with his own things from England; ... . I hear that [François] Baudouin who is already with you has collected much on the schisms in the Roman church; I ask you to enquire what he has and if he would decide to lend some out sometime...'. Nidbruck offered to lend him works of his own collection in return. ${ }^{68}$ Nidbruck here seemed to talk about the above mentioned manuscript books acquired in England, possibly even with the help of John Bale, on behalf of the Centuriators.

Why did the work of the Magdeburg Centuriators prove so much less controversial than Sleidan's work? The answer seems to lie in the fact that the Magdeburg Centuriators directed their main focus at an earlier period and thus had a much smaller potential to raise trouble than the Commentaries. The Commentaries, treating recent events and describing people who were often still alive, were published at a critical time when anything could shake the negotiations at the Augsburg Diet. The Protestants would have been concerned that any hitherto secret plans and negotiations or any offensive statements against the Catholics would be made public. On the other side, the Catholics would have read the Commentaries with a critical eye towards how they themselves were seen by their opponents. Additionally, the late 1550 s was also a time when Sleidan's connections to Calvin would have been eyed most critically. To be connected in any way with Sleidan

\footnotetext{
${ }^{67}$ 'Scriptum Magdeburgicum potes custodire, sed ne pereat;...' (Baumgarten, Briefwechsel, No. 155; Appendix I, No. 362).

68 'Si quando patruum convenias, interroga an Argentinae habeat fasciculum librorum quos in Anglia Londini emi et ipse cum sarcinis suis ex Anglia advehi curavit; si Argentinae ad manus habeat, recipe ad te.

Balduinum qui iam vobiscum audio multa collecta habere de scismatibus in ecclesia Romana; rogo interroga, quid habeat et num aliquando edere aliquid statuerit; nam si hoc scirem, mitterem et mea collectanea, quibus ille forsan non parum invaretur.' (My translation; Baumgarten, Briefwechsel, No. 149; Appendix I, No. 354).
} 
and his Commentaries, which caused great outrage during the Diet, would have been very dangerous for Nidbruck, especially as he was joining the negotiations for the Catholic court party. ${ }^{69}$

In our examination of important historiographical works of the first half of the sixteenth century in Germany we have traced several themes that would eventually be picked up by Sleidan. Like Carion and Melanchthon in the Chronicon, Sleidan periodicised the history of the world into four empires and actually devoted a whole work to this idea. His Four Empires, like the Chronicon Carionis based on the teaching of the four monarchies in the book of Daniel, were one of the most popular history books for schools and universities alike until the nineteenth century. The fourth empire found its culmination in the Holy Roman Empire, in the time of the Reformation, but this was also perceived as the time of decline, the apocalyptic end. To this period the Commentaries are devoted.

Sleidan did not directly follow the idea of a chain of witnesses of the true church; heretics and martyrs occupy only a marginal role in both works. For him, the Reformation was based on decisions and acts, not on emotions and sentiments. There is no doubt though that the Protestant church whose emergence and development he portrayed in the Commentaries for him represented the true church. Similarly to Franck, in the Commentaries cosmic phenomena are not any longer seen as the prime motors in history, but social and economic factors begin to feature.The direction taken in these earlier histories that influenced Sleidan most profoundly was their source-based approach, attempted in Franck's works and the Chronicon, and pursued on a large scale in the

\footnotetext{
${ }^{69}$ For the heated reactions the Commentaries caused at the Augsburg Diet, cf. the reports of the Strasbourg delegates (Appendix I, No. 340 and 343), see below.
} 
Magdeburg Centuries. For the readership then, the use of primary sources would have been regarded as a guarantee of the truth. Sleidan united all these different strands and applied them to the most recent history.

All the works of history writing we have considered so far could have been influential for Sleidan. None of them, however, provided a complete description of the Reformation, but rather concentrated on earlier periods of history in an attempt to link Protestantism with the early church. This was only one side of the Protestant quest for interpreting history in the light of Luther's teachings. On the other side, the spread of the Reformation had led to the creation of a new, Protestant community. Such a community 'required a collective memory of the past which defined their identity and gave meaning to their institutions and rites', as Gordon put it. ${ }^{70}$ This was what the Schmalkaldic League had in mind when they employed Sleidan as official historiographer.

\section{The need for a Protestant history}

By 1544 Sleidan had established himself as a diplomat for the Protestant cause, having attended colloquies and diets in Hagenau, Worms, Regensburg and Speyer. In his role as a historian, he had written the Two Orations and published a Latin translation of Froissart. Bucer meanwhile had contemplated the idea of a Protestant account of the Reformation, and wanted Sleidan to be employed as the official historiographer. Furthermore, he had discussed this idea with Jacob Sturm, one of the leading diplomats of the Schmalkaldic League and stettmeister of Strasbourg, who agreed with Bucer. A project of such scale and importance would naturally need support, and so Bucer made Philip of Hesse familiar with his idea and laid out his plan to him.

\footnotetext{
${ }^{70}$ Gordon, 'The Changing Face of Protestant History', pp. 21-22.
} 
On 5 August 1544, Bucer wrote to Landgrave Philip of Hesse to convince him of the necessity of having a history of the Reformation composed by an official historiographer of the Schmalkaldic League. The man of his choice was Sleidan:

'Mister Jacob [Sturm] and I think that for this work we have a perfect man, Mister Johann Sleidan, who had long been in France and now has been with us for some months... . This man is so learned and so good in both Latin and German, and possesses great reason and zeal, equally he is so inclined to this cause that we could not think of anybody else who could be better to write this history ... than him., ${ }^{, 71}$

In October, Bucer urged Philip of Hesse to officially sanction Sleidan's

employment. Sleidan himself had been informed about the plan of Bucer and Jacob Sturm and Philip of Hesse's good will. He even worked a plan out for the possible chapters of the planned history. ${ }^{72}$ Additionally, he used the opportunity to recommend himself to his possible future employers by dedicating his Latin translation of a work by Philippe Commynes to Philip of Hesse and John Frederic of Saxony. ${ }^{73}$ With the example of Commynes, Sleidan tried to underline the need for and advantages of a contemporary history. In his dedication, he expressed his wish to get access to the archives of Saxony, Hesse and their allies. Meanwhile, Martin Bucer pursued the issue with Philip of Hesse, and urged Jacob Sturm to do the same. ${ }^{74}$ On 15 March 1545, Bucer sent another letter to Philip of Hesse recommending Sleidan's employment as historiographer of the Schmalkaldic League. As a demonstration of Sleidan's skills, he included a copy of his translation of Commynes, pointing out its dedication. ${ }^{75}$

\footnotetext{
${ }^{71}$ 'Nun ... duncket hern Jacoben und mich, wir hetten zu disem werk nun einen rechten mann, herr Johann Schleidanus, der lange in Frankreich gewesen und nun etliche monat bei uns ist, .... So ist diser mann so gelert und in beiden, deutscher und latinischer sprachen so wolfertig, auch eines gar guten verstands und vleißes, desgleichen der sachen so gar geneiget, das wir warlich jetzunder keinen wußten, der dise historie ... zu beschreiben tauglicher sein mochte.' (Baumgarten, Sleidans Leben, p.67; Appendix I, No. 42). Bucer suggested a salary of 400 Gulden per year.

${ }^{72}$ Cf. Appendix I, No. 67.

${ }^{73}$ Cf. Philippi Cominaei Equitis, de rebus gestis Ludovici undecimi, Galliarum regis, \& Caroli, Burgundiae Ducis, Commentarii. Ex gallico facti Latini, a Ioanne Sleidano. Adiecta est brevis quaedam illustratio rerum. \& Galliae descriptio, Strasbourg (Josias Rihel) s.d., ff. *3r-*4r. Cf. chapter 2.

${ }^{74}$ Cf. Appendix I, No. 48.

${ }^{75}$ Cf. Appendix I, No. 50.
} 
Bucer's campaign was successful. In a letter from 27 March, Philip of Hesse finally agreed to Sleidan's employment, and informed Bucer that Hesse, Strasbourg and other Protestant states would pay his salary. Additionally, he asked Bucer to send him two more copies of Sleidan's translation of Commynes. ${ }^{76}$ Bucer informed Sleidan of the positive outcome and discussed the matter further with Philip of Hesse. He advised that the history should be written both in German and Latin, and considered the details of the contract. To make the agreement official, he arranged for Sleidan to come to the diet of Worms to discuss the terms of his employment and the historiographical issues. Bucer also contacted Saxony to convince them to support Sleidan's employment. ${ }^{77}$ Likewise, the Saxon chancellor Christoph von Carlowitz advised Moritz of Saxony to agree to Bucer's proposal. $^{78}$

In a letter from 2 May 1545, Sturm described the negotiations of the Schmalkaldic League concerning Sleidan's employment to Bucer. He informed him that an annual salary of 250 florentines had been agreed upon, and Carlowitz had promised to convince Moritz of Saxony to add another 100 florentines. Sleidan was 'to describe the history of the renewed religion', and was to assist in other matters of the Schmalkaldic League when called upon. ${ }^{79}$ Sleidan expressed his delight over his employment to Jacob Sturm in a letter from 8 May 1545 and thanked him for negotiating with the League for him. He expressed some concern as to his salary, but was determined to do his best for the sake of the good cause in writing the 'holy and outstanding history'. He asked Sturm to write to the chancelleries of Hesse and Saxony on his behalf to send him material, as he himself

\footnotetext{
${ }^{76}$ Cf. Appendix I, No. 54.

${ }^{77} \mathrm{Cf}$. Appendix I, No. 57.

${ }^{78}$ Cf. Appendix I, No. 60.

79 ،... describendi historiam renovatae religionis' (Baumgarten, Briefwechsel, No. 23; Appendix I, No. 61).
} 
and Bucer also did. ${ }^{80}$ Sleidan did not forget either to inform Jean Du Bellay of his new employment, and let him know that he earned 300 florentines a year. ${ }^{81}$

Theoretically, such a salary would have allowed Sleidan to lead quite a comfortable life, even with a family. In this period meat prices in Strasbourg remained remarkably consistent: records for 1547 and 1558 both indicate that beef for example, cost around two deniers per pound. ${ }^{82}$ In 1556 , the annual income of a builder or carpenter was about 68 florentines, and between 1538 and 1575 the Munich city scribes Dr. Onaffrius Berbinger and Martin Grueber earned 200 florentines a year. ${ }^{83}$ When in April 1556 Francis Hotman was appointed professor of law at the Strasbourg Gymnasium at the wish of Jean Sturm and Sleidan, he was paid an annual salary of 160 florentines. $^{84}$ So even with the salary from the League alone Sleidan would have done well. Additionally, as we have seen in the previous chapter, Sleidan also received a pension of 100 livres until the death of Francis I. $^{85}$ On top of that, in 1557 , Ottheinrich of Palatine mentioned to Jean Sturm that he had paid Sleidan an annual amount of 150 florentines for his Commentaries. ${ }^{86}$

\footnotetext{
80 '... scriptio tam sanctae et illustris historiae' (Baumgarten, Briefwechsel, No. 24; Appendix I, No. 62). ${ }^{81}$ Cf. Appendix I, No. 66.

${ }^{82}$ Cf. Kintz, La société strasbourgeoise, p. 505 for the meat prieces as specified below; on p. 501 , fn. 9 he defines the Strasbourg currency as following: 1 livre (pfund) $=2$ florins (gulden) $=20$ sous (schilling); 1 sous $=12$ deniers (pfennig); 1 batzen $=8$ deniers; 1 florin strasbourgeois $=126$ deniers.

For comparison: meat prices per pound in deniers:

cow calf/sheep pork

1547 March 23

1558 November $2 \quad 3 \quad 3$

${ }^{83}$ On the salaries of the Munich city scribes, see M.J. Elsass, Umriss einer Geschichte der Preise und Löhne in Deutschland. Vom ausgehenden Mittlelalter bis zum Beginn des Neunzehnten Jahrhunderts, vol. 1, Leiden 1936, p. 775. Kintz, La société strasbourgeoise, pp. 500-507, analyses the salaries of carpenters and builders in Strasbourg from mid-sixteenth century until 1650.

${ }^{84} \mathrm{Cf}$. Kelley, François Hotman, p. 83.

${ }^{85}$ Sleidan was also awarded a pension by the English court, which he possibly never received (cf. chapters 2 and 3); Appendix I, No. 185, 253. A sixteenth-century merchants' handbook suggests that the value of the livre in Paris was about the same as that of Strasbourg, cf. anon., Tariffe et Concordance des poids de plusieurs provinces les plus practiquez au temps present, par les Marchands Francoys, Allemens \& plusieurs autres. Avec les comtes et recontres qui enseignent à combien revient toute quantité de chacune marchandise, soit en poids ou en nombre, et autres choses utiles à tous marchans, Lyon (Charles Pesnot) 1571, fols. a3rb5r.

${ }^{86} \mathrm{Cf}$. Appendix I, No. 425.
} 
Sleidan had indeed been very comfortable had he received all this money, but not more than two years after his employment as historian, the League ceased to exist and with it his salary. Even during his employment, his payment was often delayed or he received only a fragment of the promised amount. As we have seen above - and as a glance through Appendix I shows - this was also the case with his other sources of income, and much of his correspondence consists of reminders to send outstanding payments. With the ascend of Henry II, Sleidan's pension from France was stopped, and in all likelihood Sleidan never received a pension from the English court despite all efforts and promises. Sleidan could have earned very well as a historian and diplomat had he received all the promised income, yet in reality he had to struggle to sustain himself and his family.

Before considering the composition process of the Commentaries, we have to briefly reflect on the existing confusion in scholarship as to when Sleidan exactly started his work on the Commentaries or when he was officially employed to do so. Since Sleidan's own remarks on this subject are rather vague, it is difficult to reconstruct this part of the background of the Commentaries. The two dates suggested for the beginning of Sleidan's work at the Commentaries are 1541 and 1544, with both theses finding supporters from earlier centuries and recent decades. The hypothesis that Sleidan started the Commentaries in 1541 has been held for example by Theodor Paur in the nineteenth century, and has been followed by Donald Kelley in $1580 .{ }^{87}$ Likewise, the case for a start in 1545 was made in the nineteenth century by Hermann Baumgarten, the collector of Sleidan's correspondence, and adopted by Ingeborg Berlin Vogelstein in $1986{ }^{88}$ There is some evidence in Sleidan's letters for both sides.

\footnotetext{
${ }^{87}$ Cf. Kelley, 'Johann Sleidan', pp.588-589; Paur, Johann Sleidans Commentare, p. 31.

${ }^{88}$ Cf. Baumgarten, Sleidans Leben, pp. 67-70; Vogelstein, Johann Sleidan's Commentaries, pp. 15-17.
} 
Kelley, following Paur and others, suggested that the Oration to the States from 1541 can be regarded as the proof that by that time Sleidan had already begun to work on the Commentaries. This theory seems to be backed up by Sleidan's own remarks in a letter to the Council of Augsburg from 19 May 1555, written in defence of his Commentaries, where he said that it was sixteen years since he had started collecting material and ten years since he had started writing. ${ }^{89}$ This would mean that around 1540 Sleidan was already aware of the idea of a Protestant history and his future employment, or was indeed already employed.

On the other hand, in his own correspondence we find remarks contradicting such a timeframe. In a letter from 24 June 1553 to John Frederic of Saxony he mentioned that he had been employed by the Protestants in 1545 and given the instructions to write a history of the Protestant religion. ${ }^{90}$ This is in accordance with Sleidan's remark in a letter to Jacob Sturm from 24 June 1545 that he had started writing the Commentaries 'a couple of days ago', and with Landgrave Philip's comment that Sleidan was officially employed in $1545 .^{91}$

When one considers the relevant documents in Appendix I, and the process of Sleidan's employment reconstructed above, there is no doubt that Sleidan was not officially employed as historiographer before 1545 . Before 1544 , there was as yet no plan to have Sleidan or anybody else compose a Protestant history. Sleidan's own remark that he had started collecting material much earlier can only refer to his general historical interest, as manifested in the Two Orations. Our analysis of the extant documents has

\footnotetext{
${ }^{89}$ Appendix I, No. 342.

${ }^{90}$ Appendix I, No. 294.

91 Appendix I, No. 79, 182.
} 
shown that it was in 1545 that Sleidan fully embarked on the project of the Commentaries.

Sleidan's official contract was in fact not issued until 1546, which we will see below.

\section{Composing the Commentaries}

Before the terms of his contract were even settled, Sleidan started working at the

Commentaries with admirable speed. The following letters show him well immersed into

the research and writing process, contacting various archives, chancellories and also

Reformers such as Luther, Calvin and Bucer. On 15 May 1545, he sent Jacob Sturm a

Latin outline of the intended chapters, and informed him that he had sent a German version

to Saxony and Hesse so it would be easier to find the desired material for him:

'On the tenth of this month I have sent letters to Saxony and Hesse, and I also sent a chapter of my future history in German, of which last year you saw the.Latin version, to get their opinion, so that they can see in which order I progress and what they desire from me. For I have been rather insufficiently instructed as to what the history is concerned, and I require more, and also what they think of what I have shown them already, when I have sent the chapter and have added some questions. It will not be difficult for their secretaries to collect this information, especially since I have everywhere indicated the number of years and the order of everything described. $^{, 92}$

On 24 June, he wrote to Jacob Sturm to tell him that he had recently started writing the history and would use the first volume of Luther's works and the archival material he was sent from Hesse and Saxony: 'A couple of days ago I have started to compose our history - may it be blessed and fortunate - which you have employed me to do. You will not believe how much I enjoy this work, which, although it requires great industry and diligence, makes me wondrously happy since I am inclined to it by nature. ${ }^{93}$ As soon as

\footnotetext{
92 'Decima die huius mensis dedi literas ad Saxonem et Hessum, ac simul misi capita futurae historiae Germaniae, illa ipsa quae superiori anno vidisti a me notata latine, idque eo consilio, ut videant quo sim ordine progessus et quid a me desideretur. Nam mediocriter sum instructus rebus necessarriis ad eam historiam, sed maiora quaedam adhuc requiro, et cuiusmodi illa sint iam his ostendi, quando capita misi et signum aliquod adieci. Secretariis illorum non erit difficile illa omnia conquirere, praesertim quum a me sit ubique numerus annorum adiectus et ordine notata omnia.' (My translation; cf. Baumgarten, Briefwechsel, No. 29; Appendix I, No. 67).

93 'Ego superioribus aliquot diebus, quod felix faustumque sit, incepi conficere historiam nostram a vobis mihi mandatam. Non credas, quantopere me delectet hic labor, qui tametsi magnam requirat industriam et
} 
11 July 1545 , after not more than a month's work, Sleidan was able to send the first book of the Commentaries to Jacob Sturm, which he had insisted on to be called 'history' rather than 'chronicle'. ${ }^{94}$ He asked him for his detailed opinion and also encouraged him to discuss the work with Franz Burkhard, the chancellor of Moritz of Saxony. ${ }^{95}$

The zealous Sleidan had already finished at least one book of the Commentaries

before he even had the contract in his hands. After several discussions concerning the exact terms and salary, it took several more months until the final contract was written, signed and sealed. ${ }^{96}$ The final contract, signed by John Frederic of Saxony and Philip of Hesse, was probably not official until spring 1546; Sleidan was to be employed for two years at first, and was to receive 350 florentines per year. Sleidan was to be available '...for our [Philip's of Hesse and John Frederic's of Saxony] or their [the Schmalkaldic League's] business, be it for missions in this or any other country or nation, .... If the need occurred that they [the League] would need somebody to translate or compose something in the languages he could speak, be it missives, instructions, advises or other things, then he was obliged to do his best. Additionally, the said Sleidan has also agreed to describe the beginning of the whole matter of religion, as it had started in our times and how far it had proceeded, and the events that had happened concerning this, in a chronicle. For this end, we will supply him with reports on these events and other material necessary for such a work. However, he is not supposed to publish or distribute such a chronicle without our consent, and without it being seen by us or our representative., ${ }^{97}$

diligentiam, mihi tamen, quoniam naturae quaedam propensione huc inclino, mirifice dulcessit.' (My translation; cf. Baumgarten, Briefwechsel, No. 38; Appendix I, No. 79).

${ }^{94}$ Cf. Appendix I, No. 81.

${ }_{95}^{95}$ Cf. Appendix I, No. 83.

${ }_{97}^{96}$ Cf. Appendix I, No. $61,62,76,78,81$, and 84.

97 'Also do wir und gemein unsere ainung ine in unser und derselben geschefften, es were in diese oder fremde land und nationen botschafts weis schicken und abvertigen wurden, das er sich darzu geprauchen lassen und solchen seinen bevelh seines besten verstands verrichten soll. ... Wurden auch gemeiner ainung sachen furfallen, in welchen man in den sprachen, darinnen er berichtet ist, schreiben verdolmetschen oder etwas anstellen musst, es were von missiven, instructionen, rathschlägen oder andern, darinnen soll er abermaln seinen vleis thun und erzeigen. Zudem so hat auch bemeiter Sleidanus uff sich genommen und bewilligt den anfang des ganzen handels der religion, wie der bei unsern zeiten angehaben und wie weit der auch gefürt und gebracht worden sei, auch was sich dieser ding halb allenthalben zugetragen, in ein cronic zu ziehen und zu beschreiben, zu welchem wir in auch mit bericht der händel und anderm, so zu solchem werk gehören will, versehen und informiren lassen sollen and wollen. Doch soll er sollich cronic, sie sei dann zuvor durch uns oder unser dazu verordnete besichtigt, und also on unser bewilligung nicht publiciren noch ußgehen lassen.' (My translation; Baumgarten, Sleidans Leben, pp. 113-114; Appendix I, No. 169).

Friedensburg in Johannes Sleidanus, pp. 37-39 also mentions the circumstances of Sleidan's employment. 
The man to supervise the writing of the Commentaries was Jacob Sturm, himself a very learned man and the intellectual head of the Protestant League. Until his death in 1553, Sturm was in close contact with Sleidan, read the first sixteen books (covering the years 1517 till 1546, the eve of the Schmalkaldic War) and 'corrected where necessary'. ${ }^{98}$ During the last year of the composition of the Commentaries, Pietro Paul Vergerio was to take over this role of a supervisor at the wish of Christoph of Württemberg, as we will see later. The proofreader was none other than Peter Martyr Vermigli. In retrospect, it is difficult to establish where scholarly advice between friends ended or where censorship began - after all, Sleidan had first been employed by the League to write the history of Protestantism, and Sturm and Vergerio were both in the service of members of the League.

The influence of these three people on the text of the Commentaries cannot be established in retrospect. It is quite possible that Jacob Sturm with his prominent role in the League and Strasbourg could have encouraged Sleidan to omit things that could make the Protestants appear in a negative light, and on the other hand mention everything that would be in their favour. The virtual absence of the Swiss Protestants and Zwingli from the Commentaries could thus perhaps be explained with an attempt on Sturm's behalf to cover up Strasbourg's close relationship with the Zwinglians of which the city had often been criticised. ${ }^{99}$ We do not know whether Sturm was actually asked by the League to supervise or correct Sleidan's history, or whether he did it out of pure interest in his

\footnotetext{
98 ' $\mathrm{Er}$ [Jacob Sturm] hat auch vor seiner krankheit der bücher 16 gelesen und, wo es die notturft erfordert, corrigirt.' (My translation; Sleidan's letter to the Council of Augsburg, 19 May 1555; Baumgarten, Briefwechsel, No. 139; Appendix I, No. 344). Sleidan paid tribute to Jacob Sturm and the role he played in correcting the Commentaries in the dedication and preface to this work: 'Besides, I had great assistances from James Sturmius, a person of noble birth and great reputation...; He having been pleased to admit me (such was his goodness) into his acquaintance and friendship, like a good governour very often shew'd me the right and even way, when I was at a loss, and doubtful which way to turm me, and at other times stuck on the rocks and shallows; and after all, read over, at my request, the greatest part of their work before his last sickness, $\ldots$ and with great industry and care admonished me of what he thought was needful.' (Sleidan/Bohun, General History, preface/dedication, fol. a2r).

${ }^{99}$ On Strasbourg's relationship with Zwinglianism, see for example Brady, Turning Swiss, pp. 202-222.
} 
friend's work. The situation is clearer when thinking of Vergerio's involvement in the months before the publication of the Commentaries at the wish of Christoph of Württemberg. It seems as if then - in the immediate period before the Diet of Augsburg the Protestant states were so concerned about the impending publication of the Commentaries that they actually sent somebody to go through the work with Sleidan and encourage him to rephrase or leave out any offensive passages. Considering this level of supervision by the Protestants, the initial negative reactions towards Sleidan after the publication seem unexplainable and staged. This is all the more so when we think how quickly the turbulences cooled down once the Augsburg Diet was over.

Only a few months after Sleidan had started his historical work, he had to fulfill his diplomatic obligations towards the Schmalkaldic League and assist with the negotiations between England and France, working towards their possible alliance with the German Protestants. ${ }^{100}$ Such a duty delayed Sleidan's work at the Commentaries, but it seems as if Jacob Sturm, who had arranged for Sleidan's involvement in this mission, considered this journey to England to be an excellent opportunity for Sleidan to gather material for his historical work. Sleidan did indeed use his spare time during this mission to advertise his project to England's elite and rally support. Shortly after his arrival at the English court, Sleidan sent Henry VIII a copy of his Latin Two Orations. He enclosed a letter to ask Henry VIII to support their mission for the sake of the general good and Christianity, signing it with his official title 'Legatum licentiatus et historiographus protestantium'. ${ }^{101}$ He also approached William Paget, one of Henry's VIII principal secretaries and involved

\footnotetext{
${ }^{100}$ Cf. chapter 2.

101 'Je congnois mon ignorance en ce que je ose presenter à vostre majeste royalle une chose si petite comme ce present livre par moy composue, mais cognoissant vostre doulceur et humanité estre si grande, qu'elle n'en scauroit estre plus en ung tel prince et monarche, je me suis enhardy de vous en faire offre, suppliant tres humblement vostre majesté de le prendre en gré et supporter benignement les faultes qui y peuvent estre.' (Baumgarten, Briefwechsel, No. 44; Appendix I, No. 97). In a letter to Paget from 24 October 1545 he called himself '....serviteur ... de (la ville de Strasbourg)...comme aussi de toute la ligue des protestans' (Baumgarten, Briefwechsel, No. 51; Appendix I, No. 107).
} 
in the negotiations with France and the German Protestants, for material on Henry's break with Rome. ${ }^{102}$ Next, he wrote a long letter to Henry VIII explaining his project and underlining his absolute insistence on using only primary material, along with the plea to supply him with documents on matters appertaining to England. He also promised to send the completed book one, as well as an outline of the complete work. ${ }^{103}$

As soon as he returned from England, Sleidan embarked on his historiographical project once again. By the eve of the Schmalkaldic war, Sleidan had carried on his work up to the year 1525, the Peasants' War. The Schmalkaldic War from July 1546 till April 1547 with the subsequent imprisonment of its leaders caused a severe delay in Sleidan's work on the Commentaries as this made both funding and the acquisition of archive material extremely difficult. The defeat of the League meant a sudden end to Sleidan's employment, but he was asked to continue his work if possible. ${ }^{104}$ By April 1547, Sleidan had not received his salary for the previous year yet, and possibly not even for 1545 ; he also still had to receive money from France. ${ }^{105}$ In this rather desperate situation his old patron Jean Du Bellay came to his aid and wrote to Henri II to urge him to continue Sleidan's employment and his yearly pension. ${ }^{106}$ This proved unsuccessful; as, as we have seen, did the appeal to England.

There was new hope for Sleidan when his efforts for Strasbourg were finally rewarded in June 1552 with his official employment as a civil servant by the city of Strasbourg. Despite his involvement in various diplomatic missions, the educational system and the French church he still found enough time to continue the Commentaries.

\footnotetext{
${ }^{102}$ Cf. Appendix I, No. 124.

${ }^{103}$ Cf. Appendix I, No. 131.

104 'Und wie die niderlag des churfursten von Sachsen ervolgt, hernacher in ir aller namen erbetten darmit furzufaren.' (Cf. Baumgarten, Briefwechsel, No. 162; Appendix I, No. 371).

${ }^{105}$ Cf. Appendix I, No. 182, 198, 200, 165.

${ }^{106}$ Cf. Appendix I, No. 185; see chapter 3.
} 
With renewed spirits, he embarked on his work and sent out another round of letters to encourage support for his project. Edward VI was sent an account of the Schmalkaldic war, William Cecil and John Cheke were again approached to send more material. ${ }^{107}$ Sleidan also wrote to John Frederic of Saxony concerning the delivery of material, and also contacted Calvin on various topics to be treated in his history. ${ }^{108}$ Furthermore, other scholars sent useful material either to him or to Wendelin Rihel, his printer; and Strasbourg informed him about any political matters. ${ }^{109}$

Despite Sleidan's personal tragedies in 1553 with the death of his wife and Jacob Sturm, he persisted with his work, and this at an outstanding speed. By June 1553 he had reached the year 1540 , by September he had covered the period until $1546{ }^{110}$ Only half a year later, on 2 April 1554, he wrote proudly to Calvin: 'I have finished the whole work and I have carried it on up to this time ... . There are 25 books, the title is: on the religion and state under Emperor Charles V'. ${ }^{111}$ Over the next few months, he seemed to have polished the work and inserted more material. ${ }^{112}$ In September he notified Calvin that Rihel intended to begin printing the Commentaries as soon as October to be completed by the following Easter. ${ }^{113}$

${ }^{107}$ Cf. Appendix I, No. 281, 283, 289, 290.

${ }^{108}$ Cf. Appendix I, No. 294, 298, 300.

${ }_{109}^{109}$ Cf. Appendix I, No. 296, 301.

${ }^{110}$ Cf. Appendix No. 294, 298.

111 'Absolvi totum opus et ad hoc usque tempus habeo confectum.... Libri sunt 25, titulus est de statu religionis et reipublicae statu Carolo quinto Caesare.' (My translation.; cf. Baumgarten, Briefwechsel, No. 132; Appendix I, No. 306). The working title of the Commentaries had been 'Historia restauratae religionis; histori der ernewter religion' as Sleidan mentioned to John Frederic of Saxony in 1553 (Baumgarten, Briefwechsel, No. 127; Appendix I, No. 294).

${ }^{112}$ Cf. Appendix I, No. 306, the above-mentioned letter to Calvin from 2 April 1554, in which he also asked him for more material, especially concerning the Waldensian persecutions. Erasmus von Minkwitz, the Saxon chancellor, sent Sleidan a supportive letter, praising his work and confirming that he would look for more material as wished (Appendix I, No. 316).

${ }^{113}$ Cf. Appendix I, No. 320. Wendelin Rihel belonged to one of the important printer families in Strasbourg, was a close friend of Sleidan and printed most of his works. He was also part of the Protestant intellectual circle in Strasbourg of that time, which included people like François Hotman, the famous martyrologists Georg Rabus, Jean Crespin and John Foxe, along with Sleidan and the Sturms. 


\section{The publication of the Commentaries and the aftermath}

At the same time, some of the members of the former Schmalkaldic League must have remembered their right that Sleidan should not publish anything without their consent, or were uneasy about the outcome of the project. Hence the Protestant Duke Christoph of Württemberg sent Pietro Paul Vergerio, the former bishop and now convinced Protestant and Christoph's right hand, to Strasbourg to meet Sleidan and discuss his Commentaries with him. In August 1554 Vergerio wrote to Christoph that he had asked Sleidan to delay the publication of the Commentaries. ${ }^{114}$ He also informed Christoph that he had fulfilled his orders and read at least a part of the work and advised Sleidan to leave out certain passages and insert others. ${ }^{115}$

By February 1555, the future troubles surrounding the Commentaries began to cast their shadows, which we can reconstruct from Vergerio's correspondence with Christoph of Württemberg. Vergerio reported to Christoph that the Strasbourg Council considered stopping the printing process and prohibiting the publication; this at a time when 20 out of the 25 books were already printed. - Such a ban could have been disastrous for the printer, Wendelin Rihel, who would have had to invest a large sum into the first print run of the Commentaries. Vergerio also reported rumours that the Strasbourg Council had received a letter warning them to stop printing the Commentaries, possibly at the instigation of the Emperor. ${ }^{116}$ A fortnight later he reported that the Council had not reached a final decision yet, but was leaning towards ignoring the warning. ${ }^{117}$ In March, Sleidan was still unsure

\footnotetext{
${ }^{114} \mathrm{Cf}$. Appendix I, No. 318.

${ }^{115}$ Cf. Appendix I, No. 324. Unfortunately, Vergerio did not specify what exactly he wanted Sleidan to change.

${ }^{116}$ Cf. Appendix I, No. 327.

${ }^{117}$ Cf. Appendix I, No. 328
} 
about the future of his lifework, and on 1 April 1555 Vergerio finally notified Christoph that the Council had after all decided to permit the publication. ${ }^{118}$

Early April 1555 finally saw the publication of Sleidan's De statu religionis et reipublicae Caesare Carolo Quinto commentarii. Contrary to intitial plans, the Commentaries were published only in Latin, not in German, to avoid even more troubles. Sleidan himself suggested to Johann Stumph that the Commentaries were actually intented for scholars and politicians rather than the common people, and therefore needed no translation into the vernacular. ${ }^{119}$ The work was dedicated to Duke August of Saxony, since the Duke of Württemberg had declined to accept the dedication, possibly because he did not want to be openly connected with Sleidan's potentially offensive work. The Commentaries were published under Wendelin Rihel's name in Strasbourg, only six months after the commencement of printing. The work in folio contained 25 books, covering the years 1517 to 1555 . Wendelin Rihel had died in late March, but his heirs continued his work and printed four editions in 1555 alone since the Commentaries proved immediately popular. The first one was a folio edition with place of print and printer in the colophon, followed by two more affordable editions in octavo without the place of print and printer's name, then another folio edition with colophon. ${ }^{120}$ By 13 April, Sleidan's

\footnotetext{
${ }^{118}$ Cf. Appendix I, No. 331 and 333. Cf. Friedensburg, Johannes Sleidanus, pp. 47-48, who briefly alludes to Vergerio's role and the trouble of the senate; see also Hollaender, 'Sleidaniana' (1899), pp. 435-436.

${ }^{119}$ Cf. Appendix I, No. 372.

${ }^{120}$ From the remarks of Peter Martyr we know that the first edition was in folio (cf. Appendix I, No. 395). Am Ende suggests that then followed two editions in octavo, and another folio-edition later in the year (cf. Carl Christian Am Ende, 'Beschreibung der beyden ersten Auflagen der Commentariorum Johann Sleidans, zu Straßburg, im Jahr 1555. in Octav.', Johann Georg Schelhorn, (ed.), Ergötzlichkeiten aus der Kirchenhistorie und Literatur, in welchen Nachrichten von seltenen Büchern, wichtige Urkunden, merkwürdige Briefe, und verschiedene Anmerkungen enthalten sind, vol. 2, Ulm 1762, pp. 674-675). After Wendelin Rihel's death in March 1555, his sons Josias and Theodosius shared his business until about 1557 and then ran separate printshops. After this split, Josias Rihel alone published only three Latin editions of Sleidan's Commentaries (Vekene, Bibliographie, E/a 014, E/a 016, E/a 019) and two German editions (ibid., $\mathrm{E} / \mathrm{b}$ 011, E/b 013), all the numerous other editions of Sleidan under the name of Rihel were published by Theodosius Rihel, who was rumoured of being a Calvinist (cf. Chrisman, Lay Culture, pp. 18-19, 31, 241).
} 
history was already sold out at the Frankfurt book fair, as the Basle printer Johannes Opporinus reported to Caspar von Nidbruck. ${ }^{121}$

The Commentaries, composed originally in 25 books, provide a chronological narrative of the Reformation from 1517 until 1555; book 26, ending with the year 1556 , was edited later and first published with a 1558 edition. Book 1 begins in 1517 with the indulgence controversy and Luther's 95 Theses. The rest of the book traces the events until 1519, ending with the Leipzig disputation between Luther and Eck and the rise of Zwingli in Zurich. Book 2 dwells on the year 1520, with Luther's famous tracts, and his relation with Emperor and Pope. The years 1521 till 1523 are the focus of book 3, with the Diet of Worms, the spread of Lutheranism, Anabaptism and Zwinglianism as well as the conduct of the Pope, Henry VIII and the Turk. Book 4 traces the widening of the Reformation across Germany, Denmark and Switzerland, ending with the Peasants' War in 1525, an event that is focused on in book 5, along with events in France, Prussia and the Marburg colloquy. Book 6 follows the events up to 1529 , relating German events like the foundation of the Schmalkaldic League and growth of Protestantism, but also proceedings concerning the Turk, France and Switzerland.

Books 7 (1529-1531) and 8 (1531-1533) continue with these themes and dwell on the consolidation of Protestantism with the Augsburg Confession and the Schmalkaldic League. Books 9 (1533-1535), 10 (1535-1537), 11 (1537) and $12(1537-1540)$ trace the further development of Protestantism, especially with the rise of the Reformation in England, and the continuing quarrels between the Emperor, France and the Pope. From book 13 onwards one can notice Sleidan's personal engagement in many events he relates, although it is only on occasion that he mentions his involvement. Book 13 (1540-1541)

\footnotetext{
${ }^{121}$ Cf. Baumgarten, Briefwechsel, p. xxv, fn. 12; Appendix I, No. 334.
} 
focuses on the political and religious scene in Germany, with the colloquy of Hagenau and the Diet of Worms. Books 14 (1541-1542), 15 (1542-1544) and 16 (1544-1546) concentrate on the ongoing strife between Emperor, Pope and France, with some reference to events in England, France and Scotland. Book 17 examines the situation before the Schmalkaldic war, the events in Germany, the spread of the Reformation to Scandinavia, and the council of Trent. Book 18 concentrates on the years of war in Germany 15461547, but also deals with the English Reformation. Book 19 (1547-1548) and 20 (1548) focus on the post-war situation with the Augsburg Interim and the Catholic reaction with the Council of Trent and the Spanish inquisition.

Book 21 (1548-1550) follows these events and the development in France and England, with books 22 (1550-1551) and 23 (1551-1552) as the turning point in the history of Protestantism in Germany: Sleidan describes the Council of Trent, and the rebellion of Moritz of Saxony against the Emperor, with references to the events in other European countries. Book 24 (1552-1553) analyses the changing political situation in Germany with the revolt of Moritz and the intervention of the French king. Book 25 describes the return to Catholicism in England and narrates the events leading up to the Diet of Augsburg in 1555 , representing the official acceptance of Protestantism. Book 26 discusses the further spread of Protestantism across Europe and ends with the Emperor's retreat to Spain. It is interesting here to note that although compiled from Sleidan's notes by an unknown editor, book 26 still very much remains loyal to Sleidan in both content and style. The work concludes with a remark on Sleidan's death: 'The last day of October John Sleidan,... a person worthy of great commendations on the account of the rare endowments of his mind, and his great learning, died at Strasburg, and was honourably buried. ${ }^{122}$

${ }^{122}$ Cf. Sleidan/Bohun, General History, p. 639. 


\section{Sleidan's sources and methodology}

Before we look closer at the circumstances of the publication of the Commentaries, let us pause to investigate Sleidan's sources and methodology. In the dedication to the

Commentaries, Sleidan summarised the content of his work: 'The main and principal scope of my design is to set forth the affairs of religion; but then I thought it needful for order sake to set down also the civil transactions. ${ }^{, 123}$ When we look at the Commentaries, it becomes apparent that Sleidan's emphasis was on the civil transactions rather than religion, which is not surprising considering his legalistic training. This preference for political documents, rather than notes of theology, also determined his choice of sources, and, beyond that, his view of the Reformation. In his eyes, the Reformation was a natural consequence of historical schemes, driven by kings, princes and Diets, not the people. For Sleidan, the Reformation was essentially a political event, based on reason, not beliefs. This is not to say that the Commentaries can be described as a non-providential historyfor Sleidan, and for all confessional historians, God was behind all history, and also the Reformation. God's role in history is a prerequisite for the Commentaries, however, and does not feature in the text as such. Sleidan does not want to convert, just to inform. Two very important aspects which we miss in the Commentaries are the social and theological aspects that accompanied the Reformation. For Sleidan as the humanist-lawyer-diplomat, these were negligible aspects. The Reformation for Sleidan was a political event, not so much a spiritual event driven by people and beliefs, reflected in the small space devoted to religious teachings and martyrs for the faith. Robert Kolb argued that for most Lutheran writers, the Lutheran teachings occupied the central role in their description of history this was not the case with Sleidan. ${ }^{124}$

\footnotetext{
${ }^{123}$ Dedication to the Commentaries in Sleidan/Bohun, General History, fols. a2r-v.

${ }^{124}$ Robert Kolb, For all the Saints. Changing Perceptions of Martyrdom and Sainthood in the Lutheran Reformation, Macon, GA 1987, p. 97.
} 
While Sleidan provided a model history for future generations with a strong emphasis on sources and neutrality, he retained a modicum of traditionalism. In the preface and dedication to the Commentaries, he referred to the traditional theory of the four monarchies from the book of Daniel, expanded in his 1556 Four Empires. The Holy Roman Empire as the embodiment of the last monarchy is praised as a great nation under a great Emperor, Charles V, who is called to rule in a hard and challenging time that forebodes the end. Although superstition does not feature in Sleidan's work, omens are still mentioned occasionally: a comet predicted the death of Zwingli and the Emperor's wife; when Duke Maurice of Saxony died, 'drops of blood were found upon the leaves of some trees', and the papal delegate to Trent Crescentio was chased to death by the vision of a 'black dog of extraordinary size, with flaming eyes'. ${ }^{25}$

Sleidan's aim was to produce a history of the Reformation that was as close to the truth as possible. To this end, he tried to obtain information from as wide a range of sources as possible. It was advantageous to him that he himself had been present at a large number of events, like various diets or the 1551/52 session of the Council of Trent, and he could also rely largely on Jacob Sturm, whose memories provided an important source for him, as has been shown by Brady. ${ }^{126}$ In this way, Sleidan had made a large number of acquaintances and friends who he would contact, and he also read the latest books on relevant topics, and accessed various archives. From Sleidan's correspondence, we can partly reconstruct his approach. A glance through Appendix I shows that Sleidan was in close contact with a number of people during his writing process, constantly asking for information or more material on certains aspects of the Commentaries. Amongst those contacted are theologians like Melanchthon and Calvin, but also politicians like William

\footnotetext{
${ }^{125}$ Sleidan (transl. Bohun), General History pp. 156, 250, 586, 548.

${ }^{126}$ This point is also emphasised by Brady in The Politics of the Reformation, pp. 137-140. Brady mentions that Sleidan's description of the Imperial Diet 1547-1548 largely reflects Jacob Sturm's account as has been preserved in PC 4, No. 791.
} 
Paget and William Cecil. Additionally, various people who knew about his project sent material to him or his printer Rihel, a tendency that increased after the publication of the first edition. Such a large public interest not only showed the popularity of the Commentaries, but also how this history rapidly came to be perceived as a communal project by the people whose history was portrayed.

Unlike Heinrich Bullinger, for example, Sleidan did not leave a large collection of documents or books with annotations behind, so that it is often complicated to establish his sources or the way he used them. ${ }^{127}$ It is difficult to reconstruct from the Commentaries which printed books Sleidan had accessed for his work. From his correspondence we know that for the early part of the Commentaries, he relied largely on Luther's works, which he acquired as far as they had been published. ${ }^{128}$ He had also read parts of Crespin's Livre des Martyrs before it was even published. ${ }^{129}$ During his participation at the Council of Trent he had made a journey to Venice, where he acquired Bembo's history of Venice and possibly other works. ${ }^{130}$ From his remarks in the apology to the Commentaries we can conclude that he also read works by Paolo Jovio, Reginald Pole and Johannes Cochlaeus. Other than these, it is difficult to reconstruct which books he used, in contrast to the Four Empires, where he frequently mentioned various works and authors. In the Commentaries, Sleidan relied largely on documents.

\footnotetext{
${ }^{127}$ There is not much material on Bullinger's historical work. I owe this information to Christian Moser, who is currently completing a Ph.D. thesis of at the University of Zurich, entitled " Vil der wunderwercken Gottes wirt man hierinn sähen.' - Studen zu Heinrich Bullingers Reformationsgeschichte".

${ }^{128}$ Cf. Appendix I, No. 78, 184. On Sleidan's use of Luther's works, cf. Moore, La Réforme Allemande, pp. 390-398.

${ }^{129}$ Cf. Appendix I, No. 317. In a letter to Calvin from 8 July 1554, Sleidan mentioned that he had read the parts of Crespin's work that were already printed. Crespin's Le Livre des martyrs was not published before August 1554; to be more precise, on 14 August 1554 Crespin asked the Geneva Council for a permission to print his martyrology, and handed in an already printed copy for inspection (cf. Jean-François Gilmont, Bibliographie des éditions du Jean Crespin 1550-1572, vol. 1, Verviers 1981, No. 54/7; by the same author, Jean Crespin, un éditeur réformé du XVle siécle, Geneva 1981, p. 149).

${ }^{130}$ Sleidan to Roger Ascham, 29 February 1552 (Baumgarten, Briefwechsel, No. 111; Appendix I, No. 258).
} 
Unfortunately, nothing has been preserved of Sleidan's private library, and from his correspondence one might assume that in the last years of his life he was forced to sell all his books for the benefit of his daughters. ${ }^{131}$ Whatever Sleidan's possessions were, one can almost be sure that he would have had access to the large library of one of his friends, Ludwig Gremp von Freudenstein, the city lawyer of Strasbourg and later councellor of the Duke of Württemberg. We know of Gremp's possessions because after his death in 1583 his books were removed to the university library in Tübingen, where they have been preserved until today. His collection of more than 3,000 books is considered to be larger than many a princely library. ${ }^{132}$ From Sleidan's correspondence we can deduce that the two men were acquainted with each other since 1545 , and Sleidan seemed to have frequently borrowed items from Gremp's library. ${ }^{133}$ Additionally, the private libraries of Sleidan's inner circle, Jacob and Jean Sturm, Martin Bucer, and also Peter Martyr, would have been open to Sleidan. ${ }^{134}$ From a letter by Christoph of Württemberg to the council of Strasbourg we know that Sleidan had also borrowed books from Pietro Paul Vergerio. ${ }^{135}$

Sleidan's focus as a politician and lawyer had been on political documents and acts. He would have had access to these for his history writing; he certainly regarded these as central to the historical process. For readers in the sixteenth century, the use of primary sources would also have been regarded as the ultimate guarantee for authenticity. When Sleidan commenced his work for the Schmalkaldic League, he had insisted on gaining access to the archives of Hesse and Saxony. With the dissolution of the League in 1547, he was forced to rely mainly on Strasbourg archives and the few documents he was sent

\footnotetext{
${ }^{131}$ Cf. Appendix I, No. 295.

${ }^{132}$ On Gremp's library, see Gerd Brinkhus, 'Drucke des 16. Jahrhunderts aus französischen Offizinen in der Universitätsbibliothek Tübingen', Werner Arnold, Bibliotheken und Bücher im Zeitalter der Renaissance, Wiesbaden 1997, pp. 77-84; also Gerhard Römer, Bücher - Stifter - Bibliotheken. Buchkultur zwischen Neckar und Bodensee, Stuttgart 1997, pp. 73-74.

${ }^{133}$ Cf. Appendix I, No. 80, 190, 412.

${ }^{134}$ On private collections in Strasbourg, see Chrisman, Lay Culture, pp. 59-75, 335-338.

${ }^{135} \mathrm{Cf}$. the letter from 14 September 1557 (Appendix I, No.428).
} 
from other Protestant states. Sleidan's employment by the Protestants in a time when confessional struggles were still dominant of course meant that Sleidan would not have had access to any Catholic archives. This inevitably creates a tendency towards an account skewed towards the Protestants.

The documents Sleidan used have been investigated by various scholars from the seventeenth century onwards. Many original documents have been collected in the early seventeenth century by Friedrich Hortleder in a monumental two-volume work. ${ }^{136}$ Christian Carl am Ende published an annotated edition of Sleidan's Latin Commentaries, in which he provided further reference to sources used. ${ }^{137}$ Finally, in the nineteenth century two more scholars directed their attention towards the sources Sleidan used, Theodor Paur and Wilhelm Weise. Paur identified several works by Louis d'Avila, Nicolaus Mameranus and Georg Sabinus as sources used by Sleidan. ${ }^{138}$ Weise in a dissertation on the sources of Sleidan's Commentaries further identified several original documents and tracts employed by Sleidan. ${ }^{139}$

Sleidan has often been praised as the 'father of Reformation history', and he can possibly even be called the father of early modern history. ${ }^{140}$ While he could adopt certain aspects of humanist historiography, like the reliance on original sources and the quest for

\footnotetext{
${ }^{136}$ Hortleder, Der Römischen Keyser- und königlichen Maiesteten, 2 vols., Frankfurt/Main 1617/18. We will come back to Hortleder in chapter 5 .

${ }^{137}$ Am Ende, Ioannis Sleidani de Statu religionis, 3 vols., Frankfurt/Main 1785.

${ }^{138}$ Cf. Paur, Johann Sleidans Commentare, especially pp. 79-118; he mentions for example Avila's Commentariorum de bello Germanico, Antwerp 1550, Mameranus' Catalogus omnium

Generalium, Tribunorum, Cologne 1550, and Sabinus' De electione et coronatione Caroli V Caesaris Historia, Mainz 1544.

${ }^{139}$ Weise, Über die Quellen, Halle 1879. To mention some of these items here would not be very helpful since as a source from the nineteenth century, Weise does not offer footnotes which help to identify these works or where they can be found. Paul Kalkoff, 'Die Anfangsperiode der Reformation in Sleidans Kommentarien', ZGO 71 N.F.32 (1917), pp.297-329, 414-467, also identified a number of documents used by Sleidan.

${ }^{140}$ See for example Kelley, 'Johann Sleidan', p. 577. Sleidan's approach to history was also one that was closely followed by Bullinger in his Reformationsgeschichte.
} 
the truth, he did not follow tradition in every way. In the Commentaries, there are no allusions to classical literature, nor any attempts to compare the events of the Reformation to classical times. For Sleidan, the Ciceronian view of history as the teacher of life was certainly still valid, but he did not see the need to express this openly in a moralising tone. In his attempt to narrate the truth in a neutral way, it is actually exactly this commenting and interpretative aspect of history-writing that Sleidan tried to leave out. Instead, by loosely connecting a large number of sources together with a few neutral sentences, Sleidan tried to let the sources speak for themselves. This for him was the ultimate proof of veracity.

In order to gain a better impression of how Sleidan actually worked with his sources, let us examine his description of two important events in the Commentaries, the Diet of Ausgburg with the presentation of the Augsburg Confession in 1530, and the 1551/52 session of the Council of Trent. Both accounts show how Sleidan's view of the Reformation as primarily a political rather than a religious event informed his description of events.

The Diet of Augsburg 1530 with the presentation of the Augsburg Confession, one of the foundation documents of Protestants, was a climactic point of the German Reformation. The description of this Diet and the Confession cover about four pages in book 7 of folio-editions of the Commentaries. Sleidan has the Diet start with a long speech by the Emperor, largely political in nature, covering about two pages. The following half folio page rushes through the majority of the Diet, briefly sums up Cardinal Campeggio's speech, the presentation of the Augsburg Confession, various speeches of the Protestant princes, the Emperor's reply and the ensuing discussions. Sleidan's account of the presentation of the Augsburg Confession is confined to a single sentence: 'After this, the 
Elector of Saxony, George Marquess of Brandenburg, the Duke of Lunenburg, and the Landgrave entreated the Emperour to hear their confession of faith, that was drawn up in writing.' It is astonishing to note here that Sleidan did not describe the content of the Augsburg Confession at all, nor did he use the opportunity for praising Protestant teaching. The only time when he touched upon Protestant theology in connection to the Augsburg Confession is his remark on the handing over of the Confessio Tetrapolitana, which differed from the Augsburg Confession in its view of the Lord's Supper. Then, however, Sleidan devotes one page to the description of the Catholics' refutation of various points of the Augsburg Confession, but leaves out the Protestant point of view. The matter is rounded up by another half paragraph on the disputation between the Elector of Saxony and the Emperor. The whole event is dominated by politicians. With the exception of Campeggio as papal delegate not a single theologian is mentioned. ${ }^{141}$

Sleidan's account of the 1551/52 session of the Council of Trent, which he personally attended, follows a similar pattern. Books 22 and 23 of the Commentaries are largely devoted to this event. Again, Sleidan's emphasis is on politics, not religion. As in the rest of the Commentaries, he only speaks about himself in the third person, and only briefly: 'Shortly after, November the twenty first, John Sleidan, the Deputy of Strasbourg, came to Trent. ${ }^{142}$ He starts with the French delegate's protest against the role and authority of the Council, underlining several papal abuses, which Sleidan then explains with a description of the history of these abuses since medieval times. ${ }^{143}$ The following two pages decribe the manner in which the Council is conducted, describing various

\footnotetext{
${ }^{141} \mathrm{Cf}$. the description of the Diet of Augsburg in Sleidan/Bohun, General History, pp. 127-130 (quotation: p. 130), and in Sleidan, De statu religionis, Strasbourg: Rihel 1559, fols. M6v-N2r.

${ }^{142}$ Sleidan/ Bohun, General History, pp. 529-530.

${ }^{143}$ This covers about three pages in Sleidan/ Bohun, General History, pp. 518-520.
} 
ceremonies and proceedings. The rest of the book then concentrates on the ongoing conflict between Emperor and King of France and the Pope's role in this. ${ }^{144}$

Book 23 divides attention between the Council and the preparation of Duke Maurice's and France's revolt against the Emperor. On one page, Sleidan sums up various decrees of the council in note form before returning to political events. ${ }^{145}$ After a short summary of the Council's decrees on penance and extreme unction, again in note-form, Sleidan turns his attention again to the politicians. Several pages are dedicated to the various attempts of Protestant delegates to be admitted to talk to papal or imperial legates, including long speeches made by various parties. ${ }^{146}$ Melanchthon and Bucer are briefly mentioned, but only because the Catholic delegate Gropper spoke out against them. For another ten pages, Sleidan then concentrates on the Protestants' negotiations for safe conducts and the way they wanted the council to be conducted. Only very occasionally does he remark on what was discussed at the Council at this time. ${ }^{147}$

Both in the account of the Ausgburg Diet 1530 and the Council of Trent 1551/52 Sleidan follows the same pattern. The description of the event is based largely on quotations or paraphrases from documents, loosely strung together by a few connecting sentences. When necessary, the historical development of an event or institution is explained. The focus is on kings, princes, and politicians. Theologians stay in the background, and even religious events like the Council of Trent are dominated by politicians. Common people hardly ever play a role, and are not more than part of the

\footnotetext{
${ }^{144}$ Ibid., pp. 520 on the Council and pp. 521-523 on Emperor and French king. In Sleidan, De statu religionis, Strasbourg: Rihel 1559, these descriptions cover fols. AA3r-AA6r.

${ }^{145}$ Sleidan/ Bohun, General History, pp. 525-526.

${ }^{146}$ Ibid., pp. 530-534.

${ }^{147}$ Ibid., pp. 535-548. In Sleidan, De statu religionis, Strasbourg: Rihel 1559, these events can be found on fols. AA6v-DD1r.
} 
background on which the Reformation, rationally guided by princes and politicians, takes place.

\section{Sleidan and the quest for veracity}

Three centuries before Ranke, Sleidan set the same main ojective for narrating the history of the Reformation: to 'recite all things as they were particularly acted. ${ }^{, 148}$ In the Latin text, this reads as 'haec omnia, .. prout quaeque res acta fuit, recito', clearly reflecting Ranke's later 'wie es eigentlich gewesen'. ${ }^{149}$ Such an objective, however, was a difficult matter in Sleidan's day and age. In the dedication/preface to the Commentaries, Sleidan specified his intentions further, proclaiming veracity and impartiality as the two main principles of history:

'Candor and truth are the two most becoming ornaments of an history; and in truth, I have taken the utmost care that neither of them might be wanting here: to that end I have taken up nothing upon surmise or light report, but I have studiously collected what I have here written from the publick records and papers; the Faith of which can justly be call'd in question by no man. [...] The second ornament which I mention'd of history, is candor or impartiality, which is ever to be observed to prevent the writers being drawn from truth by his affections, which seems the more difficult, because it is so rarely to be found in historians. ... This whole work, as I said above, is extracted out of publick acts, papers, or records; collected together with great diligence, and a great part of which have been already printed, partly in Latin, and partly in the vulgar tongues, viz. the German, Italian, and French. ... For here I do not add any thing of my own, nor do I make any judgement on them; but willingly and freely leave it to my reader. I make no rhetorical flourishes, nor do I write any thing of favour or envy to any man. ${ }^{150}$

'Veracity' is one of Sleidan's principal aims. As he states, this veracity is the natural consequence of his careful use of primary sources, not only in Latin, but also in the major vernacular languages. For the lawyer in Sleidan, these documents would naturally be to a large extent public acts and records. For the sixteenth-century mind, the use of original sources would have been the ultimate proof of veracity. The question of 'veracity'

\footnotetext{
${ }^{148} \mathrm{Cf}$. the dedication to the Commentaries to the Sleidan/Bohun, General History, fol. a2v.

${ }^{149}$ Sleidan, De statu religionis, Strasbourg: Rihel 1559, fol. a3r.

${ }^{150}$ Dedication to the Commentaries in Sleidan/Bohun, General History, fol. a2v.
} 
was all the more important at an age when historia, histoire and Geschichte not only meant semantically what in modern English is called 'history' and 'story', but when these two were frequently interlinked. It was often difficult to tell where 'history' ended and a 'story' began. - Sleidan's history offered a large number of quoted sources (or sources claimed to have been quoted) - my count of the more substantial quoted works, letters and speeches, of ten lines or longer, left me with an estimated 460 documents. Sleidan's offense thus lay not in a lack of research, but in his choice of what he was to narrate. Collinson in his interesting study of veracity in John Foxe's Acts and Monuments drew a conclusion which is also appliable to Sleidan: his "veracity is to be judged by the manner in which he composed his history, a matter not of invention, but of discrimination, interpretation, and most of all omission and deliberate exclusion., ${ }^{151}$

Sleidan's second objective was impartiality. Of course, from today's point of view he did not fulfill his goal of absolute impartiality, which in an age of confessionalisation was really nothing more than an illusion. Whether a convinced Lutheran, or a Protestant with a broader frame of mind, Sleidan was definitely not a Catholic, and narrated the Reformation from a Protestant point of view. This tendency was further strengthened by the nature of Sleidan's employment, that is by Protestant states, and by the archives he thus had access to - only Protestant ones.

For Sleidan as a Protestant, the Reformation was a logical event that fulfilled God's will. Necessarily, the Protestants as God's chosen people appear as the hero of the story, whereas the Catholics represent the aging, corrupt Catholic church in need for reform. At the same time, Sleidan did not hesitate to criticise the Protestants when necessary. The most prominent example for this is Sleidan's analysis of the Schmalkaldic war, where he

${ }^{151}$ P. Collinson, 'Truth and Legend: the Veracity of John Foxe's Book of Martyrs', A.C Duke, C.A. Tamse, (eds.), Clio's Mirror: historiography in Britain and the Netherlands, Zutphen 1985, p. 36. 
criticised the Protestants for losing the war because 'the supreme and absolute power was not in the hands of one man'. ${ }^{152}$ When describing the following pacification, Sleidan even included the most embarassing behaviour of diverse princes and cities submitting to the Emperor. The Duke of Württemberg was certainly not pleased to read the account of his submission, where, despite his illness he was carried to the Emperor, crept to his throne and humbly begged for peace and reconciliation. ${ }^{153}$ Sleidan found not only room to criticise the Protestants, but also praised the Catholics when justifiable. He lamented greatly the death of the Catholic French king Francis I, whose favour he had enjoyed during his time in Paris. When narrating the events of the Schmalkaldic War 1546 to 1547 , he did not refrain from praising the Emperor's brave behaviour without 'the least sign of fear or apprehension' in the battles. ${ }^{154} \mathrm{He}$ also mentioned the Catholic efforts to reform the church, and very enthusiastically described the Archbishop of Cologne's attempt to invite Bucer and Melanchthon to assist him in his reform programme. ${ }^{155}$

Naturally, Sleidan would also find plenty to criticise within the Catholic church. It was ruled by the Antichrist, 'the instrument of Satan', and wanting in its morals. ${ }^{156}$ Sleidan dwells on the manifold sins of the popes, and provides the reader with intimate details about the private desires and the state of the household of Pope Paul III and his sinful son. Popes poisoned each other, had illegitimate children, read about astrology and behaved badly. The Council of Trent was a mere farce, nothing was done, the Catholic Church concentrated on its own grandeur and was not interested in any kind of serious reform. ${ }^{157}$ In Sleidan's eyes, nothing like that appeared to occur on the Protestant side,

\footnotetext{
${ }^{152} \mathrm{Cf}$. Sleidan/Bohun, General History, p. 411.

${ }^{153}$ Ibid., p. 421.

154 Ibid., p. 398.

155 Ibid., pp. 223-238.

156 Ibid., p. 399.

${ }^{157} \mathrm{Ibid}$., books 22 and 23.
} 
where everything was prim and proper. For Sleidan, however, this description of the

Catholic church was not propaganda, it was the truth.

It would be wrong, however, to attribute Sleidan's portrayal of the Protestants as the good party and the Catholics as the evil party to mere polemic and lies. Sleidan determined the role of hero and antihero not by purposefully lying, but by showing a marked selectivity towards the events he chose to narrate. The reader is provided with detailed information on the sexual excesses of the Farnese family, but is kept ignorant about the double marriage of Philip of Hesse. Similarly, Henry's VIII treatment of his wives seemed perfectly reasonable, whereas a Catholic prince's affair was a great $\sin ^{158}$ An apparently serious description of a Catholic mass turned into a satire in Sleidan's words, and the reform efforts of the Franciscans in Orléans were confined to pretending to be ghosts to convert believers. ${ }^{159}$

All in all, Sleidan's description of the Reformation cannot disguise his Protestantism. Yet despite the fact that the Protestants are naturally presented in a more positive light than the Catholics, Sleidan still kept away from the polemic one encounters in most contemporary accounts of the Reformation. By the standards of his time, Sleidan did certainly adhere to what he termed 'the true Laws of History'. ${ }^{160}$ With his reliance on

\footnotetext{
${ }^{158}$ I am alluding her to the Duke of Brunswick's affair with Eva Trottina. Fearing that this affair would be discovered, they faked her illness, death and burial, while Eva was actually transported to a secret castle where she gave birth to several of the Duke's children (Sleidan/Bohun, General History, p. 322).

${ }^{159}$ Ibid., pp. 481-482, 170-172. The episode Sleidan narrates runs as follows: The provost of Orléans refused to bury his wife with the usual great ceremonies performed by the Franciscans of that city and refused to support them financially, too. Severely offended, the Franciscans circulated rumours that the provost's wife could find no rest since she had been possessed by an evil spirit and had been a Lutheran. During the next mass, one of the Franciscans climbed on the roof of the church and made great noises to show that an evil spirit was present. An exorcism was performed during the next mass, when another Franciscan assumed his position on the church roof and answered the exorcist's questions by banging on the roof. In this way, the Franciscan 'ghost' confessed that he could not find peace as he had been an adherent of the Lutheran heresy, and said he wanted his body to be digged up and buried outside the church grounds. This caused great fear in the believers until the whole farce was discovered.

${ }^{160} \mathrm{Cf}$. Sleidan's 'Apology' in Bohun, General History, fols. b1v-b2v.
} 
primary sources, Sleidan was convinced of the veracity and impartiality of his work, as he pointed out in the dedication. In fact, his quest for great detail and exact portrayal of events would offend Catholic and Protestant readers alike. This immediate response to the Commentaries would not last long, however, and after the political situation had changed it was replaced by a wide acceptance of Sleidan's history.

\section{Public responses to the Commentaries}

When Sleidan's Commentaries were published, the German cities and states had assembled at the Diet of Augsburg to settle the religious controversies in Germany. Naturally, such a work would have caught the attention of the delegates and political rulers on both the Catholic and Protestant side. Sleidan's relative, Caspar von Nidbruck, as the councillor of kings Maximilian and Ferdinand, attended the diet, and kept Sleidan informed about the reception of his work. In a short note from 15 April 1555, he expressed his surprise that Wendelin Rihel had obtained the permission to publish the Commentaries after all, and reported rumours at the Diet concerning this matter. ${ }^{161}$ In his reply to Nidbruck of 23 April, Sleidan still seemed to be happy with his recently published work, fearing no repercussions since at least parts of the work had been read and approved by several leading Protestants. Still full of enthusiasm, he even asked Nidbruck to reconsider sending a copy to King Maximilian. ${ }^{162}$

Very soon Sleidan's initial enthusiasm was destroyed. The Strasbourg legates at the Diet of Augsburg reported on 13 May 1555 that both king and estates deeply disapproved of the Commentaries and remarked that the council might even have to

\footnotetext{
${ }^{161}$ Cf. Appendix I, No. 335.

162 'Quod de duobus exemplaribus tibi videtur, velim ut iterum cogites, an tuo mittendum putes. Etenim licet eius honorifica mentio fiat libro 22., ... .' (Baumgarten, Briefwechsel, No. 138; Appendix I, No. 336).
} 
publish an apology to avoid trouble for the city of Strasbourg herself. ${ }^{163}$ On 26 May, they wrote: '...we have not been ordered to the King [Ferdinand] yet concerning Sleidan's book, but nevertheless many sharp speeches reach our ears. Thus we think it would have been better had he considered the matter more and had not [published it] at this time, when it can be disadvantageous not only for him, but also for the city [of Strasbourg]. Dr. Ludwig [Gremp] ... will be able to tell you how hated the history is at the royal court.,164 The perturbations at Augsburg soon reached Sleidan's ears, and he felt obliged to defend himself in a letter to the city of Augsburg on 19 May 1555:

'It has been reported to me as if my history, published recently, has caused much talk at yours, ..., mainly because many profess that many things which were not true were described therein. [...] I must say that this moves me greatly, especially as people profess that it lacks truth. This agitates my heart ... as I am an enemy of untruth, without flattering people, and I would rather be buried under the earth than consciously tell a lie, even more so to write it down. ... I have not acted like their writers who have covered our party with cruel, invented vices, as their books show, but I have started this work ten years ago on the admonition and request of honoured people, I have diligently inquired into all things, not from hearsay, but from real documents, ..., I have also asked the late master Jacob Sturm, God rest him in peace, for explanations whenever it was necessary, as his two brothers know very well. Equally, he has read 16 books before his illness and corrected them when necessary. As I have stated in the printed preface, I have not written it for or against anybody. ... I think I can say that one should not believe any history if mine is not true. As I have said above, I have not invented anything, but gathered everything from reliable documents which I have collected with great diligence over the past sixteen years. ${ }^{, 165}$

163 ،.des Schleydani jungst aussgangen buchs nit allein kein gefallens, sonder ganz ungnädigs missfallen. [...] aber itzo in summa darvon zu schreiben, so sein vieler grosser hern gemüter widder angeregte history dermassen bewegt, das gemeine statt, wo kein ansehenliche entschuldigung geschehen solt, mit der zeit allerhand zu bevaren haben möchten.' (PC V, No. 486, p. 601; Appendix I, No. 340).

164 'Zum dritten sein wir gleichwol von der ko. Mt. des Schleidani buch halben biss anher unerfordert plieben, aber nit desterweniger komen uns täglich vil scharpfer reden zu oren, das es unser erachtens besser, er hets bass bedacht und nit eben zu disser zeit, da nit allein ime, sonder auch der gemeiner statt viel unlusts daraus ervolgen thut, mit anlag komen. Wie verhasst diese history am konnigschen hove, würt $\mathrm{D}$. Ludwig [Gremp], der solches zum theil von furtrefflichen hern selbs gehört, wol wissen anzuzeigen.' (My translation; PC V, No. 490, p. 608-9; Appendix I, No. 343).

${ }^{165}$ 'Es ist mir angesagt worden, wie dasz meine histori, so newlich ausgangen, vielerlei reden bei euch erwecke, ... vorab weil auch etliche vorgeben, es seie viel dings neben der warheit darin beschrieben. [...] Nun bewegt mich aber disz insonderheit, dasz man fürgibt, es seie der warheit darin gefehlet. Das geht mir zu hertzen und steht mir billich zu verantworten: dann der unwarheit bin ich feind, ohn ruhm zu reden, und wolte lieber under dem grund ligen, dann wissentlich etwas unerfindlichs reden, viel weniger ausschreiben. ... Ich hab nicht gehandelt wie ihre scribenten, die unseren theil mit grausamen erdichten lasteren uberschüttet haben, wie ihre bücher ausweisen, sonderen dis werk hab ich aus grosser ansehenlicher leuth ermahnen und ansuchen vor zehen jahren angefangen, hab mich aller ding fleissig erkundiget, nicht aus 
Although Sleidan had been reasonable enough to expect criticism from the Catholic side, he had probably not foreseen attacks from the Protestant side as well. Very soon the publication of his life's work turned into a great disillusionment. Catholics felt themselves portrayed in a negative light. Many a Protestant prince or city thought that their sometimes weak defence of Protestantism before the Peace of Augsburg or certain actions should rather have remained secret. The Saxon chancellor Christoph von Carlowitz questioned whether Sleidan's concentration on documents from the chancellories of Strasbourg and Hesse did not distort the picture. Even Sleidan's friend Jean Sturm remarked that Sleidan 'had not adequately considered the position, will and opinion of the opposition'. ${ }^{166}$

Opinions were divided among the reformers themselves. Heinrich Bullinger very much approved of the history and had Johann Stumph sent his corrections and comments to Sleidan to include in later editions. ${ }^{167}$ Melanchthon on the other hand, who had long been acquainted with Sleidan and had even been consulted by him concerning the Commentaries, wrote to Christoph Leib on 18 May 1555 :

'The History of Sleidan on the events which have happened in Germany in the last thirty years, and especially on the changes of the churches, have been published. The book is dedicated to August, Duke of Saxony, who has sent the author 200 Joachimicos. I praise the generosity of the duke, but I do not praise the history, because neither is the work good nor is anything good said. He narrates much which should better be buried in eternal silence." 168

\footnotetext{
hören sagen, sondern aus warhaften bewärten actis ... hab auch herren Jacob Sturmen seliger gedächtmusz umb erklärung allezeit, so offt nöhtig geweszt, erscuht, wie noch beede seine brüder wol wissen. Er hat auch vor seiner krankheit der bücher 16 gelesen und, wo es die notturft erfordert, corrigirt. So hab ichs niemand zu lieb noch zu leid geschrieben, wie dann solches alles in der getrukten vorred weiters gemeldet wird. ... Und dörft wol sagen, wo diese meine histori nicht wahr ist, dasz man freilich gar wenig historien glauben geben soll. Dann ich hab nichts aus mir selber, wie obgesagt, sondern alles aus glaubwürdigen acten genommen, so ich seither sechszehen jahren mit höchstem fleisz gesamlet habe.' (My translation; cf. Baumgarten, Briefwechsel, No. 139, Appendix I, No. 342).

${ }^{166}$ Sleidan had 'des Gegenteils Anschlag, Wille und Meinung nicht genügend berücksichtigt' (both references from Friedensburg, Johannes Sleidanus, p. 53).

${ }^{167}$ Cf. Appendix I, No. 404. In his own history of the Reformation, Bullinger frequently referred to Sleidan as source or for further information.

168 'Edita est Sleidani historia de germanicis motibus qui his triginta annis extiterunt, ac praecipue de ecclesiarum mutationibus. Liber dedicatus est duci Saxoniae Augusto, qui misit scriptori ducentos Joachimicos. Liberalitatem principis laudo, sed historiam non laudo, quia

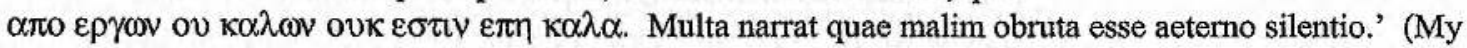
translation; CR 8, No. 5784; Appendix I, No. 341).
} 
Sleidan was in a state of utter despair and shock, as expressed in his following letters to Nidbruck: 'You cannot believe how grave my heart is. To be rewarded with such a price for these my labours! ${ }^{169}$ Sleidan was determined to defend himself against any such accusations, and prepared an 'apology', a short defense of his work to be included in further publications. ${ }^{170}$ Nidbruck became increasingly embarrassed by their connection, and urged Sleidan not to mention his name, to remain silent, and not to write an apology or contact the king. ${ }^{171}$ He warned him of certain people, especially of the emperor's Vicechancellor Jakob Jonas and of Christoph Welsinger, the chancellor of the bishop of Strasbourg, whom he denounced as 'the principal instigators of all our miseries'. ${ }^{172}$ Despite these allegations, the Commentaries were sold faster than they could be produced. By July, Sleidan wrote to Nidbruck, only 16 out of 1,000 folio copies were left, and the Rihels had started printing an octavo edition. ${ }^{173}$

Sleidan did eventually write his apology and handed it in to the magistrate of Strasbourg who approved of it but suggested delaying the publication. As Nidbruck had wished, Sleidan did not publish his defence, and it was only included after his death in the 1557 octavo edition by the heirs of Wendelin Rihel in Strasbourg:

'Tho I was not the fittest person to undertake this work, yet at the request of many good men, I entred upon it, ... . I call God to witness also, that I never designed to injure or hurt any mans reputation falsly; for what a madness would it have been to have delivered any thing otherwise than it was, in an affair which is fresh in all mens memory? [...] As to the pains I have taken, and the diligence I have used in

\footnotetext{
${ }^{169}$ 'Itaque cogitare potes, quid mihi sit mentis. Talene praemium tantis meis laboribus rependi!' (My translation; Baumgarten, Briefwechsel, No. 140; Appendix I, No. 344).

${ }^{170}$ Cf. Appendix I, No. 346, 348.

${ }_{171}$ Cf. Appendix I, No. 351, 354, 356, 373.

172 'des principaux causateurs de tout nostre malheur' (Baumgarten, Briefwechsel, No. 147; Appendix I, No. 351).

${ }_{173}^{17}$ 'Le livre se vend a merveilles. On avoit imprime mil, don't il ne reste par aventure que 16. On limprime derechef in octavo, mais tenez cela secretement; car il nest pas besoing quon le sache.' (Cf. Baumgarten, Briefwechsel, No. 148, p. 288; Appendix I, No. 353). This remark suggests again that the first edition of the Commentaries was in folio, but it does not suggest whether the first folio-edition was succeeded by another edition in folio or the one Sleidan refers to in octavo.
} 
this work, no man could possibly have done more to find out the truth, as many men can bear me witness, and the very work itself will in great part shew. [...] Where ever there are factions, wars and seditions, besure there are complaints, accusations, and answers, and all places are fill' $\mathrm{d}$ with opposite and contradictory papers: now he that truly relates these as they are, doth neither of the parties any injury, but follows the laws of an historian.... I do not doubt but all impartial men will yield that I have in this, which I have said, clearly given the true laws of history; and I can as little think they will judge that I have broke those laws; the far greatest part of my history being extracted out of pieces which were printed before. $^{174}$

The subsequent letters show the ups and downs Sleidan had to go through. Once he rejoiced to hear that King Maximilian himself as well as his court read the Commentaries, then again he had to justify himself against allegations that he had been bribed to flatter certain people in his work or purposely had written lies. ${ }^{175}$ Worse even, rumours appeared that the Commentaries would be publicly condemned and Sleidan would be declared an outlaw. ${ }^{176}$ At the same time, Sleidan was sent letters praising his work as well as additional material from various sides to be included in subsequent editions, since he continued adding to the Commentaries for further editions. ${ }^{177}$ People would also write to have their own or somebody else's reputation improved, like the historian Georg Sabinus, who sent material to show the virtues of his employers Johann and Albrecht of Brandenburg. ${ }^{178}$

\footnotetext{
${ }^{174}$ Sleidan/Bohun, General History, fol. b1v. - Otto Winckelmann in 'Zur Geschichte Sleidans und seiner Kommentare', ZGO 53 (1899), p. 606, published a German 'additio' to this apology which he came across in the Thomasarchiv in Strasbourg (Varia eccl. XI f, 304). The short text elaborates more on the greatness of Emperor and King and pronounces admiration and support. This addition was not included in the printed apologies.

${ }^{175}$ Cf. Appendix I, No. 354, 357, 353. In the letter in which Nidbruck informed Sleidan that King Maximilian was reading the Commentaries, he also reported an amusing conversation between one of Sleidan's opponents and Jacob Fugger: The opponent had heard that Sleidan had written a letter to him, and wanted to know whether Fugger had replied, which the latter confirmed. The opponent shouted agitatedly: 'If he had written to me, I would have wiped my behind with it, sent the letter back to Sleidan and would have written: there you are, bite yourself with this.' ('Tunc ille: wahn er mir geschriben hette, wollt ich den hindern doran gewuschet und ihm, dem Sledano, den brief wider geschickt und darunder geschriben haben: dahe, beisz dich mit dem.' (My translation; Baumgarten, Briefwechsel, No. 149; Appendix I, No. 356). ${ }^{176}$ Cf. Appendix I, No. 358, 362.

${ }^{177}$ Cf. Appendix I, No. 353, 361, 362, 364, 371. In a letter to Bernhard Meyer, Heinrich Walter remarked on 29 November that Sleidan was working daily at his Commentaries ('Dweil mir nun bewuszt, das gedachter Schledanus solich opus täglich mehret ...'; Baumgarten, Briefwechsel, No. 162, p. 310; Appendix I, No. 371). - Collinson in his article 'Truth and Legend', pp. 33-34, reports that various people were also sending material to John Foxe to be incorporated in further editions of the Acts and Monuments.

${ }^{178}$ Cf. Appendix I, No. 406.
} 
Nidbruck kept Sleidan informed about the reception of his work at the Diet, and himself alternated between embarrassed attempts to silence Sleidan and advice for later editions and orders of more copies. ${ }^{179} \mathrm{He}$ also reported to Sleidan what exactly people criticised about the Commentaries: he had given way to his affections and expressed his anger occasionally; he had used only the information from the acts and documents that suited him and his account; he had been partial and possibly even written for somebody, and had betrayed secret affairs. ${ }^{180}$

Whilst the publications of the French and German translations went ahead against the will of their author, Sleidan was busy defending himself against allegations from all sides. ${ }^{181}$ From France came the news of the rage of the Duke of Lorraine and Diane de Poitiers against him, and within Germany he encountered threats of a similar kind. ${ }^{182}$ Nidbruck had advised him to keep a low profile and seek employment at the court of a duke or count; in September 1556 he warned Sleidan to remain in Strasbourg for the moment since it would be too dangerous for him to travel. ${ }^{183}$

This apparent danger came especially from one of the persons who were unhappy about the role they played in the Commentaries, Count Albrecht of Brandenburg. He saw himself portrayed as a mad, raging destroyer, and this at a time when he tried to rehabilitate himself publicly. ${ }^{184}$ In April 1556, he published a writing against the cities

\footnotetext{
${ }^{179}$ Cf. Appendix I, No. 347, 351, 362.

${ }^{180}$ Cf. Baumgarten, Briefwechsel, No. 147; Appendix I, No. 351. Nidbruck's Latin is very confused and abbreviated in this letter, and only unclearly preserved, often he only alludes to different matters.

${ }^{181}$ On the German and French translations, see chapters 5 and 6.

${ }_{182}$ Appendix I, No. 379, 394; see chapter 6.

${ }^{183}$ Cf. Baumgarten, Briefwechsel, No. 177; Appendix I, No. 405.

${ }^{184}$ Cf. Karl Schottenloher, 'Johann Sleidanus und Markgraf Albrecht Alcibiades', ARG 35 (1938), pp. 193 202. In the Commentaries, Sleidan described Albrecht of Brandenburg's role in the 1552 revolt of Maurice of Saxony, mentioning that he 'burnt and plundered' many places on his way, especially in the case of Nuremberg: 'He therefore began a cruel war, and having plundered an hundred villages within their
} 
Nuremberg, Würzburg and Bamberg, which he regarded as the chief instigators for his public shaming and exile. In this work, edited by Karl Pruschius, a Protestant humanist and historiographer, he included long threats against Sleidan and his Commentaries for spreading lies about him, at the same time accusing the three cities of having prompted and supported the author. ${ }^{185}$ Along with this accusation, he demanded Sleidan change the Commentaries where it dealt with his person and mentioned that a real refutation against Sleidan's 'thousand lies' might be published. ${ }^{186} \mathrm{He}$ even went as far as to menace him with a trial in front of the imperial court. Additionally, one of Albrecht's supporters, the noble Wilhelm von Grumbach, published a similar writing against the three cities, equally accusing Sleidan of deliberate misrepresentation. ${ }^{187}$

In a letter of 3 October 1556 Nidbruck informed Sleidan that the Count had recently published a writing against him and intended to bring him to the imperial court, which shows that Sleidan knew at least of Albrecht's writing. ${ }^{188}$ Nidbruck also reported rumours

territories, about seventy mannor, and farm-houses belonging to the citizens, with the churches, he burnt, not only them, but also three thousand acres of wood in a vast forest of theirs... .' (Sleidan/Bohun, General History, pp. 561-562). Sleidan's account of the situation here was actually correct, but one can understand Albrecht's anger about the role he played then.

${ }^{185}$ The first trace of this story stems from the remarks of Carl Christian Am Ende, the editor of the 1785 annotated edition of the Commentaries and one of the first to show interest in Sleidan after the sixteenth century, in his Vermischte Anmerkungen über den berühmten Geschichtsschreiber Johann Sleidan, Nuremberg 1780, fol. a5v. He mentioned that a certain Pruschius had published a writing against the thousand lies of Sleidan, which upset Sleidan so much that he died of sadness and grief; Pruschius himself died soon after, full of remorse of his bad deed. ('Editus fuit liber contra mille mendacia Schleidani in area non procul dissita ab urbe Ratisbona; cuius libri corrector fuit N. Pruschius. Schleidanus tantum moerorem concepit ex editione ipsius libri, ut paullo post moreretur. Et post huius obitum Pruschius etiam poenitentia facti ductus moerore exstinctus fuit.') Schottenloher in his article traced this remark.

${ }^{186}$ Albrecht of Brandenburg raged against the 'lateinisch Gedicht von einem neuen angeschifften

Geschichtsschreiber, Sleidanus genannt... . Derhalben wir auch gemelten Sleidanum, wer der sein mag, hiemit gütlich ermant haben wöllen, dißfals seinen als wir noch achten übel berichten irrthumb aus diesem unsern warhafften und beweißlichen Ausschreiben zu endern oder jetzt unser Ausschreiben seinen in disem handel vorigen ausgegangenen geschichtsschrifften $\mathrm{zu}$ annectiren. Geschicht es von jme, hat es seinen weg, wo nit, so seien noch mehr leut, die auch schreiben und mit der warheit durchtringen werden.' (Cf. Schottenloher, 'Johannes Sleidanus', p. 196).

${ }^{187}$ Cf. ibid., pp. 201-202. Grumbach demanded the incorporation of his and Albrecht's protests into the Commentaries, otherwise he would have a refutation published and instigate a trial at the imperial court, similarly to Albrecht. The three cities immediately asked King Ferdinand to prohibit these writings. The editor of Albrecht's pamphlet, Karl Pruschius, was mysteriously shot in a forest.

188 'Editus est non ita nuper a Marchione [Albrecht of Brandenburg] liber qui non nisi fidis hominibus et notis datur neque communicatur omnibus, licet impressus sit. In eo tui fit mentio ab initio, ut videbis ex inclusa scheda. ... sunt qui dicant editum iri librum De mille mendaciis Sledani, ... . Loquitur quidam, 
that another work was being written called 'The thousand lies of Sleidanus' and advised him to remain silent and not to do anything. No response of Sleidan has been preserved as he died three weeks later, and thus avoided any further consequences.

\section{Sleidan is dead - but not forgotten}

With Sleidan's death, all the turbulations ceased almost immediately. On the Protestant side, Sleidan's history was soon accepted as the authoritative source on the Reformation once the Diet of Augsburg had been successfully concluded. With the religious peace secured, more editions of Sleidan were printed, and the discussion about a possible continuation was quickly raised. ${ }^{189}$ On the Catholic side, Sleidan was not forgiven quite so quickly. A Protestant work of such popularity as Sleidan's would needs attract the attention of the Catholic church, the Inquisition and the Index librorum prohibitorum. Sleidan made it into virtually all the different Indices, be it with a specific work like the Commentaries or as a generally condemned author.

In the Roman Index of 1559 , the first official censorship undertaken directly under papal authority, repeated in 1564 , Sleidan was condemned under his real name, his pseudonym Baptista Lasdemius or Lasdenus, and as 'Ioannes Splendianus', an obvious misspelling. ${ }^{190}$ The Index of the Portuguese Inquisition of 1561 , which incorporated the 1559 Roman Index, equally condemned Sleidan and all his works, repeated in the 1581 version. ${ }^{191}$ The Index of the Spanish Inquisition of 1559 condemned Sleidan's Commentaries, and in the 1583 version all of Sleidan's works are condemned, together illud quod alii ad camerae iudicium te pertractum iri augurantur.' (Cf. Baumgarten, Briefwechsel, No. 149, p. 328; Appendix I, No. 410)

${ }_{189}$ Cf. Appendix I, No. 425; see chapter 5.

${ }^{190}$ Bujanda (ed.), Index de Rome 1557, 1559, 1564, No. 66, No. 556, No. 559.

${ }^{191}$ Bujanda, (ed.), Index de l'Inquisition Portugaise, No. 88, No. 642, No. 646. 
with Calvin and all other banned authors in all languages. ${ }^{192}$ The 1570 Index of Antwerp repeated this general condemnation of Sleidan, Calvin and others, as had been done already by the Louvain Index of 1558 , which condemned both Sleidan as an author and the Commentaries. ${ }^{193}$ Sleidan was of course also included in the Tridentine Index, first published in 1564, where he was listed as a 'heretic of the first class'. 194

This harsh official response was completely ignored by most Catholics. Instead, Sleidan's works, mainly the Commentaries, were incorporated into Catholic libraries and used as teaching material. In my research I came across an unusually large number of editions of Commentaries owned by religious orders. The first folio-edition of the Latin Commentaries published by Wendelin Rihel in 1555 survived in the Bayerische Staatsbibliothek in Munich, bearing the provenance 'Collegii Societatis Jesu Monachii. 1608 ', and a copy of the same work in the Bibliotheque Municipale in Lyon was owned by the local convent of the Carmelites, who had indicated on the title-page that the work was condemned on the Tridentine Index. ${ }^{195}$ Similarly, one of the early German translations from 1557, Warhafftige Beschreibung aller Geistlichen unnd Weltlichen Sachen was

\footnotetext{
${ }^{192}$ Bujanda (ed.), Index de l'Inquisition Espagnole, No. 260; Bujanda (ed.), Index des Livres Interdits: VI. Index de 1'Inquisition Espagnole 1583, 1584, Geneva/Sherbrooke 1993, No. 121, No. 1051, No. 2057, No. 2063: 'Iehan Calvin, Iehan Sleidan, \& touts les autheurs condamnès, \& inutils, comprins soubs la lettre de .I. sont aussi defendus en toutes langues: ainsi comme tous les autheurs semblables, soubs toutes les autres lettres.'

${ }^{193}$ Bujanda (ed.), Index des Livres Interdits: VII. Index d'Anvers 1569, 1570, 1571, Geneva/Sherbrooke 1988, No. 429, No. 432: On p. 291 the editor mentions that on the list of books burned in Tournai in 1569, there was also 'Oeuvres de Sleidan'; Bujanda (ed.), Index de L'Université de Louvain, No. 145, (No. 146: Four Empires), No. 147.

${ }^{194}$ The Tridentine Index was first published in 1564 in Rome by Paul Manutius; I consulted a later reprint, Sacrosancti et Oecumenici Concilii Tridentini Paulo III. Iulio III. \& Pio IIII. Pont Max. celebrati, Canones et Decreta ... Item Catalogus \& Index librorum prohibitorum, Lyon (Guillaume Roville) 1577; fol. Ii7v lists 'Ioan. Sleidanus' under 'Auctores primae classis'.

195 The Munich copy bears the pressmark 2 Eur. 85; the Lyon copy is to be found under the pressmark 108085, with the inscription: 'Conuentus Lugdunensis Carmelitae Discale. Prohibitus in Judic Conc. Trid.'.
} 
owned again by the Jesuits in Munich. ${ }^{196}$ A French summary of the Commentaries, Sommaire de l'histoire de Jean Sleidan, was owned by the Benedictines. ${ }^{197}$

At least Antwerp's printer-publisher, Christopher Plantin, adhered to this official Catholic condemnation. When asked in 1574 by Seroskerke to send him a copy of the Four Empires, he declined to do so because the work was still on the Index. ${ }^{198}$ Ten years later he still refused to print Sleidan's Commentaries. ${ }^{199}$ Plantin's example was rather unusual. Sleidan remained popular across the confessions for centuries. Neither the rage of political authorities nor the official Catholic condemnation had any negative influence on the sales figures of Sleidan's work, which remained buoyant. When Sleidan's last work, the Four Empires, was published in June 1556, this also achieved immediate popularity, and was sold out by September $1556 .^{200}$

The Commentaries sold faster than they could be printed. Wendelin Rihel and his heirs published four editions between April and December 1555, two in the more affordable octavo format directed at the common people, as well as two more expensive folio editions, typically owned by richer people, political rulers, and libraries, especially monastic ones. The following year, Rihel's heirs already had to encounter fierce competition: alongside their two Latin editions of that year two others were published by different printers in Geneva, Simon Du Bois and Jacques Darbilly, and one in Basle by

\footnotetext{
${ }^{196}$ Warhafftige Beschreibung aller Geistlichen unnd Weltlichen Sachen, s.1. (s.n.) 1557, Bayerische Staatsbibliothek Munich, 2 H.Eur. 59: 'Collegii Societatis JESU Monachii'.

${ }^{197}$ This Strasbourg edition from 1558 has been preserved in the Bibliotheque Municipale of Rouen under the pressmark U 3343, bearing the provenance: 'Monasterii S. Georgii ordinis St. Benedicti C. J.'.

${ }^{198}$ Christoph Plantin to Phil. de Seroskerke, 6 November 1574, in Max Rooses (ed.), Correspondance de Christophe Plantin, 8 vols., Antwerp 1883 1918, reprinted Nendeln/Liechtenstein 1968, vol. 4, No. 583, pp. 196-198; Appendix I, No. 437.

${ }^{199}$ Ibid.,vol. 7, No. 1029, pp. 173-176 (Appendix I, No. 438): Alexandre Grapheus wrote to him on 1 November 1584, recommending him to reprint the first folio-edition (Strasbourg: Wendelin Rihel 1555) of Sleidan's Commentaries, which he himself had edited and supplied with the 26 th book. Plantin never printed a work by Sleidan.

${ }^{200} \mathrm{Cf}$. a letter by Hubert Languet to Philip Melanchthon, 18 September 1556; Appendix I, No. 408.
} 
Nicolaus Brylinger. ${ }^{201} 1556$ also saw the publication of the first unauthorised German and French translations: a German folio-edition by Basle's Brylinger, and two French octavoeditions by Crespin in Geneva. In 1557, the demand for the Commentaries boomed, reflected in the publication of four Latin editions, eight German editions, and five French editions. In the same year, even an Italian edition of the Commentaries was published in Geneva by François Jaquy, Antoine Davodeau and Jacques Bourgeois.

In 1558 , the production of Sleidan's Commentaries still went full speed ahead. Josias Rihel's Latin edition of the Commentaries for the first time contained the 26 th book of Sleidan's history, which Sleidan himself had largely compiled; it was rounded off by an unknown editor, who also concluded the work by mentioning the death of Sleidan. Not only were three editions in Latin, three in German and two in French published that year, but also a Dutch edition was published in Emden by Steven Mierdmans and Jan Gaillart. By 1560 , only five years after the first publication, altogether twenty editions of the Commentaries in Latin, fourteen in German, eleven in French, and one in Italian, one in Dutch, and one in English had been published. Apart from the full text of this history, also various editions of extracts and tables were produced. ${ }^{202}$ By the year 1600,35 editions in Latin had been published, 38 in German, 14 in French, six in Dutch, one in Italian and one in English. Additionally, seven editions of all of Sleidan's works had been published in French.

In this chapter, we have placed Sleidan into the wider context of German history writing. Both predecessors like Franck, Carion and Melanchthon, and contemporary projects like that of Flacius have shown similar ideas to Sleidan, but Sleidan was the one who first applied these methods to an account of the Reformation. In this process, he

\footnotetext{
${ }^{201}$ This examination of different editions of Sleidan's works is based on Vekene's Bibliographie.

${ }^{202}$ Cf. Vekene, Bibliographie, pp. 289-304.
} 
moved away from the tendency of confessional writers to interpret history as purely a display of God's providence and salvation history. In Sleidan's eyes, God is still behind everything, but the driving force of the Reformation is the politicians, not the general people or theologians. History does not need to be interpreted or used for moralising purposes, instead an array of primary sources should speak for themselves. Sleidan's struggle for veracity and neutrality is an approach that is much closer to our modern outlook than the earlier historical writings. To provide an account of the Reformation that would fulfill these two principles, Sleidan based his Commentaries on primary sources without closer analysis or interpretation. This was for him, and the sixteenth century reader, the ultimate guarantee of truth.

Such a reading of the Commentaries is reflected in the reactions it prompted. The Commentaries were published in the middle of the Diet of Augsburg, when the religious peace was at stake and both confessional parties were keen to avoid unrest. Both Catholics and Protestants tried to prevent the publication of Sleidan's history, the Protestants even sent Vergerio to help polishing the work to make it less offensive. The planned publication of the Commentaries in German was delayed in order to prevent further troubles. Critical voices on both sides muted quickly once the Diet had been successfully concluded. Sleidan's Commentaries became the ultimate source on the history of the Reformation for both Catholics and Protestants. After the initial rash responses to the history, only few people spoke openly out against Sleidan, who was already dead by then.

Sleidan could not have expected such a ferocious reaction to his Commentaries, and died a desperate man. A work of such seriousness had an impact beyond the disapproving reactions of those personally touched by his judgements. Over the coming decades, Sleidan's achievement would come to be widely appreciated by scholars and readers as the 
historical craft continued to develop. This appreciation extended not only to his native lands, the German Empire, but to what Sleidan might have seen almost as his second homeland, France. There, Sleidan would have a resonance beyond that of many native scholars. If Sleidan is to be accorded one primary distinction, it might even perversely be as the father of French Protestant history writing. For now, we will examine the role of Sleidan and his work in a German context. 


\section{CHAPTER 5: SLEIDAN'S RECEPTION IN GERMANY}

Writers of history in the sixteenth century faced a peculiar complex of problems. The new development of Renaissance scholarship had taught them to value accuracy and textual integrity. These two inevitably would have their impact on the writing of history. In the age of the Reformation, history could not but be a polemical tool. A central debate of the Reformation was for possession of the past, not least because a leading argument of the Protestants' opponents was that they had no past. This it was necessary to refute.

We have seen in the last chapter how even a work constructed with the utmost attention to notions of accuracy and impartiality had fallen foul of both Catholic and Protestant readers, but Sleidan's problems extended beyond this. The initial trouble and confusion after the publication of the Latin Commentaries and the unauthorised German and French translations soon ceased. Part of this diminution of expressions of outrage after the publication of the Commentaries is certainly due to Sleidan's untimely death in October 1556.

Across the border in France conditions were dissimilar: the religious question was at a much earlier stage of development than in the Empire. Far from being solved in a peaceful manner, the future troubles only began slowly to unfold. In France, historians and laymen alike would read the Commentaries as a guideline for solutions for contemporary questions. Since the confessional conflict was not resolved until the end of the century, an active French reading of Sleidan would continue for several decades, as we will see in chapter 6 . In Germany, the Commentaries only really offended during the Diet of Augsburg where the will for reconciliation had to be demonstrated on both sides. The resulting Peace of Augsburg diminished the immediately controversial nature of Sleidan's 
history. Very soon the Commentaries would be regarded as the standard work on the Reformation until 1555/56. Only few Catholics spoke out against it, and the Protestants kept altogether quiet. Instead, Sleidan was silently accepted and virtually canonised by Protestants and Catholics alike.

Despite the condemnation the Commentaries had received at the Diet of Augsburg and the criticism from leading Protestants themselves, scarcely half a year after Sleidan's death the idea for a continuation of the Commentaries was voiced. ${ }^{1}$ The Protestant prince Ottheinrich of Palatine approached Jean Sturm with the proposal to carry on Sleidan's history. The Count must have supported Sleidan financially, too, since he offered to pay Sturm 150 florentines a year, the same salary Sleidan had received from him, as he remarked in his letter to Sturm. ${ }^{2}$ This plan must have been rather concrete, since in October 1562 Roger Ascham wrote to Sturm to express his happiness about the planned continuation, of which he had also informed the Queen. ${ }^{3}$

In this chapter, we will examine the reception of Sleidan in Germany. The Latin original of the Commentaries was so popular that very soon plans for a German translation were made, much against Sleidan's will. The large demand for such a German version is best illustrated in the fierce competition that arose between various places of print to publish the first and best translation. These editions sold fast and were so successful that the printing industry in Strasbourg virtually survived on the production of works of Sleidan alone. In the second part of this chapter, we will look at the small number of literary reactions towards Sleidan within Germany, which will bring material to light which so far has not been examined.

\footnotetext{
${ }^{1}$ We have discussed the reactions by Bullinger, Melanchthon, Carlowitz and Sturm in chapter 4 .

${ }^{2}$ Cf. Appendix I, No. 425.

${ }^{3}$ Cf. Appendix I, No. 435.
} 


\section{The race for a German translation}

'Thus all nations have desired his history so much before it was printed, and afterwards have so much cherished and praised it that at this time there is nobody in any corner of Europe ... who does not have assiduously his eyes on it, who does not carry it at his chest, who does not usually talk about it.... ${ }^{44}$ - The editor of this 1558 Sommaire de l'Histoire de Jean Sleidan, a summary of Sleidan's history, might naturally have been convinced of the quality of Sleidan's work, but there was truth in his statement. The Commentaries sold so well that the Rihels had their printing presses constantly producing new editions of Sleidan's Commentaries in Latin. A German translation was not officially pursued yet due to the unforeseen reactions to the Latin edition.

However, very soon rumours about an unauthorised, clandestine German translation were spread. These must have been more than mere speculation, as Sleidan himself addressed the issue already in the first folio edition of 1555 . In a short note addressed to 'the printers' he underlined that Wendelin Rihel had undertaken the project in dangerous circumstances and with many costs, and therefore should not be undermined by clandestine printing. ${ }^{5}$ In another Rihel edition from September 1556 Sleidan felt obliged to state that the Rihel publications were the only trustworthy editions of his work, and warned

\footnotetext{
4 'A ceste cause toutes nations ont tant desiré ceste sienne histoire deuant qu'elle fust mise en lumiere, \& apres l'avoir veuë, tant cherie \& prisée, qu'il n'y a pour le present personne en nul coin de 1'Europe pour peu savant qu'il soit, qui n'ait les yeux assiduellement dessus, qui ne la porte en son sein, qui ne l'ait ordinairement en la bouche... .', Sommaire de 1'Histoire de Jean Sleidan, disposé par tables, En tel ordre et facilité, que le Lecteur pourra aisément \& sans travail comprendre par iceluy tout le long narré de ladite Histoire, Strasbourg (s.n.) 1558, fol. AA2r.

5 'Author Typographis: Librario sum usus ad hoc meum institutum Wendelino Rihelio, cui certe iuventus non parum debet, ipsius adiuta fideli ministerio \& opera. Et licet dispendium ille se posse magnum subire videret, in hac multorum cupiditate qui rem quoquo modo facere student, \& quaestum undecunque captant, tamen, ut hac quoque parte publice prodesset, periculum fecit, \& procudendum volumen suscepit. Quare vos omnes obsecro maiorem in modum, ut liberaliter agatis atque candide: neque tam, quid utile sit vobis, quam quid honestum, consideretis. [...] Nam qui primus hoc in se munus recepit, eius ego, cum dabitur occasio, prae caeteris omnibus rationem sum habiturus in posterum.', Ioan. Sleidani, de Statu Religionis et Reipublicae, Carolo Quinto, Caesare, Commentarii. Cum Indice luculentissimo. M.D.LV., (Strasbourg: Wendelin Rihel) 1555, fol. a1v.
} 
against the unauthorised printing of the Commentaries, be it in Latin or German, the full text or abridgements. ${ }^{6}$

Originally, the Schmalkaldic League and Sleidan had intended to prepare a Latin and a German version to reach beyond academics to a wider audience, but with the increasingly negative attention the Commentaries had received and the changing political climate, a German publication seemed unreasonable. ${ }^{7}$ Jacob Sturm, who had supervised the first sixteen books of the Commentaries, had shared these concerns. He warned of haste and counselled care with choosing a translator, who should be equally well acquainted with the matter as Sleidan. ${ }^{8}$ When Sleidan wrote the above preface in September 1555 , rumours about an unauthorised German translation must have already been circulating. Sleidan had heard that Johann Stumpf in Basle was preparing a German translation, and in November he wrote to him to ask him not to do so without his consent. He reminded him of the trouble the Latin edition had caused, and underlined that the Commentaries were rather directed towards scholars and politicians than to common people. Possibly to deter Stumpf from publishing his work, he hinted that Josias Rihel already had a German edition printed, but was holding it back at his wish. Sleidan also

\footnotetext{
${ }^{6}$ ‘... deinde, nunc etiam latinum eripuit idem Rihelio, quantum in ipso fuit, aliisque typis procudit, \& emolumentum ad se derivare studet, meisque fruitur laboribus, \& veluti fucus alienis insidiatur alueariis ac mellificio:... . Ne sordidum hoc $\&$ avarum institutum, ei fructuosum esse velint, sed meum ac genuinum sciant illud exemplar esse, quod Rihelius exponit. Nimis enim confidentur agit ille, ne dicam temerarie, quod me vivo sibi tantum usurpat, non cogitans interim, quam sit mihi facile, spem eius omnem atque rationes perturbare. Consimilis etiam est eorum audacia, qui sine meo consilio quandam operis epitomen colligunt \& edunt, homines, quos minime quis credat esse tales, ut alterius cum iniuria suis ipsi commodis velint \& cupiditati servire.', Ioan. Sleidani, De Statu Religionis et Reipublicae, Carolo Quinto, Caesare, Commentarij. Sub calcem adiectae sunt Tabulae, quibus singulari industria ac compendio Religionis Reipublicaeque negotium universum, ceu in pictura, spectandum exhibetur, (Strasbourg: Rihel brothers 1556), fol. alv.

${ }^{7}$ Cf. Martin Bucer's letter to Philip of Hesse from 7 April 1545 (Appendix I, No. 57): Bucer advised to have the history composed in both Latin and German.

${ }^{8}$ 'Daher hat her Jacob Sturm allewegen, ehe es in truck uszgangen, anzeugt noch zer zit nit gerathen sin, das es vertutscht, es wurde dann durch ein furtrefflichen, der im vertütschen ein sonder art hette, vertiert. Derselb müsste auch glich so wol als diser Sledanus aller sachen grundlichen bericht haben.' (Baumgarten, Briefwechsel, No. 162; Appendix I, No. 371).
} 
mentioned that a similar unauthorized project was undertaken in Basle. He had already written to Basle with the request to stop their plans. ${ }^{9}$

It was from Basle in fact, not from Zurich, from where real danger arose. ${ }^{10}$ There the situation seemed even more urgent. In the same month, in November 1555, Strasbourg's city scribe Heinrich Walter wrote to the mayor of Basle to prevent the publication of the translation of the Commentaries, since Sleidan had heard that the printer Brillinger had already started his work. He remarked that a German translation could raise a lot of trouble at the Diet, and that Sleidan himself planned a German version at a more favourable time. ${ }^{11}$ Basle seemed unimpressed, and after Sleidan's complaint to the XIII of Strasbourg the council sent an official letter to the mayor and council of Basle. ${ }^{12}$ They asked the city authorities to ban the German translation prepared by Heinrich Panthaleon to be printed by Nicolaus Brillinger, and pointed out the negative consequences which the Latin edition had had for both Sleidan and Strasbourg. ${ }^{13}$

\footnotetext{
9 'Audio te, vir doctissime, laborem suscepisse vertendae meae historiae, et quantam id benevole fieri non dubito, cuperem ex animo tamen, si ita res se habet, abs te fuisse praemonitus. Nimirum propter latinam editionem non credas quam fremant et indignentur nonnuli ... . Cogitandum et hoc est multa inesse in mea historia, quae nihil ad promiscuam multitudinem spectant, sed ego literatis tantum et policitis hominibus ea scipsi. ... Nam alioqui, si vos non desistatis, tum Rihelius qui Latina dedit Germanica quoque cogetur edere, quae nunc habet parata, sed in mei gratiam supprimit. ... Basilae quoque vertitur, sed et eo scripsi, hortatus ut quiescant.' (Baumgarten, Briefwechsel, No. 161; Appendix I, No. 372). Sleidan did not mention who prepared the German translation to be published with Rihel. Winckelmann, 'Zur Geschichte Sleidans' on pp. 578-586 mentions the different German translations.

${ }^{10}$ Contrary to the rumours, Johann Stumpf did not prepare a translation of Sleidan's Commentaries; Manfred Vischer lists not a single edition of any of Sleidan's works printed in Zurich in his bibliography Bibliographie der Zürcher Druckschriften des 15. und 16. Jahrhunderts, Baden-Baden 1991.

${ }^{11}$ 'Nun hat sich gedachter Schledanus, ... gegen mir hören lassen, wie der Stumpff zu Zürich im werk sein solle disz buch zu vertutschen, und einer zu Basel auch des furhabens, schon etlich bogen vertuscht durch den Brillinger trucken lassen, und ime gschriben, das ers nit fur unguet haben wolte. ... Dweil mir nun bewuszt, das gedachter Schledanus solich opus täglich mehret und er selbst, so es gefertigt, und die zit basz dann jetzo geben wurd, furhabens vertutschen und hie denjenigen, so den costen im latinen zu trucken erlitten, trucken zu lassen und uffsehens ze haben, das es im grund und rechter art nach gefertigt werde, mochte dises beden zu groszem schaden dienen.' (Baumgarten, Briefwechsel, No. 162; Appendix I, No. 371).

${ }^{12}$ Cf. Appendix I, No. 374.

13 'Weil wir nun aber vor der zeit bestendiglich bericht seind, das die Römisch königlich mat, und daneben etlich, sonderlich aber geistlich fursten ab solchem buech ein besonder ungnad, nit allein gegen dem dichter des buchs, sonder auch gegen gemeiner stat gefasst und sich desselben zum hochsten beschwert haben, ... und wir derhalben besorgen müessen, so es erst in teutsch sprach solt divulgiert und ausgebraitet werden, das es gemeiner stat zu noch groszer ungnad, verwisz und so balt etwan auch zu schaden reichen möcht, darmit doch sonst niemant geholfen.' (Baumgarten, Briefwechsel, No. 163, Appendix I, No. 375).
} 
The Basle council replied in December to inform Strasbourg that both Pantaleon and Brillinger had confirmed that Sleidan and Strasbourg had contacted them, but insisted that there was no official ban of a German translation. They also emphasised that Brillinger was so far advanced with printing the work that aborting it would ruin him. ${ }^{14}$ Despite further correspondence between Sleidan, Pantaleon, Brillinger, Rihel and the councils of Strasbourg and Basle the German edition was printed and published in spring 1556. ${ }^{15}$ In the preface to this edition, Pantaleon paid tribute to Sleidan's skills and the popularity of his work, which he had been asked to translate into German. He remarked on the need for a German translation of such important a work, since it primarily concerned German events. The German edition would allow access to this knowledge not only to the educated elite who could read Latin, but to everybody else. ${ }^{16}$

\section{Pantaleon's translation, Warhaftige Beschreibüng Geistlicher und Welttlicher}

sachen, was immediately very popular. Contrary to expectation, it did actually not increase the uproar that had followed the Latin edition, nor did it 'incite a new fire', as Sleidan had feared. ${ }^{17}$ Since the religious question had now been settled with the Peace of

\footnotetext{
14 'Darnach wir auch von dem vertierer und trucker ... anzeigung empfangen, das ditz ... cronick nun mer kein geheumbd, sonder ein offenbar werk, so under dheinem sonderbarn privilegio uszgangen und nimand nachzetrucken, geschweige zuvertütschen abgestrickt noch verpoten, sondern fri sin, usz dem dann si keiner unbefugten gestalten hierob gehandlet haben verhoffen, sonder vertruwen wollen, das si mit sollichem iren werk, so si mer dann zum halben theil gefertigt, procediren und fürfaren möchten.' (Baumgarten, Briefwechsel, No. 165; Appendix I, No. 377).

${ }^{15}$ Cf. Appendix I, No. 378, 380, 382, 386.

${ }^{16} \mathrm{Cf}$. Sleidan/Pantaleon, Warhaftige Beschreibüng Geistlicher und Welttlicher sachen/ under dem großmechtigen Keyser Carolo dem fünfften verloffen/ erstlichen von dem hochgelehrten Herren Johansen Sleidan in Latein fleysig zusammen getragen: nun aber zu gutem der Teütschen nation/ auff das treuwlichest verteütschet/ durch Doctor Heinrichen Pantaleon, Basle 1556, fol. A2v: 'Deßhalben sich niemand zu verwunderen/ daß dises buch mencklichem also wolgefallen/ und der massen nachfrag gehabt daß man/ob es wol zu mehrmalen in Latein außgangen/ nit gnügsam exemplaria mögen ankommen. Dieweil aber solliche Historien zum grösseren theil Teütsch nation belanget/ habend viel treffenlicher und weyse menner vermeinet/ zu ehren Gottes und wolstands gemeines vatterlands nutzlichen zesein/ wo yemand die arbeit auff sich nemmen/ und dise Historien vertolmetschen und zu Teütsch bringen. Dann ob wol fürsten und herren/ auch ein yede Oberkeit dises buchs innhalt von iren geleerten und schreiberen verstanden/ were doch viel komlicher/ wo ein yeder die sach/ wie sich die in der warheit verloffen/ selbs versten möchte.' 17 ....so ists doch nit freuntlich, ... das sie gleichwoll fortfaren, ein new fewr wiederumb anzünden' (my translation; from Sleidan's supplication to the XIII of Strasbourg of February 1556, in Baumgarten, Briefwechsel, No. 168; Appendix I, No. 380).
} 
Augsburg, Sleidan's Commentaries had lost their immediate controversial nature. Sleidan himself had read a part of the translation which Rihel had obtained from Brillinger, and criticised the bad quality of the German text as 'too constrained, too close to the Latin text, and not elegant enough'. ${ }^{18}$ There is no evidence that Sleidan received any financial reward for the publication of the German translation.

The Basle edition by Pantaleon was very successful and was soon printed in Frankfurt, too, although the exact circumstances are unclear. ${ }^{19}$ Seeing the success of the Basle translation, Josias Rihel was keen to publish his official German translation by the history professor Marcus Stamler, a friend of Sleidan. In May 1556 he asked the magistrate for permission, which was granted, but due to the turmoil the Latin original had caused the council deferred the publication until June $1557 .^{20}$ Stamler in his preface pointed out that Sleidan himself had asked him to translate the Commentaries, and they had been in constant contact throughout the process; only due to Sleidan's untimely death was the publication delayed. ${ }^{21}$

By 1557 , a year after Sleidan's death, and two years after the publication of the Latin original, three different German translations were circulating, the authorised edition by Stamler from Strasbourg, the initial Basle/Frankfurt edition by Pantaleon, and another translation by Israel Achacius from Pforzheim, who courteously sent a copy to the

\footnotetext{
18 ،.. das die verteutschung mir nit zum besten gefiele, denn sie were gezwungen, gieng zu serr uff das latein, und were nit anmütig...' (Baumgarten, Briefwechsel, No. 168, p. 315; Appendix I, No. 380). ${ }^{19}$ The German 1557 editions listed in Vekene, Bibliographie as E/b 002 (s.1., s.n.), E/b 003 (colophon: Frankfurt/Main [Weigand Han]), E/b 004 (s.l., s.n.) and E/b 008 (s.l., s.n.) are Pantaleon's translation. ${ }^{20}$ Cf. Appendix I, No. 391; also Winckelmann, 'Zur Geschichte Sleidans', p. 585.

${ }^{21}$ Sleidan/Stamler, Joanniß Sleidani Warhafftige und Eigentliche beschreibung der Geistlichen und Weltlichen sachen/so sich under der Regierung des Großmechtigsten Keysers Caroli diß namen des V. verlauffen. Durch Marcum Stamler/ von Augspurg/auß dem Latin in die rechte Hochteutsche Sprach auff das fleissigst verdolmetschet. Sampt einer Apologia von dem Authori selbers angestellet, Strasbourg (Wendelin Rihel heirs) 1557. Stamler's preface is dated from 13 June $1557:$ ' $\ldots$ auch in dem des authoris bericht in verdolmetschung diser historien, so ich von im selbs empfangen, auf das fleissigest meines besten vermögens nachkommen .... . und wiewol ich tröstlicher hoffnung gewesen, soliche mein fürgenommene arbeit lang vor diser zeit zu gewünschtem end zu füren und in den truck zu bringen, so ist doch solichs aus zufelliger krankheit des authoris, deren dann er auch entlich gestorben, bis anher anstehn bliben ... '.
} 
Strasbourg council. ${ }^{22}$ This testifies to the popularity of Sleidan's Commentaries; not only were a large number of German editions printed, the market was large enough that different printing houses, in Basle, Frankfurt, Strasbourg and Pforzheim, would publish separate translations. Only one year later, in 1558 , another, fourth German translation was published in Frankfurt, that of a friend of Sleidan, Michael Beuther, professor of history at the university of Greifswald and academy of Strasbourg. ${ }^{23}$

Once Beuther's translation was placed on the market, it soon achieved a dominant position, but competition was apparently still so great that over the next decades different printers struggled for the rights to the translation, as Beuther's remarks in the 1570 edition suggest. ${ }^{24}$ From 1560 onwards, it seems as if only Beuther's translation together with a constantly updated continuation of Sleidan's history was further published. Between 1561 and 1567 six further editions of what seems to be Beuther's translation were published in Frankfurt/Main. In 1567 this translation was also printed by Theodosius Rihel in Strasbourg, who from then onwards printed only Beuther's translation. In the 1570 edition of Beuther's translation published with Rihel, Beuther himself felt urged to address the public. He remarked that he had undertaken that translation out of friendship with Sleidan since he had noticed how bad the quality of some of these translations was, be it due to a

\footnotetext{
${ }^{22}$ Cf. Appendix I, No. 430; Achacius' translation is Chronica: das ist Warhaftige und gewisse Beschreibung/deß Hochgelehrten herrn Johannis Sleidani/ darinn angezeigt / was sich in Geistlichen und Weltlichen sachen under dem Großmechtigsten Keiser Carolo dem fünfften/verloffen hab / auff ein neüwes Teütscher Nation zu gut verdolmetschet / in ordenliche Capitel / deren jedem sein besonder Argument und Innhalt vorgsetzt / abgetheilt / der gleichen vormals nie getruckt worden / durch Israelem Achacium / von Heilbrunn. Sampt einer Apologia vom Authore darïber verlassen, Pforzheim (Georg Rab) 1557.

${ }^{23}$ Imke Schmid in Die Bücher aus der Frankfurter Offizin Gülfferich - Han/Weigand Han - Erben. Eine literaturhistorische und buchgeschichtliche Untersuchung zum Buchdruck in der zweiten Hälfte des 16. Jahrhunderts, Wiesbaden 1996, p. 167, states that Beuther's translation of Sleidan's work was first published in 1561. Vekene, Bibliographie, however, lists the first edition of Beuther's translation for $1558(\mathrm{E} / \mathrm{b} 010$, Frankfurt/Main: [David Zöpfl]), an identification I can confirm through my own studies.

${ }^{24} \mathrm{Cf}$. the preface to Sleidan/Beuther, Der erste [und ander] Theyl Ordenlicher Beschreibunge unnd Verzeychnisse/ allerley fürnemer Händel/ so sich in Glaubens und anderen Weltlichen sachen/bei Regierung vorweilen des Großmächtigsten/ Keysers Carl des Fünfften/mehrerntheyls in Teutscher Nation zugetragen, Strasbourg (Theodosius Rihel) 1570.
} 
lack of lingustic skills of the translator or a mere ignorance of the historical facts. ${ }^{25} \mathrm{He}$ complained about all those who had printed his work falsely or paraphrased it wrongly. Although his first, hastily prepared translation had first been printed in Frankfurt, he had not authorised or did not even know about what was printed there now, he remarked. Beuther was anxious to distance himself from the Frankfurt editions, calling them forgeries. $^{26}$

Even fifteen years after the first publication of the Commentaries the German translation was in such large demand that competition between publishing houses remained fierce. The Commentaries were not only printed in large number, but their content was also continuously updated. Beuther's first translation of Sleidan's history had already contained some additional material. By the time the 1570 edition was published, this had grown into an additional part added to the original Commentaries, summarising the most recent events, but also providing additional information on events which fell into the years described by Sleidan. By the beginning of the seventeenth century, in this way a massive body of work had been accumulated in the form of Sleidanus Redivivus, a monumental edition published in $1618 .^{27}$ This work contained the original 26 books of Sleidan, then the continuation carrying the narrative to 1595 in 12 books by Beuther and an unknown

\footnotetext{
${ }^{25} \mathrm{He}$ remarked that Sleidan's work was printed 'mit vil tausent Exemplaren/ bey männiglichen außgebreytet worden. Wiewol aber mir dazumale nicht unbewust/ daß solche Histori bei vilen Hohes und Nidern Standes Personen/ nicht gar ohn ursach/ etwas unangenem/ dannoch und dieweil der mehr ertheyl/ von Gelehrten unnd Laien/ dieselbige mit sonderlicher begirde annamen/ lasen/ und ungeacht daß sie auß unverstande der Tollmetschen aller miteynander /demnach ihnen die gestalt und gelegenheyt der Reichshändel unbekannt/ an vilen orten des Sleidano meynunge / Latinischer Sprache/ und den sachen an sich selbs ungemeß/ dem gemeynen Leser under die hände geschoben wurde/ nicht wenig darrauf hielten/ wolte ich von wegen der freundschaffte/ so sich etwa zwischendem Sleidans und mir erhalten/ das gantz Werck von newen fürzunemmen...'. (Ibid., fol. $)(2 r)$.

${ }^{26}$ Ibid., fol. $)(8 v$. Beuther called the Frankfurt editions 'leichtfärtig Sudel und Hümpelwerck', and denounced the printers as having added a false privilege by the emperor.

${ }^{27}$ Sleidanus Redivivus, Das ist ein grundtliche beschreibung auch Historische erzehlung der fürnembsten Händel, so sich in Religions und anderen Politischen Sachen bey Regierung des Unuberwindlichsten Kaysers Caroli de $\beta$ V. Ferdinandi deß I. Maximiliani und Rudolphi der II. hochlöblichster Gedächtnuß: Und dann Matthiae des Ersten, jetzo noch Regierenden Römischen Keysers, in und ausserhalb des Heyligen Römischen Reichs vorgelauffen und zugetragen, Frankfurt/Main (Egenolff Emmel), 1618.
} 
author. This was followed by Gotthard Arthusius' contribution covering the years 15961618 in 23 books.

The competition that arose around the publication of Sleidan's Commentaries shows how profitable this work was for the printer. Sleidan's final place of residence Strasbourg was naturally one of the main centre of production of Sleidan's works. The printer Wendelin Rihel and heirs, personal friends of Sleidan, made a large part of their income through publications of various works of Sleidan, both in Latin and German. Not only the Rihels profited from Sleidan's works, but the printers of Strasbourg on the whole. If we examine the publication numbers offered by Miriam Usher Chrisman in her article on historical publications in Strasbourg 1480-1599, the importance of Sleidan's works for the output of the printing press in Strasbourg becomes immediately clear. ${ }^{28}$ The overall publication of historical works from 1480-1600 show that 32 of 122 works are editions of Sleidan, $26.2 \%$ of the total. If we concentrate on the years $1550-1600$, when Sleidan's Commentaries and Four Empires were published, this proportion increases to 32 out of 87 works, making up $36.8 \%{ }^{29}$ These figures become even more impressive if we focus on the publication of contemporary histories. Between 1480 and 1600,67 such works are published; the 32 works of Sleidan make up $47.8 \%$ of the total. In the relevant period 1550 till 1600,32 out of the published 58 histories are Sleidan's works, or $55.2 \%{ }^{30}$

\footnotetext{
${ }^{28}$ Miriam Usher Chrisman, 'Les Publications historiques à Strasbourg 1480-1599', Marijn de Kroon/Marc Lienhard (eds.), Horizons Européens de le Réforme en Alsace. Das Elsass und die Reformation im Europa des XVI. Jahrhunderts, Strasbourg 1980, pp. 19-36; cf. table 1, p. 35: 'Auteurs d'ouvrages historiques publiés à Strasbourg 1480-1599 et nombre d'éditions (Ouvrage avec trois éditions ou plus)' (based on publications of three or more editions).

${ }^{29}$ If we split these numbers up into decades, then the picture again changes dramatically: from $1550-59,14$ out of 27 publications, or $51.9 \%$, are Sleidans. From $1560-69,8$ out of 14 publications are Sleidans, that is $57.1 \%$. From $1570-79,6$ out of 14 works are Sleidans, making up $42.6 \%$.

${ }^{30}$ When split up into decades, Sleidan becomes even more important: from 1550-59, 14 out of 23 publications, or $60.9 \%$ are Sleidans. From $1560-69,8$ out of 11 publications are Sleidans, that is $72.7 \%$. From $1570-79$, all 6 works published are Sleidans, a full $100 \%$. These numbers would be even more impressive if one was to calculate the sheets of Sleidan's works and compare them with those of the other publications.
} 


\section{The distribution of Sleidan's work}

We have seen the unexpected and dramatic sales figures of Sleidan's Commentaries. Not only did they sell well in the original Latin, but in only a few years they had also been translated into the major European languages and were the focus of fierce competition of printers. In this context it is interesting also to explore who read these thousands of copies of Sleidan's Commentaries in various languages and formats. Since they were produced in both large and small formats, they were affordable by both the wealthier elements, like professors and clergy, and also by students and laity, as Higman argued. ${ }^{31}$ The documents assembled in Appendix I alone show that Sleidan's readers included some of the most illustrious people of the sixteenth century, Melanchthon and Bullinger, King Maximilian, Johannes Opporinus and Basilius Amerbach. ${ }^{32}$ A survey of various catalogues of libraries and private collection will allow us a further indication of the distribution of Sleidan's work. Naturally, his works were found in numerous libraries in Germany, but also across Europe and even in the New World.

Within German lands, Sleidan's books were present in virtually every library of importance and also in smaller collections. Sleidan's works were of course present where one would expect to find his books, like the libraries of cities, princes, and universities - at least in Protestant areas, but also in various Catholic libraries. Yet Sleidan also infiltrated the book collections of religious orders. We have seen above that both Commentaries and Four Empires were read and even used for teaching purposes by various religious orders, especially the Jesuits. ${ }^{33}$ Sleidan was also read by German intellectuals like the

\footnotetext{
${ }^{31}$ This distinction is phrased in imitation of Francis M. Higman in Francis M. Higman/Yann Morvant/Marc Vial, 'A bookseller's world: the 'inventaire' of Vincent Réal', Andrew Pettegree, Paul Nelles, and Philip Conner (eds.), The Sixteenth-Century French Religious Book, Aldershot 2001, p. 317

${ }^{32}$ Cf. Appendix I, No. 341, 402, 354, 431, 334, 402

${ }^{33} \mathrm{Cf}$. chapters 3 and 4 . - The Jesuits of Molsheim/Strasbourg also owned copies of the Commentaries in German and Latin, which were later incorporated into the library of the Grand Séminaire at Strasbourg (cf.
} 
seventeenth-century philosopher and political thinker Samuel Pufendorf, who possessed the Commentaries in Latin, French and Swedish, along with a Latin epitome, as well as Latin editions of the Four Empires and the Two Orations. ${ }^{34}$

In France, Sleidan's works were equally well distributed across libraries and seminaries. They were also owned by famous private collectors, such as the diplomat, theologian and polemicist Philippe Du Plessis-Mornay (1549-1632), whose substantial library also included a 'Sleidan in 8o'. ${ }^{35}$ Equally, Claude Dupuy (1545-1594), councillor of the Paris Parlement in the last quarter of the sixteenth century and most probably a Catholic, owned a 1559 Latin edition of the Commentaries. ${ }^{36}$ In the eighteenth century, Sleidan was still consulted, for example by the great political thinker Charles de Montesquieu, who owned a 1559 Latin edition of the Commentaries, and a 1574 French edition of Sleidan's works. ${ }^{37}$

Sleidan also made it into private libraries in Eastern Europe, more specifically in Bohemia/Hungary. One of the collectors there was Johannes Dernschwam (1494-1568), the head of the Neusohl mining industry owned by the Fuggers. Among his collection of books were the Latin Commentaries and Four Empires. ${ }^{38}$ Another reader of Sleidan's works was the humanist and court historian Johannes Sambucus (1531-after 1575), whose large library of around 2,618 books was later incorporated in the National Library in

Louis Schlaefli, Catalogue des livres du seizième siècle (1531-1599) de la bibliothèque du Grand Séminaire de Strasbourg, Baden-Baden/Bouxwiller 1995, No. 2796-2798).

${ }^{34}$ Fiammetta Palladini, La Biblioteca di Samuel Pufendorf. Catalogo dell'asta di Berlin del settembre 1697, Wiesbaden 1999, No. 1536, 1586-1590.

${ }^{35} \mathrm{Cf}$. Roger Kuin, 'Private library as public danger: the case of Duplessis-Mornay', Andrew Pettegree/Paul Nelles/Philip Conner (eds.), The Sixteenth-Century French Religious Book, Aldershot 2001, p. 353. Two manuscript catalogues of Duplessis-Mornay's massive library, encompassing about 1048 and 1203 titles, were drawn up in 1605 and between 1607 and 1611. The second catalogue contains the 'Sleidan in 80'. ${ }^{36}$ Jérôme Delatour, Une bibliothèque humaniste au temps de guerre de religion. Les livres de Claude Dupuy d'après l'inventaire dressé par le libraire Denis Duval (1595), Paris/Geneva 1998, No. 199.

${ }^{37}$ Louis Desgraves (ed.), Catalogue de la Bibliothèque de Montesquieu, Geneva/Lille 1954.

${ }^{38}$ Jenõ Berlász (ed.), Die Bibliothek Dernschwam. Bücherinventar eines Humanisten in Ungarn, Szeged 1984, pp. 127, 161, 185. 
Vienna. His collection included two Latin editions of the Commentaries as well as a Latin summary of $1557 .^{39}$ It is not surprising that Sleidan's works were also to be found in Geneva in Calvin's Academy, which possessed Latin and French editions of the Commentaries and the Latin Four Empires. ${ }^{40}$ These two works were also owned in a Dutch edition by the library of the princes of Orange-Nassau in the Netherlands, along with the 1555 Latin Commentaries. ${ }^{41}$

With the discovery of the New World Sleidan also made his journey across the Atlantic. The Irish merchant James Logan (1674-1751), a well educated man, accompanied William Penn as his secretary to what became Pennsylvania in 1699 . During his many journeys to Europe for trading purposes Logan spent much of his money on acquiring a large library, which included also two Latin edtions of the Commentaries, one from 1556 and the other from $1566 .^{42}$ Incomes from trade also allowed William Byrd II (1674-1744) from Wetsover in Virginia to build himself an impressive collection of about 2,300 books. Amongst these were seventeenth century editions of the Commentaries in English and the Four Empires in Latin, of which he also possessed a 1599 edition. $^{43}$

If we look at the few preserved examples of sixteenth-century trade catalogues, Sleidan also appears frequently. As we have seen above, in 1560 Sleidan's Commentaries had been published in English, and were apparently so popular that editions in other languages were imported. The Emden bookseller Gaspar Staphorst included a large

\footnotetext{
${ }^{39}$ András Varga/ Péter Ötvös, Die Bibliothek Sambucus. Katalog. Bibliothecae Ioannis Sambuci Catalogus Librorum 1587, Szeged 1992, No. 615/1, 615/2, 1014.

${ }^{40}$ Alexandre Ganoczy, La Bibliothèque de l'Académie de Calvin. Le Catalogue de 1572 et ses Enseignements, Geneva 1969, No. 177, 194, 259.

${ }^{41}$ A.D. Rending/ J.T.C Renting-Kuijpers, The Seventeenth-Century Orange-Nassau Library, Utrecht 1993, No. 1527,1800 .

${ }^{42}$ Edwin Wolf, The Library of James Logan of Philadelphia 1674-1751, Philadelphia 1974, No. 1854 and 1855.

${ }^{43}$ Kevin H. Hayes, The Library of William Byrd of Westover, Madison 1997, No. 104, 1647, 1790.
} 
number of editions of various works of Sleidan in his broadsheet catalogue of books offered for sale sent to England in 1567. This was the time when the traditional English book trade with Antwerp, Geneva and other cities was almost impossible after the outbreak of the second War of Religion. ${ }^{44}$ To cater for the demand for Latin and French editions of Sleidan in England, aimed both at the intellectual elite and the exile community, Staphorst offered Latin editions of the Commentaries as well as the Two Orations and Four Empires, next to French editions of the Commentaries, the Four Empires and Crespin's edition of Sleidan's works. ${ }^{45}$

Both the massive demand for Sleidan's Commentaries and his other works, represented in numerous editions in all major languages, and the distribution of his works across Europe and even America is in total contrast to the initial disapproving reactions. From the Protestant side, Sleidan had not actually been accused of fabricating material. Criticism concentrated on the way Sleidan had presented the accumulated material: the distortion of the truth by presenting a one-sided picture from a Protestant perspective, and by selecting events for inclusion or omission in the narrative. In short, people criticised not so much what Sleidan wrote, but how he wrote it.

These reproaches from the Protestant side are somewhat surprising. After all, Sleidan had been sponsored by the Protestant states to compose his history, and leading Protestants such as Jacob Sturm, Peter Martyr Vermigli and Pietro Paul Vergerio had

\footnotetext{
${ }^{44} \mathrm{Cf}$. Andrew Pettegree, 'Emden as a centre of the sixteenth-century book trade. A catalogue of the bookseller Gaspar Staphorst', Quaerendo 24/2 (1994), pp. 114-135.

${ }^{45} \mathrm{Cf}$. ibd., Latin editions:

No. 59: De quatuor summis Imperiis, 8o, Strasbourg: Rihel 1564

No. 60: Orationes duae, 4o, Strasbourg 1544

No. 61-63: Commentarii, Strasbourg: Rihel 1559 (20), Strasbourg: Rihel 1566, Geneva:Badius 1559 French editions:

No. 131: Histoire des quatre Empires, 8o, Geneva: Courteau 1565

No. 132: Oeuvres, 2o, Geneva: Crespin 1566

No. 133: Histoire entiere, Geneva: Crespin 1558
} 
supervised various stages of the project. Protestant criticism, however, was only voiced in the immediate months after the publication of the Commentaries, and mainly from prominent figures such as Strasbourg's Jean Sturm, the Saxon chancillor Carlowitz and Melanchthon. Sleidan's crime was not the composition of the Commentaries, it was the time of publication. The work appeared in the middle of the crucial Augsburg Diet, when the Protestants' chance had come to have their faith publicly acknowledged and finally procure peace. The reactions from the Diet as reported by the legates from Strasbourg and Augsburg showed the turmoil Sleidan's history caused at a crucial stage of the negotiations, with the Catholic parties greatly angered. For this reason it was necessary for the Protestants to distance themselves from Sleidan's work and avoid any further disturbances. Once the Diet was over and the religious peace secured, Sleidan's Commentaries were openly read, published, translated and distributed. It had become the standard work on the Reformation

\section{Reactions and echos in German history writing}

On the Catholic side, a Protestant history such as Sleidan's could not be accepted as easily. Sleidan's unbalanced representation of the Catholic and Protestant side by a clever choice of stories to be included or excluded was much more offensive to the Catholics. The Commentaries had presented the triumphant conquest of the Reformation over corrupt Catholics. The Catholics were now forced to give their own interpretation of this time period. Catholic reactions in the form of histories were rather slow in the Reformation period, and were often produced in response to Protestant works such as the Commentaries or the Magdeburg Centuries. In the case of the Commentaries the situation was further complicated by the fact that despite the official condemnation of Sleidan in various Indices even the Catholics widely regarded Sleidan as the prime source on the Reformation period. Responses to Sleidan in print were rare and made so little impact that they have proved 
very difficult to trace for the purpose of this study. The few fragments that have been

identified will be considered here.

$\underline{\text { Johannes Gropper }}$

One of the earliest and most interesting reactions to Sleidan's work came from the German

Catholic Johannes Gropper (1503-1559). Gropper, a priest and lawyer, knew Sleidan

personally from various colloquies and diets. He was involved in Hermann von Wied's

attempt of a reform in Cologne and a favourite of the Pope. This resulted in his

appointment as Cardinal in 1555 , though in his last years he became a victim of the

Inquisition. In 1556, Gropper published a treatise on the sacrament of the Eucharist, Vonn

Warer, Wesenlicher und Pleibender Gegenwertigkeit des Leybs und Bluts Christi, in which

he criticised Sleidan at various places, accusing him of being a spy and a liar. ${ }^{46}$

From the comments of the printer Caspar Gennep, a printer in Cologne and friend

of Gropper, and Laurentius Surius, a Catholic historian, we know that around this time

Gropper was planning to write a refutation of Sleidan. ${ }^{47}$ In reality, however, this plan was

\footnotetext{
46 ،... nit aber wie mir der Untrewer Verspeher diß h. Reichs sachen Joannes Schleidanus in seim Lügenbuch De statu Religionis \& Reipubl. Sub Carolo...', Johann Gropper, Vonn Warer, Wesenlicher und Pleibender Gegenwertigkeit des Leybs und Bluts Christi nach beschener Consecration/ Und derselben Anbetung im Hochwirdigsten Heiligsten Sacrament des Altars. Und von der Communion under Eyner gestalt. Wider jetziger zeht entstandene und weith verpreitete Ketzereien und Secten, Cologne (Caspar Gennep) 1556, fol. cccliii v.

${ }^{47}$ Gennep mentioned the names of those who wanted to write a refutation of Sleidan in his work Epitome Warhafftiger Beschreibung der vornembsten Händel, so sich in Geistlichen und Weltlichen Sachen, v. Jar uns. Herren MD. biß in das J. d. mynderen Zal LIX. Zugetragen u. verloffen haben. . Mit höchstem fleiß auß den Bereumpten Hystorischreibern. Iohanne Nauclero, Paulo Iovio, Sebastiano Munstero, Iohanne Catione, Doctore N. Fontano, Conrado Licosteno, Actis Lutheri, Iohanne Sleidano, Neben anderen Fürstlichen vnnd viler guter freundt Schrifften/ zusamen gestelt. Mit anzeigung wie offt vnd vil Sleidanus mehe auß neigung des Affects/ dan liebe der Warheit/ etliche dyng beschriben hat, Cologne (Caspar Gennep) 1559, which was translated into Latin by the Carmelite Roverus Pontanus as Rerum. Memorabilium, iam inde ab anno Domini M. D. ad annum ferè LX. In Rep. Christiana gestarum, libri quinque. Ex plerisque nostrorum temporum historiographis, praecipue autem D. Fontano Theologe Parisiensi, \& Ioanne Sleidano collecti: Cum diligenti annotatione eorum, quae Sleidanus ex affectu potius, quam veritatis studio conscripsisse depraehenditur, published by Gennep himself in the same year, 1559. Gennep mentioned that Gropper as well as Eberhard Billick, see below, were planning a refutation of Sleidan, cf. Pontanus, Rerum Memorabilium, fol. A5v. Laurentius Surius drew attention to this fact in Commentarius brevis rerum in orbe gestarum (1568), which I read in the German and French translations. In the French translation (transl. Jacques Estourneau), Histoire ou Commentaires de toutes choses memorables, advenues depuis LXX. ans en ca par toutes les parties du monde, tant au faict seculier que Ecclesiastic, Paris (Guillaume Chaudiere) 1572, fol. 242r, Surius assured that Gropper would have composed a refutation had he lived long enough. In the German translation (transl.
} 
never put into practice, but rumours prevailed. In the 1621 German edition of Sleidan's

Commentaries, edited and continued until 1620 by Oseas Schadaeus, the astonished reader is presented with an extract from what appears to be a letter from Pope Paul IV to Gropper from 1 December 1556, in which the Pope sharply reproached Gropper for criticising Sleidan and other Protestants in his tract on the sacrament of the Eucharist. ${ }^{48}$ This extraordinary letter was accidentally rediscovered in the twentieth century by Jean Rott, and published in $1967 .^{49}$ It provides Gropper with an advice of conduct after being appointed Cardinal. The writer reminds Gropper of his unfortunate involvement in Hermann von Wied's reform attempt in Cologne in the early 1540 s and of his responsibility towards the Catholic Church. At the end attention is brought to Sleidan, and Gropper is reproached for criticising the historian in his Vonn Warer, Wesenlicher und

\section{Pleibender Gegenwertigkeit des Leybs und Bluts Christi:}

'But was it necessary that you in your work about the sacraments had to irritate Melanchthon, still alive, the dead Bucer, and Sleidan, who our delegates and friends used to talk to and meet in a cordial way? Cardinal [Du] Bellay, when he first saw the part about Sleidan, was surprised that you, a man from Westphalia, wrote such things about somebody from the Eiffel, and that you, the neighbour, did not know which testimony should be given to a man regarded as a teacher for and of his homeland, whose children he educated, and [a man] then familiar and friends with so many learned men. [...] No abuse or anything else can be thrown against somebody that cannot fall back on us, ... so that you know that these words which you write about Sleidan are also thrown against you and are believed by all who are our enemies. 50

\footnotetext{
Henricus Fabricius), Kurtze Chronik oder Beschreibung der vornembsten händeln und geschichten / so sich beide in Religions und weltlichen sachen / fast in der gantzen Welt zugetragen / vom jar unsers lieben Herren M.D. biß auff das jar M.D.LXVIII, Cologne (Gerwinum Calenium \& Heirs Johan Quentel) 1568, Surius lamented on fol. A6r that Gropper did not live to compose a refutation of Sleidan.

${ }^{48}$ Sleidan/ Oseas Schadaeus, Joannes Sleidanus verus et ad nostra tempora usque continuatus, das ist: Warhafftige und ordentliche beschreibung allerely fürnemer händel..., Strasbourg 1621, fol. (ii r.

${ }^{49}$ Rott, 'Nouveaux Documents', pp. 638-647.

${ }^{50}$ Ibid., p. 646: 'Tu vero in tuo volumine sacramentario quid opus erat Melanchthonem irritare adhuc vivum, quid mortuum Bucerum, quid Sleidanum, quos nostri legati atque amici in comitiis etiam solent appellare et amplecti humaniter? Bellaius cardinalis, cum primum illum locum de Sleidano vidit, mirabatur te, hominem Westphalum, de Eiflio ita scribere et te, vicinum, non scire, cujusmodi testimonium illi dare debeat, si cogatur, patriaque et patriae magistratus, cujus liberos educavit, deinde tot viri docti, quibus familiaris et amicus fuit. [...] Nullum convitium tantum et tale in ullum conjici potest, quod non retorqueri in nos queat, aut non possit com aliquo simili commutari, ut ea verba quibus tu Sleidanum notas, scis tibi quoque objecta esse et ab omnibus credi qui nobis sunt adversarii.'
} 
A letter from the Pope reproaching a Cardinal for anti-Protestant statements and for denouncing Sleidan would be astonishing indeed. Rott discovered this letter in a collection of various works, including some of Jean Sturm's letters, printed in $1581 .^{51}$ The letter quoted is the last item in the collection. It ends conventionally with place and date, but is then followed by a quotation from Horace's Satires: 'Why not say the truth with a laugh? ${ }^{52}$ It is this rather unfitting addition to a papal letter that makes one think twice about its authenticity. In any case this curiosity must have been composed before Gropper's death in March 1559. Rott identified the forger as Jean Sturm himself. He deduced this from the various comments on Sleidan's role as a teacher, the mention of Jean Du Bellay and different reformers, as well as the knowledge about Gropper, whom Jean Sturm knew personally. With this forged letter Jean Sturm seemed to have attempted to defend his deceased friends Sleidan and Bucer and to prevent Gropper from writing the anticipated refutation of Sleidan by reminding him of his unseemly involvement in the Cologne reforms. Gropper's intended refutation itself was never written, and his opposition against Sleidan was confined to a handful of critical remarks.

\section{$\underline{\text { Laurentius Surius }}$}

Gropper did not live long enough or dare to write a refutation, but he found a successor in the person of Laurentius Surius, a Carthusian from Cologne. In his 1566 Commentaritus brevis rerum in orbe gestarum he ventured to accomplish what Gropper could not complete. ${ }^{53}$ Parts of this work, a history covering the sixteenth century with concentration on the church, are devoted to a criticism of Sleidan. Franck and Carion also earn nothing

\footnotetext{
${ }^{51}$ Rott, 'Nouveaux Documents', p. 568, fn.1. The work in question is Oratio illustris et generosi domini Ioannis comitis ab Ostrorog ... His additae sunt Rogeri Aschami et Ioannis Sturmii epistolae duae de nobilitate Anglicana. Item Pauli IV. Pontificis Maximi ad Ioannem Gropperum, cardinalem designatum. epistola, Strasbourg (Nicolaus Wyriot) 1581, available in Geneva.

${ }^{52}$ Cf. Rott, 'Nouveaux Documents', p. 647. The quotation is from Horace's Satires I, 1, 24-25: 'Ridentem dicere verum, quid vetat?'.

${ }^{53}$ I read the German and French translations mentioned above, Histoire ou Commentaires de toutes choses memorables, and Kurtze Chronik oder Beschreibung der vornembsten händeln und geschichten.
} 
but contempt for their historiographical enterprises. ${ }^{54}$ Surius accused Sleidan of absolute partisanship, consciously lying to portray Luther and his followers in the best light, 'by the same means making the reader taste the poison of the errors already condemned without showing consciousness of lying impudently at any time. ${ }^{55}$ Sleidan used his pernicious skills so craftily that even Catholic readers enjoyed reading his Commentaries since all people liked reading everything that is printed, even by suspect authors; fortunately some people could tell right from wrong. ${ }^{56}$

In retracing the history of his century, Surius also tried to show the many errors and lies Sleidan was culpable of in his history. The documents which Surius seems to have consulted are difficult to reconstruct. He seems to have narrowed his reading to only a few, relying heavily on the Bible and Church fathers. Interesting for us here are a few interesting anecdotes Surius provides us with. He remarked that Gropper, falsely accused by Sleidan of being a 'heretic' (i.e. Lutheran) or at least being favourable towards the Protestant cause, had planned to write a refutation of Sleidan. Equally members of the Cologne clergy, Cardinal Jean Esleu and the Carmelitan provincial Eberhard Billick had intended to do the same, but all three of them died before they could fulfill their aim. ${ }^{57}$ Surius also described immediate reactions to the Commentaries: Julius Pflug, an eye-

\footnotetext{
${ }^{54}$ Surius, Kurtze Chronik, fol. A5v.

${ }^{55}$ Surius, Histoire, fols. 55v-56r: 'A quoy faire je suis d'autant plus incité, que je voy Jehan Sleidan avoir escrit ses Commentaires de l'estat de la religion \& Republique, surant l'Empire de Charles le quint, (à fin que je ne touche rien des autres autheurs) esquels il favorise si dextrement à la cause de Luther \& ses disciples, qi' il entre-mesle le afict de la religion avec plusieurs autres affaires, par une douece \& emmiellee eloquence: de maniere que retenant le lecteur par delectation \& varieté de l'histoire, il luy fait par mesme moyen gouster la poison des erreurs pieça condamnez, sans faire quelque fois conscience de mentir impudemment.'

${ }^{56}$ Ibid., fol. $55 \mathrm{v}$ : 'Au moyen dequoy je suis tout esmerveillé comment plusieurs Catholiques se delectent tant à lire Sleidan: ce qui adveint, pour-ce que chacun desire de lire toutes choses escrites, mesmes par autheurs suspects: \& nous semble que nous sommes si resoluz, \& avons le jugement si meur \& aigu, que nous pouvons aysement cognoistre toutes choses, \& discerner le vray d'entre le faux. Et à cause de ce plusieurs d'entre nous se laissent precipiter puerilement és erreurs les plus absurdes du monde, desquels non seulement les hommes graves auroient honte, mais bien encores les plus grossiers de tout le monde.'

${ }^{57}$ Cf. ibid., fols. 241v-242r and 306v; Surius, Kurtze Chronik, fol. A6r. Gennep also mentioned that Billick had started a refutation of Sleidan, but died before he could finish it, $\mathrm{cf}$. Pontanus, Rerum memorabilium, fol. A5v. The Carmelite Billick (ca. 1499/1500-1557), an enemy of Bucer, had become provincial in 1542, and like Sleidan had been present at the colloquies of Hagenau, Worms and Regensburg (cf. Al. Postina, Der Karmelit Eberhard Billick, Freiburg im Breisgau 1901, pp. 141-142).
} 
witness of many events described by Sleidan, is reported to have commented on many passages: 'Ha, the villain is lying here' when they were read out to him. Similarly, Charles V apparently could not help exclaiming 'The rogue is lying, the rogue is lying!', and entrusted somebody with the task of publishing all the acts of the imperial diets to contradict Sleidan. ${ }^{58}$

Such tales are likely to be grounded on fiction, not facts. All in all Surius expressed his sharp disapproval of Sleidan in his work, but he did not really attempt to correct Sleidan on faulty details in the Commentaries. The tenor of Surius' work has more the character of a polemical treatise rather than offering historical criticism. The conclusion Surius drew from Sleidan's Commentaries was: 'Never believe a man adhering to a heresy." 59

\section{Caspar Gennep - and Cyriakus Spangenberg}

The main purpose of Surius' work had not been to prove Sleidan wrong, but rather to offer a history of his century. Whenever it seemed necessary to him, he used the opportunity to criticise Sleidan, lamenting that all the people who had planned a refutation of Sleidan, Gropper, Esleu and Billick, had died before they could fulfill their aim. What Surius apparently was not aware of or ignored was the fact that already in 1559 a German writer had indeed fulfilled this aim, namely Caspar Gennep, the Cologne printer and author. Gennep had already demonstrated his disapproval of Sleidan with his publication of a Latin edition of Simon Fontaine's French refutation of Sleidan in 1558, and the publication of Gropper's 1556 treatise on communion. ${ }^{60}$ Gennep's attempt at a refutation of the

\footnotetext{
${ }^{58}$ Surius, Kurtze Chronik, fol. A5v: 'Ja auch der unuberwindligst und allerfrombst Römisch Keiser Carolus V. wie er sie etwan hören lesen/ hat er zu mehrmalen geruffen : Der böswicht leugt/ der böswicht leugt.' ${ }^{59}$ Surius, Histoire, fol. 306v: 'Conclusion, on ne doit jamais croire un homme addonné à son heresie.'

${ }^{60}$ Fontaine (transl. Roverus Pontanus), Historiae Ecclesiasticae nostri temporis, libri XVII. In quibus preterquam nuda veritas, \& rerum gestarum series fideliter recensetur, etiamque multa quae Iohannes
} 
Commentaries escaped not only Surius, but also the attention of the existing scholarship on

Sleidan.

Gennep's Epitome Warhaftiger Beschreibung is briefly referred to in several earlier works. In the sixteenth century, Heinrich Bullinger in his Reformationsgeschichte mentioned Gennep's 'mendacious work against Sleidan' amongst those which had falsely portrayed the war of Kappel. ${ }^{61}$ Gennep's work is also alluded to in an early seventeenthcentury document collection by Friedrich Hortleder, and in the eighteenth century in an article by Christian Carl Am Ende. ${ }^{62}$ In the nineteenth century finally, Theodor Paur listed a number of Sleidan's enemies who were either planning to write a refutation or did indeed do so, including the Cologne author-printer Caspar Gennep. ${ }^{63}$ None of these authors offered more than a few references to Gennep, however, and in modern scholarship Gennep's work has been completely ignored.

Gennep's 1559 work Epitome Warhaftiger Beschreibung is actually mentioned in Vekene's bibliography of Sleidan's works under 'Miscellaneous', but not recognised for what it is. ${ }^{64}$ It is preceded by a Latin work of a similar title, Rerum Memorabilium, which Vekene described as 'abrigdement of the Commentaries edited by Roverus Pontanus' ${ }^{65} \mathrm{~A}$

Sleidanus in suis de Statu Religionis \& Reipublicae Commentariis nugatur, luculentissime reteguntur, Cologne (Caspar Gennep) 1558; cf. chapter 6.

${ }^{61}$ Heinrich Bullinger, Reformationsgeschichte, (ed. J.J. Hottinger, H.H. Vögeli), 3 vols., Frauenfeld 18381840; vol. 3, p. 162: 'Dahin ouch hört das verlogen buch das Caspar Jenepp, ein drucker zu Cölln, wider Schleidanum hatt ußgang laßen: in welchem er, besonders von disem krieg, den betrügen und lügen siner Mönchen, insonders Cochlei volget. Hab ich alles zu gutem der warheit in einem fürgan, denocht anzeygen müßen.'

${ }^{62}$ Cf. Hortleder, Der Römischen Keyser- und königlichen Maiesteten, vol. 2, fol. a5r; Am Ende, 'Nachricht von den beyden ersten Ausgaben der Commentariorum Johannis Sleidani, zu Strasburg, im Jahr 1555. in Folio', Johann Georg Schelhorn, (ed.), Ergötzlichkeiten aus der Kirchenhistorie und Literatur, in welchen Nachrichten von seltenen Büchern, wichtige Urkunden, merkwürdige Briefe, und verschiedene

Anmerkungen enthalten sind, vol. 2, Ulm 1762, p. 415.

${ }^{63}$ Paur, Johann Sleidans Commentare, Leipzig 1843, p. 148.

${ }^{64}$ Gennep, Epitome Warhaftiger Beschreibung, Cologne (Caspar Gennep) 1559.

${ }^{65}$ Gennep, (transl. Roverus Pontanus), Rerum Memorabilium, Cologne (Caspar Gennep) 1559. Vekene lists Gennep's German version under E/k 014 and Pontanus' Latin version under E/k 013 . Only very few copies of Gennep's German original have survived; the Latin version equally survived only in small numbers. 
closer examination of this work reveals that it is certainly not a summary of the Commentaries, but a Latin translation of Gennep's Epitome Warhaftiger Beschreibung, published like the German original by Gennep himself in 1559 . This work, at first glance a history describing the years 1500-1559, advertises itself on the titlepage as an epitome of the works of famous historians, amongst which Sleidan is listed. Then, however, it mentions 'comments on how often Sleidan described events more out of affect than love for the truth'.66

Caspar Gennep was an educated printer and author in Cologne, who printed from the 1530 s to the 1560 s. In January 1540 he obtained an imperial privilege under the condition that he print only Catholic works. ${ }^{67}$ Both as author and printer he became deeply involved in the polemical debates between Protestants and Catholics of his time. His translator Roverus Pontanus was a Cologne Carmelite, and had already translated a French refutation of Sleidan by Simon Fontaine which Gennep published in $1558 .^{68}$

Let us now turn our attention to Gennep's refutation itself as well as Pontanus' Latin translation. Pontanus preceded Gennep's original work with his own dedication to Viglius Zuichemus. After the usual praise of the importance of history, Pontanus lamented the deplorable fact that there were many bad historians around at his time, like Sleidan, who had recently published his Commentaries. This work proved immensely successful, was greatly admired everywhere and read just as if it was the sybillic oracle-much to

\footnotetext{
${ }^{60}$ 'Mit anzeigung wie offt vnd vil Sleidanus mehe auß neigung des Affects/dan liebe der Warheit/ etliche dyng beschriben hat' as part of the title page of the German edition, and 'Cum diligenti annotatione eorum. quae Sleidanus ex affectu potius, quam veritatis studio conscripsisse depraehenditur' on the title page of the Latin edition.

${ }^{67}$ Cf. Josef Benzing, Die Buchdrucker des 16. und 17. Jahrhunderts im deutschen Sprachgebiet, Wiesbaden 1982, p. 240.

${ }^{68}$ Simon Fontaine, Historiae Ecclesiasticae nostri temporis, libri XVII. In quibus preterquam nuda veritas, \& rerum gestarum series fideliter recensetur, etiamque multa quae Iohannes Sleidanus in suis de Statu Religionis \& Reipublicae Commentariis nugatur, luculentissime reteguntur, Cologne (Caspar Gennep), 1558. We shall examine this work in chapter 6 .
} 
Pontanus' surprise and contempt. ${ }^{69}$ He regarded such a positive response to Sleidan's

work as totally incomprehensible since for him it was obvious that Sleidan had not always adhered to the truth and often falsely narrated what had been said, written and done. ${ }^{70}$ Pontanus also blamed Sleidan for criticising and mocking the Catholic church and its believers, while praising and extolling the 'Lutheran heresy' and the Protestants in general. ${ }^{71}$ Fortunately, a few good people looked through Sleidan's lies and dared to speak out against him, like the Parisian Simon Fontaine or indeed Caspar Gennep in Cologne, determined to describe what really happened and correct Sleidan's errors.

\section{Gennep's own dedication to Johannes Gebhard, archbishop of Cologne, is of a}

similar tenor. He explained that he himself and other learned men found many faults and lies in Sleidan's work that he felt compelled to correct. ${ }^{72}$ Despite the huge success of Sleidan's Commentaries, it seemed obvious to him that Sleidan often bent the truth and even 'hallucinated' ${ }^{73}$ A number of learned men had also noticed Sleidan's lies, and some even had prepared refutations, like the unfortunate Carmelite Eberhard Billick who died before he could fulfill his task. Gennep then pointed out that Johannes Gropper had also

\footnotetext{
${ }^{69} \mathrm{Cf}$. Pontanus' dedication in Rerum Memorabilium, fol, A2v: 'Nimirum annis superioribus cuiusdam de statu religionis \& Reipublicae Carolo quinto Caesare commentaria in lucem edita sunt, quae sane promiscue quique tam avide de tamqu. religiose colunt, \& observant, non aliter quam paradoxa, non secus suspiciunt atque oracula caelitus probata, denique, non minus exosculantur, quam si verissima sint omnia illa tanquam Sibillarum folia.'

${ }^{70}$ Ibid., fol. A2v: 'Atqui vero hos errare constat ex eo, quod author Joannes Sleidanus veritati parcens, plerumque falso narrat quaedam, aut dicta, aut scripta, aut procusa, aut denique gesta fuisse, ....'

${ }^{11}$ Ibid., fols. A2v-3r: 'Ommitam hic dicere quae latius in nostra hac historia explicantur \& probantur, quantum scilicet author ille Luthero heresiarchae nostri seculi primo tribuat, quantum pro pugnatoribus Apostolicae seu Christianae religionis deroget, quantum nomen ac titulum Protestantium exornet atque extollat, quo tamen nullus fere est inter Christianos iniquior \& arrogantior, quantum denique negocium Ordinesque Catholicorum \& Ecclesiasticorum obscuret derideatque, Protestantium autem illustret ac praedicet, quaque acerbe traducat probos quosque \& taxet.'

72 'So hab ich aber gleich nach Publicierung des Buchs/ von etlichen nit geringer achtung und erfahrung/ offtmals gehört/Sleidanus solle sich gröblich in vil dingen verlauffen/ und nit allein Sophistisch und Affectuos sonder auch gar untrewlich die geschichten in Religion sachen beschreiben.' (Gennep, Epitome Warhaftiger Beschreibung, fol. [ ]2r).

73 'Sed cum illud passim a doctis pariter \& indoctis tereretur, intellexit tandem a Viris sane non obscuris, nec vulgariter doctis, Sleidanum in plurimis hallucinari, \& a veritatis scopo saepius deflectere \& evagari, nec sophistice modo, aut etiam ex privato \& perverso mentis affectu, quinetiam infideliter plane, res ipsas in negocio religionis gestas describere.' (Gennep/Pontanus, Rerum Memorabilium, fol. A5v).
} 
planned a refutation, but gave up his task after Sleidan's death since he did not want to attack a dead man. The many errors Sleidan made in his work, often out of partisanship, gave Gennep the impetus to examine other historians and correct the errors of the Commentaries in order to show that Sleidan's work was in fact not the Gospel many people read it as. ${ }^{74}$ On the contrary, Gennep complained, it failed to adhere to the promised impartiality and calmness of style. ${ }^{75}$ Gennep concluded by mentioning that he himself was reluctant to attack a dead enemy as well, but felt compelled to publish his Epitome because Sleidan's ghost still seduced many men. ${ }^{76}$

The actual text itself is introduced by a heading reflecting that of the German title of the work, mentioning the authors used for Gennep's work, a rather colourful group of Protestants and Catholics: Johannes Naukler, Paolo Jovio, Sebastian Münster, Johannes Carion, Simon Fontaine, Conrad Lycosthenus, Johannes Cochlaeus, Sebastian Franck and Johann Sleidan. ${ }^{77}$ The intention to point out when Sleidan erred or was purposefully lying is followed throughout the work, but is more a marginal affair. Rather, Gennep's description of the years 1500 to 1559 or 1560 in Pontanus' translation is a quite wellwritten, rather unpolemical historical work. Gennep strides through history chronologically, and lines up the events year after year, with references to the sources in the margins.

\footnotetext{
${ }^{74}$ Ibid., fol. A6r: '...Sleidani scriptum, non esse Evangelium, vel tanque Evangelio credendum, maxime cum in rebus adeo manifestis.'

${ }^{75}$ Gennep criticised that Sleidan's preface was 'weit von der Warheit/ unnd seyn schreiben nit allein Affectuoß/ sonder sehr Sophistisch und Calumnioß ist. Und so er je nit umbgehen kan/ das er etwan des keiser Carls/ oder der Catholischen Religion in gutem gedencken muß/thut er es so obscure/ das die meinung nit leichtlich zu verstehen ist/ So ers aber nit verfynstern kann/ hengt er daran/ Wie man sagt,' (Gennep, Epitome Warhaftiger Beschreibung, fol. [ ]2v).

${ }^{76}$ 'War ists das man mit todten oder larven schim nit fechten sol/ So aber die gemeyn durch larven gespenst in gefahr/ und lügen für warheit dem volck eyngepflantzt werden/ duncket mich nit unbillich/ das in dem fal wehre wer wehren kann.' (Ibid., fol. [ ]3r).

${ }^{77}$ The name of Sebastian Franck does actually not appear on the titlepage of the German version, which could possibly be to avoid censorship. However, Carion's name on the titlepage could equally have raised eyebrows.
} 
The purpose of refuting Sleidan is often just confined to marginal comments like 'Sleidan lies here', or '[h]ere Sleidan writes unfaithfully'. ${ }^{78}$ In the text itself, Gennep only refers to Sleidan every now and then, usually in the style of the marginal comments and without any polemic, just pointing out Sleidan's mistakes in the description of certain events. The only time Gennep devoted more effort to proving Sleidan wrong is in the description of the Peasants' War, where he noted an obvious partiality of Sleidan to Luther, who he struggled to defend, whereas he blamed Thomas Müntzer. Even in this incident Gennep only spent two short sentences noting Sleidan's shortcomings, again only in a matter-of-fact style without any polemic. ${ }^{79}$

Gennep's work is the closest to a refutation of Sleidan we have in Germany. As the title and content showed, it was not primarily intended to be solely a refutation of Sleidan. What Gennep offered instead is a historical account of the Reformation, based on contemporary Protestant and Catholic historians, one of which was Sleidan. In his intention to correct Sleidan Gennep generally stayed neutral and calm. The only time he showed anger or open criticism of Sleidan was really in his dedication, and even then he did not venture into open polemic. Gennep's work was primarily a historical description, and only briefly referred to Sleidan when it seemed necessary to correct him on a certain date, name or event. If we consider the heated reactions after the publication of the Commentaries, and the number of failed attemps to compose a refutation of Sleidan, Gennep's work is certainly not what one would be expect. Much more than a refutation, it is a history in its own right.

\footnotetext{
${ }^{78} \mathrm{Cf}$. Gennep/Pontanus, Rerum Memorabilium, fol. H1r: 'Sleydanus mentitur'; fol. K5r: 'Et hic Sleidanus infideliter scripsit'.

${ }^{79}$ Ibid., fol. I1r. In the margin, Gennep remarked: 'Sleidanus in Evangelio Lutheri omnino sanguinario connivet.', and further down: 'Sleidanus Thomas Muncero iniquior, Lutheri ubique defensor'. In the text itself, he wrote: 'Luctatur hic Sleidanus, \& satis operose se torquet atque volutat modo huc, modo illuc. Cuperet eqidem causam perquam libenter palliare, Lutherum purgando, sed Thomam Muntzerum accusando.'
} 
More surprising than its actual content is the reception of Gennep's work. Since it came closest to what one could call a refutation of Sleidan in Germany, it did not seem to attract much attention. In my entire research, I have not come across a single reference or even quotation of Gennep either in German or in Latin by any of Sleidan's enemies. Apart from a few early historians who merely hinted at Gennep's work scholarship on Sleidan has completely ignored Gennep's work. Even in the sixteenth century, Gennep's work seemed not to have been popular. Only one edition of the original German version was published, and only one edition of Pontanus' Latin translation, both printed in 1559 by Gennep himself. He did not publish another edition of the German or Latin version, and nobody else cared to do so after his death. Only a handful of copies of the German original or the Latin translation have survived, accessible only in few libraries.

The only person who seems to have given any attention to Gennep's work was the reformer and historian Cyriakus Spangenberg (1528-1604), who had been a friend of Sleidan. The ensuing literary debate between Spangenberg and Gennep concerning the Commentaries and the Epitome has again been ignored by scholarship on Sleidan. My attention was drawn to Spangenberg by glancing through Gennep's publications in various bibliographies, which mentioned a work by Gennep addressed to Spangenberg concerning Sleidan. A look at Spangenberg's publications shed more light on the affair. One year after Gennep had published his Epitome, Spangenberg opened a literary debate with the Cologne printer concerning the value of Gennep's work and of Sleidan's Commentaries. His 1560 Antwort Und Bericht auff das Buch/welchs Jaspar Gennep ... wider des Sleidani Commentarios in druck geben, an answer and report concerning the Epitome, provided a short criticism of Gennep's attempt to provide a better history of the Reformation than 
Sleidan and refute the Protestant historian. ${ }^{80}$ This work has proved elusive; to this date I have been unable to trace a copy.

However, the contents of Spangenberg's attack can be reconstructed from Gennep's response, Eyn Ernsthafftigs Gesprech/zwischen Jaspar Gennep...Unnd Cyriaco Spangenberg/ über die Geschicht Beschriebung/Johannis Sleidani, which he published himself in $1561 .^{81}$ This 'serious conversation between Caspar Gennep, citizen and printer in Cologne, and Cyriakus Spangenberg, concerning Sleidan's history' is written as a dialogue. Gennep quoted or paraphrased from Spangenberg's Antwort Und Bericht, and then replied to the various accusations. Though advertising a dialogue on Sleidan's work, the 'conversation' centered largely on doctrinal points like the sacraments and the apostolic succession, but the topic of Sleidan is brought up throughout the work. In his dedication to the Christian reader, Gennep emphasised that he only entered the confrontation with Spangenberg reluctantly since the latter had been turned into an enemy of the truth by Satan himself, an offense prompting his response. ${ }^{82}$ At various places throughout this dialogue, Gennep's use or criticism of Sleidan is brought up, alongside long discussions on doctrinal points.

Spangenberg's main point of accusation concerning Gennep's handling of Sleidan was that Gennep had just picked up the evidence provided by the Protestant and like a

\footnotetext{
${ }^{80}$ Full title: Cyriakus Spangenberg, Antwort Und Bericht auff das Buch/ welchs Jaspar Gennep/ Bürger und Buchdrucker zu Cöllen/ unter dem Titel [Epitome warhafftiger Beschreibung] wider des Sleidani Commentarios in druck geben/ mit anzeigung worinnen sich gedachter Gennep anders dan einem Historienschreiber gebüret/gehalten, Eisleben (Urban Gaubisch) 1560; $\mathrm{cf}$. Verzeichnis der im deutschen Sprachraum erschienenen Drucke des 16. Jahrhunderts, (hereafter VD 16), Stuttgart 1983-1988, vol. 19.

${ }^{81}$ Caspar Gennep, Eyn Ernsthafftigs Gesprech/ zwischen Jaspar Gennep/ Burger und Buchtrucker zu Cöllen/ Unnd Cyriaco Spangenberg/ über die Geschicht Beschriebung/ Johannis Sleidani, Cologne (Caspar Gennep) 1561.

${ }^{82}$ Cf. ibid., fols. a1r-4v.
} 
monkey imitated him; as a historian he failed. ${ }^{83}$ Furthermore, he had only picked from Sleidan and other authors what suited his argument while he had portrayed the history of the Reformation in a partial way. All in all, in Spangenberg's eyes Gennep's Epitome was mere revenge on Sleidan since he had exposed the tyranny and blasphemy of the Catholic church. ${ }^{84}$ Gennep sharply contradicted these accusations with reference to the many lies to be found in Sleidan's history. He showed himself convinced that in contrast to Sleidan he had written the complete truth in a neutral way. He also rejected Spangenberg's criticism that he had consulted Sleidan for his history at all, underlining that Augustine had recommended using even pagan sources if useful. ${ }^{85}$ Spangenberg's advice not to blindly believe historians Gennep countered with the witty question why Spangenberg himself put so much trust in Sleidan. ${ }^{86}$

Spangenberg was not yet prepared to give up the controversy with Gennep and in 1562 entered a new round with the publication of Wider die böse Sieben/ins Teufels Karnöffelspiel. This work attacked 'seven evil' Catholic enemies of the truth and their offenses against God, including Pope Pius IV and Cardinal Contarini. Included in this illustrious circle was also Caspar Gennep, portrayed on the titlepage of a copy printed in Eisleben as a fool riding a donkey with a monkey sitting behind him. ${ }^{87}$ In the preface directed at the Christian reader, Spangenberg explained that he had given his work such an

\footnotetext{
${ }^{83}$ Spangenberg: 'Du hast gesehen das Johannes Sleidanus sich hat bearbeitet in beschreibung der furnemsten geschichten/ so sich im Römischen Reich/ ...zugetragen/ hast dich dessen verwundert/ dich drüber gemacht/ im wöllen nach thun/ und alßpald Sleidanus gestorben/ wie jener Aff/ holtz/ beihel und keil/so zuvor von dem Sleidano zu sammen getragen gefunden/ und also understanden das hantwerck noch werklicher zu treibenn/ bist aber den sachen zu seicht und gerynge.' (ibd., fols. Alv-A2r).

${ }^{84}$ Cf. ibid., fols. K8v, M1r.

${ }^{85}$ Cf. ibid., fol. C5r.

${ }^{86}$ 'Und weil du sprichs alle zeit habe dir mißhaget so man under dem namen Warhafftiger Historien/ Lügen last aussgehen/ So verwundert mich sehr was dich verursacht des Sleidani schreiben so trötzlich/ wider deyn eygen Gewissen/ und die öffentliche warheit zu vertädigen.' (Ibid., fol. D3r).

${ }^{87}$ Cyriakus Spangenberg, Wider die böse Sieben/ ins Teufels Karnöffelspiel, Eisleben (Urban Gaubisch) 1562. Attacked were also Dominicus Limpricius, Friedericus Staphylus, Stephan Agricola, and Stanislaus Hosius. - While Gennep's 1561 work was not reprinted, Spangenberg's work was printed four times in 1562, twice in Eisleben (Urban Gaubisch), once in Frankfurt/Main (Nicolaus Basse), and once in Jena (Thomas Rhebart/Donat Richtzenhayn); cf. VD16, vol. 7 on Gennep, and vol. 19 on Spangenberg.
} 
unusual title since the Catholics, Satan's horde, played with religion and councils like other people played cards or other games. ${ }^{88}$

Satan's disciple number six is introduced as 'Against the old fool Caspar Gennep, printer at Cologne'. ${ }^{89}$ Spangenberg mentioned the literary controversy with Gennep leading up to this point, starting with his reply to Gennep's Epitome, which enraged the Cologne printer so much that he wrote a response, to which this present work replied. ${ }^{90}$ Again, he accused Gennep of being a poor writer and historian, failing to provide a convincing and truthful history and defending the Catholic church. Spangenberg repeated his accusation that Gennep had falsely accused Sleidan of lying while failing to point out these lies or providing a better account of the Reformation. ${ }^{91}$ Much more than Spangenberg's 1560 work, Wider die böse Sieben concentrated on theological points. It is largely a refutation of doctrinal points on which Spangenberg and Gennep disagree, like the sacraments and the apostolic tradition. Nonetheless their old controversy on Sleidan and his Commentaries was so important for Spangenberg that he had brought it up again.

Gennep's Epitome, although essentially a history of the Reformation with a criticism of Sleidan as a side-effect, was the only serious attempt of a Catholic refutation of Sleidan in Germany. The Cologne printer had composed a surprisingly convincing and calm account of the main events of the Reformation, which had been swiftly rendered into Latin by Roverus Pontanus to be accessible by a wider audience. This suggests that Gennep did indeed expect a considerable interest in his work, both within Germany and

\footnotetext{
${ }^{88}$ Spangenberg, Wider die böse Sieben, fol. [ ] $3 \mathrm{r}$.

89 'Wider den alten Gecken/ Jaspar Gennep Buchdrucker zu Cöllen'. The section on Gennep is to be found on fols. Eelr-Aaalr.

${ }^{90} \mathrm{Nu}$ hat mein kleines Büchlin/ welchs nicht mehr dan vier bogn begreifft/dem alten Gecken die schellen an der Narrenkappen also rege gemacht/ das er dafur nicht rugen können/ sondern davon so töricht worden/ das er ein Büchlin von zwelff bogen dawider geschrieben ...' (ibid., fols. Eelr-v).

91 'Seine beste kunst ist/ das ers alles Lügen heisset/ was im nicht gefellet/ und sagen darff/ Sleidanus habe plus mille mendacia geschrieben/ da er in doch nicht einer lügen kann uberweisen. ...' (ibid., fol. Ee4v).
} 
amongst other readers of Latin. Yet it seems as if there was virtually no audience for Gennep's work. No reference to him was to be found in the histories published in France or Germany I examined, nor did many copies of the work survive. Both the German and the Latin version were only printed once, and the only person who found Gennep worthy a response was the Protestant Cyriakus Spangenberg. It seems again as if the initial turmoil the Commentaries had caused in the immediate period around the 1555 Diet of Augsburg ceased quickly once the diet was over and the religious question resolved. In the resulting religious peace the Commentaries could be widely accepted, and the interest in a refutation waned.

\section{$\underline{\text { Johannes Avicinius }}$}

To all appearances, the attempts of Gropper, Surius and Gennep are the only serious attempts by Catholic intellectuals in German lands to criticise or even refute Sleidan. Only one further attempt of a criticism of Sleidan deserves mentioning here, not so much because of its success, but rather because of its originality. Gropper, Surius and Gennep had embedded their opposition to Sleidan in theological or historical works, and had inserted the occasional comment on Sleidan and his Commentaries. Johannes Avicinius instead devoted a mock poem to Sleidan in his Chronologia Evangelica. Das ist ein Summarischer Außzug der Newevangelischen Chronicken. ${ }^{92}$ This work from 1570 , roughly called 'a summary of Protestant chronicles, describing the beginning, expansion and fruits of the new Christianity planted by Luther', is very different in style and character fiom the three cases analysed above. Avicinius also aimed to criticise the Protestants, but he did so in satyrical rhymes.

\footnotetext{
${ }^{92}$ Avicinius, Chronologia Evangelica, Ingolstadt (Alexander Weissenhorn d.J.) 1570.
} 
One of the number of mock poems Avicinius offered is devoted to Sleidan. ${ }^{93}$ These verses are not only refreshingly different from the usual Catholic polemic, but also offer interesting details as to why Sleidan attracted so much criticism and even hatred. Sleidan is introduced as an inhabitant of Strasbourg, writing about events in different countries during the time of Charles V. He did not refrain from inventing things, leaving out others, or describing them falsely. - So far this is still the usual tenor of all of Sleidan's critics, but then Avicinius moves on to more concrete criticism: Sleidan readily gave away secret details about Germany and the whole Empire. This upset King Ferdinand and Emperor Charles, whereas the Turks cheered the Commentaries since they provided them excellent information about how best to attack the Empire. Jacob Sturm, characterised as a Zwinglian, helped Sleidan by informing him about everything that happened in Germany. The poem ends by accusing Sleidan of being a liar and a Calvinist - not a Lutheran. Avicinius' accusation of Sleidan betraying state secrecies is fascinating. While it is difficult to ascertain this since there is simply no knowledge about the Turks's reception of the Commentaries, it is interesting to see what a role a historian played if he could even be accused of such grave betrayal.

Although Avicinius did not provide the amount of historical or theological scholarship of Gropper, Surius and Gennep in his work, he curtly summed up what might

\footnotetext{
${ }^{93}$ Because Avicinius' poem is so interesting, I offer the full text here (ibid., fols. 20r-v):

'Zu Straßburg auch Schleidanus was,/ Der seiner Feder nit vergaß,/ Fieng an von Kayser Carols Zeit/ zu schreiben, was sich bab für streit/ begeben, in des glaubens sach/Im Reich, auch ander ungemach/ Was sunsten mehr vorgloffen ist/ Beschrib er, doch mit falschen list,/ Was man gehandelt in dem Reich/ Gab er an tag, galt im als gleich/ Thet vil darvon, setzt vil darzu/ Stifft an bey vilen groß unrhu/ Dann er vil schreibt so unerhört/ Den gmainen Mann darmit bethört/Sein Buch das wird auch transferirt/ In alle Künigreich spargirt,/ Durch solches männiglich bekannt/ wie es im Reich und Teutschland stand./ Der Türck hat sich des niemals bschwert/ Kain beßer kundtschafft nit begert./ Dardurch er uns erlernen kan/ Mit gutem vortail greiffen an,/ dann eben wie auß disem buch,/ darumb dann auch Schleidano gflucht,/ bayd Kayser Carl und Ferdinand/ In Gott entschlaffen baydesant,/ Das er all haimlichheit im Reich/ In sachen Gaystlich Weltlich gleich/ Bey menigklich hat offenbart/ Die Warheit doch darneben gspart./ Ihm hat geholffen Jacob Sturm,/ Von Straßburg, ein vergiffer wurm,/ Was man gehandelt in dem Reich/ Hat er im zugschrieben gleich./ Jedoch war sein Religion/ Den Zwinglianern zugethon/ Wie dann auch gwesen ist ist Schleidan/ Ein Calvinist, verlogner Mann./ Auß dem wol anzunemen ist/ Das er dem Kayser vil zumißt,/ Deßgleichen andern Ständen mehr/ Das von der Warheit ist noch sehr.'
} 
well have been the common opinion amongst Sleidan's enemies: he had consciously lied and betrayed secrets which the Empire's enemies - he mentioned explicitly the Turks could make use of. Jacob Sturm, one of the leading men in Protestant politics, had provided him with all the necessary material, himself as an inhabitant of liberal Strasbourg possibly a Zwinglian. Finally, Sleidan is called a Calvinist, an accusation which is not that surprising if one thinks of the close relation Sleidan had to Bucer and Calvin, calling himself vaguely a 'member of the Reformed Church' rather than a Lutheran, Calvinist or anything else. ${ }^{94}$ However, despite these interesting aspects and entertaining style, Avicinius' criticism of Sleidan was as quickly forgotten as that of his predecessors,

The initial widespread outcry against Sleidan's Commentaries in Germany was scarcely reflected in literary reactions. The few attempts that were made were hardly noticed at best and had simply no impact whatsoever. On the Protestant side we encounter complete silence. Far from improving or criticising Sleidan's work, soon translations and continuations were prepared. On the Catholic side, only a few people ventured to provide literary criticism of Sleidan. This failure on the Catholic side to provide a sucessful response to a Protestant work underlines Bob Scribner's well-accepted thesis that the Catholic response in general was 'too meagre and too limited to have any large-scale or long-term impact'. ${ }^{95}$ A similar view was also held by Mark Edwards, who argued that the Catholics in general were much slower to adopt the new medium print for their purposes. ${ }^{96}$ This was certainly the case with Sleidan's opponents. Gropper never fulfilled his plan of composing a proper refutation of Sleidan, and, like Surius, only made a few negative, polemical references to the Commentaries. Only Gennep's work comes closest to what one would call a refutation, although it is rather a history on its own, not so much a

\footnotetext{
${ }^{94} \mathrm{Cf}$. the apology in Sleidan/Bohun, General History, fol. blv.

${ }^{95}$ Robert W. Scribner, For the Sake of Simple Folk: Popular Propaganda for the German Reformation, Cambridge 1994, p. 239.

${ }^{96}$ Mark U. Edwards, Printing, Propaganda, and Martin Luther, London 1994, especially pp. 76-82.
} 
polemical refutation. Yet Gennep's work did not apparently attract attention, neither at his own time, nor in the following centuries. Avicinius voiced his criticism in the form of amusing verses, and was equally forgotten soon. After the first massive public outcry against Sleidan, Catholics failed to defeat his ghost. Sleidan's incorporation into most Indices librorum prohibitorum did not even impact on official Catholic bodies. The sales figures - 48 editions of the Commentaries in six languages by 1560 , and 95 editions by 1600 - prove Sleidan's lasting popularity, while the works of his enemies were quickly forgotten. ${ }^{97}$

\section{Friedrich Hortleder}

On the Protestant side, reactions to the Commentaries were only positively expressed in continuations and translations. Charles' V project of collecting the original documents never took shape, but at the start of the seventeenth century an ambitious German scholar put this idea into practise. Friedrich Hortleder (1579-1640) set out to compile a collection of all the sources useful for an account of the Reformation. For this purpose, he spent a decade collecting this material, ordered into different 'causes of the German war', and published in two monumental works in $1617 / 1618 .^{98}$ He did not see himself primarily as a collector of sources, but more as a pedagogue. He taught history to his pupil, the future Duke Johann Ernst of Saxony, following Sleidan's Commentaries and Four Empires, and a source collection was to allow a more detailed study of history. ${ }^{99}$ Although in its title the work does not refer to Sleidan, it becomes clear in Hortleder's long prefaces to both volumes that in effect his work served as a document collection of all the sources Sleidan used or could have used. Hortleder did not quite reach the conclusion from this

\footnotetext{
${ }^{97}$ Figures based on Vekene, Bibliographie.

${ }^{98}$ Hortleder, Der Römischen Keyser- und königlichen Maiesteten, vol.1: Frankfurt/Main (Hartm. Palthenius) 1617; vol. 2: (Nicolaus Hoffmann) 1618.

${ }^{99}$ Cf. Hortleder, Der Römischen Keyser- und königlichen Maiesteten, vol. I, fol. a2r.
} 
undertaking that Charles V would have envisaged. For Hortleder, the collected documents proved the veracity of Sleidan.

The explanation of the purposes and values of Hortleder's studies are intertwined with eulogies on Sleidan and his outstanding achievement as a historian. Additionally, the reader is provided with biographic information on Sleidan, as well as references to literary reactions to his Commentaries, unfortunately of a rather cryptic nature. Hortleder also offered six letters concerning Sleidan, two of which seem unique and even escaped Hermann Baumgarten, the compiler of Sleidan's correspondence in the nineteenth century. Hortleder was also aware of the great uproar the Commentaries caused, making a great number of enemies who in his view could have played a role in Sleidan's untimely death. $^{100}$

In the interesting preface to the second volume Hortleder traced principal complaints against Sleidan: Firstly, Sleidan was a servant of Strasbourg and a subject of the Emperor and as such was not really entitled to speak out against him. He portrayed Protestant actions that were not always correct and which many Protestants would have liked to be ignored, especially events in Hesse and Saxony. Additionally, Sleidan portrayed the Schmalkaldic war as just and affirmed the right of resistance. He included the infamous writings of Nuremberg against Albrecht of Brandenburg and other such writings, but left out responses to them. Interestingly, Hortleder admitted that Sleidan did not always tell the complete truth or omitted vital aspects and thus earned a lot of criticism. He explained this due to Sleidan's employment by Protestant states which would mean that

\footnotetext{
${ }^{100}$ Cf.ibid., fol. a4v: 'Weil aber/ fürnemblich umb der Teutschen Kriegshistori willen/ ein anders erfolgt/ und nicht wenig hohes und niders Standes Personen deroselben sich beschweret/ Der löbliche Sleidanus auch/ weiß nicht in was vor welche/ Aber doch solche gefahr/gerahten/ daß er zum exempel der gefährligkeit/ welche rechtschaffenen historicis bißweilen zubegegnen pfleget/ mit fürgestellet wirdt/ zugeschweigen/ was von der ursach seines todtes/ etliche geargwöhnet haben sollen.'
} 
he would naturally be more in favour of the Protestant party. Moreover, he remarked, no human being and thus also no historian can be entirely objective. ${ }^{101}$ All in all Hortleder was convinced of Sleidan's excellence as a historian. He was equally confident of having reinforced Sleidan's outstanding contribution to history with his work.

This examination has attempted to highlight the various sides of Sleidan's reception in Germany, his home country. Strangely enough, the turmoil and immediate irate reactions accompanying the publication of the Commentaries were not reflected in German literature. Any political or legal consequences were cut short by Sleidan's sudden death. Literary reactions were rare and originated only from the Catholic side. An eminent theologian like Gropper could not accomplish his mission to refute Sleidan. Surius, Gennep and Avicinius did live long enough to speak out against Sleidan, but their works were soon forgotten. The Commentaries, however, were continued and translated, and remained popular across borders, confessions and centuries. ${ }^{102}$ All in all, none of Sleidan's enemies could triumph over him, and 'are long since cast to the Bats and Moles', as Bohun expressed it in his 1689 English translation. ${ }^{103}$

Despite their immediate polemical context, the Commentaries were soon accepted in German lands. In France one could observe an exact reverse reaction. The Commentaries were equally popular as in Germany, but were read there as a contemporary history by an author of a neighbouring country and thus did not trigger public outcry. Initial reactions were very positive and Sleidan even received admiring letters from France,

\footnotetext{
${ }^{101}$ Ibid., vol. 2, fols. a5r-v.

${ }^{102}$ It is quite interesting to compare Sleidan's reception with that of John Foxe. His Acts and Monuments was immediately popular, but many of those named as persecutors were very bitter, like the Jesuit Robert Parsons who called Foxe 'the father of lyes' (cf. Glyn Parry, 'John Foxe, 'Father of Lyes', and the Papists', David Loades (ed.), John Foxe and the English Reformation, Aldershot 1997, p. 296). Foxe addressed these criticisms in his second edition of Acts and Monuments, The First (-Second) Volume of the Ecclesiasticall History contaynyng the Actes and Monuments, London (John Day) 1570.

${ }^{103}$ Sleidan/Bohun, General History, 'An account of the author's life', fol. A2v.
} 
which he regarded as his second home country. The religious settlement in Germany took on the function of almost a role-model for its neighbour country. When religious troubles in France increased, however, and eventually led to the Wars of Religion, works like Sleidan's were perceived differently and thus took on a new role. Literary reactions towards Sleidan, be it on the Protestant or Catholic side, were numerous and varied in France. These reactions will be examined in the next chapter. 


\section{CHAPTER 6: SLEIDAN AND THE FRENCH HISTORIANS}

Sleidan's life was spent to a large extent in France and in the service of France. He had an acute understanding of French society, French culture and of the French political elite in whose service he had spent many successful years. Sleidan had many admirers at the French court, where he had given such able and devoted service. Therefore it is hardly surprising that his scholarly work should find appreciative readers in what had been for many years almost his adopted home.

All that considered, the extent of the popularity of Sleidan's work in France went far beyond what anyone could have anticipated or what Sleidan could have dared to hope. The publication of the Commentaries was greeted with a near immediate success. Almost immediately, French readers wrote to signal their enjoyment. The opportunity for a French translation was quickly seized and the first of numerous French editions was published within a year of the first Latin edition - a remarkable achievement for such a large and expensive volume.

Of course within the immediate French context, Sleidan's work could be appreciated without quite the same level of personal sensitivity; the individuals and communities whose conduct was described lay within the Empire. There would have been few in France who would have felt personally touched by Sleidan's presentation of events. Nevertheless, the interest in the religious settlement within the Empire was still keen and would remain so for some years. In the years immediately after publication, French diplomats still looked to the Protestants of the Empire as potential allies in the long lasting 
conflict with the Habsburgs. With that conflict concluded, the German religious settlement took on a new role as a possible model for France in newly troubled times. ${ }^{1}$

But of course this was only half of the story. Sleidan's work might have been shorn of its immediate polemical context when read in France, where it described foreign events: however, it still remained a highly charged text. It would immediately have been apparent that Sleidan's works in French emanated mostly from Geneva, identified since the 1540 s as the fountainhead of French heresy. As France descended into civil war and political chaos, the orthodox increasingly came to see Sleidan's history as a part of that deluge of evangelical writings which they considered to be largely responsible for the growth of religious discord. This fact helps explain why Catholic authors in France engaged Sleidan with an immediacy and persistence that went beyond that of German historians. Sleidan was published and read in France at a time when religious questions were unresolved. This in itself was enough to place his work in an entirely different political and religious context.

This chapter aims to examine Sleidan's Commentaries within a French context. Such an examination becomes particularly interesting when considering Sleidan's personal connections to France. Additionally, it will provide a fascinating contrast to the situation in Germany, as explored in the previous chapter. We shall firstly look at the spontaneous reactions towards the Commentaries in France, where editions imported from Germany were eagerly read. This huge demand on the French market was quickly observed by the Genevan printer Jean Crespin, who dominated the early production of French translations of Sleidan's work. An examination of Crespin's various editions of Sleidan's works will

\footnotetext{
${ }^{1}$ On the idea of religious peace in Germany and France see Christin, La paix de religion, esp. pp. 36-39, 103 114, 149-168.
} 
highlight the importance of the printing industry for spreading new thoughts and also show the economic factors involved.

An analysis of French historiography in the first half of the sixteenth century will explore the context which the Commentaries entered. An examination of several works of the second half of the century will show the many different ways in which Sleidan's Commentaries feature in French historiography. Approval or disapproval was not bound to a specific confessional side, but varied dramatically among French historians. The reception of Sleidan's Commentaries in France also showed two rather unexpected phenomena, that is criticism from Protestant historians and the use of the Commentaries by Catholic polemical writers.

\section{Sleidan's Commentaries in France: French demand and Crespin's supply}

Sleidan's Commentaries proved to be especially popular in the country to which he had dedicated almost a decade of his life, France. He spent the years from about 1533 till 1543 there, the formative period of his life both regarding his career as well as his private life. He entered a long-lasting friendship with his employer Jean Du Bellay, which did not cease even after he left Paris, as their correspondence shows. For a substantial period after this, Sleidan still worked for the French court, at the same time being active in diplomatic service for Strasbourg and the Schmalkaldic League. This double commitment was to complicate his life. In France he was accused of partisanship and possible espionage for the Germans at the court of Francis I in 1541. Back in Germany he had to hand in a formal apology defending himself against 'French practices' in Strasbourg together with the other Francophiles Jean Sturm, Johann Nidbruck and Ulrich Geiger in $1548 .^{2}$ His continued involvement in French affairs, be it the negotiations with the French during the 1552

\footnotetext{
${ }^{2}$ Cf. PC 4/2, No. $732,901$.
} 
military threat of Henri II or the administration of the French church in Strasbourg after 1554 further stressed his obscure position between France and Germany. ${ }^{3}$ One can assume that Sleidan's name was as well known in France as it was in Germany.

As anywhere else, the Commentaries were also popular in France. The Latin original of the Commentaries, first published in Strasbourg in April 1555, was widely available there. In September 1555 Sleidan revealed his surprise that the Commentaries were sold publicly in Paris. He showed concern for the booksellers who sold the work in the proximity of the Sorbonne with its strict censorship. ${ }^{4}$ This statement from Sleidan clearly refers to the original Latin edition since the French edition would not be printed for another year. Such an initial open sale of the Latin edition leaves room for speculating whether there was a higher tolerance of unorthodoxy towards Latin books rather than vernacular ones. Latin books naturally only reached a small, sophisticated audience, whereas vernacular books would be accessible by far greater numbers, and thus potentially cause more trouble.

The popularity of the Commentaries in France was immense. Readers would even write to Sleidan to express their enthusiasm. In December 1555 a French informant wrote to Sleidan: 'I can very well assure you that I have never seen any work which is as desired as yours.' Another source wrote from France in January 1556: 'Your recent history is so required here that, if there were ten thousand copies of it, they would be sold in less than

\footnotetext{
${ }^{3}$ For Sleidan's involvement in the French church in Strasbourg see Denis, L'Eglise Etrangère, esp. pp. 40-90. Cf. chapter 3.

${ }^{4}$ 'Luteciae palam venditur liber quod valde miror, et tribus, ut aiunt, coronatis. Metuo librariis, ubi Sorbona resciverit.' (Sleidan's letter to Caspar von Nidbruck from 17 September 1555; Baumgarten, Briefwechsel, No. 157; Appendix I, No. 366).

${ }^{5}$ 'Car je vous puis bien asseurer, que je nay oncques veu oeuvre qui soit tant desiree qui la vostre...'. (My translation; Baumgarten, Briefwechsel, No. 164, p. 311; Appendix I, No. 376).
} 
an hour. It is a work that will bring great fruit, [and] for which the posterity will be similarly indebted [to you]., 6

With his old connections to France in mind, and convinced of the quality of his work, Sleidan himself seemed to have planned the publication of a French edition, with François Hotman as the translator. This seems to become apparent in a letter by Sleidan to Calvin from August 1555. Sleidan mentioned that he had written to Hotman, and remarked that a French translation should not be published in such difficult times. He asked Calvin to convince Hotman of Sleidan's opinion on this matter. ${ }^{7}$ In January 1556 , a French translation became even less advisable when Sleidan was informed that the Cardinal de Lorraine had petitioned the Parliament of Paris to proceed against the Commentaries in the manner of the Spanish inquisition. ${ }^{8}$ The Commentaries had also offended somebody at the royal court, Diane of Poitiers, the influential concubine of the French king. Book 25 of the Commentaries had mentioned that in order to pay the ransom for her captured son-in-law, the Duc (Claude) d'Aumale, she had demanded the confiscated possessions of the Huguenots, thereby causing the severe persecutions in 1553. 9

For Sleidan, a French translation seemed out of question. The Genevan printer Jean Crespin (ca. 1520 - 1572) thought differently on this. The recent article by David Watson

\footnotetext{
${ }^{6}$ 'Vostre histoire derniere y est tant requise, que, sil y en avoit dix mil, je croy, quelles seroient expediees a moins d'une heure. Cest une oeuvre qui fera grand fruict, don't la posterite vous sera semblablement redevable.' (My translation; Baumgarten, Briefwechsel, No. 167, p. 313; Appendix I, No. 379).

${ }^{7}$ 'Sal. Julio mense scripsi ad d. Hotmanum. Eas literas ait Losanae sibi redditas. Nunc idem sentio, nimirum ut nondum tentetur versio gallica, sed aliud tempus exspectetur. Ut igitur in eo curam adhibeas, plurimum oro.' (Baumgarten, Briefwechsel, No. 153, p. 295; Appendix I, No. 360).

8 'Je vous envoye la response du parlement a lentreprinse du cardinal de Lorraine qui vouloit mectre sus linquisition d'Espaigne.' (Baumgarten, Briefwechsel, No. 167; Appendix I, No. 378). Also mentioned by Hasenclever, 'Johann Sleidan', pp.121.

${ }^{9} \mathrm{Cf}$. Commentaries, Book 25.
} 
has shown Crespin's influence on history writing during the French Reformation period. ${ }^{10}$

Crespin saw the large opportunity the French market offered, especially since a publication of the Commentaries in Catholic France drifting towards the Wars of Religion seemed highly unlikely. Additionally, the popularity of the Commentaries showed an obvious interest in the latest account of recent affairs in France where at the time there was a pronounced lack of contemporary histories. The business-minded Crespin realised the favourable situation and employed the French Protestant minister Robert Le Prevost to translate the Commentaries into French. ${ }^{11}$

Sleidan seemed unaware of the translation Crespin had initiated for quite a while. From Sleidan's letters we know that he was acquainted with Crespin, and had read Crespin's own work, Le Livre des Martyrs. ${ }^{12}$ By early 1556 though rumours about a French translation to be published by Crespin had also reached Sleidan. In a letter to Calvin from early May 1556 Sleidan reported an unexpected meeting with Crespin in Strasbourg and expressed the utmost astonishment that Crespin did not mention a word about his French translation: 'I am surprised about such a deception and wonder how he wants to excuse that in my presence he denied that he or anybody else worked on this., ${ }^{, 13}$ Despite Sleidan's disapproval, Jean Crespin was soon fully engaged with the Sleidan project. ${ }^{14}$ By mid-1556, Le Prevost had translated the Commentaries into French and the

\footnotetext{
${ }^{10}$ David Watson, 'Jean Crespin and the Writing of History in the French Reformation', Protestant History and Identity in Sixteenth-Century Europe, vol. 2: The Later Reformation, Aldershot 1996, pp. 39-58.

"Robert Le Prevost was a reformed minister from Paris who lived in Geneva until 1551, then moved back to France and finally returned to Geneva in 1565 (cf. Gilmont, Jean Crespin, p. 194).

${ }^{12}$ Jean Crespin, Le Livre des Martyrs, qui est un recueil de plusieurs Martyrs qui ont enduré la mort pour le Nom de nostre Seigneur Iesus Christ, depuis Jean Hus iusques à ceste année presente M.D.LIIII, s.n., s.1., 1554. Sleidan mentions this work to Calvin in a letter from 10 September 1554 (Cf. Bg 135; Appendix I, No. 320 ).

${ }^{13}$ 'Miror tantam dissimulationem et expecto, quomodo velit excusare quod mihi negavit se quicquam in eo agere.' (Bg 173; Appendix I, No. 388).

${ }^{14}$ For the following examination of Crespin's editions of Sleidan's works, see Gilmont, Bibliographie, vol. 1, and Vekene, Bibliographie. I will follow the chronological order of editions as suggested by Gilmont, Bibliographie, vol.1. The classification numbers are Gilmont's.
} 
first edition was published in August 1556. This rapidity would suggest that Crespin was actually printing book by book while Le Prevost was translating the next.

In the second half of 1556, Crespin published a Latin summary of the Commentaries, still bearing the place of print 'Geneva' on the title-page, along with Crespin's name as the printer. ${ }^{15}$ This Latin work was succeeded by the first French version of the Commentaries, Histoire de l'estat de la religion et republique sous Charles $V$, the translation by Robert Le Prevost, published in three editions within eighteen months. ${ }^{16}$ This first edition was published in two different states, both omitting Geneva as place of print on the title page. State $a$ gives Jean Crespin and Nicolas Barbier as printers, state $b$ only has Jean Crespin. The work must have appeared soon after August 1556, since the preface by Le Prevost is dated 12 August 1556. The following edition from March 1557 gives only Crespin as printer on the title page, but mentions Barbier in the colophon. ${ }^{17}$ The second edition from 1557 appeared, like the first one, in two different states, one bearing Crespin only as printer, the other including Barbier. ${ }^{18}$ This was also the first edition to include a preface by Crespin. Crespin's partial partnership with Nicolas Barbier shows the financial implications such large-scale productions like Sleidan's works had for the printer. ${ }^{19}$ All three octavo editions omit Geneva as place of print on the title page, a clear indication that they were destined for the French market, where a book from Geneva would immediately raise suspicion. Of all of Sleidan's works published by Crespin, it is in fact

\footnotetext{
${ }^{15}$ Gilmont, Bibliographie, 56/16.

${ }^{16}$ Gilmont, Bibliographie, 56/17: State a: [Geneva] Jean Crespin/Nicolas Barbier, state b: [Geneva] Jean Crespin.

${ }^{17}$ Gilmont, Bibliographie, 57/14: [Geneva] Jean Crespin. 'Achevé đ'imprimer ...au mois de Mars...'. This edition is paginated, whereas the following 1557 edition is foliated. Surprisingly, it omits the preface by Le Prevost, which then reappears in the next edition (57/15).

${ }^{18}$ Gilmont, Bibliographie, 57/15: State a: [Geneva] Jean Crespin/Nicolas Barbier, state b: Jean Crespin.

${ }^{19}$ Cf. Gilmont, Jean Crespin, pp. 90-101.
} 
only one state of the 1566 edition of Sleidan's collected works which bears Geneva as place of print on the title page. ${ }^{20}$

In his preface to the second 1557 edition, Jean Crespin praised the accomplishment of Sleidan, but also admitted deficiencies in his work due to his ignorance of certain facts, such as information about different cities. He also announced an expanded edition should there be sufficient demand, containing more information on the Swiss cities. ${ }^{21}$ The first three French editions of Sleidan's Commentaries published by Crespin and Barbier did not have a privilege. Only on 29 June 1557 did Crespin and Le Prevost present a copy of the Commentaries to the Geneva council in order to obtain a privilege, which was granted for three years. $^{22}$ Gilmont identified this copy as being the third edition of the Commentaries, which in turn would mean that within only four months, that is after March 1557 (as stated in the colophon of the second edition 57/14) and before 29 June 1557, Crespin and Barbier would have printed two editions - an impressive achievement based on impressive sales figures. $^{23}$

\footnotetext{
${ }^{20}$ Gilmont, Bibliographie, 66/11, state a. State b omits Geneva on the title page.

${ }^{21}$ Crespin's preface in Sleidan/Le Prevost, Histoire de l'estat de la religion, s.l. (Jean Crespin/Nicolas Barbier) 1557 (Gilmont 57/15), fol. *ii.v: 'Quant au present auteur, combien qu'il ait omis plusieurs choses pertinentes, voire et qu'en certains endroits il n'ait esté assez informé de certains faits particuliers conernans aucunes villes ou pays, neantmoins il n'y aura homme ... qui ... se puisse plaindre qu'il n'ait gardé en son histoire integrité et rondeur sans affection. [...] Si le labeur vous est plasaint et aggreable, nous esperons en bref, moyennant l'aide du Seigneur, donner à ceste histoire additions, et appostiles necessaires, specialement en ce qui conerne la religion et reformation des villes à l'Evangile.' Gilmont, Bibliographie, p. 87 suggests that Crespin must have referred there mainly to the Swiss cities and the translation of the Swiss chronicle by Johannes Stumpf by François Bonivard. Such an augmented edition is not known to us, however.

${ }^{22}$ Gilmont, Bibliographie, pp. 87-88 quotes the council notes (AEG, RC 53, fols. 209r-v): 'Spectable Crespin, avecq. le translateur a presenté l'impression de la copie par nous permise à imprimer soub le tiltre ascavoir Histoyre de le Estat de la religion et republique soub 1'empereur Charles Ve, pour distribuer aux Srs du petit Conseil, suyvant nostre mandement sans estre reliez, supplians leurs pardonner et aud. imprimeur donner privilege pour temps qu'il nous playra, avecq. Deffenses. A esté arresté qu'on les remercie desd. impressions, mais quant aud. privilege requis, l'on luy oultroye par trois ans prochains avecq. deffenses en ce necessaires sinon que fust à aultres donné ou vrayement par nous pourveu.' Crespin only had the privilege for the original books 1-25, book 26 did not fall under this regulation (cf. Gilmont, Jean Crespin, p. 100). ${ }^{23}$ Cf. Gilmont, Bibliographie, p. 88.
} 
Immediately after this, Crespin published the French translation of Sleidan's Four Empires, again omitting Geneva on the title page, with Crespin as the only printer discernible. ${ }^{24}$ In 1558 , Crespin's presses produced their largest output of Sleidan's works. Crespin had Sleidan's Two Orations translated into French, like the Four Empires without offering the name of the translator. The Deux oraisons historiales do not bear the date of publication on the title page, but Gilmont has identified it as $1558 .^{25}$ This work is followed by another edition of the Commentaries in August 1558, a reedition of the second 1557 edition (Gilmont 57/15). ${ }^{26}$ This is the first French edition of the Commentaries to include Sleidan's apology. Two more editions of the Four Empires follow, succeeded by the $26^{\text {th }}$ book of the Commentaries, omitting date and names of printers and place of publication on the title page. ${ }^{27}$ In 1559 , Crespin published a Spanish translation of the Two Orations, followed by another French edition of the Commentaries in August. ${ }^{28}$ In 1560 Crespin $^{2}$ published no works of Sleidan at all, but in 1561 he published the Four Empires, Two Orations and Commentaries together as Histoire entiere depuis le deluge jusques au temps present, which was reedited in 1563 under a similar title. ${ }^{29}$ In 1566 , Jean Crespin published the last sequence in his row of Sleidans, Oeuvres, appearing in two states, with and without Geneva on the title page. ${ }^{30}$ This edition included all of Sleidan's historical works as well as an abridgement of the chronicles of Froissart.

During the ten years of producing works of Sleidan, between 1556 and 1566 , Crespin published 16 editions of Sleidan's works, 14 of which were in French, one in Latin and one in Spanish. Competition was so great that in Strasbourg and Lyon both

\footnotetext{
${ }^{24}$ Gilmont, Bibliographie, 57/16.

${ }^{25}$ Gilmont, Bibliographie, 58/16, printer: Jean Crespin.

${ }^{26}$ Ibid., $58 / 17$, printer: Jean Crespin.

${ }^{27}$ Gilmont, Bibliographie, 58/18, 58/19 and 58/20. Gilmont identifies the date of the publication of the 26th book of the Commentaries as 1558, printed in Geneva by Crespin and Barbier.

${ }^{28}$ Gilmont, Bibliographie, 59/10 and 59/11.

${ }^{29}$ Gilmont, Bibliographie, 61/9, 63/12.

${ }^{30}$ Gilmont, Bibliographie, 66/11. State a: Geneva: Jean Crespin, state b: Jean Crespin.
} 
Commentaries and Four Empires were re-edited. The large demand and thus the secure profit involved also encouraged several forgeries. In 1557 an unknown printer working for Claude Senneton in Lyon published the Four Empires with the forged printer's device of Crespin, the anchor, indicating the printer as 'Chez Jean Crespin'. ${ }^{31}$ The edition must have proved profitable because in 1558 , the same forger printed a second edition. ${ }^{32}$ Another extraordinary case is a copy stating the printer Jean Bonnefoy and the year 1560 on the title page and the year 1559 in the colophon. After a detailed examination, Gilmont was able to identify three printers involved in this work: the unknown printer from Lyon, Jean Bonnefoy and Jean Crespin, who each produced a part of the work. ${ }^{33}$ Crespin's shady connections to the unknown Lyon forger and Bonnefoy again emphasise the economic side of the printing industry: big publications would have considerable financial implications for the printer, but could also promise large profits. Crespin also published French translations of a historical work by another German historian, Paul Eber, a pupil of Melanchthon, along with the work of the French historian Jean de Hainault. ${ }^{34}$ With these works and his own martyrology, Crespin absolutely controlled the publication of historical works in French for a decade - and this as a Protestant printer working in Geneva.

Crespin in Geneva was not the only printer to produce French translations of Sleidan's works. Editions of Sleidan destined for the French market were also produced

\footnotetext{
${ }^{31}$ Gilmont, Bibliographie, 57/16*, a copy of Crespin's own edition of that year, 57/16. The forger could be identified by the typographical material used.

${ }^{32}$ Gilmont, Bibliographie, 58/19*. Gilmont points out that the print of the last gathering $(G)$ of this work differs slightly from the preceeding gatherings, and suggests that Crespin had re-bought this edition and finished it off himself. In his preface to the 1561 edition of Sleidan's works (61/9) Crespin showed himself aware of the forgers of his works: '... certaines autres qui ont esté contre drout evulguées sous mon nom, portans ma marque contrefaite.' (Jean Sleidan, Histoire entiere depuis le deluge jusques au temps present, [Geneva] Jean Crespin 1561, fol. *ii.v).

${ }^{33} \mathrm{Cf}$. Gilmont, Bibliographie, 59/12; also by the same author, Jean Crespin, pp. 150, 253, where Gilmont still attributed this edition to only two printers, the Lyon forger and Jean Crespin. Since Crespin and the Lyon forger had already come into contact with the 1558 edition of the Four Empires (58/19*), Gilmont hinted at a possible agreement between the two.

${ }^{34}$ Paul Eber, L'estat de la religion et republique du peuple judaique; Jean Crespin, Livre des martyrs 1554 ; Sleidan's works; Jean de Hainaut (Hesnault), L'Estat de L'Eglise, see below. Cf. Gilmont, Jean Crespin, p. 152 .
} 
for example in Strasbourg. ${ }^{35}$ Yet Crespin's large and rapid output of Sleidan's works secured him the prime role as a producer of these works for the French market, verging on a monopoly. Once more Geneva's role as the prime distributor of Protestant thought in French lands is demonstrated. Furthermore, Crespin's large production of Sleidan's histories and the forged editions highlight the massive demand for such works in France. Unfortunately, we are not informed about the practical side of Crespin's sales of Sleidan's works. Catalogues from booksellers from the 1570 s have survived, however, which show that Sleidan was still popular then. At a time when the religious divide was shaking France, and French historiography had begun to produce French accounts of recent events, Sleidan was still consulted.

One of these catalogues is that of Laurent de Normandie, the Genevan publisher and principal organiser of book exportation from Geneva between 1550 and 1570, which has been explored by Schlaepfer. After Normandie's death, a large catalogue inventory was drawn up in which Sleidan featured with several editions. ${ }^{36}$ This 'Inventaire du fonds de librairie de Laurent de Normandie, 1570 ' is especially interesting since it also contains the prices for the listed (unbound) works. ${ }^{37}$ Various editions of different works of Sleidan printed in Geneva are included: 'Historia' printed by Conrad Badius in 16o, of which 360 copies for four sous each are on stock, a value of 72 Livre and five sous; one copy on parchment is left for five sous. ${ }^{38}$ Further down the list the same item is offered again, 'Historia' in 16o, 174 copies for four sous, amounting to 34 Livres and 16 sous. Since Conrad Badius printed both a Latin edition of the Commentaries and the Four Empires in

\footnotetext{
${ }^{35}$ For bibliographical information on other French translations and further editions of Sleidan's works, $\mathrm{cf}$. Vekene, Bibliographie. For works of Sleidan produced in Strasbourg, a potential tradecentre for both Germany and France, see Muller, Bibliographie Strasbourgeoise, and Benzing, Bibliographie Strasbourgeoise.

${ }^{36}$ See Heidi-Lucie Schlaepfer, 'Laurent De Normandie', G. Berthoud et al. (eds.), Aspects de la Propagande Religieuse, Geneva 1957, pp. 176-230.

${ }^{37}$ Conversion: 1 Livre $=20$ sous, 1 sous $=12$ deniers.

${ }^{38}$ Schlaepfer, 'Laurent De Normandie', No. 7, p. 208, and No. 158, p. 216.
} 
1559 , it is not quite clear here which work is referred to, or whether both items are actually the same since they are the same price. ${ }^{39}$ Such a large stock in Sleidan's historical writings suggests that Normandie expected a large demand for these. The copy in parchment would have been specifically produced with a richer clientele in mind who could afford a more expensive version of a desired book. Furthermore, eight copies of 'Tables' printed by (Jean) Rivery are listed, refering to the 1558 Sommaire de l'histoire, for two sous each. ${ }^{40}$ The $26^{\text {th }}$ book of the Commentaries by Crespin (printed in 1558) features with 250 copies for four deniers each, altogether four Livres, three sous and four deniers. ${ }^{41}$ The overall wholesale value of Sleidan's works listed constitutes 112 Livres and five sous.

Another inventory from 1575 , 'Compte de 1575', lists five copies of Crespin's 1558 French edition of the Four Empires in octavo, for one sous each, and two copies of 'Sleidan, in-8, complet' for nine sous each. ${ }^{42}$ The list of books returned to Normandie's widow in April 1570 by Antoine de Harsy from Lyon contained also 26 folio editions listed as 'Sleidan', for 18 sous each, amounting to 23 Livres and eight sous. ${ }^{43}$ How do these prices compare? In general, one can say that books were priced according to the number of printed sheets and the quality of paper used; in France around 1570 the large formats folio and octavo were usually priced in Livres, the small formats in sous and derniers. ${ }^{44}$ However, if one looks through Normandie's inventory, these estimations do not always match up. Working with this list suggests that for one sheet of printed paper roughly one denier was charged, depending on the quality of the paper, the nature,

\footnotetext{
${ }^{39}$ For Badius' editions, cf. Vekene, Bibliographie, D/a 006 and E/a 018; cf. Gustave Moeckli, Les Livres imprimés à Genève de 1550 à 1600 , Geneva 1966, p. 40.

${ }^{40}$ Schlaepfer, 'Laurent De Normandie', No. 61, p. 211; Vekene, Bibliographie, E/k 008.

${ }^{41}$ Schlaepfer, 'Laurent De Normandie', No. 158, p. 216; Vekene, Bibliographie, E/k 009.

${ }^{42}$ Schlaepfer, 'Laurent De Normandie', p. 224; Crespin published two editions of Quatre Empires in 1558, in Vekene, Bibliographie, as D/c 005 and D/c 006.

${ }_{43}$ Schlaepfer, 'Laurent De Normandie', p. 228.

${ }^{44} \mathrm{Cf}$. Higman, 'A bookseller's world', p. 317.
} 
popularity and age of the work. If parchment was used, this price would increase considerably. ${ }^{45}$

A similar booklist has been preserved of the stock of the bookseller Vincent Réal (or Réau) of Bordeaux, after whose death in 1571 an inventory of his possessions was drawn up. So far only a short passage of this extensive list has been published by Higman and others. ${ }^{46}$ The complete list contains some 80 folio-pages with text on the recto- and verso-side, encompassing roughly 3,000 mainly reformed Protestant titles. One of the items listed are the French Two Orations, worth two sous and six deniers.

All this shows that Sleidan's popularity in France was certainly great. Ultimately, such a popularity goes back to the decade or so he lived in France, both as a student and an employee of Jean Du Bellay. This position had transported him into the heart of the French court, where he became the link to the German Protestants. The advice of such a man would have been sought. Besides, the religious concord reached in the Empire, as demonstrated in Sleidan's works, could well have served as a model for France. The religious conflict that had been solved in the Empire was still a pressing issue in France, where the Commentaries would have been read almost as a guide for achieving peace. Sleidan's Commentaries naturally occupy a central role when one considers that in this period between 1555 and 1565 his account of the Reformation was the only encompassing report on the Reformation available in France. A quick survey of French historiography in

\footnotetext{
${ }^{45}$ This calculations are derived from the starting point of a pamphlet by Luther of four sheets, Quatorze images de consolation, listed with the price of four deniers (No. 71, p. 211). Bullinger's Adversus anbaptistas (Zurich: Froschauer) in octavo was sold for four sous, Calvin's Sermons sur les Xe et Xie des Corinthiens in octavo were three sous six deniers (38 sheets), his 8 o Plusieurs sermons were sold for the same price (40,5 sheets). Beze's L'authorité du magistrat, printed in octavo by Badius was two sous (29 sheets).

${ }^{46}$ Cf. Higman, 'A bookseller's world', p. 315.
} 
the decades before and around the publication of Sleidan's Commentaries will demonstrate this.

\section{French historiography}

In the 1550 s French historiography was still rather traditional in its outlook. ${ }^{47}$ French histories were usually annalistic in character and mainly served the purpose of gloryfying France. One of the immensely popular historians of the time was, for example, Nicolas Gilles, the royal historiographer, who became known in the 1520 s for his Annales Des trespreux, tresnobles, treschrestiens et tresexcellens moderateurs des belliqueuses Gaules. ${ }^{48}$ This work went through various stages and editions, and in the late $1550 \mathrm{~s}$ parts of it were edited and augmented by Denis Sauvage as Les Annales et Croniques de France. ${ }^{49}$ In the 1570 s another famous writer re-edited and continued this work, François de Belleforest, an edition which continued to be published into the seventeenth century. ${ }^{50}$ Gilles' work, with its continuing influence across almost the whole sixteenth century, was still very much rooted in traditional historiography, which becomes most apparent in its division into the classical six ages of the world. Like many other French histories of its time, it followed a very Francocentric approach, focusing on France's achievement throughout the ages. Even in the continuations by Sauvage and Belleforest in the second half of the sixteenth century, when the question of religion turned the country upside down, the Reformation merits only a few occasional remarks.

\footnotetext{
${ }^{47} \mathrm{Cf}$. Jean-François Gilmont's judgement in 'La naissance de l'historiographie protestante', Andrew Pettegree, Paul Nelles, and Philip Conner (eds.), The Sixteenth-Century French Religious Book, Aldershot 2001, p. 125: 'Avant 1550, aucune innovation dans l'historiographie ne vient de France.'

${ }^{48}$ Nicolas Gilles, Les tres elegantes Tresveridiques et copieuses Annales Des trespreux/ tresnobles/ treschrestiens et tresexcellens moderateurs des belliqueuses Gaules, Paris (Galiot Du Pré/Anthoine Couteau) 1525.

${ }^{49}$ Nicolas Gilles (ed. Denis Sauvage), Les Annales et Croniques de France, depuis la Destruction de Troye, iusques au temps du Roy Loys vnziesme, Paris (Jean Ruelle) 1558.

${ }^{50}$ For example Nicolas Gilles, (ed. Denis Sauvage/François de Belleforest (eds.), Les Chroniques et Annales de France dez l'Origine des Francoys, et leur venuës és Gaules, Paris (Nicolas du Chemin) 1573.
} 
The humanistic emphasis on classics had also reached France. The invention of the printing press had enabled the production of various translations and re-editions of earlier historians, be it classical authors such as Caesar and Pliny or French authors like de Seyssel. These were printed on a large scale alongside more recent histories of France such as Gilles. Additionally, general world histories by contemporary authors such as Jan de Maumont's Les Histoires et Chroniques $d u$ Monde were published. ${ }^{51}$ Works attempting to analyse more recent events were still rather scarce in France in the middle of the sixteenth century. Even works claiming to analyse recent events, like the immensely popular Histoire de nostre temps by Guillaume Paradin, first published in Lyon in 1550, often did not fulfill their promise and usually devoted more space to the glorification of France than to a thorough investigation of historical events. ${ }^{52}$

This delay or complete lack of literary reactions to important events in the form of histories is actually not too dissimilar from Germany. There, the Reformation had started earlier, and soon witnessed a large production of printed works like pamphlets, theological writings and shorter historical accounts. These works, however, were usually more descriptive than analytic in nature and often had a strong polemical outlook. Works attempting to analyse and explain these events from a historical rather than a polemical point of view like the Commentaries and the Magdeburg Centuries were not composed until about four decades after the Reformation started. A similar pattern can be witnessed in France. There, the Reformation did not pose such an imminent problem as it did in Germany, where the national factor connected with Luther further heightened tensions. Yet Protestant thought soon infiltrated France, too, and found positive responses in humanist, evangelical circles and even at the court of Francis I. However, it was not until

\footnotetext{
${ }^{51}$ Jan de Maumont, Les Histoires et Chroniques du Monde, Paris (Michel de Vascosan) 1561, another edition in 1583 .

${ }_{52}$ Guillaume Paradin, Histoire de nostre temps, Lyon (Jean de Tournes/Guillaume Gazeau) 1550.
} 
the rise of Calvin and his followers several decades later that the religious question became much more important in France. With the Wars of Religion the confessional discord had finally developed into a major political issue. This is reflected in a huge wave of historical writings in the late sixteenth century and continuing into the seventeenth century. We shall now investigate various attempts to tackle the challenges posed by these historical events, especially concentrating on reactions to Sleidan's work.

\section{$\underline{\text { Jean de Hainault }}$}

One of the first attempts to analyse the religious controversies aimed specifically at the French market was that of another Protestant author, Jean de Hainault, published in 1557 by none other than Jean Crespin in Geneva. ${ }^{53}$ As can be seen above in the analysis of Crespin's publications of Sleidan's works, Crespin was able to sell his vernacular contemporary histories to an eager French audience and effectively controlled the market in this category for a long time. ${ }^{54}$ Like the Commentaries, Hainault's work was published without stating the place of print or even the printer's name on the title page, a clear sign that it was aimed for distribution in France.

Hainault embarked on his work from a far more theological point of view than Sleidan, the lawyer and diplomat. His L'Estat de l'Eglise followed a similar line as Flacius' Catalogue of the Witnesses of the Truth and the Magdeburg Centuries, based on the theory that the true church had always existed and had been persecuted through the

\footnotetext{
${ }^{53}$ Jean de Hainault, L'Estat de l'Eglise, avec le Discours des Temps, depuis les Apostres, sous Neron, iusques à present, sous Charles V, s.l. (s.n.; inferred place of publication: Geneva, inferred printer: Jean Crespin) 1557.

${ }^{54}$ Towards the end of his life, Crespin was still aware of the need and the demand for contemporary histories such as Sleidan's and Hainault's. He encouraged Jean de Serres (1540-1598) to compose a chronicle of events in France starting from 1557. In 1570, Crespin published a first work of de Serres, Rerum in Gallia ob religionem gestarum libri $I I I$, followed by various editions of Commentariorum de statu religionis et reipublicae in regno Galliae in 1571 and 1572 (note the similarity to the title of Sleidan's Commentaries!) In 1570 and 1571, Crespin had also published three editions of an anonymous French account of the third war of religion, Memoires de la troisieme guerre civile.
} 
centuries. In his preface, he emphasised the devastating role of the Antichrist, persecuting the true church. At his present time, he saw this happening especially in Germany, England, Scotland and recently also in France. It was the historian's obligation to show the evil in the world and teach people about history so one might learn from it. ${ }^{55}$ The work is divided into two parts, with the first part reiterating important events from the time of the Emperor Augustus until Hainault's own time. Part two concentrates entirely on French affairs in the sixteenth century.

In his analysis, Hainault stayed on rather traditional ground. Like many of the German histories examined above, the chronological basis for his work was the four monarchies from the book of Daniel. The L'Estat de l'Eglise followed the rigid style of annals, especially in the first part of the work. Unlike Sleidan, whose portrayal of contemporary history concentrated on political events, Hainault devoted equal attention to religious affairs with the concepts of the Antichrist and the survival of the true church dominating the narrative. Hainault's work went through several editions, but achieved neither the notoriety nor the sales figures of Sleidan. ${ }^{56}$

Both Hainault's and Sleidan's history had been printed in Geneva for exportation to France. In general, Protestant works were brought into France from Geneva and other places, thus avoiding problems with French censorship. Despite the fact that the 1551 Edict of Chateaubriant expressively forbade such activities, the import of Protestant works into France flourished until the outbreak of the Wars of Religion. ${ }^{57}$ Prominent reformers

\footnotetext{
${ }^{55}$ Jean de Hainault, L'Estat de L'Eglise, des le Temps des Apostres, iusques à l'an present. Avec un recueil des troubles advenues en France, sous le Roy Francoys II. \& Charles IX, Strasbourg (Jan Zimmermann) 1567 , fols. ee $3 v-4 r$.

${ }^{56}$ Crespin himself printed only three editions: 1557 (57/8), 1558 (58/11) and 1562 (62/3); cf. Gilmont, Bibliographie.

${ }^{57}$ Cf. Francis M. Higman, 'Genevan Printing and French Censorship, 1520-1551', Jean-Daniel Candaux, Bernard Lescaze (eds.), Cinq siècles d'imprimerie Genevoise: Actes du colloque international sur l'histoire
} 
such as Théodore de Bèze would still have their work published in Geneva to be distributed in France. But also within France, the French Protestants felt the need to express their views on the religious and political troubles. French histories of the Reformation in France were also needed to help create a group identity for French Protestants and serve as a defense against the Catholics. To avoid censorship, these works were often published anonymously or under a pseudonym, as was the case with the works by two of the most important French Protestant historians, Pierre de la Place and Henri Lancelot Voisin de la Popelinière.

\section{Pierre de la Place, official historian of the Protestant party}

Almost a decade after Sleidan and Hainault, in 1565, another contemporary history was published, omitting the author, printer and place of print on the title page. The title of this work, Commentaires de l'Estat de la Religion et République soubs les Rois Henry et François Seconds et Charles Neufieme, was modelled on Sleidan's, Commentaries on the state of religion and republic under Emperor Charles $V$. The anonymous author was Pierre de la Place (ca. 1520-1572), who in the preface to his work expressed his sorrow that in his times it was too dangerous to speak the truth and write a book like his. La Place had been the first President of the Cour des Aides under Henri II. His open conversion to Protestantism in 1560 cost him his position and honour, he was stripped of all offices and eventually became a victim of the St Bartholomew's Day massacre. Similar to Sleidan, his work was commissioned by a political authority to set forth the history of a religious group in a process of self-definition and justification. In La Place's case this was the group industry and would sometimes forbid the publication of a book, especially in French, that could be offensive to the French authorities (cf. Ingeborg Jostock, 'La censure au quotidien: le contrôle de l'imprimerie à 
around Louis de Condé, who wanted to provide the Huguenots with the recent history leading into the first War of Religion. ${ }^{58}$

La Place's work was published an impressive five times in 1565 . Subsequent editions stated the name of the author. With his examination of the years 1556 till 1561 , the colloquy of Poissy, La Place's aim was to analyse the events leading up to the outbreak of the first war of religion in 1562 . In doing so, the author followed the traditional chronological style of annals, but incorporated a fair number of documents. La Place did not mention Sleidan in this work, but his history was born out of similar circumstances as Sleidan's. His 1564 L'Epistre au roi sur le faict de la Religion already reminds us of Sleidan and his 1544 Orations to Emperor and Estates. ${ }^{59}$ His 1565 Commentaires, reedited several times as L'Histoire de notre temps, arose from the same need for a Protestant authority to provide believers with an account of their history. Though not obvious in the work itself, La Place's admiration for Sleidan and his work is expressed in the title of his own work, modelled exactly after Sleidan's.

\section{Théodore de Bèze - a Calvinist praising Sleidan}

The close contacts between Sleidan and Calvin, and the latter's approval of Sleidan's work have already been examined. Hence, it is not surprising that Calvin's successor in Geneva, French-born Théodore de Bèze (1519-1605), should also rally to Sleidan. To make up for the lack of a comprehensive account of the Reformation in France since Luther's 95 Theses until 1575, Bèze published the Histoire ecclésiastique des Eglises réformées du

\footnotetext{
${ }^{58} \mathrm{Cf}$. Gilmont, 'Les premières éditions des ouvrages historiques de La Place et de La Popelinière', Revue Française d'Histoire du Livre N. S. 50 (1986), pp. 120-121. Printers involved in the publication of La Place's work have been identified as Abel Clémence in Rouen, Barthélemy Berton in La Rochelle, and Eloi Gibier in Orléans (ibid., p. 123). Gibier, Condé's offical printer, had himself assembled various tracts connected with the prehistory of this war and gathered them in a recueil known as the 'Mémoires de Condé' (ibid., p. 120-121).

${ }^{59}$ Pierre de La Place, L'Epistre au roi sur le faict de la Religion, Paris (Robert Estienne) 1564.
} 
royaume de France in $1580 .^{60}$ In the preface, Bèze emphasised the fact that he tried to follow the example set by the most recent historians Jean Crespin and John Foxe with their martyrologies and Johann Sleidan with his excellent history, still unsurpassed by any other historian. ${ }^{61}$ With his own work, to be based on reliable sources, he hoped to offer a similarly comprehensive and good account of the events in France. For this aim, his main principles were impartiality and veracity, based on sound research and primary documents, the principles propagated by Sleidan.

In his own history of the Reformation, Bèze had set forth Sleidan as a role model for the historian. In honour of Sleidan's achievements, he was included in Bèze's 'book of fame', published in French in 1581 as Vrais pourtraits des hommes illustres en pieté et doctrine. $^{62}$ In this interesting work, Bèze included a large number of people who had stood out for their piety and services to the Reformation, mentioning not only the famous reformers and predecessors of the Reformation, as well as Protestant statesmen like Jacob Sturm, but also Catholics with Protestant tendencies like Hermann von Wied, Marguerite de Navarre and Francis I. Each person is introduced with a portrait, followed by a description of their life and achievements, concluding with a panegyric poem.

In the section on Sleidan, Bèze praised his knowledge, prudence and piety as shown in his many engagements for faith and country, like his mission to England and to the

\footnotetext{
${ }^{60}$ Published in 3 volumes under the faked place of print Antwerp by Jean Remy in Geneva.

${ }^{61} \mathrm{Cf}$. Théodore de Bèze's preface in Histoire ecclésiastique des Eglises réformées du royaume de France, Antwerp (= Geneva, Jean Remy) 1580, vol. 1, fol. *4r: 'Et pourtant sont dignes de tresgrande \& perpetuelle louange, Jean Sleidan Alemand, Foxus Anglois, \& Jean Crespin d'Arras, le premier desquels a si diligemment escrit l'histoire de la restauration des Eglises d'Alemagne depuis la venue de Luther qui fut en l'an 1517, iusques en l'an 1556: estant une chose grandement deplorable qu'entre tant de gens doctes en un si grand pays, il ne se soit depuis trouvé pas un qui ait poursuivi cest ouvrage.'

${ }^{62}$ Théodore de Bèze, Vrais pourtraits des hommes illustres en pieté et doctrine, du travail desquels Dieu s'est servi en ces derniers temps, pour remettre sus la vraye religion en divers pays de la Chrestienté. Avec les descriptions de leur vie et de leurs faits plus memorables, s.1. (Jean de Laon) 1581. This French version, translated by S. Goubert, was first published in the Latin original in 1580 in Geneva.
} 
Council of Trent. As the greatest achievement Bèze valued Sleidan's Commentaries, which he considered to be unsurpassed by any other historian, since nobody could reach his excellent Latin or his outstanding historical skills. ${ }^{63}$ The accompanying poem on Sleidan is equally full of praise. Sleidan is described as the great historian who can see and hear God's deeds, how he blesses those who believe in him and defeats his enemy; and with a 'celestial hand' he describes this in his history. The poem concludes by underlining that nobody else was more worthy of the admiration of his time than Sleidan, who made people comprehend the era they lived in. ${ }^{64}$

\section{A banned Protestant contra Sleidan: Henri Lancelot Voisin de la Popelinière - and Jean}

\section{$\underline{\text { Bodin }}$}

Recent French history, and especially the Wars of Religion, was also the focal point of Henri Lancelot Voisin de la Popelinière (1541-1608) in his La Vraye et Entiere Histoire de ces derniers Troubles. This work was first published in Cologne in 1571 in ten books, and, like La Place's work which La Popelinière admired, omitted the name of the author. ${ }^{65}$ In this first edition the author's future troubles were already beginning to cast their shadows: in the author's preface one reads that many people had warned him to delay the publication of the work since it would displease Protestants and Catholics alike, a prediction that proved all too true. ${ }^{66}$

\footnotetext{
${ }^{63}$ Ibid., fols. I2r-v.

64 '...Mais pourroit on trouver homme qui peust descrire/ Les effects du soleil celeste renaissant,/ Ou les defauts du monde en sa nuict perissant,/ Brief du Dieu Souverain la grand' douceur \& l'ire ?/ Voici l'historien, qui de celeste main/ La face de temps depaint à tout humain/ Qui void ce qu'il faut voir, qui a cœur pour entendre.

Si que dire ne puis, lequel a merité/ D'estre plus admiré de la posterité,/ Ou ce temps, ou Sleidan qui nous le fait comprendre.' (Ibid., fol. I3v).

${ }^{65}$ Henri Lancelot Voison de La Popelinière, La Vraye et Entiere Histoire de ces derniers Troubles: advenus, tant en France, qu'en Flandres, \& pays circonvoisins. Comprinse en dix Livres. Dediee a la Noblesse de France, Cologne (Arnould Birckman) 1571.

66 'Vous iugerés du devoir que $\mathrm{j}$ 'y ay fait. Et m'asseure, quant à la verité, que vous ne vous eslongnerés gueres de mon opinion. Elle y est si expresse, que maints personnages envieux du profit \& contentement qu'un chacun y pourra prendre, m'en ont voulu faire retarder l'edition, m'asseurans qu'elle desplairoit, tant aux Catholiques que Protestans...' (ibid., fol. *3 v). Sleidan had encountered similar problems both in the
} 
La Popelinière, born in 1541, had chosen a military career in the Huguenot camp. He fought alongside Le Fèvre, Condé and La Noue and took over the leadership of La Rochelle in La Noue's absence. At the same time, he was engaged in diplomatic missions on behalf of the Protestants. Like Sleidan's Commentaries, his work proved to be a bestseller. Encouraged by the popularity of the first edition and the belief in his own qualities as a historian, La Popelinière continued to work on the history, and in 1572 a revised edition was published, comprising 14 books (Basle: Pierre Devantès), while the 1578/79 edition (Basle: Barthelemy Germain) contained $18 .^{67}$

In 1581 the final version was published by Pierre Haultin in La Rochelle, as Histoire de France. This edition finally revealed the author's identity, who after the popularity of the former editions expected nothing but praise for his work. ${ }^{68}$ Like Sleidan, he largely relied on his insider's perception of recent events, based on primary sources, which he wanted to share with the public in a balanced, critical approach. Hence he avoided the usual eulogies on one's own side in the religious controversy and polemic against the opponent, and used neutral terms rather than polemical ones, like 'Catholics' instead of 'Papists'. Equally, he saw the reasons for the outbreak of the religious wars on both the Catholic and Protestant side, and did not refrain from pointing out atrocities committed by both parties. To avoid an immediate condemnation of his work by the Catholics, La Popelinière dedicated it to Henry III and Catherine de Medici. This gesture was not well received by the Protestants, however, who regarded it as an insult. Like

\footnotetext{
months preceeding the first edition of the Commentaries and with the publication of the first German and French translations; see chapters 3 and 4.

${ }^{67}$ On the different editions, cf. Jean-François, 'Les premières éditions des ouvrages historiques de La Place et de La Popelinière', Revue Francaise d'Histoire du Livre Nouvelle Série 50 (1986), pp. 126-135.

${ }^{68}$ Henri Lancelot Voison de La Popelinière, L'Histoire de France. Enrichie des plus notables occurrances survenues ez Provinces de l'Europe \& pays voisins, soit en Paix soit en Guerre: tant pour le fait Seculier qu'Eclesiastic: Depuis lan 1550 iusques a ces temps, (s.l.: Abraham H.) 1581.
} 
Sleidan, La Popelinière had intended to please both sides, and had managed to displease both.

One of the first reactions to the Histoire de France came from Henri de Navarre, who wrote to the magistrates of La Rochelle on 3 June 1581 to complain about 'ung nommé Popellynyère', who had written against his reformed religion and his house, and urged them to punish both author and printer. ${ }^{69}$ This demand was followed promptly by Odet de Nort, La Rochelle's leading minister. At his insistence La Popelinière's history was officially condemned at the meeting of the national synod of Calvinist churches in $\mathrm{La}$ Rochelle in the summer of 1581 , on the grounds that it 'speaks in many places very irreverently and irreligiously of holy things, and that it contains several things vain, profane, full of falsities, lies, and calumnies, to the prejudice of God, the detriment and dishonor of holy doctrine and reformed religion, and to the defamation of several worthy people both living and deceased. ${ }^{70} \mathrm{La}$ Popelinière was ordered to recant and rewrite his history. The ministers themselves went through the work and drew up a list of corrections, with the aim of improving the Protestants' image. ${ }^{71}$

\footnotetext{
69 ‘...de vouloir faire faire telle et si exemplaire justice d'ung Popellynyère et de son imprimeur, qu'elle donne occassion de retenyr les aultres en leur debvoir.' (Joël Cherbuliez (ed.), La France Protestante ou Vie des Protestants Francais qui se sont fait un nom dans l'histoire, Paris 1853-59, vol. 9, p. 530).

${ }^{70}$ George Wylie Sypher, 'La Popelinière's Histoire de France: A case of historical objectivity and religious censorship', Journal of the History of Ideas 24 (1963), p. 44, originally taken from John Quick, Synodicon in Gallia reformata, London 1692, p. 138 and the acts of the synod of La Rochelle, 9 July 1581, Bibliothèque Nationale de France (BNF), Coll. Dupuy, vol. 744, fol. 254r. The text continues to read: 'And moreover [the synod] has decided that all the churches ought to be warned of this, so that they may guard themselves against it and suppress the book insofar as the are [informed] of it. And by the same judgment [the synod] has declared the author of the said book, if he calls himself one of ours, unworthy to be recognized in the communion of the saints and admitted to participation in the sacraments until he has confessed his fault and atoned by suitable means for the scandal which he has inflicted on the churches.'

${ }^{71}$ Kevin C. Robbins identified a hand-corrected copy of the Histoire de France in the Bibliothèque Municipale of La Rochelle (Rés. $40 \mathrm{~A}$ ), cf. his article 'Rewriting Protestant history: printing, censorship by pastors, and the dimensions of dissent among the Huguenots - the La Popelinière case at La Rochelle, 158185', Andrew Pettegree, Paul Nelles, and Philip Conner (eds.), The Sixteenth-Century French Religious Book, Aldershot 2001, pp. 240, 251.
} 
La Popelinière was as shocked by such a negative reaction as Sleidan had been, and similarly set out to defend himself against these allegations. In letters to Navarre and Condé he admitted that he 'might have written too briefly or unclearly and so have given material to men of bias or of weak understanding', but insisted on his good will and orthodoxy. At the same time he warned that if Protestants did not write down their history future generations would only learn about these events from biased Catholic accounts. ${ }^{72}$ In a letter to Bèze he underlined his commitment to the Protestant faith and the service of God. He explained to him that with the dedication to Henry III and Catherine de Medici he had intended to address both confessional sides with his history. ${ }^{73}$ To a friend La Popelinière complained that the proceedings of the Protestants ministers against him had been performed 'in the style of the Spanish Inquisition'. ${ }^{74}$ Despite all attempts to clear himself of false allegations La Popelinière could not avoid having to sign a general confession of error on 12 February 1585 . At this time, however, numerous copies of the original version were circulating and he himself actually never made changes to the text. In 1608 La Popelinière, who never recovered his integrity and honour, died 'of a disease common to men of learning and virtue, that is, of misery and of want. ${ }^{, 75}$

La Popelinière referred to Sleidan's Commentaries several times within his work, but these handful of references differ in no discernible way to his treatment of other authors. In the preface to the 1571 La Vraye et Entiere Histoire de ces derniers Troubles, however, he drew attention to several authors writing about political and religious events under Charles V. In his view, all these historians, Protestant and Catholic alike, be it Louis

\footnotetext{
${ }^{72}$ Cf. Donald R. Kelley's transcriptions of manuscripts of the Bibliothèque Nationale, Paris, MSS, Collection Dupuy, vol. 744, 'Lettres et memoires touchant l'Histoire de Lancelot du Voisin, Sr de la Popeliniere', fol. $240 \mathrm{r}$ (undated) and fol. $238 \mathrm{r}$ (12 August 1581), in The Writing of History and the Study of Law, Aldershot 1997 , p. 780.

${ }^{73}$ Ibid., pp. 779-780, letter transcriptions from BNF, Collection Dupuy, vol. 744, Ms. fols. 235 r-236 r (15 January 1581), fol. $237 \mathrm{r}$.

${ }^{74}$ Ibid., p. 782, from BNF, Collection Dupuy, vol. 744, Ms. fol. 263 r-v.

${ }^{75}$ Ibid., p. 777, quoted from L.-R. Lefèvre/A. Martin, Journal de l'Estoile pour le régne de Henri IV, Paris 1958, vol. 2, p. 412.
} 
d'Avila, Hortensius, or Sleidan, contradicted each other, according to him, their pens had been led by their passion for their respective church. Sleidan seemed to him 'to belong to no other rank than that of a church historian: because his first motif, and last aim, was to concentrate his narration totally on religion, [with] some short discourses on secular and religious matters: which are $[\ldots]$ so short, and of so little instruction, that in this respect he should rather be called chronicler than historiographer. ${ }^{76}$ Such a criticism of Sleidan by a Protestant historian seems surprising and is indeed rather unusual for the time. It seems to be an especially harsh judgement when considering that La Popelinière's aims and methods as well as his fate as a historian had in so many ways been similar to Sleidan's.

After he had signed the confession of error in 1585 , not much was heard of $\mathrm{La}$ Popelinière until 1599, when he published L'Histoire des Histoires. ${ }^{77}$ This theoretical work on history stemmed from his extensive reading of the works of Jean Bodin (15301596), mainly his 1566 Methodus ad facilem historiarum cognitionem. ${ }^{78}$ In this work on the philosophy of history, Bodin had described three different ways of writing history, that of inventing subjects and elaborating on them, the compilation of already existing histories, and the correction of old histories. In his analysis of historians it becomes clear that his view on Sleidan was quite different from La Popelinière's.

\footnotetext{
${ }^{76}$ 'L'Empereur Charles cinquième, qui si heureusement feist faire ioug aux forces Alemandes, \& plusieurs autres, que Protestans, qu'Imperiaux, ont receu les histoires des troubles d'Alemagne pour le fait de la Religion, mises en lumiere par Loys d'Avila, Sleidan, Hortense, \& plusieurs autres, qui presque tous se contrarioyent, selon les passions qui leur commandoyent (encor que Sleidan ne me semble devoir estre couché en autre rang, que des Historiens Ecclesiastics: car son premier motif, \& dernier but, fut d'embellir seulement son narré de Religion, par quelques briefs discours du fait seculier \& politie: qui sont au reste si courts, \& de si petite instruction, que pour ce regard il doit plustost estre nommé Chroniqueur, qu'Historiographe.' (My translation ; La Popelinière, La Vraye et Entiere Histoire, Cologne (Arnould Birckman) 1571, fol. *4 r).

${ }^{77}$ Henri Lancelot Voison de La Popelinière, L'Histoire des Histoires, avec l'idée de l'histoire accomplie. Plus le dessein de l'histoire nouvelle des François. This work was published by Marc Orry in Paris. I consulted the reedition edited by Philippe Desan, Paris 1989.

${ }^{78}$ I consulted an edition from 1610: Jean Bodin, Ioannis Bodini Methodus ad facilem historiarum cognitionem; accurate denuo recusa: Subiecto rerum Indice, Geneva : Jacob Stoer 1610.
} 
In the Methodus, Bodin also examined existing histories as to their historical value. Amongst those mentioned was Sleidan, listed amongst the authors qualified to analyse and judge their times correctly, along with Macchiavelli and a few others. ${ }^{79}$ Sleidan was also ranked among what for Bodin were the best writers, that is those which were read and closely scrutinised by their contemporaries, like Thucydides, Sallust, Xenophon, Commynes, Guicciardini, and Caesar. ${ }^{80}$ Though honoured as one of the best historians and recommended for reading, Sleidan also attracted the criticism of Bodin: he was allegedly partial to those he worked for or was close to, like Francis I, the Duke of Saxony, Jean Du Bellay and John à Lasco. ${ }^{81}$ Why Bodin should mention John à Lasco among those Sleidan was partial to is unclear. Although à Lasco as minister and theologian is mentioned several times in the Commentaries, Sleidan had no direct relations with him. À Lasco appeared only one time in connection with Sleidan, when he signed the petition for Sleidan's English pension initiated by Bucer. ${ }^{82}$

Apart from his comments on Sleidan, we mention Bodin here primarily because La Popelinière's 1599 work was a close analysis and criticism of the work of Bodin discussed above, composed in the form of a fictitious dialogue with Bodin. L'Histoire des Histoires calls for a historian who does not intervene in the narrative and stays as objective as possible. La Popelinière underlined that it had been Sleidan's aim to set out the events

\footnotetext{
79 'Atque haec cum bona eorum venia dicta sint, qui nuda historia nihil magis insipidum esse putant. Neque enim magnorum virorum de rebus gestis iudicia reprehendo, si modo tales sunt, qui recte iudicium ferre possint. Laudatur ... in principum arcanis \& aulicavita, Tranquillus, Lampridius, Spartianus, Sleidanus, Machiavellus.' (ibid., fol. D3v).

80 'Optimi vero scriptoris indicium est ab omnibus probari, eo praesertim tempore quo vigentii, qui rebus gestis interfuerunt, in quo genere sunt opinor, Thucydides, Salustius, Xenophon, Cominius, Guicciardinus, Caesar, Sleidanus ...' (ibid., fol. D4r).

81 'At Thucydides Periclem, Sleidanus Franciscus regem, ducem Saxonium, Bellaium, Alasconem verissimis ac propriis laudibus extulerunt, comparationes tamen odiosas reiecerunt. ... fuit enim Sleidanus Francisci regis interpres, \& pro sua Republica legationes saepissime suscepit. cum autem praecipue de religionibus (ut erat pius ac religiosus) scribere proposuisset.' (Ibid., fols. D4v/p. 56). Bodin included Sleidan's Commentaries in his list of recommendable histories towards the end of the work under 'Historici Christiana religionis' (ibid., fol. X8r).

${ }^{82}$ Cf. Appendix I, No. 209; chapter 3.
} 
resulting from the Reformation, and actually acknowledged that in this respect he had succeeded, not losing authority despite the attacks of his enemies. Yet again $\mathrm{La}$ Popelinière stuck to his former conviction that Sleidan should be counted among the ecclesiastical historians, not among the secular ones. ${ }^{83}$

As we have seen, Sleidan's Commentaries had a great impact on France. This showed itself not only in sales figures, but - equally manifold and impressive - in the reception of his work by French historians. Essentially, reactions towards the work of Sleidan - ironically called the 'Livy of the Lutherans' by one of his most raging critics, Florimond de Raemond - were similar to those in Germany, ranging from enthusiastic praise through disguised usage of the Commentaries down to open criticism. ${ }^{84}$ In Germany, however, the tumult that followed the publication of the Commentaries soon died away, and apart from a few exceptions Sleidan's work was quickly accepted. In France instead, with a totally different political and confessional situation, Sleidan's work would be eagerly examined by all confessional groups and discussed on paper. The Commentaries would be discussed throughout the sixteenth century, since the issues considered there were still prominent in France until the end of the religious wars and the ensuing peace.

Especially in the first decades after the publication of the Commentaries, any criticism of the work had a highly confessional tenor to it. However, it was not simply the case that the Protestants supported Sleidan and the Catholics opposed him. Theodore de Bèze offered the kind of hagiography of Sleidan that one would almost naturally expect from a Protestant. La Popelinière's attitude towards Sleidan on the other hand was quite

\footnotetext{
${ }^{83}$ La Popelinière, L'Histoire des Histoires, p. 392-393.

${ }^{84}$ Florimond de Raemond, L'Histoire de la Naissance, Progrez et Decadence de L'Heresie de ce Siecle, Rouen (Daniel Loudet) 1647, fol. A2v.
} 
contrary to Bèze's, and also to Bodin's. He would allow Sleidan only the title of a chronicler, or a church historian, because he had narrated religious events - not too dissimilar from himself. On the Catholic side, readings of Sleidan were even more interesting. Several attempts to compose a criticism or even refutation of Sleidan were made, which were often restricted to an attack on his Protestantism rather than a constructive assessment of his historiographical method and accomplishment. Strikingly, some Catholics would even shamelessly use evidence from Sleidan in the literary battle against the Protestants.

\section{A Catholic refutation: the work of Simon Fontaine}

Only three years after the Commentaries were first published, the Parisian doctor of theology Simon Fontaine wrote the Histoire de notre temps, a 'History of our time', the only real refutation of Sleidan in France. ${ }^{85}$ This work was first published in 1558 in a French edition and a Latin translation by Roverus Pontanus. The same Pontanus had also translated the German refutation by Caspar Gennep, who in turn printed Fontaine's Latin work. Fontaine's Histoire was to a large extent a translation or paraphrase of the 1549 Commentaries on the acts and writings of Luther by Johannes Cochlaeus (1479-1552), one of the earliest attempts to write a history of the German Reformation. ${ }^{86}$ Both works,

\footnotetext{
${ }^{85}$ Simon Fontaine, Histoire catholique de notre temps, touchant l'estat de la religion chrestienne contre 1'histoire de Jean Sleydan, Antwerp (Jean Steelsius) 1558. Latin version: Historiae Ecclesiasticae nostri temporis, libri XVII. In quibus preterquam nuda veritas, \& rerum gestarum series fideliter recensetur, etiamque multa quae Iohannes Sleidanus in suis de Statu Religionis \& Reipublicae Commentariis nugatur. luculentissime reteguntur, Cologne (Caspar Gennep) 1558. Hardly any reference to Fontaine is found elsewhere, nor are the dates of his life known. The entry in Michel Simonin (ed.), Dictionnaire des Lettres Françaises. Le XVIe siècle, Farese 2001, p. 523 only describes Fontaine as 'théologien et historien dont on a plus vanté le zèle que la capacité.' - On Gennep and Pontanus, cf. chapter 5.

${ }^{86}$ Johannes Cochlaeus, Commentaria Ioannis Cochlaei, de actis et scriptis Martini Lutheri saxonis, Chronographice, Ex ordine ab Anno Domini M.D.XVII. usque ad Annum M.D.XLVI. inclusive, fideliter conscripta, s.1. 1549. This work, though immensely popular, focused primarily on theology and polemic against the Protestants, especially Luther. As an attempt to describe a period of history it failed in a modern sense. Sleidan mentioned this work both in his dedication and apology to the Commentaries as a negative example of a history. In the dedication, he did not mention Cochlaeus' name, but characterised his work as 'stuffed with Accusations, Slaunders, Trifles and Reproaches.' In the apology, he actually named Cochlaeus, whose history was full of 'horrible, unheard of, and invented flaunders.' (Both quotations from Bohun, General History, fols. A2v, b2v).
} 
however, were characterised by religious polemic rather than historical examination. At this stage it is worth attempting a comparison between Sleidan's Commentaries and Fontaine's Histoire.

Fontaine had chosen the title Catholic (in the French version) or Ecclesiastical History (in the Latin version) of our time, ... against the history of John Sleidan for his work, advertising its polemical purpose on the title page. Fontaine's preface offers some striking parallels but also differences when compared to the preface of Sleidan's Commentaries. Sleidan set off with a quick run through world history as foretold in the bible, a kind of summary of his Four Empires. Fontaine on the other hand started with a Ciceronian description of history. Both authors offered the motives behind their work: Fontaine mentioned his calling to write an ecclesiastical history as a new Eusebius. Sleidan instead described how he had been asked to compose a history, wondering whether he would have the required talents to do well. Both authors claimed not to use any 'ornaments' and to tell nothing but the truth. Not surprisingly, their respective visions of the truth were very different from one another.

When examining the outer framework of the two histories, one can already see fundamental disparities. Sleidan described the years 1517 - 1556 in 26 books, Fontaine started in the same year and carried on his narrative in 17 books up to 1546 , the year of Luther's death. Sleidan strode in fairly even steps in a chronological manner through history and tried to describe all important events, often in great depth. Fontaine on the other hand picked out the times which offered most room for criticism; for example he covered the year 1521 in two books but rushed through the period 1535-1543 in one book. The starting point for both was Luther and his 95 theses. However, from here onwards the two stories drift apart. Sleidan set off to describe the course of the Reformation started by 
Luther, born as an ordinary man into an ordinary family. Fontaine with his polemical purpose interpreted this differently: Luther was conceived by the devil who, in the form of a handsome young man, often visited his mother before her marriage. ${ }^{87}$ The confessional stand of Sleidan and Fontaine becomes clear in their definition of good and evil. For Sleidan, Luther assumed the role of the hero with the Pope as antagonist, the Antichrist. Fontaine inverted this, the Pope is the keeper of good faith, challenged by the Antichrist that is Luther. This role distribution determines the narrative of the entire work, for Fontaine every word and deed of Luther proved his fanatical and devilish nature. ${ }^{88}$

Despite the title of Fontaine's book, Sleidan never really plays a dominant role in the entire work. In that Fontaine's Histoire is very similar to Gennep's German refutation. Sleidan does not feature before the end of the first book, where he is accused of glorifying Luther's behaviour during his interview with Cajetan. ${ }^{89}$ Generally, Sleidan is more often referred to as a reliable source rather than as a work to be refuted, as we have observed with Gennep. This is for example the case with Fontaine's description of the rise of anabaptism in Münster or the Augsburg confession, both based on Sleidan's account. ${ }^{90}$ Fontaine corrected his opponent on the circumstances surrounding Zwingli's death and accused him of minor errors, like exaggerating Hermann von Wied's reform in Cologne or overemphasising Protestant efforts at reconciliation at the Diet of Regensburg. ${ }^{91}$ His

\footnotetext{
${ }^{87}$ 'Ce que j' ayme mieux affermer, que de m'arrester à l'opinion probable redigee en escrit, laquelle maintient que ladicte Marguerite la conceu par operation d'un diable, qui en figure d'un jeune homme coucha quelquefois avec elle, avant qu'elle fust mariee avec ledit Jean Luder.' (Fontaine, Histoire, fol. C1r). ${ }^{88} \mathrm{Cf}$. for example Fontaine's remark on Luther's time at the monastery in Erfurt: '....il est certain qu'en un sermon il à publiquement dit qu'il cognoissoit bien le diable, \& le diable luy: \& qu'ils avoient mangé ensemble plus d'un morceau de sel.' (ibid., fol. A8r). Later on Fontaine referred back to this when again underlining Luther's pact with the devil: 'Or iuge, lecteur, si comme $\mathrm{j}$ 'ay allegué au premier liure, Luther ne fait ici subçoncer de la familiarité \& colloques, qu'il auoit par fois auec le diable?' (ibid., fol. H5v).

89 'Jean Sleidan en ses Commentaires pour ne rien dire au preiudice de Luther, racompte ce faict au large, \& tellement que Luther mesme ne l'eust peu faire si proprement.' (ibid., fol. C1r).

${ }^{90}$ Ibid., fols. I3v and X7r.

${ }^{91}$ Ibid., fols. f2r and f5v.
} 
criticism of Sleidan is confined to a few corrections of certain misrepresented events motivated by Sleidan's partisanship to Luther.

When comparing the methods of the two authors, one can see a marked difference. The Commentaries are structured by the events of the Reformation, the Histoire follows Luther's life and ends with his death in 1546. Sleidan as a lawyer, politician and historian was very much concerned about documentation and quoted more than 500 documents, often at great length. His account offers a large number of documents, loosely embedded into a narrative. On the other hand Fontaine used a limited number of primary material, mainly parts of the writings of Luther, Cochlaeus and Sleidan, which are selected to fit his argument of Luther as the antichrist.

Sleidan attempted not to betray his role as author in the narrative. Even with events he was involved in he mentioned his name only occasionally, and then in the third person, avoiding to address the reader directly. Fontaine instead concentrated on his task of showing Luther as the antichrist. Throughout his book, he is present as the author, and very passionately so. He offers interior monologues of Luther, has mock conversations with him and shows his own despair with the antihero. Throughout the work, comments and exclamations are directed towards the reader, rhetorical questions are to be found on nearly every page. $^{92}$ This whole interactive style, so very different from Sleidan, highlights the polemical purpose of his work.

\footnotetext{
${ }^{92}$ Fontaine's description of the immediate events before the outbreak of the Peasants' War and the role the reformed teachings played serves as a good example to illustrate his language: 'Et quel esprit monstre avoit Luther, lecteur, qu'il ayt monstré, qu'on ayt peu congnoistre, sinon l'esprit de contradiction, blasphemes, contumelies, impostures, mensonges, iniures, execrations, abominations, audaces, menaces, ordures, villennies, mocqueries, brocars, divisions, seditions, inobeissances \& irreverences? Aprent on autre chose en la lecture de ses livres? Chanta il jamais autre chose en ses sermons?' (ibid., fol. N1r).
} 
In order to show how different the perspective of a Sleidan as a Protestant and Fontaine as a Catholic author were, it is interesting to compare their descriptions of one particular event. The story of the unfortunate Protestant martyr Pierre Brully, almost a saint for the Protestants, but an heretical enemy of the faith for the Catholics, would be a good example. ${ }^{93}$ Brully, a Protestant preacher and Calvin's successor in Strasbourg, arrived in Tournai in late 1543 , where he gave many sermons to his huge number of followers. After a while, word was brought to him that the city authorities were trying to capture him. With the help of his friends, he managed to climb down the city wall and arrived safely on the ground, as one of his friends leaned down to wave good bye and set a stone loose. Unfortunately, this stone fell down and landed on Brully's leg. Brully moaned and groaned in pain, which in turn alarmed the city guards who captured him. Up to this point, the story is the same in both works, albeit Sleidan finds it unfortunate, Fontaine amusing.

As the story continues, we can see the divergence of perspectives. For Fontaine, Brully met his just fate in being condemned to 'roast' slowly for greater torment in February 1544. Strasbourg, Saxony and Hesse got to know of the planned execution and pleaded for the convicted. In trying to please the supplicants who pleaded for Brully, the Catholics in an act of mercy allowed to have Brully burned faster so he would suffer less. In his account, Fontaine confined the narrative to the main points of the plot, arrest, condemnation and lenient execution. Details about the person of Brully and his beliefs are omitted in a description that stays away from emotions. From a Catholic point of view, Brully was a heretic who met his just punishment.

\footnotetext{
${ }^{93}$ The account of Pierre Brully's martyrdom can be found in Fontaine, Histoire, fol. G3r; and in Sleidan, De Statu Religionis \& Reipublicae, Strasbourg (Josias Rihel) 1559, fols. Gg5v-6r.
} 
Sleidan instead used the story for Protestant propaganda. His account describes the usual stages of the demise of a Protestant martyr from arrest to execution, well known from the martyrologies of Crespin, Foxe, Rabus and Haemstede. The focus lies on Brully's constancy in confessing the Protestant faith. From prison, Brully wrote letters to family and friends encouraging them to remain steadfast in their faith. During the trial, he was asked to give his opinions on various doctrines and articles of faith, such as the Eucharist, purgatory, mass, baptism, confession, free will, good works and justification, which conveniently presents the opportunity of a long summary of Protestant doctrine. In Sleidan's account, the pleading letters from the Protestant states arrived too late. Brully was burned slowly, 'professing his doctrine even to the last breath', showing Catholic cruelty and Protestant heroism. One event - two stories. It shows us how differently the two denominations could regard the same event. For Sleidan, a righteous martyr died, for Fontaine a heretic found his just death.

Fontaine's history, similarly to that of Gennep in Cologne, did not provide a constructive criticism of Sleidan nor can it justly be called a refutation. In both cases, critique of Sleidan and his work turned out to be more of a side issue, despite ardent promises in the prefaces to offer a proper refutation of Sleidan. Fontaine offered no indepth criticism of Sleidan or a real attempt to rectify historical incorrectness. Fontaine's only real accusation against Sleidan was that he wrote his history with the purpose of showing Luther in the most positive light possible and therefore twisted the truth. His focus was to portray Luther as the devil and the Catholic church as the only true church. Fontaine's Histoire was much more a theological than a historical work, coloured by polemic. 
Fontaine's refutation of Sleidan's Commentaries did not quite fulfill what it had promised in its thundering title. It provided neither a detailed criticism and corrections of Sleidan's errors nor a reliable, complete account of the Reformation. Instead, Fontaine surpassed Sleidan in that point about which he had criticised him most: partisanship. It is interesting to note that the only French copy to openly advertise Fontaine's work as a refutation of Sleidan was that printed by Jan Steelsius in Antwerp in 1558. The Paris edition printed in the same year by Claude Fremy and other later editions reduced the title to Histoire catholique de notre temps, touchant l'estat de la Religion Chrestienne, without any allusion to its refutational purposes. The references to Sleidan in the text itself are reduced to a mere handful. ${ }^{94}$ One wonders whether contemporaries were not pleased with Fontaine's attempt of a refutation of Sleidan, or whether Sleidan as a historian was so tolerated and popular at the time that not many were interested in a critique of his work.

Fontaine's Histoire seemed to be the only French attempt of a refutation of Sleidan. It turned out to be so unpopular or so uneffective that in later editions references to the original purpose or criticism of Sleidan in the text itself were omitted. Only few Catholics would express their disagreement with Sleidan on paper, and then confine themselves to occasional remarks.

\section{Catholic polemic: Florimond de Raemond}

One of the more prominent French historians to mention their disagreement with Sleidan was Florimond de Raemond (ca. 1540-1601). After a short liaison with Protestantism the counsellor of the Parlement in Bordeaux had become an ardent defender of the Catholic

\footnotetext{
${ }^{94}$ I consulted a copy of 1562 , Simon Fontaine, Histoire catholique de notre temps, touchant l'estat de la Religion Chrestienne, Paris (Guillaume Julien) 1562.
} 
faith. ${ }^{95}$ His L'Histoire de la Naissance, Progrez et Decadence de L'Heresie de ce Siecle was published after his death in 1605 . He had composed his work in French to enable his readers to find out the truth about the threatening heresies of the time. ${ }^{96}$ Like Sleidan's Commentaries, Raemond's Histoire was dedicated to the Reformation period, already labelled 'heresy' on the title page. In eight books, Raemond examined the spread of the Reformation in Germany, Eastern Europe, the British Isles and France. The general method resembles that of the Magdeburg Centuries, with each book concentrating on a special topic, which is then approached in a semi-chronological order. All in all Raemond offered less a reliable, source-based description of events than a polemical condemnation of Protestantism. From his point of view, the church had lived in peace until Satan in the form of Luther and his followers appeared. These troubles had already been foretold in the bible and by astrologers, and were also reflected in widespread sedition and wars.

Raemond's argument was largely based on the Bible and Church Fathers; like Fontaine, his main purpose was to attack Protestantism. The style of his narrative is again similar to Fontaine, a very passionate and angry author trying to interact with his reader. ${ }^{97}$

Though not officially providing a refutation of the Commentaries, Sleidan's 'false history' is a recurring theme in Raemond's work; he denied him the title 'historian' and preferred to call him a 'liar'.98 ${ }^{98}$ Throughout the text, we find criticisms of Sleidan's method and conclusions, 'twelve thousand lies' can be discovered. ${ }^{99}$ In Raemond's view Sleidan had falsely described the heresies of his time, his purpose was to bring things into the right

\footnotetext{
${ }^{95}$ For biographical information, cf. Barbara Sher Tinsley, History and Polemics in the French Reformation. Florimond de Raemond: Defender of the Church, Selinsgrove/London/Toronto 1992, ch. 1.

${ }^{96}$ Raemond's Fistoire de la Naissance was first published in 1605 by Simon Millanges in Bordeaux. I consulted a 1647 edition (Rouen: Daniel Loudet).

${ }^{97}$ Like Fontaine's Histoire, Raemond also used a large number of rhetoric questions to address the reader directly, for example: 'Innocente posterité qui te riras de nos folies, ou plutost qui pleureras de nos miseres, pourras-tu jamais croire que le veritable tableau de l'Heresie, que je vais tirer au naturel, te representera? Croiras-tu qu'un seul siecle ait peu porter tant des monstres ? un seul Moine produire tant d'Apostats ?' (fol. $\mathrm{H} 3 \mathrm{r}$ ).

${ }_{98}$ Raemond, L'Histoire de la Naissance, fols. A2r-v.

${ }^{99}$ Ibid., fol, A2r.
} 
perspective again. To this end Raemond even incorporated two astrological tables into his work, both illustrating negative star constellations for the general time period as well as for Luther's birth. ${ }^{100}$ Like Fontaine, Raemond criticised Sleidan's partisanship when at the same time he failed to disguise his own.

Raemond openly expressed his hatred for the one who "has cloaked and adorned the heresy in such beautiful colours, so that one could say it is the chaste spouse of Jesus Christ, ... plastering his history with so many lies and falseties that one single author could (easily) well dare to find $11.000 .^{101}[\ldots]$ Sleidan disguises often, and hides away what is reproachable in Luther, ... whom he rebuilds and pulls to his advantage, not always that well, [so] that the wrinkles and stains do not vanish totally. He could not plaster them so much that his pride, his hypocrisy, his presumption, and his carnal and dismeasured passions would not show themselves [at] every time. ${ }^{102}$ Raemond's mission was to offer an antidote to the book of 'the Titus Livy of the Lutherans', whose work was 'in the hands of everybody, in all languages'. ${ }^{103}$ Raemond then underlined the fact that he had written his work in the vernacular, since the Protestant writers themselves had done so in order to incite more people to rebellion - an argument misdirected in the case of Sleidan who-in fact did not publish his Commentaries in the vernacular at first, but in Latin.

\footnotetext{
${ }^{100}$ Ibid., fols. b6v-7r: the tables prove Luther to be another Antichrist after Mohammed.

${ }^{101}$ The subject tables at the end of the work even attributed 12.000 lies to Sleidan (Raemond, L'Histoire de la Naissance, fol. Bbbb 5r).

102 .... [il] a revestu et paré l'Heresie de si belles couleurs, qu'on diroit que c'est l'Espouse chaste de JesusChrist, ... plastrant son Histoire avec tant de mensonges et faussetez qu'un seul autheur en a bien osé remarquer onze mille. [...] Sleidan desguise souvent, et cache ce qui est reprochable à Luther, sous je ne sçay quelles parties, qu'il releve et tire à son advantage, non toutesfois si bien, que les rides et taches n'y paroissent par tout. Il n'a peu tellement les plastrer, que son orgueil, sa fierté, son outrecuidance, et ses charnelles et desmesurees passions, ne s'y voyent à tous coups.' (My translation; Raemond, L'Histoire de la Naissance, fol. A2v).

103 'Ce livre de Tite-Live des Lutheriens est en la main d'un chacun, en toutes langues, fort plaisantes \& delectables ... ' (my translation; Raemond, L'Histoire de la Naissance, fol. A2v). This remark again shows the popularity of Sleidan's works, especially when it comes from the pen of a Catholic author.
} 
The reactions of Fontaine and Raemond towards Sleidan, at the middle and end of the sixteenth century, are just what one would expect from Catholic historians: a fierce counterattack on their Protestant opponent. As ardent Catholics, they felt obliged to defend their faith with long tirades against a seemingly untrustworthy Protestant. As historians, their objective was to correct Sleidan's mistake and to provide a better account of the period described. Both works, however, offered more polemic than a historical evaluation of Sleidan's work. They did certainly not succeed in minimising the popularity of the Commentaries. These continued to be read across denominations, since in France the religious question was not yet solved. Sleidan was read for possible answers, with sometimes surprising outcomes, as will be seen when examining the historians Noel Tallepied, Gabriel de Saconay, an anonymous author, Nicolas Vignier, or Paolo Sarpi. They were all Catholics, but did not hesitate to use evidence taken from Sleidan for their historical description. In some cases, they even based their anti-Protestant polemic on evidence derived from the Commentaries, conveniently ignoring the fact that the very source from which they drew their arguments was a Protestant one.

\section{Sleidan as a source for Catholic historiography: Noel Tallepied}

One such case was the French priest Noel Tallepied (1540-1589) with his Histoire des Vies, Meurs, Actes, Doctrine, et Mort de quatre Prinicipaux Heretiques de nostre Temps. ${ }^{104}$ The title page announces that "this whole work was made to advise and admonish the Catholics not to let themselves be tempted and abused by the heretics' mortifying doctrines'. ${ }^{105}$ In this tract, composed together with Hierosme Hermes Bolsec, possibly in 1577 , Tallepied informed the reader about 'the lifes, habits, doctrines and

\footnotetext{
${ }^{104}$ Noel Tallepied, Histoire des Vies, Meurs, Actes, Doctrine, et Mort de quatre Prinicipaux Heretiques de nostre Temps, à sçavoir Martin Luther, André Carlostad, Pierre Martyr, \& Jean Calvin, Iadis ministre de Geneve...., Paris (Jean Parant) (1577).

${ }^{105}$ 'Le tout faict pour advertir \& divertir les Catholiques de ne se laisser abuser par leurs doctrines mortifiees.' (title page).
} 
deaths of the four principal heretics of our time', with the purpose of showing the falsety of Protestantism. These four heretics were Martin Luther, Andreas Karlstadt, Jean Calvin, and Peter Martyr. The book offers the vitae of these Reformers, providing the reader with an outline of their lives, their main writings and their apostasy.

The first chapter is devoted to Luther, and bears the stunning title 'The life of Martin Luther, extracts of the works of Monsieur Simon Fontaine and Sleidan' - a 'heretic' along with his rival as the source of information. In his description of Luther, Tallepied referred frequently to both Fontaine and Sleidan, without ever mentioning the latter's adherence to Protestantism or correcting him on some points. At no point in this section, however, did Tallepied argue against the reliability of Sleidan; he drew the information from both sources, using whatever fitted best into his argument. In the case that the two authors contradicted themselves, Tallepied actually preferred Sleidan to Fontaine.

This work was followed by a later one of a similar title, Histoire des Vies, Meurs, Actes, Doctrine, et Mort de trois prinicipaux Heretiques de nostre Temps, now concentrating on Luther, Calvin and Théodore de Bèze. ${ }^{106}$ In this later version Fontaine and Sleidan still featured in the heading of the section on Luther, but were not mentioned in the text any more. Like the initial work, the author's aim was again more a portrayal of evil heretics than an attempt to present reliable biographies of historical value.

Tallepied and Bolsec had written their Reformers' biographies with the explicit purpose of exposing their mortifying doctrines and deterring Catholics. This aspiration did

\footnotetext{
${ }^{106}$ Noel Tallepied/ Hierosme Hermes Bolsec, Histoire des Vies, Meurs, Actes, Doctrine, et Mort de trois prinicipaux Heretiques de nostre Temps, à sçavoir Martin Luther. Jean Calvin, \& Theodor de Beze, iadis Archiministre de Geneve, Douai (Jean Bogard) 1616.
} 
not prevent them from basing their work on the writing of an adherent of these very doctrines. It was the irony of fate that as their second source they consulted precisely Sleidan's opponent, Fontaine. The use of Sleidan of this kind was not necessarily what one would have expected from Catholic historians. Again this can be explained by the void in France regarding accounts of the recent religious events. It also shows the acceptance Sleidan's Commentaries widely received by the educated elite who regarded him as a reliable source. Even Fontaine with his aim of providing a refutation of Sleidan had simultaneously used him as a source. Other French writers went even further than that, as we will see with one of the works of Gabriel de Saconay.

\section{Gabriel de Saconay: Sleidan in Catholic polemic}

Gabriel de Saconay (?-1580) was an ardent Catholic theologian. Based in Lyon, he composed a number of writings on the religious controversies of his time, often with a fiercely hostile tone. Having experienced the Protestant takeover of the city and its subsequent recovery by the Catholics as well as the outbreak of the Religious Wars, he published polemic and doctrinal works through the 1560 s till the 1580 s. One of these, the 1568 Discours catholique, Sur les causes \& remedes des Malheurs intentés au Roy, \& escheus à son peuple, par les rebelles Calvinistes, critically examines Protestant doctrine and conduct. ${ }^{107}$ The work was published in the typical tenor of the violent anti-Protestant polemic which was characteristic of the first years after the Catholics had regained Lyon after a brief phase of Protestant rule. Accordingly, Saconay's work goes to extremes in its ardent portrayal of the Protestants as mere barbarians and heretics.

Towards the start of the work Saconay analysed the consequences the Protestant movement had had in the German lands, pointing out that Luther preaching his teachings

\footnotetext{
${ }^{107}$ Gabriel de Saconay, Discours catholique, Sur les causes \& remedes des Malheurs intentés au Roy, \& escheus à son peuple, par les rebelles Calvinistes, Lyon (Michel Jove) 1568.
} 
and the princes rebelling against the Emperor had opened the door to mayhem and the intrusion of the Turks. His marginal reference to supporting literature cites book 14 of Sleidan's Commentaries. ${ }^{108}$ As the argument continues, he points out that all actions of the Protestants were to end in trouble, even obvious in the initially rather mild and pleasantly phrased writings to the Emperor. Here the marginal comment even went further, and pointed out that Sleidan had reached exactly the same conclusion on this point. ${ }^{109}$ For supporting his theories, Saconay conveniently ignored the fact that Sleidan was a Protestant author. This in turn enabled him to conclude in the later part of his work that 'the books and writings, histories and paintings' of the Protestants were altogether 'abominable, atrocious and diabolic'.110

Saconay's use of Sleidan was not an isolated case. An anonymous 1572 pamphlet justifying the murder of Coligny and the St. Bartholomew's massacre, Brieve Remonstrance sur la mort de l'Admiral, \& ses adherans also drew evidence from Sleidan. ${ }^{111}$ As a means of portraying the murder of the Huguenots the author referred to the example of Germany where the Protestant princes had risen against their lawful ruler, the Emperor, and had been punished for their folly with defeat and imprisonment. In the margin the author mentioned the source for this information: the histories of Surius, known from chapter 5, and Sleidan's Commentaries. ${ }^{112}$

\footnotetext{
${ }^{108}$ Ibid., fol. A8r.

${ }^{109}$ Ibid., fol. B1r: 'Sleidan en est tout plein'.

110 'Et quant à leurs [the Protestants'] livres \& escritures, histories \& peinctures, qu'ilz font contre nostre Religion, je m'esbahy qu'ilz n'ont honte de vivre, tant elles sont abominables, execrables, \& diaboliques, n'espargnans hommes, ou ordre, qui soyent contre leur goust \& avertin.' (ibid., fol. E1v).

${ }^{111}$ Anon., Brieve Remonstrance sur la mort de l'Admiral, \& ses adherans, Lyon (Benoit Rigaud) 1572.

${ }^{112}$ Ibid., fol. C2r.
} 


\section{League polemic discovers Sleidan}

Saconay was not the only ardent Catholic who consulted Sleidan to support anti-Protestant polemic. A few decades later, he was rediscovered as a source to back up the argument of a fervent Catholic Leaguer in the anonymous Coppie D'Une Lettre Escripte Par Un Catholicque à un Politique, Sur l'Arrest prononcé en la Synaguogue de Tours, le cinquiesme d'Aoust dernier 1591. contre la Bulle monitoire de nostre sainct Pere le Pape Gregoire XIIII from 1591. ${ }^{113}$ The pamphlet argues that the Royalists were not much better than heretics and schismatics and in supporting Henry of Navarre in fact undermined the power of the Pope and endangered the Gallican church.

The anonymous author continued to argue for the authority of the Pope over the king. At the climax of the accusation of the Royalists, they are compared to Henry VIII, who invited heresy into his country only to triumph over the Pope. Just like the Royalists with the 'arrest' referred to in the title, Henry VIII had forbidden his subjects to submit to papal authority, 'as Sleidan witnesses'. ${ }^{114}$ Sleidan as a support for the argument finds himself in illustrious company here: he is the only contemporary author mentioned alongside the Bible, St. Cyprian and St. Augustine.

Sleidan's Commentaries were one of the most popular histories in sixteenth-century France. In the decades after their publication, his controversial work was widely read, by Protestants and Catholics alike. Their respective reactions were not always what one would expect. Amongst Protestant authors opinions stretched from secret or open

\footnotetext{
${ }^{113}$ Anon., Coppie D'Une Lettre Escripte Par Vn Catholicque à vn Politique, Lyon (s.n. [Jean Pillehotte]) 1591. The pamphlet is addressed to 'un Politique', which in this case means a Royalist.

114 'De mesmes fit Henry 8. Roy d'Angleterre, comme le tesmoigne Sleidan, lequel si tost qu'il eut apostasé \& receu l'heresie en son Royaume pour se vanger du Pape, qui n'avoit pas voulu approuver son incestueux adultere, il se declara chef de l'Eglise par Angleterre immediatement apres Jesus Christ : rejetta la Pape \& la Papauté, \& deffendit par edict exprés (comme vous par vostre arrest) à tous ses subjects, sur peine de la vie, de n'attributer souveraine puissance au Pape.' (ibid., fols. A4v-B1r).
} 
admiration to sharp criticism. On the Catholic side, the expected reactions were even more distorted: on one side there was indeed the expected outcry and condemnation, on the other side, any criticism of Sleidan was replaced by a reliance on the Commentaries in the polemical debate against the Protestants. Towards the end of the century and into the seventeenth century, the picture changed again. By then, the initial excitement surrounding works like the Commentaries had subsided. Furthermore, the political situation had changed with the ascendancy of Henry of Navarre, and the religious schism was accepted. Accordingly, the Commentaries had become one of the main sources on Reformation history, and as such was used by historians from both confessional sides, be it Agrippa d'Aubigné as a Protestant or Jacques-Auguste de Thou and Nicolas Vignier as Catholics.

\section{Sleidan canonized? Nicolas Vignier and Paolo Sarpi}

At the end of the century, Sleidan's Commentaries had developed into one of the most widely consulted sources on the Reformation. This was the case not only for Protestants, but also for Catholics. Accordingly, at the turn of the century the royal historiographer Nicolas Vignier (1530-1596) relied heavily on Sleidan's account in his own histories. ${ }^{115}$ In his 1601 Recueil de l'Histoire de l'Eglise, Depuis le Baptesme de nostre Seigneur Jesus Christ, iusques à ce temps Vignier offered an account of the history of the church starting

\footnotetext{
${ }^{115}$ Nicolas Vignier, Recueil de l'Histoire de l'Eglise, Depuis le Baptesme de nostre Seigneur Jesus Christ, iusques à ce temps, Leiden (Christoffle de Raphelengien) 1601. In his 1610 Théatre de l'antichrist, auquel est repondu au Cardinal Bellarmin, au Sieur de Remond, à Pererius, Riberia, Viegas, Sanderus et autres qui par leurs escrits condamnent la doctrine des Eglises Reformees sur ce subjet, s.1./s.n., Vignier also referred to Sleidan as a source (for example on p. 650 : 'Sleidan. Livre 14, de 1'estat de la religion \& de la Republique.'). It has to be mentioned here, however, that as a young man,Vignier had converted to Protestantism and fled with his family to Germany. In the mid-1570s, he decided to abjure and return to France, where Henry III appointed him 'médecin et historiographe du roi' (cf. entry 'Vignier (Nicolas)' in Simonin, Dictionnaire, pp. 1186-1189).
} 
with the birth of Jesus Christ. Sleidan was occasionally mentioned as a source, alongside other historians. ${ }^{116}$ Neither his Protestantism or his work are criticised.

Another historian to consult Sleidan for his own work was Paolo Sarpi (15521623). After accusations of heresy against him, the Catholic cardinal was never able to fully rehabilitate himself. The Italian Sarpi is mentioned in this context because he as a Cardinal provides a good example of how accepted Sleidan had become, but mainly because he was later translated into French by Pierre-François Le Courayer. Sarpi's History of the Council of Trent was apparently first published in London in Italian, and then translated into Latin. ${ }^{117}$

The cardinal prided himself on the neutrality and verity of his writing. However, as had been the case with Sleidan, the reaction towards this work was unforeseen and troublesome. Criticism was voiced mainly by Catholics, Sarpi's own fellow believers, who found themselves portrayed in an unbecoming light. Several refutations against Sarpi's work were published, all from the Catholic side. ${ }^{118}$ Sarpi had tried to base his accounts on a wide range of sources, including eye-witness reports and recent historians, amongst these also Sleidan, whose Commentaries are frequently mentioned. At the very beginning of the history, Sarpi praised Sleidan's description of the Council of Trent as that of a 'strong and exact author [who] carefully wrote about the causes and motives'. ${ }^{19}$

\footnotetext{
${ }^{116} \mathrm{Cf}$. for example Vignier's description of the Reformation, which he also started with Luther's criticism of indulgences, '[q]ui est aussi l'endroict ou Jehan Sleidan commence son histoire de l'estat de la Republique \& de la Religion sous l'Empereur Charles 5.' (Vignier, Recueil de l'Histoire, fol. Llli2v). In other places, like with the account of the Reuchlin affair, Vignier referred to Sleidan's work (ibid., fol. Kkkk3v).

${ }^{117}$ Cf. the biographical notes on Sarpi by the editor Le Courayer in his 1738 edition of Paolo Sarpi, Histoire du Concile de Trente... avec des notes critiques, historiques et theologiques, par Pierre-Francois Le Courayer, 2 vols., Basle (Jean Brandmuller\&fils) 1738.

${ }^{118}$ The most important refutations were Philipp Quorli, Historia Concilii Tridentini Petri Suavis Polani ex autorismet affertionibus confutata a Philippo Quorlio, sacrae Theologiae legumque Doctore, Panormi (Augustinus Boffio) 1661, and Scipio Henrici (Messina), Censura theologica \& historica de concilio Tridentino adversus Petri Suavis Polani pseudohistoriam ad Cardinalem Berhardinum Spadam, Messanae, 1651. The Jesuit Alciati was asked by the Vatican to write a refutation, which was continued and finalised by Pallavicini (cf. Courayer's preface to Sarpi, Histoire, pp. XL-LXXII).

119 'Auteur fort exact en ait décrit avec soin les causes \& les motifs' (ibid., fol. A3r).
} 
In the eighteenth century, Le Courayer, himself a victim of confessional struggles, translated Sarpi's history into French and added an intensive apparatus of footnotes and comments. Quite frequently he corrected Sarpi, offering the Latin quotation of the Commentaries as the tool against which one should measure Sarpi's account. In his comment on the above mentioned reference of Sarpi to Sleidan, Courayer characterised Sleidan as a man 'raised by Catholics and subsequently turned Zwinglian and Lutheran with the city of Strasbourg'. He reported that Sleidan had been helped with the composition of the Commentaries by Jacob Sturm, which he characterised as having been well written and, although partial to the Protestant cause, full of truth. He mentioned that many people had striven to criticise the work and complained about numerous mistakes, but pointed out that these allegations were wrong since Sleidan's work was based on original sources. ${ }^{120}$

Both Nicolas Vignier and Paolo Sarpi, one a historiographer and the other a cardinal whose work was reedited in the early eighteenth century by a Frenchman, had based their own history to a large extent on Sleidan's Commentaries. Their acceptance of Sleidan as a historian was so great that they did not correct Sleidan under any circumstance nor did they ever express concerns about Sleidan's Protestantism or a possible

${ }^{120}$ Cf. ibid., pp. 5-6: 'Cet Historien, qui prit le nom du lieu de sa naissance, nâquit à Sleide village proche de Cologne, au commencement de 1506. \& mourut de peste à Strasbourg au mois d'Octobre 1556. Peu considèrable par sa naissance, il se distingua par son merite \& ses talens. Elevé parmi les Catholiques, il se fit successivement Zvinglien \& Luthérien avec la ville de Strasbourg, qui l'employa en différentes occasions, $\&$ dont il fut député au Concile de Trente. Son Histoire, dans la composition de laquelle il fut aidé par Sturmius, est bien écrite; \& quoique partiale pour la Parti Protestant, on y reconnoit beaucoup de fidélité. Plusieurs de nos Ecrivains ont tâché d'en décréditer l'autorité: mais comme, pour ce qui regarde les affaires d'Allemagne, on voit que tout est appuyé sur des monumens originaux, on ne peut douter qu'à cet égard du moins on ne doive compter sur sa verité, quoique peut-être il puisse y avoir quelques fautes. Sleidan, dit d'Aubigné, L.i.c.i. «est un Auteur qui n'a été ni assez leu ni assez estimé en ce siècle; duquel les labeurs sentent un esprit général, duquel les passions ne $s^{\prime}$ employent que contre le vice, duquel la diligence ne s'attache à aucune chose indigne, \& de qui la grandeur ne meprise rien de convenable à l'Histoire »; loix qui m'ont donné goût de lui, \& m'ont dégô̂té de plusieurs autres. Il est vrai que ce jugement peut paroitre partial, comme venant d'un Protestant : mais pour peu qu'on lise Sleidan sans préjugé, on trouvera dans son Histoire un air de véracité, qui dément un peu l'opinion desavantageuse que s'en sont formé bien des Catholiques.' 
partisanship. Even on the Catholic side, Sleidan had entered the canon of histories sine qua non and had developed into one of the most popular histories consulted on the Reformation. This was also the case on the Protestant side, where Sleidan's Commentaries were soon counted amongst the classics. Often, these Protestant historians would have to share Sleidan's fate and meet extensive criticism.

\section{Jacques-Auguste de Thou and Theodore Agrippa d'Aubigné: a fate shared}

Jacques-Auguste de Thou (1553-1617), one of the most famous French historians, was styled the 'first and in another sense the last of the French historians' by his editor. ${ }^{121}$ The president of the Parlement and counsellor of state was in fact Catholic, but like Sleidan his attempted neutrality earned him the hatred of many. ${ }^{122}$ His Latin Histoire Universelle, describing the years $1543-1607$, was also to include Sleidan as one of the main works consulted, and as one of the characters featuring in it. Like Sleidan and many of the above-mentioned authors, he emphasised his wide range of reliable sources, assembled in a quest to present the truth. De Thou was another in the row of historians regarded as controversial; his history, first published in Latin in 1604, found the approval of the king but deep contempt on the side of the League. In 1607 the work fell under the censorship as the work of an 'heretic of the first class', and in 1609 it was finally condemned, followed by several refutations. $^{123}$

Sleidan is often quoted as a source, alongside Guiccardini, Paradin, Commynes, Jove, Livy, Sallust, Tacitus, as well as acts of the Parlement of Paris and other public acts.

\footnotetext{
121 'Il est le premier \& dans un autre sens le dernier des Historiens François.' (p. 2 in:) Jacques-Auguste de Thou, Histoire Universelle, avec la Suite par Nicolas Rigault; les Memoires de la Vie de L'Auteur, (...), Et Augmenté de Remarques Historiques \& Critiques de Casaubon, de Du Plessis Mornay, G. Laurent, Ch. De L'Ecluse, Guy Patin. P. Bayle, J. le Duchat, \& autres, 11 vols., La Haye (Henri Scheurleer), 1740. The first edition was published in Latin in Paris in 1604 (Mamert Patisson veuve).

${ }_{122}$ Cf. Simonin (ed.), Dictionnaire, pp. 1123-1125.

${ }^{123} \mathrm{Cf}$. de Thou, Histoire Universelle, preface of the editor, p. VII. Refutations include Scioppius' Scaliger Hypobolimaeus, or Ecclesiasticus auctoritati Jacobi magnae Britanniae Regis oppositus, or Jean de Machaud's In Jacobi Aug. Thuani Historiarum libros annotationes autore Joanne-Baptista Gallo.
} 
Additionally, many aspects of his life are mentioned, spanning his youth and education, his involvement in the Council of Trent and Strasbourg politics to his achievement as historian and his death. De Thou reported that Sleidan, who had written about his age with 'exactness and fidelity', had secured himself a position of fame through his erudition. He had made his career under Jean Du Bellay, who had also secured him an honorary pension from the French court. ${ }^{124}$ In de Thou's eyes, he deserved to be ranked amonst the best historians.

This view was also shared by the Protestant Theodore Agrippa d'Aubigné (15521630). A soldier in the Huguenot army, he was close to Henry of Navarre, and a renowned author, poet and historian. He was another author who had set out to describe the most recent history and had met public disapproval and outrage, just like Sleidan. ${ }^{125}$ Aubigné also attempted to assemble first-hand documents in his work, presented from a point of neutrality. He was aware that it was rather conventional for historians to point out truthfulness and sincerity, characteristics rarely to be found in a historian. He especially defended La Popelinière, and praised his perfection, competiting with that of the most illustrious historians Machiavelli, Guiccardini - and Sleidan. ${ }^{126}$ Aubigné's work was not received well. After his work had been burned publicly by order of the Parlement in 1617 , he escaped to Geneva, where he spent the rest of his life. Aubigné with his analysis of the

\footnotetext{
${ }^{124}$ Cf. de Thou, Histoire Universelle, Vol. II, book 17, p. 451: 'Jean Sleidan, qui a écrit avec beaucoup d'exactiłude \& de fidelité l'Histoire de son temps, mourut d'une maladie épidemique sur la fin d'Octobre, âgé de cinquante \& un ans. Il étoit né à Sleida, dont il portoit le nom, ville de la dépendance de Cologne, peu éloignée de Duren. II s'étoit rendu illustre dans ce siècle, non seulement par son érudition, mais par le talent qu'il avoit pour les affaires. Il passa presque toute sa jeunesse en France, attaché à la maison du Bellay, \& fit des grands progrès sous les yeux du Cardinal de ce nom. Mais ensuite, comme l'on commençoit à punir en France ceux qui étoient suspects de Luthéranisme, il se retira en Allemagne, \& s'attacha à la République de Strasbourg, c'est-là qu'il commença à écrire les choses dont il avoit été lui-même témoin, \& celles que des gens dignes de foi lui avoient apprises.'

${ }^{125}$ Théodore Agrippa de Aubigné, Histoire universelle, 3 vols., Maillé (Jean Moussat), 1616 ; cf. Simonin, Dictionnaire, pp. 82-87, for biographical remarks.

${ }^{126}$ Aubigné, Histoire universelle, pp. 4-5.
} 
years 1550 to 1561 fell into disgrace for the same reasons as several of his predecessors: he had written too frankly about controversial matters of public concern.

In the investigation of the reception of Sleidan in France we have seen various, often recurring, patterns. Sleidan's works were immediately very popular in France. This large demand by the French for an account of the recent history can partially be explained by the lack of French histories of that time. The religious peace within the Empire was looked upon as a model for France, where religious controversies were shaking the country and the need for a solution became apparent. The Commentaries were regarded as the source from whence the inspirition for such a solution might be gathered. This readiness of the French market for a work such as Sleidan's was quickly perceived by the printing press, first and foremost by Jean Crespin. The Genevan printer produced an impressive number of French editions of both Sleidan's Commentaries and the Four Empires, especially destined for the French market.

In the decades after the Commentaries had been published, French historiography began to engage itself in reflections upon recent history, necessitated by the acute religious and political situation in France shaken by the Wars of Religion. The religious turmoil in the Empire as described by Sleidan had come to a peaceful end with the Peace of Augsburg in 1555. In the Empire, the turmoil following the publication of the Commentaries died down once the religious question had been solved at the Augsburg Diet, and literary responses to Sleidan were rare. Scribner has shown that especially in German lands the Catholic response to Protestant publications was slow. ${ }^{127}$ For the French scene, Racaut has argued that this was not the case: 'Unlike German Catholics, the French were quick to

${ }^{127}$ Scribner, For the Sake of Simple Folk, p. 239. 
respond to Protestant material in the vernacular justifying their stance..., ${ }^{28}$ The French responses to Sleidan certainly show that the French were rather quick to respond to Sleidan, but these responses were not always what one would expect. Sleidan was read with the aim of finding a model solution to the problems created by the religious divide that would be applicable to France. French historians soon realised that the situation in France needed a closer analysis. As a consequence, the French turned to history writing. Often, information was gathered from Sleidan, so were his methods. These historians followed Sleidan in their quest to base their histories on reliable primary sources, claiming candour and neutrality to be their prime objectives. Not infrequently, they were also to share Sleidan's fate and receive widespread criticism, often even from their fellow believers.

Outrage against Sleidan's Commentaries was especially bitter on the Catholic side, which accounted for refutations or fierce criticism by the likes of Fontaine and Raemond. Yet the Catholic reception of Sleidan was not at all altogether negative. Even convinced Catholics such as Tallepied or Saconay actually ignored Sleidan's Protestantism when convenient and used him as a source to argue from against the Protestants. On the other hand, the reactions on the Protestant side were equally unforeseeable. Sleidan was largely praised as a historian, but he also received criticism from other Protestant historians such as La Popelinière.

The reception of Sleidan and his works in France had followed quite a reverse pattern from that in Germany. There, after initial turmoil, passions cooled down quickly and Catholic opponents failed to surpass their enemy by offering a more reliable account of the Reformation or a convincing refutation. Instead, Sleidan's works were distributed 
among Protestants and Catholics alike and even used for teaching purposes by religious orders such as the Catholics. In France instead, the Commentaries were generally greeted with enthusiasm, there was hardly any of the outrage that followed their publication in Germany. Only when the confessional struggles in France began to polarise the kingdom a literary debate began. Just like in Germany, Sleidan received praise and blame from both confessional sides, but often it did not quite come from the religious camp one would expect. Catholics were often even more prepared than the Protestants to rely on Sleidan. He had become the prime source on the early Reformation. Both France and Germany had been Sleidan's home, and even his final domicile, Strasbourg, was influenced by both cultures. In his lifetime, Sleidan had done these countries great services, both as a diplomat and as a historian. The extent to which his memory was kept alive in history books across borders and centuries reflects his importance. Both France and Germany paid tribute to 'their' Sleidan. 


\section{CONCLUSION}

'Therefore I beseech my Reader to lay aside all prejudice, and that he would first consider the things proposed, and my Labour, which was very great, and then bestow his good will and favour on it." ${ }^{11}$ This plea of Sleidan in the preface and dedication of the Commentaries expresses the hopes he connected with his work, but also his fears. The troubles of his last years, both on the personal side and in connection with the Commentaries, had made a deep impact on Johann Sleidan. This plea was no longer the voice of the young, talented man who had won the trust and respect of political and theological leaders in France and Germany. It was the plea of an old, desperate man, near the end of a life and career that had once looked so promising.

With this thesis, I hoped to shed oblique light on the life of Sleidan, who shaped his age in so many ways, be it as historian or as diplomat. We have established a much more secure base for understanding Sleidan because his career crosses so many boundaries. Although the amount of literature on Sleidan especially in the earlier centuries is quite large, it fails to investigate Sleidan's life and influence as a whole. The most valuable tool in reconstructing Sleidan's biography were the documents assembled in Appendix I, which enabled us to reconstruct a far clearer picture of his life than hitherto known. The literary reactions to Sleidan in France and Germany are so far largely unknown, and showed Sleidan's vital role and influence in both countries.

The case of Sleidan has provided us with a fine study of the struggle of a historian in a confessional age. In his Four Empires, Sleidan adhered largely to the guiding principles of Protestant historiography as defined by Gilmont: 'rejet de la papauté, lecture

\footnotetext{
${ }^{1}$ Sleidan/Bohun, General History, fol. A2v.
} 
de l'histoire à la lumière des Écritures, en particulier de Daniel, mise en évidence du témoignage des martyrs et recherche du petit reste d'Israël. ${ }^{2}$ With the Four Empires, Sleidan followed the approach of most other Protestant historians of his time, aiming to provide an unbroken line from the pure, early Church to the Protestant community. With the Commentaries, Sleidan and with him the political body of the Protestants attempted to offer the complementary part of this process of creating a communal Protestant identity through history. Of course, a history on most recent events would be a much more delicate affair, especially at such a crucial time as the Diet of Augsburg. A historian of the Reformation would have to answer for his account of these most recent events to all religious parties involved. Providing an as truthful description as possible and pleasing every party involved meant walking a very fine line.

Before he turned to history, Sleidan had been a lawyer and diplomat, not a theologian. This is reflected in his Commentaries, depicting the Reformation largely as a political event, albeit part of God's plan. Sleidan's aim was not to explain the role of God in history. For him a logical accumulation of documents without a moralising interpretation was a logical proof of the veracity of his account and therefore a justification of the Reformation. The role of God is still silently acknowledged, but needs no further explanation, original documents suffice. God's will is self-evident and needs no explanation. Secular authorities are those fulfilling God's will, and so even the Emperor has his rightful place in the Reformation, and his authority is acknowledged throughout the work.

More than that, we managed to shed more light on so many important but not always well understood parts of Reformation history. Strasbourg's role as the gate and

\footnotetext{
${ }^{2}$ Gilmont, 'La naissance de l'historiographie protestante', p. 112.
} 
mediator between France and Germany has once more been shown, confirming the influential works by Brady and Chrisman. ${ }^{3}$ Sleidan's role provides corroborative evidence for the centrality of Strasbourg, which was the centre of an open-minded, educated and well-connected elite which was influential in many aspects of German policy. This elite was part of a network that spread across Germany, France and England. This crossconfessional and cross-national circle was far more concerned with peace and education than confessional struggles. This is reflected in Sleidan's attempt to incorporate and address a pan-European audience, in which he preceded his time.

On a broader front, the study of Sleidan showed how a network of personal friendship and connections formed the heart and soul of the Schmalkaldic League. Clearly, the Schmalkaldic League would have been little without the military power of the German princes. But the work of coordinating disparate and at times confrontational German princely states fell to a group of theologians, politicians and city councellors that were remarkably small in number. The biography and especially the correspondence of Sleidan sheds a crucial additional light on the works of this circle, the importance of which has also been the subject of the recent work of Thomas Brady on Jacob Sturm. ${ }^{4}$ Sleidan developed a relationship of considerable importance with both Jean and Jacob Sturm, who quickly perceived the value of the position of trust Sleidan occupied at the French court. In this respect Sleidan was in the service of the the Schmalkaldic League long before he had begun to draw a salary.

Sleidan's position of intimacy with the key figures of the Schmalkaldic League helps explain why he was promoted as official historian even when his education,

\footnotetext{
${ }^{3} \mathrm{Cf}$. Brady's Ruling Class, Regime and Reformation at Strasbourg. 1520-1555, Leiden 1978, and Turning Swiss: Cities and Empire, 1450-1550, Cambridge 1981. Chrisman's work include Chrisman's works are Strasbourg and the Reform, and Lay Culture, Learned Culture.

${ }^{4}$ Brady, Protestant Politics, and The Politics of the Reformation in Germany.
} 
connections and personal predilections made him something other than a model of Protestant orthodoxy. This represents one other fascinating aspect of the career of Sleidan, the francophone scholar who played a vital bridge between France and the Empire. Modern bibliographical scholarship is only now beginning to chart the full extent of the movement of text around the various cultural communities of Europe. Popular works were read not only in the national cultures for which they were first written, but often very broadly across the European continent. This movement of text occurred first in the broader international communities of those who read Latin, but there was a surprising number of vernacular translations of these works, from Spanish to French, from French to English, from French to Dutch. The quantity of German works available in French or vice versa was much smaller and negligible before the Reformation. The works of Sleidan that we have investigated demonstrate how important a role the Reformation played in accelerating this exchange. Sleidan played his first role in this process through the translation of French histories into Latin and in making his German political works available in France in Latin translation. The later French translation of his histories completed the circle. None of Sleidan's works were short, and the investment in creating such a translation is not to be underestimated. The fact that publishers were prepared to undertake it shows their confidence in the market. The frequent repeated editions show that this confidence was not misplaced.

The success of Sleidan's works in France in the second half of the sixteenth century completed a process of confessional adjustment that was remarkable even in Sleidan's own day. Associated for much of his lifetime with the broad strand of evangelical opinion active at the French court in the 1530 s and 1540 s, Sleidan passed then into the service of the Lutheran Schmalkaldic League before his books became a core text and inspiration for French Calvinism. This sort of spiritual journey, largely unplanned in the case of Sleidan, 
is by no means unusual in the mid-decades of the sixteenth century when events would spiral to render a middle way far more difficult. But it is perhaps in his association with French evangelism in the first half of the century that Sleidan's career is most surprising. His important position in the liberal circle at the French court around Marguerite and the Du Bellays made him the vital link to the German Protestants and the connected negotiations for a possible alliance between France and Germany. It is difficult to label this reform-minded group, the most prominent members of which actually never made the open conversion to Protestantism. They can probably be best identified with the reformfriendly group characterised by Thierry Wanegffelen as 'Catholiques critiques', a group interest more in a peaceful middle way rather than in confessional consolidation. ${ }^{5}$ Sleidan demonstrated the vitality of this stream but also the difficult strategic choices members of this moderate group had to make when there was always a danger of being regarded as disloyal.

The development of the 1560 s with the rise of Calvinism made life more difficult for people like those of Sleidan's strand but did not end the quest for moderation. Many scholars continued to feel restless about the theological divisions and controversies that separated men of similar temperaments into different churches. Sleidan's career, and more than that his books provide further evidence, fragmented and scattered though it often is, of attempts of European citizens to build bridges across the confessional divide. We see something of this in the eclectic choice of educational institutions made by European scholars, with Catholic students studying in Protestant places and vice versa. Students returned from these travels with their album amicorum, a peculiar sixteenth century genre in which intellectuals collected authographed inscriptions of their friends in the scholarly community. These inscriptions expressed the humanist desire for peace and friendship

\footnotetext{
${ }^{5}$ Wanegffelen, Une difficile fidélité, p. 1 for the concept of the 'Catholiques critiques', and chapter 2 'Le Concile des Tridentins' on pre-Tridentine France.
} 
elevated above the confessional struggle. In Sleidan's case, we see the same instinct at work in the respect shown for his published works by many Catholic owners and users. Sleidan's history of the Reformation was recognised as a Protestant book and criticised as such by those who feared its influence, but at the same time it was eagerly seized upon for its valuable collection of documents by friend and foe.

This study hopes to restore the important place in Reformation history which Johann Sleidan deserves. It has attempted to sort and rearrange the existing pieces of the puzzle that was his life and work, and add more pieces to complete this puzzle. The picture of Sleidan that evolved from this is that of a skillful diplomat and historian, connected to the most influential men of his time. In this sense, a study of Sleidan transcends the frame of a mere biography, it illustrates the whole period in which he lived. This study particularly showed his Franco-German nature, his connections to the two countries which he called his home. His two countries honoured his efforts by making him the father of their Reformation history, of the German, and of the French. 


\section{APPENDIX I: SLEIDAN'S CORRESPONDENCE AND RELATED DOCUMENTS}

The following database comprises all letters to and by Sleidan, as well as correspondence concerning him. 182 of these letters are printed in Hermann Baumgarten, Sleidan's Briefwechsel, Strasbourg 1881, and a few others are listed in Jean Rott, 'Nouveaux Documents sur Jean Sleidan Historien de la Réforme (1506-1556)', Bulletin Philologique et Historique (Jusqu'à 1610) du Comité des Travaux Historiques et Scientifiques, Année 1967/II, Paris 1969, pp. 551-647. Further research into a wide range of printed sources has unearthed additional valuable material, included below.

The documents are given in chronological order and include their source, as well as a short summary of the contents as relevant to Sleidan, his life and works.

\section{Sources:}

Bg Baumgarten, Hermann, Sleidans Briefwechsel, Strasbourg 1881

Bg b Baumgarten, Hermann, Über Sleidans Leben und Briefwechsel, Strasbourg 1878

Böhmer Sleidan, Johann, (ed. Böhmer, Eduard), Zwei Reden an Kaiser und Reich von Johannes Sleidanus, Tübingen 1879

Bonnet Bonnet, Jules (ed.), Letters of John Calvin. Compiled from the original manuscripts and edited with historical notes, 3 vols., New York 1972

Bourrilly a Bourrilly, V.L., 'Deux nouvelles lettres de Jean Sleidan', BSHPF 55 (1906), pp. 212-219

Bourrilly b Bourrilly, V.L., 'Jean Sleidan et le Cardinal Du Bellay. Premier séjour de Jean Sleidan en France (1533-1540)', BSHPF 50 ( 1901), pp. 225-245

Brandenburg Brandenburg, Erich (ed.), Politische Korrespondenz des Herzogs und Kurfürsten Moritz von Sachsen, vol. 2, Leipzig 1900-1904

Crusius Crusius, Martin, Annales Suevici sive Chronica rerum gestarum antiquissimae et inclytae Suevici gentis, 3 vols., Frankfurt (Nicolaus Bassaeus) 1596

LP Brodie, R.H., Gairdner J., Letters and Papers, Foreign and Domestic, of the Reign of Henry VIII, preserved in the Public Record Office, the British Museum and elsewhere in England, vols. XX/II, XXI/I, London 1907-1908 
CF Catalogue des actes de Francois Ier, Collections des ordonnances des rois de France, vols. 4-10, Paris 1890-1908

CR Corpus Reformatorum, Vol. 1- 8, Bretschneider, Karl Gottlieb (ed.), (Halle 1834-41), Vol. 39-44, Baum, Wilhelm, Cunitz, Eduard, and Reuss, Eduard (eds.), (Braunschweig 1873-76) repr. Bad Feilnbach 1990

Ernst Ernst, Viktor (ed.), Briefwechsel des Herzogs Christoph von Wirtemberg, 4 vols., Stuttgart 1899-1907

Franz Franz, Günther, Urkundliche Quellen zur hessischen Reformationsgeschichte, 4 vols., Marburg $1915 \mathrm{ff}$.

Friedensburg Friedensburg, Walter, 'Die Entstehung der Kommentarien Sleidans', ELJB 12 (1933), pp. 83-108

Geiger Geiger, L., 'Briefe Joh. Sleidans an den Kardinal Joh. Du Bellay, 15421547', Forschungen zur deutschen Geschichte 10 (1980), pp. 167-198

Amerbach Hartmann, Alfred, Die Amerbachkorrespondenz, 10 vols., Basle 1942-95

Hasenclever a 'Neue Aktenstücke zur Friedensvermittlung der Schmalkaldener zwischen Frankreich und England im Jahre 1545', ZGO 59 (N.F. 20, 1905), pp. 224-251

Hasenclever b 'Notiz über einen bisher unbekannten Brief Johann Sleidans an Calvin', ZGO 61 (N.F.22,1907), pp. 170-171

Hasenclever c Hasenclever, Adolf, 'Sleidania', ZGO 63 (N.F.24, 1909, pp. 92-116

Hasenclever d Hasenclever, Adolf, Sleidan-Studien. Die Entwicklung der politischen Ideen Joh. Sleidans bis zum Jahre 1545, Bonn 1905

Hasenclever e Hasenclever, Adolf, 'Ein poetischer Nachruf Johann Sleidans auf Martin Bucer', ZGO 65 (N.F. 26, 1911), pp. 715-718

Hasenclever f Hasenclever, Adolf, 'Ein ungedruckter Brief Johann Sleidans an Dr. Leonhard Badehorn', ZGO 61 (N.F.22, 1907), pp. 528-532

Hasenclever g Hasenclever, Adolf, 'Ein ungedruckter Brief Johann Sleidans aus dem Jahre 1548', ZGO 83 (N.F. 44, 1930), pp. 134-136

Hermann Hermann, Johannes, Wartenberg, Günther, and Winter, Christian, Korrespondenz des Herzogs und Kurfürsten Moritz von Sachsen, 6 vols., Berlin 1998 
Herminjard Herminjard, A.L., Correspondance des Réformateurs dans les pays de langue francaise, 9 vols., Geneva/Paris/Basle/Lyon 1866-1897

Hollaender a Hollaender, Alkuin, 'Beiträge zur Biographie Sleidans', Korrespondenzblatt der Westdeutschen Zeitschrift für Geschichte und Kunst 7/5 (1888) cols.150-153

Hollaender b Hollaender, Alkuin, 'Sleidaniana', ZGO 53 (1899), pp. 428-437

Hollaender c Hollaender, Alkuin, 'Sleidaniana', ZGO 43 (N.F. 4, 1889), pp. 337-342

Hortleder I Hortleder, Friedrich, Der Römischen Keyser- und königlichen Maiesteten: Auch des Heiligen Römischen Reichs Geistlicher und Weltlicher Stände/ Churfürsten/Fürsten/ Graffen/ Reichs- und anderer Stätte/ Sampt des hochlöblichen kaiserlichen CammerGerichts/Fürstlicher Regierungen/ und etlicher der H. Schrifft und beyder Rechte Gelehrten/ Handlungen und Außschreiben/ Send-Brieffe/ Bericht/ Underricht/ Kalg- und SupplicationSchrifften/Befelch/Fürladungen/ Rathschläge/ Bedencken / Entschuldigungen/ Protestationes, Recusationes, Ableynungen / Außführungen/ Urtheyls und Hülffs Brieffe/ Bündnissen/ und GegenBündnissen/ Bundts-Ordnungen und Abschiede/ Fehde- oder VerwahrungsBrieffe/ An- und Fried-Stände/ Verträge/ und viel andere treffliche Schrifften und Kunden mehr/ Von den Ursachen des Teutschen Kriegs Kaiser Carls des Fünfften/ wider die Schmalkaldische Bundts Oberste Chur- und Fürsten/ Sachsen und Hessen/ und Ihrer Chur- und F.G.G. Mitverwandte/ Anno 1546. und 47., Frankfurt/Main (Hartm. Palthenius) 1617

Hortleder II Hortleder, Friedrich, Der Römischen Keyser- und königlichen Maiesteten: Auch des Heiligen Rö. Reichs/geistlicher und weltlicher Stände/ Churfürsten/Fürsten/ Graffen/ Herren /Reichs- und anderer Stätte/ zusampt der heiligen Schrifft/geistlicher und weltlicher Rechte Gelehrten Handlungen und Außschreiben/ Rathschläge/ Bedencken/ Send-und andere Brieffe/ Bericht/ Supplicationsschrifften/ BefehlEntschuldigungen/ Protestationes, Recusationes, Außführungen Verantwortungen/ Ableinungen/Absagungen/ Achtserklärungen/ Hulffsbrieffe/ Verträge/ Historische Beschreibungen/ und andere viel herrliche Schrifften und Kunden mehr: Von Rechtsmässigkeit/ Anfang/ Fort- und endlichen Außgang deß Teutschen Kriegs/Keyser Carls deß Fünfften/ wider die Schmalkaldische Bundsoberste/ Chur- und Fürsten/Sachsen und Hessen/ und J. Chur- und Fürstl. G.G. Mitverwandte. Vom Jahr 1546 biß auff das Jahr 1558., Frankfurt/Main (Nicolaus Hoffmann) 1618

Hubert Hubert, Friedrich, Vergerios publizistische Thätigkeit, Göttingen 1893 
KS Klausler von, Eduard, Schott, Theodor, Briefwechsel zwischen Christoph, Herzog von Württemberg und Petrus Paulus Vergerio, Tübingen 1875

Krafft Krafft, P.K., Briefe und Dokumente aus der Reformationszeit, Elberfeld 1876

Lenz Lenz, Max, Briefwechsel Landgrafs Philipps des Großmütigen von Hessen mit Bucer, 3 vols., Leipzig 1880/87/91

BV Noodt, J.-F., 'Epistolarum Jo. Sleidani hactenus ineditarum fasciculus prior', Brem- und Verdische Bibliothek, worin zur. Aufnahme der Wissenschaften, insbesonderheit der theologischen, philologischen und historischen, allerley brauchbare Abhandlungen und Anmerkungen mitgetheilt werden, Vol.1, II, (s.1.) 1753, pp. 87-122

Noodt, J.-F., 'Epistolarum Jo. Sleidani hactenus ineditarum fasciculus posterior', Brem- und Verdische Bibliothek, worin zur Aufnahme der Wissenschaften, insbesonderheit der theologischen, philologischen und historischen, allerley brauchbare Abhandlungen und Anmerkungen mitgetheilt werden, Vol. 1, III, (s.1.) 1753, pp. 103-128

Ascham Rogeri Aschami Epistolarum Libri Quatuor. Accessit Joannis Sturmii. aliorumque ad Aschanum, anglosque alios eruditos Epistolarum liber unus, Oxford 1703

Plantin Rooses, Max (ed.), Correspondance de Christophe Plantin, 8 vols., Antwerp1883-1918, repr. Nendeln/Liechtenstein 1968

Rott Rott, Jean, 'Nouveaux Documents sur Jean Sleidan Historien de la Réforme (1506-1556)', Bulletin Philologique et Historique(Jusqu'à 1610) du Comité des Travaux Historiques er Scientifiques, Année 1967/II, Paris 1969, pp. 551-647

Sabinus Sabinus, Georg, Poemata Georgii Sabini Brandeburgensis V. CL. et numero librorum et aliis additis avcta, et emendatius denuo edita, Leipzig (Johannes Steinmann) 1581

Scheible Scheible, Heinz, Melanchthons Briefwechsel: kritische und kommentierte Gesamtausgabe, 10 vols., Stuttgart/Bad Cannstatt, 1978-1998

PC Virck, Hans, Winckelmann, Otto, and Friedensburg, Walter et al. (eds.), Politische Correspondenz der Stadt Strasbourg im Zeitalter der Reformation, vols. 3-5, vol. 3 : Strasbourg 1898; vols. 4-5 : Heidelberg 1928-1933

SP State Papers. King Henry the Eight, 11 vols., London 1830-1852 
Vos Vos, Alvin (ed., transl. Hatch, Maurice, Vos, Alvin.), Letters of Roger Ascham, , New York/Bern/Frankfurt am Main/Paris 1989

Winckelmann Winckelmann, Otto, 'Zur Geschichte Sleidans und seiner Kommentare', ZGO 53 (N.F.14, 1889), pp. 565-606

Wolff Wolff, Richard, 'Sleidaniana', ZGO 62 (N.F.23, 1908), pp. 265-275 
Letters to and from Sleidan

(numbers in brackets indicate Sleidan as one of a group of addressees or writers)

\begin{tabular}{|c|c|c|c|}
\hline Date & To Sleidan & From Sleidan & Total \\
\hline 1530 & 0 & 1 & 1 \\
\hline $1531-1537$ & 0 & 0 & 0 \\
\hline 1538 & 1 & 1 & 1 \\
\hline 1539 & 0 & 1 & 1 \\
\hline 1540 & 1 & 6 & 7 \\
\hline 1541 & 0 & (1) & (1) \\
\hline 1542 & 1 & 1 & 2 \\
\hline 1543 & 0 & 0 & 0 \\
\hline 1544 & 0 & 1 & 1 \\
\hline 1545 & $6(+5)$ & $42(+12)$ & $48(+17)$ \\
\hline 1546 & $2(+2)$ & 11 & $13(+2)$ \\
\hline 1547 & 0 & 2 & 2 \\
\hline 1548 & 0 & 5 & 5 \\
\hline 1549 & 0 & 0 & 0 \\
\hline 1550 & 1 & 5 & 6 \\
\hline 1551 & 3 & 8 & 11 \\
\hline 1552 & 5 & 22 & 27 \\
\hline 1553 & 1 & 6 & 7 \\
\hline 1554 & 3 & 5 & 8 \\
\hline 1555 & 10 & 19 & 29 \\
\hline 1556 & 8 & 7 & 15 \\
\hline TOTAL & $41(+7)$ & $143(+13)$ & \begin{tabular}{|l|}
$184(+20)$ \\
\end{tabular} \\
\hline
\end{tabular}


Letters to Sleidan

\begin{tabular}{|c|c|c|}
\hline $1530-1537$ & & 0 \\
\hline 1538 & Jean Du Bellay & 1 \\
\hline 1539 & & 0 \\
\hline 1540 & Jean Du Bellay & 1 \\
\hline 1541 & & 0 \\
\hline 1542 & Jean Du Bellay & 1 \\
\hline 1543 & & 0 \\
\hline 1544 & & 0 \\
\hline \multirow{4}{*}{1545} & William Paget & 3 \\
\hline & Jean Du Bellay & 1 \\
\hline & Johann von Nidbruck & 1 \\
\hline & $\begin{array}{l}\text { J.Nidbruck/Jean } \\
\text { Sturm/Venningen }\end{array}$ & 1 \\
\hline \multirow[t]{2}{*}{1546} & Jean Du Bellay & 1 \\
\hline & Philip of Hesse & 1 \\
\hline 1547 & & 0 \\
\hline 1548 & & 0 \\
\hline 1549 & & 0 \\
\hline 1550 & Hans Kilian & 1 \\
\hline 1551 & XIII of Strasbourg & 3 \\
\hline \multirow[t]{2}{*}{1552} & XIII of Strasbourg & 4 \\
\hline & Baptiste Praillon & 1 \\
\hline 1553 & Caspar von Nidbruck & 1 \\
\hline \multirow[t]{3}{*}{1554} & XIII of Strasbourg & 1 \\
\hline & Erasmus von Minkwitz & 1 \\
\hline & Jean Calvin & 1 \\
\hline \multirow[t]{3}{*}{1555} & Caspar von Nidbruck & 8 \\
\hline & Jacobus Faber (Fabricius) & 1 \\
\hline & $?$ & 1 \\
\hline \multirow[t]{6}{*}{1556} & Caspar von Nidbruck & 2 \\
\hline & $?$ & 2 \\
\hline & (Johann Stumph?) & 1 \\
\hline & Peter Martyr Vermigli & 1 \\
\hline & Philip Melanchthon & 1 \\
\hline & Georg Sabinus & 1 \\
\hline
\end{tabular}


Letters from Sleidan

\begin{tabular}{|c|c|c|}
\hline 1530 & Rutger Rescius & 1 \\
\hline $1531-1537$ & & 0 \\
\hline 1538 & Jean Du Bellay & 1 \\
\hline 1539 & Jean Calvin & 1 \\
\hline \multirow{2}{*}{1540} & Jean Sturm & 4 \\
\hline & Martin Bucer & 2 \\
\hline 1541 & (for Morelet) Philip of Hesse & 1 \\
\hline 1542 & Jean Du Bellay & 1 \\
\hline 1543 & & 0 \\
\hline 1544 & Jean Du Bellay & 1 \\
\hline \multirow[t]{8}{*}{1545} & Jacob Sturm & 24 \\
\hline & Jean Du Bellay & 7 \\
\hline & Henry VIII & 4 \\
\hline & William Paget & 3 \\
\hline & Nicolaus Pruckner & 1 \\
\hline & Ludwig Gremp & 1 \\
\hline & Philip of Hesse & 1 \\
\hline & N. & 1 \\
\hline \multirow[t]{4}{*}{1546} & Jean Du Bellay & 7 \\
\hline & Philip of Hesse & 2 \\
\hline & William Paget & 1 \\
\hline & Francis I & 1 \\
\hline \multirow[t]{2}{*}{1547} & Jean Du Bellay & 1 \\
\hline & Veit Dietrich & 1 \\
\hline \multirow[t]{5}{*}{1548} & Jacob Sturm & 1 \\
\hline & Jean Du Bellay & 1 \\
\hline & Ludwig Gremp & 1 \\
\hline & Nicolaus Brom & 1 \\
\hline & Antoine Perrenot de Granvelle & 1 \\
\hline 1549 & & 0 \\
\hline \multirow[t]{4}{*}{1550} & Jean Du Bellay & 2 \\
\hline & Martin Bucer & 1 \\
\hline & Franz Dryander & 1 \\
\hline & Johann von Nidbruck & 1 \\
\hline \multirow[t]{4}{*}{1551} & XIII of Strasbourg & 5 \\
\hline & Jacob Sturm & 1 \\
\hline & Wolfgang Musculus & 1 \\
\hline & Thomas Obrecht & 1 \\
\hline \multirow[t]{5}{*}{1552} & XIII of Strasbourg & 7 \\
\hline & William Cecil & 5 \\
\hline & Johann Marbach & 3 \\
\hline & Jacob Sturm & 2 \\
\hline & Philip Melanchthon & 1 \\
\hline
\end{tabular}




\begin{tabular}{|c|c|c|}
\hline & Roger Ascham & 1 \\
\hline & Leonhard Badehorn & 1 \\
\hline & Edward VI & 1 \\
\hline & Franz Dryander & 1 \\
\hline \multirow[t]{5}{*}{1553} & Jean Calvin & 2 \\
\hline & William Cecil/John Cheke & 1 \\
\hline & Senate of Strasbourg & 1 \\
\hline & John Frederic of Saxony & 1 \\
\hline & (Burkhard?) & 1 \\
\hline \multirow[t]{3}{*}{1554} & Jean Calvin & 3 \\
\hline & Stiftsherren St. Thomas & 1 \\
\hline & XIII of Strasbourg & 1 \\
\hline \multirow[t]{9}{*}{1555} & Caspar von Nidbruck & 9 \\
\hline & Jean Calvin & 2 \\
\hline & Ludwig Gremp & 2 \\
\hline & Johann Marbach & 1 \\
\hline & Augsburg council & 1 \\
\hline & Caspar Lanius & 1 \\
\hline & Nicolaus Specht & 1 \\
\hline & Peter Paul Vergerio & 1 \\
\hline & Johann Stumph & 1 \\
\hline \multirow[t]{7}{*}{1556} & Caspar von Nidbruck & 1 \\
\hline & Ludwig Gremp & 1 \\
\hline & Friedrich von Gottesheim & 1 \\
\hline & Johann Stumph & 1 \\
\hline & Nicolaus Specht & 1 \\
\hline & Jean Calvin & 1 \\
\hline & Christoph von Württemberg & 1 \\
\hline
\end{tabular}


1. $\quad$ Spring (Liège) - SLEIDAN to Rutger Rescius -Bg 1; Krafft pp. 63-65

Political news from Germany. Praises Melanchthon.

1535

2. December 8 (Orléans) - University register - Bg b, p. 52

Johann Sleidan of the diocese of Cologne is matriculated at Orléans university.

\section{8}

3. May 15 (Avignon) - Jean Du Bellay to SLEIDAN - Bourrilly b, pp. 232-234 Informs Sleidan about his opinion on Jean Sturm's tract, finds it slightly heated. ${ }^{I}$ Sturm to receive a pension of 50 ècus. Asks Sturm to send letters to Sleidan, without their names. Sleidan should also omit names in correspondence.

4. October 27 (Paris?) - SLEIDAN to Jean Du Bellay - Bourrilly b, pp. 236-238 Jean Sturm rector of Strasbourg Gymnasium. Forming of a Protestant and Catholic faction in Germany, both seem to gather their forces. ${ }^{2}$

1539

5. May 22 (Paris) - SLEIDAN to Jean Calvin - Bg 2; CR 38, No. 173; Herminjard 5, No. 791, pp. 320-1

Praises Calvin. Friendship with Jean Sturm.

6. October 8 (?) - Martin Bucer to Louis Du Tillet - Herminjard 6, No. 825, pp.61-70 Asks Du Tillet to send back certain letters to him through Sleidan.

7. October 23 (Strasbourg) - Martin Bucer to Dr. Gereon Sailer - Lenz I, No. 34, pp. 113-114

They [German Protestants] have a man in Paris who has kept them informed about the affairs there for a while [=Sleidan].

\footnotetext{
${ }^{1}$ The tract in question is Epistola Joannis Sturmi, De eadem re ad Cardinales caeterosque viros ad eam consultationem delectos. Sturm had written this as a response to the investigation by the Cardinals Sadolet, Contarini, Pole, Aleander and others, who were to examine the abuses in the Catholic church.

${ }^{2}$ The German Catholic princes had formed the 'Christian Union' on 10-12 June 1538 under the leadership of the Duke of Bavaria.
} 
8. December 3 (Arnstadt) - Jacob Sturm's and Batt von Duntzenheim's report to Strasbourg - PC 2, No. 655, p. 656

Jean Sturm has a good contact in Paris with access to the king's counsellors [=Sleidan].

\section{0}

9. January 2 (Paris) - SLEIDAN to (Jean Sturm) - Bg 3

France, Emperor and German Protestants. Correspondence between pope and Jean Du Bellay.

10. January 17 (Strasbourg) - XIII of Strasbourg to Philip of Hesse - PC 3, No. 10, p. 12

They have a good friend at the French court with good connections, who will enquire about the attitude towards the German Protestants (=Sleidan).

11. May 16-Mandement-CF 4, No. 11492, p. 107

'Mandement' to the treasury to pay 1.800 livres tournois to Lazare de Baïf, Sleidan's companion for the Hagenau colloquy, for his mission to Germany from 16 May till 14 August 1540 (Saint-Germain-en-Laye, 16 May 1540).

12. June 4-Mandement - CF 4, No. 11517, p. 113

'Mandement' to the treasury to pay 562 livres and 10 sous to Sleidan, for his journey and mission to Germany (Fontainebleau, 4 June 1540).

13. June 7-Mandement - CF 4, No. 11524, p. 115

Mandement to the treasury to pay 225 livres to Sleidan for his mission to diverse princes in Germany (Fontainebleau, 7 June 1540).

14. July 20 (Hagenau) - Martin Bucer to Philip of Hesse - Lenz I, No. 75, pp. 197 A friend of Jean Du Bellay transmitted his messages for the last years [=Sleidan]. Sleidan on mission.

15. July 23 (Hagenau) - Hesse Councillors to Philip of Hesse - Rott p. 576 Bucer introduced Sleidan who presented his mission and objectives.

16. September 16 (Strasbourg) - Martin Bucer to Philip of Hesse - Lenz I, No. 82, pp. 210-214

Received two letters by Cardinal Du Bellay's legate to Hagenau [=Sleidan)].

17. October 2 (Saint-Maur-des-Fossés?)) - Jean Du Bellay to SLEIDAN - Bg 4 Sleidan is to urge German Protestants to send ambassadors to Francis $I$. 
18. October 4 (Paris)) - SLEIDAN to Martin Bucer - Bg 5

Francis I insists he did not order persecutions of French Protestants. Urges for negotiations between France and the German Protestants. Chancellor Poyet.

19. October 15 (Paris)) - SLEIDAN to Martin Bucer - Bg 6

Urges to send a Protestant delegation to France.

20. October 16 (Paris)) - SLEIDAN to Jean Sturm - Bg 7

Relation between Francis I and Jean Du Bellay. Character of Francis I.

21. November 3 (Paris)) - SLEIDAN to (Jean Sturm) - Bg 9

King agrees with Philip of Hesse's double marriage. Cruel persecutions in France, Francis probably unaware.

22. November 3 (Paris)) - SLEIDAN to (Jean Sturm) - Bg 10

Francis I' views on Protestants, lax attitude.

23. November 4 (Worms) - Jacob Sturm and Mathis Pfarrer to XIII of Strasbourg PC3, No. 124 , p. 116

Sleidan as Du Bellay's legate at Hagenau together with Baïf.

24. November 17 (Worms) - Martin Bucer to Saxon Chancellor Franz Burkhardt PC3, No. 134, pp. 125-127; Bg pp. 8-11

Du Bellay is keen to arrange negotiations with German Protestants through

Sleidan. The Voré-affair, who was to deceive the Protestants. Thinks Du Bellay convinced Francis I to send Sleidan to Hagenau without Baif's knowledge.

25. December 25 (Worms) - Jacob Sturm to Franz Burckhardt - PC 3, No. 160, p. 151 Sends letters from Sleidan and Du Bellay.

1541

26. February 4 (Strasbourg) - Martin Bucer to Landgrave Philip of Hesse - Lenz II, No. 115 , pp. $3-7$

Sleidan arrived with Jean Morelet du Museau. Praises Sleidan, who recently wrote 'Oration to the States'.

27. February 4 (Strasbourg) - (SLEIDAN for) Jean Morelet du Museau to Philip of Hesse - Bg 11

Willingness of French king to form an alliance with German Protestants. Urges mission. Sleidan and Lazare Baïf attented colloquy at Hagenau. 
28. February 10 (Marburg) - Philip of Hesse to Martin Bucer - Lenz II, No. 117. pp.

9-10

Wants a copy of Sleidan's 'Oration to the States'.

29. February 11 (?) - Philip of Hesse to Jean Morelet du Museau - Bg 12

Mission to France impossible at moment: persecutions in France and Emperor's willingness to make peace with Protestants, but later on possible.

30. February 22 (Strasbourg) - XIII of Strasbourg to Francis I- Bg 13; PC 3, No. 174, p. 167

Thank for mildening persecutions; are confident after having talked to Morelet and Sleidan.

31. April 29 (Strasbourg) - Jacob Bedrotus to Simon Grynaeus - Bg b, p. 63 After leaving the diet of Regensburg, Sleidan stopped at Strasbourg on his way back to France.

32. June 23 (Strasbourg) - Strasbourg Council to Francis I- Bg 14; PC 3, No. 197, p.191

Refutation of news from Jean Sturm and others that Sleidan's enemies have spread rumours to the king that Sleidan tried to avoid negotiations between France and Germany by spreading bad remarks about persecutions in France. Plead for Sleidan's trustworthiness.

33. July 25 (De la Chaussière) - Marguerite de Navarre to Jean Calvin - Herminjard 7, No.1017, p.198f.; CR 39, No. $226^{3}$

Confirmation of receipt of Calvin's letter through Sleidan. Francis I trusts Sleidan more than bad rumours.

\section{2}

34. (late April - beginning of June) (Paris) - SLEIDAN to Jean Du Bellay - Rott, p. 579

Political news.

35. June 19 (Paris) -SLEIDAN to Jean Du Bellay - Bg 15; Geiger, p. 171-172

Events in Saxony. After death of his father his family wants him to come home.

\section{3}

36. June 19 (Paris) - Barthélemy Latomus to Martin Bucer - Rott, p. 579 About his friendship with Sleidan at Paris.

\footnotetext{
${ }^{3}$ The CR quotes this letter under the year 1540 .
} 
37. July 12 (Koblenz) - Geregorius Belenesius to Conrad Hubert - Rott, p. 579 Together with Sleidan he will take care of Hubert's debts.

\section{4}

38. January 7-Mandement-CF 4, No. 13537, pp. 542-543

Mandement to the treasury to pay 225 livres tournois for Cardinal Du Bellay and the chancellor of d'Alençon, for their missions to the diets of Speyer and Worms, to pay to Sleidan for his mission to these diets (Fontainebleau, 7 January 1543).

39. March 23 (Speyer) - Jacob Sturm to XIII of Strasbourg - PC 3, No. 448, p. 474 Warns Jean Sturm and Geiger of 'French practices' as there are rumours they are too friendly with the French.

40. May 2 (Strasbourg)) - SLEIDAN to Jean Du Bellay - Bg 16; Geiger, p. 172-3 Report about Speyer Diet. Du Bellay's writing. Emperor-Protestants. His close relations to France cause him problems.

41. May 9 (Konstanz) - Thomas Ambrosius Blarer to Konrad Huber - Wolff, p. 273 Request to find out who 'Baptista Lasdenus' was, since many think this was a pseudonym. ${ }^{4}$

42. August 5 (Strasbourg) - Martin Bucer to Philip of Hesse - Lenz II, No. 194, pp. 257-263; Bg b, pp. 67-68

Sleidan as the best man to write the history of the Reformation. Suggests a salary of 400 florentines; various Protestant cities and states will contribute.

43. September 9 (Strasbourg) - Martin Bucer to Philip Melanchthon, Scheible 3, No. 3682

Milichius has instructions for Melanchthon concerning Sleidan, who comes from the same area as Jean Sturm.

44. October 1 (Strasbourg) - Martin Bucer to Philip of Hesse - Lenz II, No. 195, pp. 263-270

Asks for answer whether Sleidan should be employed.

\section{5}

45. January 22 (Strasbourg) - SLEIDAN to Jean Du Bellay - Bg 17; Geiger, p. 173 174

News about disappointing Worms Diet. Events in Cologne. Trent: Protestants will not participate.

\footnotetext{
4 'Baptista Lasdenus' was the pseudonym Sleidan used for the first publications of his 'Orations'.
} 
46. January 25 (Strasbourg) - SLEIDAN to Jacob Sturm - Bg 18; BV 1/II, No. 1, pp. 89-93

Sends translation of Commynes with dedication to Hesse/Saxony. Heard about Philipp of Hesse and Bucer wanting to employ him, asks to speed up. Peace of Crépy. Theological conference.

47. February 15 (Paris) - Jean Du Bellay to SLEIDAN and Jean Sturm - Rott, pp. 624626

Enquires about policy of German Protestants and Emperor.

48. February 26 (Strasbourg) - Martin Bucer to Jacob Sturm - Rott, p. 581

Recommends Sleidan again as a historiographer of the Schmalkaldic league.

49. March 6 (St-Maur-des Fossés) - Jean Du Bellay to SLEIDAN and Jean Sturm Rott, pp. 626-627

About policies France-England-Empire.

50. March 15 (Strasbourg) - Martin Bucer to Philip of Hesse - Lenz II, No. 205, pp. 309-315; Bg b, pp. 71-72

Sends Sleidan's Latin translation of Commynes. Philip should urge estates at Worms to employ Sleidan. Heard about rumours that Saxony would prefer to have somebody else employed.

51. March 16 (Strasbourg) - Martin Bucer to (Jacob Sturm) - Rott, pp. 581-582 Complains that Philip of Hesse had not replied concerning Sleidan yet. Sends Du Bellay's letter to Sleidan and Jean Sturm (No. 49)

52. March 20 (Strasbourg) - Martin Bucer to (Jacob Sturm) - Rott, p. 582 Sends him Jean DuBellay's letter to Sleidan and Jean Sturm (No. 49).

53. March 27 (Strasbourg) - SLEIDAN to Jacob Sturm - Bg 19; BV 1/II, No.2, pp. 93-95

Concerned that the sent Commynes has not arrived yet. Illness of French king. Pleads for his cause.

54. March 27 (Weißenstein) - Philipp of Hesse to Martin Bucer - Lenz II, No. 207, pp. 317-319

Wants two more copies of Commynes. Sleidan is employed. Hesse and Strasbourg will pay his salary, and other states, too.

55. April 1 (Strasbourg) - Georg Fabricius to Wolfgang Meurer-Hasenclever d, p. 17 , fn. 5

Sleidan has translated Commynes' work on Louis IX and Charles of Burgundy. Recommends it warmly. 
56. April 4 (Strasbourg) - SLEIDAN to Jacob Sturm - Bg 20; BV 1/II, No. 3, pp. 95 101

Reflections on peace of Crépy. Possible Peace France-England. Trent. Sends letters by Guillaume Du Bellay which he translated three years ago. Pleads for his cause.

57. April 7 (Strasbourg) - Martin Bucer to Philip of Hesse - Lenz II, No. 209, pp. 331333; Bg b, pp. 72-73

Saxony agrees to Sleidan's employment. Sleidan needs an employee and will come to Worms to negotiate. Protestant history to be written in German and Latin.

58. April 10 (Strasbourg) - SLEIDAN to Jacob Sturm - Bg 21; BV 1/II, No. 4, pp.

101-104

On peace Emperor-France. Trent/Worms. Improvement of Francis' health.

59. April 13 (Strasbourg))- SLEIDAN to Jacob Sturm - Bg 22; BV 1/II, No. 5, pp. 104-109

French delegation. Crépy. France fears alliance Protestants-England. Emperor furious about his 'Orations', but positive acceptance in Wittenberg, also by Luther.

60. April 28 (Worms) - Christoph von Carlowitz to Moritz of Saxony - Brandenburg No. 688 , pp. $224-225$

Jacob Sturm and others suggested a Protestant history written by Sleidan. Sends their recommendation and advices to support this.

61. May 2 (Worms)) - Jacob Sturm to Martin Bucer - Bg 23

Schmalkaldic League will pay Sleidan 250 (gold) florentines to write a history, Maurice of Saxony promised another 100 florentines. Sleidan contracted to fulfill diplomatic missions.

62. May 8 (Strasbourg)) - SLEIDAN to Jacob Sturm - Bg 24; BV 1/II, No. 6, pp.109114

Thanks for support with his employment. Asks for material. News about England/France.

63. May 8 (Strasbourg) - SLEIDAN to Nicolas Pruckner - Bg 25

Thanks for a book. Political events.

64. May 9 (Strasbourg)) - SLEIDAN to Jacob Sturm - Bg 26; BV 1/II, No. 7, pp.114115

Waldensian persecutions and Francis' attitude. Council of Trent.

65. May 10 (Kassel) - Moritz of Saxony to Christoph von Carlowitz - Brandenburg No. 700 , p. 267

Accepts to support Sleidan, wants a copy of his history. 
66. May 14 (Strasbourg) - SLEIDAN to Jean Du Bellay - Bg 27; Geiger, p.174-77 Political news; Waldensians. Asks to pay his extant salary. Is employed by Protestants for 300 florentines. Pessimistic about relations France-Germany. 'Two Orations' brought him the Emperor's hatred and Luther's approval.

67. May 15 (Strasbourg) - SLEIDAN to Jacob Sturm - Bg 29; BV 1/II, No. 8, pp.115117

Sent the proposed chapters of his history to Hesse and Saxony so that they can find the material for him. Waldensians and other news from France.

68. May 15-16 (Strasbourg)) - SLEIDAN to Jean DuBellay - Bg 28

Sees no hope for alliance France-German Protestants any more. Sleidan will remain faithful to the Cardinal.

69. May 26 (Strasbourg)) - SLEIDAN to Jean Du Bellay - Bg 30; Geiger, pp.177-181 Political considerations on Emperor, Cologne archbishop and others. Negative verdict on French government.

70. May 29 (Strasbourg) - Martin Bucer to Jacob Sturm - PC 3, No. 570, p. 599 Wants Sleidan to compose a writing to the Emperor for Protestants to incite him against the Pope.

71. May 29 (Strasbourg) - SLEIDAN to Philip of Hesse-Bg 31; Heinemayer No. 2928 , p. 541

Wrote to Luther for material, are in correspondence. Calvin's recent visit.

72. May 29 (Strasbourg)) - SLEIDAN to Jacob Sturm - Bg 32; BV 1/II, No. 9, pp.117-121

Bucer wants Sleidan to compose a French writing for the emperor, to show that it is in his position to reform the church. Correspondence with Luther and Philip of Hesse.

73. May 31 (Strasbourg) - SLEIDAN to Jacob Sturm - Bg 33; BV 1/II, No. 10, pp.121-122

Saxon Chancellor Carlowitz recommended Sleidan to Duke Maurice of Saxony to write the history of the Reformation. Carlowitz will talk to him personally.

74. June 5 (Strasbourg)) - SLEIDAN to Jacob Sturm - Bg 34; Geiger, p. 196-7 Bucer still wants him to write to Emperor. Will start his history and send samples to Sturm. About the German-French negotiations. Warns of France.

75. June 8 (Strasbourg)) - SLEIDAN to Jacob Sturm - Bg 35; BV 1/III, No. 11, pp.105-109

The legate Grignan complained about Sleidan, concerning rumours about Sleidan and the 'misery' of the Waldensians. About France and England. 
76. June 13 (Strasbourg) - SLEIDAN to Jacob Sturm - Bg 36; BV 1/III, No. 12, pp. 109-112 $2^{5}$

Is content with the terms of his contract. Bucer still wants him to write to Emperor.

77. June 14 (Weida) - John Frederic of Saxony to Franz Burckhardt - Hasenclever d, p. 35 , fn. 3

Asks him to send a copy of the peace of Crépy and the papal bull for the Council of Trent to Sleidan to translate into German.

78. June 16 (Strasbourg) - SLEIDAN to Jacob Sturm - Bg 37; BV 1/III, No. 13, pp. 112-114 Accepts his contract. Will use the first volume of Luther's works for the start of the 'Commentaries'. On Grignan and his speech to the states.

79. June 24 (Strasbourg) - SLEIDAN to Jacob Sturm - Bg 38, BV 1/III, No. 14, pp.114-118

Has recently started working on the 'Commentaries', enjoys his work very much. Has not had time yet for the writing to the Emperor. Uses Luther's works for the early years and contacted Hesse and Saxony to get material. Mentions Rabelais' 'Pantagruel'. Expects his books from France.

80. s.d. (June/July 1545) - SLEIDAN to Ludwig Gremp - Bg 182

Jacob Sturm wants him to return a certain writing. News from Bucer.

81. July 3 (Strasbourg) - SLEIDAN to Jacob Sturm - Bg 39; BV 1/III, No. 15, pp.119120

Wants that his contract states 'history' rather than 'chronicle'. Thinks that with additional material from Saxe and more of Luther's works he can make quite good progress.

82. July 10 (Strasbourg) - Martin Bucer to Jacob Sturm - Rott, No. *39a, p. 586 On the merits of Sleidan and Jean Sturm.

83. July 11 (Strasbourg) - SLEIDAN to Jacob Sturm - Bg 40; BV 1/III, No. 16, pp.120-125

Thinks that Francis is in favour of negotiations and peace with England. Hopes that Dauphin can attend the negotiations. Sends the first book of the 'Commentaries' and asks for opinion.

84. July 21 (Strasbourg) - SLEIDAN to Jacob Sturm - Bg 41; BV 1/III, No. 17, pp.125-126

His due payment is received. Argument with Grignan.

\footnotetext{
${ }^{5} \mathrm{BV}$ lists this letter wrongly under 13 January.
} 
85. July 23 (Strasbourg) - SLEIDAN to Jacob Sturm - Bg 42; BV 1/III, No. 18, pp. 126-127

Jean Sturm asks about lost letters sent to France (concerning the negotiations between France and German Protestants). Sleidan's brother negotiates with the Chancellor of Jülich-Cleve whether Wilhelm of Jülich-Cleve would employ Sleidan.

86. (July) 24 (Strasbourg) - Martin Bucer to Jacob Sturm - Rott, No. *42a, p. 587 Sleidan's brother-in-law bought wood at Strasbourg to renovate his house in Düren.

87. July 26 (Strasbourg) - SLEIDAN to Jacob Sturm - Bg 43; BV 1/III, No. 19, pp.127-128

Congratulates Sturm for his engagement for the missions to England and France. Would have preferred to be sent to France instead of England.

88. August 5 (Worms) - Christopher Mont to William Paget - LP XX/I, No. 48, p. 23 Sleidan one of the ambassadors to go to England.

89. August 6 (Worms) - Schmalkaldic League to Henry VIII - LP XX/II, No. 58, p. 29 Letter of recommendation for Sleidan and Ludwig Baumbach, marshal of Hesse.

90. August 6 (Worms) - Schmalkaldic League to Sleidan and Ludwig Baumbach Hasenclever a, pp. 229-231 Instructions for Sleidan and Baumbach.

91. August 6(Worms) - Schmalkaldic League to Francis I - Hasenclever a, pp. 231233

'Memorial' of the League for Sleidan, Baumbach, Johann von Nidbruck and Christoph von Venningen.

92. August 19 (Friedwald) - Philipp of Hesse to SLEIDAN, Ludwig Baumbach, Johann von Nidbruck and Christoph von Venningen - Hasenclever a, pp. 235-236 Instructions concerning the negotiations with France and England.

93. August 28 (Strasbourg) - Jean Sturm to Christopher Mont - LP XX/II, No. 239, p. 105, Hasenclever c, $99 \mathrm{f}$

Recommends Sleidan and asks to recommend Sleidan to the king.

94. September 15 (Frankfurt) - Martin Bucer and Christopher Mont to Henry VIII - LP XX/II, No. 381, p. 168

Sturm said that Sleidan and companions left Strasbourg on 28 August.

95. September 21 (Amiens) - Jean Sturm to Jacob Sturm - PC3, No. 604, pp. 636-638 Sleidan and Baumbach left for Calais. He gave them a letter. 
96. September 21 (Windsor) - Van der Delft to Charles V - LP XX/II, No.421, pp. 185-6; Hasenclever c, pp.101-03

Sleidan and companions dined with Council and spoke to Henry VIII.

97. September (20-27) (Windsor)) - SLEIDAN to Henry VIII - Bg 44; LP XX/II, No.490, p. 211

Sends him the Latin version of the 'Two Orations', hopes for successful negotiations. Signs with 'legum licentiatus et historiographus protestantium'.

98. September 29 (Windsor) - SLEIDAN to Jacob Sturm - Bg 45

Arrived on 19 September. Reception by the Henry VIII; negotiations. Death of Charles of Orléans. Henry gratiously accepted a copy of his 'Orations'.

99. s.d. (1545, late September-mid-October) - SLEIDAN to N. - Bg 180

On the Emperor and the Pope (to be passed on to Jacob Sturm).

100. October 10 (Ham/Picardie) - Jean Sturm to Jacob Sturm - PC 3, No. 617, p. 654

On missions to France and England. Wrote to Sleidan about misbehaviour of the Pope so he can relate it to the King if the opportunity arises.

101. October (11) (Windsor)) - SLEIDAN and Baumbach to William Paget Hasenclever c, pp.104-5

They have decided to leave.

102. October 19 (Calais) - SLEIDAN and Baumbach to William Paget - Bg 46;LP $\mathrm{XX} / \mathrm{II}$, No. 614, p. 282

Arrival at Calais and correspondence with legates in France.

103. October 22 (Chauny) - Johann von Nidbruck to SLEIDAN - Bg 47; LP XX/II, No.635, p. 292

Information on their impending arrival at Ardres.

104. October 22 (Chauny) - Venningen, Johann von Nidbruck and Jean Sturm to SLEIDAN - Bg 48; LP XX/II, No.634, p. 292

They are on their way. French king will send councillors.

105. October 24 (Calais) - SLEIDAN and Baumbach to Henry VIII - Bg 49; LP XX/II, No.647, p.297

French legates to leave France, they intend to do the same.

106. October 24 - SLEIDAN to Henry VIII - Bg 50; LP XX/II, No.648, p. 297 Expresses his regret for the negative outcome of the negotiations. Thanks Henry for his good will. Is convinced that Henry would do nothing to the detriment of their states and has indeed warned them of danger.

107. October 24 (Calais) - SLEIDAN to William Paget - Bg 51; LP XX/II, No.649, p. 298 
French legates have left France. Recommends writing letter to princes and Strasbourg (calls himself a servant of both Strasbourg and the Protestant princes). Regrets the interference of Emperor who apparently convinced the English king to negotiate with him and tries the same with France.

108. October 25 (Calais) SLEIDAN and Baumbach to Henry VIII - Bg 52; LP XX/II, No.651, p. 299

Good news from France: King will send legates to meet with German legates at Ardres. Hopes that England will do the same.

109. October 25 (Calais) - SLEIDAN to William Paget - Bg 53; LP XX/II, No.652, p. 299

Hopes that England will send legates.

110. October $28^{6}$ - William Paget to SLEIDAN - Bg 54; LP XX/II, No.675, pp. 305306

He and Bishop of Durham will meet them at Ardres, but wants confirmation that French delegates have arrived.

111. October 30-31 (Calais) - SLEIDAN and Baumbach to Henry VIII - Bg 55; LP XX/II, No.693, p. 314

About the planned meeting and negotiations at Calais on11/12 November 1545. England to give Boulogne back to France.

112. October 31 (Calais) - SLEIDAN to William Paget - LP XX/II, No.702, p. 817;

Hasenclever c, pp. 105-6

Waiting for French diplomats. French position.

113. November 2 (Windsor) - William Paget to SLEIDAN - PC 3, No. 631, pp. 667668

Wants to defer meeting with French legates from 11 November to 15 November. Peace negotiations should not be tied to Protestant suggestions.

114. November 5 (Calais) - SLEIDAN and Baumbach to William Paget - PC 3, No. 632, p. 668-669

Agree with his suggestions concerning the negotiations.

115. November 8 (Calais) - SLEIDAN and Baumbach to William Paget - Rott, No. 55 d, p. 590

Send Jean Sturm's response to the letter by Venningen and Nidbruck from 31 October, and shortly await his response to their demand from 4 November to analyse Francis' I position in the negotiations.

116. November 10 - SLEIDAN and Baumbach to William Paget - PC 3, No. 634, p. 670

\footnotetext{
${ }^{6} \mathrm{Bg} 54$ lists this letter under 27 October.
} 
French legates agree to meet at Ardres, but want truce until early December and free conduct.

117. November 11 (Ottelant?) - William Paget to SLEIDAN - PC 3, No. 635, p. 670671

Concerning the meeting at Ardres.

118. November 12 (Calais) - SLEIDAN, Baumbach, Nidbruck and Venningen to Ulrich of Württemberg - PC 3, p. 671, fn. 2; Hasenclever c,pp. 105-6, fn. 4 Mission, death of Venningen.

119. November 12 (Calais) - SLEIDAN to Jacob Sturm - Bg 56

Preparations for the negotiations between England and France (to begin on 15 November) and the tactics of the German Protestants. Death of Venningen.

120. November 14 (Calais) - SLEIDAN and Baumbach to William Paget - PC 3, No. 638 , p. 673

Send a copy from their fellow legates in France.

121. November 15 (Calais) - SLEIDAN and Baumbach to William Paget - PC 3, No. 639 , pp. 673-4

Conditions for truce between France and England. Conduct for French legates to Ardres.

122. November 21 (Calais) - William Paget to Henry VIII - LP XX/II, No.836,p. 402 404

Reports his meeting with Sleidan and Bruno.

123. November 22 (Paris) - Jean Du Bellay to SLEIDAN - Bg 57

Inquiries about state of negotiations between England, France and Germany. Apologises for delay in sending money.

124. November 30 (Calais) - SLEIDAN to Jacob Sturm - Bg 58

Arrival of English and French legates. Start of negotiations. Asks to remind Saxon chancellor Burkhard to send material for the 'Commentaries'. Informed Paget about his historical project who promised material.

125. December 2 (Calais) - William Paget to Henry VIII - LP XX/II, No. 917, pp. 459460

Reports his meeting with Jean Sturm and also mention Sleidan. Sleidan and Baumbach referred to as being like 'sheep'.

126. December 2 (Calais) - William Paget to Henry VIII - LP XXX/II, No. 918, p. 460 Sleidan and Bruno showed him a letter from Jacob Sturm.

127. December 3 (Calais) - SLEIDAN to Jacob Sturm - Bg 59

Negotiations between France and England. 
128. December 4 (Calais) - William Paget to Henry VIII - LP XX/II, No. 927, pp. 465 Sleidan showed him another letter from Jacob Sturm.

129. December 5 (Calais) - SLEIDAN to Jean Du Bellay - Bg 60; Geiger, pp. 181-2 On the negotiations. Wishes that Du Bellay was present.

130. December 9 (Ardres) - SLEIDAN to Jean Du Bellay-Bg 61; Geiger, pp.182-3 Hopes for Du Bellay's interference. German Protestants wish to keep good relations with both France and England rather than to form an alliance with one and annoy the other.

131. December 11 (Calais) - SLEIDAN to Henry VIII - Bg 62; LP XX/II, No.972, p. 480

Has been asked by German Princes to write 'Commentaries'. Book 1 is finished, will send copy, as well as an outline of the whole work.

132. December 11 (Calais) - SLEIDAN to Henry VIII - Bg 63; LP XX/II, No.973, p. 480 Pleads for alliance between England, German Princes and France. ${ }^{7}$

133. December 17 (Calais) - SLEIDAN to Jean DuBellay - Bg 64; Geiger, p. 184 Hard and treacherous times. Complains about intercepted letters.

134. December 25 (Frankfurt/Main) - Delegates of the Schmalkaldic league to SLEIDAN, Baumbach, Nidbruck and Jean Sturm - PC 3, pp. 691-692, fn. 5 Received Jean Sturm's report and want them to pursue their missions with zeal.

135. December 26 (Calais) - SLEIDAN and Baumbach to Henry VIII - Bg 65; LP XX/II, No.1041, p. 521

Bids farewell to Henry. Offer to carry a letter by him to the German princes if he wishes to send one.

136. December 28 (Calais) - William Paget to Petre - LP XX/II, No.1050, p. 525 On dinner with Protestant ambassadors. Sleidan will send Henry VIII a copy of a French letter to Francis I which he wrote at Calais on the jurisdiction of the Pope in France.

137. December 30 (Westminster) - Henry VIII to the Schmalkaldic league - Rott, No. *65b, pp. 592-593

Thanks them for their efforts to negotiate a peace, praises their legates.

Emphasises that the negative outcome of the negotiations is not his fault.

\footnotetext{
${ }^{7}$ Sleidan also composed a similar writing to Francis I which he did not send after all.
} 
138. January 6 (Strasbourg) - Caspar Hedio to Jean Calvin - CR 40, No. 749 Heard that Sturm, Sleidan and others attend a council with the English.

139. January 8 (Thérouanne) - French legates to SLEIDAN, Baumbach, Nidbruck and Jean Sturm - Rott, No. 65c, p. 593

The bishop of Soissons' indisposition hinders them from joining them at Ardres and hand them over Francis' letter to the Schmalkaldic league.

140. January 9 (Saint-Germain-en-Laye) - Francis I to SLEIDAN, Baumbach, Nidbruck and Jean Sturm - Rott, No. 65d, p. 593

Has heard of departure of English legates and thanks them for their efforts.

141. January 27 (Utrecht) - Stephen Gardiner to William Paget - LP XXI/I, No.128, p. 56-57

The imperial counsellor Gérard complained about the indiscretion and clumsiness of the legates of the Schmalkaldic league, especially Sleidan, Baumbach and Jean Sturm.

142. February 3 (after) - SLEIDAN's bill of his mission to England - Bg p. 87-88 Sleidan's report of his travel to England and his expenses. Left Strasbourg on 28 August 1545, 15 September in Calais, 19 September till 12 October in Windsor, 18 October back in Calais. 26 January 1546 Sleidan arrived back in Strasbourg, until 30 January, then left for Frankfurt, where he arrived on 3 February. ${ }^{8}$

143. February 4 (Frankfurt/Main) - Jacob Sturm's diary of Frankfurt diet - PC 3, No. 651, p. 711

Johann von Nidbruck, Jean Sturm and Sleidan report about their negotiations with France and England.

144. February 6 (Frankfurt) - SLEIDAN to Jean Du Bellay - Bg 66; Geiger, pp.184-5 News about the colloquy at Frankfurt. Asks to recommend him to the king.

145. February 8 (Frankfurt/Main) - SLEIDAN to William Paget - Bg 67; LP XXI/I, no. 180, p. 89

Reports about the colloquy at Frankfurt and other news.

146. February 8 (Frankfurt/Main) - Christoph von Carlowitz to Moritz of Saxony Brandenburg No. 860 , p. 517

Sleidan, 'the historiographer', took part in mission to England.

147. February 8 (?) - Caspar Hedio to Jean Calvin - CR 40, No. 763

Sleidan, Sturm and the other legates went to Frankfurt to report about their negotiations.

\footnotetext{
${ }^{8}$ Sleidan was accompanied by Ludwig von Baumbach and Philip von Nidbruck, a son of Johann von Nidbruck.
} 
148. February 10 (Frankfurt) - Christopher Mont to William Paget - LP XXI/I, No.192, p. 95

Sends greetings from Sleidan and Bruno.

149. February 18 (Abbey St Maure des Fossées) - Jean Du Bellay to SLEIDAN Hasenclever c, pp. 96-97

Bad rumours about Sleidan which are also negative for himself.

150. February 20-24 (Strasbourg) - Jacob Sturm and others to Strasbourg Council - PC $4 / 1$, No. 31, pp. 35-37

Their report about the negotiations with France and England (Sleidan).

151. February 25 (?) - William Paget to Christopher Mont - LP XXI/I, No. 272, p. 129 Sends his regards to Johann von Nidbruck (=Bruno) and Sleidan, will write soon.

152. February 26 (Greenwich) - William Paget to Johann von Nidbruck - LP XXI/I, No. 278 , p. 131

Sends his regards to Sleidan and Jean Sturm.

153. March 12 (Strasbourg) - SLEIDAN to Jean DuBellay - Bg 68; Geiger, p.

185

Will get married on 15 March. Sturm informed him about new false accusations against him.

154. March 12 (Strasbourg) - SLEIDAN to Jean Du Bellay - Bg 69; Geiger, p. 186

Is in contact with Saintail, the French agent sent several times to the German Protestants. Is upset about new allegations against him. Will write to Francis I and send Du Bellay a copy of that letter (No. 155).

155. March 12 (Strasbourg) - SLEIDAN to Francis I-Bourrilly a, pp. 212-216 Describes the meeting of the Schmalkaldic league at Frankfort. Is innocent of any allegations that he spread rumours about Francis I and France's policy. The Schmalkaldic league itself is prepared to give testimony of the integrity of Sleidan's private and public reports about France.

156. March 13-14 (Strasbourg) - Church register - Baumgarten b, p. 91

Sleidan gets married to Jola, the daughter of Johann von Nidbruck, at the church of St. Wilhelm in Strasbourg.

157. March 22 (Strasbourg) - Strasbourg's instructions to its legates in Worms - PC 4/1, No. 51, pp. 52-69

Sleidan's payment for England mission (250 florentines?).

158. March 27 (Strasbourg) - SLEIDAN to Jean DuBellay - Bg70; Geiger, pp. 186-7

Wrote to Francis I (No. 155) to defend himself. News of his marriage. 
159. April 3-23 (Worms) - Jacob Sturm about Worms diet - PC 4/1, No.63, pp. 63-92 Sleidan present, concerning his payment, Sleidan received 150 florentines.

160. April 13 (Strasbourg) - Martin Bucer to Philip of Hesse - Lenz II, No. 232, pp. 427-8 Asks to send material for Sleidan's work.

161. April 26 (Strasbourg)) - Jean Sturm to Jean Du Bellay - Bg p. 125, fn. 1 Sleidan is very upset about the allegations against him since he is convinced of his innocence.

162. April 27 (Strasbourg) - SLEIDAN to Jean Du Bellay - Bg 71; Geiger, p.187-9 Has sent a justification to Francis I and to Du Bellay. Meeting of the states and princes at Worms, have written a declaration defending him. Underlines his innocence. Murder of Juan Díaz.

163. May 6 (Regensburg) - Christoph von Carlowitz to Moritz of Saxony Brandenburg 2, No. 894, p. 579

'Announcements' have been written in Latin and German. If Moritz wants to have them also in French, he will ask Sleidan to do so.

164. May 8 (Strasbourg) - Martin Bucer to Philip of Hesse - Lenz II, No. 233, pp. 42831

Asks to send material from Landgrave and Saxony to Sleidan.

165. May 10 (Strasbourg) - SLEIDAN to Jean Du Bellay - Bg 72; Geiger, pp.189-92 If Francis I will not accept his apologies he will quit his service and stop the contact. Asks for his payment. Political news. Will go home until July, will also visit Count Franz von Manderscheid, his former pupil.

166. May 14 (Strasbourg) - SLEIDAN to Jean Du Bellay - Bg 73; Geiger, pp. 192-193 Is very upset about the Cardinal's seeming suspicion and distrust.

167. May 15 (Strasbourg) - SLEIDAN to Philip of Hesse-Bg 74; Hortleder II, fol. cv v, Heinemayer, No. 2928 , p. 541

Mentions that he was employed by Schmalkaldic League in 1545. Asks for more material. On his denunciation that he had purposefully misrepresented the French attitude towards an alliance with the German Protestants, Du Bellay defended him, and he sent an apology to Francis. Du Bellays have many enemies at court, are rumoured to be Lutherans. Persecutions in France enforced by evil people, the king himself is a nice person.

168. May 15 (Kassel) - Philip of Hesse to Jacob Sturm and Martin Bucer-Bg p. 136, fn. 1

Sleidan will get access to archive, but should come himself to pick up what he needs or send somebody else. Will ask Saxony to do the same. 
169. May 15 (before) - Sleidan's contract with the Schmalkaldic League - Bg b, pp. 113-114

John Frederic of Saxony and Philip of Hesse employ Sleidan for the Schmalkaldic League as diplomat, translator and historian for a history of the Reformation. Is to be paid 350 florentines per year.

170. May 20 (Kassel) - Philip of Hesse to SLEIDAN - Bg 75; Heinemayer, No. 2928, p. 541

Is convinced about Sleidan's innocence concerning the allegations, will even write to Francis I if he wants. Will inform Saxony about the material Sleidan wants. Sleidan's contract to be sent soon.

171. May 21 (Kassel) - Philip of Hesse to John Frederic of Saxony - Hortleder II, fols. cv v-cvi r; Heinemayer, No. 2928, p. 542

Passes Sleidan's letter from 15 May (No. 168) on, and asks to fulfill his wish and send more material.

172. June 10 (Torgau) - John Frederic of Saxony to Philip of Hesse - Bg 76, Hortleder II, fo. cvi $\mathrm{r}-\mathrm{v}$

All the archival documents Sleidan wanted cannot be found, but they will send material about diets in Nuremberg 1522 and Augsburg 1530.

173. June 17 (Kassel) - Philip of Hesse to John Frederic of Saxony - Bg p. 138, fn. 6 Thinks that Sleidan should be admitted to the archives to lookfor the material he wants himself.

174. July 4 (Ichtershausen) - John Frederic of Saxony/Philip of Hesse to Strasbourg Council - PC 4/1, No. 186 , pp. 215-216

Sleidan planned in for another mission to England together with Johann von Nidbruck, but could not come.

175. July 7 (Strasbourg) - Michael Han (Syndikus of Strasbourg) to Philip of Hesse PC 4/1, No. 194, pp. 221-224

Recommends another mission to France and England, Sleidan to participate.

176. September 3 (Bonn) - SLEIDAN to Philip of Hesse - Bg 77; Heinemayer, No. 2928 , p. 341

Sleidan offers his services. He agrees to send a French writing to the Emperor.

177. November 16 (?) - Johann von Nidbruck to Jacob Sturm - PC 4/1, No. 457, pp. 486-488

About another mission to France and England, recommends Sturms and Sleidan. 


\section{7}

178. January 7 (Kassel) - Philip of Hesse to Martin Bucer - Lenz II, No. 244, pp. 47578

Sends his 'Rechenschaftbericht' about Schmalkaldic war, should be passed on to Sleidan.

179. January 19 (Strasbourg) - SLEIDAN's receipt for the payment of his expenses from the mission to England - Bg p. 89 Acknowledges the payment of his expenses from the mission to England, amounting to 764 Gulden and 6 Batzen ( 1 Gulden $=15$ Batzen).

180. January $25^{9}$ (Strasbourg) - SLEIDAN to Jean Du Bellay - Bg 78; Geiger, pp. 193195

News about the Schmalkaldic war; many cities and princes surrendered. Has composed a writing on relation of Emperor with the Pope, sends it to Du Bellay. Asks whether he would find a way to give it to Pope as the writing of a Catholic so he would read it. Asks whether he should publish it.

181. March 19 (Strasbourg) - Church register - Rott, No. *78a, p. 597

Baptism of Sleidan's oldest daughter, Magdalena, in the church of St. Wilhelm in Strasbourg.

182. April 1 (Kassel) - Philip of Hesse to XIII of Strasbourg - Bg 79

Sleidan has asked him to remind Strasbourg that they owe him his salary for the previous two years, 250 florentines.

183. April 2 (Kassel) - Philip of Hesse to Martin Bucer - Lenz II, No. 252, pp. 493-497 Latest events, emperor on march. Should pass on letter to Sleidan after reading.

184. April 30 (Strasbourg) - SLEIDAN to Veit Dietrich ${ }^{10}$ - Rott, pp. 629-630 A request to buy second volume of Luther's works for him.

185. August 13 (Rome) - Jean Du Bellay to Henry II - Bg 80; Geiger, p. 170 Asks to maintain the payment of a yearly pension of 100 livres to Sleidan, the 'secretary of the Protestant states'; recommends him warmly.

\section{8}

186. February 14 (?) - Jacob Sturm, Max Hag, Hans von Odratzheim to Council of Strasbourg - PC 4/2, No.732, pp. 871-872

\footnotetext{
${ }^{9}$ Geiger lists this letter under 27 January.

${ }^{10}$ Veit Dietrich (1506-1549) was minister in Nuremberg since 1535 and an editor of Luther.
} 
Sleidan and others accused by Anton Perrenot de Granvella [the bishop of Arras] of too close relation and even intrigues with France. Think that Sleidan if not all are innocent. Sleidan handed in an apology.

187. February 20 (?) - SLEIDAN to Jacob Sturm - Winckelmann, pp. 566-568 Denies any indecent attitudes or practices with France. Asks him to defend him. Johann von Nidbruck out of town (thus can not defend himself yet).

188. March 10 (Strasbourg) - SLEIDAN to Anton Perrenot de Granvella, Bishop of Arras - Hasenclever g, pp. 134-136

Denies any conspiracies with the French against the Emperor.

189. March 14 (Strasbourg) - SLEIDAN to Nicolaus Brom - Bg 81; Geiger, pp. 197-8 Saxony will give money (50 florentines) for Sleidan to him which they still owe him from 1545. Asks Brom to hand these over to Crato Mylius. ${ }^{11}$

190. (July 9, shortly after) - SLEIDAN to Ludwig Gremp - Bg 82 Has to cancel the dinner invitation. His translations of Commynes and Seyssel have been published, will send him copies. Asks for text of the Interim.

191. December 1 (Strasbourg) - SLEIDAN to Jean DuBellay - Bg 83 Asks Du Bellay to protect the son of Wolfgang Rechlinger [diplomat] who studies in France and other German students there.

192. April 8 (Mainz) - John Hooper to Heinrich Bullinger - Bg p. 254, fn. 1 Sleidan wrote a history book addressed to Edward VI.

193. May 27 (Strasbourg) - Strasbourg Council to Dr. Heinrich Kopp - PC 4/2, No. 901, pp. 1206-1207

Deny any 'practices' of Strasbourg with France, and obtained oaths and apologies from all the people accused of such (i.e. Sleidan, Jean Sturm, Johann von Nidbruck, and Ulrich Geiger; they all wrote 'confessions'/apologies in Feb./March 1548).

194. May 28 (?) - Joss Münch von Rosenberg to Friedrich von Fürstenberg - Rott, No. *83b, p. 598

Friedrich's brother, Count Guillaume von Fürstenberg, wanted to ask Sleidan to plead for him at the imperial court, but Ludwig Gremp dissuaded him from doing so.

\footnotetext{
"Crato Mylius had published Sleidan's Latin Two Orations in 1544.
} 
1550

195. (late January/early February) (Strasbourg) - City protocol - Rott, p. 630-31

Sleidan translates $a$ 'mandement' by the magistrate for the French refugees in Strasbourg into French.

196. March 20 (Strasbourg) - SLEIDAN to Martin Bucer-Bg 84 Asks him to recommend him to Cranmer. Political news. Rumours that Pole might become the next pope.

197. May 11 (Greenwich) - John Cheke to Martin Bucer - Rott, No. *84a, p. 599 Cranmer is willing to ask for the payment of Sleidan's pension, but he just takes his time.

198. (July 1) (Strasbourg)) - SLEIDAN to Franz Dryander - Bg 85

He contacted Jacob Sturm concerning accommodation. Political news.

199. August 26 (Speyer) - Caspar von Nidbruck to Franz Dryander - Bg p. 156, fn. 9 Says that he wrote about all the other news from Augsburg to Sleidan.

200. September 13 (Strasbourg) - Strasbourg council to John Frederic of Saxony - PC5, No. 45 , p. 67

Reminder to pay wages for 1545 missions (includes Sleidan).

201. September 17 (after; London) - Roger Ascham to Edward Raven - Ascham III, No. 1, pp. 225-226

Tries his best to foster Sleidan's cause. The distrust in England against Johann von Nidbruck is equally negative for Sleidan.

202. October 8 (Augsburg) - Caspar von Nidbruck to Franz Dryander - Bg p. 156, fn. 9

Mentions that he can get to know about all other news in the letters to Sleidan.

203. October 10 (Strasbourg) - Annales Suevici - Hollaender c, p. 431; Crusius III, p. 676

The noble von Werthern had dinner in Strasbourg with Sleidan, Caspar Hedio and Ludwig Rabus; Nicolaus Gerbelius was invited but was ill. Discussions at dinner table; Sleidan remarked that Melanchthon was too moderate. Description of Sleidan's appearance.

204. November 10 (Strasbourg) - SLEIDAN to Jean DuBellay - Bourrilly a, pp. 216219

Political situation in Germany, especially Magdeburg.

205. November 27 (Heidelberg) - Hans Kilian to SLEIDAN - Bg 86

Concerning the sending of acts and papers. 
206. December 13 (Strasbourg) - SLEIDAN to Jean DuBellay - Bg 87; Geiger, pp.1956 Political news.

207. December 29 (Strasbourg) - SLEIDAN to Johann von Nidbruck - Bg 88 About Magdeburg and the council/pope. Political news. Private affairs. Asks to recommend him to Paget and Cheke. Is disappointed about Cranmer, says his own former efforts for England seemed to have been in vain.

208. (late December) - Martin Bucer to Earl Northampton - Hasenclever d, pp. 45-47 Praises God for the Reformation, which deserves a history to be written on it. This has been done by the fine historian Sleidan 'for five years', but due to the political and religious situation in Germany there is no money available for him to continue his work. Asks to inform king about this and hand in a supplication by Bucer, Peter Martyr and John a Lasco to pay Sleidan a salary so he can continue this work.

1551

209. January 24 (Augsburg) - Roger Ascham to Jean Sturm - Vos No. 42, p. 188

Passes on regards to Valentine Erythraeus, professor of rhetorics, and to Sleidan.

210. February 18 (Cambridge) - Martin Bucer to William Cecil - Bg 89 Asks him to give an answer to 'our supplication' for Sleidan.

211. February 18 (Schleiden) - Hospital register - Rott, No. *89a, p. 601 Sleidan assists with the financial registers of the hospital.

212. August 18 (Strasbourg) - SLEIDAN to Wolfgang Musculus - Bg 90 Heard that Cranmer wants him as successor of Bucer. Has written to Cranmer. News about the council and general affairs.

213. August 21 (Augsburg) - Roger Ascham to Jean Sturm - Vos No. 45, p. 194 Passes on regards to Valentine Erythraeus, Michael Toxites (=Schütz, teacher at Gymnasium) and Sleidan.

214. October $18(?)$ - Johann von Nidbruck to Strasbourg Council - Winckelmann, p. 596

Sleidan will only travel to Trent if Nidbruck's wife (Sleidan's mother-in-law) will come to Strasbourg to stay with Sleidan's family.

215. October 31 (Strasbourg) - XIII of Strasbourg to SLEIDAN - PC 5, No.161, pp. 227-8

'Werbung' to Württemberg concerning legates to Trent.

216. October 31 (Strasbourg) - Recommendation of the XIII of Strasbourg - Bg p. 166 
The senate of Strasbourg recommends Sleidan to the Council of Trent.

217. November 1 (Strasbourg) - XIII of Strasbourg to Christoph of Württemberg -Ernst I, No. 281, pp.308-09

Sleidan is to visit Christoph of Württemberg on the way to Trent.

218. (November 1) (Strasbourg) - Memorandum to Christoph of Württemberg - Ernst I, p. 309 , fn. 1

Memorandum to Christoph of Württemberg to be handed over by Sleidan.

219. November 2 (Strasbourg) - SLEIDAN to Thomas Obrecht ${ }^{12}$ - Rott p. 632

Left a note for him, is leaving soon.

220. November 7 (Tübingen) - SLEIDAN to XIII of Strasbourg - Bg 91

Left Strasbourg on 3 November and met Duke Christoph of Württemberg and Brenz in Tübingen to discuss the legates for the Council of Trent. Free conduct granted by Council.

221. November 7 - (Strasbourg?) - Walther Heinrich to Bernhard Meyer/Basel - PC 5, p. 240 , fn. 5

The great Sleidan has been sent to Trent.

222. November 15 (Strasbourg) - Council Acts - PC5, No. 173, pp. 252-256

Receipt of Sleidan's letter from 7 November, agree to write to him.

223. November 16 (Innsbruck) - SLEIDAN to XIII of Strasbourg - Bg 93 Arrived in Innsbruck 15 November, other legates have arrived. Negotiations between Pope and France. Political news.

224. November 19 (Strasbourg) - XIII of Strasbourg to Dr. Bernhard Botzheim - Ernst I, No. 291, pp. 316-319

Sleidan sent a writing from Christoph to XIII when he visited him.

225. November 20 (Strasbourg) - XIII of Strasbourg to SLEIDAN - Bg 92 Instructions for the council. Will ask Württemberg and Saxony to find a common line.

226. November 22 (Innsbruck) - Franz Kram to Herzog August - Hermann V, No. 267a, p. 517

Sleidan visited Innsbruck on his way to Trent.

227. November 22 (Strasbourg) - Strasbourg Mayor and Council to Frankfurt - PC 5, No. 177 , pp. $259-260$

Sleidan has been sent to Trent.

\footnotetext{
${ }^{12}$ Thomas Obrecht was secretary of the municipal treasury in Strasbourg.
} 
228. November 29 (Trent) - SLEIDAN to XIII of Strasbourg - Bg 94 Arrived in Trent on 21 November. Met other Protestant legates. On legates present. Proceedings of Council sessions. Rumours of an agreement between France and the Pope and a forthcoming meeting between the Pope and the Emperor.

229. November 29 (Trent) - SLEIDAN to Jacob Sturm - Bg 95 News from the council. Unclear about his instructions. Brandenburg legate called them all heretics. Unfriendly declaration of the French king.

230. November 29 (Trent) - H.D. von Plieningen/H.H. Hecklin to Christoph of Württemberg - Ernst I, No. 296, pp. 323

Sleidan asked them to send some letters to Strasbourg via Christoph's chancellory.

231. December 10 (Trent) - SLEIDAN to XIII of Strasbourg - Bg 97

Meeting with the imperial legate. Council dominated by Catholics and no real negotiations going on. Sends articles from the council.

232. December 15 (Strasbourg) - XIII of Strasbourg to SLEIDAN - Bg 96

Is to meet the Emperor's orator, Montfort. No news from Saxony and Württemberg yet. Instructions.

233. December 15 (Strasbourg) - XIII of Strasbourg to Christoph of Württemberg - PC 5, No. 182, p. 264; Ernst I, No. 305, p. 334

According to Sleidan's letters doubts whether Saxony will send legates.

234. December 22 (Trent) - SLEIDAN to XIII of Strasbourg - Bg 98

On the different groups of legates and their decrees. Gropper's disputation.

Protestants called heretics when referred to by the Catholics. King Maximilian arrived.

235. December 22 (Strasbourg) - Strasbourg Council acts - PC 5, No. 185, p. 266

Hedio's recommendations after Sleidan's reports from Trent.

1552

236. January 7 (Trent) - SLEIDAN to XIII of Strasbourg - Bg 101

Various remarks on the council and its proceedings. News about Emperor and Pope. Rumours that Catholics might accept communion in two kinds and priestly marriage.

237. January 10 (Trent) - SLEIDAN to XIII of Strasbourg - Bg 102

Saxon legates have arrived, their instructions. Württemberg delegation is to leave.

Other news. 
238. January 15 (Strasbourg) - XIII of Strasbourg to SLEIDAN - Bg 99

New instructions. Strasbourg will not send theologians yet, waits for other states and cities. Sleidan is to make up excuses for delay in sending legates.

239. January 16 (Trent) - SLEIDAN to XIII of Strasbourg - Bg 103 Concerning the different confessions and safe conducts. Had a meeting with the imperial legate, complained about the Catholic stubbornness, frustration. Invited for dinner with elector of Cologne, also attended by Julius Pflug.

240. January 16 (Trent) - H.D. von Plieningen to Christoph of Württemberg - Ernst I, No. 330 , pp. $355-357$

Met Saxon legates with Sleidan. Sleidan sends letters to Strasbourg through him.

241. January 17 (Innsbruck) - Florenz Graseck to Christoph von Württemberg - Ernst I, No. 331 , pp. 357-359

Sleidan asks to send letters to Strasbourg.

242. January 18 (Strasbourg) - XIII of Strasbourg to SLEIDAN - Bg 100

Instructions. Saxon legates should have arrived in December.

243. January 29 (Trent) - SLEIDAN to XIII of Strasbourg - Bg 104

Received their last letter and 200 florentines from Anton Fugger. Meeting of Saxon and imperial legates. Other news about council and general politics. Rumours about an impending end of the council.

244. January 29 (Trent) - SLEIDAN to Jacob Sturm - Bg 105 Asks Sturm to look after his wife; wants to leave soon. Rumours of a peace between Pope and Henri II. Other news.

245. January 30 (Trent) - Hans Dietrich von Plieningen/H.H.Hecklin to Christoph of Württemberg-Ernst I, No. 343, pp. 367-372

Sleidan and Saxony agree with handing over of gravamina/confession.

246. January 30 (Trent) - Saxon legates to Moritz of Saxony - Hermann V, No. 325, pp. $604-608$

Safe conduct was handed over to them, Württemberg legates and Sleidan.

247. January 31 (Trent) - SLEIDAN to XIII of Strasbourg - Bg 106

Imperial legate handed over the conducts to Sleidan, Saxony and Württemberg. Will send a copy.

248. January (Trent) - Notes of Württemberg legates in Trent - Ernst I, No. 316, pp. 343-345

Montfort said the Strasbourg legate (=Sleidan) met him and announced Saxon legates. 
249. February 1 (Trent) - SLEIDAN to Johann Marbach - Bg 107

Concerning the free conduct. Asks him to come soon.

250. February 3 (Trent) - SLEIDAN to Philip Melanchthon - Bg 108; CR 7, No. 5042; Scheible 6, No. 6330

Says he noticed in Melanchthon's letter to Badehorn that his letter from the $10^{\text {th }}$ has not arrived yet. News from Trent. Will visit Venice. Marbach is on his way to Trent. Greetings to Georg Major.

251. February 3 (Trent) - Leonhard Badehorn to Philip Melanchthon - CR 7, No. 5043, p. 935

Quite a number of legates want to leave, also Sleidan, as Melanchthon can see from the enclosed letters.

252. February 4 (Nuremberg) - Philip Melanchthon to Paul Eber - CR 7, No. 5045, pp. 936-7

Sleidan writes that the Württemberg legates will shortly leave Trent because they are dissatisfied.

253. February 18 (?) - Christoph of Württemberg to XIII of Strasbourg - Ernst I, No. 364, pp. 390-391

Their delegate (=Sleidan) will inform them about reactions to gravamina etc..

254. February 18-20 (Trent) - SLEIDAN to XIII of Strasbourg - Bg 109

Württemberg legates left. His trip to Venice. Rumours that council will be deferred because of the war. Wishes for Brenz, Martyr and Calvin to attend the council. Latest news.

255. February 20 (Trent) - Leonhard Badehorn to Moritz of Saxony - Hermann V, No. 340, pp. 629-630

Sleidan sent report to Strasbourg, is waiting for theologians.

256. February 25 (Strasbourg) - XIII of Strasbourg to SLEIDAN - Bg 110

Since Saxony sends its legates Strasbourg will do the same. Legates will stop in Augsburg for discussions with Melanchthon and Duke Christoph of Württemberg.

257. February 26 (Strasbourg) - XIII of Strasbourg to Christoph of Württemberg - Ernst I, No. 374, p. 399

Received Sleidan's letter on this, will send theologians.

258. February 29 (Trent) - SLEIDAN to Roger Ascham - Bg 111; CR 42; No. 1608 Has not received his pension from England yet. Bought Bembo's history of Venice, noticed that Jovius had published his history. News from the council; his trip to Venice.

259. March 8 (Trent) - SLEIDAN to XIII of Strasbourg - Bg 112 
Problems with delivery of letters. Melanchthon and other theologians will probably not come after all. Political news and rumours.

260. March 19 (Strasbourg) - XIII of Strasbourg to SLEIDAN - Bg 113 Is to defend Strasbourg's integrity. Rumours that France wants to attack

Germany; Saxony and Hesse summon troops. All is well with Sleidan's family.

261. March 23 (Trent) - Werner von Münchingen/Hieronymus Gerhard to Christoph of Württemberg - Ernst I, No. 427, pp. 449-454

Saw Montfort together with Sleidan. Sleidan sends letters to Strasbourg.

262. March 28 (Trent) - Werner von Münchingen/Hieronymus Gerhard to Christoph of Württemberg - Ernst I, No. 441, pp. 466-469

Sleidan asked to leave Trent, went despite protest of congregation.

263. April 9 (Tübingen) - SLEIDAN to Johann Marbach - Bg 115

His journey. Württemberg will provide money for his work ('Commentaries'?).

French army not far away from Strasbourg now.

264. April (14) (Strasbourg) - SLEIDAN's summarizing report of his mission to Trent - Bg 117

Summarizes his experiences in Trent. Protestant theologians arrived, with a printed confession. Insist that they are heard on all topics. Told orator Pictavia on 27 March that he would leave the next day. They tried to make him stay, but he left 28th March.

265. April 16 (Strasbourg) - SLEIDAN to Johann Marbach - Bg 116

On the confusion caused in Germany by the march of Maurice of Saxony against Emperor.

266. April 16 (Strasbourg) - XIII of Strasbourg to Christoph of Württemberg - Ernst I, No. 502, pp. 517-519

Heard Sleidan's report on Trent and meeting with Christoph.

267. April 18 (Strasbourg) - SLEIDAN to William Cecil - Bg 118

Marbach is on his way. Other news from the council.

268. April 23 (after) (Strasbourg) - Council acts - PC 5, No. 224, pp. 309-310 Costs for mission to Trent. Sleidan's payment (his bill amounted to 498 Gulden and 2,5 Batzen).

269. April 23 (after) - Report of Marbach and Söll - PC 5, No. 223, pp. 307-9 Sleidan left Strasbourg on 3 November 1545, left Trent on 28 March 1546.

270. April 27 (Strasbourg) - Recommendation of the XIII of Strasbourg - PC 5, No. 229, p. 315 
The senate of Strasbourg recommends Sleidan, Friedrich von Gottesheim and Peter Sturm to Henry II.

271. April 28 (Basle) - Basle to XIII of Strasbourg - PC 5, No. 230, p. 315

Possible mission (of Sleidan) to Henry II and Montmorency.

272. May 1 - Basle legates to Henry II - PC 5, No. 233, pp. 317-22

Suggest Sleidan as possible negotiator and translator.

273. May 2 (Strasbourg) - Council meeting - PC 5, No. 275, pp. 360-1

About the reports of Sleidans and his colleagues concerning the negotiations with Henry II.

274. May 5 (Strasbourg) - Report of SLEIDAN, Peter Sturm, Friedrich Gottesheim to senate - Rott, No. ${ }^{*} 118$ b, p. 606

Their report on their second mission to Henry II.

275. May 8 (Hagenau) - Baptiste Praillon to SLEIDAN - Bg 119

Thanks for his letter and the letter to the Constable. Wishes to have the food delivered the following day.

276. May 18-24 (Strasbourg) - SLEIDAN to William Cecil - Bg 120

French king with his army travelling through Elsass. Strasbourg provided them with food (so they would not take the city). Negotiations between Moritz of Saxony and King Ferdinand, other news.

277. May 30 (Strasbourg) - SLEIDAN to William Cecil - Bg 121

Moritz of Saxony's attack on imperial troops, Emperor fled from Innsbruck. Sends regards to archbishop of Canterbury and John Cheke. Asks to sort out his recommendation and the stipend granted by Edward VI. Other news.

278. June 24 (Strasbourg) - City Protocol - Bg b, pp. 114-117

Sleidan signs a four-year contract with the city of Strasbourg. Is to be paid 150 florentines and expenses.

279. July 28-30 - City protocol - PC 5, No. 275, pp. 360-361

Sleidan's report about the appeal of Albrecht of Brandenburg to Strasbourg for an alliance with him and France, and answer of the council.

280. August 31 (Strasbourg) - SLEIDAN to Leonhard Badehorn ${ }^{13}$ - Hasenclever f, pp. 530-31

His return from Trent. Henri II, Albrecht. Complains that Melanchthon does not write.

281. September 2 (Strasbourg)) - SLEIDAN to Edward VI-Bg b, p. 88

\footnotetext{
${ }^{13}$ Leonhard Badehorn was the rector of the university of Leipzig.
} 
Sleidan sends him an account of the events of 1552 ('Commentarii belli Germanici in gratiam R. Eduardi VI. descripti 1552').

282. September 3 (Strasbourg) - City Protocol - Hollaender a, col. 150-51

Concerning Sleidan's employment for Strasbourg and salary.

283. September 20 (Strasbourg) - SLEIDAN to William Cecil - Bg 122

Has written a tract about the events of this year to be sent to the king (see No.

281). Philip of Hesse and Frederic of Saxony are free again. News on the war.

Emperor's visit to Strasbourg. Asks to arrange his contract and payment.

284. September 28 (Strasbourg)) - SLEIDAN to Franz Dryander - Bg 123

Description of the stay of Charles $V$ in Strasbourg on his way to Metz.

285. October (early) (Strasbourg)) - SLEIDAN to Jacob Sturm - Bg 124

Political news.

286. October 3 (Strasbourg) - City Protocol - Hollaender a, col. 151

Sleidan's employment will start after Johanni.

287. October 17 (Strasbourg) - City Protocol - Hollaender a, col. 151

Sleidan to be employed for four years.

288. October 19 (Strasbourg) - City Protocol - Hollaender a, col. 151

Sleidan's formal entry into employment.

289. December 17 (Strasbourg) - SLEIDAN to William Cecil - Bg 125

Albrecht of Brandenburg has joined forces with Emperor. Other news. Asks to recommend his cause to the archbishop of Canterbury. Is surprised about the delay (in sending material?) since he arranged it with the king, and he needs it for the 'Commentaries'. Wants material on Henry VIII and the pope.

\section{3}

290. March 15 (Strasbourg) - SLEIDAN to William Cecil and John Cheke - Bg 126 Sends a description of the Council of Trent for the king. Has reached the year 1536 in his 'Commentaries' now. Asks again for material on Henry VIII and the pope. Says that in March 1551 the king granted him an annual stipend of 200 gold crowns, but has not been paid yet. Hopes they will sent the money soon. Wants Robert Hilss, a London merchant, 'who once lived with us', to send the 'things' he owes him through Bruno von Nidbruck's servant.

291. March 15 (Strasbourg) - Church acts St. Wilhelm - Hollaender c, p. 433; Crusius III, 11, p. 688 Baptism of Sleidan's third daughter Jola. 
292. March 20 (Strasbourg) - SLEIDAN to senate of Strasbourg - Rott, No. *126a, p. 608

Sleidan sends a German analysis of 'Epistola Regis christianissimi ad amplissimos sacri Imperii ordines' (printed at Paris on 27 February 1553).

293. March 21 (Strasbourg) - Church acts St. Wilhelm - Hollaender c, p. 433; Crusius III, 11, p. 688

Funeral of Sleidan's wife.

294. June 24 (Strasbourg) - SLEIDAN to John Frederic of Saxony - Bg 127

Reminds him of his employment since 1545 and the hardships during the war. Has carried on the narrative until 1540. Shortcomings of other histories. Hopes that the final work will also be read in other countries. Asks for financial support (has only been paid once).

295. (around June?) (Strasbourg) - SLEIDAN to ? (Franz Burkhardt?) - Bg 129 Visited Jacob Sturm, who asked to write to that person. Shows concern about his family. Hints that he had to sell his library.

296. July 9 (Meissen) - Georg Fabricius to Jacob Fabricius - Hollaender c, pp. 433-34 Send his account of 'Bohemian affairs' and other events to Rihel to give to Sleidan.

297. August 26-September 16 (Strasbourg)) - City protocol - PC 5, No. 361, pp. 457458, No. 377, pp. 473-474

Sleidan translated a letter by Henry II into German, including the complaint by Étienne Chalopin, and translated the senate's response into French.

298. September 13 (Strasbourg) - SLEIDAN to Jean Calvin - Bg 128; CR 42, No. 1797 Has reached the year 1546 in his 'Commentaries' now. Asks for material on the Waldensian persecutions and Vergerio and the Tridentine council in 1546.

299. September 27 (?) - Caspar von Nidbruck to SLEIDAN - Bg 130 Is sorry about the death of Sleidan's wife, promises support for his daughters. No post available for Sleidan at Maximilian's court.

300. December 28 (Strasbourg) - SLEIDAN to Jean Calvin - Bg 131; CR 42, No. 1881 Asks again about material on the Waldensians and on Servet. Peter Martyr has arrived at Strasbourg on 30 October, the day on which Jacob Sturm died. Events in England and other news.

\section{4}

301. January 1 (Strasbourg) - Heinrich Walter (Stadtschreiber) to Bernhard Meyer Friedensburg p. 107 
Sleidan is informed of everything concerning diets and colloquies.

302. January 8 (Strasbourg) - Diarium Marbachii - Bg b, pp. 92-93

Asked Sleidan for Jacob Meyer, whether he wanted to marry the latter's

stepdaughter. Sleidan declined.

303. January 13 (Strasbourg) - SLEIDAN to Stiftsherren of St. Thomas - Winckelmann, p. 594-595

Recommends that Bopp should be substituted (by Peter Martyr).

304. February 1 (Strasbourg) - City protocol - Rott, No. *131c, p. 609

Jean Garnier, the minister of the French church in Strasbourg, and his opponents are questioned by Sleidan and Friedrich von Gottesheim.

305. March 17 (Strasbourg) - City protocol - Rott, No. *131c, p. 609

Jean Garnier, the minister of the French church in Strasbourg, and his opponents are again questioned by Sleidan and Friedrich von Gottesheim.

306. April 2 (Strasbourg) - SLEIDAN to Jean Calvin - Bg 132; CR 43, No. 1940

Has finished the 'Commentaries', 25 books, to be called 'De Religionis et

Reipublicae statu Carolo quinto Caesare'. Heard about the publication of

Crespin's 'Livre des Martyrs', is interested. Events in England, many refugees.

Other news. Strasbourg is very happy to have convinced Peter Martyr to stay and teach there.

307. May 12 (Strasbourg) - XIII of Strasbourg to SLEIDAN - PC 5, No. 429, pp. 537-8 Instructions concerning Naumburg colloquy.

308. May 23 (Naumburg) - Philip Melanchthon to Caspar Peucer - Scheible 7, No.

7187; CR 8, No. 5605

Sends a letter of the English guest (John Hales), which Sleidan brought.

309. May 29 (Naumburg) - Philip Melanchthon to Johannes Marbach - Scheible 7, No. 7197; CR 8, No. 5613

On Naumburg colloquy; Sleidan also present.

310. May 30 (Leipzig) - Philip Melanchthon and Valentin Paceus to August of Saxony - Scheible 7; No. 7200

On 20 May the Saxon legates arrived, on 21 May the Hesse legates and Sleidan.

311. (June 9) (Strasbourg) - Diarium Marbachii - Bg p. xxvi

Sleidan left for Naumburg on 11 May, and returned on 9 June.

312. June 13 (?) - SLEIDAN to XIII of Strasbourg - PC 5, No. 435, pp. 537-8;

Hollaender b, pp. 340-341

Sleidan's report about the Naumburg colloquy. 
313. June 14 (Gera) - Justus Menius to Philip Melanchthon-Bg p. 304, fn. 1 Has discussed the Naumburg colloquy with Sleidan.

314. June 17 (Wittenberg) - Philip Melanchthon to Johannes Marbach - Scheible 7, No. 7236; CR 8, No. 5643

Sends regards to Sleidan and others.

315. June 18-Diarium Marbachii - Hollaender b, p. 341

He met with Sleidan and others to discuss the problems of the French church in Strasbourg.

316. June 22 (Weimar) - Erasmus von Minkwitz to SLEIDAN - Bg 133

Praises Sleidan's work and reassures him that they will search for more material in Weimar archives for him.

317. July 8 (Strasbourg) - SLEIDAN to Jean Calvin - Hasenclever b, pp. 170-171; Rott pp. 633-635

German news, Albrecht of Brandenburg. Read Crespin's book ('Livre des martyrs'). Met Melanchthon, his reaction to Calvin's book against M. Servet. Inquiry about French persecutions.

318 August 26 (Stuttgart) - Peter Paul Vergerio to Christoph of Württemberg - KS, No. 10 , pp. $67-9$

He asked Sleidan to delay the publication of the 'Commentaries'.

319. August 27 (Geneva) - Jean Calvin to SLEIDAN - Bg 134; Bonnet III, No.

CCCLVII, pp. 57-9; CR 43, No. 2004 (September 6)

Congratulates Sleidan on his election as one of the governours of the French church. Thinks that Melanchthon is too hesitant. Calls Sleidan an 'outstanding man who deserves my highest respect'.

320. September 10 (Strasbourg) - SLEIDAN to Jean Calvin - Bg 135; CR 43, No. 201 Will buy Crespin's 'Livre des martyrs' as soon as he can get it. Wendelin Rihel will start printing the 'Commentaries' in October to be finished by Easter (14 April) 1555. On the French church in Strasbourg. Political news.

321. September 24 (Strasbourg) - Peter Martyr to Jean Calvin - CR 43, No. 2014 Hopes that Sleidan's 'Commentaries' are being printed.

322. September 30 (Strasbourg) - City protocol - Rott, No. *135b, p. 610

More hearings concerning the problems within the French church of Strasbourg, led by Sleidan and colleagues.

323. October 20 (Tübingen) - Martin Frecht to Matthaeus Negelinus - Hollaender c, pp. 435-6 Vergerio visited Sleidan. 
324. October 23 (Stuttgart) - Peter Paul Vergerio to Christoph of Württemberg - KS, No. 12 , p. 71

Has advised Sleidan to leave out certain passages in the 'Commentaries' and insert others, as Christoph wanted him to do.

325. November 14 (Strasbourg) - City protocol - Rott, No. ${ }^{*} 135$ b, p. 610 More hearings concerning the problems within the French church of Strasbourg, led by Sleidan and colleagues.

\section{5}

326. January 18 (Geneva) - Jean Calvin to Peter Martyr - CR 43, No. 2089 Passes on greetings to Jean Sturm and Sleidan.

327. February 3 (Göppingen) - Peter Paul Vergerio to Christoph of Württemberg - KS, No. 19 , p. 91

Sleidan wrote that 20 books of the 'Commentaries' have already been printed and now the senate wants to stop the production. Thinks that this is due to the Emperor who fears his portrayal in the work. Wonders whether Geneva or other place will print them.

328. February 15 (Göppingen) - Peter Paul Vergerio to Christoph of Württemberg - KS, No. 21 , p. 98

Strasbourg will print the 'Commentaries' after all despite possible consequences. Apparently they received letters forbidding the print; does not know by whom.

329. March 8 (Strasbourg) - Peter Martyr to Jean Calvin - CR 43, No. 2142 Jean Sturm, Zanchus and Sleidan pass on regards.

330. March 25 (Strasbourg) - City protocol - Hollaender b, p. 342 As one of the governors of the French church in Strasbourg, Sleidan was sent to help negotiate in the conflict with the minister Garnier.

331. (March) (Strasbourg) - SLEIDAN to Johann Marbach - Winckelmann, p. 568 Asks him to enquire from Mathis Pfarrer how the senate decided 'concerning the book and the preface' (of the 'Commentaries').

332. April 1 (Augsburg)) - Caspar von Nidbruck to SLEIDAN - Bg 136

Inquires about Dryander's children. Death of pope.

333. April 1 (Stuttgart) - Peter Paul Vergerio to Christoph of Württemberg - KS, No. 27, p. 106

Strasbourg has finally decided to have the 'Commentaries' printed, will send a copy when ready. 
334. April 13 (Frankfurt/Main) - Johannes Opporinus to Caspar von Nidbruck - Bg p. $\mathrm{xxv}, \mathrm{fn} .12$

No copy of Sleidan's 'Commentaries' left.

335. April 15 (Augsburg) - Caspar von Nidbruck to SLEIDAN - Bg 137 About the Augsburg Diet. Doubts whether it was within the law that Rihel could obtain a privilege (for the 'Commentaries'). Rumours about this at the council.

336. April 23 (Strasbourg) - SLEIDAN to Caspar von Nidbruck - Bg 138

Death of Wendelin Rihel. 'Commentaries' have been published; Josias Rihel at Frankfurt book fair. Dryander's children. Asks whether Nidbruck would want to send a copy of the 'Commentaries' to Maximilian.

337. April 27 (Strasbourg) - City protocol - Hollaender b, p. 342

Sleidan is sent again to intervene in the problems of the French church in Strasbourg.

338. May 3 (Strasbourg) - City protocol - Hollaender b, p. 342

Sleidan has to assist again with the problems of the French church in Strasbourg.

339. May 10 (Strasbourg) - City protocol - Hollaender b, p. 342

Sleidan is sent again to intervene in the problems of the French church in Strasbourg.

340. May 13 (Augsburg) - Strasbourg's legates at Augsburg to XIII - PC 5, No. 486, p. 601

Sleidan's 'Commentaries' caused great trouble at the Diet. Strasbourg might need to apologise.

341. May 18 (Wittenberg) - Philip Melanchthon to Christoph Leib - Scheible 7, No. 7492; CR 8, No. 5784

Sleidan's 'Commentaries' were published. August of Saxony gave him 200 Taler for the dedication to him. It would be better if some things would have remained in eternal silence. Wants to know when Sleidan's book reaches Brandenburg.

342. May 19 (Strasbourg) - SLEIDAN to Council of Augsburg - Bg 139 Has heard about the trouble the 'Commentaries' have caused at Augsburg. He had foreseen criticism from the Catholic side, but is upset about allegations that he did not always write the truth. Has started his work ten years ago, worked diligently with public acts, Jacob Sturm read and corrected books 1-16.

343. May 26 (Augsburg) - Strasbourg's legates at Augsburg to XIII - PC 5, No. 490, pp. 608-9

Still troubles about 'Commentaries'. The work is despised at court. 
344. May 31 (Strasbourg) SLEIDAN to Caspar von Nidbruck - Bg 140 Is shocked about negative reaction towards his book at court. Expresses surprise that Nidbruck did not inform him.

345. June 1 (Basle) - ? to Basilius Amerbach - Am. IX, No. 3898, pp. 601-2 Sleidan's 'Commentaries' have been published and are very good, precise and thruthful. ${ }^{14}$

346. June 6 (Strasbourg) SLEIDAN to Caspar von Nidbruck - Bg 141

Cannot believe the outrage his work caused, after all his effort. Vice-chancellor Welsinger is against him. Intends to prepare an apology.

347. June 16 (Augsburg) - Caspar von Nidbruck to SLEIDAN - Bg 142

The outrage about the 'Commentaries' will cease with time. Doubts about Welsinger. Asks to send back the 'Magdeburg script'.

348. June 18 (Strasbourg) - SLEIDAN to Caspar von Nidbruck - Bg 143 Has written an apology and suggests again to send a copy of 'Commentaries' to Maximilian.

349. (June) (Strasbourg)- SLEIDAN to Ludwig Gremp - Bg 145

Justifies what he wrote about Seld. Is surprised about Seld's criticism, it upset him greatly.

350. (June)(Strasbourg) - SLEIDAN to Ludwig Gremp-Bg 146

Rumours about Seld.

351. July 3 (Augsburg) - Caspar von Nidbruck to SLEIDAN - Bg 147

Wants him not to write an apology. What is disliked about his 'Commentaries'; complains that Sleidan did not make use of a sufficiently wide range of sources. Warns Sleidan of certain people. Advices not to write to King and encourages him to find employment with Duke of Württemberg or other Duke.

352. July 16 (Geneva) - Jean Calvin to Jean Sturm - CR 43, No. 2246

Recommends Hotman, whom Sleidan and Peter Martyr know. Passes on greetings to them.

353. July 20 (Strasbourg)) - SLEIDAN to Caspar von Nidbruck - Bg 148

Complains about negligence of his parents-in-law. He will publish his apology when necessary. Defends 'Commentaries'. Rumours that he accepted money from different people so he would flatter them in his work. Also gets praise for his work. Almost 1.000 copies sold, an octavo edition to be printed.

354. July 22 (Augsburg) - Caspar von Nidbruck to SLEIDAN - Bg 149

\footnotetext{
${ }^{14}$ Amerbach possessed a copy himself, the 1555 edition printed by Wendelin Rihel in Strasbourg, bought for 44 plap. and bound for 0.5 fl. (cf. ibd., p. 602, fn. 44).
} 
Wants Sleidan not to appeal to individual people nor to write apology. A conversation between Fugger and one of Sleidan's opponents. King Maximilian has the 'Commentaries' in his chamber. Collects books.

355. July 27 (Strasbourg)) - SLEIDAN to Caspar von Nidbruck - Bg 150 Does not trust the vicechancellor. Warns Nidbruck that he and his party might plan something against them.

356. July 30 (Augsburg) - Caspar von Nidbruck to SLEIDAN - Bg 151

Tries to calm Sleidan, advices against apology. Will talk to Duke of Württemberg on Sleidan's behalf.

357. July 30 (Strasbourg)) - SLEIDAN to Caspar von Nidbruck - Bg 152

He heard that his 'Commentaries' are read secretly at the Emperor's court.

358. July (?) - Philotus to Conrad Hubert - Bg p. 296, fn. 1

Reports a rumour that Sleidan has been outlawed in the whole Empire because of his 'Commentaries'.

359. August 8 (Geneva) - Jean Calvin to Peter Martyr - Bonnet III, No. CCCCXI, p. 218; CR 43, No. 2266

About reestablishment of French church in Strasbourg. Jean Sturm and Sleidan will help.

360. August 17 (Strasbourg) - SLEIDAN to Jean Calvin - Bg 153; CR 43, No. $2271^{15}$ Wrote to Hotman in July, thinks that a French translation should not be undertaken just yet. Political news. Sends him a copy of the 'Commentaries' and asks for his opinion.

361. August 21 (Strasbourg) - SLEIDAN to Caspar von Nidbruck - Bg 154 More rumours against his 'Commentaries'. He received praise from Hamburg.

362. September 1 (Augsburg) - Caspar von Nidbruck to SLEIDAN - Bg 155 Tells Sleidan not to mention his name nor write letters. 'Commentaries' will not be publicly condemned, contrary to rumours. Wants 8-10 copies of the octavoedition. Different opinions on the 'Commentaries'. People have offered to send additional source material for the next edition.

363. September 3 (Strasbourg) - City Protocol - Hollaender a, col. 151 Concerning Sleidan's salary.

364. September 9 (Strasbourg) - SLEIDAN to Caspar Lanius - Bg 156

Regrets Lanius' silence, complains that often learning and effort is not acknowledged in these times. Received many letters of learned men praising his 'Commentaries'.

\footnotetext{
${ }^{15}$ This letter seems to imply that Sleidan had asked Hotman to translate the Commentaries into French.
} 
365. September 14 (Greenwich) - Roger Ascham to Jean Sturm - Vos No. 48, p. 212; Ascham I, No. 10, p.53

Passes on regards to Valentin Erythraeus, Michael Toxites and Sleidan.

366. September 17 (Strasbourg) - SLEIDAN to Caspar von Nidbruck - Bg 157

Allegations against him and his work are false. Missed Count of Württemberg.

'Commentaries' sold publicly at Paris, for three coronae, despite Sorbonne.

367. October 3 - SLEIDAN to Nicolaus Specht - Bg 158

Thanks for his writing and still thinks about their nice last meeting. Political news.

368. October 11 (Strasbourg) - SLEIDAN to Jean Calvin - Bg 159; CR 43, No. 2319

Thanks for his positive comments on the 'Commentaries'. Hotman brought

Calvin's letters. Augsburg diet and other political news.

369. (October)(Strasbourg) - SLEIDAN to Peter Paul Vergerio - Bg 144

In October 1547 he had given the first four books of the 'Commentaries' to

Nicolaus Gerbelius to read. He had liked them and wrote a poem on his work which Sleidan passes on to him.

370. November 21 (after) (Saxony) - Jacobus Faber (Fabricius) to SLEIDAN - Rott pp. 635-37

Agricola died. Church inspections.

371. November 29 (Strasbourg) - Heinrich Walter to Bernhard Meyer - Bg 162

Praises Sleidan and his history, but emphasises that a German translation would cause a lot of trouble at diet, as Jacob Sturm had foreseen. Sleidan heard that Stumph in Zurich and somebody in Basle (Heinrich Pantaleon) worked on German translation, but wants to avoid to have somebody not skilled enough translate it. He plans a German translation to be published with Rihel.

372. November (?) - SLEIDAN to Johann Stumph - Bg 161

Heard that Stumph prepares a German translation of the 'Commentaries'.

Reminds him of the trouble for him after the Latin edition, fears worse with a German edition. Wrote many things in his 'Commentaries' which are directed rather towards scholars and politicians than to common people. Wants him to wait with the translation. Has also asked Basle to stop the translation that is prepared there. Rihel, the printer of the Latin edition, has also a German version ready but holds it back for now at Sleidan's request.

373. November (?) - Caspar von Nidbruck to SLEIDAN - Bg 160

Defends him against critics. Advices against an apology.

374. November 30 (Strasbourg) - City Protocol - Hollaender a, col. 151

Mathis Pfarrer reports Sleidan's complaint about a planned German translation of the 'Commentaries' at Basle. 
375. December 19 (Strasbourg) - XIII to Mayor and Council of Basle - Bg 163; Bg b, pp. 117-118

Ask mayor and council to prevent the publication of Panthaleon's German translation of the 'Commentaries' with Brillinger, to avoid further damage for Sleidan and Strasbourg. Only a skilled person should translate it.

376. December 26 (Paris?) - ? to SLEIDAN- Bg 164

Sends remonstrance of parliament to king for Sleidan to incorporate in a continuation of his 'Commentaries', which he thinks many people wait for. Knows of no other work as desired as 'Commentaries'.

377. December 30 (Basle) - XIII of Basle to XIII of Strasbourg- Bg 165

They had questioned Panthaleon and Brillinger; both said that Sleidan had asked them to defer the printing of a German translation but had not forbidden it, no official ban of a reprint. Brillinger was too far proceeded with print, would go bankrupt if stopped.

\section{6}

378. January 8 (Strasbourg) - Heinrich Walther to Bernhard Meyer - Bg 166 Heard of problems between Strasbourg and Basle. Is concerned that a German translation might be forbidden after the trouble the Latin version caused for Sleidan.

379. January 30 (Bar?) - ? to SLEIDAN - Bg 167

'Commentaries' sell very well at Paris, 'if there were 10.000 copies, they would be sold out in less than an hour'. Praises the work. The Paris parlement will launch an investigation of the 'Commentaries' at the wish of the Cardinal de Lorraine in the method of the Spanish inquistion. Will send various documents.

380. February (early) - (Strasbourg) - SLEIDAN's supplication to the XIII of Strasbourg - Bg 168

Toxites reported rumours from Frankfurt book fair in September that in Basle Johannes Herold translated the 'Commentaries' into German, to appear with Brillinger. Informed Josias Rihel who got first quarter from Brillinger for Sleidan to read. Panthaleon wrote to him to express regret that no German translation existed yet. In another letter Panthaleon said books 1-10 were printed. Hopes for translation to be published after the Augsburg diet.

381. February (before 4) (Strasbourg) - SLEIDAN to Friedrich von Gottesheim - Bg 170

Sends copies of letters (from 26 December 1555 and 30 January 1556).

382. February 4 (Strasbourg) - Heinrich Walther to Bernhard Meyer - Bg 169 
Sleidan had asked Strasbourg council to urge Basle to wait with publication of German 'Commentaries' until the end of the diet in March to prevent any further harm. Strasbourg did not pass this supplication (to stop a German translation) on to Basle since to their surprise they did not grant the last one on that matter.

383. s.d. (February -March 1556?) (Strasbourg)) - Winckelmann, p. 568

Wants him to ask Mathis Pfarrer what the decision of the Council concerning the 'book and preface' (of the 'Commentaries'?) are.

384. March 25 (Strasbourg) - Francis Hotman to Jean Calvin - CR 44, No. 2416

On Calvin's writing against Westphal. Calvin has the support of his friends and Sleidan in Strasbourg.

385. March 25 (Strasbourg) - Francis Hotman to Heinrich Bullinger - CR 44, No. 2417 Sleidan, Sturm, and others are on their side to foster the Gospel.

386. April 8 (Strasbourg) - SLEIDAN to Johann Stumph - Bg 171 Somebody at Basle translates the 'Commentaries' into German, not happy about this. Congratulates him on his history of Emperor Henry IV.

387. April 16 (Strasbourg) - SLEIDAN to Nicolaus Specht-Bg 172

Thanks for a picture of Moritz of Saxony. Political news.

388. May (early: 4 or 5?) (Strasbourg)) - SLEIDAN to Jean Calvin - Bg 173

Had been invited out for lunch; met Crespin there by chance who said not a single word (about his intended French translation of the 'Commentaries'). Expresses his surprise about this.

389. May (Strasbourg) - Peter Martyr to Jean Calvin - CR 44, No. 2453

Has been called to Heidelberg University, Sleidan and Jean Sturm tried do hold him back.

390. May 1 (Strasbourg) - City Protocol - Hollaender a, col. 152

Josias Rihel asks for permission for German translation of 'Commentaries', is refused.

391. May 4 (Strasbourg) - Francis Hotman to Jean Calvin - CR 44, No. 2447

Thanks for recommending him to Sleidan. Has also met Melanchthon who gave Sleidan one of his writings and even wrote a dedication in it for him. Melanchthon invited him, Sleidan and others for dinner.

392. May 24 (Strasbourg) - Francis Hotman to Philip Melanchthon - Scheible 7, No. 7835

Gremp and Sleidan recommended to ask Melanchthon where Hotman's family originally comes from.

393. June 1 (Paris) - ? to SLEIDAN - Winckelmann, p. 591 
Praises the 'Commentaries'; deserve to be printed much more often, and in excellent quality.

394. June 3 (Bar) - Michel Savaige to Jean Lenfant, Sieur de Chambray Winckelmann, p. 591

'Madame la Seneschalle' (=Diane de Poitiers) is annoyed with Sleidan's portrayal of her two sons-in-law (Claude d'Aumale and Robert de la Mark) in the

'Commentaries'; seem to plan something against him. Asks him to advice Sleidan to be careful.

395. June 14 (Strasbourg) - Peter Martyr to Jean Calvin - CR 44, No. 2479

Sleidan and Jean Sturm visited him shortly ago. Handed over to Sleidan two folios of his work of which he had been the corrector at the suggestion of the printer.

396. July 2 (?) - Johann Lenglin to Martin Frecht (?) - Hollaender c, p. 437 Had a discussion with Sleidan, who said he had never read a book by Schwenckfeld. Sleidan mentioned that he had the information on the Heidelberg disputation and other such theological events from the first volume of Luther's works. Sleidan wants to know about the damnation of Kaspar von Schwenkfeld and Sebastian Franck. ${ }^{16}$

397. July 7 (Strasbourg) - Peter Martyr to Jean Calvin - CR 44, No. 2494

Sturm, Sleidan and Zancus send regards.

398. July 9 (Strasbourg) - SLEIDAN to Caspar von Nidbruck - Bg 174

Is unhappy that Peter Martyr left Strasbourg.

399. July 16 (Strasbourg) - SLEIDAN to Christoph of Württemberg - Hasenclever c, pp.112-16

On the 'Four Empires'. Wants to continue 'Commentaries', as he had discussed with Vergerio. Needs money to do so.

400. July 18 (Stuttgart) - Stuttgart Acts - Hasenclever c, p. 110

Sleidan got 18 Dukaten by Christoph von Württemberg.

401. July 25 (Wittenberg) - Philip Melanchthon to Jean Sturm - Scheible 7, No. 7899;

CR 8, No. 6039

Sends regards to Sleidan.

402. (Summer - after July) (Zurich?) - ? (Johann Stumph?) ${ }^{17}$ to SLEIDAN Winckelmann, pp.588-589

Bullinger, who thoroughly read the 'Commentaries', asked him to send some corrections and comments. Also includes his own remarks.

\footnotetext{
${ }^{16}$ The minister Frecht had taken part in the 1540 theologians' convent at Schmalkalden when Schwenkfed and Franck were damned.

${ }^{17}$ It is also possible that this letter could have been sent by Johann Stumph's son, Johann Rudolf Stumph.
} 
403. August 9 (Zurich) - Peter Martyr Vermigli to SLEIDAN - Bg 175

Has arrived in Zurich and was received very well. General news. Bullinger was happy to hear from Sleidan. Passes on regards to Hotman.

404. August 31 (Wittenberg)) - Philip Melanchthon to SLEIDAN - Bg 176; Scheible 7, No. 7934

Sad about controversy on Eucharist; shares Sleidan's wish for a theological convent, will try to arrange it.

405. September 1 (Stuttgart) - Caspar von Nidbruck to SLEIDAN - Bg 177

Negotiated with several people about another employment for Sleidan; has been unsuccessful. Thinks that because of the 'Commentaries' it might not be safe for Sleidan to leave Strasbourg. Did not convince the Duke of Württemberg yet to support a continuation of Sleidan's 'Commentaries'. Will talk to the Count of Palatine.

406. September 1 (Frankfurt/Oder) - Georg Sabinus to SLEIDAN - Bg 178; Sabinus pp. 475-81

Long eulogy on the historian. Provides him with information on Count Johann (and Albrecht) of Brandenburg and their writing against Hesse and Saxony. Recommends to include this in his 'Commentaries'.

407. September 16 (Strasbourg) - Conrad Hubert to Caspar von Nidbruck - Bg, p. xxix Sleidan is suffering from a fever. He has consulted several other people and they all think and hope that it will get better soon.

408. September 18 (Frankfurt/Main) - Hubert Languet to Philip Melanchthon - Scheible 7, No. 7959

Problems with Magdeburg Centuries. Sleidan's Four Empires sold out. ${ }^{18}$

409. September 22 (Strasbourg)) - Francis Hotman to Jean Calvin - CR 44, No. 2539

Sleidan has been ill for 40 days already, but only lightly.

410. October 3 (Regensburg) - Caspar von Nidbruck to SLEIDAN - Bg 179

Count Albrecht has published a book which mentions Sleidan and apparently wants to bring him to court. Rumours that a book 'on the thousand lies of Sleidan' will be published. Still tries his best with the Dukes of Württemberg and Palatine.

411. October 3 - Zacharias Ursinus to Johann Crato/Breslau - Hasenclever c, p.109, fn. 3

The 'Four Empires' and an epitome of the 'Commentaries' have been published.

412. s.d.(after 1553) - SLEIDAN to Ludwig Gremp - Bg 181

\footnotetext{
${ }^{18}$ The first edition was published in June 1556.
} 
Thanks for a book. On the possible marriage of one of Johann von Nidbruck's daughters to a rich man (Franz von Mörsberg). ${ }^{19}$

413. October 30 (Strasbourg) - City register - Bg b, p. 104 Sleidan died on 30 October 1556.

414. November 5 (Hornberg) - Johann von Nidbruck to Strasbourg Council Winckelmann, p. 597

Expresses his thanks for caring for Sleidan's children after his death.

415. November 8 (Strasbourg) - Francis Hotman to Jean Calvin - CR 44, No. 2546 Laments Sleidan's death (says he died peacefully on November 5!) and values him as historian and friend.

416. November 24 (Strasbourg) - Johann Segger to Caspar von Nidbruck - Bg, p. xxix Laments Sleidan's death.

417. November 25 (Strasbourg) - Conrad Hubert to Caspar von Nidbruck - Bg, pp. xxix-xxx

Sleidan died on the last day of October, and was buried with all honours on November 1. Laments the loss of such a man to the state and his family.

418. November (?) - Zacharias Ursinus to Johann Crato/Breslau - Hasenclever c, p.109, fn. 3 Sends him a copy of the 'Four Empires' as Sleidan wanted him to do. Could not get an epitome of the 'Commentaries' yet.

419. December 4 (Meissen) - Georg Fabricius to Philip Melanchthon - Scheible 7, No. 8046

Sleidan died on 31 October.

420. December 5 (Meissen) - Georg Fabricius to Andreas Fabricius - Hasenclever c, pp.111-12, fn.4

Informs him that the great Sleidan died.

421. December 9 (Wittenberg) - Philip Melanchthon to David Chytraeus - Scheible 7, No. 8050

Sleidan died.

\footnotetext{
${ }^{19}$ A Strasbourg city protocol from 18.09 .1557 , cited in Hollaender b, p. 339 , mentions him as the son-in-law of Johann von Nidbruck.
} 
1557

422. 1556/57 (Württemberg) - Württembergische Landschreiberrechnung - Ernst IV, No.133, pp. 143-44, fn.6; Hasenclever c, p.111, fn.3

Sleidan got 30 florentines for his dedication of the Four Empires to Duke Eberhard of Württemberg.

423. January 26 (?) - Caspar von Nidbruck to Conrad Hubert - Bg p. xxx Laments Sleidan's death. Asks him to thank Jean Sturm for being with Sleidan when he died (he was there together with Hubert). Asks him to make sure that all things are managed for Sleidan's three little daughters.

424. February 4 (Regensburg?) - Caspar von Nidbruck to Jean Sturm - Bg p. xxx-xxxi Asks Sturm to make sure that there is no doubt about the nature of Sleidan's illness and who was with him when he died.

425. March 14 (?) - Ottheinrich of Palatine to Jean Sturm - Bg p. 150, fn.2 Offers financial support of 150 florentines per year for his intended continuation of the 'Commentaries', the same amount as he had given to Sleidan.

426. March 29 (Strasbourg) - City Protocols - Hollaender c, pp. 337-338 Due to general hardships of the time Sleidan's brother asks to pay less customs and wants to have Sleidan's books and papers. Will be sent those iffound.

427. June 26 (Vienna) - Caspar von Nidbruck to Conrad Hubert - Bg p. xxxi Jean Sturm has not replied yet. Asks him to make sure Sleidan's daughters are comfortable.

428. September 14 (Stuttgart) - Christoph of Württemberg to the XIII of Strasbourg Ernst IV, No. 330, pp. 416-17; KS, No. 50a, p. 144-5

Asks that at opening of Sleidan's testament books borrowed 'for the increase of the history' will be returned to Vergerio.

429. September 18 (Strasbourg) - City Protocol - Hollaender a, col. 153

Somebody from Pforzheim brought a German translation, was given some money for it.

430. September 26 (Strasbourg) - Francis Hotman to Basilius Amerbach - Amerbach $\mathrm{X} / \mathrm{II}$, No. 4216 , p. 504

Mentions that Sylvius (Franciscus du Boys, Paris) composed tables for the 'Commentaries.'20

\footnotetext{
${ }^{20}$ Amerbach X/II, p. 506, fn. 11 hints that Sylvius also translated these tables into French.
} 
431. October 6 (7?)(Basle) - Johannes Oporinus to Philip Melanchthon - Scheible 7, No. 8381

He has not read Basilius Monner's negative writing against Moritz of Saxony. ${ }^{21}$

The editor Nicolaus Brylinger was imprisoned for it; but thinks it fits with

Sleidan's account in the 'Commentaries' which Brylinger is printing in German at the moment.

\section{1}

432. September 14 (Tübingen) - Peter Paul Vergerio to Christoph of Württemberg KS, No. 126, p. 289

Reports what Sleidan truthfully wrote about council of Mantua. Confirms that he himself told Sleidan as much as he could remember, and Sleidan additionally used public acts.

433. December - Brenz to Christoph of Württemberg - KS, No. 139, p. 316

Recommends not to publish a work of Vergerio on the Council of Trent, says the first part of it is word by word from Sleidan.

434. December - Christoph of Württemberg to Vergerio - KS, No. 140, p. 317 Composed by Brenz, giving the same verdict on Vergerio's book which he passed on to Christoph in the above letter. Says again that first part of Vergerio's work was almost identical with Sleidan's 'Commentaries'.

\section{2}

435. October 20 (London) - Roger Ascham to Jean Sturm - Vos No. 50, p. 222;

Ascham I, No.13, pp. 60-61

Thinks Sturm would make a very good historian, so 'This longing of mine has been eased a good deal by a report carried here from Germany that the princes there have given you the charge of completing with your pen the omissions of your John Sleidan. ...I have strongly maintained to the Queen that this is the case.'

\section{4}

436. July 15 (Strasbourg) - Josias Rihel to Strasbourg Council - Winckelmann, p. 597598

He was appointed guardian of Sleidan's daughters at the wish of Sleidan's brothers-in-law Franz von Mörsberg and Philip von Nidbruck. Invested Sleidan's

\footnotetext{
${ }^{21}$ Bedencken von dem Kriege, der Anno sechs-, sieben- und viertzig im Landt zu Meißen und Sachsen gefurth ist, gestelt durch Christian Aleman, mit einer kurtzen Vorrede Christof Cunrads, Basle (Bartolomäus Stähelin) 1557
} 
money for his children. After the death of Johann von Nidbruck his heritage was used to pay off Mörsberg's debts. Sleidan's children did not receive any money of this heritage yet, despite the promises of the Nidbruck family.

\section{4}

437. November 6 (Antwerp) - Christoph Plantin to Phil. de Seroskerke - Plantin 4, No. 583, pp. 196-198

Sends him the desired books, but cannot send Sleidan's 'Four Empires' because they are still on the Index.

\section{4}

438. November 1 (Delft) - Alexandre Grapheus to Christoph Plantin - Plantin 7, No. 1029, pp. 173-176

Sends him a copy of Sleidan's 'Commentaries', the 'first edition', to which he added the $26^{\text {th }}$ book in his own hand. ${ }^{22}$ This caused errors with the pagination, which he then describes. Tries to convince Plantin to print this work (which Plantin never did).

\footnotetext{
${ }^{22}$ The first edition was De statu religionis et reipublicae, Carolo Quinto Caesare, commentarii, (Strasbourg: Wendelin Rihel) 1555 , in 2o; the $26^{\text {th }}$ book was not published until 1559.
} 


\section{APPENDIX II: DEDICATIONS, PREFACES, POSTSCRIPTS, POEMS}

1. 1537: July 12 , Paris - To Jean DuBellay

Dedication of Frossardi, nobilissimi scriptoris gallici, historiarum opus omne, iam primum et breviter collectum et latino sermone redditum, Paris (Simon de Colines) 1537; fols. A2r-B2v

2. 1544: June 25, Strasbourg - To the reader

Dedication of Orationes duae, Strasbourg (s.n.), 1544; fols. A2r-v

3. 1545: January 1, Strasbourg - To John Frederic of Saxony and Philip of Hesse Dedication of De rebus gestis Ludovici, eius nominis vndecimi, Galliarum Regis, \& Caroli, Burgundiae Ducis, Philippi Cominaei, viri patrici, \& equestris ordinis, Commentarii, Strasbourg (Crato Mylius) 1545; pp. 3-8

4. 1545: February 15, Paris $^{23}$ - To the reader Postscript Illustratio rerum et Galliae descriptio to De rebus gestis Ludovici, eius nominis vndecimi, Galliarum Regis, \& Caroli, Burgundiae Ducis, Philippi Cominaei, viri patrici, \& equestris ordinis, Commentarii, Strasbourg (Crato Mylius) 1545; pp. 357-376

5. 1545: February 27, Strasbourg - To the reader Preface and annotations to Caspar Hedio's German translation of Sleidan's 1545 Latin translation of Commynes, Histori Ursprung und Ursach des Burgundischen Kriegs, Strasbourg (Wendelin Rihel) 1551

5. 1548: May, Strasbourg - To Edward Seymour, Duke of Somerset Dedication of Philippi Cominaei equitis, de Carolo Octavo, Galliae rege, \& bello Neapolitano, Commentarii, Strasbourg (Wendelin Rihel) 1548; fols. A2r-A4r

6. 1548: May 27, Strasbourg $^{24}$ - To the reader Postscript to Philippi Cominaei equitis, de Carolo Octavo, Galliae rege, \& bello Neapolitano, Commentarij, Strasbourg (Wendelin Rihel) 1548; fols. P4r-Q6v

7. 1548: June, Strasbourg - To Edward VI

Dedication of Claudii Sesellii, viri partricii, de republica Galliae \& regum officiis, Strasbourg (Wendelin Rihel) 1548; fols. a2r-a3r

\footnotetext{
${ }^{23}$ In later editions, this dedication is sometimes mentioned under a different date: $\underline{T r e s}$ gallicarum rerum scriptores nobilissimi: Philippus Cominaeus de rebus gestis a Ludovico XI et Carolo VIII, Francorum regibus: Frossardus in brevem Historiarum memorabilium epitomen contractus: Claudius Sesellius de Republ. Galliae, \& Regum officiis, Frankfurt/Main (Andreas Wechel) 1578, fol. k5r states 22 February 1545 as the date of this dedication.

${ }^{24}$ Again, Tres gallicarum rerum scriptores nobilissimi, fol. p6v, offers a different date for this dedication, that is 6 June 1548.
} 
8. 1548: June, Strasbourg - To William Paget

Dedication of Summa doctrinae Platonis de republica et legibus, published with Claudii Sesellii, viri partricii, de republica Galliae \& regum officiis, Strasbourg (Wendelin Rihel) 1548; fols. $73 r-47[=74] r$

9. 1550: late September/October, Strasbourg

$A$ verse 'O tandem redeas' by Sleidan on a rainy autumn which threatens the wine harvest, cf. Rott, pp. 631-632

10. 1550: (Strasbourg)

Sleidan's inscription 'Ut ferrum rubigine consumitur' in a book of friends; $c f$. Rott, No. $88 a$, p. 600

11. 1550: (Strasbourg)

Sleidan's inscription 'Sicut Evangelii post' in a book of friends; cf. Rott, p. 632

12. 1551: January 1 (Strasbourg)

Poem 'Jam, quando sol propior redit' by Sleidan for Jacob Sturm; in Jean Sturm, Consolatio ad senatum Argentinensem de morte ... Jacobi Sturmii, Strasbourg (Wendelin Rihel) 1553, fols. C2r-C3r; $\mathrm{Bg}$ b, pp. 94-95

13. (1551: after February 28, Strasbourg)

Poem 'Ergo te rapuit dira' composed by Sleidan on the death of Martin Bucer.

Hasenclever e, pp. 717-18

14. (1553: after October 30, Strasbourg)

Poem 'Extincto jam sole, Deum' by Sleidan on the death of Jacob Sturm; in Jean

Sturm, Consolatio ad senatum Argentinensem, de morte Jacobi Sturmii,

Strasbourg (Wendelin Rihel) 1553, fols. C3r; $\mathrm{Bg}$ b, p. 95

15. 1555: March 23 (Strasbourg)

Dedication of De statu religionis et reipublicae, Carolo Quinto Caesare, commentarii, (Strasbourg: Wendelin Rihel) 1555, fols. a2r-a4v

16. (1555: end May/before June 6, Strasbourg)

Sleidan writes the 'Apology' for the 'Commentaries', first published in De statu religionis et reipublicae, Carolo Quinto Caesare, commentarii libri XXVI,

Strasbourg (Wendelin Rihel) 1558, fols. 6v-8v

17. (1555: June, Strasbourg)

Sleidan writes an 'Additio' to his 'Apology' for the 'Commentaries'; $c f$.

Winckelmann, p. 606

18. (1556: June, Strasbourg)

Dedication of De quatuor summis imperiis libri tres, in gratiam juventutis confecti, (Strasbourg: Rihel brothers) 1556, fols, a2r-a4r 
19. s.d.(Strasbourg)

Five inscriptions by Sleidan into books of friends; Rott, pp. 637-638 


\section{APPENDIX III: SLEIDAN'S LOST CORRESPONDENCE}

Sleidan's extant correspondence refers to a large number of letters to or by Sleidan which are unfortunately lost. The list below attempts to reconstruct this corpus of lost correspondence from the extant letters. The references provided follow the abbreviations of Appendix I.

$\mathrm{SP}=$ State Papers. Henry VIII, 11 vols. London 1830-1852 (vol. 10: 1849, vol. 11: 1852)

\begin{tabular}{|c|c|c|c|c|}
\hline Date & & To Sleidan & From Sleidan & Reference \\
\hline 1529 & $?$ & Jean Sturm & & Bgp. 1 \\
\hline \multirow[t]{2}{*}{1530} & Spring & & Jean Sturm & Bg p. 2 \\
\hline & May & Henricus Bremensis & & Bg p. 1 \\
\hline \multirow[t]{4}{*}{1538} & April/May & & Jean Du Bellay & $\begin{array}{l}\text { Bourrilly b, p. } \\
232\end{array}$ \\
\hline & May & & Jean Du Bellay & $\begin{array}{l}\text { Bourrilly b, p. } \\
232\end{array}$ \\
\hline & October (early) & Jean Sturm & & $\begin{array}{l}\text { Bourrilly b, pp. } \\
236-238\end{array}$ \\
\hline & October & & Jean Du Bellay & $\begin{array}{l}\text { Bourrilly b, p. } \\
238\end{array}$ \\
\hline \multirow[t]{9}{*}{1539} & May 22 (before) & Jean Calvin & & Bg p. 3 \\
\hline & June 7 (before) & & $\begin{array}{l}\text { Sleidan's friends in } \\
\text { Strasbourg }\end{array}$ & Lenz I, p. 80 \\
\hline & Summer & & Martin Bucer & Lenz I, p. 93 \\
\hline & July 7 (before) & & $\begin{array}{l}\text { Sleidan's friends in } \\
\text { Strasbourg }\end{array}$ & Lenz I, p. 93 \\
\hline & $\begin{array}{l}\text { October } 23 \\
\text { (before) }\end{array}$ & & $\begin{array}{l}\text { Sleidan's friends in } \\
\text { Strasbourg }\end{array}$ & Lenz I, p. 113 \\
\hline & October & Martin Bucer & & Lenz I, p. 113 \\
\hline & December & $\begin{array}{l}\text { Jean Sturm (for the } \\
\text { XIII of Strasbourg) }\end{array}$ & & Bg p. 11 \\
\hline & December & & $?$ & Bg p. 13 \\
\hline & December & & $\begin{array}{l}\text { Sleidan's friends in } \\
\text { Strasbourg }\end{array}$ & Bg p. 13 \\
\hline \multirow[t]{5}{*}{1540} & January & XIII of Strasbourg & & PC III. p. 12 \\
\hline & $\begin{array}{l}\text { August/Septemb } \\
\text { er }\end{array}$ & & Martin Bucer & Lenz I, p. 212 \\
\hline & $\begin{array}{l}\text { August/Septemb } \\
\text { er }\end{array}$ & & $\begin{array}{l}\text { Sleidan's friends in } \\
\text { Strasbourg }\end{array}$ & Lenz I, p. 212 \\
\hline & 19 September & Martin Bucer & & Bg p. 14 \\
\hline & September & Jean Sturm & & Bg p. 14 \\
\hline
\end{tabular}




\begin{tabular}{|c|c|c|c|c|}
\hline & September & & Jean Du Bellay & Bg p. 14 \\
\hline & September & Martin Bucer & & Bg p. 14 \\
\hline & October (early) & & Philip of Hesse & $\begin{array}{l}\text { Bg p. 18; Lenz I, } \\
\text { p. } 226\end{array}$ \\
\hline & October & Martin Bucer & & PC III, p. 125 \\
\hline & $\begin{array}{l}\text { October } 15 \\
\text { (before) }\end{array}$ & & $\begin{array}{l}\text { Martin Bucer/Jean } \\
\text { Sturm }\end{array}$ & $\begin{array}{l}\text { PC III, pp. 125- } \\
126\end{array}$ \\
\hline & October 27 & & $\begin{array}{l}\text { Martin Bucer? Jean } \\
\text { Sturm? }\end{array}$ & $\begin{array}{l}\text { PC III, p. 126; } \\
\text { Bg p. } 7\end{array}$ \\
\hline & October (late) & Jean Sturm & & Bg p. 7 \\
\hline & $\begin{array}{l}\text { November } 23 \\
\text { (before) }\end{array}$ & Martin Bucer & & Lenz I, p. 270 \\
\hline & November 23 & & Martin Bucer & Lenz I, p. 270 \\
\hline & December & & Martin Bucer? & Lenz I, p. 285 \\
\hline 1541 & July 25 (before) & Jean Calvin & & $\begin{array}{l}\text { Herminjard 7, } \\
\text { pp. 198-199 }\end{array}$ \\
\hline \multirow[t]{6}{*}{1542} & Spring & $\begin{array}{l}\text { Count Dietrich von } \\
\text { Manderscheid }\end{array}$ & & Bg b p. 12 \\
\hline & $\begin{array}{l}\text { February } 7 \\
\text { (before) }\end{array}$ & Jacob Sturm & & Lenz II, p. 51 \\
\hline & $\begin{array}{l}\text { February } 7 \\
\text { (before) }\end{array}$ & Jean Sturm & & Lenz II, p. 51 \\
\hline & June 4 & & Jean Du Bellay & Bgp. 30 \\
\hline & Summer (early) & $?$ & & Bgp. 30 \\
\hline & Summer (early) & Sleidan's family & & Bg p. 31 \\
\hline \multirow[t]{7}{*}{1544} & March 27 & & Jean Du Bellay & Bgp. 32 \\
\hline & March 28 & & Jean Du Bellay & Bg p. 32 \\
\hline & March 29 & & Jean Du Bellay & Bg p. 32 \\
\hline & April 13 & & Jean Du Bellay & Bgp. 32 \\
\hline & August 1 (after) & & Philip Melanchthon & \begin{tabular}{|l|} 
Böhmer, pp. \\
253,278
\end{tabular} \\
\hline & October & Philip of Hesse & & $\begin{array}{l}\text { Bg p. } 35 ; \text { Lenz } \\
\text { II, p. } 270\end{array}$ \\
\hline & December 30 & & Jean Du Bellay & Bgp. 33 \\
\hline \multirow[t]{6}{*}{1545} & $\begin{array}{l}\begin{array}{l}\text { January } 25 \\
\text { (before) }\end{array} \\
\end{array}$ & $?$ & & Bg p. 35 \\
\hline & January $(25)$ & & Johann von Nidbruck & Bg p. 36 \\
\hline & $\begin{array}{l}\text { February } 13 \\
\text { (before) }\end{array}$ & & $\begin{array}{l}\text { (+ friends) Jean Du } \\
\text { Bellay }\end{array}$ & Rott pp. 624-626 \\
\hline & $\begin{array}{l}\text { February } 15 \\
\text { (before) }\end{array}$ & $\begin{array}{l}\text { (+ friends) Jean Du } \\
\text { Bellay }\end{array}$ & & Rott pp. 624-626 \\
\hline & $\begin{array}{l}\text { March } 14 \\
\text { (before) }\end{array}$ & & $\begin{array}{l}\text { John Frederic of } \\
\text { Saxony }\end{array}$ & Bgp. 37 \\
\hline & $\begin{array}{l}\text { March } 14 \\
\text { (before) }\end{array}$ & & Philip of Hesse & Bg p. 37 \\
\hline
\end{tabular}




\begin{tabular}{|c|c|c|c|}
\hline $\begin{array}{l}\text { March 14 } \\
\text { (before) }\end{array}$ & & Jacob Sturm & Bg p. 37 \\
\hline $\begin{array}{l}\text { March } 14 \\
\text { (before) }\end{array}$ & & Franz Burkhardt & Bg p. 37 \\
\hline March 27 & & Friedrich Thinn & Bg p. 37 \\
\hline March 27 & & $\begin{array}{l}\text { Son of John Frederic } \\
\text { of Saxony }\end{array}$ & Bg p. 37 \\
\hline March 28 & Jean Du Bellay & & Bg p. 42 \\
\hline April 4 (before) & Jacob Sturm & & Bg p. 41 \\
\hline April 4 & & Jean Du Bellay & Bgp. 42 \\
\hline April 12 & & Jean Du Bellay & Bgp. 46 \\
\hline April 24 & Jean Du Bellay & & Bgp. 48 \\
\hline May 3 & & Grignan & Bg p. 54 \\
\hline May (early) & & Jacob Sturm & Bg pp. xvii-xvii \\
\hline May (early) & $?$ & & $\begin{array}{l}\text { Bg pp. 49, 51, } \\
53\end{array}$ \\
\hline May 8 (before) & & Sleidan's brothers & Bg p.50 \\
\hline May 8 (before) & & Johann von Nidbruck & Bg p. 50 \\
\hline May 8 & & Philip of Hesse & Bg pp. 50,56 \\
\hline May (8) & & $\begin{array}{l}\text { Christoph von } \\
\text { Carlowitz }\end{array}$ & Bg p. 50 \\
\hline May 10 & & $\begin{array}{l}\text { John Frederic of } \\
\text { Saxony }\end{array}$ & Bg p. 56 \\
\hline May 13 (before) & Grignan & & Bgp. 54 \\
\hline May 14 (before) & Jean Du Bellay & & Bg pp. 55,57 \\
\hline May (14) & & Martin Luther & Bg p. 60 \\
\hline May 15 & & Grignan & Bg p. 55 \\
\hline May 19 & Philip of Hesse & & Bg p. 60 \\
\hline May 23 (before) & Antonius (Carlaeus?) & & Bg p. 57 \\
\hline May (23) & & Antonius (Carlaeus?) & Bg p. 58 \\
\hline May 24 & Johann von Nidbruck & & Bg p. 65 \\
\hline May 27 & $\begin{array}{l}\text { Christoph von } \\
\text { Carlowitz }\end{array}$ & & $\begin{array}{l}\text { Bg p. } 65, \\
\text { Brandenburg p. } \\
267\end{array}$ \\
\hline May 29 & & Johann von Nidbruck & Bg pp. 64-65 \\
\hline May (29) & & Philip of Hesse & Bg p. 64 \\
\hline May 31 & & \begin{tabular}{|l|}
$\begin{array}{l}\text { Christoph von } \\
\text { Carlowitz }\end{array}$ \\
\end{tabular} & Bg p. 65 \\
\hline June 9 & & Jean Du Bellay & Bgp. 70 \\
\hline June 11 & Jacob Sturm & & Bg p. 69 \\
\hline June 14 (after) & Franz Burkhard & & Bgp. 75 \\
\hline June 15 & & Johann von Nidbruck & Bg p. 71 \\
\hline June 15 & & \begin{tabular}{|l|} 
Johann von \\
Nidbruck's wife
\end{tabular} & Bg p. 71 \\
\hline June 16 & & Claudius Peutinger & Bgp. 71 \\
\hline
\end{tabular}




\begin{tabular}{|c|c|c|c|c|}
\hline & (June 20) & Jacob Sturm & & Bg p. 72 \\
\hline & June (before 24) & Barthélemy Latomus & & Bg p. 73 \\
\hline & June (before 24) & $\begin{array}{l}\text { Grisorius (= Martin } \\
\text { Bucer) }\end{array}$ & & Bg p. 74 \\
\hline & June 25 & Jean Du Bellay & & Bg pp. $76-77$ \\
\hline & June 27 & Jacob Sturm & & Bg p. 75 \\
\hline & July 15 & Jacob Sturm & & Bg p. 78 \\
\hline & July 21 (before) & Johann von Nidbruck & & Bg p. 79 \\
\hline & July 21 (before) & & $\begin{array}{l}\text { French noble man } \\
\text { (Jacques Reynauld, Sr. } \\
\text { D'Alleins?) }\end{array}$ & $\begin{array}{l}\text { Bg p. } 79 \text {; } \\
\text { Hasenclever d, } \\
\text { p. } 53\end{array}$ \\
\hline & July 22 & & Johann von Nidbruck & Bg p. 79 \\
\hline & July 23 (before) & & $\begin{array}{l}\text { Sleidan's brother } \\
\text { (Sigebert) }\end{array}$ & Bg p. $79-80$ \\
\hline & July 24 & & Jacob Sturm & Bg p. 80 \\
\hline & July (26) & & Johann von Nidbruck & Bg p. 80 \\
\hline & September 17 & & $\begin{array}{l}\text { (+ Baumbach) to Jean } \\
\text { Sturm and others }\end{array}$ & PC III, p. 638 \\
\hline & September 19 & $\begin{array}{l}\text { (+ Baumbach) Jean } \\
\text { Sturm and others }\end{array}$ & & PC III, p. 638 \\
\hline & September 20 & $\begin{array}{l}\text { (+ Baumbach) Jean } \\
\text { Sturm and others }\end{array}$ & & PC III, p. 637 \\
\hline & September 29 & & Christopher Mont & Bg p. 91 \\
\hline & $\begin{array}{l}\text { October } 10 \\
\text { (before) }\end{array}$ & Jean Sturm & & PC III, p. 654 \\
\hline & October 11 & & $\begin{array}{l}(+ \text { Baumbach) to } \\
\text { legates in France }\end{array}$ & $\begin{array}{l}\text { Hasenclever d, } \\
\text { p. } 104\end{array}$ \\
\hline & October 19 & & $\begin{array}{l}\text { (+Baumbach) to } \\
\text { legates in France }\end{array}$ & Bg p. 92 \\
\hline & November 12 & & Sleidan's brothers & Bg p. 104 \\
\hline & $\begin{array}{l}\text { November } 14 \\
\text { (before) }\end{array}$ & $\begin{array}{l}\text { (+ Baumbach) Legates } \\
\text { in France }\end{array}$ & & PC III, p. 673 \\
\hline & November 28 & & Jean Du Bellay & Bg p. 110 \\
\hline & November 28 & & Jean du Fresse & LP XX/II, p. 460 \\
\hline & $\begin{array}{l}\text { December } 1 \\
\text { (before) }\end{array}$ & $\begin{array}{l}\text { (+ Nidbruck) Jean } \\
\text { Sturm }\end{array}$ & & $\begin{array}{l}\text { SP X, pp. 744- } \\
748\end{array}$ \\
\hline & December (9) & & $?$ & Bg p. 112 \\
\hline & December (mid) & & Johann von Nidbruck & SP X, p. 781 \\
\hline & December 17 & & Jean du Fraisse & Bg p. 119 \\
\hline 1546 & January 6 (after) & & Jean Du Bellay & Bg p. 120 \\
\hline & April 23 & Jean Du Bellay & & Bgp. 125 \\
\hline & April & $\begin{array}{l}\text { Etienne Lorens, Sr de } \\
\text { Saint-Ayl }\end{array}$ & & Bg p. 125 \\
\hline & April 27 & & Francis I & Bg p. 127 \\
\hline & May 14 (before) & & Philip of Hesse & Bg p. 131 \\
\hline
\end{tabular}




\begin{tabular}{|c|c|c|c|c|}
\hline & Summer & & Philip of Hesse & Bg p. 139 \\
\hline & Summer & & Philip of Hesse & Bg p. 139 \\
\hline & August 11 & & Philip of Hesse & Bg p. 139 \\
\hline \multirow[t]{3}{*}{1547} & \begin{tabular}{|l}
$\begin{array}{l}\text { January } 25 \\
\text { (before) }\end{array}$ \\
\end{tabular} & Jean Du Bellay & & Bg p. 140 \\
\hline & March & & Philip of Hesse & Bg p. 143 \\
\hline & April (early) & Jean Du Bellay & & Bg p. 143 \\
\hline \multirow[t]{2}{*}{1548} & January 19 & $\begin{array}{l}\text { Christoph von } \\
\text { Carlowitz } \\
\end{array}$ & & Bg p. 144 \\
\hline & February 12 & & Jacob Sturm & $\begin{array}{l}\text { Winckelmann, p. } \\
567\end{array}$ \\
\hline \multirow[t]{2}{*}{1549} & December (late) & & Martin Bucer & Bg pp. 147 \\
\hline & December (late) & & Emanuel (Tremellius) & Bg p. 149 \\
\hline \multirow[t]{11}{*}{1550} & March 29 & & Johann von Nidbruck & Bg p. 148 \\
\hline & Spring & $?$ & & Bg p. 148 \\
\hline & April 22 & Martin Bucer & & Bg p. 149 \\
\hline & $\begin{array}{l}\begin{array}{l}\text { August } 26 \\
\text { (before) }\end{array} \\
\end{array}$ & Caspar von Nidbruck & & Bg p. 156 \\
\hline & $\begin{array}{l}\text { October } 8 \\
\text { (before) }\end{array}$ & & Caspar von Nidbruck & Bg p. 156 \\
\hline & November 1 & & Jean Du Bellay & Bg p. 150 \\
\hline & November 10 & & Jean Du Bellay & $\mathrm{Bg} \mathrm{p} .150$ \\
\hline & November 24 & & Johann von Nidbruck & Bg p. 152 \\
\hline & November & & Christopher Mont & Bg p. 155 \\
\hline & December 16 & Christopher Mont & & Bg p. 155 \\
\hline & December 29 & & Christopher Mont & Bg p. 155 \\
\hline \multirow[t]{8}{*}{1551} & August (15) & & Thomas Cranmer & Bg p. 157 \\
\hline & $\begin{array}{l}\text { November } 3 \\
\text { (before) }\end{array}$ & & Thomas Cranmer & Bg p. 236 \\
\hline & $\begin{array}{l}\begin{array}{l}\text { November } \\
\text { (early) }\end{array} \\
\end{array}$ & & John Cheke & Bg p. 250 \\
\hline & November 7 & & Jacob Sturm & Bg p. 178 \\
\hline & November 16 & & Jacob Sturm & Bgp. 178 \\
\hline & November 29 & & Sleidan's wife & Bg p. 180 \\
\hline & December 29 & (Florenz) Graseck & & Bg p. 201 \\
\hline & December & & Roger Ascham & Bg p. 234 \\
\hline \multirow[t]{8}{*}{1552} & January 10 & & Philip Melanchthon & Bgp. 225 \\
\hline & January (mid) & & (Florenz) Graseck & Ernst I, p. 358 \\
\hline & January 16 & XIII of Strasbourg & & Bg p. 226 \\
\hline & January 18 & XIII of Strasbourg & & Bg p. 237 \\
\hline & January (late) & $?$ & & Bg p. 215 \\
\hline & $\begin{array}{l}\text { January (before } \\
29 \text { ) }\end{array}$ & Jacob Sturm & & Bg p. 218 \\
\hline & January 26 & Roger Ascham & & Bg p. 234 \\
\hline & January 30 & Alemani & & Bg p. 231 \\
\hline
\end{tabular}




\begin{tabular}{|c|c|c|c|c|}
\hline & January (end) & (Florenz) Graseck & & Bg p. 227 \\
\hline & February 1 & & Roger Ascham & Bg p. 234 \\
\hline & February 8 & (Florenz) Graseck & & Bg p. 232 \\
\hline & February (mid) & $?$ & & Bg p. 235 \\
\hline & February & $\begin{array}{l}\text { (Hans Dietrich von) } \\
\text { Plieningen }\end{array}$ & & Bg pp. 237,302 \\
\hline & $\begin{array}{l}\text { February } 20 \\
\text { (after) }\end{array}$ & (Florenz) Graseck & & Bg p. 237 \\
\hline & February (29) & XIII of Strasbourg & & Bg p. 239 \\
\hline & $\operatorname{March}(19)$ & Sleidan's relatives & & Bg p. 240 \\
\hline & April 2 & & Johann Marbach & Bg pp. 241-242 \\
\hline & April (before 18) & Johann von Nidbruck & & Bg p. 249 \\
\hline & April/May & & Baptiste Praillon & Bg p. 250 \\
\hline & May 28 & Johann von Nidbruck & & Bg pp. $253-254$ \\
\hline & September 18 & Franz Dryander & & Bg p. 255 \\
\hline & September 29 & Johann von Nidbruck & & Bg p. 256 \\
\hline & Autumn/winter & William Cecil & & Bg p. 259 \\
\hline 1553 & May 7 & & Caspar von Nidbruck & Bg p. 264 \\
\hline & July 7 & & Caspar von Nidbruck & Bg p. 264 \\
\hline & August 16 & Georg Fabricius & & $\begin{array}{l}\text { Hollaender } b, p \text {. } \\
433\end{array}$ \\
\hline 1554 & February 15 & Jean Calvin & & Bg p. 266 \\
\hline & June (early) & & $\begin{array}{l}\text { Erasmus von } \\
\text { Minkwitz }\end{array}$ & Bg p. 269 \\
\hline & July 8 (before) & Jean Calvin & & $\begin{array}{l}\text { Hasenclever b, } \\
\text { pp. } 170-171\end{array}$ \\
\hline & July (end) & Caspar von Nidbruck & & Bg p. 290 \\
\hline & August 26 & Peter Paul Vergerio & & Hubert, p. 153 \\
\hline & $\begin{array}{l}\text { August } 26 \\
\text { (after) }\end{array}$ & & Peter Paul Vergerio & KS, p. 69 \\
\hline 1555 & January & & Peter Paul Vergerio & KS, p. 91 \\
\hline & March 13 & Nicolaus Specht & & Bg p. 304 \\
\hline & March 22 & & Caspar von Nidbruck & Bg p. 273 \\
\hline & March & Caspar von Nidbruck & & Bgp. 273 \\
\hline & April 15 & Caspar von Nidbruck & & Bg p. 273 \\
\hline & April 23 (before) & $?$ & & Bg p. 274 \\
\hline & May (end) & Ludwig Gremp & & Bg p. 281 \\
\hline & June (18) & & Christoph Welsinger & Bg pp. 283,285 \\
\hline & June (18) & & $\begin{array}{l}\text { Member of King } \\
\text { Ferdinand's court }\end{array}$ & $\begin{array}{l}\text { Winckelmann, } p \text {. } \\
576\end{array}$ \\
\hline & July 20 (before) & & Jacob Fugger & Bg p. 286 \\
\hline & July 22 (before) & Jacob Fugger & & Bg pp. 285,289 \\
\hline & July $(22-30)$ & & Johann von Nidbruck & Bg pp. 290,294 \\
\hline & July 30 (before) & Peter Paul Vergerio & & Bg p. 294 \\
\hline & July & & Francis Hotman & Bg p. 295 \\
\hline
\end{tabular}




\begin{tabular}{|l|l|l|l|l|}
\hline & $\begin{array}{l}\text { August 21 } \\
\text { (before) } \\
\text { September 7 }\end{array}$ & Caspar von Nidbruck & & Bg p. 296 \\
\hline $\begin{array}{l}\text { September 9 } \\
\text { (before) }\end{array}$ & & Caspar Lanius & Bg p. 300 \\
\hline $\begin{array}{l}\text { October 4 } \\
\text { (before) }\end{array}$ & Jean Calvin & & Bg p. 305 \\
\hline & November 13 & Heinrich Panthaleon & & Bg pp. 312, 315 \\
\hline December 5 & Heinrich Panthaleon & & Bg p. 315 \\
\hline & December 19 & & Heinrich Panthaleon & Bg p. 315 \\
\hline $\mathbf{1 5 5 6}$ & $\begin{array}{l}\text { March 19 } \\
\text { (before) }\end{array}$ & Johann Stumph & & Bg p. 318 \\
\hline & March (late) & Caspar von Nidbruck & & Bg p. 320 \\
\hline & April 16 (before) & Nicolaus Specht & & Bg p.319 \\
\hline & April & Caspar von Nidbruck & & Bg p. 320 \\
\hline May (early) & & Caspar von Nidbruck & Bg p. 320 \\
\hline May (early) & & Jean Calvin & Bg p. 320 \\
\hline & Summer & & Peter Martyr Vermigli & Bg p. 321 \\
\hline $\begin{array}{l}\text { August 31 } \\
\text { (before) }\end{array}$ & & Philip Melanchthon & Bg p. 324 \\
\hline
\end{tabular}


IOAN. SLEIDANI,

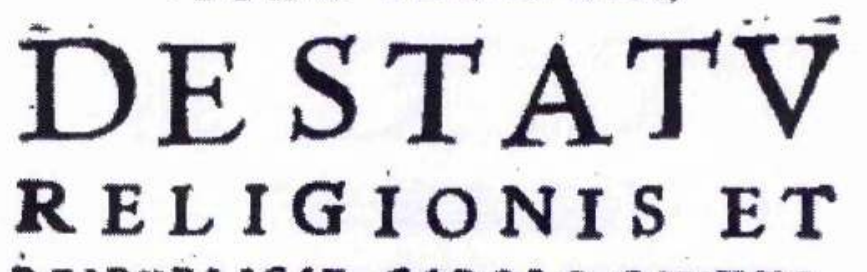

REIPVBLICAE, CAROLO QVINTO,

Cajare, Commentarij.

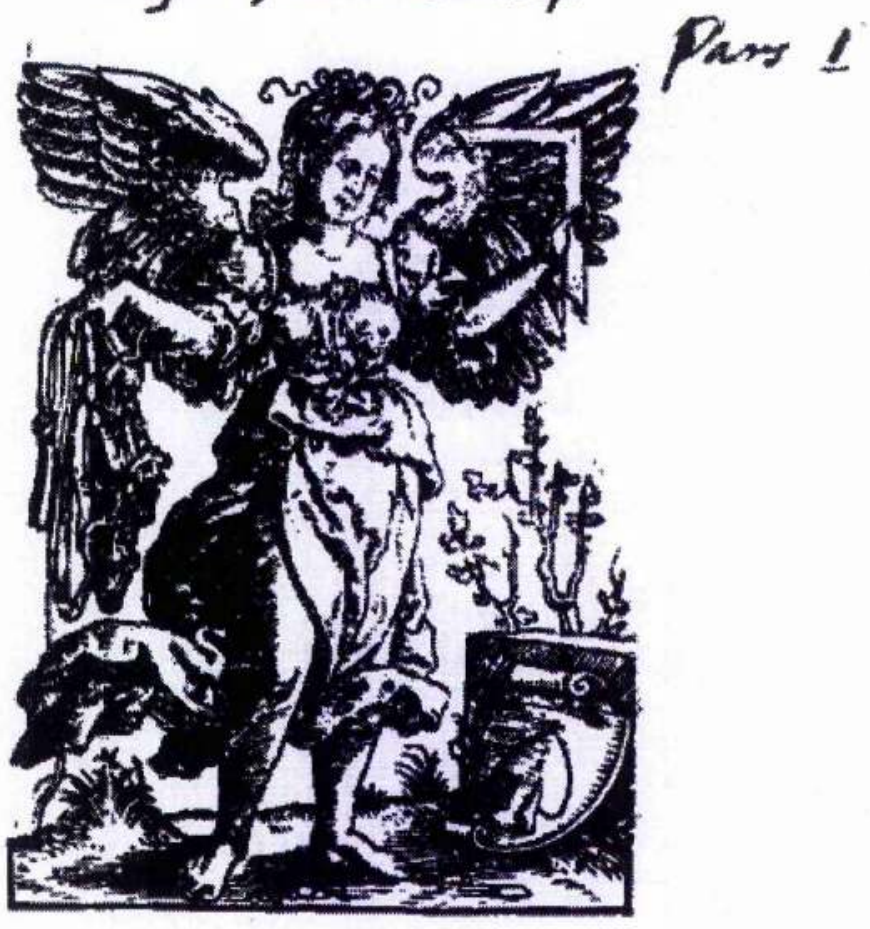

Cum Indice luculentifimo:

s. D. iv.

Titlepage of a 1555 edition of the Commentaries in $8 \mathrm{o}$, printed by Wendelin Rihel in Strasbourg (Vekene, Bibliographie, E/a 002; Bibliothèque Nationale Luxembourg $\mathrm{AL} / \mathrm{Sle} .55$; he classifies this edition as the second edition in 8o). 

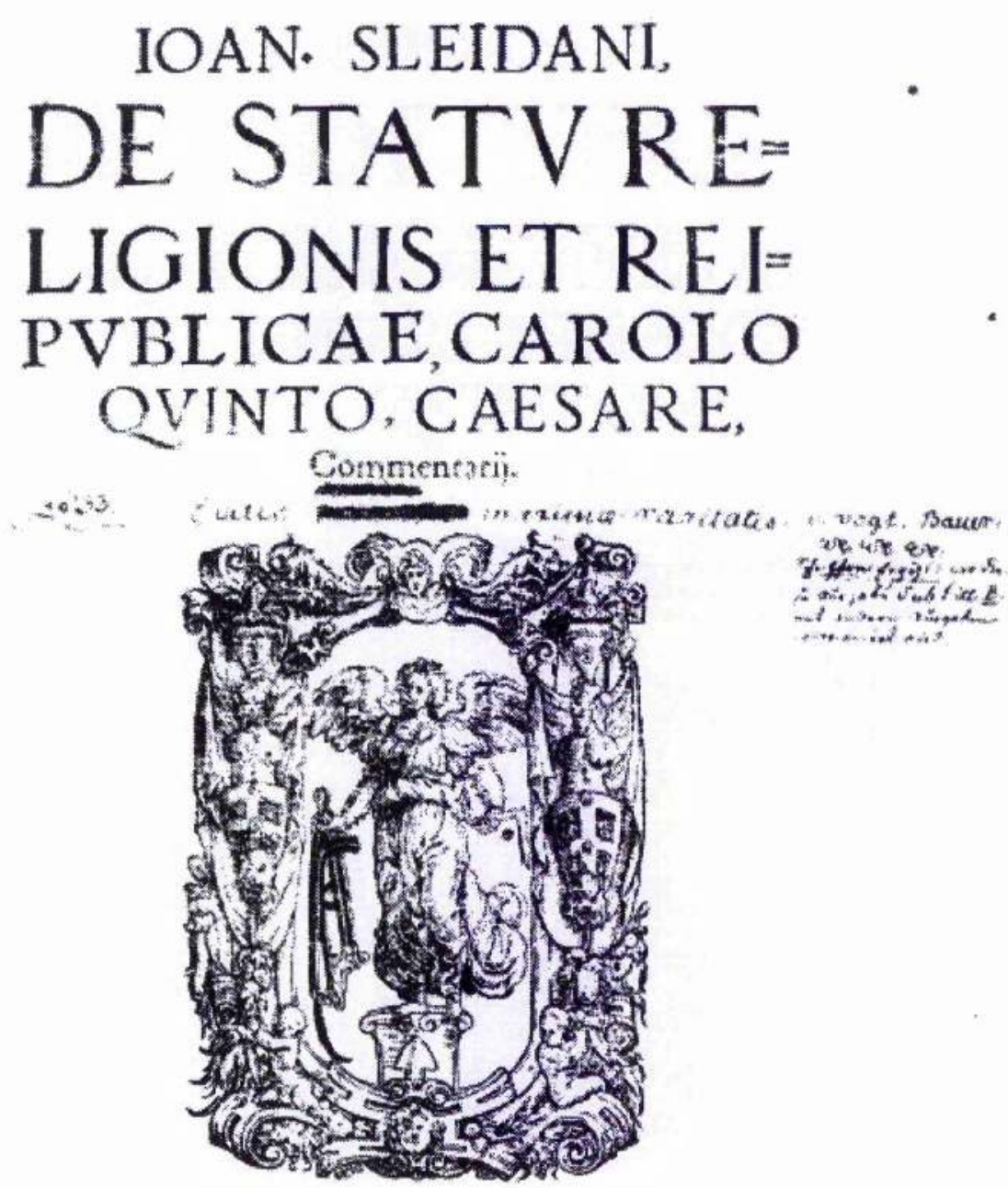

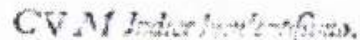
A: I) $1, i$.

Titlepage of a 1555 folio edition of the Commentaries, printed by the heirs of Wendelin Rihel in Strasbourg (Vekene, Bibliographie, E/a 004; Bibliothèque Nationale Luxembourg $\mathrm{AL} / \mathrm{Sle} .19$; Vekene classifies this edition as the second edition in 2o). 


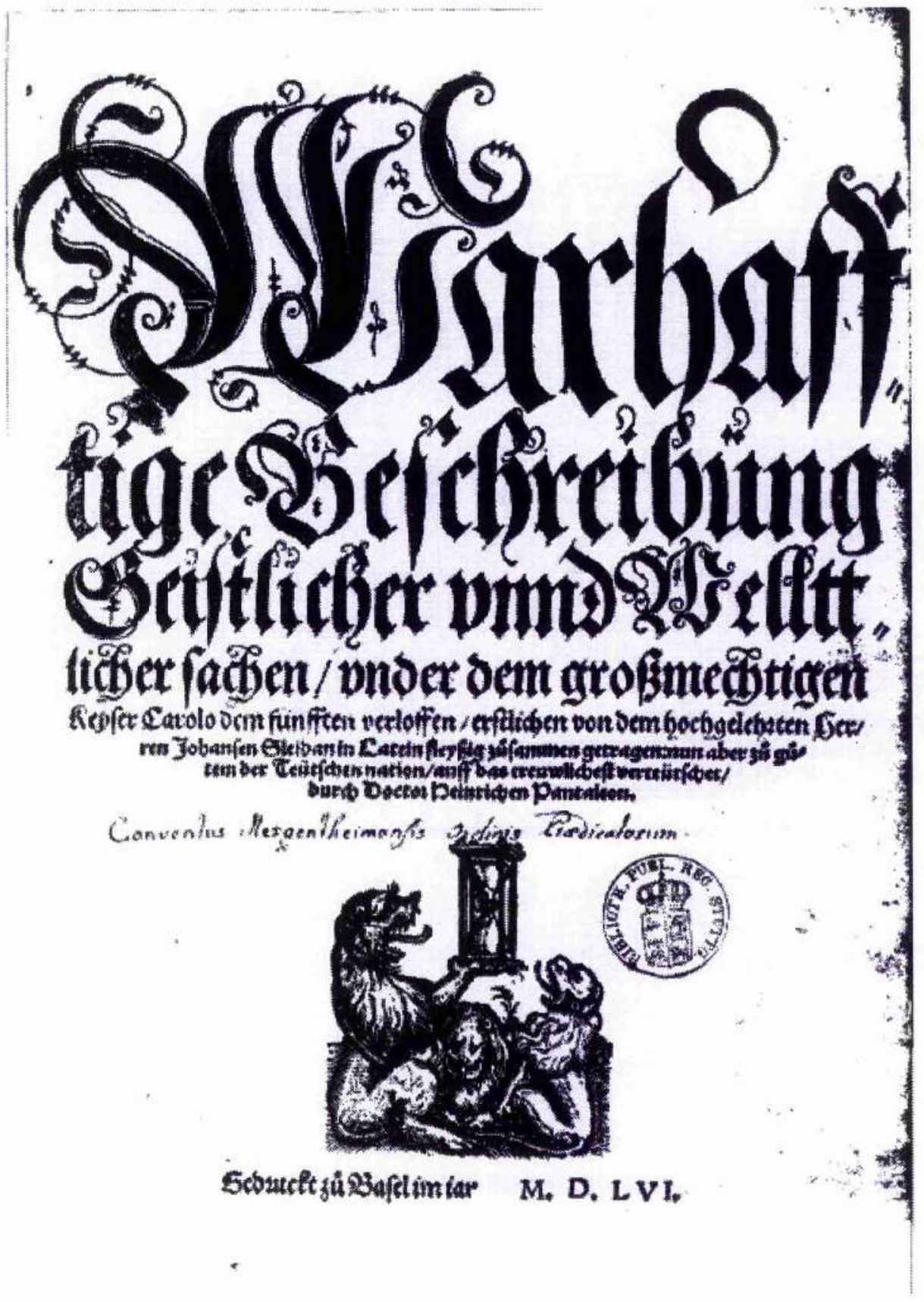

Titlepage of the first German translation of the Commentaries by Heinrich Pantaleon printed in Basle by Nicolaus Brylinger (Vekene, Bibliographie, E/b 001;

Württembergische Landesbibliothek Stuttgart Kirch.-G.fol.680). This copy from a monastery collection in Bad Mergentheim in Bavaria bears the provenance 'Conventus Mergentheimensis Ordinis Praedicatorum'. 


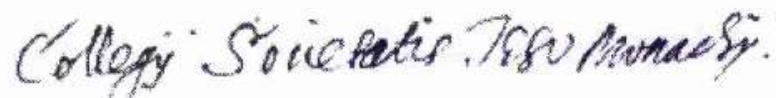

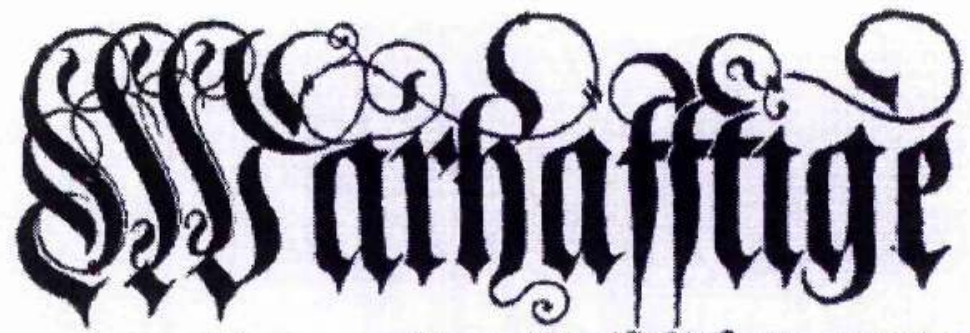

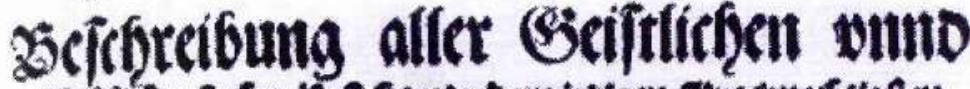

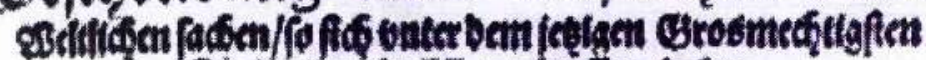
srofír scarolo.V. veriaulien gaben.

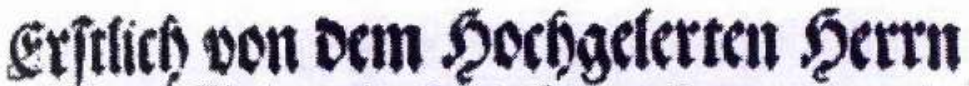

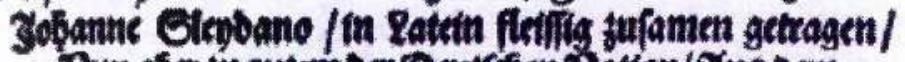

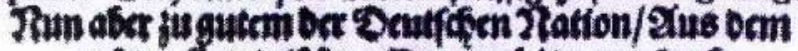

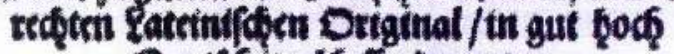 Datfकु/ otd uor/ wberfeget.}

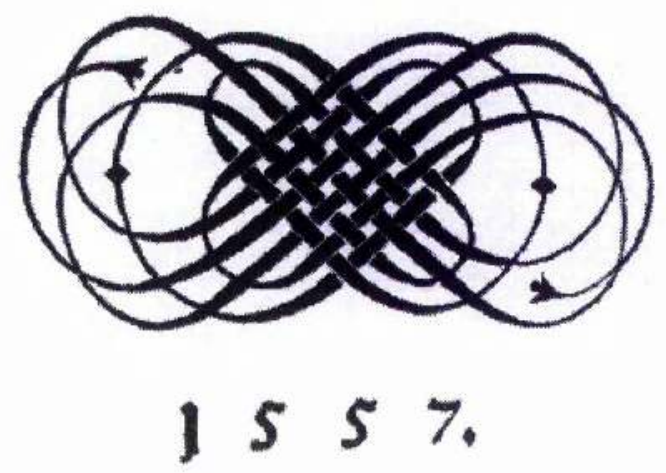

Titlepage of a 1557 German edition of the Commentaries translated by Heinrich Pantaleon, printed anonymously (Vekene, Bibliographie, E/b 004; Bayerische Staatsbibliothek Munich 2o. H. Eur.59). This copy owned by the Munich Jesuits bears the provenance 'Collegij Societatis JESU Monachij'. 


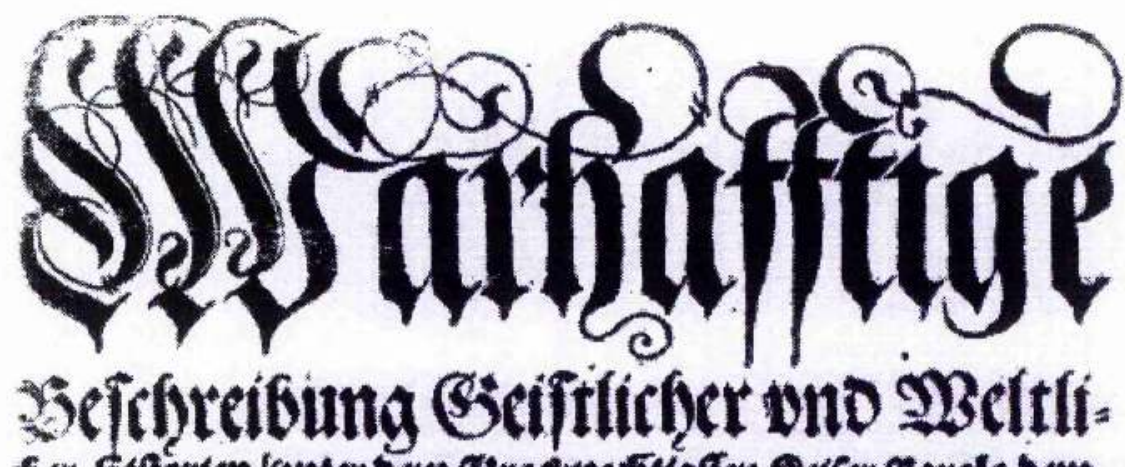

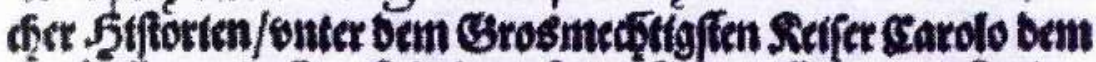

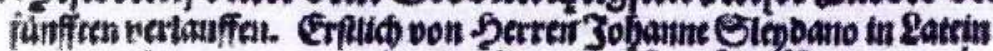

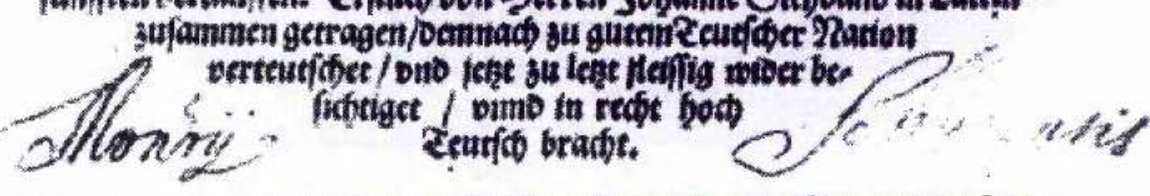

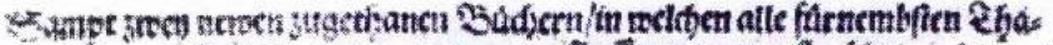

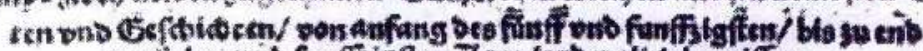

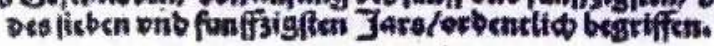

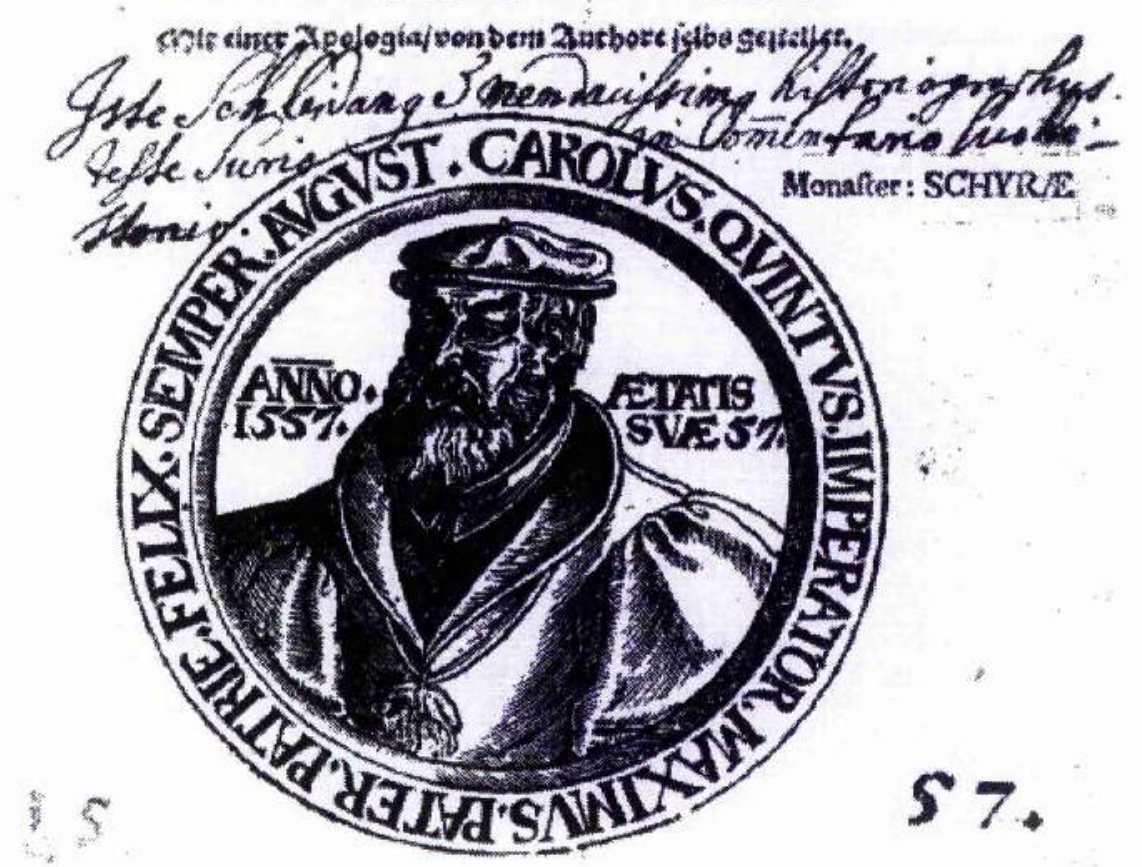

Titlepage of a 1557 edition of a German translation of the Commentaries by Heinrich Pantaleon, printed anonymously (Vekene, Bibliographie, E/b 008; Munich UB 2o Hist.956). Originally held in a monastery collection in Scheyern, Bavaria, it bears the provenance 'Mon[aste]rij Schyrensis' and the inscription 'Iste Schleidanus mendacissimus historiographus. Teste Surio in cõmentario suo historio’. 


\section{$\mathrm{H} I S \mathrm{~T} O \mathrm{I} R \mathrm{R}$ 5) 5 เ \\ DIELA RELIG $10 \mathrm{~N}$, \\ E T R E P D I QVE, tous IEmpercur Charles $V$.}

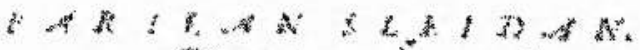

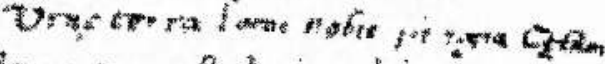

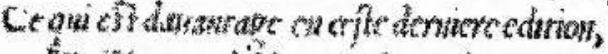

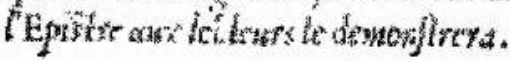
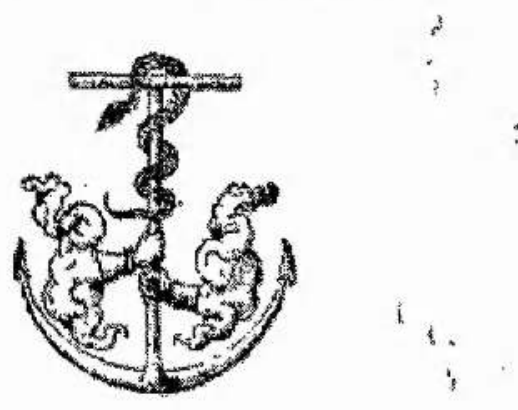

\section{CHEZ IEAN CRESPIN.}

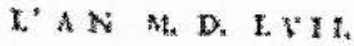

Titlepage of a 1557 French edition of the Commentaries in 8 o by Robert Le Prevost, printed by Jean Crespin in Geneva (Vekene, Bibliographie, E/c 004; Gilmont, Bibliographie, 57/15b; Bibliothèque Nationale Luxembourg AL/Sle.32). 


\section{BIBLIOGRAPHY}

\section{Primary Literature}

Anon., Antwort auf das Auffruerisch buechlin/ Welches die Protestirende wider die Rö. Kayserliche Mayestat feindtlicher weise zuziehen und kriegen/ fürnemlich angehetzt. Dargegen dise Antwort auß grund und warhait verfertiget ist/ zu erhaltung der Kayserlichen vnd Königlichen Mayestat vorige Reputation/ in gegenwertiger grausamen widerwertigkait, s.l. (s.n.) 1547

Anon., Coppie d'une Lettre Escripte par un Catholicque à un Politique, sur l'Arrest prononcé en la Synagogue de Tours, le cinquiesme d'Aoust dernier 1591. contre la Bulle monitoire de nostre sainct Pere le Pape Gregoire XIIII, Lyon (s.n. [Jean Pillehotte]) 1591

Anon., Memoires, et Recueil de L'Origin, Alliances, \& succession de la Royale famille de Bourbon, Branche de la maison de France, La Rochelle (Pierre Haultin) 1587

Anon., Sacrosancti et Oecumenici Concilii Tridentini Paulo III. Iulio III. \& Pio IIII. Pont Max. celebrati, Canones et Decreta ... Item Catalogus \& Index librorum prohibitorum, Lyon (Guillaume Roville) 1577

Anon., Tariffe et Concordance des poids de plusieurs provinces les plus practiquez au temps present, par les Marchands Francoys, Allemens \& plusieurs autres. Avec les comtes et recontres qui enseignent à combien revient toute quantité de chacune marchandise, soit en poids ou en nombre, et autres choses utiles à tous marchans, Lyon (Charles Pesnot) 1571

Aubigné, Théodore Agrippa de, Histoire universelle, 3 vols., Maillé (Jean Moussat), 1616

----, Mémoires, Buchon, J.A.C. (ed.), Choix de Chroniques et Mémoires sur l'Histoire de France, vol. 7, Paris 1884

Avicinius, Johannes, Chronologia Evangelica. Das ist ein Summarischer Außzug der Newevangelischen Chronicken/ darinn der Anfang/ erweiterung/ unnd früchten des newen Christenthumbs/ wie es D. Martin Luther selbst/gepflanzt hat/ ordenlich beschriben/ unnd menigklich zulesen in lustige Reymen gestellt, Ingolstadt (Alexander Weissenhorn d.J.) 1570

Baronio, Cesare, Martyrologium Romanum ad novam Kalendarii Rationem, et Ecclesiasticae historiae veritatem restitutum, Rome (Dominicus Basaeus) 1586

Bèze, Théodore de, Histoire ecclésiastique des Eglises réformées du royaume de France, 3 vols., Antwerp (=Geneva, Jean Remy) 1580

-----, Histoire ecclésiastique des Eglises réformées du royaume de France, vol. 1, Toulouse 1882

----, Vrais pourtraits des hommes illustres en pieté et doctrine, du travail desquels Dieu s'est servi en ces derniers temps, pour remettre sus la vraye religion en divers pays 
de la Chrestienté. Avec les descriptions de leur vie et de leurs faits plus memorables, s.1. (Jean de Laon) 1581

Bodin, Jean, Ioannis Bodini Methodus ad facilem historiarum cognitionem; accurate denuo recusa : Subiecto rerum Indice, Geneva (Jacob Stoer) 1610

Bullinger, Heinrich, (Hottinger, J.J. and Vögeli, H.H., eds.), Reformationsgeschichte, 3 vols., Frauenfeld 1838-1840

Calvin, John, (transl. Beveridge, Henry), Institutes of the Christian Religion, Grand Rapids 1995

Carion, Johann, (transl. Melanchthon, Philip), Chronica Carionis ganz new Latine geschrieben. Von dem Ehrwirdigen Herrn Philippo Melanchthone verdeutscht, Wittenberg (Georg Rhawen heirs) 1570

------, (transl. Le Blond, Jean), Histoire, ou Cronique des choses plus memorables depuis la creation du monde, iusques au regne du Tres-chrestien Roy Henry III. de ce nom, Roy de France \& de Polongne, Lyon (François Arnoullet) 1577

Chappuys, Gabriel, Histoire de nostre temps. Soubs les regnes des Roys Tres-Chrestiens Henry III. Roy de France \& de Pologne, \& Henry IIII. Roy de France et de Navarre, Paris (Guillaume de la Noue, 1606)

Cochlaeus, Johannes, Commentaria Ioannis Cochlaei, de actis et scriptis Martini Lutheri saxonis, Chronographice, Ex ordine ab Anno Domini M.D.XVII. usque ad Annum M.D.XLVI. inclusive, fideliter conscripta, s.l. (s.n.) 1549

Commelinus, Hieronymus (ed.), Rerum britannicarum, id est Angliae, Scotiae, vicinarumque insularum ac regionum, scriptores vetustiores ac praecipui. ... Ioannis Frossardi Historiarum Epitome, Lyon (René Postellier) 1587

Commynes, Philipppe de, Les Croniques de Messire Philippe de Commines chevalier. seigneur d'Argenton, sur les faicts de Loys unzieme, \& de Charles huictiesme son fils, Rois de France. De nouveau y est adiousté une epistre et annotations de Jean Sleidan, en la recommandation \& illustration de 1'Autheur, Paris (Pierre Du Pré) 1567

------, (transl. Hedio, Caspar) Historia Das ist Gründliche Beschreybung allerley wichtigernamhaffter Sachen unnd Händel/so sich bey Regierung der Großmächtigsten und Durchleuchtigsten Fürsten und Herren/Herren Ludwigen des Eylfften/Königs von Franckreich/Herren Carles Herzogen zu Burgund/und volgends Herren Carles des achten/auch Königs von Frankreich/vom 1464 biß auff das 1497 Jare nach nach Christi unsers Herren und Seligmachers Geburt/in Franckreich/Engellande/in den Burgundischen oder Nider Teutschen Landen/und desgleichen in Italia von wegen des Königreichs Sicilia zu Neapolis/haben verlauffen und zugetragen, Strasbourg (Josias Rihel) 1566

-----, (ed. Sauvage, Denis), Les Memoire de Messire Philippe de Commines, Chevalier, seigneur d'Argenton. Sur les principaux faicts \& gestes de Loys XI. \& Charles 
VIII. son fils, Rois de France. Deux Epistres de Iean Sleidan, avec la vie de l’Autheur, Paris (Jaques Chouët) 1603

Les Memoire de Messire Philippe de Commines, Chevalier, Seigneur d'Argenton. sur les faicts \& gestes abbregees de Loys XI. \& Charles VIII. son fils, Roys de France. Avec deux Epistres en la recommandation de l'Autheur, Antwerp (Martin Nutius), 1597

-----, (transl. Sleidan, Johann), De rebus gestis Ludovici, eius nominis vndecimi, Galliarum Regis, \& Caroli, Burgundiae Ducis, Philippi Cominaei, viri patrici, \& equestris ordinis, Commentarii, vere ac prudenter conscripti: Ex Gallico facti $\underline{\text { Latini, à Ioanne Sleidano. Adiecta est brevis quaedam illustratio rerum, \& Galliae }}$ descriptio, Strasbourg (Kraft Müller) 1545

-.---., (transl. Sleidan, Johann), Philippi Cominaei equitis, de Carolo Octavo, Galliae rege, \& bello Neapolitano, Commentarii. Ioanne Sleidano, Interprete. Accessit breuis quaedam explicatio rerum, \& authoris vita, Strasbourg (Wendelin Rihel) 1548

------, (transl. Sleidan, Johann), Philippi Cominaei Equitis, de rebus gestis Ludovici undecimi, Galliarum regis, \& Caroli, Burgundiae Ducis, Commentarii. Ex gallico facti Latini, a Ioanne Sleidano. Adiecta est brevis quaedam illustratio rerum, \& Galliae descriptio, Strasbourg (Josias Rihel) s.d. (1562/64)

Corrozet, Gilles, Les Antiquitez Croniques et Singularitez de Paris, Ville Capitalle du Royaume de France, Paris (Nicolas Bonfons) 1586

Le Courayer, Pierre-François, Defense de la Nouvelle Traduction de l'Histoire du Concile de Trente contre les Censures de quelques Prélats \& de quelques Théologiens, Amsterdam (Guillaume Smith) 1742

Crespin, Jean, (ed. Baum, G./Cunitz, E.), Histoire ecclésiastique des églises réformées au royaume de France, 3 vols., Paris 1883-1889

------, Histoire des vrays Tesmoins de la verité de l'Evangile, qui de leur sang l'ont signée, depuis Jean Hus iusques au temps present. Comprinse en VIII Livres contenant Actes memorables du Seigneur en l'infirmité des siens: non seulement contre les forces \& efforts du monde, mais aussi à l'encontre de diverses sortes d'assauts \& heresies monstrueuses, Geneva (Jean Crespin) 1570

-----, Le Livre des Martyrs, qui est un recueil de plusieurs Martyrs qui ont enduré la mort pour le Nom de nostre Seigneur Iesus Christ, depuis Jean Hus iusques à ceste année presente M.D.LIIII, s.l. (s.n.) (Geneva, Jean Crespin) 1554

------, Märtyrbuch: Darinnen merckliche/ denckwürdige Reden und Thaten viler heiligen Märtyrer beschriben werden/ welche nach den zeiten der Apostel/ biß auffs jar Christi M.D.LXXIIII, hin und wider in Teutschland/ Frankreich/ Engelland/ Schottland/Flandern/Braband/Italien/ Hispanien/ Portugall/ etc. umb der Evangelischen warheit willen jämmerlich verfolget/gemartert/ unnd endlich auch auff allerley weise entleibet worden, Herborn 1590 
Crusius, Martin, Annales Suevici sive Chronica rerum gestarum antiquissimae et inclytae Suevici gentis, 3 vols., Frankfurt (Nicolaus Bassaeus) 1596

Du Bellay, Guillaume, (ed. Bourrilly, V.-L.), Fragments de la Première Ogdoade du Guillaume Du Bellay Seigneur de Langey. Publiés avec une introduction et des notes, Paris 1904

Du Bellay, Jean, Defense pour le Roy de France Treschrestien, a lencontre des iniures \& detractions de Iaques Omphalius, faicte nagueres en Latin par ung Serviteur du Roy, \& maintenant traduicte en Francois par Simon Brunel, Paris (Robert Estienne) 1544

, Orasion escripte suyvant lintention du Roy treschrestien, aux Serenissimes, Reverendissimes, Tresillustres, Tresexcellens, Magnifiques, Treshauls Seigneurs, $\&$ a tous les estas du sainct Empire assemblez en la ville de Spire, Paris (Robert Estienne) 1544

Du Bellay, Martin, Les Mémoires de Mess. Martin Du Bellay Seigneur de Langey. Contenans le discours de plusieurs choses advenues au Royaume de France, depuis 1'an M.D.XII. jusqu'au trespas du Roy Francois premier, ausquels 1'Autheur a inseré trois livres, \& quelques fragmens des Ogdoades de Mess. Guillaume Du Bellay Seigneur de Langey son frere, Paris (Pierre L'Huillier) 1569

------, Les Mémoires de Martin Du Bellay, Petitot, M. (ed.), Collection complète des Mémoires relatifs a l'Histoire de France, depuis le régne de Philippe-Auguste, jusqu'au commencement du dix-septième siècle; avec des notices sur chaque auteur, et des observations sur chaque ouvrage, vol. 17, Paris 1821

Eber, Paul, Calendarium historicum conscriptum, Wittenberg 1550

---.--, L'Estat de la religion et republique du peuple judaique, Depuis le retour de l'exil de Babylone iusques au dernier saccagement de Jerusalem, s.l. (Jean Bavent) 1582

Flacius Illyricus, Matthias, Catalogus testium veritatis, qui ante nostram aetatem reclamarunt Papae, Basle (Johannes Opporinus) 1556

et al.,Ecclesiastica Historia, integram Ecclesiae Christi ideam, quantum ad locum. Propagationem. Persecutionem, Tranquillitatem, Doctrinam, Haereses, Ceremonias, Gubernationem, Schismata, Synodos, Personas, Miracula, Martyria, Religiones extra Ecclesiam, \& statum Imperii politicum attinet, secundum singulas Centurias, perspicuo ordine complectens: singulari diligentia \& fide ex vetustissimis \& optionis historicis, patribus, \& aliis scriptoribus congesta: Per aliquot studiosos \& pios viros in urbe Magdeburgica, Basle (Johannes Oporinus) 1559

--.---, (transl. Bourgoing, François), L'Histoire ecclesiastique, proposant l'entiere et vraye forme de l'eglise de nostre Seigneur Iesus, monstrant aussi les lieux ausquels le Royaume d'iceluy a este dressé, soit de son temps ou apres, Geneva (Artus Chauvin) 1560 
-----, (transl. Wigand, Johannes/Judex, Matthäus), Kirchenhistoria/ darinnen ordenlich und mit höchstem vleiss beschrieben werden die Geschicht der Kirchen Christi, 4 vols., Jena (Thomas Rebart) 1560-65

-----, De Translatione Imperii Romani ad Germanos. Item de electione episcoporum. quod aeque ad plebem pertineat, Basle (Johannes Opporinus) 1566

Fontaine, Simon, Histoire catholique de notre temps, touchant l'estat de la religion chrestienne contre 1'histoire de Jean Sleydan, Antwerp (Jean Steelsius) 1558

------, Histoire catholique de notre temps, touchant l'estat de la Religion Chrestienne, Paris (Guillaume Julien) 1562

-----, (trans1. Pontanus, Roverus), Historiae Ecclesiasticae nostri temporis, libri XVII. In quibus preterquam nuda veritas, \& rerum gestarum series fideliter recensetur. etiamque multa quae Iohannes Sleidanus in suis de Statu Religionis \& Reipublicae Commentariis nugatur, luculentissime reteguntur, Cologne (Caspar Gennep) 1558

Foxe, John, The First (-Second) Volume of the Ecclesiasticall History contaynyng the Actes and Monuments, London (John Day) 1570

Franck, Sebastian, Chronica Zeitbuch unnd Geschichtbibell von anbegyn biß in diss gegenwertig M.D.xliij. iar verlengt/ Darinn bede Gottes und der welt lauff/ händel/ aert/ wort/ werck/ thun/ lassen/ kriegen/ wesen/ und leben ersehen und begriffen wirdt. ....Summa hierinn findestu gleich ein begriff/ summari/innhalt und schatzkammer/ nit aller/ sonder der Chronickwirdigsten/außerlesnen Historien...., s.1. (s.n.) 1543

-----, Germaniae Chronicon. Von des gantzen Teutschlands aller Teutschen völcker herkommen/ Namen/ Händeln/ Guten und bösen Thaten/ Reden/ Rächen/ Kriegen/ Sigen/ Niderlagen/Stifftungen/ Veränderungen der Sitze/ Reich/ Länder/ Religion/ Gesatze/ Policei/Spraach/Völcker/ und sitten/ Vor unnd nach Christi geburt/ Von Noe biß auff Carolum V. Ankunfft unnd Stifftung der Reich/ Bistumb/ Füstenthumb/ Herschafftenn/ Stett/ Clöster und Stifft...Auß glaubwirdigen angenommen/Geschichtschreibernn/ zu ruck diß blats verzeichenet/ zusamen getragen/ Unnd die Teutschen den Teutschen zu Teutsch/sich selbs darin/als in einem Spiegel zu ersehen/ fürgestelt, Augsburg (Alexander Weyssenhorn) 1538

------, Erst theil dieses Weltbuchs/ von Newen erfundnen Landtschafften. Warhafftige Beschreibunge aller theil der Welt, s.1. (s.n.) 1567

------, Weltbuch/spiegel und bildnis des ganzen Erdtbodens/ ...nitt auß Beroso/ Joanne de Monte villa/ S. Brandons Histori/ unnd dergleichen fablen/ sunder auß angenommnen/glaubwürdigen/ erfarnen Weltbeschreibern/müselig zuhauff getragen/ unn auß vilen weitleüffigen büchern in ein handtbuch eyngeleibt und verfasset/ vormals dergleichen in Teütsch nie außgangen, s.1. (s.n.) 1542

Le Frere de Laval, Jean, La vraye et entiere histoire des troubles et guerres civiles, avenuës de nostre temps, pour le faict de la religion, tant en France, Allemaigne que pays bas, Paris (Marc Locqueneulx) 1575 
Froissart, Jean, (transl. Sleidan, Johann), Frossardi, nobilissimi scriptoris gallici, historiarum opus omne, iam primum et breviter collectum et latino sermone redditum, Paris (Simon de Colines) 1537

------, Le premier (-quart) volume de messire Iehan Froissart/ lequel traicte des choses dignes de memoire advenues/tant es pays de France/ Angleterre/ Flandres/ Espaigne que Escoce/ et autres lieux circonvoisins, Paris (Poncet Le Preux) 1530

Gennep, Caspar, Epitome Warhaftiger Beschreibung der Vornembsten Händel/ so sich in Geistlichen unnd Weltlichen sachen/Vom Jar unsers Herren M.D. biß in das jar der mynderen zal Lix. zugetragen vnd verlauffen haben. Mit höchstem fleiß auß den Bereumpten Hystorischreibern. Iohanne Nauclero, Paulo Iovio, Sebastiano Munstero, Iohanne Catione, Doctore N. Fontano, Conrado Licosteno, Actis Lutheri, Iohanne Sleidano, Neben anderen Fürstlichen vnnd viler guter freundt Schrifften/ zusamen gestelt. Mit anzeigung wie offt vnd vil Sleidanus mehe auß neigung des Affects/ dan liebe der Warheit/ etliche dyng beschriben hat, Cologne (Caspar Gennep) 1559

, Eyn Ernsthafftigs Gesprech/zwischen Jaspar Gennep/ Burger und Buchtrucker zu Cöllen/ Unnd Cyriaco Spangenberg/ über die Geschicht Beschriebung/Johannis Sleidani, Cologne (Caspar Gennep) 1561

-.----, (transl. Pontanus, Roverus), Rerum Memorabilium, iam inde ab anno Domini M. D. ad annum ferè LX. in Rep. Christiana gestarum, libri quinque. Ex plerisque nostrorum temporum historiographis, praecipue autem D. Fontano Theologe Parisiensi, \& Ioanne Sleidano collecti: Cum diligenti annotatione eorum, quae Sleidanus ex affectu potius, quam veritatis studio conscripsisse depraehenditur, Cologne (Caspar Gennep) 1559

Gilles, Nicole, Annales et Croniques de France, depuis la Destruction de Troye iusques au temps du Roy Loys unziesme, iadis composées par feu maistre Nicole Gilles, en son vivant Secretaire, Iudiciaire du Roy, \& Contrerolleur de son tresor, Paris (Gabriel Buon), 1562

Girard, Bernard de, De la Fortune et Vertu de la France, Ensemble un sommaire Discours sur le desseing de l'Histoire de France, Paris (Olivier l'Huillier) 1571

Gropper, Johann, Vonn Warer, Wesenlicher und Pleibender Gegenwertigkeit des Leybs und Bluts Christi nach beschener Consecration/ Und derselben Anbetung im Hochwirdigsten Heiligsten Sacrament des Altars. Und von der Communion under Eyner gestalt. Wider jetziger zeht entstandene und weith verpreitete Ketzereien und Secten, Cologne (Caspar Gennep) 1556

Hainault, Jean de, L'Estat de L'Eglise, des le Temps des Apostres, iusques à l'an present. Avec un recueil des troubles advenues en France, sous le Roy Francoys II. \& Charles IX, Strasbourg (Jan Zimmermann) 1567

Hedio, Caspar, Ein Außerleßne Chronick von anfang der welt bis auff das jar nach Christi unsers eynigen Heylands gepurt M.D.xxxix, Strasbourg (Krafft Müller) 1539 
Hortleder, Friedrich, Der Römischen Keyser- und königlichen Maiesteten: Auch des Heiligen Römischen Reichs Geistlicher und Weltlicher Stände/ Churfürsten/ Fürsten /Graffen /Reichs- und anderer Stätte /Sampt des hochlöblichen kaiserlichen CammerGerichts/ Fürstlicher Regierungen/ und etlicher der H. Schrifft und beyder Rechte Gelehrten/ Handlungen und Außschreiben/ Send-Brieffe/ Bericht/ Underricht/ Kalg- und Supplication-Schrifften/Befelch/ Fürladungen/ Rathschläge/ Bedencken/Entschuldigungen/ Protestationes, Recusationes, Ableynungen/ Außführungen/Urtheyls und Hülffs Brieffe/ Bündnissen/ und Gegen-Bündnissen/ Bundts-Ordnungen und Abschiede/ Fehde- oder Verwahrungs-Brieffe/ An- und Fried-Stände/ Verträge/ und viel andere treffliche Schrifften und Kunden mehr/ Von den Ursachen des Teutschen Kriegs Kaiser Carls des Fünfften/ wider die Schmalkaldische Bundts Oberste Chur- und Fürsten/Sachsen und Hessen/ und Ihrer Chur- und F.G.G. Mitverwandte/ Anno 1546. und 47., Frankfurt/Main (Hartm. Palthenius) 1617

, Der Römischen Keyser- und königlichen Maiesteten: Auch des Heiligen Rö. Reichs/geistlicher und weltlicher Stände/ Churfürsten/Fürsten/Graffen/ Herren/ Reichs- und anderer Stätte/ zusampt der heiligen Schrifft/geistlicher und weltlicher Rechte Gelehrten Handlungen und Außschreiben/ Rathschläge / Bedencken/ Sendund andere Brieffe / Bericht/ Supplicationsschrifften/ Befehl/ Entschuldigungen/ Protestationes, Recusationes, Außführungen/Verantwortungen/Ableinungen/ Absagungen/Achtserklärungen/ Hulffsbrieffe/Verträge/ Historische Beschreibungen/ und andere viel herrliche Schrifften und Kunden mehr: Von Rechtsmässigkeit/ Anfang/ Fort- und endlichen Außgang deß Teutschen Kriegs/ Keyser Carls deß Fünfften/ wider die Schmalkaldische Bundsoberste/ Chur- und Fürsten/ Sachsen und Hessen/ und J. Chur- und Fürstl. G.G. Mitverwandte, Vom Jahr 1546 biß auff das Jahr 1558., Frankfurt/Main (Nicolaus Hoffmann) 1618

Jovio, Paulus, (transl. Pantaleon, Heinrich), Pauli Jovij xlv Bücher. Ein warhafftige beschreybung aller nammhafftigen Geschichten / so sich bey den fürtreffenlichesten Geistlichen oder Wältlichen Fürsten und Herren, Basle (s.n.) 1560

Knox, John, (ed. Guthrie, C.J.), The History of the Reformation in Scotland, London 1898

Lauterbeck, Georg, Regentenbüch. Auffs fleissigst und herrlichst itzt von newen ubersehen/ vnd durchaus an vielen orten Corrigiert/Gemehret/ und Gebessert, Leipzig (Johannes Marttroff) 1572

Lawlor, Hugh Jackson/Oulton, John Ernest Leonard, Eusebius, Bishop of Caesarea. The Ecclesiastical History and the Martyrs of Palestine, 2 vols., London 1927/28

Maimbourg, Louis, Histoire du Lutheranisme, 2 vols., Paris 1680

Marnix, Philippe de, Le Tableau des Differens de la Religion: Traictant de 1'eglise, du Nom, Definition, Marques, Chefs, Proprietés, Conditions, Foy, \& Doctrines d'icelle, 2 vols., Leiden 1603-05

------, (ed. Quinet, Edgar), Oeuvres de Philippe de Marnix de Sainte Aldegonde. Tableau des Différends de la Religion, Amsterdam (F.Gunst) 1857 
Maumont, Jan de, Les Histoires et Chroniques de Monde, tirees tant du gros volume de Jan Zonoras Aucteur Byzantin, que de plusieurs autres bons \& anciens scripteurs Hebrieus \& Grecs, Paris (Michel de Vascosan) 1561

Münster, Sebastian, Cosmographia. Beschreibung aller Lender, Basle (Heinrich Petri) 1545

Myconius, Friedrich, Historia Reformationis, vom Jahr Christi 1517. bis 1542, Leipzig 1718

Paradin, Guillaume, Histoire de nostre temps, Paris (Jean Ruelle) 1557

Pasquier, Estienne, Des Recherches de la France, Paris (Vincent Sertenas) 1560

Perrin, Jean-Paul, Histoire des Chrestiens Albigeois. Contenant les longues guerres, persecutions qu'ils ont souffert à cause de la doctrine de l'Evangile, Geneva (Matthieu Berjon) 1618

Histoire des Vaudois, 3 vols., Geneva (Pierre \& Jacques Chouët) 1619

La Popelinière, Henri Lancelot Voisin de, (ed. Desan, Philippe), L'Histoire des Histoires, avec l'idée de l'histoire accomplie. Plus le dessein de l'histoire nouvelle des Francois, Paris (Marc Orry) 1599, repr. Paris 1989

-----, La Vraye et Entiere Histoire de ces derniers Troubles: advenus, tant en France, qu'en Flandres, \& pays circonvoisins. Comprinse en dix Livres. Dediee a la Noblesse de France, Cologne (Arnould Birckman) 1571

-----, La Vraye et Entiere Histoire des Troubles et Choses Memorables, Avenues tant en France qu'en Flandres, \& pays circonvoisins, depuis l'an 1562. Comprins en quatorze livres: les trois premiers, \& dernier desquels sont nouveaux: les autres reveus, enrichiz, \& augmentez de plusieurs choses notables. Avec les considerations sur les guerres ciuiles des Francois, La Rochelle (Pierre Davantes) 1573

Rabus, Ludwig, Der Heiligen außerwöhlten Gottes Zeugen/ Bekennern und Martyrern/ so inn angender Ersten Kirchen/Alts und Neues Testaments/ zu yeder zeit gewesen seindt/ warhaffte Historien/ aus Heyliger Göttlicher/ und der Alten Lehrer Glaubwürdigen Schrifften, Strasbourg (Balthasar Becken heirs) 1552

Raemond, Florimond de, L'Histoire de la Naissance, Progrez et Decadence de L'Heresie de ce Siecle, Rouen (Daniel Loudet) 1647

Regnier de la Planche, Louis, Histoire de 1'Estat de France, Tant de la République que de la Religion, sous le Règne de Francois II., Buchon, J.A.C. (ed.), Choix de Chroniques et Mémoires sur l'Histoire de France, vol. 7, Paris 1884

Reuss, Rodolphe, Les Collectanées de Daniel Specklin, chronique strasbourgeoise du seizième siècle. Fragments, Strasbourg 1890 
Reussner, Nicolaus (ed.), Rerum Memorabilium in Pannonia sub Turcarum imperatoribus, a capta Constantinopoli usque ad hanc aetatem, bello militiaque gestarum, Frankfurt (Claudius Marnius/Johannes Aubrius heirs) 1603

La Place, Pierre de, Commentaires de 1'Estat de la religion et République soubs les Rois Henry et Francois Seconds, et Charles Neufieme, s.l. (s.n.) 1565

Sabinus, Georg, Poemata Georgii Sabini Brandenburgensis V. CL. et numero librorum et aliis additis avcta, et emendatius denuo edita, Leipzig (Johannes Steinmann) 1581

Saconay, Gabriel de, Discours catholique, Sur les causes \& remedes des Malheurs intentés au Roy, \& escheus à son peuple, par les rebelles Calvinistes, Lyon (Michel Jove) 1568

Sarpi, Paolo, (ed. Le Courayer, Pierre-François), Histoire du Concile de Trente... avec des notes critiques, historiques et theologiques, 2 vols., Basle (Jean Brandmuller \& sons) 1738

-----, (ed. Rambach, Friedrich Eberhard), Historie des Tridentinischen Concilii mit des D. Courayer Anmerkungen, 2 vols., Halle 1761

Sastrow, Bartholomäus, (ed. Coler, Christfried), Lauf meines Lebens. Ein deutscher Bürger im 16. Jahrhundert, Berlin 1956

Schopper, Jacobus, Neuwe Chorographia und Histori Teutscher Nation, Frankfurt/Main 1585

Schurzfleisch, Konrad Samuel, Schurzfleischii Epitomes historicae a Jo. Sleidano coeptae, Wittenberg 1678

Schwartz, Eduard (ed.), Eusebius Kirchengeschichte, Leipzig 1908

Seckendorf, Veit Ludwig, (transl. Frick, Elias), Historie des Luthertums, Leipzig (Joh. Friedrich Gleditsch \& son) 1714

Serres, Jean de, Inventaire general de l'histoire de France depuis Pharamond iusques a present. Illustre par la conference de l'Eglise et de l'Empire, Paris (A. Saugrain/ G. de Rues) 1600

Seyssel, Claude de, Histoire singulier du Roy Louis XII. de ce nom, pere du peuple, faicte au parangon des regnes \& gestes des autres Roys de France ses predecesseurs, particularisez selon leurs felicitez ou infelicitez, Paris (Jacques du Puys) 1587

-.--, (transl. Sleidan, Johann), Claudii Sesellii, viri partricii, de republica Galliae \& regum officiis. Libri duo. Ioanne Sleidano, Interprete. Adiecta est summa doctrinae Platonis, de Repub. \& Legibus, Strasbourg (Wendelin Rihel) 1548

Sleidan, Johann, Ain beschaidner historischer/ unschmählicher Bericht/ and alle Churfürsten/ Fürsten und Stennde dess Reichs. Von des Pabstums auf und abnemen/ desselben geschicklichhait/ unnd was endtlich darauß folgen mag, (Augsburg: Melchior Kriegsstein 1541) 
-----, (trans1. Koch, Huldrich), Johannis Sleidani Beschreibung der vier Monarcheyen oder höchsten Regimenten/so Gott allein in der wält verordnet/ sampt denen geschichten/ so sich darunder verlauffen haben und sollen, Basle (Nicolaus Brylinger) 1557

-..---, (transl. Wythers, Stephan), A briefe Chronicle of the foure principall Empyres, London (Rowland Hall) 1563

-----, (transl. Alchacium, Israel), Chronica: das ist Warhaftige und gewisse Beschreibung/ deß Hochgelehrten herrn Johannis Sleidani/darinn angezeigt/ was sich in Geistlichen und Weltlichen sachen under dem Großmechtigsten Keiser Carolo dem fünfften/verloffen hab/ auff ein neüwes Teütscher Nation zu gut verdolmetschet/... Sampt einer Apologia vom Authore darüber verlassen, Pforzheim (Georg Rabus) 1557

-.-----, 'Ein Dialogus oder Gesprech von der Platonischen Lehre/ ob auch/ und wie weit dieselbige zu Regierung des gemeinen nutzes dienlich sey', Lauterbeck, Georg, Regentenbüch. Auffs fleissigst und herrlichst itzt von newen ubersehen / vnd durchaus an vielen orten Corrigiert / Gemehret / und Gebessert, Leipzig (Johannes Marttroff) 1572

-.----, (transl.), Duo gallicarum rerum scriptores nobilissimi. Frosssardus in brevem historiarum memorabilium epitomen contractus: Philippus Cominaeus de reb. Gestis a Ludovico XI, \& Carolo VIII, Francorum regibus, Frankfurt/Main (Andreas Wechsel heirs, Claude de Marne \& Jean Aubry) 1594

Epitome commentariorum Ioannis Sleidani, de statu religionis et reipublicae, Carolo V. Caesare, Geneva (Jean Crespin) 1556

-----, (transl. Beuther, Michael), Der erste [und ander] Theyl Ordenlicher Beschreibunge unnd Verzeychnisse/ allerley fürnemer Händel/so sich in Glaubens und anderen Weltlichen sachen/ bei Regierung vorweilen des Großmächtigsten/Keysers Carl des Fünfften/ mehrerntheyls in Teutscher Nation zugetragen, Strasbourg (Theodosius Rihel) 1570

-.---., (transl. Day, John), A famous chronicle of oure time, called Sleidanes commentaries, London (John Day) 1560

------, (transl. Bohun, Edmund), The General History of the Reformation of the Church from the errors and corruptions of the Church of Rome: begun in Germany by Martin Luther, with the progress thereof in all parts of Christendom, from the year 1517 , to the year 1556 . To which is added a continuation to the end of the Council of Trent in...1562, London (Edward Jones for Abel Swall and Henry Bonwicke) 1689

-------, (transl. Le Prevost, Robert), Histoire entiere de 1'Estat de la Religion, \& Republique, sous 1'Empereur Charles V, s.1. (Jean Crespin) 1558

---.--, (transl. Le Prevost, Robert), Histoire de l'estat de la religion et republique sous Charles V, s.l. (Geneva) (Jean Crespin/Nicolas Barbier) 1557 
-----, Histoire de 1'estat de la religion, et republique, sous l'Empereur Charles

Cinquiesme, par Jean Sleidan. Ce qui est davantage en ceste derniere edition. 1'Epistre aux Lecteurs le demonstrera. En outre ont esté adionts trois livres des Quatre Empires souverains, nouuellement mis en lumiere par ledit Autheur peu de temps avant son trespas, Strasbourg (s.n.) 1558

-----, (transl./ed. Le Courayer, Pierre François), Histoire de la Reformation, ou Memoires de Jean Sleidan, sur 1'État de la Réligion et de la République sous 1'Empire de Charles Quint, 3 vols., The Hague (Frederic Staatman) 1767

Les ouvres de I. Sleidan qui concernent les histoires qu'il a escrites: a savoir, III. Livres de ses commentaires des quatre principaux empires du monde. XXVI livres des histoires de la religion \& republique de nostre temps. II. remonstrances pleines d'histoires, l'une aux estats de l'empire, l'autre à l'empereur Charles V. IIII. volumes de Frossard historien, abbregez d'un singulier artifice par Sleidan: avec quelques prefaces sur l'histoire de Commines. Le discours de l'estat du royaume \& des maisons illustres de France, est adiousté sur la fin, Geneva (Jean Crespin), Geneva 1566

Oration an alle Churfürsten/ Fürsten/ und Stende des Reichs/Von des Bapsttumbs auffkommen und abnemen/ auch von seinen Practicken/ und was man sich endtlich/ diser zeit/ zu im versehen soll, s.l. (Strasbourg: Kraft Müller) 1541

Ioannis Sleidani orationes duae. Una ad Carolum Quintum Caesarem. Altera ad Germaniae principes omnes, ac ordines Imperij, Strasbourg (Krafft Müller) 1544

----, Oration an Keiserliche Maiestat. Von dem/ Das der ietzige Religionshandel/ kein menschlich/sonder Gottes werck und wunderthat sei. Idem/Das der Eide/ damit jre Maiestat dem Bapst verwandt/ tyrannische/ und gar nit zuhalten sei, (Strasbourg: Georg Messerschmid 1544)

, Oration an Kayserliche Mayestat. Von dem/ Das der yetzige Religionshandel/ kain menschlich/sonder Gottes werck/ und wunderthat sey. Item/Das der Eide/ damit ire Maiestat dem Bapst verwandt/ tyrannisch/ und gar nit zuhalten sey, Augsburg (s.n.) 1544

----, Ioan. Sleidani, de quatuor summis imperiis, libri tres, Strasbourg (Rihel brothers) 1556

----, Ioan. Sleidani, de quatuor summis imperiis, libri tres, In gratiam iuventutis confecti. Cum Indice luculentissimo, (Strasbourg : Rihel brothers) 1557

-----, Sommaire de l'Histoire de Jean Sleidan, disposé par tables, En tel ordre et facilité, que le Lecteur pourra aisément \& sans travail comprendre par iceluy tout le long narré de ladite Histoire, Strasbourg (s.n.) 1558

-----, Ioan. Sleidani, de Statu Religionis et Reipublicae, Carolo Quinto, Caesare, Commentarii. Cum Indice luculentissimo, Strasbourg (Wendelin Rihel) 1555

--.--, Ioanni Sleidani, de statu religionis \& reipublicae, Carolo Quinto, Caesare, commentariorum libri XXVI...Unà cum apologia ab ipso authore conscripta, et 
indice locupletissimo. Sub calcem adiectae sunt tabulae, quibus singulari industria ac compendio religionis et reipublicaeque negotium uniuersum, ceu in pictura, spectandum exhibetur, Strasbourg (Wendelin Rihel) 1555

, Ioan. Sleidani, De Statu Religionis et Reipublicae, Carolo Quinto, Caesare, Commentarij. Sub calcem adiectae sunt Tabulae, quibus singulari industria ac compendio Religionis Reipublicaeque negotium universum, ceu in pictura, spectandum exhibetur, (Strasbourg: Rihel brothers 1556)

-_--, Ioan. Sleidani, De Statu Religionis \& Reipublicae, Carolo Quinto, Caesare, Commentariorum libri XXVI, Strasbourg (Josias Rihel) 1559

, (ed. Am Ende, Carl Christian) Ioannis Sleidani de Statu religionis et reipublicae Carolo quinto Caesare Commentarii, 3 vols., Frankfurt/Main 1785

------, (transl./ed. Beuther, Michael), Sleidanus Redivivus, Das ist ein grundtliche beschreibung auch Historische erzehlung der fürnembsten Händel, so sich in Religions und anderen Politischen Sachen bey Regierung des Unuberwindlichsten Kaysers Caroli deß V. Ferdinandi deß I. Maximiliani und Rudolphi der II. hochlöblichster Gedächtnuß: Und dann Matthiae des Ersten, jetzo noch Regierenden Römischen Keysers, in und ausserhalb des Heyligen Römischen

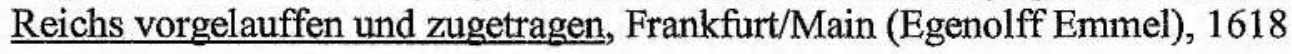

------, Tabulae in libros historiarum, de Religione \& Republica Ioannis Sleidani, Strasbourg (Wendelin Rihel heirs) 1557

--.--, (trans1.), Tres gallicarum rerum scriptores nobilissimi: Philippus Cominaeus de rebus gestis a Ludovico XI et Carolo VIII. Francorum regibus: Frossardus in brevem Historiarum memorabilium epitomen contractus: Claudius Sesellius de Republ. Galliae, \& Regum officiis, Frankfurt/Main (Andreas Wechel) 1578

-----, Trois livres des quatre empires souverains, Assavoir, de Babylone, de Perse, de Grece, \& de Rome, (Geneva: Jean Crespin) 1557

------, Le vingt-sixième livre de l'histoire de J. Sleidan, (Geneva: Jean Crespin and Nicolas Barbier) 1558

-----, (transl. Stamler, Marcus), Joanniß Sleidani Warhafftige und Eigentliche beschreibung der Geistlichen und Weltlichen sachen/so sich under der Regierung des Großmechtigsten Keysers Caroli diß namen des V. verlauffen. .... Sampt einer Apologia von dem Authori selbers angestellet, Strasbourg (Wendelin Rihel heirs) 1557

------, (transl. Pantaleon, Heinrich), Warhaftige Beschreibüng Geistlicher und Welttlicher sachen/ under dem großmechtigen Keyser Carolo dem fünfften verloffen/ erstlichen von dem hochgelehrten Herren Johansen Sleidan in Latein fleysig zusammen getragen: nun aber zu gutem der Teütschen nation / auff das treuwlichest verteütschet / durch Doctor Heinrichen Pantaleon, Basle (s.n.) 1556

------, (transl. ?) Warhaftige Beschreibung aller gaistlichen unnd Weltlichen sachen/ so sich undter dem jetzigen Großmechtigsten Keiser Carolo v. verlauffen haben, Frankfurt/Main (s.n.) 1557 
------, (ed. Böhmer, Eduard), Zwei Reden an Kaiser und Reich von Johannes Sleidanus, Tübingen 1879

Soter, Johannes (ed.), Epigrammata aliquot graeca veterum, Cologne (Johannes Soter) 1528

Spangenberg, Cyriakus, Antwort Und Bericht auff das Buch/ welchs Jaspar Gennep/ Bürger und Buchdrucker zu Cöllen/ unter dem Titel [Epitome warhafftiger Beschreibung] wider des Sleidani Commentarios in druck geben/mit anzeigung worinnen sich gedachter Gennep anders dan einem Historienschreiber gebüret/ gehalten, Eisleben (Urban Gaubisch) 1560

, Hennebergische Chronica. Der uralten löblichen Grafen und Fürsten Zu Henneberg, Genealogia, Stamm-Baum und Historia, Threr Ankunfft, Lob und denckwürdigen Thaten, Geschichten und Sachen wahre und gründliche Beschreibung, Meiningen (Johann Günther Scheidemantel) (1755)

-----, Wider die böse Sieben/ ins Teufels Karnöffelspiel, Eisleben (Urban Gaubisch) 1562

Sturm, Jean, Consolatio ad senatum Argentinensem de morte ... Jacobi Sturmii, Strasbourg (Wendelin Rihel) 1553

Surius, Lorenz, (transl. Estourneau, Jacques), Histoire ou Commentaires de toutes choses memorables, advenues depukiis LXX, ans en ca par toutes les parties du monde. tant au faict seculier que Ecclesiastic, Paris (Guillaume Chaudiere) 1572

------, (transl. Fabricius, Heinrich), Kurtze Chronik oder Beschreibung der vornembsten händeln und geschichten/so sich beide in Religions und weltlichen sachen/ fast in der gantzen Welt zugetragen/vom jar unsers lieben Herren M.D. biß auff das jar M.D.LXVIII, Cologne (Gerwinus Calenius \& Johan Quentel Heirs) 1568

Tallepied, Noel, Histoire des Vies, Meurs, Actes, Doctrine, et Mort de quatre Prinicipaux Heretiques de nostre Temps, à sçavoir Martin Luther, André Carlostad, Pierre Martyr, \& Jean Caluin, Iadis ministre de Geneve, Paris (Jean Parant) 1577

-----/Bolsec,Hierosme Hermes, Histoire des Vies, Meurs, Actes, Doctrine, et Mort de trois prinicipaux Heretiques de nostre Temps, à scavoir Martin Luther, Jean Calvin. \& Theodor de Beze, iadis Archiministre de Geneve, Douai 1616 (Jean Bogard)

------, Le Thresor de L'Église Catholique contenant l'origine des institutions statutz. ordonnances, ceremonies \& estatz d'icelle. Euvre de long temps desiré de tous vrays Catholiques, Paris (Jean de Bordeaux) 1578

De Thou, Jacques-Auguste, Histoire Universelle, avec la Suite par Nicolas Rigault; les Memoires de la Vie de L'Auteur ... . Et Augmenté de Remarques Historiques \& Critiques de Casaubon, de Du Plessis Mornay, G. Laurent, Ch. De L'Ecluse, Guy Patin, P. Bayle, J. le Duchat, \& autres, 11 vols., The Hague 1740

Townsend, George/Cattley, Stephen (eds.), The Acts and Monuments of John Foxe, 8 vols., London 1837-41 
Verdier, Antoine du, La Bibliotheque d'Antoine du Verdier, Seigneur de Vauprivas, Lyon (Barthelemy Honorati) 1585

Vignier, Nicolas, La Bibliotheque Historiale de Nicolas Vignier Historiographe du Roy, 3 vols., Paris (Abel L'Angelier) 1600

--.--, Recueil de 1'Histoire de 1'Eglise, Depuis le Baptesme de nostre Seigneur Iesus Christ, iusques à ce temps, Leiden (Christoffle de Raphelengien) 1601

-----, Théatre de l'antichrist, auquel est repondu au Cardinal Bellarmin, au Sieur de Remond, à Pererius, Riberia, Viegas, Sanderus et autres qui par leurs escrits condamnent la doctrine des Eglises Reformees sur ce subiet, s.n. (s.1.) 1610

Voragine, Jacques de, Legenda aurea, Leuwen (s.n.) 1485

------, La legende Doree et vie des Sainctz \& Sainctes qui Jesuchrist ayment de pensees non sainctes, Paris (Jean Macé) 1557 


\section{Reference Material}

(Ascham, Roger), Rogeri Aschami Epistolarum Libri Quatuor. Accessit Joannis Sturmii, aliorumque ad Aschanum, anglosque alios eruditos Epistolarum liber unus, Oxford 1703

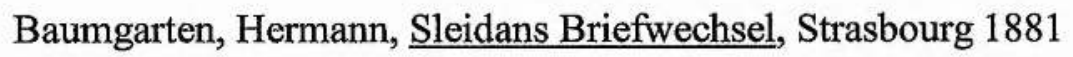

Benzing, Josef, Bibliographie Strasbourgeoise: Bibliographie des ouvrages imprimés à Strasbourg (Bas-Rhin) au XVIe siècle, Baden-Baden 1981

------, Die Buchdrucker des 16. und 17. Jahrhunderts im deutschen Sprachgebiet, Wiesbaden 1982

Berlász, Jenõ (ed.), Die Bibliothek Dernschwam. Bücherinventar eines Humanisten in Ungarn, Szeged 1984

Bonnet, Jules (ed.), Letters of John Calvin. Compiled from the original manuscripts and edited with historical notes, 3 vols., New York 1972

Bradford, William, Correspondance of the Emperor Charles V and his Ambassadors at the Courts of England and France (together with the Emperor's Itinerary from 15191551), London 1850

Brandenburg, Erich (ed.), Politische Korrespondenz des Herzogs und Kurfürsten Moritz von Sachsen, 2 vols., Leipzig 1900-1904

Brodie, R.H./Gairdner J., Letters and Papers, Foreign and Domestic, of the Reign of Henry VIII, preserved in the Public Record Office, the British Museum and elsewhere in England, vols. XX/II, XXI/I, London 1907-1908

Bujanda, J.M. de (ed.), Index des Livres Interdits: I. Index de L'Université de Paris 1544, $\underline{1545,1547,1549,1551,1556}$, Geneva/Sherbrooke 1985

-----, Index des Livres Interdits: II. Index de L'Université de Louvain 1546, 1550, 1558, Geneva/Sherbrooke 1986

----, Index des Livres Interdits: III. Index de Venise 1549, Venise et Milan 1554, Geneva/Sherbrooke 1987

-----, Index des Livres Interdits: IV. Index de 1'Inquisition Portugaise 1547, 1551, 1561. 1564, 1581, Geneva/Sherbrooke 1995

-----, Index des Livres Interdits: V. Index de l'Inquisition Espagnole 1551, 1554, 1559, Geneva/Sherbrooke 1984

----, Index des Livres Interdits: VI. Index de 1'Inquisition Espagnole 1583, 1584, Geneva/Sherbrooke 1993

-.--, Index des Livres Interdits: VII. Index d'Anvers 1569, 1570, 1571, Geneva/Sherbrooke 1988 
-----, Index des Livres Interdits: VIII. Index de Rome 1557, 1559, 1564, Geneva/Sherbrooke 1990

-----, Index des Livres Interdits: IX. Index de Rome 1590, 1593, 1596. Avec étude des index de Parme 1580 et Munich 1582, Geneva/Sherbrooke 1994

------, Index des Livres Interdits: X. Thesaurus de la Littérature interdite au XVIe Siècle, Geneva/Sherbrooke 1996

Catalogue des actes de François Ier, Collections des ordonnances des rois de France, 10 vols., Paris $1885-1908$

Cherbuliez, Joël (ed.), La France Protestante ou Vie des Protestants Francais qui se sont fait un nom dans l'histoire, 9 vols., Paris 1853-59

Corpus Reformatorum, vols. 1- 8, Bretschneider, Karl Gottlieb (ed.), (Halle 1834-41), vols. 39-44, Baum, Wilhelm, Cunitz, Eduard, and Reuss, Eduard (eds.), (Braunschweig 1873-76) repr. Bad Feilnbach 1990

Delatour, Jérôme, Une bibliothèque humaniste au temps de guerre de religion. Les livres de Claude Dupuy d'après l'inventaire dressé par le libraire Denis Duval (1595), Paris/Geneva 1998

Delius, Hans-Ulrich (ed.), Der Briefwechsel des Friedrich Mykonius (1524-1546), Tübingen 1960

Desgraves, Louis (ed.), Catalogue de la Bibliothèque de Montesquieu, Geneva/Lille 1954

Döllinger, Johann Joseph Ignatius von, Beiträge zur politischen, kirchlichen und Culturgeschichte der sechs letzten Jahrhunderte, vol. 1: Dokumente zur Geschichte Karl's V., Philipp's II. und ihrer Zeit, Regensburg 1862

Druffel, August von, Beiträge zur Reichsgeschichte 1546-1555, Briefe und Akten zur Geschichte des 16. Jahrhunderts, 3 vols., Munich 1873-82, vol.4 (ed. K.Brandi) 1896

Böhlau, Hermann (ed.), D. Martin Luthers Werke, Kritische Gesammtausgabe, vols. 2, 6, $8,12,18,28,30,53,54$, Weimar 1883 -

Dumont, J. (ed.), Corps universel diplomatique du droit des gens, vols. IV/I-III, Amsterdam/The Hague1726

Enders, Ernst Ludwig, Kawerau, Gustav et al. (eds.), Dr. Martin Luthers Briefwechsel, 19 vols., Leipzig 1884-1932,

Ernst, Viktor (ed.), Briefwechsel des Herzogs Christoph von Wirtemberg, 4 vols., Stuttgart 1899-1907

Ficker, Johannes, Winckelmann, Otto, Handschriftenproben des sechszehnten Jahrhunderts, 2 vols., Strasbourg 1902-1905 
Franz, Günther, Urkundliche Quellen zur hessischen Reformationsgeschichte, 4 vols., Marburg 1915

Ganoczy, Alexandre, La Bibliothèque de l'Académie de Calvin. Le Catalogue de 1572 et ses Enseignements, Geneva 1969

Gilmont, Jean-François, Bibliographie des éditions du Jean Crespin 1550-1572, 2 vols., Verviers 1981

Hartmann, Alfred, Die Amerbachkorrespondenz, 10 vols., Basle 1942-95

Hayes, Kevin H., The Library of William Byrd of Westover, Madison 1997

Hermann, Johannes, Wartenberg, Günther, and Winter, Christian (eds.), Korrespondenz des Herzogs und Kurfürsten Moritz von Sachsen, 6 vols., Berlin 1998

Herminjard, A.L., Correspondance des Réformateurs dans les pays de langue française, 9 vols., Geneva/Paris/Basle/Lyon 1866-1897

Jung, Rudolf (ed.), Quellen zur Frankfurter Geschichte, vol. 2: Frankfurter Chroniken und annalistische Aufzeichnungen der Reformationszeit, Frankfurt/Main 1888

Kaczerowsky Klaus, Sebastian Franck: Bibliographie, Wiesbaden 1976

Kentzinger, Antoine, Documents historiques relatifs à l'histoire de France, tirés des archives de la ville de Strasbourg, vol. 1, Strasbourg 1818

Klausler von, Eduard, Schott, Theodor, Briefwechsel zwischen Christoph. Herzog von von Württemberg und Petrus Paulus Vergerio, Tübingen 1875

Krafft, P.K., Briefe und Dokumente aus der Reformationszeit, Elberfeld 1876

Küch, Friedrich, Heinemayer, Walter (eds.), Politisches Archiv des Landgrafen Philipp des Großmütigen von Hessen. Inventar der Bestände, 3 vols., vols. 1-2: Leipzig 1904/1910, vol. 3: Marburg 1954

Lanz, Karl, Correspondenz des Kaisers Karl V.: aus dem königlichen Archiv und der Bibliothèque de Bourgongne zu Brüssel, 3 vols., Leipzig 1844-46

------, Staatspapiere zur Geschichte des Kaisers Karl V.: aus dem königlichen Archiv und der Bibliothèque de Bourgongne zu Brüssel, Stuttgart 1845

Lenz, Max, Briefwechsel Landgrafs Philipps des Großmütigen von Hessen mit Bucer, 3 vols., Leipzig 1880-91

Marchand, Prosper, Dictionaire historique, ou Mémoires critiques et litteraires, Concernant la Vie et les Ouvrages de divers Personnages Distingués. Particulierement dans la Republique des Lettres, 3 vols., La Haye 1758-1759

Mentz, Ferdinand, Erichson, A. (eds.), Bibliographische Zusammenstellung der gedruckten Schriften Butzers, Strasbourg 1891 
Muller, Jean, Bibliographie Strasbourgeoise. Bibliographie des ouvrages imprimés à Strasbourg (Bas-Rhin) au XVIe siècle (Répertoire bibliographique des livres imprimés au France au seizième siècle 148), 3 vols., Baden-Baden 1985/86

Noodt, Johann Friedrich, 'Epistolarum Jo. Sleidani hactenus ineditarum fasciculus prior', Brem- und Verdische Bibliothek, worin zur Aufnahme der Wissenschaften. insbesonderheit der theologischen, philologischen und historischen, allerley brauchbare Abhandlungen und Anmerkungen mitgetheilt werden, vol. 1/II, (s.1.) 1753 , pp. $87-122$

-----, 'Epistolarum Jo. Sleidani hactenus ineditarum fasciculus posterior', Brem- und Verdische Bibliothek, worin zur Aufnahme der Wissenschaften, insbesonderheit der theologischen, philologischen und historischen, allerley brauchbare Abhandlungen und Anmerkungen mitgetheilt werden, vol. 1/III, (s.1.) 1753, pp. $103-128$

Palladini, Fiammetta, La Biblioteca di Samuel Pufendorf. Catalogo dell'asta di Berlin del settembre 1697, Wiesbaden 1999

Pollet, Jacques.V., Martin Bucer. Études sur la correspondance avec de nombreux textes inédites, 2 vols., Paris 1958-62

------, Martin Bucer. Etudes sur les rélations de Bucer avec les Pays-Bas, 1'électorate de Cologne et l'Allemagne du Nord, avec des nombreux textes inédits. Tome II: Documents, Studies in Medieval and Reformation Thought XXXIV, Leiden 1985

Regner, F., Oddos, J.P. (eds.), La Bibliothèque de François Juret (1553-1626), Troyes 1986

Rending, A.D., Renting-Kuijpers, J.T.C., The Seventeenth-Century Orange-Nassau Library, Utrecht 1993

Renouard, Philippe, Bibliographie des éditions de S. de Colines (520-1546), Paris 1894

Ritter, François, Répertoire bibliographique des livres imprimés en Alsace aux Xve et $\underline{\text { XVle siècles, part II: Répertoire bibliographique des livres imprimés en Alsace au }}$ XVIe siècle de la Bibliothèque Nationale et Universitaire de Strasbourg, 4 vols., Strasbourg 1932-55

Rooses, Max (ed.), Correspondance de Christophe Plantin, 8 vols., Antwerp1883-1918, repr. Nendeln/Liechtenstein 1968

Rott, Jean, Correspondance de Martin Bucer, Studies in Medieval and Reformation Thought 43, 2 vols., 1979-1989

------, Correspondance de Martin Bucer. Liste alphabétique des correspondants, Association des Publications de la Faculté de Théologie Protestante de l'Université des Sciences humaines de Strasbourg Bulletin No. 1, Strasbourg 1977

Scheible, Heinz, Melanchthons Briefwechsel: kritische und kommentierte Gesamtausgabe, 10 vols., Stuttgart/Bad Cannstatt, 1978-1998

Scheurer, Rémy, Correspondance du cardinal Jean du Bellay, 2 vols., Paris 1969-73 
Schiess, Traugott (ed.), Briefwechsel der Brüder Ambrosius und Thomas Blaurer, 3 vols., Freiburg im Breisgau 1908-1912

Schlaefli, Louis, Catalogue des livres du seizième siècle (1531-1599) de la bibliothèque du Grand Séminaire de Strasbourg, Baden-Baden/Bouxwiller 1995

Schmidt, Charles, Répertoire bibliographique strasbourgeois, 6 vols., Strasbourg 1893-96

Selwyn, David G., The Library of Thomas Cranmer, Oxford 1996

Stalla, Gerhard, Bibliographie der Ingolstädter Drucker des 16. Jahrhunderts, Baden-Baden 1977

State Papers. King Henry the Eight, 11 vols., London 1830-1852

Simonin, Michel (ed.), Dictionnaire des Lettres Francaises. Le XVIe siècle, Farese 2001

Theologische Realenzyklopädie, Krause Gerhard, Müller, Gerhard (eds.), Berlin/New York 1977-1999

Varga, András/Ötvös, Péter, Die Bibliothek Sambucus. Katalog. Bibliothecae Ioannis Sambuci Catalogus Librorum 1587, Szeged 1992

Vekene, Emil van der, Johann Sleidan (Johann Philippson). Bibliographie seiner gedruckten Werke und der von ihm übersetzten Schriften von Philipe de Comines, Jean Froissart und Claude de Seyssel. Mit einem bibliographischen Anhang zur Sleidan-Forschung, Stuttgart 1996

Virck, Hans, Winckelmann, Otto, and Friedensburg, Walter et al. (eds.), Politische Correspondenz der Stadt Strasbourg im Zeitalter der Reformation, vols. 3-5, vol. 3: Strasbourg 1898; vols. 4-5: Heidelberg 1928-1933

Verzeichnis der im deutschen Sprachraum erschienenen Drucke des 16. Jahrhunderts (VD 16). Stuttgart 1983-1988

Vischer, Manfred, Bibliographie der Zürcher Druckschriften des 15. und 16. Jahrhunderts, Baden-Baden 1991

Vos, Alvin (ed.), (transl. Hatch, Maurice, Vos, Alvin), Letters of Roger Ascham, New York/Bern/Frankfurt am Main/Paris 1989

Wolf, Edwin, The Library of James Logan of Philadelphia 1674-1751, Philadelphia 1974 


\section{Secondary Literature}

Abray, Lorna Jane, The People's Reformation. Magistrates, Clergy and Commons in Strasbourg, 1500-1598, Ithaca, New York 1985

Adam, Johann, Evangelische Kirchengeschichte der elsässischen Territorien bis zur französischen Revolution, Strasbourg 1928

-..---, Evangelische Kirchengeschichte der Stadt Strassburg bis zur französischen Revolution, Strasbourg 1922

Ainsworth, Peter F., Jean Froissart and the Fabric of History. Truth, Myth, and Fiction in the Chroniques, Oxford 1990

Allen, J.W., A history of political thought in the sixteenth century, London 1957

Am Ende, Carl Christian, Vermischte Anmerkungen über den berühmten Geschichtsschreiber Johann Sleidan, Nuremberg 1780

------, 'Beschreibung der beyden ersten Auflagen der Commentariorum Johann Sleidans, zu Straßburg, im Jahr 1555. in Octav.', Schelhorn, Johann Georg, (ed.), Ergötzlichkeiten aus der Kirchenhistorie und Literatur, in welchen Nachrichten von seltenen Büchern, wichtige Urkunden, merkwürdige Briefe, und verschiedene Anmerkungen enthalten sind, vol. 2, Ulm 1762, pp. 653-698

--.----, 'Beschreibung eines sehr merkwürdigen Exemplares der Geschichte Sleidans, mit Anmerkungen des Sächsischen Canzlers, Erasmi von Minckwitz', Schelhorn, Johann Georg, (ed.), Ergötzlichkeiten aus der Kirchenhistorie und Literatur, in welchen Nachrichten von seltenen Büchern, wichtige Urkunden, merkwürdige Briefe, und verschiedene Anmerkungen enthalten sind, vol. 3, Ulm/Leipzig 1764, pp. 1029-1075

-----, 'Nachricht von den beyden ersten Ausgaben der Commentariorum Johannis Sleidani, zu Strasburg, im Jahr 1555. in Folio', Schelhorn, Johann Georg, (ed.), Ergötzlichkeiten aus der Kirchenhistorie und Literatur, in welchen Nachrichten von seltenen Büchern, wichtige Urkunden, merkwürdige Briefe, und verschiedene Anmerkungen enthalten sind, vol. 2, Ulm 1762, pp. 414-461

------, 'Nachricht von einem sehr merkwürdigen Exemplar der Geschichte Sleidans, mit Anmerkungen Johann Sebastian Schertlins, von Burtenbach', Schelhorn, Johann Georg, (ed.), Ergötzlichkeiten aus der Kirchenhistorie und Literatur, in welchen Nachrichten von seltenen Büchern, wichtige Urkunden, merkwürdige Briefe, und verschiedene Anmerkungen enthalten sind, vol. 3, Ulm/Leipzig 1764, pp. 900-942

Archambault, Paul, Seven French chroniclers. Witness to history, Syracuse 1974

Arnold, W., Die ethisch-politischen Grundanschauungen des Philippe de Commines, Dresden 1873 
Augustijn, Cornelis, 'Bucer und die Religionsgespräche von 1540/41', Krieger, Christian, Lienhard, Marc (eds.), Martin Bucer and Sixteenth Century Europe. Actes du colloque de Strasbourg (28-31 aout 1991), vol. 2, Leiden/New York/Cologne 1993, pp. $671-680$

Bagchi, David, 'Luther and the problem of martyrdom', Wood, Diana (ed.), Martyrs and Martyrologies, Studies in Church History 30, Oxford 1993, pp. 209-219

Barnes, Harry Elmer, A History of Historical Writing, New York 1962

Barnes, Robin, Kolb, R.A., and Presley, P.L. (eds.), Books Have Their Own Destiny, Kirksville 1998

Barton, Peter F., 'Matthias Flacius Illyricus', Die Reformationszeit II, ed. Greschat, Martin, Stuttgart/Berlin/Cologne/Mainz 1981, pp. 277-294

Bastin, J., Les Mémoires de Philippe de Commines, Brussels 1944

Bäumer, R. (ed.), Reformatio Ecclesia. Beitraege zu kirchlichen Reformbemühungen von der Alten Kirche bis zur Neuzeit, Paderborn/Munich/Vienna/Zurich 1980

Bauer, Barbara, 'Die göttliche Ordnung in der Natur und Gesellschaft. Die Geschichtsauffassung im Chronicon Carionis', Leonhardt, Jürgen (ed.), Melanchthon und das Lehrbuch des 16. Jahrhunderts, Rostock 1997, pp. 217-229

Baumann, Heidrun, Der Geschichtsschreiber Philippe de Commynes und die Wirkung seiner politischen Vostellungen in Frankreich um die Mitte des 16. Jahrhunderts, Munich 1981

Baumgarten, Hermann, Jacob Sturm, Strasbourg 1876

-----, 'Zur Geschichte des Schmalkaldischen Kriegs', Historische Zeitschrift 36 (1876), pp. 26-82

--.-, 'Sleidan', ADB 34 (repr. Berlin 1971), pp. 454-461

-..----, Über Sleidans Leben und Briefwechsel, Strasbourg 1878

Baynes, Norman H., Constantine the Great and the Christian Church, 1929

Benoit, J.D., Calvin à Strasbourg 1538-1541. Quatre études publiées à 1'occasion du 400e anniversaire de l'arrivée de Calvin à Strasbourg, (Strasbourg) 1938

Bertoud, Micaël, Le monde à l'empire de Pierre Viret: une conception de l'histoire au

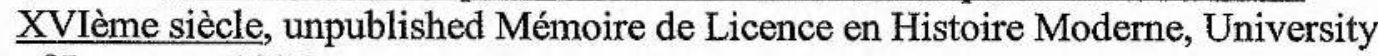
of Lausanne 1996

Berton, Eugène, L’Église de Calvin à Strasbourg, Montauban 1881

Betteridge, Thomas, Tudor Histories of the English Reformations, 1530-83, Aldershot 1989 
Bibl, Victor, 'Der Briefwechsel zwischen Flacius und Nidbruck', Jahrbuch der Gesellschaft für die Geschichte des Protestantismus in Österreich 17 (1896), pp. 124; 18 (1897), pp. 201-238.; 19 (1898), pp. 96-110; 20 (1899), pp. 83-116

, Maximilian II. Der rätselhafte Kaiser. Ein Zeitbild, Hellerau 1929

-----, 'Melanchthon und Nidbruck', Jahrbuch der Gesellschaft für die Geschichte des Protestantismus in Österreich 18 (1897), pp. 34-55

------, 'Nidbruck und Tanner. Ein Beitrag zur Entstehungsgschichte der Magdeburger Centurien und zur Charakteristik König Maximilians II.', Archiv für österreichische Geschichte 85 (1898), pp. 379-430

Bietenholz, Peter G., Basle and France in the Sixteenth Century. The Basle Humanists and Printers in Their Contacts with Francophone Culture, Geneva 1971

Blaschke, Karlheinz, 'Moritz von Sachsen', Die Reformationszeit II, ed. Greschat, Martin, Stuttgart/Berlin/Cologne/Mainz 1981, pp. 295-314

Bodenmann, Reinhard, 'Martin Bucer 1491 à 1991. Plaidoyer pour une nouvelle bibliographie', Krieger, Christian, Lienhard, Marc (eds.), Martin Bucer and Sixteenth Century Europe. Actes du colloque de Strasbourg (28-31 aout 1991), vol. 2, Leiden/New York/Cologne 1993, pp. 733-752

------, 'Rapport sur le travail du groupe: Bucer dans l'espace strasbourgeois', Krieger, Christian, Lienhard, Marc (eds.), Martin Bucer and Sixteenth Century Europe. Actes du colloque de Strasbourg (28-31 aout 1991), vol. 1, Leiden/New York/Cologne 1993, pp. 271-274

Bopp, M.J., Die evangelischen Geistlichen und Theologen in Elsass und Lothringen von der Reformation bis zur Gegenwart, Neustadt an der Aisch 1959

Bornert, René, La Réforme Protestante du Culte à Strasbourg au XVIe Siècle (1523-1598). Approche sociologique et intérpretation théologique, Studies in Medieval and Reformation Thought 28, Leiden 1981

Boudou, Bénédicte, 'Henri Estienne éditeur d'historiens, ou Comment écrire l'Histoire?', Nouvelle Revue du XVIe siècle 19/1 (2001), pp. 37-50

Bourrilly, V. L./Vaissieère, P. de, Ambassades en Angleterre de J. du Bellay: La première ambassade (septembre 1527-février 1529). Correspondance diplomatique, Archives de l'histoire religieuse de la France, Paris 1905

Bourrilly, V.-L., 'Le cardinal Du Bellay en Italie', Revue des études rabelaisiennes 5/3 (1907), pp. 233-285; 5/4 (1907), pp. 329-390

------, 'Deux nouvelles lettres de Jean Sleidan', BSHPF 55 (1906), pp. 212-219

------, ‘Études sur Sleidan', BSHPF 55 (1906) pp. 188-190 
-------, 'François Ier et les Protestants: Les essais de concorde en 1535', BSHPF 49 (1900), pp. 337-365, 477-495

, Guillaume DuBellay, Seigneur de Langey 1491-1543, Paris 1904

/Weiss, Nathaniel, 'Jean Du Bellay, les Protestants et la Sorbonne', BSHPF 52 (1903), pp. 97-127, 193-231; 53 (1906), pp. 97-143

, 'Jean Sleidan et le Cardinal Du Bellay. Premier séjour de Jean Sleidan en France (1533-1540)', BSHPF 50 (1901), pp. 225-245

Brady, Thomas A., 'Aristocratie et régime politique à Strasbourg à l'époque de la Réforme (1525-1555)', Livet, Georges, Rapp, Francis (eds.), Strasbourg au coeur religieux du XVIe siècle. Hommage à Lucien Febvre. Actes du Colloque International de Strasbourg (25-29 mai 1975), Strasbourg 1977, pp. 19-36

------, 'Jacob Sturm of Strasbourg and the Lutherans at the Diet of Augsburg, 1530', Church History 42/2 (1973), pp. 183-202

------, The Politics of the Reformation in Germany. Jacob Sturm (1489-1553) of Strasbourg, Atlantic Highlands, NJ 1997

------, Protestant Politics: Jacob Sturm (1489-1553) and the German Reformation, Atlantic Highlands, NJ 1995

-----, Ruling Class, Regime and Reformation at Strasbourg. 1520-1555, Leiden 1978

----, "The Earth is the Lord's, and our homeland as well": Martin Bucer and the politics of Strasbourg', Krieger, Christian, Lienhard, Marc (eds.), Martin Bucer and Sixteenth Century Europe. Actes du colloque de Strasbourg (28-31 aout 1991), vol.1, Leiden/New York/Cologne 1993, pp. 129-143

------, Turning Swiss: Cities and Empire, 1450-1550, Cambridge 1981

------, Zwischen Gott und Mammon. Protestantische Politik und deutsche Reformation, Berlin 1996

Brandi, Karl, 'Karl V. vor Metz', ELJB 16 (1937), pp. 1-30

------, Kaiser Karl V. Werden und Schicksal einer Person und eines Weltreiches, München 1959

Braunisch, Reinhard, 'Johannes Gropper', Die Reformationszeit II, ed. Greschat, Martin, Stuttgart/Berlin/Cologne/Mainz 1981, pp. 171-184

Bremme, Hans Joachim, Buchdrucker und Buchhändler zur Zeit der Glaubenskämpfe. Studien zur Genfer Druckgeschichte 1565-1580, Geneva 1969

Brieger, Th., 'H. Baumgarten's Bitte, Joh. Sleidan betreffend', Zeitschrift für Kirchengeschichte 3 (1879), pp. 185-188 
Brown, Peter, The Cult of Saints. Its Rise and Function in Latin Christianity, Chicago 1981

Burgess, Richard W., Studies in Eusebian and Post-Eusebian Chronography, Historia Einzelschriften 135, Stuttgart 1999

Burke, Peter, History and Social Theory, Ithaca/New York 1992

----, Popular Culture in Early Modern Europe, London 1994

-.----, The Renaissance Sense of the Past, London 1969

Cahill, Richard Andrew, Philipp of Hesse and the Reformation, Mainz 2001

Cameron, Euan, Reformation of the Heretics. The Waldenses of the Alps, 1480-1580, Oxford 1984

Carr, E.H., What is History, London 1961

Certeau, Michel de, The Writing of History, New York 1988

Chevreul, Henri, Étude sur le XVIe Siècle. Hubert Languet, Paris 1852, repr. Nieuwkoop 1967

Chrisman, Miriam Usher, 'L'édition protestante à Strasbourg, 1519-1560', Gilmont, JeanFrançois (ed.), La Réforme et le livre. L'Europe de l'imprimé (1517-v.1570), Paris 1990 , pp. $217-238$

------, 'L'imprimerie à Strasbourg de 1480 à 1599', Livet, Georges, Rapp, Francis (eds.), Strasbourg au coeur religieux du XVIe siècle. Hommage à Lucien Febvre. Actes du Colloque International de Strasbourg (25-29 mai 1975), Strasbourg 1977, pp. 539550

-----, Lay Culture, Learned Culture. Books and Social Change in Strasbourg, 1480-1599, New Haven/London 1982

------, 'Les Publications historiques à Strasbourg 1480-1599', Kroon, Marijn de, Lienhard, Marc (eds.), Horizons Européens de le Réforme en Alsace. Das Elsass und die Reformation im Europa des XVI. Jahrhunderts, Strasbourg 1980, pp. 19-36

--.--, Strasbourg and the Reform. A study in the process of change, New Haven/London 1967

-----, Bibliography of Strasbourg Imprints, 1480-1599, New Haven/London 1982

Charton-LeClech, Sylvie, Chancellerie et culture: Au XVIe sièce (les notaires et secrétaire du roi de 1515 à 1547), Toulouse 1993

Christin, Olivier, La paix de religion. L'autonomisation de la raison politique au XVIe siècle, Paris 1997

Clemen, Otto, 'Die Schmalkaldener und Frankreich im Mai 1543', ARG 37 (1940), pp. $222-227$ 
Collinson, P., 'Truth and Legend: the Veracity of John Foxe's Book of Martyrs', Duke, A.C., Tamse, C.A. (eds.), Clio's Mirror: historiography in Britain and the Netherlands, Zutphen 1985, pp. 31-54

Conner, Philip, 'A provincial perspective: Protestant print culture in southern France', Pettegree, Andrew, Nelles Paul, and Conner Philip (eds.), The Sixteenth-Century French Religious Book, Aldershot 2001, pp. 286-302

Craemer, Ulrich, Die Verfassung und Verwaltung Strassburgs von der Reformationszeit bis zum Fall der Reichsstadt (1521-1681), Frankfurt 1931

Crouzet, Denis, La Genèse de la Réforme Francaise 1520-1560, Paris 1996

Davis, Natalie Zemon, Society and Culture in Early Modern France, Oxford 1995

Déjean, Jean-Luc, Marguerite de Navarre, Mesnil-sur-1'Estrée 1987

Denis, Philippe, Les Églises d'Étrangers en Pays Rhénans (1538-1564), Paris 1984

Dickens, A.G., 'Johannes Sleidan and Reformation History', Buick Knox, R. (ed.), Reformation, Conformity and Dissent. Essays in honour of Geoffrey Nuttall, London 1977, pp. 17-43

Dickens, A.G./Tonkin, John M., The Reformation in Historical Thought, Oxford 1985

Ditchfield, Simon, Liturgy, Sanctity and History in Tridentine Italy. Pietro Maria Campi and the Preservation of the Particular, Cambridge 1995

Dixon, C. Scott, 'Popular Astrology and Lutheran Propaganda in Reformation Germany', History 84/275 (1999), pp. 403-418

Druez, Laurence, 'État présent des études sleidaniennes', Bibliothèque d'Humanisme et Renaissance 58 (1996), pp. 685-700

------, 'L'Humaniste Allemand Jean Sleidan: De la Diplomatie à l'Histoire', Cahiers de Clio 123 (1995), pp. 15-32

Dubois, Claude-Gilbert, 'L'individu comme moteur historiographique: formes de la biographie dans la période 1560-1600', Nouvelle Revue du XVIe siècle 19/1 (2001), pp. 83-105

Duffy, Eamon, The Stripping of the Altars: Traditional Religion in England, c. 1400-c. 1580, New Haven 1992

Edwards, Mark U., Printing, Propaganda, and Martin Luther, London 1994

Ehmer, H, 'Reformatorische Geschichtsschreibung am Oberrhein: Franciscus Irenicus, Kaspar Hedio, Johannes Sleidan', Historiographie am Oberrhein im späten Mittelalter und in der frühen Neuzeit, Sigmaringen 1988, pp. 227-245 
Elby, F. (ed.), Early Protestant Educators, New York 1531

Elsass, M.J., Umriss einer Geschichte der Preise und Löhne in Deutschland. Vom ausgehenden Mittlelalter bis zum Beginn des Neunzehnten Jahrhunderts, vol. 1, Leiden 1936

Erichson, Alfred, L'Eglise francaise de Strasbourg au seizième siècle d'apres des documents inédits, Strasbourg 1896

Ernst, Fritz, Philippe de Commynes, Memoiren, Europa in der Krise, Stuttgart 1972

Fabian, Ekkehart, Die Entstehung des Schmalkaldischen Bundes und seiner Verfassung, Tübingen 1956

Faerber, Robert, 'Bucer et Jean Sturm', Krieger, Christian, Lienhard, Marc (eds.), Martin Bucer and Sixteenth Century Europe. Actes du colloque de Strasbourg (28-31 aout 1991), vol. 1, Leiden/New York/Cologne 1993, pp. 329-341

------, 'La communauté anglaise à Strasbourg pendant le règne de Marie 1553-1558', Livet, Georges, Rapp, Francis (eds.), Strasbourg au coeur religieux du XVIe siècle. Hommage à Lucien Febvre. Actes du Colloque International de Strasbourg (25-29 mai 1975), Strasbourg 1977, pp. 431-441

------, 'La Pensée religieuse et theologique de Jean Sturm', Livet, Georges, Rapp, Francis (eds.), Strasbourg au coeur religieux du XVIe siècle. Hommage à Lucien Febvre. Actes du Colloque International de Strasbourg (25-29 mai 1975), Strasbourg 1977, pp. 189-196

Farge, James K., Le Parti Conservateur au XVIe siècle. Université et Parlement de Paris à l'époque de la Renaissance et de la Réforme, Paris 1992

Fax, Levi (ed.), English Historical Scholarship in the Sixteenth and Seventeenth Century, London 1956

Fester, Richard, 'Sleidan, Sabinus, Melanchthon', Historische Zeitschrift 89 (1902), pp. 116

Figgis, John, 'Political thought in the sixteenth century', Cambridge Modern History, vol. 3, Cambridge 1904, pp. 736-769

Flood, John. L., 'Le livre dans le monde germanique à l'époque de la Réforme', Gilmont, Jean-François (ed.), La Réforme et le livre. L’Europe de l'imprimé (1517-v.1570), Paris 1990, pp. 29-104

Fraenkel, Peter, Testimonia Patrum: The Function of the Patristic Argument in the Theology of Philip Melanchthon, Geneva 1961

Franklin, Julian, Jean Bodin and the Sixteenth Century Revolution in Historical Methodology, New York/London 1970 
-.--, Martin Bucer and Matthew Parker, Florilegium patristicum, Studies in Medieval and Reformation Thought, vol. 41, Leiden 1988

Friedensburg, Walter, 'Die Entstehung der Kommentarien Sleidans', ELJB 12 (1933), pp. 83-108

------, 'Vom französischen Agenten zum Geschichtsschreiber des deutschen Protestantismus; Ein Beitrag zur Lebens- und Entwicklungsgeschichte Johann Sleidans', ELJB 11 (1932), pp. 109-147

-.-.--, 'Die Tausend Lügen bei Sleidan', ELJB 14 (1935), pp. 105-113

-----, Johannes Sleidanus. Der Geschichtsschreiber und die Schicksalsmächte der Reformationszeit, Leipzig 1935

Fritsch, P., Die Strassburger Chronik des Johannes Stedel, Strasbourg 1934

Fuchs, François-Joseph, 'L'immigration artisanale à Strasbourg de 1544 à 1565', Artisans et ouvriers d'Alsace IX (1965), pp. 185-199

Fueter, Eduard, Geschichte der neueren Historiographie, Berlin 1936

Fussner, F.S., Tudor History and Historians, New York 1970

Garrett, Christina H., The Marian Exiles. A Study in the Origins of Elizabethan Puritanism, Cambridge 1966

Geary, P.J., Phantoms of Remembrance. Memory and Oblivion at the End of the First Millennium, Princeton 1994

Gebhart, Bruno, 'Johann Sleidan', Zeitschrift für Allgemeine Geschichte, Kultur-, Literatur-, und Kunstgeschichte 3 (1886), pp. 546-552

Geiger, L., 'Briefe Joh. Sleidans an den Kardinal Joh. Du Bellay, 1542-1547', Forschungen zur deutschen Geschichte 10 (1870), pp. 167-198

Gilbert, Felix, Machiavelli and Guicciardini, Politics and History in Sixteenth Century Florence, Princeton 1965

Gilmont, Jean-François, ‘La correspondence de Jean Crespin', Lias VI (1979), pp. 3-37

------, Jean Crespin, un éditeur réformé du XVIe siécle, Geneva 1981

-----, Jean Calvin et le Livre Imprimé, Geneva 1997

-----, Les martyrologes protestants du XVIe siècle, Louvain 1966

-----, 'La naissance de l'historiographie protestante', Pettegree, Andrew, Nelles Paul, and Conner Philip (eds.), The Sixteenth-Century French Religious Book, Aldershot 2001, pp. $110-126$ 
---n--, 'Les premières éditions des ouvrages historiques de La Place et de La Popelinière', Revue Française d'Histoire du Livre N.S. 50 (1986), pp. 119-152

------, 'Trois villes frontières. Anvers, Strasbourg et Bale', Gilmont, Jean-François (ed.), La Réforme et le livre. L'Europe de l'imprimerie (1517-v.1570), Paris 1990, pp. $187-190$

Goez, W., Translatio Imperii, Tübingen 1958

Gordon, Bruce, 'The Changing Face of Protestant History and Identity in the Sixteenth Century', Gordon, Bruce (ed.), Protestant History and Identity in Sixteenth-Century Europe, vol. 1: The Medieval Inheritance, Aldershot 1996, pp. 1-22

Graham, Timothy, 'Matthew Parker and the conservation of Manuscripts; the case of Cul Ms Ii.2.4 (Old English Regula pastoralis, $\mathrm{s}$. xi $3 / 4$ )', Transactions of the Cambridge Bibliographical Society X (1995), pp. 630-641

Gransden, Antonia, Historical Writing in England, vol. 2, Ithaca 1982

Grant, Robert M., Eusebius as Church Historian, Oxford 1980

Greengrass, Mark, The Reformation in France, Oxford 1987

Gregory, Brad S., Salvation at Stake. Christian Martyrdom in Early Modern Europe, Cambridge, Massachusetts/London 1999

Greschat, Martin, Martin Bucer: Ein Reformator und seine Zeit, Munich 1990

Grundmann, Herbert, Geschichtsschreibung im Mittelalter. Gattungen - Epochen Eigenart, Göttingen 1978

Guenée, Bernard, 'Les Grandes Chroniques de France. Le Roman aux roys (1274-1518)', Nora, Pierre (ed.), Les Lieux de Mémoires. Vol. II: La Nation (1), pp. 189-213

Guerdan, René, Francois Ier, Saint-Amand (Cher) 1976

Guilleminot-Chrétien, Geneviève, 'Le contrôle de l'édition en France dans les années 1560: la genèse de l'édit de Moulins', Aquilon, Pierre, Martin, Henri-Jean (eds.), Le Livre dans l'Europe de la Renaissance. Actes du xxviiie Colloque international d'Etudes humanistes de Tours, s.1. 1988, pp. 378-385

Hackett, Francis, Francois Ier, Paris 1984

Hale, J.R., The Evolution of British Historiography, Cleveland/New York 1964

Hall, Basil, 'Bucer et l'Angleterre', Livet, Georges, Rapp, Francis (eds.), Strasbourg au coeur religieux du XVIe siècle. Hommage à Lucien Febvre. Actes du Colloque International de Strasbourg (25-29 mai 1975), Strasbourg 1977, pp. 401-430

Harbison, E. Harris, The Christian Scholar in the Age of the Reformation, New York 1983 
Harran, Marylin J., 'Luther as Professor', Harran, Marylin J. (ed.), Luther and Learning. The Wittenberg University Luther Symposium, Cranbury/US 1985, pp. 29-51

Hartley, David, 'Religion and the State: Joachim du Bellay's views on the duties of the Most Christian King and his subjects', Pettegree, Andrew, Nelles, Paul, and Conner, Philip (eds.), The Sixteenth-Century French Religious Book, Aldershot 2001, pp. 127-137

Hartmann, Martina, Humanismus und Kirchenkritik: Matthias Flacius Illyricus als Erforscher des Mittelalters, Stuttgart 2001

Hasenclever, Adolf, 'Mundt, Christoph M.', ADB 52 (1906, repr. Berlin 1971), pp. 537-40

-.-.-., 'Naves, Johann von', ADB 52 (1906, repr. Berlin 1971), pp. 598-605

-...m-n, 'Neue Aktenstücke zur Friedensvermittlung der Schmalkaldener zwischen Frankreich und England im Jahre 1545', ZGO 59 (N.F. 20,1905), pp. 224-251

------, 'Notiz über einen bisher unbekannten Brief Johann Sleidans an Calvin', ZGO 61 (N.F. 22,1907), pp. 170-171

------, 'Ein poetischer Nachruf Johann Sleidans auf Martin Bucer', ZGO 65 (N.F. 26, 1911), pp. 715-718

-.-.-., Die Politik Kaiser Karls V. und Landgraf Philipps Von Hessen vor Ausbruch des Schmalkaldischen Kriegs (Januar bis Juli 1546), Marburg 1903

------, Die Politik der Schmalkaldener vor Ausbruch des Schmalkaldischen Krieges, Historische Studien von Ebering 23, Berlin 1901

---, 'Sleidaniana', ZGO 63 (N.F. 24, 1909), pp. 92-116

------, 'Johann Sleidan über Clément Marot', ZGO 76 (N.F. 37,1922), pp. 221-226

-----, 'Sleidans Darstellung des böhmischen Aufstandes (1547)', ZGO 63 (N.F. 24, 1909), pp. 364-365

-.----, 'Johann Sleidan und Frankreich', ELJB 10 (1931), pp. 101-122

---.--, Sleidan-Studien. Die Entwicklung der politischen Ideen Joh. Sleidans bis zum $\underline{\text { Jahre 1545, Bonn } 1905}$

-----, 'Ein ungedruckter Brief Johann Sleidans aus dem Jahre 1548', ZGO 83 (N.F. 44, 1930), pp. 134-136

--.---, 'Ein ungedruckter Brief Johann Sleidans an Dr. Leonhard Badehorn', ZGO 61 (N.F. 22,1907), pp. 528-532

Hazlett, Ian, 'A pilot-study of Martin Bucer's relations with France 1524-1548', Krieger, Christian, Lienhard, Marc (eds.), Martin Bucer and Sixteenth Century Europe. 
Actes du colloque de Strasbourg (28-31 aout 1991), vol. 2, Leiden/New York/Cologne 1993, pp. 513-522

Headley, John M., Luther's View of Church History, New Haven and London 1963

-----, 'The Reformation as Crisis in the Understanding of Tradition', ARG 78 (1987), pp. 5-23

Hermann, Jean-Frédéric, Notices historiques, statistiques et littéraires, sur la ville de Strasbourg, 2 vols., Strasbourg 1817-19

Higman, Francis M., Morvant, Yann, Vial, Marc, 'A bookseller's world: the 'inventaire' of Vincent Réal', Pettegree, Andrew, Nelles Paul, and Conner Philip (eds.), The Sixteenth-Century French Religious Book, Aldershot 2001, pp. 303-318

-----, Censorship and the Sorbonne. A bibliographical study of books in French censured by the faculty of theology of the university of Paris, 1520-1551, Geneva 1979

--.---, 'Genevan Printing and French Censorship, 1520-1551', Candaux, Jean-Daniel, Lescaze, Bernard (eds.), Cinq siècles d'imprimerie Genevoise: Actes du colloque international sur l'histoire de l'imprimerie et du livre à Genève 27-30 Avril 1978, Geneva 1980, pp. 31-53

----, Lire et découvrir. La circulation des idées au temps de la Réforme, Geneva 1998

Hillerbrand, Hans J., Landgrave Philipp of Hesse 1504-1567. Religion and Politics in the Reformation, Reformation Essays \& Studies 1, Saint Louis/Missouri 1967

-----, 'Philipp von Hessen', Die Reformationszeit II, ed. Greschat, Martin, Stuttgart/Berlin/Cologne/Mainz 1981, pp. 185-196

Hobbs, R.G., 'Le félin et le dauphin: Martin Bucer dédie ses commentaires sur le psautier au fils de François Ier', Revue Francaise d'Histoire du Livre (N.S. 50, 1986), pp. 217-232

Hollaender, Alkuin, 'Beiträge zur Biographie Sleidans', Korrespondenzblatt der Westdeutschen Zeitschrift für Geschichte und Kunst 7/5 (1888), cols. 150-153

--..--, 'Sleidaniana', ZGO 43 (N.F. 4, 1889), pp. 337-342

---.--, 'Sleidaniana', Z ZGO 53 (N.F. 14, 1899), pp. 428-437

-----, Eine Strassburger Legende. Ein Beitrag zu den Beziehungen Strassburgs zu Frankreich im 16. Jahrhundert, Beiträge zur Landes- und Volkskunde von ElsassLothringen und den angrenzenden Gebieten 17, Strasbourg 1893

------, 'Straßburgs Politik im Jahre 1552', ZGO 48 (N.F. 9, 1894), pp. 1-48

--.----, Strasburg im Schmalkaldischen Kriege 1552, Strasbourg 1888 
------, 'Der Theologe M. Flacius Illyricus in Strassburg', Deutsche Geschichtswissenschaft N.F. II (1897/98), pp. 203-224

Holtzmann, R., 'Niedbruck, Kaspar von', ADB 52 (repr. Berlin 1971), pp. 621-629

Hubert, Friedrich, Vergerios publizistische Thätigkeit, Göttingen 1893

Hudson, Anne, The Premature Reformation: Wycliffite Texts and Lollard History, Oxford 1988

Hughes, Michael, Early Modern Germany, 1477-1806, European Studies Series, London 1992

Jaccquart, Jean, Francois Ier, Paris 1981

Jacobson Schutte, Anne, Pier Paolo Vergerio: The Making of an Italian Reformer, Geneva 1977

Janelle, Pierre, 'Le voyage de Martin Bucer et Paul Fagius de Strasbourg en Angleterre en 1549.', Revue d'Histoire et de Philosophie religieuses 8/2 (1928), pp. 162-177

Jones, Norman L., 'Matthew Parker John Bale and the Magdeburg Centuriators', SCJ 3/12 (1981), pp. 35-49

Jostock, Ingeborg, 'La censure au quotidien: le contrôle de l'imprimerie à Genève, 15601600, Pettegree, Andrew, Nelles, Paul, and Conner, Philip (eds.), The SixteenthCentury French Religious Book, Aldershot 2001, pp. 210-238

Jung, Andreas, Geschichte der Reformation der Kirche in Strassburg und der Ausbreitung derselben in den Gemeinden des Elsasses, Beiträge zur Geschichte der"Reformation II,1, Strasbourg/Leipzig 1830

Jung, M., 'Jean Sleidan, Historien contemporain de la Réformation', Doin, Guillaume T. (ed.), Musée des Protestans Célèbres, ou Portaits et Notices biographiques et littéraires des personnages les plus énimens dans l'histoire de la réformation et du protestantisme, vol. I/2, Paris 1821, pp. 123-135

Kalkoff, Paul, 'Die Anfangsperiode der Reformation in Sleidans Kommentarien', ZGO 71 (N.F. 32, 1917), pp. 297-329, 414-467

Kampschulte, F.W., 'Über Johann Sleidanus als Geschichtsschreiber der Reformation', Forschungen zur deutschen Geschichte 4 (1864), pp. 59-69

Kelley, Donald R., The Beginning of Ideology: Consciousness and Society in the French Reformation, Cambridge 1981

------, Foundations of Modern Historical Scholarship, New York/London 1970

(ed.), History and the Disciplines: the Reclassification of Knowledge in Early Modern Europe, Rochester 1997 
-----, History, Law and the Human Sciences. Medieval and Renaissance Perspectives, London 1984

-----, Francois Hotman: A Revolutionary's Ordeal, Princeton/New Jersey 1973

------, 'Martyrs, Myths, and the Massacre: The Background of St. Bartholomew', American Historical Review 77 (1972), pp. 1323-1342

-----/Popkins, R.H., The Shapes of Knowledge from the Renaissance to the Enlightenment, Dordrecht/Boston/London 1991

--.---, 'Johann Sleidan and the Origins of History as a Profession', Journal of Modern History 52 (1980), pp. 577-598

----- (ed.), Versions of History from Antiquity to the Enlightenment, New Haven/London 1991

------, The Writing of History and the Study of Law, Aldershot 1997

King, John, 'Fiction and Fact in Foxe's Book of Martyrs', Loades, David (ed.), John Foxe and the English Reformation, Aldershot 1997, pp.12-35

Kingdon, Robert M., 'The Political Thought of Peter Martyr Vermigli', McLelland, Joseph C. (ed.), Peter Martyr Vermigli and Italian reform, Waterloo/Ontario 1980, pp. 121139

Kintz, Jean-Pierre, La société strasbourgeoise du milieu du XVIe siècle à la fin de la Guerre de Trente Ans 1560-1650. Essai d'histoire démographique, économique et sociale, Strasbourg 1984

Knape, Joachim, 'Historie' im Mittelalter und Früher Neuzeit. Begriffs- und gattungsgeschichtliche Untersuchungen im interdisziplinären Kontext, BadenBaden 1984

Knape, Joachim, 'Melanchthon und die Historien', ARG 91 (2000), pp. 111-126

Knecht, R.J., Francis I, Cambridge 1982

Knecht, R.J., Renaissance Warrior and Patron: Reign of Francis I, Cambridge 1994

Krieger, Christian, 'Bericht der Arbeitsgruppe Bucers Wirken im europäischen Raum', Krieger, Christian, Lienhard, Marc (eds.), Martin Bucer and Sixteenth Century Europe. Actes du colloque de Strasbourg (28-31 aout 1991), vol. 2, Leiden/New York/Cologne 1993, pp. 473-477

Koebner, R., 'The Imperial Crown of this Realm', Bulletin of the Institute of Historical Research 26 (1953), pp. 29-52

Kohler, Alfred, 'Kaiser Karl V.', Die Reformationszeit II, ed. Greschat, Martin, Stuttgart/Berlin/Cologne/Mainz 1981, pp. 147-170 
Kolb, Robert, For all the Saints. Changing Perceptions of Martyrdom and Sainthood in the Lutheran Reformation, Macon, GA 1987

Krieg, A., Zur Charakteristik Johann Sleidans, Zehlendorf 1907

Krieger, Leonhard, Ranke: The Meaning of History, Chicago 1970

Kuin, Roger, 'Private library as public danger: the case of Duplessis-Mornay', Pettegree, Andrew, Nelles Paul, and Conner Philip (eds.), The Sixteenth-Century French Religious Book, Aldershot 2001, pp. 319-358

Kuller Shuger, Debora, The Renaissance Bible. Scholarship, Sacrifice and Subjectivity, Berkeley 1994

Kuperty-Tsur, Nadine, 'Le moi, sujet de l'Histoire', Nouvelle Revue du XVIe siècle 19/1 (2001), pp. 63-81

Hartmann, Martina, Humanismus und Kirchenkritik: Matthias Flacius Illyricus als Erforscher des Mittelalters, Beiträge zur Geschichte und Quellenkunde des Mittelalters 19, Stuttgart 2001

Lang, Jack, François Ier ou le rêve italien, Saint-Amand/Cher, 1997

Lebeau, Jean, Valentin, Jean-Marie, L'Alsace au siècle de la Réforme 1482-1621, Nancy 1985

Lenz, Max, Geschichtsschreibung und Geschichtsauffassung im Elsass zur Zeit der

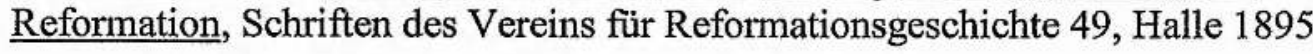

Lefebvre, G., La naissance de l'historiographie moderne, Paris 1971

Leonhardt, J., Melanchthon und das Lehrbuch, Rostock 1997

Levine, Joseph M., Humanism and History: Origins of Modern Historiography, Ithaca 1987

Levy, F.J., Tudor Historical Thought, San Marino/California 1967

Lewin, Wera Rahel, Claude de Seyssel. Ein Beitrag zur politischen Ideengeschichte des 16. Jahrhunderts, Heidelberg 1933

Lienhard, Marc, 'Jakob Sturm', Die Reformationszeit I, ed. Greschat, Martin, Stuttgart/Berlin/Cologne/Mainz 1981, pp. 289-306

-----, Magistrat und Reformation in Straßburg, Badische Landesbibliothek, Vorträge 3, 1984

------, "Personnalisme", "territorialisme", "triomphalisme"? Remarques sur l'histoire et l'historiographie du XVIe siècle strasbourgeois', Livet, Georges, Rapp, Francis (eds.), Strasbourg au coeur religieux du XVIe siècle. Hommage à Lucien Febvre. 
Actes du Colloque International de Strasbourg (25-29 mai 1975), Strasbourg 1977, pp. 603-612

--.---, Religiöse Toleranz in Straßburg im 16. Jahrhundert, Mainz 1991

, Willer, Jakob (eds.), Straßburg und die Reformation, Keh1/Strasbourg/Basle 1982

Lieseberg, Ursula, Studien zum Mätyrerlied der Täufer im sechzehnten Jahrhundert, Frankfurt 1991

Livet, Georges, 'Jacques Sturm, stettmeister de Strasbourg. Formation et idées politiques 1489-1532', Livet, Georges/Rapp, Francis (eds.), Strasbourg au coeur religieux du XVIe siècle. Hommage à Lucien Febvre. Actes du Colloque International de Strasbourg (25-29 mai 1975), Strasbourg 1977, pp. 207-242

Loades, David (ed.), 'John Foxe and the traitors: the politics of the Marian persecution (presidential address)', Wood, Diana (ed.), Martyrs and Martyrologies, Studies in Church History 30, Oxford 1993, pp. 231-244

Magnien, Catherine, 'Estienne Pasquier Historien', Nouvelle Revue du XVIe siècle 19/1 (2001), pp. 51-62

Maissen, Thomas, 'Le "Commynisme" italien: Louis XI, héros de la contre-réforme', Bibliothèque d'Humanisme et Renaissance 58/2 (1996), pp. 213-349

Martin, Henri-Jean, The French Book: Religion, Absolutism, and Readership, 1585-1715, Baltimore 1996

McGrath, Alister E., Reformation Thought: An Introduction, Oxford 1988

McNiel, John T., 'John Foxe: historiographer, disciplinarian, tolerationist', Church History 43 (1974), pp. 216-29

Menke-Glückert, E., Die Geschichtsschreibung der Reformation und Gegenreformation. Bodin und die Begründung der Geschichtsmethodologie durch Bartholomäus Keckermann, Osterwieck/Harz 1912

Michaud, H., 'Les bibliothèques des sécretaires du roi au XVIe siècle', Bibliothèque de L'École des Chartes 126 (1968), pp. 332-375

-----, La Grande Chancellerie et les Écritures Royales au Seizième Siècle (1515-1589), Paris 1967

Michelet, J., François Ier et Charles-Quint 1515-1547, Paris 1887

Millet, Olivier, 'Wolfgang Fabricius Capiton à Marguerite de Navarre (1528): Dédicace de In Hoseam prophetam commentarius', Revue Française d'Histoire du Livre (N.S. 50, 1986), pp. 201-216

Moeckli, Gustave, Les Livres imprimés à Genève de 1550 à 1600 , Geneva 1966

Momigliano, Arnaldo, Essays in Ancient and Modern Historiography, Oxford 1977 
--.--, Studies in Historiography, Worcester/London 1966

Monstiers-Mérinville, Marquis de, Un évèque ambassadeur au XVI. siècle, Jean des Monstiers, seigneur de Fraisse, évèque de Bayonne, Limoges 1895

Moore, W.G., La Réforme Allemande et la Littérature Française. Recherches sur la Notoriété de Luther en France, Publications de la Faculté des Lettres de l’Université de Strasbourg 52, Strasbourg 1930

Moreau, Gérard, ‘Contributions à l'histoire du Livre des martyrs', BSHPF 103 (1957), pp. 173-199

-----, Histoire du Protestantisme à Tournai jusqu'à la veille de le Révolution des PaysBas, Paris 1962

Mours, Samuel, Le protestantisme en France au XVIe siècle, Paris 1959

Mozley, J.F., John Foxe and His Book, London/New York 1940

Müller, Julius Otto, Aus den Eifelbergen. Die Reformation in der ehemaligen Grafschaft Schleiden, Langenberg 1887

Münch, Gotthard, 'Das Chronicon Carionis Philippicum', Sachsen und Anhalt 1 (1925), pp. $199-283$

Neddermayer, Uwe, Das Mittelalter in der deutschen Historiographie vom 15. bis zum 18. Jahrhundert. Geschichtsgliederung und Epochenverständnis in der frühen Neuzeit, Cologne/Vienna 1988

Nelles, Paul, 'Historia magistra antiquitatis: Cicero and Jesuit history teaching', Renaissance Studies 13/2 (1999), pp. 130-172

----, 'Lipsius, Scaliger and the Historians', Bulletin de L'Institut Historique Belge de Rome LXVIII (1998), pp. 233-254

---.--, 'Three audiences for religious books in sixteenth-century France', Pettegree, Andrew, Nelles, Paul, and Conner, Philip (eds.), The Sixteenth-Century French Religious Book, Aldershot 2001, pp. 256-285

Neuser, Wilhelm H., 'Bucers konfessionelle Position', Krieger, Christian, Lienhard, Marc (eds.), Martin Bucer and Sixteenth Century Europe. Actes du colloque de Strasbourg (28-31 aout 1991), vol. 2, Leiden/New York/Cologne 1993, pp. 693-704

Niedhart, G., 'Politisches Denken in Frankreich im 16. Jahrhundert', Francia 3 (1976), pp. $669-688$

Oberman, Heiko A., Masters of the Reformation: The Emergence of a New Intellectual Climate in Europe, Cambridge 1981

Oberreiner, C., 'Sleidan, Jean Sturm et Bruno en Mission Diplomatique en 1545', Revue d'Alsace-Lorraine 68 (1920), pp. 89-132 
Old, H.O., Patristic Roots for Reformed Worship, Züricher Beiträge zur Reformationsgeschichte 5, Zurich 1975

Ozment, Stephen, The Reformation in the Cities, New Haven 1975

Paillard, Charles, Le procès de Pierre Brully, successeur de Calvin comme ministre de L'Église française de Strasbourg. Poursuites intentées contre ses adhérents à Tournai, Valenciennes, Lille, Douay et Arras, 1544-1545 d'après les papiers inédits des Archives du Royaume de Belgique, Paris/The Hague 1878

Pannier, Jacques, Calvin à Strasbourg, Strasbourg 1925

Pariset, J.-D., 'L'activité de Jacques Sturm, Stettmeister de Strasbourg de 1532 à 1553', Livet, Georges, Rapp, Francis (eds.), Strasbourg au coeur religieux du XVIe siècle. Hommage à Lucien Febvre. Actes du Colloque International de Strasbourg (25-29 mai 1975), Strasbourg 1977, pp. 253-268

-----, Les Relations diplomatiques Franco-Allemandes au milieu du XVIe Siècle, $\mathrm{PhD}$ Thesis, 2 vols., University of Strasbourg 1979

------, Les relations entre la France et l'Allemagne au milieu du XVIe siècle, Société savante d'Alsace et des Régions de l'est, 'Grandes Publication' 19, Strasbourg 1981

Parry, Glyn, 'John Foxe, 'Father of Lyes', and the Papists', Loades, David (ed.), John Foxe and the English Reformation, Aldershot 1997, pp. 295-305

Paulus, N., 'Ein merkwürdiges Urtheil über Sleidan's Geschichtswerk', Der Katholik 75/ II (1895), pp. 573-574

Paur, Theodor, Johann Sleidans Commentare über die Regierungszeit Karls V. historischkritisch betrachtet, Leipzig 1843

Péronnet, Michel, 'Les évêques français et le livre au XVle siècle: auteurs, éditeurs et censeurs', Aquilon, Pierre, Martin, Henri-Jean (eds.), Le Livre dans 1'Europe de la Renaissance. Actes du xxviiie Colloque international d'Etudes humanistes de Tours, s.l. 1988, pp. 159-169

Petri, Franziskus, 'Strassburgs Beziehungen zu Frankreich während der Reformationszeit', ELJB 8 (1929), pp. 134-165; 10 (1931), pp. 123-192

Pettegree, Andrew, 'Adriaan van Haemstede: the Heretic as Historian', Gordon, Bruce (ed.), Protestant History and Identity in Sixteenth-Century Europe, vol. 2: The Later Reformation, Aldershot 1996

------, 'Emden as a centre of the sixteenth-century book trade. A catalogue of the bookseller Gaspar Staphorst', Quaerendo 24/2 (1994), pp. 114-135

------, Marian Protestantism. Six Studies, Aldershot 1996 
------, 'Religious printing in sixteenth-century France: the St Andrew's project', Proceedings of the Huguenot Society XXVI/5 (1997), pp. 650-659

------, 'The Sixteenth-Century French Religious Book Project', Pettegree, Andrew, Nelles, Paul, and Conner, Philip (eds.), The Sixteenth-Century French Religious Book, Aldershot 2001, pp. 1-17

Peyer, Hans Conrad, 'Der St. Galler Reformator Vadian als Geschichtsschreiber. Pragmatische und mythische Geschichtsauffassung in der Schweiz des 16. Jahrhunderts', Schweizer Monatshefte 65 (1985), pp. 315-28

Pfister. J.C., Herzog Christoph zu Wirtemberg, aus größtentheils ungedruckten Quellen, Tübingen 1819

Pinvert, Lucien, Lazare de Baïf (1496(?)-1547), Paris 1900

Polman, Pontien, L'elément historique dans la controverse religieuse du XVIe siècle, Gembloux 1932

Postina, Al., Der Karmelit Eberhard Billick, Freiburg im Breisgau 1901

Potter, David, 'Foreign Policy in the Age of the Reformation: French Involvement in the Schmalkaldic War, 1544-1547', Historical Journal 20 (1977), pp. 525-44

Poujol, Jacques (ed.), Claude de Seyssel: La monarchie de France et deux autres fragments politiques, Paris 1961

Quick, John, Synodicon in Gallia reformata, London 1692

Racaut, Luc, Hatred in Print: Catholic Propaganda and Protestant Identity during the French Wars of Religion, Aldershot 2002

Randall Coats, Catherine, (Em) bodying the Word. Textual Resurrection in the Martyrological Narratives of Foxe, Crespin, de Bèze and d'Aubigné, New York/Berlin/Bern/Frankfurt M./Paris/Vienna 1992

Ranke, Leopold von, Deutsche Geschichte im Zeitalter der Reformation, 3 vols., Berlin 1840-1843

------, Zur Kritik neuerer Geschichtsschreiber, Leipzig/Berlin 1824

-----, The Theory and Practice of History, New York 1983

Rathgeber, Jules, 'Jean Sleidan', BSHPF 22 (1873), pp. 337-351

Reid, Jonathan Andrew, King's Sister - Queen of Dissent. Marguerite of Navarre (14921549) and her Evangelical Network, unpublished PhD dissertation, University of Arizona 2001

Reid, William Stanford, 'The four Monarchies of Daniel in Reformation Historiography', Historical Reflections 8 (1981), pp. 115-123 
Reinartz, Nikolaus, 'Das Leichenbegängnis des Grafen Dietrich IV. von ManderscheidSchleiden 1551', Annalen des Historischen Vereins für den Niederrhein 125 (1934), pp. 111-116

-----, 'Der Schleidener Stadtschreiber Paul Petri (1510-1588) und seine Verschronik', Mitteilungen der Westdeutschen Gesellschaft für Familienkunde 7/12 (1933), cols. 451-457

Reuss, Rodolphe, Histoire d'Alsace, Paris 1912

-----, Histoire de Strasbourg depuis ses origines jusqu'à nos jours, Paris 1922

------, Notes pour servir à l'histoire de l'Église francaise de Strasbourg 1538-1794, Strasbourg 1880

Ritter, François, Histoire de l'imprimerie alsacienne, au Xve et XVIe siècles, Strasbourg/Paris 1955

Ritter, Moritz, 'Studien über die Entwicklung der Geschichtswissenschaft 3: Das Zeitalter des Humanismus, der Reformation und Gegenreformation', Historische Zeitschrift 109 (1912), pp. 284-302

Robbins, Kevin C., 'Rewriting Protestant history: printing, censorship by pastors, and the dimensions of dissent among the Huguenots - the La Popelinière case at $\mathrm{La}$ Rochelle, 1581-85', Pettegree, Andrew, Nelles, Paul, and Conner, Philip (eds.), The Sixteenth-Century French Religious Book, Aldershot 2001, pp. 239-255

Roberts, Penny, 'Martyrologies and martyrs in the French Reformation: heretics to subversives in Troyes', Wood, Diana (ed.), Martyrs and Martyrologies, Studies in Church History 30, Oxford 1993, pp. 221-229

Röhrich, Timotheus Wilhelm, Geschichte des Reformation im Elsass und besonders in Strassburg nach gleichzeitigen Quellen bearbeitet, 3 vols., Strasbourg 1830-32

------, Mittheilungen aus der Geschichte der evangelischen Gemeinden des Elsasses, 3 vols., Strasbourg 1855

Römer, Gerhard, Bücher - Stifter - Bibliotheken. Buchkultur zwischen Neckar und Bodensee, Stuttgart 1997

Rott, Jean, 'L'Eglise des réfugiés de langue française à Strasbourg au XVIe siècle: aperçu de son histoire, en particulier de ses crises à partir de 1541', BSHPF 122 (1976), pp. 525-550

'Jacques Sturm, Scolarque de la Haute-Ecole (Gymnase) de la ville de Strasbourg 1526-1553', Livet, Georges, Rapp, Francis (eds.), Strasbourg au coeur religieux du XVIe siècle. Hommage à Lucien Febvre. Actes du Colloque International de Strasbourg (25-29 mai 1975), Strasbourg 1977, pp. 243-252

-------, 'Jean Sturm, premier recteur de Gymnase et de l'Academie de Strasboirg (15071589), Livet, Georges, Rapp, Francis (eds.), Strasbourg au coeur religieux du XVIe 
siècle. Hommage à Lucien Febvre. Actes du Colloque International de Strasbourg (25-29 mai 1975), Strasbourg 1977, pp. 185-188

---.--., 'Nouveaux Documents sur Jean Sleidan Historien de la Réforme (1506-1556)', Bulletin Philologique et Historique (Jusqu'à 1610) du Comité des Travaux Historiques er Scientifiques 1967/II, Paris 1969, pp. 551-647

------, 'Politique rhénane entre Habsbourg et Valois: le rôle du comte Dietrich IV de Manderscheid', Investigations historicae 2, Strasbourg 1986, pp. 339-361

-.-.--, 'Un recueil de correspondances strasbourgeoises du XVIe siècle à la Bibliothèque de Copenhague', Bulletin Philologique et Historique (Jusqu'à 1610) du Comité des Travaux Historiques er Scientifiques 1968, Paris 1971, pp. 749-818

Roussel, Bernard, 'La dédicace à François Ier du De vera et falsa religione Commentarius de H. Zwingli (mars 1525)', Revue Francaise d'Histoire du Livre (N.S. 50, 1986), pp. 187-199

Ruble, A. de, Le mariage de Jeanne d'Albret, Paris 1877

Ryrie, Alec, 'The Problem of Legitimacy and Precedent in English Protestantism', Gordon, Bruce (ed.), Protestant History and Identity in Sixteenth-Century Europe, vol. 2: The Medieval Inheritance, Aldershot 1996, pp. 78-92

Saulnier, V.-L., 'Le parti Du Bellay devant 1'affaire de Nicolas Cop. Ou de quelques fonctions du silence', Actes du colloque Renaissance-Classicisme du Maine (1971), pp. 19-34, Paris 1975

Scheible, Heinz (ed.), Die Anfänge der reformatorischen Geschichtsschreibung. Melanchthon, Sleidan, Flacius und die Magdeburger Zenturien, Texte zur Kirchen- \& Theologiegeschichte 2, Gütersloh 1966

-----, Die Entstehung der Magdeburger Zenturien. Ein Beitrag zur Geschichte der historiographischen Methode, Schriften des Vereins für Reformationsgeschichte 183, Gütersloh 1972

---- (ed.), Melanchthon in seinen Schülern, Wiesbaden 1997

---.--, 'Melanchthon und Bucer', Krieger, Christian, Lienhard, Marc (eds.), Martin Bucer and Sixteenth Century Europe. Actes du colloque de Strasbourg (28-31 aout 1991), vol.1, Leiden/New York/Cologne 1993, pp. 369-393

Scherer, E.C., Geschichte und Kirchengeschichte an den deutschen Universitäten, Freiburg/Breisgau 1927

Schindling, Anton, 'Gymnase et Académie à Strasbourg 1538-1621', Livet, Georges, Rapp, Francis (eds.), Strasbourg au coeur religieux du XVIe siècle. Hommage à Lucien Febvre. Actes du Colloque International de Strasbourg (25-29 mai 1975), Strasbourg 1977, pp. 551-558

--.----, Humanistische Hochschule und freie Reichsstadt - Gymnasium und Akademie in Strassburg 1538 bis 1621 , Wiesbaden 1976 
Schlaepfer, Heidi-Lucie, 'Laurent De Normandie', Berthoud, G. et al. (eds.), Aspects de la Propagande Religieuse, Geneva 1957, pp. 176-230

Schlütter-Schindler, Gabriele, Der Schmalkaldische Bund und das Problem der causa religionis, Frankfurt am Main/Bern/New York 1986

Schmidt, Charles, Histoire littéraire de l'Alsace a la fin du XVe et au commencement du XVIe siècle, 2 vols., Paris 1879

-.---, La vie et les travaux de Jean Sturm, premier recteur du Gymnase et de l'Académie de Strasbourg, Paris 1855

Schmidt, Imke, Die Bücher aus der Frankfurter Offizin Gülfferich - Han/Weigand Han Erben. Eine literaturhistorische und buchgeschichtliche Untersuchung zum Buchdruck in der zweiten Hälfte des 16. Jahrhunderts, Wiesbaden 1996

Schnabel, Franz, Deutschlands geschichtliche Quellen \& Darstellungen in der Neuzeit, vol. 1, Leipzig/Berlin 1931, pp. 257-273

Schottenloher, K., 'Johannes Sleidanus und Markgraf Albrecht Alcibiades', $\underline{\text { ARG }} 35$ (1938), pp.193-202

Schrenck, Gilbert, 'Livres du Pouvoir et pouvoirs du Livre: L'historiographie royale et la conversion d'Henri IV (A.d'Aubigné, P.Cayet, P.Matthieu et J. de Serres)', $\underline{\text { Revue }}$ Francaise d'Histoire du Livre (N.S. 50, 1986), pp. 153-179

Scribner, Robert W., For the Sake of Simple Folk: Popular Propaganda for the German Reformation, Cambridge 1994

Seguenny, André, 'Historia Magistra Vitae. Quelques rémarques à propos de la Chronique de Sébastien Franck', Kroon, Marijn de, Lienhard, Marc (eds.), Horizons Européens de la Réforme en Alsace. Das Elsass und die Reformation im Europa des XVI. Jahrhunderts, Strasbourg 1980, pp. 107-118

-----, Répertoire des non-conformistes religieux des seizième et dix-septième siècles, Bibliotheca Dissidentium 7, Baden-Baden 1986

-----, Les Spirituels. Philosophie et religion chez les jeunes humanistes allemands au seizième siècle, Bibliotheca Dissidentium, Scripta et Studia 8, BadenBaden/Bouxwiller 2000

Seidel, Karl Josef, Frankreich und die deutschen Protestanten: die Bemühungen um eine religiöse Konkordie und die französische Bündnispolitik in den Jahren 1534/35, Reformationsgeschichtliche Studien und Texte 102, Münster 1970

Seyboth, Ad., Strasbourg historique et pittoresque depuis son origine jusqu'en 1870, Strasbourg 1894

Shears, F.S., Froissart. Chronicler and Poet, London 1930

Sherer, E.C., Geschichte und Kirchengeschichte an den deutschen Universitäten, Freiburg 1927 
Siebel, W., 'Johannes Sleidanus, der Geschichtsschreiber der Reformation. Zur Erinnerung an seinen Todestag am 30. Okt. 1556', Monatshefte für Evangelische Kirchengeschichte des Rheinlandes 6 (1957), pp. 1-21

Skinner, Quentin, The Foundations of Modern Political Thought, 2 vols., Cambridge 1990/92

Sluhovsky, Moshe, 'Calvinist Miracles and the Concept of the Miraculous in SixteenthCentury Huguenot Thought', Renaissance and Reformation 19/2 (1995), pp. 5-25

Sohm, Walter, Die Schule Johann Sturms und die Kirche Strasbourgs in ihrem gegenseitigen Verhältnis, 1530-1581. Ein Beitrag zur Geschichte deutscher Renaissance, Munich/Berlin 1912

Spijker, Willem van't, 'Bucer and Calvin', Krieger, Christian, Lienhard, Marc (eds.), Martin Bucer and Sixteenth Century Europe. Actes du colloque de Strasbourg (2831 aout 1991), vol.1, Leiden/New York/Cologne 1993, pp. 461-470

Spitz, Lewis W./ Tinsley, Barbara Sher, Johann Sturm on Education. The Reformation and Humanist Learning, St. Louis 1995

Spuffard, Peter, Handbook of Medieval Exchange, London 1986

Stegmann, André, 'Comment constituer une bibliothèque en France au début du XVIIe siècle: examen méthodologique', Aquilon, Pierre/Martin, Henri-Jean (eds.), Le Livre dans l'Europe de la Renaissance. Actes du xxviiie Colloque international d'Etudes humansites de Tours, s.1. 1988, pp. 467-501

Steinmann, Martin, Johannes Oporinus. Ein Basler Buchdrucker um die Mitte des 16. Jahrhunderts, Basle/Stuttgart 1967

Stöve, Eckehart, 'Kirchengeschichtsschreibung', Theologische Realenzyklopädie, vol. 18, pp. $535-560$

Strasburger, Hermann, Die Wesensbestimmung der Geschichte durch die antike Geschichtsschreibung, Wiesbaden 1966

Struever, Nancy, The Language of History in the Renaissance, Princeton 1970

Swanson, R.N., Religion and Devotion in Europe, c.1215-c.1515, Cambridge 1995

Sypher, George Wylie, 'La Popelinière's Histoire de France: A case of historical objectivity and religious censorship', Journal of the History of Ideas 24 (1963), pp. $41-54$

Tetel, Marcel, 'Montaigne's Glances at Philippe de Commynes', Bibliothèque d'Humanisme et Renaissance 6/1 (1998), pp. 25-39

Tinsley, Barbara Sher, History and Polemics in the French Reformation. Florimond de Raemond: Defender of the Church, Selinsgrove/London/Toronto 1992 
Thompson, J.W., A History of Historical Writing, Gloucester/Massachusetts 1967

Ulmann, Heinrich, 'Zur politischen Entwicklung Sleidans im Jahre 1544', ZGO 49 (N.F.10, 1895), pp. 547-564

Veyrin-Forrer, J., 'Simon de Colines, imprimeur de Lefèvre d'Étaples', Jacques Lefèvre d’Étaples (1450?-1536). Actes du colloque d'Étaples, Paris 1995, pp. 97-118

Vogelstein, Ingeborg Berlin, 'Johann Sleidan's Commentaries: New Insights from an Old History', Storia della Storiografia 11 (1987), pp. 5-21

-.---, Johann Sleidan's Commentaries. Vantage Point of a Second Generation Lutheran, Rochester 1986

Wabuda, Susan, 'Henry Bull, Miles Coverdale, and the making of Foxe's Book of Martyrs', Wood, Diana (ed.), Martyrs and Martyrologies, Studies in Church History 30 , Oxford 1993, pp. 245-258

Wagner, Fritz, Die Anfänge der modernen Geschichtswissenschaft, Bayerische Akademie der Wissenschaften, Sitzungsberichte 1979/2, Munich 1979

------, Geschichtswissenschaft, Freiburg/Munich 1951, pp. 69-76

Wallace-Hadrill D.S., Eusebius of Caesarea, London 1960

Wanegffelen, Thierry, Une difficile fidélité. Catholiques malgré le concile en France XVIe -XVIIe siècles, Paris 1999

Ward, John O., "“Chronicle" and "History": The Medieval Origins of Postmodern Historiographical Practice?', Parergon 14/2 (1997), pp. 101-128

Watson, David, 'Jean Crespin and the First English Martyrology of the Reformation', Loades, David (ed.), John Foxe and the English Reformation, Aldershot 1997, pp. 192-209

-----, 'Jean Crespin and the Writing of History in the French Reformation', Protestant History and Identity in Sixteenth-Century Europe, vol. 2: The Later Reformation, Aldershot 1996, pp. 39-58

Wegele, F.-X., Geschichte der deutschen Historiographie seit dem Auftreten des Humanismus, Munich/Leipzig 1885

Weise, Wilhelm, Über die Quellen der Commentare Sleidans, Halle 1879

Weiss, Nathaniel, 'Paris et la Réforme sous François I', BSHPF 43 (1894), pp. 242-270

Williams, Glamor, Reformation Views of Church History, London 1970

Winckelmann, Otto, 'Zur Geschichte Sleidans und seiner Kommentare', ZGO 53 (N.F.14, 1889), pp. 565-606

------, 'Niedbruck, Johann Bruno von', ADB 52 (1906, repr. Berlin 1971), pp. 618-621 
------, 'Sturm, Jakob', ADB 37 (repr. Berlin 1971), pp. 5-20

Wolff, Christian, 'Strasbourg, cité du Refuge', Livet, Georges, Rapp, Francis (eds.), Strasbourg au coeur religieux du XVIe siècle. Hommage à Lucien Febvre. Actes du Colloque International de Strasbourg (25-29 mai 1975), Strasbourg 1977, pp. 321330

Wolff, Richard, 'Sleidaniana', GGO 62 (N.F.23, 1908), pp.265-275

Wriedt, Markus, 'Luther's Concept of History and the Formation of an Evangelical Identity', Gordon, Bruce (ed.), Protestant History and Identity in Sixteenth-Century Europe, vol.1: The Medieval Inheritance, Aldershot 1996, pp. 31-45

Wright, David F., 'Martin Bucer and England - and Scotland', Krieger, Christian, Lienhard, Marc (eds.), Martin Bucer and Sixteenth Century Europe. Actes du colloque de Strasbourg (28-31 aout 1991), vol. 2, Leiden/New York/Cologne 1993, pp. 523-532

Wulczyn, Heidi, 'The relationship between Martin Bucer and Philip of Hesse: A reforming politician and a political reformer', Krieger, Christian, Lienhard, Marc (eds.), Martin Bucer and Sixteenth Century Europe. Actes du colloque de Strasbourg (2831 aout 1991), vol. 1, Leiden/New York/Cologne 1993, pp. 451-459

Yates, Frances, Astraea: The Imperial Theme in the Sixteenth Century, London 1975

Zeller, Jean, La diplomatie francaise vers le milieu du XVIe siècle d'après la correspondance de Guillaume Pellicier, Ėveque de Montpellier, Ambassadeur de François Ier à Venise (1539-1542), Paris 1881

Ziegler, Hildegard, Chronicon Carionis. Ein Beitrag zur Geschichtsschreibung des 16. Jahrhunderts, Halle/S. 1898

Ziegler, Theobald, ‘Sturm, Johann', ADB 37 (repr. Berlin 1971), pp. 21-38

Zur Mühlen, Karl-Heinz, 'Martin Bucer und das Religionsgespräch von Hagenau und Worms 1540/41', Krieger, Christian, Lienhard, Marc (eds.), Martin Bucer and Sixteenth Century Europe. Actes du colloque de Strasbourg (28-31 aout 1991), vol. 2, Leiden/New York/Cologne 1993, pp. 659-669 